MSc. DENISE MÔNACO DOS SANTOS

\title{
Espaços hibridos na cidade: interfaces computacionais para comunidades locais
}

Tese apresentada ao Programa de Pós-Graduação do Departamento de Arquitetura e Urbanismo da Escola de Engenharia de São Carlos da Universidade de São Paulo como parte dos requisitos para obtenção do título de Doutor em Arquitetura e Urbanismo.

Área de concentração: Teoria e História da Arquitetura e Urbanismo

Orientador: Prof. Associado Dr. Marcelo Tramontano 
AUTORIZO A REPRODUÇÃO E DIVULGAÇÃO TOTAL OU PARCIAL DESTE TRABALHO, POR QUALQUER MEIO CONVENCIONAL OU ELETRÔNICO, PARA FINS DE ESTUDO E PESQUISA, DESDE QUE CITADA A FONTE.

Ficha catalográfica preparada pela Seção de Tratamento da Informação do Serviço de Biblioteca - EESC/USP

\begin{tabular}{|c|c|}
\hline \multirow[t]{3}{*}{$\mathrm{S} 237 \mathrm{e}$} & $\begin{array}{l}\text { Santos, Denise Mônaco dos } \\
\text { Espaços híbridos na cidade : interfaces computacionais } \\
\text { para comunidades locais / Denise Mônaco dos Santos ; } \\
\text { orientador Marcelo Tramontano. -- São Carlos, 2008. }\end{array}$ \\
\hline & $\begin{array}{l}\text { Tese (Doutorado-Programa de Pós-Graduação em } \\
\text { Arquitetura e Urbanismo e Área de Concentração Teoria e } \\
\text { História da Arquitetura e Urbanismo) -- Escola de } \\
\text { Engenharia de São Carlos da Universidade de São Paulo, } \\
\text { 2008. }\end{array}$ \\
\hline & $\begin{array}{l}\text { 1. Espaços híbridos. 2. Comunidades. 3. Interfaces } \\
\text { computacionais. 4. Tecnologias de informação e } \\
\text { comunicação. 5. Inclusão digital. I. Título. }\end{array}$ \\
\hline
\end{tabular}


FOLHA DE APROVAÇÃO

MSc. Denise Mônaco dos Santos

Espaços híbridos na cidade: interfaces computacionais para comunidades locais

\begin{abstract}
Tese apresentada ao Programa de Pós-Graduação do Departamento de Arquitetura e Urbanismo da Escola de Engenharia de São Carlos da Universidade de São Paulo como parte dos requisitos para obtenção do título de Doutor em Arquitetura e Urbanismo.

Área de concentração: Teoria e História da Arquitetura e Urbanismo
\end{abstract}

Aprovado em:

\title{
Banca Examinadora
}

Prof. Dr.

Instituição: Assinatura

Prof. Dr.

Instituição: Assinatura:

Prof. Dr.

Instituição: Assinatura:

Prof. Dr.

Instituição: Assinatura:

Prof. Dr

Instituição: Assinatura: 
Aos meus queridos amores MARIANA e PEDRO, que repartiram, nos primeiros anos de suas vidas, a minha atenção e dedicação com este trabalho.

Ao meu pai, que sempre deu grande valor ao saber científico.

À memória da minha mãe. 
Agradeço especialmente,

ao Prof. Dr. Marcelo Tramontano, pesquisador provocativo, por quem tenho enorme

admiração;

aos pesquisadores do Nomads.usp, e em particular à Prof. Dra. Varlete Benevente, à Prof. Dra.

Anja Pratschke e à Arq. Gabriela Carneiro;

ao MSc. Carlos Alberto Cordeiro de Sá Filho e à MSc. Heloísa Mônaco dos Santos;

a todos que participaram, direta ou indiretamente, do projeto Comunidades_online, em particular ao pessoal do Instituto Pombas Urbanas;

à Fundação de Amparo a Pesquisa do Estado de São Paulo, FAFESP, pela concessão da bolsa de doutorado e pelo apoio financeiro para a realização desta pesquisa;

aos professores, alunos e funcionários do Departamento de Arquitetura e Urbanismo da EESC -

USP, sempre gentis;

e com carinho, à Graça, ao Zé, à Simone e, em particular, ao Pedro, que viabilizaram, no dia-

a-dia, o desenvolvimento deste trabalho. 


\section{RESUMO}

SANTOS, D. M. dos. Espaços híbridos na cidade: interfaces computacionais para comunidades locais. 2008. Tese (Doutorado) - Escola de Engenharia de São Carlos, Universidade de São Paulo, São Carlos, 2008.

A reflexão sobre as espacialidades atuais, em Arquitetura e Urbanismo, pressupõe o estudo de suas relações com as apropriações das tecnologias de informação e comunicação (TIC). Esse trabalho busca discutir a criação de espaços híbridos em fragmentos urbanos considerando-os como espaços constituídos a partir da inserção de comunicação mediada por sistemas computacionais em comunidades geograficamente referenciadas. Situa sua investigação a partir da implantação de uma experiência desta natureza, levada a cabo pelo projeto Comunidades_online: domesticidade $e$ sociabilidade em políticas públicas para inclusão digital, entre 2004 e 2008, no distrito paulistano de Cidade Tiradentes, financiado pela FAPESP e coordenado pelo Nomads.usp. Examina, também, por um lado, a conformação das dimensões e complexidades de projetos que buscam inserir os usos das TIC na vida das pessoas e comunidades, relacionando-as ao campo das discussões da chamada inclusão digital. Investiga, por outro lado, a natureza da comunidade na contemporaneidade e apresenta as especificidades e abrangências de suas porções física e virtual. Busca relacionar comunidades e espaços híbridos, e investiga, por fim, a constituição de interfaces computacionais para interação comunitária, ou seja, os suportes tecnológicos lógicos e físicos capazes de dotar comunidades locais de uma instância virtual.

Palavras-chave: 1. Espaços híbridos. 2. Comunidades. 3. Interfaces computacionais. 4. Tecnologias de informação e comunicação 5. Inclusão digital. 


\section{ABSTRACT}

SANTOS, D. M. dos. Hybrid space in the city: computational interfaces for local communities. 2008. Thesis (Doctoral) - Escola de Engenharia de São Carlos, Universidade de São Paulo, São Carlos, 2008.

Reflecting on current spatialities, in Architecture and Urbanism requires studying their relations to information and communication technologies (ICT) appropriations. This work discusses the creation of hybrid spaces in urban fragments defining the former as constituted spaces from mediated communication insertion by computational systems in geographically-based communities. This work is based on an experiment of this nature, carried out by the Online_communities project: domesticity and sociability in public policies for digital inclusion which took place between 2004 and 2008 in the Sao Paulo district of Cidade Tiradentes, funded by FAPESP and coordinated by Nomads.usp. It also examines, on the one hand, the dimensions and complexities of projects that intend to make ICT part of people's lives, as well as the community, relating them to the discussion on digital inclusion. On the other hand, it investigates the contemporary nature of the community and it presents the specificities and scope of the physical and virtual parts. The aim is to relate hybrid communities and hybrid spaces, as well as investigate the constitution of computational interfaces for social interaction, or in other words, the logical and physical technological support which can provide local communities with a virtual dimension.

Keywords: 1. Hybrid spaces. 2. Communities. 3. Computational interfaces. 4. Information and Communication Technologies 5. Digital inclusion. 
INTRODUÇÃO_Construindo caminhos para se pensar os espaços híbridos na cidade

1 Algumas delimitações conceituais

2 Problemas, hipóteses e objetivos da pesquisa

3 Desafios metodológicos: considerações sobre a natureza da pesquisa

CAPITLO 1_ As dimensöes das iniciativas que envolvem tecnologias de informação e comunicação

1.1 Abrangências da chamada inclusão digital

1.2 Os agentes em iniciativas envolvendo o uso das TIC

1.3 Os recursos alocados nos projetos

1.4 Aspectos estruturais de iniciativas envolvendo TIC

1.4.1 Instrumentos tecnológicos

1.4.2 Aproximações com o contexto sócio-econômico-cultural

1.4.3 Estrutura de implementação

1.5 Iniciativas envolvendo TIC: universo dos possíveis

Capitulo 2_Comunidades e tecnologias de informação e comunicação

2.1 Definições e conceituações de comunidade

2.1.1 Comunidade: um conceito antigo

2.1.2 Comunidade na contemporaneidade: as redes sociais

2.1.3 As chamadas comunidades virtuais

2.1.4 Comunidades em espaços híbridos

2.2 Considerações sobre transformações a partir das TIC 156

2.2.1 Transformação social $\quad 158$

2.2.2 Capital Social: as redes sociais potencializam a mobilização de recursos 160

2.2.3 Empoderamento

2.2.4 Os recursos locais: Asset-Based Community Development

2.2.5 Participação: a metodologia de Extremadura 169

2.2.6 Animação sociocultural 
2.3 Reflexões sobre comunidades em espaços híbridos 175

2.3.1 Uma nova agenda de pesquisa 176

2.3.2 A complementaridade da sociabilidade online e offline $\quad 181$

2.3.3 Resultados a partir de alguns estudos

2.4 As redes sociais e os espaços híbridos: recursos e transformações 192

Capitulo 3_Interfaces computacionais de interação comunitária 197

3.1 Propriedades do digital $\quad 202$

3.1.1 A natureza das mídias digitais $\quad 202$

3.1.2 Reconfigurações e recombinações $\quad 208$

3.1.3 Convergência digital $\quad 210$

$\begin{array}{ll}3.1 .4 \text { Considerações sobre a internet } & 212\end{array}$

3.2 Em comum: ferramentas e práticas colaborativas $\quad 215$

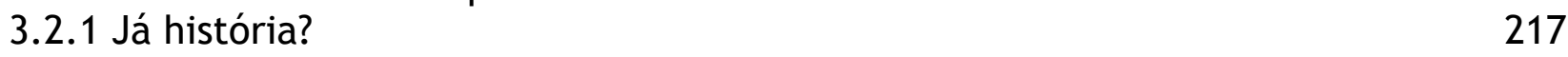

3.2.2 A questão da produção de conteúdo na rede $\quad 222$

3.2.3 Infra-estrutura compartilhada $\quad 231$

3.2.4 Design colaborativo, Software Livre e Participatory Design $\quad 234$

3.2.5 Colaboração em questão $\quad 236$

$\begin{array}{ll}3.3 \text { Paradigmas de interação } & 239\end{array}$

3.3.1 HCl - Human-Computer Interaction $\quad 241$

3.3.2 Interação, interatividade: outras reflexões $\quad 243$

3.3.3 Design de Interação $\quad 246$

3.3.4 Design para a Experiência $\quad 248$

3.3.5 Como pensar o diálogo? $\quad 254$

3.4 Interfaces: conceitos $\quad 255$

3.4.1 Para além das telas $\quad 255$

3.4.2 Infra-estruturas técnicas $\quad 260$

3.4.3 Perspectiva cultural e simbólica $\quad 261$

3.4.4 As idéias que chegam com os teóricos da arte digital 263

$\begin{array}{ll}3.4 .5 \text { Idéia em aberto } & 267\end{array}$

3.5 Ambientes interativos digitais: instantâneos $\quad 269$

3.5.1 Telas: padrões GUI / WIMP $\quad 271$

$\begin{array}{ll}3.5 .2 \text { Além telas } & 277\end{array}$

$\begin{array}{ll}3.5 .3 \text { Panorama } & 288\end{array}$ 
3.6 Estruturas para as redes sociais online

3.6.1 Requisitos projetuais e tecnológicos para redes sociais online 293

3.6.2 Interacões sociais e algumas ferramentas específicas

3.7 Interfaces computacionais de interação comunitária: um elemento do espaço híbrido

\section{Capitulo 4 _ Experiência em Cidade Tiradentes: exame critico}

4.1 0 projeto Comunidades_online

4.1.1 Concepção do projeto

4.1.2 Diferentes momentos do projeto Comunidades_online

4.2 Olhares analíticos e conclusivos: parcerias e interface

4.2.1 As parcerias no âmbito do projeto Comunidades_online

4.2.2 A interface do projeto Comunidades_online

4.3 Considerações sobre projeto Comunidades_online

4.3.1 Os equipamentos, a conexão e a inclusão digital

4.3.2 Sobre a interface

4.3.3 Além da parceria: ações culturais e transformações

Conclusões

Referências

APÊNDICE a Quadros resumos das iniciativas envolvendo TIC

APÊNDICE B Quadros resumos das ferramentas de comunicação na internet 


\section{FOLHA DE JULGAMENTO}

Candidata: Arquiteta e Urbanista DENISE MÔNACO DOS SANTOS

Tese defendida e julgada em 17/09/2008 perante a Comissão Julgadora:

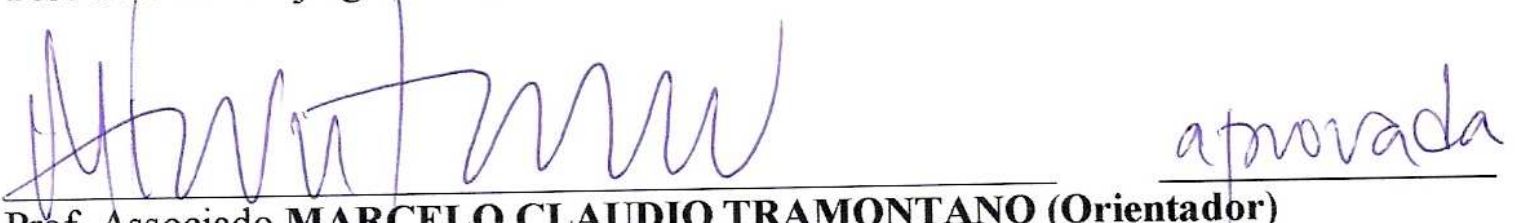

Prof. Associado MARCELO CLAUDIO TRAMONTANO (Orientador)

(Escola de Engenharia de São Carlos/USP)
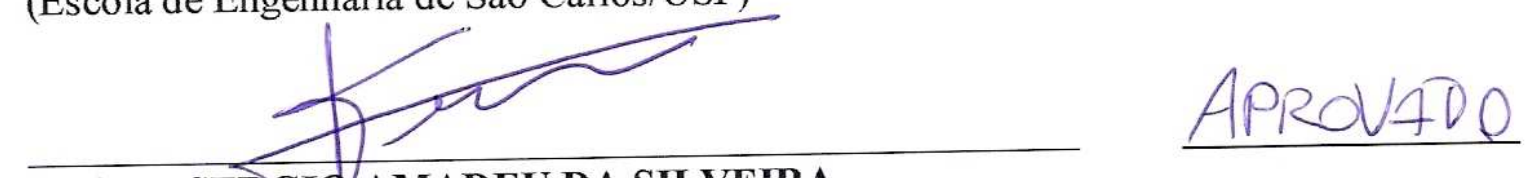

Prof. Dr. SERGIO AMADEU DA SILVEIRA

(Faculdade Casper Libero)

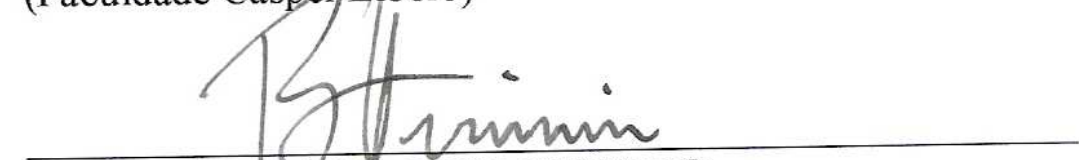

\section{ADROVADA}

Prof. Dr. RODREGO JOSE FIRMINO

(Pontificia Universidade Católica/PUC/Paraná)

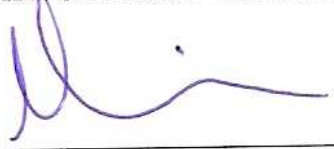

Prof. Dr. JOSE DOS SANTOS CABRAL FILHO

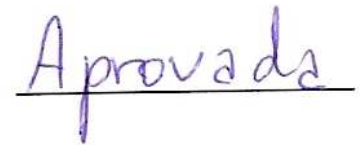

(Universidade Federal de Minas Gerais/UFMG)

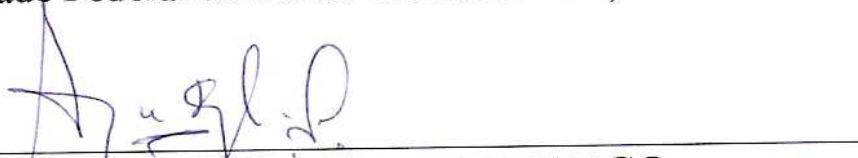

A PROVADA

Prof. Associado AZAEL RÁNGEL CAMARGO

(Escola de Engenharia de São Carlos/USP)

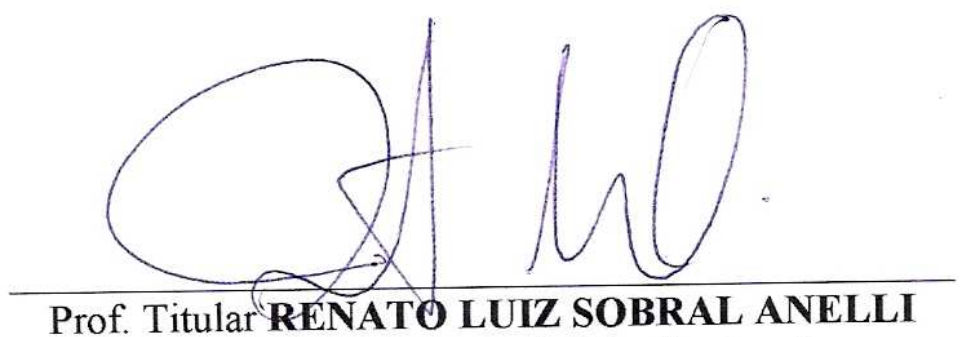

Coordenador do Programa de Pós-Graduação em

Arquitetura e Urbanismo

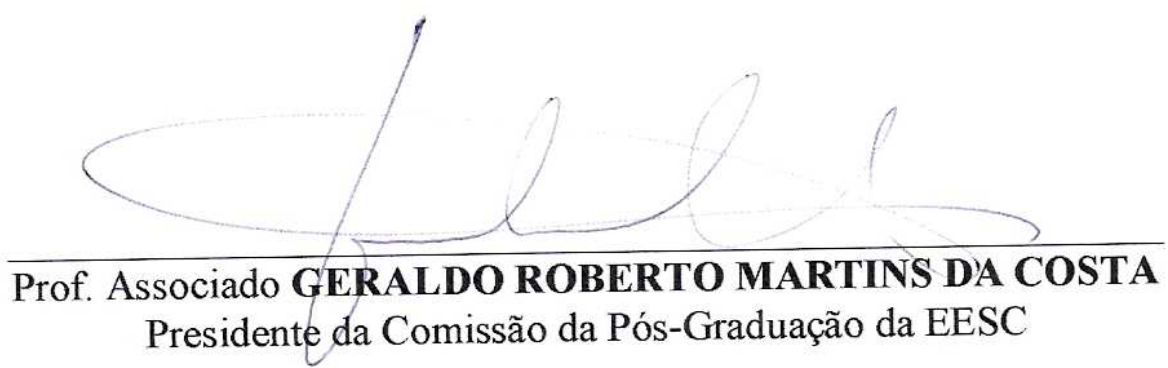


INTRODUCÃ̃o

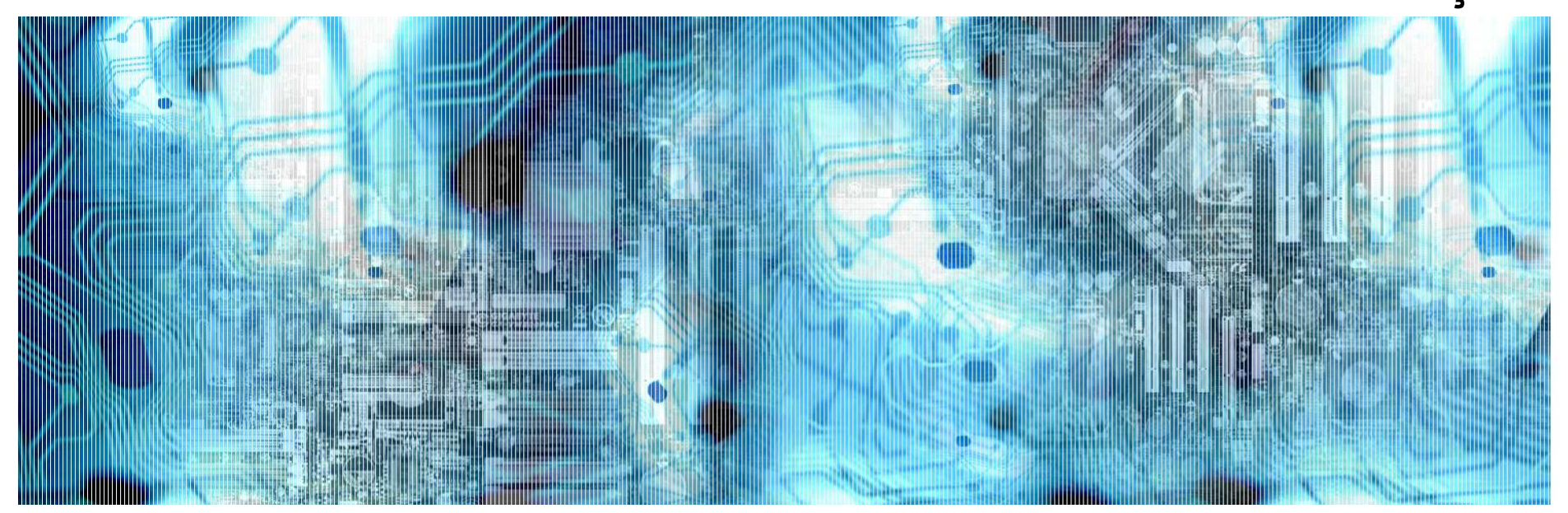




\section{Construindo caminhos para se pensar os espaços hibridos na cidade}

O exercício de desvendar as especificidades das espacialidades permeadas pelas tecnologias de informação e comunicação (TIC) tem atraído arquitetos e urbanistas neste início do século XXI. Formados sob a batuta de diferentes ciências, alguns desses profissionais não costumam ter dificuldades para entender a configuração desses espaços, o que pressupõe a incursão em universos disciplinares bastante distintos. Não por terem a destreza necessária ou as presunções suficientes para se percorrerem áreas do conhecimento distintas das suas, mas, antes, por conseguirem permanecer em zonas de dúvidas, apesar dos marcos impostos pela rigidez de certas atribuições convencionais dos saberes e fazeres. À Arquitetura e Urbanismo tem interessado investigar os limites dos espaços contemporâneos dado que a vida cotidiana se dá, cada vez mais, no entroncamento de lugares concretos e virtuais, numa instância híbrida que não pode mais, nem deve, ser desconsiderada.

As transformações que a comunicação estabelecida a partir das redes e suportes digitais instauram na vida cotidiana estão sendo vivenciadas ao mesmo tempo em que se procura apreendê-las. Ainda que bastante recentes, suas discussões se distanciam cada vez mais dos primeiros embates dicotômicos travados entre entusiastas e pessimistas que titubeavam, ambos, diante de uma realidade empírica pouco explorada e frente a um futuro bastante incerto, assentando-se em patamares mais moderados. Hoje, os discursos se sustentam a partir de instantâneos de um presente constituído e limitado pela rapidez das mudanças na configuração das tecnologias digitais. 
A reflexão sobre os espaços contemporâneos situa-se dentro do amplo campo de investigações dos fenômenos relacionados às implicações das tecnologias de informação e comunicação nos modos de vida atuais. O estudo dessas tecnologias no cotidiano das pessoas parte da constatação da intensificação de seus usos em diferentes escalas, do corpo às cidades. Incorporada a corpos, objetos, espaços e edifícios privados e coletivos, a comunicação digital expande-os de forma significativa, criando outras instâncias de interação, além de novos processos de percepção, intelecção, e experimentação. Numa época em que pesam a ubiqüidade das tecnologias digitais, suas convergências, reconfigurações e recombinações, e as intersecções estabelecidas entre diferentes sistemas, pesam também habilidades para tratar tamanha diversidade.

Há um consenso de que se está vivendo uma era cuja “[...] característica é a transformação de nossa 'cultura material' pelos mecanismos de um novo paradigma tecnológico que se organiza em torno da tecnologia da informação" (CASTELLS, 2000, p.49), ainda que haja controvérsia em relação à amplitude e à real dimensão dessa transformação. As TIC se entrelaçam à sociedade contemporânea participando da conformação de cenários múltiplos, como, por exemplo, da economia globalizada, da divisão internacional do trabalho, da constituição de novos mercados, da automação dos edifícios, da otimização da comunicação e dos serviços através de dispositivos imóveis e móveis, da realização de trabalho remoto e do caráter deste nas organizações, ao acesso facilitado a informações de forma geral, entre tantos outros.

O presente estudo insere-se particularmente em uma sub-área de pesquisa em construção que relaciona comunidades e tecnologias de informação e comunicação, situada, em princípio, entre as Ciências Sociais e as Ciências da Computação. Os limites e abrangências dessa nova sub-área são ainda bastante imprecisos, demandando algumas vezes a formulação de novos paradigmas de investigação. Envolve estudos que apresentam, em comum, interesses (1) por ações envolvendo o uso das TIC, (2) por comunidades geograficamente delimitadas, e (3) pelo desenvolvimento comunitário e transformação social. 
Assim, este trabalho instaura-se intencionalmente numa destas zonas de dúvidas acima citadas. Situase em um território de incertezas que lhe garante a permanência em contextos de interdisciplinaridade. Volta-se a objetos que têm sido apropriados por diferentes campos temáticos, sem, entretanto, pertencer exclusivamente a nenhum deles. Requer a habilidade maior de integração das disciplinas. Mas considera que o advento das tecnologias digitais trouxe a vários campos disciplinares novas demandas, e que por mais que isto pareça uma imposição em determinados contextos, trata-se de um momento de transição, esperado, de certa forma. Cada vez mais parece que a formação exemplar se aproximaria do perfil citado pelo filósofo francês Pierre Lévy (2001), que une os conhecimentos das máquinas, das engrenagens complicadas das coisas, e a competência cognitiva e social, a visão de novos agenciamentos na coletividade formada por homens e seus artefatos. A perspectiva aqui é, entretanto, mais modesta, mas não menos importante: que se construa um trabalho a partir de uma visão abrangente sobre o tema tratado, uma visão panorâmica, que justamente parece faltar a muitas análises desta natureza.

A arquitetura, o design e a arte são disciplinas que requerem, em grande medida, esta habilidade. Requisitam exercícios constantes de combinar visões de mundo, perspectivas críticas, modos de vida, comportamentos, diferentes disponibilidades materiais e possibilidades técnicas na construção de concepções de objetos, na amplitude mesma que estas questões podem exibir. Trabalham com componentes objetivos e também com outros que independem deles: o subjetivo, o impalpável, o imaterial, o abstrato. A construção do espaço, seja ele concreto ou virtual, exige esta qualidade. Como bem ressalta Lévy (2000, p.24) “Por trás das técnicas agem e reagem idéias, projetos sociais, utopias, interesses econômicos, estratégias de poder, toda a gama dos jogos dos homens em sociedade. Portanto, qualquer atribuição de um sentido único à técnica só pode ser dúbia”.

Trabalhos desta natureza requerem o cuidado de evitar o determinismo tecnológico, que propõe que a invenção e a adoção de uma dada tecnologia molde resultados particulares. "Teorias baseadas em determinismo tecnológico são geralmente teleológicas, explicam resultados em termos de propósitos ao 
invés de causas, e concebem uma série de resultados a longo prazo como inevitáveis. [...] 0 determinismo tecnológico pode ser rejeitado em ambos os terrenos empírico e teórico"1 (JONES, 1997). É preciso, antes de tudo, reforçar a idéia de que a tecnologia e a produção técnica são inseridas em determinados contextos sociais, econômicos e ideológicos, que devem ser sempre considerados, e portanto, não são neutras. Lévy (2000) foi um dos pensadores que primeiro chamou atenção para esta importante questão:

Uma técnica é produzida dentro de uma cultura, e uma sociedade encontra-se condicionada por suas técnicas. E digo condicionada, e não determinada. [...] Dizer que a técnica condiciona significa dizer que abre algumas possibilidades, que algumas opções culturais ou sociais não poderiam ser pensadas a sério sem a sua presença. [...] Muitas vezes, enquanto discutimos sobre os possíveis usos de uma dada tecnologia, algumas formas de usar já se impuseram. Antes de nossa conscientização, a dinâmica coletiva escavou seus atratores. Quando finalmente prestamos atenção, é demasiado tarde... Enquanto ainda questionamos, outras tecnologias emergem na fronteira nebulosa onde são inventadas as idéias, as coisas e as práticas. Elas ainda estão invisíveis, talvez prestes a desaparecer, talvez fadadas ao sucesso (LÉVY, 2000, p.25).

Este trabalho se insere nas investigações do Nomads.usp - Núcleo de Estudos sobre Habitares Interativos da Escola de Engenharia de São Carlos da Universidade de São Paulo que tem se esforçado para construir uma visão plural e ampliada do habitar contemporâneo, entendendo-o como um “[...] território onde se desenvolvem múltiplos aspectos do quotidiano do habitante urbano, onde ações e espacialidades se combinam e interagem, e processos de comunicação de diferentes naturezas se efetivam" (NOMADS.USP, 2008). O Nomads.usp tem se preocupado em investigar hibridismos, considerando-os realidades resultantes da sobreposição de espaços físicos e dimensões virtuais, possibilitadas pela inserção de sistemas digitais de comunicação e transmissão de informações.

\footnotetext{
${ }^{1}$ Tradução da autora. No original: "Theories based on technological determinism are generally teleological, that is they explain outcomes in terms of purpose rather than cause, and conceive of a certain set of long-term outcomes as inevitable. [...] Technological determinism can be rejected on both empirical and theoretical grounds."
} 
Esta introdução apresenta as linhas gerais da pesquisa, através dos problemas que foram seu ponto de partida, das suas hipóteses, objetivos, estratégias e metodologia, e considerações sobre sua natureza. Também contém algumas definições adotadas no trabalho, e apresenta e justifica a estrutura da tese, com o resumo do conteúdo e a relevância de cada capítulo.

\section{Algumas delimitações conceituais}

Esta pesquisa parte da constatação de que, nos dias de hoje, os espaços e lugares tendem a ser cada vez mais híbridos, ou seja, envolvendo duas dimensões, a concreta e a virtual. Essa instância híbrida é obtida, principalmente, a partir da inserção da comunicação mediada por suportes informatizados na vida cotidiana. Como se disse, os hibridismos podem ser verificados numa escala crescente, do corpo à cidade. No Nomads.usp entende-se que na dimensão do corpo a exploração desses cruzamentos se dá nas possibilidades da computação vestível, dos objetos, através dos mobiliários com mídias integradas, do edifício, considerando a habitação como interface de comunicação, e no urbano, por meio das redes comunitárias. É especificamente nessa escala que se insere essa pesquisa e o projeto ao qual está ligada, o Comunidades_online: domesticidade e sociabilidade em políticas públicas para inclusão digital.

Tramontano (2007) define a hibridação a partir da relação entre os espaços arquitetônicos e a comunicação através das mídias digitais. Segundo o autor “[...] o espaço arquitetônico vê adensar-se sua natureza concreta pelo aporte de instâncias virtuais. Isto o dota de um caráter híbrido, 
aproximando-o à própria noção de meio de comunicação, regido por dinâmicas próprias e recentes que constituem a atual matéria prima da arquitetura e do design"² (TRAMONTANO, 2007, p.49).

Karahalios (2004), que desenvolve pesquisas sobre interfaces no Sociable Media Group, no MIT Massachussets Institute of Technology, destaca a importância e relevância de pesquisas sobre hibridismos:

Do mundo online, queremos manter a facilidade de interação com estranhos, a facilidade de entrar em espaços públicos, e o baixo risco associado com a interação. Do mundo físico, queremos manter os recursos (navegação, senso de toque, campo visual, etc.) do espaço físico que nos circunda, a presença das formas físicas e tangíveis, e a percepção sensorial do espaço. Criando estes mundos híbridos, nós não mais interagimos como nós fazemos somente em um espaço online ou somente no espaço físico. Nós criamos um novo estilo de espaço que reúnem pessoas de maneira desconhecida e com descobertas e acasos felizes. Porque isto é importante? Conexões existem em todo o nosso redor e dado o mercado da tecnologia, estas continuarão aumentando. [...] Quando as combinamos, as conexões multiplicam exponencialmente ${ }^{3}$ (KARAHALIOS, 2004, p.94).

Também o grupo Electronic Shadow explora a discussão a respeito dos espaços híbridos a partir das possibilidades de uso das TIC em suas obras, que se situam nos campos da arquitetura, arte e design.

\footnotetext{
${ }^{2}$ Tradução da autora. No original: "[...] el espacio arquitectônico ve adensarse su naturaleza concreta por el aporte de instancias virtuales. Eso lo dota de un carácter híbrido, aproximándolo a la própria noción de médio de comunicación, regido por dinámicas proprias y recientes que constituyen la actual materia prima de la arquitectura y del diseño."

${ }^{3}$ Tradução da autora. No original: "One of the major inspirations for creating these installations is the blending of the online and the physical. From the online world, we wanted to maintain the ease of interaction with strangers, the ease of entry into public, spaces, and the low risk associated with interaction. From the physical world, we wanted to maintain the affordances (navigation, sense of touch, visual field, etc.) of the physical space surrounding us, the presence of physical, tangible forms, and the sensory perception of space. In creating these hybrid worlds, we no longer interact as we do in an online-only space or in a physical-only space. We have created a new style of space that brings people together in unfamiliar and serendipitous ways. Why is this important? Connections exist all around us and given the market for technology, they will continue to increase. [...]. When we combine them, the connections multiply exponentially."
} 
0 conceito original do $25^{\circ}$ fuso horário imaginado por Electronic Shadow e explorado em vários projetos põe em questão nossa percepção do espaço-tempo propondo de maneira realista a integração das novas tecnologias ao nosso entorno físico, não apenas de um ponto de vista tecnológico mas de um ponto de vista social, criando as fundações de uma nova relação com a territorialidade e portanto de uma nova realidade. [...] Nessa ótica, nós realizamos vários modelos de espaços híbridos, híbridos entre sua realidade física e sua presença na internet, ou divididos entre muitos lugares. Trata-se de criar uma ponte entre o público presente em um espaço de exposição, por exemplo, e o público presente através de computadores distantes, em casa ou em outro lugar (ELECTRONIC SHADOW, 2006).

Para Zellner (1999) as TIC têm transformado o campo da arquitetura, principalmente no sentido da redefinição dos seus limites, e dos seus códigos, frente a um mundo volátil e flexível. 0 autor apresenta a idéia de espaço híbrido como um novo arranjo de espaço entre, que se situa a partir de opostos, dentre os quais estão as porções concreta e virtual, a inclusão e a mistura:

O 'espaço híbrido' define uma arquitetura que é produzida pela criação de idéias ou conceitos de contraste e heterogeneidade - o forte e o fraco, o formal e o disforme, o real e o virtual - e que envolve a completa personificação de identidades concorrentes - desembaraçando e dissipando geometrias e postulados espaciais opostos. Esta arquitetura nova organiza o mundo pelo arranjo dos espaços entre as coisas ao invés da perpetuação do mito da forma ideal. Os espaços híbridos liberam uma arquitetura de inclusão e absorção, recombinação e mistura ${ }^{4}$ (ZELLNER,1999, p.8).

O espaço hibrido seria então essa zona de cruzamentos e combinações de lugares, de justaposições e entrelaçamentos entre esferas físicas e virtuais, estabelecida a partir da comunicação mediada por sistemas computacionais.

\footnotetext{
4 Tradução da autora. No original: “Hybrid space' defines an architecture that is produced by breeding ideas or concepts of contrast and heterogeneity - the strong and the weak, the formed and the formeless, the real and the virtual - and that evolves through the embodiment of competing identities - unraveling and consuming opposed geometries and spatial postulates. This new architecture organizes the world by arranging the spaces between things rather than perpetuating the myth of the ideal form. Hybrid space unbinds an architecture of inclusion and absorption, recombination and admixture."
} 
Interessa a esse trabalho o exame da criação de espaços híbridos a partir de comunidades locais, ou referenciadas geograficamente, que correspondem àquelas comunidades cujas relações sociais se baseiam em vínculos espaciais, em um território delimitado. Neste trabalho este território é uma porção da cidade, um fragmento urbano. Como se verá adiante, as comunidades estabelecidas a partir de espaços híbridos são redes sociais que sobrepõem às interações sociais vinculadas a um determinado recorte territorial as interações estabelecidas no ciberespaço. ${ }^{5}$

Muitos estudos discutem as relações entre os usos das tecnologias de informação e comunicação e o espaço físico no plano das cidades. Pautados também na incorporação das TIC nas estruturas urbanas, procuram entender os desdobramentos da intensificação dos sistemas digitais apresentando diferentes leituras para os novos fenômenos envolvendo TIC e cidades, propondo, inclusive, diferentes conceituações e expressões. Firmino e Duarte (2008) chamam a cidade permeada pela expansão das capacidades de comunicação de espaço ampliado e cidade infiltrada, alertando para a importância e necessidade de instrumentos conceituais e metodológicos que dêem conta dessa nova condição. Este trabalho interessa menos pela temática da relação entre a apropriação das TIC e os cenários das configurações urbanas contemporâneas, e mais pelos recortes locais, delimitados pelos vínculos sociais estabelecidos a partir de um determinado local geográfico.

São justamente esses vínculos e laços que compõem a conceituação de comunidade adotada neste trabalho, como se verá no capítulo 2 . Neste trabalho se entende a comunidade a partir das relações sociais, a partir do modelo de redes sociais, estruturadas por conjuntos de nós, que podem ser diferentes unidades sociais, e de laços inter-relacionados, que apresentam, por sua vez, diferentes atributos.

\footnotetext{
${ }^{5}$ O ciberespaço é entendido aqui de acordo com a definição de Lévy (2000, p.17): "[...] é o novo meio de comunicação que surge da interconexão mundial dos computadores. O termo especifica não apenas a infra-estrutura material da comunicação digital, mas também o universo oceânico de informações que ela abriga, assim como os seres humanos que navegam e alimentam esse universo".
} 
As interfaces computacionais são entendidas neste trabalho como meios, suportes lógicos e físicos, não restritos a elementos gráficos e a telas, suportando a interatividade que se processa com elas e através delas. De natureza multidisciplinar, a interface é entendida aqui como superfície de contato, ambiente de comunicação, objeto simbólico, suporte de linguagens e de tradução de signos.

\section{Problemas, hipoteses e objetivos da pesquisa}

As indagações estabelecidas durante o desenvolvimento dessa pesquisa foram de diferentes ordens e assumiram pesos distintos em determinados momentos. Entretanto, algumas delas nortearam 0 trabalho desde o seu início e contribuíram para demarcar suas principais discussões. Uma questão importante que sempre esteve presente diz respeito à exploração das possibilidades de conformação de espaços híbridos na escala dos fragmentos urbanos. Considerando como base a comunicação mediada pelas tecnologias digitais, quais seriam estas possibilidades em termos de infra-estrutura, de interfaces computacionais e de recursos sociais? 0 que deveria ser proposto no sentido de se avançar na experimentação de alternativas sobre o que comumente é disponibilizado? Qual seria, por exemplo, neste contexto, o papel de uma interface especialmente desenhada? Ainda neste mesmo sentido, outra questão se fazia premente: como se estabeleceria o redesenho dos espaços de comunicação e interação nas comunidades locais a partir da inserção de mídias digitais? Quais seriam as balizas e guias principais a orientar este redesenho? As questões da conexão, dos suportes sociais para uso das TIC, da produção de conteúdos através da interface assumiriam quais pesos em uma iniciativa que busca estabelecer espaços híbridos? Se necessário, do que poderia se abrir mão, ou o que exatamente seria imprescindível?

Outra questão central, em torno da qual se colocaram questões secundárias, diz respeito às especificidades da experiência de implementação de instâncias virtuais de interação em comunidades 
socialmente vulneráveis e geograficamente referenciadas. Quais seriam estas especificidades? Em que sentido elas se estabelecem e em relação a quais padrões? Comunidades locais com perfis socioeconômicos diferentes requerem ações especialmente desenhadas em função de quais aspectos, da infra-estrutura de conexão e dos equipamentos diferenciados, das habilidades cognitivas, das realidades culturais? Uma preocupação também sempre presente seria os desdobramentos e perspectivas, as oportunidades e desafios que a experiência da comunicação mediada pelas tecnologias digitais instauraria em comunidades locais. Poderia levar a transformações nos planos coletivo e individual? Poderia dispor recursos, se sim, em que nível e amplitude? De que forma? Qual a abrangência possível de se conseguir dentro do universo prático?

Todas estas questões pautaram o desenvolvimento desse trabalho, e inda que não tenham sido respondidas com a exatidão desejada, foram marcos importantes, contribuíram para alavancar a pesquisa em diferentes sentidos, inclusive na formulação de outras questões.

A hipótese principal desta pesquisa é a de que a constituição de espaços híbridos em fragmentos urbanos se dá a partir do entrelaçamento das dimensões concreta e virtual nas maneiras de habitar a cidade, com a ampliação e o adensamento das esferas de comunicação. Sugere-se também que, nas comunidades geograficamente referenciadas, particularmente naquelas em situação de vulnerabilidade social, a implementação de instâncias híbridas de interação tenderia a se aproximar de um caráter transformador de condições sociais, resultando da melhoria na qualidade de vida das pessoas, seja no plano individual ou coletivo.

Partindo-se desses pressupostos, trabalhou-se com alguns objetivos principais: (1) Explorar de que forma e modo as tecnologias de informação e comunicação poderiam ser inseridas em comunidades locais, a partir de diferentes práticas relacionadas à inserção do uso, das possibilidades com TIC, no cotidiano dessas comunidades; (2) Apontar quais são as práticas que tendem a explorar as potencialidades das TIC de forma a poderem resultar em transformações, para a comunidade e os 
indivíduos, e neste sentido, atentar para os possíveis efeitos das TIC em comunidades geograficamente referenciadas; (3) Analisar a amplitude e qualidade de transformação, de desenvolvimento comunitário e fortalecimento de vínculos sociais locais, a partir do adensamento da comunicação a partir das tecnologias digitais em comunidades locais; (4) Determinar as configurações das instâncias virtuais de interação que podem favorecer e potencializar as redes sociais em espaços online; e por fim (5) Explorar a infra-estrutura material e os suportes e instrumentos lógicos e físicos necessários e possíveis para o estabelecimento da comunicação em ambientes virtuais em comunidades locais. A partir desses objetivos foram estabelecidas as estratégias metodológicas da pesquisa, apresentadas a seguir.

\section{Desafios metodologicos: consideraçōes sobre a natureza da pesquisa}

0 presente estudo constitui uma pesquisa qualitativa. Essa abordagem de pesquisa envolve um conjunto de práticas interpretativas e ressalta a relação presumidamente íntima entre pesquisador e objeto de estudo, e as limitações circunstanciais que influenciam a pesquisa (DENZIN; LINCOLN, 2006). É adequada a este estudo dado o seu objetivo de procurar compreender como se dá a conformação de espaços híbridos na escala dos fragmentos urbanos e como se constitui especificamente a experiência de implementação desses espaços - e o modo de alcançá-lo - a partir da observação de uma intervenção em uma comunidade local.

A abordagem de pesquisa adotada merece considerações relacionadas à natureza impermanente das tecnologias, ao caráter interdisciplinar, à adoção de estratégia de pesquisa próxima a uma pesquisaação, travada no âmbito do projeto Comunidades_online: domesticidade e sociabilidade em políticas 
públicas para inclusão digital, e ao método de coleta de dados preponderantemente baseado na observação.

Esta pesquisa esteve intimamente ligada a uma experiência prática desenvolvida no âmbito do projeto Comunidades_online, uma pesquisa financiada pela FAPESP, Fundação de Amparo a Pesquisa do Estado de São Paulo, com o objetivo de formulação de diretrizes para o estabelecimento de políticas públicas. Trata-se de um projeto abrangente que busca implantar uma instância de interação virtual em um determinado fragmento urbano do distrito paulistano de Cidade Tiradentes, e teve interesses específicos na discussão do uso de equipamentos alternativos em relação ao computador tradicional; a re-qualificação dos espaços coletivos de acesso as TIC, com propostas de mudanças no espaço físico e com relação a estruturação de suas atividades; no plano do design de infra-estrutura de redes e de conexões; no projeto e arquitetura de interfaces computacionais para uso comunitário; na renovação de procedimentos metodológicos avaliativos, entre outros. Ainda que dotado de uma instância reflexiva, concentram-se basicamente suas atividades na execução prática. Foi implementado sob a coordenação da equipe de pesquisadores do Nomads.usp, seu principal idealizador, e contou com a participação principalmente do Instituto Pombas Urbanas, organização de interesse público, sediada na Cidade Tiradentes e do NUTAU - Núcleo de Pesquisa em Tecnologia da Arquitetura e Urbanismo da Faculdade de Arquitetura e Urbanismo também da Universidade de São Paulo. 0 projeto Comunidades_online teve início em 2003 e término previsto para meados de 2008, adotando-se o limite de referência nesta pesquisa dos últimos meses de 2007.

0 presente estudo contribui com este projeto maior oferecendo uma parte do embasamento teórico sobre o qual se sustenta, e uma análise da experiência do projeto em si, a partir de alguns recortes, ambos apresentados nesta tese. Ainda que os resultados dessa pesquisa contribuam diretamente para traçar os contornos do horizonte teórico do projeto Comunidades_online, este se configura de forma muito mais extensa do que aparece nesta tese, como se verá no capítulo 4. 
A participação no desenvolvimento deste projeto é o mais significativo instrumento de investigação adotado nesta pesquisa. Possibilitou um meio privilegiado de entender em profundidade a experiência de implementação de espaços híbridos virtual-concreto a partir da inserção da comunicação mediada na vida cotidiana a partir de uma comunidade local. Ao colaborar para a viabilização da experiência em Cidade Tiradentes, construiu-se uma parte importante do próprio objeto de estudo desta pesquisa. Teve-se a ocasião de entender, na prática, a dimensão das ações que investiga no plano teórico, apreendendo alianças, implicações e relações, que perpassam esta tese como um todo.

Outro instrumento importante utilizado nesta pesquisa foi a construção de dois bancos de dados. Um, que reúne um conjunto de informações a respeito de inúmeras iniciativas envolvendo o uso de TIC no âmbito de alguns projetos implantados em comunidades locais, e outro, que buscou coletar e sistematizar informações sobre interfaces computacionais voltadas à interação comunitária. No caso do primeiro, o objetivo foi dar suporte as investigações sobre os contornos das iniciativas dessa natureza, sistematizando inúmeros aspectos de suas configurações. O segundo foi entender o estado da arte da produção destes artefatos, seus principais criadores, princípios e constituições. As informações contidas em ambos os bancos e os estudos que derivaram aparecem indiretamente nesta tese como um todo, mas principalmente nos capítulos 1 e 3 , respectivamente.

Além da construção dos bancos de dados, uma das atividades desta pesquisa qualitativa foi a revisão sobre o tema a partir da literatura, que era, em meados de 2003, bastante restrita. Os principais propósitos dessa atividade são compartilhar os resultados de outros estudos relacionados com a temática do trabalho, vincular o presente estudo ao diálogo em andamento na literatura sobre o assunto, oferecer uma estrutura para estabelecer a importância da pesquisa, assim como uma forma de comparação de resultados com outras conclusões (CRESWELL, 2003). É importante ressaltar que a seleção dos autores que estabelecem a fundamentação teórica deste trabalho privilegiou abordagens amplas, que buscassem relações entre diferentes temáticas da pesquisa. Nas Ciências Sociais, procurou-se por autores envolvidos com questões referenres às tecnologias de informação e 
comunicação, assim como nas matérias mais técnicas buscou-se os aportes daqueles que conseguiam inserir aspectos sociais e culturais no âmbito das suas discussões. Privilegiaram-se também as abordagens vindas do saber artístico, que se mostram, quase sempre, livres da estanqueidade das disciplinas puras.

Gergen e Gergen (2006) argumentam que as transformações tecnológicas observadas neste início de século convidam a rever os conceitos e métodos relacionados à pesquisa. Tradicionalmente, as metodologias estão associadas a um objeto relativamente fixo cuja investigação pode levar anos, desde a coleta dos dados até a publicação dos resultados. No entanto, com o rápido desenvolvimento das tecnologias de informação e comunicação, os valores, as atitudes e as opiniões estão sujeitos a uma rápida oscilação. Para os autores, a relevância temporal de uma pesquisa é cada vez mais circunscrita. Dessa forma, o pesquisador se posicionaria mais como “[...] comentador do contemporâneo em oposição à função de pedreiro do edifício do conhecimento progressivo” (GERGEN; GERGEN, 2006, p.382).

Está tese envolve várias disciplinas. Aram (2004), em seu estudo sobre conceitos de interdisciplinaridade, cita a definição de Klein e Newell (1998, apud ARAM, 2004) ${ }^{6}$, que sumariza um corpo de estudos clássicos sobre interdisciplinaridade. Para esses autores, o estudo interdisciplinar é um processo de responder uma questão, resolver um problema ou abordar um tópico abrangente ou complexo para ser tratado adequadamente por uma única disciplina ou profissão; e que faz uso de perspectivas disciplinares e integra as visões dessas disciplinas através da construção de uma perspectiva mais abrangente. Aram (2004) também identificou várias tipologias para tratar a integração entre disciplinas e observou que essas tipologias compartilham uma variação de pouca a intensa integração do conhecimento, e evidenciam a ausência de uma nomenclatura padrão na área. Por

\footnotetext{
${ }^{6}$ KLEIN, J.T.; NEWELL, W.H. Advancing interdisciplinary studies. In: NEWELL, W.H. (Ed.) (1998). Interdisciplinarity: Essays from the literature. New York: College Entrance Examination Board, p. 3-22.
} 
exemplo, cita o trabalho de Klein (1996, apud ARAM, 2004) ${ }^{7}$ que diferencia entre interdisciplinaridade instrumental, epistemológica e transdisciplinaridade. Para a autora, a interdisciplinaridade instrumental envolve a construção de pontes entre campos; a interdisciplinaridade epistemológica prevê a reestruturação de uma abordagem para definir um campo; e a transdisciplinaridade é um movimento que procura coerência, unidade e simplicidade do conhecimento. Aram (2004) também cita o trabalho de Lattuca (2001 apud ARAM, 2004) ${ }^{8}$ que define quatro tipos de interdisciplinaridade: disciplinaridade informada, que envolve ter contato com outras disciplinas ou ser informado por elas; interdisciplinaridade sintética, que implica um vínculo mais estreito entre disciplinas através de cursos e questões de pesquisa; transdisciplinaridade, que para o autor implica cursos e questões de pesquisa que cruzam disciplinas; e interdisciplinaridade conceitual, que reflete um trabalho intelectual que não tem base disciplinar e localiza-se em novos espaços intelectuais.

Nesta tese percebe-se um projeto interdisciplinar que envolve uma comunicação entre disciplinas e uma troca de conhecimento entre especialistas, próximo ao tipo de interdisciplinaridade denominado disciplinaridade informada definido por Lattuca (2001; apud ARAM, 2004). Por outro lado, considerando que o projeto aqui descrito direciona os recursos intelectuais para problemas do mundo real, pode-se também classificá-lo como transdisciplinar, dado que para alguns autores pesquisados por Aram (2004) a transdisciplinaridade está associada à utilização social do conhecimento.

A adoção de uma abordagem de pesquisa interdisciplinar apresenta alguns desafios. Segundo Fourez, Mathy e Englebert-Lecomte (1997) o sentido de uma abordagem interdisciplinar está no seu relacionamento com um projeto: seu propósito é produzir uma representação teórica adaptada a uma situação específica e em relação a um projeto definido. 0 projeto, assim como as decisões relacionadas

\footnotetext{
${ }^{7}$ KLEIN, J.T. (1996). Crossing boundaries: Knowledge, disciplinarities, and interdisciplinarities. Charlottsville: The University of Virginia Press.

${ }^{8}$ LATTUCA, L.R. (2001). Creating interdisciplinary: Interdisciplinary research and teaching among college and university faculty. Nashville, TN: Vanderbilt University Press.
} 
a ele, provê a estrutura da abordagem interdisciplinar, delimitando a pesquisa. Como mencionado anteriormente, esta tese é parte de um projeto interdisciplinar e sua contribuição está na inclusão de perspectivas da Arquitetura no grupo das disciplinas que compõem a representação teórica de análise do objeto. As principais disciplinas seriam aquelas que se voltam aos estudos de comunidades e redes sociais, ao desenvolvimento, construção e avaliação de ambientes de interação virtuais, e ainda aquelas voltadas ao estudo da implantação de projetos e ações em comunidades locais. Representou um desafio para essa tese permanecer nos limites definidos pelo projeto interdisciplinar. Em determinados momentos do desenvolvimento do trabalho, observou-se que outros aspectos poderiam ser aprofundados - como, por exemplo, a constituição das redes sociais -, porém o escopo do projeto interdisciplinar não comportava tal análise. Algumas dessas questões estão mencionadas nos tópicos finais que, entre outros, discorre sobre estudos futuros.

A estratégia adotada neste estudo aproxima-se de modo significativo da pesquisa-ação adotada no âmbito do projeto Comunidades_online, e ainda encontra elementos de estudo de caso e de etnografia. A intervenção em Cidades Tiradentes pode ser considerada um estudo de caso instrumental, segundo a visão de Stake (2000), dado que um caso particular é explorado visando investigar o tema da pesquisa; o caso tem um papel de suporte e facilita a compreensão do fenômeno estudado. No que se refere a etnografia, argumenta-se que existem diversas tradições etnográficas, porém essas perspectivas compartilham características comuns como, por exemplo, o comprometimento com a experiência direta (observação) e a exploração de locais e contextos - sociais e culturais - particulares, através da observação participante (ATKINSON et al., 2001), método adotado nesta pesquisa.

A pesquisa-ação envolve processos colaborativos de geração e de aplicação do conhecimento do pesquisador como participante em projetos de mudança social, ignora fronteiras entre disciplinas e defende a troca entre o meio acadêmico e a sociedade (GREENWOOD; LEVIN, 2006). Thiollent resume do seguinte modo os principais aspectos da pesquisa-ação: 
[...] a) há uma ampla e explícita interação entre pesquisadores e pessoas implicadas na situação investigada; b) dessa interação resulta a ordem de prioridade dos problemas a serem pesquisados e das soluções a serem encaminhadas sob forma de ação concreta; c) o objeto de investigação não é constituído pelas pessoas e sim pela situação social e pelos problemas de diferentes naturezas encontrados nesta situação; d) o objetivo da pesquisa-ação consiste em resolver ou, pelo menos, em esclarecer os problemas da situação observada; e) há, durante o processo, um acompanhamento das decisões, das ações e de toda a atividade intencional dos atores da situação; f) a pesquisa não se limita a uma forma de ação (risco de ativismo): pretende-se aumentar o conhecimento dos pesquisadores e o conhecimento ou o 'nível de consciência' das pessoas e grupos considerados (THIOLLENT, 2000, p.16).

Além disso, para Thiollent (2000), a pesquisa-ação opera a partir de determinadas instruções, ou diretrizes, ou quase-hipóteses, com relação à situação investigada e aos modos de ação. Tais instruções possuem um caráter menos rígido que hipóteses, porém desempenham função semelhante; isto é, com os resultados da pesquisa, essas instruções podem fortalecer-se ou serem alteradas, abandonadas ou substituídas. Com relação ao alcance das transformações de uma pesquisa-ação, esse autor alerta para a dificuldade de definição da noção de transformação e esclarece que "[...] quando se consegue mudar algo dentro das delimitações de um campo de atuação de algumas dezenas ou centenas de pessoas, tais mudanças são necessariamente limitadas pela permanência do sistema social como um todo, ou da situação geral" (THIOLLENT, 2000, p.43).

Ainda é relevante citar algumas regras associadas a aspectos éticos de uma pesquisa-ação, segundo Thiollent (2000), tais como: todos os interessados na situação ou nos problemas investigados devem ser consultados - não se pode conduzir a pesquisa à revelia de uma das partes; cada parte tem o direito de interromper a pesquisa quando sentir que os objetivos acordados não são respeitados; a avaliação dos resultados é efetuada pelos participantes e pelos pesquisadores; e os resultados são difundidos sem restrição. Para Foth (2006b), a natureza da pesquisa-ação - local, flexível e orientada à prática - 
posiciona-a como uma estratégia de pesquisa privilegiada em estudos envolvendo pessoas, lugares e tecnologia.

A adoção do método de observação para a coleta de dados merece também considerações. A observação é um método de coleta de dados apropriado no caso de várias estratégias, como, por exemplo, a fenomenologia, a etnometodologia e a etnografia. Tem sua origem no trabalho etnográfico de estudo de sociedades pequenas, relativamente homogêneas, na qual o pesquisador vive por um longo período de tempo, aprendendo a linguagem local, participando da vida cotidiana e observando atentamente. Alguns autores classificam a observação, segundo o papel do observador, em dois extremos: participante e não-participante. Outros autores consideram uma tipologia mais detalhada que prevê as possibilidades de atuação: observador completo, observador como participante, participante como observador e participante completo. Porém, além dessas classificações outras variações podem ser observadas. Por exemplo, (a) se aqueles que são estudados - todos, alguns ou nenhum - foram informados do papel do pesquisador como pesquisador; (b) quanto e o que conhecem da pesquisa; (c) que tipo de atividades o pesquisador realiza em campo e como os participantes classificam essas atividades; e (d) qual a orientação do pesquisador, seja imerso ou não no contexto investigado, como “um nativo” ou alguém “de fora” (ATKINSON; HAMMERSLEY, 1994).

A observação desenvolvida nesta tese está distante daquela prevista no trabalho etnográfico. Pode-se dizer que o papel do pesquisador na implementação da intervenção em Cidade Tiradentes foi de um observador como participante, isto é, de um observador que foi além do papel de espectador, interagiu com os membros da comunidade, mas o fez de modo pontual. Além disso, pode-se afirmar que os participantes conheceram o pesquisador como pesquisador, foram informados da pesquisa, consideraram as atividades do pesquisador como compondo o projeto e contribuindo com o seu resultado, e o pesquisador não teve a intenção de "tornar-se um nativo". Com relação ao projeto Comunidades_online em si, como foco de análise, pode-se dizer que o papel do pesquisador foi de um participante como observador, isto é, pesquisador alocado no projeto, portanto, alguém “de dentro", 
porém também observando o seu desenrolar. Além disso, pode-se afirmar que no caso da análise do projeto em si, não se definiu claramente, para aqueles participantes do projeto, que o próprio projeto seria foco da análise do pesquisador desta tese. 0 papel de participante como observador apresenta o desafio para o pesquisador de executar duas atividades ao mesmo tempo: participar e observar, com o risco de envolver-se demasiadamente com o projeto e com seus participantes, não conseguindo a distância necessária para a observação.

\section{Estrutura do trabalho}

Nesta introdução, busca-se delinear o pano de fundo sobre o qual o trabalho deve ser lido, apresentando algumas delimitações conceituais. Apresenta os problemas da pesquisa, suas hipóteses e objetivos. Tratam-se também as questões metodológicas.

O capítulo 1 leva a incursão acurada no universo das iniciativas envolvendo o uso das tecnologias de informação e comunicação, buscando apropriar-se das inúmeras dimensões que estas intervenções possuem, esmiuçando suas naturezas, abrangências e implicações. Busca-se apreender as diferentes ações que buscam enlaçar as tecnologias de informação e comunicação e vida cotidiana, e verificar como estas tecnologias podem ser inseridas em comunidades geograficamente referenciadas. 0 entendimento das dimensões das iniciativas envolvendo TIC por meio de categorias analíticas aqui estabelecidas leva à compreensão das diferentes acepções da chamada inclusão digital, também discutida neste capítulo. 
No capítulo 2 investiga-se a natureza da comunidade na contemporaneidade, considerando os aportes teóricos das Ciências Sociais que buscam estabelecer as bases para o entendimento da comunidade também a partir da introdução das tecnologias de informação e comunicação na vida cotidiana. Apresentam-se alguns conceitos e abordagens relacionados a parâmetros de desenvolvimento comunitário, amplamente utilizados e aceitos, que servem de referências para delimitações de padrões de condições e qualidade de vida em comunidades locais, e ainda algumas abordagens metodológicas relacionadas a propósitos de mobilização de recursos. Averiguam-se então suas relações com a introdução das TIC, principalmente através do estabelecimento de instâncias virtuais de comunicação e interação em comunidades locais, no âmbito de alguns projetos.

O capítulo 3 trata das interfaces computacionais de interação comunitária. Volta-se aos requisitos tecnológicos, lógicos e físicos, necessários para dar suporte às relações sociais nos ambientes virtuais de interação. Discorre sobre as principais questões que envolvem hoje tecnologias computacionais e digitais, e investiga a colaboratividade, dando destaque às ações de produção de conteúdo. Aborda os paradigmas de interação e os conceitos de interface. Apresenta um panorama de como está estruturada e pensada hoje a comunicação e interação no universo das mídias digitais através de uma diversidade de caminhos possíveis. Faz referências também a projetos e interfaces exemplares cujas informações estão dispostas em pequenos boxes inseridos no texto.

O capítulo 4 aborda especificamente o projeto Comunidades_online. Concentra as análises sobre a concepção, desenvolvimento, implantação e resultados da experiência em Cidade Tiradentes, a partir dos recortes temáticos e aportes teóricos apresentados nos capítulos anteriores. Trata-se da elaboração de um exame crítico, de amplas reflexões sobre esta iniciativa, incluindo grande parte do seu percurso, tendo como referência o horizonte teórico desenvolvido nas diferentes etapas da pesquisa. 
As conclusões apresentam as considerações gerais sobre o trabalho, avalia seus resultados, as a luz das hipóteses estabelecidas, procuram apontar limitações e caminhos futuros. 


\section{AS DIMENSÕES DAS INCLATIVAS QUEE \\ ENVOLVEM TIC}
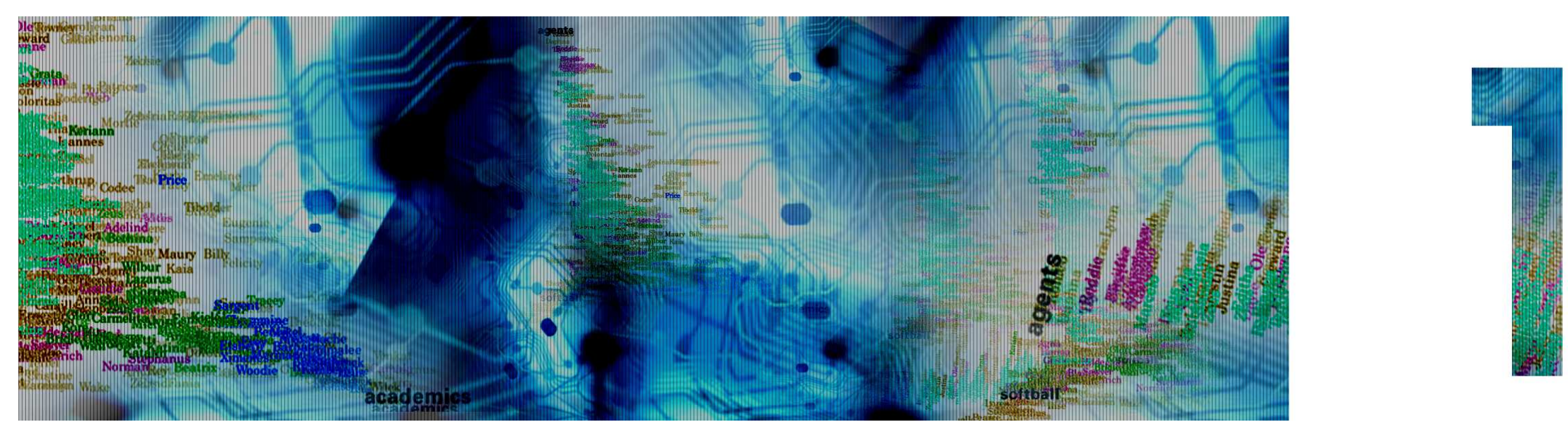
Os projetos e programas que visam a integração do uso das tecnologias de informação e comunicação na vida cotidiana, em particular das pessoas pertencentes às camadas empobrecidas e marginalizadas da sociedade, são cada vez mais abundantes em todo o mundo, assim como são também os esforços em inventariá-los, analisá-los e promovê-los. De modo geral, tais projetos possuem objetivos e finalidades distintas, decorrem de iniciativas por parte de agentes com diferentes atuações, envolvem e sobrepõem governos, organizações da sociedade civil, instituições acadêmicas e organizações privadas. Com amplitudes muito variadas, esses projetos se dão no âmbito de ações consideradas favorecedoras da chamada inclusão digital, e não raro também estão associados a promoção de capital social, e a práticas mais extensas de inclusão social. Buscam promover, ainda que com interesses variados, a pertinência e adequação das TIC ao cotidiano das pessoas e grupos, tendo como parâmetro transformar os potenciais e benesses dessas tecnologias em melhoria na qualidade de vida. Frente a esta multiplicidade, o exame desses projetos pressupõe a construção de universos analíticos complexos. A elaboração de modelos avaliativos, assim como a definição de parâmetros de aferição de resultados, têm sido objetos de investigação de alguns poucos autores preocupados e empenhados em apreender a natureza dos projetos envolvendo o uso tecnologias digitais, e também direcionados, muitas vezes, a estabelecer diretrizes para ações futuras. Este capítulo leva a incursão mais acurada nesse universo, buscando mais que explorá-lo. 0 objetivo é apropriar-se das inúmeras dimensões que as intervenções envolvendo TIC possuem, esmiuçando suas naturezas, abrangências e implicações. Busca-se apreender as diferentes ações que enlaçam as tecnologias de informação e comunicação e vida cotidiana, e verificar como, de que forma, estas tecnologias podem ser inseridas em comunidades geograficamente referenciadas. A ênfase são as comunidades cuja maioria das pessoas, por razões diversas, não têm acesso a estas tecnologias, são impossibilitadas de se apropriarem delas de forma plena e de torná-las significativas às suas realidades.

Estrutura-se aqui as diversas dimensões de projetos envolvendo o uso das TIC a partir de uma reflexão sobre a chamada inclusão digital, um conceito passível de muitas controvérsias, e da determinação de algumas categorias de análise, que têm como panorama um conjunto de iniciativas inventariadas e 
estudadas ao longo dessa pesquisa. O entendimento das dimensões das iniciativas TIC por meio das categorias analíticas leva ao entendimento das diferentes acepções da chamada inclusão digital, sendo que o contrário, neste caso, é também verdadeiro. É importante sublinhar que só foi possível a apreensão da complexidade de iniciativas desta natureza, ou o entendimento de suas dimensões, pela realização de um estudo detalhado da constituição de um conjunto dessas iniciativas.

Assim, o propósito do estabelecimento dessas categorias não é delinear uma metodologia, que poderia implicar na formulação precisa de tipologias de projetos que envolvem o uso das TIC, na qual deveriam estar especificadas, em detalhes, as possibilidades de intervenções desta natureza. Trata-se do estabelecimento de parâmetros de análise, decorrentes da decomposição e classificação dos principais elementos constituintes destas iniciativas, formulados a partir, primeiro, da elaboração de informações resultantes de revisão bibliográfica, segundo, de informações e dados a respeito de iniciativas envolvendo TIC sistematizados em um banco de dados, já citado, e por fim, da participação no projeto Comunidades-online: domesticidade e sociabilidade em políticas públicas para inclusão digital. Propõese, assim, o exame de vários elementos dessas iniciativas fundamentados sob estas três bases, que por sua vez, emergiram dessa busca por compreender suas naturezas e dimensões.

Neste sentido, a categorização analítica proposta aqui é um recurso metodológico, e por sua vez, não pode, nem deve, ser considerada estanque. Estas categorias explicitam as questões que se mostraram proeminentes no contexto desta pesquisa, que se apresentaram, principalmente, no desenvolvimento da experiência em Cidade Tiradentes, e também em outros projetos já implantados, e são portanto, um recorte dentre outros possíveis. Quando necessário, faz-se referência a assuntos relevantes, apresentados à observação, sem necessariamente vincular-se a esta ou aquela experiência concreta. Assim, pode-se dizer que esta categorização abarca não somente discussões restritas ao universo prático, mas como um exercício, envolve também reflexões. É importante dizer que alguns conceitos que aparecem aqui sem um devido aprofundamento, como por exemplo, capital social e interface, serão tratados mais à frente, nos capítulos seguintes. 
São citadas especificamente neste capítulo as seguintes iniciativas: Acessa São Paulo; Blacksburg Electronic Village; Camfield Estate - MIT Creating Community Connections Project; Casa Brasil; GESAC; Helsinki Virtual Village; Information Technology Initiative; Les Courtillières de Pantin; Making Healthy MUSIC; Novos Centros de Conhecimento; NetVille; OLPC; Piraí Digital; Plurall; Projeto Cidadão Conectado; SARI; Solonópole; Sud Mennucci; The HomeNet Project; VAN Bohechio e Viva Favela. Tais iniciativas são apresentadas à medida que são citadas, entretanto, um conjunto resumido de informações complementares referentes a cada uma delas está alocado no Apêndice $A$ desta tese. ${ }^{1}$

Também estão alocadas neste apêndice as referências mais significativas utilizadas para estudo de cada uma destas iniciativas. 


\subsection{Abrangências da chamada inclusão digital}

As iniciativas que envolvem o uso das TIC assumem grande evidência, no momento atual, porque estão diretamente relacionadas a uma nova forma de desigualdade que se soma àquelas a que estão sujeitas parcelas significativas da população, seja nos países ricos, seja nos pobres, seja nos países em desenvolvimento. A grande maioria delas nasce, declaradamente, como tentativa ou recurso para amenizar, ou reverter, as diferenças existentes entre as pessoas e grupos com relação ao acesso, uso e apropriação plena dessas tecnologias, e também buscando favorecer àqueles desprovidos de condições de realizá-los com recursos próprios, sejam materiais, intelectuais, cognitivos, sociais, entre outros. Neste sentido, pode-se dizer que estas iniciativas se dão no âmbito das ações de inclusão digital, cuja definição não é simples, e muito menos consensual.

No campo das Ciências Sociais, puras e aplicadas, são múltiplas e abrangentes as conceituações em torno da inclusão digital, e da questão de que esta possui estreitas relações com o amplo universo da inclusão social. E isso vale, da mesma forma, para a definição de seus pares opostos, exclusão digital ${ }^{2}$ e exclusão social. Agências de desenvolvimento e instituições governamentais, promotores e ativistas sociais, pesquisadores acadêmicos, assessores técnicos, entre outros, também se esforçam em discussões que visam delimitar e definir tais termos e relações, justamente por se conceber que ambos estão intimamente associados à natureza das transformações vivenciadas no mundo contemporâneo, e mais precisamente, ao complexo e persistente problema da pobreza. Entretanto, no geral, adotam-se esses termos de forma indiscriminada nos mais diferentes meios, sem defini-los de forma apurada, reunindo em torno deles, algumas vezes, idéias distintas, e diferentes posturas ideológicas.

\footnotetext{
${ }^{2}$ É comum para este termo o uso das locuções em inglês digital divide, digital gap e technology gap, e brecha digital em espanhol e em português. Neste trabalho traduz-se digital divide como exclusão digital, como é comum às publicações vertidas para o português. Há, entretanto, quem adote as expressões divisão digital ou mesmo brecha digital.
} 
Nos meios onde prevalece o senso comum, e mesmo na maioria das instâncias especializadas, têm-se usado as expressões inclusão / exclusão digital para elucidar as disparidades entre as pessoas, grupos e territorialidades em termos de acesso as tecnologias de informação e comunicação. Enquanto alguns ignoram as qualidades do que seria esse acesso, outros se referem precisamente a lacuna, a separação, existente entre aqueles que têm e os que não têm acesso físico e material a computadores e a internet. É sabido, porém, que a problemática que circunda a promoção da inclusão digital ou combate à exclusão digital é ampla, e abarca muito mais que a universalização do acesso físico e material a hardware e software, a conexão à internet e a alfabetização tecnológica. Sabe-se também que a ênfase exclusiva a esta forma de acesso já se mostrou bastante ineficiente como estratégia única para favorecer a apropriação plena das TIC, independente do contexto (MOSSBERGER; TOLBERT; STANBURY, 2003; SERVON, 2002; WARSCHAUER, 2006). Sabe-se, inclusive, que se trata de um fenômeno de várias dimensões, que deveria ser formulado a partir de diferentes proposições.

Hoje há um consenso no entendimento de que as iniciativas vinculadas a propósitos de inclusão digital pressupõem outros fatores, que associados, permitem ultrapassar as barreiras da falta de recursos materiais e mesmo da alfabetização digital e caminhar no sentido da apropriação das TIC para fins mais significativos, como por exemplo, para auxiliar e dar suporte à resolução de problemas sociais mais amplos. É neste contexto que exclusão digital e exclusão social se tocam, quando se sobrepõe o primeiro a um sistema social complexo que relaciona indivíduos, grupos e comunidades a uma variedade de instâncias da vida cotidiana como trabalho, direitos e cidadania, saúde, educação, cultura, moradia, lazer, entre outros. A exclusão digital não é algo isolado, que se sanada trará de forma determinada resultados positivos pragmáticos, é sim parte de um contexto político e social amplo, que relaciona as possíveis benesses das TIC no combate a processos de exclusão social.

Por sua vez, a idéia de exclusão social está intimamente relacionada aos problemas da pobreza, isto é, aos mecanismos que criam, preservam ou agravam a pobreza; compreende complexas situações de privação de diferentes ordens, mas, principalmente, econômica e social. Frente aos inúmeros dissensos 
que o termo exclusão social abarca há um consenso: trata-se de um conceito multifacetado e multidimensional. "[...] o conceito traz implícita a problemática da desigualdade, já que os excluídos só o são pelo fato de estarem privados de algo que outros (os incluídos) usufruem" (REIS; SCHWARTZMAN, 2002). Para estes autores:

O conceito de exclusão é portanto inseparável do de cidadania, que se refere aos direitos que as pessoas têm de participar da sociedade e usufruir certos benefícios considerados essenciais. A literatura costuma distinguir três tipos de direito - os direitos civis, políticos e sociais. [...] Os direitos sociais, finalmente, são direitos ao acesso a um conjunto de bens e serviços considerados indispensáveis para a vida digna e para a convivência social - o direito à educação, à saúde, ao trabalho, a um salário decente, à proteção em situações de doença e velhice, e assim por diante (REIS; SCHWARTZMAN, 2002).

Segundo Nascimento (1994), o conceito sociológico de exclusão social refere-se sempre a um processo social de não reconhecimento do outro, dos seus direitos. Tal conceito possui três acepções. Uma primeira que se aproximaria das discriminações de qualquer ordem, e neste contexto, estariam os grupos sociais sujeitos a formas particulares de socialização, ainda que não formalmente excluídos de direitos, entre eles, negros, homossexuais, delinqüentes. Uma segunda acepção estaria relacionada a exclusão de direitos, e neste sentido se aproxima da definição de Reis e Schwartzman: "São grupos sociais que não têm uma integração no mundo do trabalho, não possuindo, em decorrência, condições mínimas de vida. Por vezes, esta não integração produz efeitos de não inserção social. Paugan irá denominá-los de 'desfavorecidos' (1993), enquanto Castels irá chamá-los de 'desfiliados'(1991)”3 (NASCIMENTO,1994). Por último, a acepção denominada nova exclusão, que diz respeito à situação em que o não reconhecimento ultrapassa a recusa ao direito para determinados grupos sociais, instaurando a negação, o não ao direito a ter direito. Tratam-se, segundo o autor, daqueles que não são

\footnotetext{
${ }^{3}$ PAUGAN, S. (1993). La disqualification sociale: essai sur la nouvelle pauvreté. 2.ed. Paris: PUF., e CASTELS, R. (1991). L'indigence à L'exclusion la désaffiliation. Precaríté du travail et vulnerabilité relationelle. In: DONZELOT; R. Face à l'exclusion: le modéle français [s.I.], Esprit.
} 
reconhecidos como semelhantes, dos que estão sujeitos a uma tendência de forças que tenta expulsálos da sociedade. Nascimento (1994) ressalta: “embora relacionados, e por vezes de forma muito estreita, os três conceitos podem ser trabalhados separadamente, possuindo uma relativa autonomia, que se estreita ou se amplia segundo o caso em estudo." A exclusão social é, portanto, um fenômeno que embora diretamente relacionado a desigualdade social, a distribuição de riqueza, a pobreza, transcende-as. É importante salientar que o uso do conceito exclusão também é criticado no âmbito da sociologia, principalmente quando pressupõe, no limite, que o ideal seria a integração dos chamados excluídos à sociedade de consumo. "Em outras palavras, valorizando a sociedade existente, o que se demanda não é a transformação da ordem social, mas, antes e tão somente, a reafirmação dela" (NEUHOLD , 2004). ${ }^{4}$

Silveira (2001, p.18) destaca que “[...] não é correto classificar a exclusão digital como mera conseqüência da exclusão social. [...] a exclusão digital impede que se reduza a exclusão social, uma vez que as principais atividades econômicas, governamentais e boa parte da produção cultural da sociedade vão migrando para a rede, sendo praticadas e divulgadas por meio da comunicação informacional." Warschauer (2006) reconhece o valor histórico do conceito de exclusão digital, porém considera-o datado e superficial, ligado a uma idéia equivocada de existência de uma linha divisória entre duas realidades, uma antiga e uma nova, fonte de prosperidade. 0 autor prefere situar a exclusão digital em termos de interseção entre TIC e inclusão social.

A mudança de foco da exclusão digital para a inclusão social baseia-se em três premissas principais: 1) a nova economia da informação e a nova sociedade de rede emergiram; 2) a TIC desempenha um papel decisivo em todos os aspectos dessa nova economia e nova sociedade; e 3) o acesso à TIC, definido de

${ }^{4}$ Desde a década de 1970, discute-se, sistematicamente, em âmbito internacional, a noção de exclusão e exclusão social, sendo demasiado extenso o rol dos autores que tratam o assunto. Não cabe aqui estabelecer uma discussão acurada a respeito, apenas delimitar, ainda que superficialmente, alguns pontos a respeito desta noção. 
modo amplo, pode ajudar a determinar a diferença entre marginalização e inclusão nessa nova era socioeconômica (WARSCHAUER, 2006, p.31).

Neste sentido, é pertinente considerar que nos dias de hoje, promover o acesso pleno as TIC faz parte das premissas e ações bem sucedidas de inclusão social, de políticas sociais orientadas ao combate à exclusão. $O$ que interessa é pensar as TIC como favorecedoras de processos amplos de transformação, nos planos individual e coletivo, e não simplesmente como ferramentas tecnológicas. É consenso entre os autores que tratam da questão que as práticas circunscritas neste contexto são complexas e contém aspectos múltiplos que devem ser considerados em conjunto.

Assim, alterar a concepção do que venha a ser inclusão e exclusão digital, através de redefinições para os próprios termos, ainda muito atrelados aos recursos físicos, parece ser um caminho que poder levar a criação de soluções práticas apropriadas e satisfatórias, além de propiciar análises mais consistentes. Não é de se espantar que Mossberger, Tolbert e Stanbury (2003) e Servon (2002) tenham destinado o primeiro capítulo de seus livros a este tópico. Outros autores também argumentam que uma das principais limitações dos projetos ligados ao uso das TIC estaria associada ao próprio entendimento do que seria a exclusão digital. Concepções parciais gerariam projetos e ações parciais. Warschauer (2006) ressalta que, em todo o mundo, cada vez mais problemas ocorrem em projetos de tecnologias centrados apenas no oferecimento de hardware e software, frutos também dessa visão estreita atrelada à retórica da exclusão digital. Para o autor, o enfrentamento da exclusão digital passa pela atenção aos recursos humanos e sociais, pelas questões de conteúdo e linguagem, de alfabetização e educação, e pelas estruturas institucionais e comunitárias. Servon (2002) ainda alerta que em função das disparidades tecnológicas serem definidas de forma limitada, como uma questão de acesso físico, políticas e programas têm também sido limitadamente focados. Embora, cada vez mais, se reconheça que iniciativas de inclusão digital abarcam outros recursos, além do acesso físico, relacionados a adequação de conteúdos e linguagens, a treinamentos e habilitação, e mesmo a decisões de gestão de recursos em telecomunicações, entre outros, muitas iniciativas ainda não conseguem caminhar em 
outros sentidos. Servon, ao analisar políticas e programas públicos norte-americanos filiados à inclusão digital, ressalta:

As políticas de exclusão digital podem ser divididas em duas categorias. Uma categoria consiste de programas explicitamente endereçados a este problema [foco no acesso] e que são desenhados para minorá-lo. A outra consiste de programas em que alguns recursos distribuídos são flexíveis, isto é, o estado e/ou instâncias públicas locais têm alguma voz a respeito de como usar estes recursos $^{5}$ (SERVON, 2002, p.77).

Quanto aos primeiros, ressalta que têm enfatizado na questão do acesso sem dar suporte adequado a treinamentos e provisão de conteúdos (SERVON, 2002).

Sorj (2003) procura definir as dimensões da exclusão digital a partir de cinco fatores, referindo-se aos dois primeiros como fatores passivos de acesso e aos três últimos como de apropriação ativa:

1) a existência de infra-estruturas físicas de transmissão; 2) a disponibilidade de equipamento / conexão de acesso (computador, modem, linha de acesso); 3) o treinamento no uso dos instrumentos do computador e da Internet; 4) a capacitação intelectual e inserção social do usuário, produto da profissão, do nível educacional e intelectual e de sua rede social, que determina o aproveitamento efetivo da informação e das necessidades de comunicação pela Internet; 5) a produção e uso de conteúdos específicos adequado às necessidade dos diversos segmentos da população (SORJ, 2003, p.63).

O autor destaca que a distinção destes níveis é fundamental para desenvolver metodologias de atuação

e avaliação no campo do combate a exclusão digital, sublinhando que os programas públicos geralmente estão voltados aos fatores de dimensões passivas.

\footnotetext{
${ }^{5}$ Tradução da autora. No original: "Digital divide policy can be divided into two categories. One category consists of programs that explicitly address this problem [access-focused] and are designed to alleviate it. The other consist of program in which some of the funding allocated is flexible; that is, state and / or local officials have some say regarding how they use these funds."
} 
DiMaggio e Hargittai (2001) criticam os paradigmas que têm guiado as pesquisas e políticas inclusivas centradas tanto na visão binária da desigualdade implícita na noção de exclusão digital, como na visão de que para entender desigualdade de acesso é suficiente focar em recursos individuais e de comportamento. Para os referidos autores, que preferem usar o termo desigualdade digital à exclusão digital $^{6}$, a internet é transformada constantemente por outros fatores que modelam padrões de acesso e desigualdades, entre eles, as ideologias das ferramentas de busca da web, as escolhas estratégicas de corporações, as respostas individuais a estas escolhas, as decisões de programadores sobre códigos, os regulamentos governamentais. Neste sentido, seria essencial conhecer esta dinâmica para entender a desigualdade digital. DiMaggio e Hargittai (2001) acreditam que com o aumento da penetração da internet no contexto norte-americano, tem-se reduzido as desigualdades de acesso, e tem-se dado ênfase a outros tipos de desigualdades, como a entre os próprios usuários da internet. Ou seja, estariam em evidência estratificações quanto a qualidade de uso, ou seja, desigualdades relacionadas a extensão e medida da capacidade dos usuários em colher os benefícios do uso das tecnologias digitais. Os autores destacam cinco formas de desigualdades: [1] em termos de meios técnicos de acesso a internet (hardware, software e conexões); [2] em termos de alcance no exercício de autonomia no uso da web (acesso de casa ou trabalho, uso monitorado ou não, uso limitado de tempo); [3] em termos de habilidade no uso da internet; [4] em termos de suporte social e [5] em termos de propósitos de uso da tecnologia.

Embora Silveira (2001, p.33) destaque que "o acesso à informática e aos computadores é o primeiro passo da inclusão digital", alerta para o fato de que "o combate à exclusão não se resume ao ensino popular da informática ou a cursos rápidos de montagem de computadores; [...] o manuseio, a elaboração e a compreensão dos softwares são instrumentos primários [...]” (SILVEIRA, 2001, p.28). Para uma ampla política de inclusão e alfabetização tecnológica distingue oito pontos, que incluem questões de aprendizagem, de geração de conhecimento e práticas cooperativas. 0 autor também

\footnotetext{
${ }^{6}$ Em inglês digital inequality e digital divide.
} 
destaca, em outro momento, que as comunidades territoriais socialmente excluídas podem se apropriar das TIC a partir de três tipos de ações. [1] Ações de acesso: realizadas em telecentros e infocentros, nas quais as tecnologias estão direcionadas para a educação formal, a profissionalização, ao acesso a serviços públicos e/ou privados, ao entretenimento. 0 uso da tecnologia está ligado ao dia-a-dia da comunidade, e o telecentro cumpre papel importante na integração comunitária. Trata-se de fase em que a comunidade usa a tecnologia para acesso a internet. [2] Ações de provimento: são ações mais avançadas, onde a comunidade coloca sua produção na rede, ou seja, há produção simbólica [cultura] local para a rede; faz-se comércio eletrônico; há organização e venda de serviços locais, entre outros. [3] Ações de interações complexas: são ações abrangentes de desenvolvimento de códigos e produtos compartilhados; as pessoas da comunidade colaboram com projetos em rede em dimensões extraregionais e as comunidades participam de redes de interesses comunitários (SILVEIRA, 2005b).

As discussões acima apresentam um pequeno recorte dentro do universo teórico voltado as questões da inclusão / exclusão digital. Entretanto parece que estas discussões fazem mais sentido quando associadas ao campo dos seus possíveis desdobramentos práticos. Trata-se de uma área que envolve muitos conceitos, que são utilizados operacionalmente nas iniciativas ligadas ao uso das TIC sob a forma dos programas de inclusão social, com recortes específicos. São políticas públicas, ou práticas de organizações privadas ou de agências de desenvolvimento, que assumem formatos muito variados, derivando um conjunto de ações bastante heterogêneo. Santos (2006) alerta para o caráter relacional entre discurso e prática no campo da inclusão / exclusão digital chamando atenção para algumas incoerências, entre elas o fato de alguns autores que defendem veementemente uma perspectiva mais crítica e emancipadora deixarem transparecer, às vezes, uma visão instrumentalista: “Apesar da abertura de foco em seus discursos, a maioria dos autores, ao se debruçarem sobre o projeto de operacionalização da inclusão digital, rende-se ao pensamento instrumental e produz projetos muito pobres de intervenção" (SANTOS, 2006, p.126). 
É importante destacar que, à parte os esforços em definir conceitualmente o que é a exclusão / inclusão digital, permanece o imbróglio. Parece não ser ainda possível uma definição precisa e fechada a respeito do que abarca a expressão inclusão digital. Diferentes autores procuram delimitá-la na medida que desenvolvem seus raciocínios em torno do fenômeno que abrange as desigualdades em torno das TIC. A significação estrita do conceito inclusão digital parece se manter em aberto, esperando talvez que as ações empíricas possam também, de alguma forma, alimentar a compreensão e apreensão de alguns aspectos ainda bastante difusos neste universo. Por exemplo, o que estaria especificamente e concretamente para além do acesso físico? A própria inadequação semântica da expressão inclusão digital em relação ao objeto que representa causa um certo desconforto. 0 termo digital, cuja primeira acepção remete aos valores binários que representam as informações nos computadores e sistemas de comunicação, parece inadequado e restritivo como adjetivo qualitativo de inclusão. Entretanto o uso corrente e estabelecido em diferentes contextos parece indicar que tal expressão, embora algumas vezes posta em questão, cumpre ainda seu papel.

A inclusão digital nesta pesquisa é entendida como um processo contínuo de tornar as tecnologias de informação e comunicação portadoras de sentido, de razão de ser, para uma pessoa, grupo ou comunidade local. Está ligada ao universo da inclusão social, no sentido de objetivar um caráter transformador para as instâncias pessoal e coletiva, especialmente com relação a construção de autonomia, a formação de um espírito crítico, de possibilidade de re-interpretação de si e do contexto circundante. Acredita-se que a inclusão digital começa quando as TIC passam a ser significativas para as pessoas e comunidades, quando passam a fazer parte das suas narrativas. Neste sentido, as práticas, ações e iniciativas ligadas ao uso das TIC podem ou não estar relacionadas à inclusão digital, na medida em que cumprem ou não estes pressupostos. Porém, parece difícil delimitar precisamente quando começa e termina um processo inclusivo, um indicador positivo parece ser o momento a partir do qual as pessoas ou comunidades conseguem caminhar sozinhas pelo universo das TIC, agregando-as naturalmente às suas práticas cotidianas. Nesta perspectiva, a inclusão digital não está relacionada, necessariamente, só aos iletrados digitalmente, ou àqueles que não têm acesso físico e material a 
equipamentos informatizados ou conexão à internet, como se faz crer muitas vezes. Inclui, sim, àqueles que são impossibilitados de usufruir plenamente das potencialidades que as TIC abarcam. Entretanto seria ingênuo descartar que para que esta perspectiva se concretize, pressupõe-se que meios estejam disponíveis, sejam físicos ou cognitivos. Santos (2006) apresenta uma visão semelhante quando fala a respeito da inclusão digital agregada a determinados programas de grande amplitude:

A Inclusão Digital 'ampliada' ou 'autonomista' leva à idéia de uso instrumental das TIC por um sujeito que age com objetivos autônomos, superando objetivos utilitaristas, para incorporar o fator 'finalidade'. Trata-se de uma visão libertária, isto é, universalizar o uso dos recursos das TIC para alavancar a aprendizagem contínua e autônoma, fomentar o exercício da cidadania, dar voz aos setores e comunidades que normalmente não têm acesso à grande mídia. A inclusão digital articula-se com outras questões críticas, como a capacitação para o exercício da cidadania ativa e a inserção do sujeito na esfera pública como interlocutor e não apenas como receptor e/ou 'sujeito de direitos' (SANTOS, 2006, p.206).

Ainda que não seja objetivo deste estudo levar a exaustão o tema da inclusão / exclusão digital faz-se relevante pontuar outros aspectos importantes neste contexto: a questão dos telecentros, da dimensão quantitativa da chamada exclusão digital, e a questão fundamental dos software com códigos-fonte abertos, livres de restrição proprietária. Este último tratado mais adiante.

Os programas de implantação de telecentros é uma das ações mais conhecidas e importantes voltadas ao universo da inclusão digital, que possui vertentes em vários países, com diferentes características e diretrizes. Trata-se de centros que disponibilizam equipamentos informatizados para uso comunitário. A função maior é promover acesso à computadores e internet e, eventualmente, disponibilizar meios para a alfabetização digital. 0 exame exaustivo de experiências dessa natureza não faz parte do escopo deste trabalho, mas vale registrar que são iniciativas significamente numerosas, que envolvem custos 
relativamente baixos com uma perspectiva de ação em termos quantitativos. ${ }^{7}$ Considerando-os nos moldes convencionais, os telecentros podem ser vistos como iniciativas pontuais, medidas paliativas, que estão dissociadas de inserções mais substanciais e precisas em relação a apropriação plena das TIC, na medida que, a maioria deles, oferecem um acesso limitado, seja em termos de qualidade de equipamentos e, de tempo de utilização, pela restrição a determinados conteúdos, entre outros. ${ }^{8} \mathrm{E}$ neste sentido, embora considerados eficazes no combate à exclusão digital, podem muitas vezes se distanciar de práticas efetivas de inclusão social, se colocando apenas a serviço do uso operacional, funcional das TIC.

Muitos estudos, ainda que não considerados aqui, avançam em questões das diferenças quantitativas de acesso e operacionalização das TIC a partir de determinados recortes geográficos, baseadas em um arsenal de números e outros instrumentos metodológicos. As dimensões quantitativas da inclusão / exclusão digital são, hoje, sistematicamente pesquisadas, analisadas, acompanhadas por diferentes instituições, públicas e privadas, além de divulgadas por diversos órgãos, através de veículos especializados e mídias de grande público. Não é pertinente a este estudo abordar a questão quantitativa do acesso físico a equipamentos informatizados e conectividade, seja em termos locais, regionais, nacionais ou mundiais. Mesmo porque o conjunto de implicações metodológicas, controvérsias, e imprecisões que estudos desta natureza suscitam abrem muitos precedentes e demandam averiguações aprofundadas. Trata-se apenas de destacar que tais informações são também importantes porque podem balizar, de certa forma, os resultados das ações em prática em determinados contextos.

\footnotetext{
${ }^{7}$ Versões dos telecentros voltadas exclusivamente a fins lucrativos, os chamados cibercafés e lan houses, em determinados contextos, desempenham um papel também importante de favorecimento de acesso às TIC.

${ }^{8}$ Para uma visão mais profunda e exaustiva das experiências tipo telecentros ver TREVISAN, N. (2005). Por mares nunca dantes navegados: estudos para a inclusão da população de baixa renda na sociedade da informação. Dissertação (Mestrado) - Escola de Engenharia de São Carlos, Universidade de São Paulo, São Carlos, 2005.
} 
O exame acima, ainda que breve, induz a pensar que os projetos e iniciativas vinculados ao uso das TIC atrelados à questão da inclusão digital estão sujeitos a uma gama extensa de variáveis que estabelecem entre si laços de dependência. A partir deste entendimento, tornou-se premente neste estudo reconhecer e destacar estas variáveis. O que se dá, então, a partir do estabelecimento de categorias de análise, apresentadas a seguir.

\section{As categorias de análise}

Iniciativas, programas, projetos, experiências, práticas, desenvolvimentos, intervenções: todos esses termos são, de certa forma, sinônimos no sentido empregado aqui, que é o de designar ações e empreendimentos que se propõem a promover as TIC, assim como a empregá-las, utilizá-las, desenvolvê-las e aplicá-las visando melhorar a vida das pessoas. 0 uso alternado destas palavras é neste trabalho, um recurso de redação, decorrência de pressupostos sintáticos, e não deve comprometer a intelecção. Na literatura acadêmica voltada ao tema é também muito recorrente o uso aleatório destes termos, como se verá, também, no próximo capítulo, quando se discute a respeito da nova agenda de pesquisa que abarca grande parte de ações desta natureza. Uma exceção são Gaved e Anderson (2006) que, concordando com Day e Cupidi (2004 apud GAVED; ANDERSON, 2006) ${ }^{9}$, preferem utilizar em seus estudos a palavra iniciativa, em inglês initiative, à palavra projeto, em inglês project. Os autores salientam que o termo projeto relaciona-se a período determinado, metas definidas e recursos limitados, não estando associado a idéia de sustentabilidade social. Enquanto iniciativa enfatizaria a necessidade das TIC na comunidade local como parte da infra-estrutura, com sentido de manutenção contínua e de duração em aberto. Esta diferenciação parece fazer sentido nos estudos de Gaved e Anderson (2006) que se voltam, justamente, a iniciativas populares envolvendo o uso de TIC que nascem de forma espontânea no âmbito de comunidades locais. Os autores parecem estabelecer

\footnotetext{
${ }^{9}$ DAY, P.; CUPIDI, R. (2004). A human-centred approach to community informatics research. CIRN 2004. Inaugural Conference and Colloquium, Prato, Italy.
} 
qualificações diferentes aos referidos termos, o que não faria sentido nesta pesquisa porque, como se disse, abarca-se um conjunto bastante heterogêneo de ações envolvendo o uso das tecnologias digitais, que são devidamente particularizadas quando necessário.

A partir dos diferentes aspectos e características que compõem as iniciativas vinculadas ao uso das TIC, se estabelecem aqui três grandes categorias de análise, de acordo com a importância e destaque que assumiram nos estudos realizados. A primeira categoria, disposta no próximo item deste capítulo, diz respeito aos proponentes, executores e financiadores dessas iniciativas, abarca questões relativas à procedência e origem, assim como destaca as implicações referentes à gestão administrativa e financeira. Através dela elaboram-se reflexões a respeito do que é intrínseco a projetos que possuem, seja em suas esferas administrativas, financiadoras ou mesmo de origem, instâncias como o poder público, as entidades acadêmicas, as organizações do terceiro setor e as entidades comunitárias locais, assim como o setor privado.

A segunda categoria, apresentada no item 3 deste capítulo, é relativa a disponibilização de recursos envolvendo TIC. Averigua aquilo que é utilizado e usufruído. Trata-se da razão pela qual uma iniciativa é criada, da sua face mais externa, aquela que é palpável e acessível às pessoas. Nesta categoria examinam-se os objetivos dos projetos, suas proposições. São observadas iniciativas centradas na provisão de infra-estrutura de conexão; no acesso a equipamentos e conexão; em ações voltadas à chamada alfabetização digital, em capacitação profissional e geração de renda, na disponibilização de informações e serviços, na produção e publicação de conteúdos, e na promoção de interações sociais online e presenciais.

A terceira categoria, disposta no item 4 deste capítulo, abarca aspectos distintos relacionados à estrutura de implementação de iniciativas envolvendo o uso das TIC. Primeiro se apresenta as questões relativas aos instrumentos tecnológicos, que trata as especificidades dos meios técnicos necessários a iniciativas dessa natureza e busca examinar as possíveis relações, e mesmo influências mútuas, entre 
dispositivos técnicos e os desempenhos pretendidos. São estudadas, nesta perspectiva, questões relativas a conectividade, a hardware e a software. Depois se examina a questão do contexto sócioeconômico-cultural, destacando-se os meios disponíveis de apreender a realidade socioeconômica e cultural das comunidades locais sujeitas às ações de projetos envolvendo TIC. De certa forma, esta categoria tem uma feição metodológica, relacionada aos procedimentos que são adotados para estruturação desses projetos. Apresenta as diferenças entre conhecer a realidade por meio de dados estatísticos e através de instrumentos participativos. Por último, reúnem-se três aspectos distintos, porém fundamentais de serem considerados na implementação de iniciativas envolvendo o uso das TIC: avaliações, sustentabilidade e interfaces computacionais. Neste caso, trata-se de dar destaque a aspectos que são, na maioria das vezes, deixados de lado em iniciativas dessa natureza.

Para cada uma das categorias analíticas procura-se, por um lado, destacar relevâncias a partir de determinados marcos teóricos, e por outro, referenciá-las a partir de experiências concretas, ora concluídas, ora em andamento. Enquanto o recorte temático dessa pesquisa são as iniciativas TIC associadas a comunidades geograficamente delimitadas, este estudo em específico expande este limite quando necessário, e abarca um conjunto de programas e projetos significativos, que suscitam e ilustram, ao mesmo tempo, questões importantes. ${ }^{10}$ Todos os projetos mencionados são apresentados de forma sistematizada no Apêndice $A$ desta tese, como se disse. ${ }^{11}$ Cada categoria apresenta um conjunto de variáveis relacionadas e mesmo interligadas entre si, formando um todo entrelaçado. Algumas questões, por exemplo, são citadas dentro de mais de uma categoria, corroborando a idéia de

\footnotetext{
${ }^{10}$ É importante sublinhar que mesmo que se destaque apenas um aspecto específico de uma determinada iniciativa, isto não significa que ela seja relevante apenas neste determinado sentido, ou ainda que seja parcial. Busca-se apresentar experiências significativas relacionadas com o assunto em questão.

11 Alguns desses projetos fazem parte do banco de dados, oportunamente citado, que forma um conjunto bastante representativo e exemplar, mas que não pode, entretanto, ser tomado como uma amostra sistematizada do universo em questão. As iniciativas apoiadas apenas no funcionamento de telecentros estão excluídas deste banco de dados, por exemplo. De forma geral, as reflexões deste tópico não abarcam as iniciativas que possuem caráter comercial, assim como aquelas centradas exclusivamente em sistemas web, sejam voltadas à constituição das chamadas comunidades virtuais, ou ainda aos portais oficiais de cidades, conhecidas como iniciativas de e-governo.
} 
que tais categorias não são estanques, e não se prestam a aplicabilidade e operacionalização formais. Procura-se, através dessa sistematização, abrir o foco para formalizar um conjunto de abrangências, implicações e vínculos. Trata-se um aparato que deve ser considerado no todo, um complexo exercício de investigação a respeito das diversas dimensões das iniciativas ligadas às TIC. O objetivo é traçar caminhos para desvendar quais poderiam ser as boas práticas em experiências desta natureza. 


\subsection{Os agentes em iniciativas envolvendo o uso das IIC}

Os projetos vinculados ao uso das tecnologias digitais podem ter procedências, gestões e recursos de diferentes espécies. Destacam-se, quanto a origem, execução e financiamento, iniciativas vinculadas ao poder público, a instituições acadêmicas, a organizações do terceiro setor e a comunidades locais, e também a ações de empresas ou instâncias de interesse privado. As iniciativas estudadas nesta pesquisa, quase sempre, se estruturam de forma a abarcar ações realizadas em conjunto, através de parcerias diversas. Ainda que uma iniciativa seja financiada por uma instituição ou organização em particular, sua execução e administração quase sempre são realizadas em conjunto. 0 agente que propõe ou mesmo financia uma ação quase sempre busca parcerias em outras instâncias para melhor por em prática o que idealizou. Em alguns projetos, gestores, coordenadores e financiadores são os próprios propositores, em outros, os desdobramentos práticos ou desenvolvimentos futuros são transferidos, direta ou indiretamente, a comitês gestores ou a outras instituições ou organizações.

Governos, em âmbito federal e municipal, ligados ao planejamento e gestão, aparecem em algumas iniciativas estudadas, como em Helsinki Virtual Village ${ }^{12}$, VAN Bohechio ${ }^{13}$, Les Courtillières de Pantin ${ }^{14}$,

\footnotetext{
${ }^{12}$ HVV - Helsinki Virtual Village: iniciativa voltada ao desenvolvimento local de uma área portuária de Helsinque, em implantação desde 1999, centrada na implantação de infra-estrutura, no acesso doméstico as TIC e em aplicações para tecnologias móveis. Esta experiência é a que mais se assemelha a um projeto de política pública, para ser efetivada a longo prazo, com características abrangentes, inclusive envolvendo amplas parcerias com setores privados, que visam uma continuidade sustentável.

${ }^{13}$ VAN Bohechio - Village Area Network: projeto desenvolvido na República Dominicana por meio de parcerias entre o MIT Massachusetts Institute of Technology, governos e instituições locais, em 2000 e 2001, voltado a implantação de telecentros, a aplicativos para tecnologias móveis e infra-estrutura de conexão a internet.

${ }^{14}$ Les Courtillières de Pantin: projeto desenvolvido em um bairro de baixa renda de Paris, em 2000, voltado a re-qualificação de espaços coletivos e no design de interface gráfica.
} 
Blacksburg Electronic Village, ${ }^{15}$ Casa Brasil ${ }^{16}$, NCC - Novos Centros de Conhecimento ${ }^{17}$, entre outros. Há, neste conjunto, iniciativas com forte participação acadêmica, como Netville ${ }^{18}$, The HomeNet Project ${ }^{19}$ e Camfield Estate $^{20}$. No entanto, em Blacksburg Electronic Village, VAN Bohechio, Making Healthy MUSIC $^{21}$ e no projeto SARI ${ }^{22}$ há também a presença marcante das instâncias acadêmicas. Assim como em Camfield Estate e Viva Favela ${ }^{23}$ há a presença forte de uma organização não governamental local nas atividades de gestão, como na experiência Information Technology Initiative ${ }^{24}$. Interesses privados e parcerias com empresas de várias áreas fazem parte das iniciativas NetVille, Camfield Estate, Helsinki Virtual Village, Blacksburg Electronic Village, e outras. Assim, mais que uma característica, a diversidade de parcerias na constituição das iniciativas ligadas ao uso das TIC parece ser de fundamental importância para a implementação de projetos desta ordem.

\footnotetext{
${ }^{15}$ BEV - Blacksburg Electronic Village: iniciativa em vigor desde 1993, implantada pela universidade norte-americana conhecida como Virginia Tech e pelo governo local da cidade de Blacksburg, Virigínia, EUA, baseada a princípio em provisão de infraestrutura de conexão à internet e em um portal web.

${ }^{16}$ Casa Brasil: iniciativa do governo federal brasileiro, em vigor desde 2004, centrada na implantação de telecentros.

${ }^{17}$ NCC - Novos Centros de Conhecimento: telecentros onde se efetiva o plano de alfabetização tecnológica, um dos projetos que fazem parte da iniciativa de desenvolvimento regional do governo da comunidade autônoma de Extremadura, Espanha, em vigor desde 1999.

${ }^{18}$ NetVille - The Intercom Ontario Trial: uma das mais conhecidas pesquisas acadêmicas envolvendo acesso doméstico a internet e uma rede intranet em um conjunto residencial, realizada em 1996 em Toronto, Canadá.

${ }^{19}$ The HomeNet Project: pesquisa acadêmica realizada a partir de 1995 nos Estados Unidos, centrada no uso da internet a partir do acesso domiciliar.

${ }^{20}$ Camfield Estate - MIT Creating Community Connections Project: pesquisa acadêmica desenvolvida no MIT - Massachusetts Institute of Technology, EUA, implantada em 2000, voltada ao acesso doméstico as TIC a partir de um conjunto residencial.

${ }^{21}$ Making Healthy MUSIC - Multi-User Sessions In Community: pesquisa acadêmica realizada em 1995, também pelo MIT Massachusetts Institute of Technology, centrada no acesso doméstico a internet e em um projeto de interface computacional gráfica.

${ }^{22}$ SARI - Sustainable Access in Rural India: projeto desenvolvido na Índia desde 2002 cujos pontos fortes são a infra-estrutura de conexão a internet e o design de interface computacional.

${ }^{23}$ Viva Favela: iniciativa do terceiro setor implantada, a partir de 2001, na cidade do Rio de Janeiro, voltada a criação e manutenção de um portal web e à produção de conteúdo.

24 Information Technology Initiative: iniciativa norte-americana desenvolvida nos anos de 1995 e 1996 baseada na criação de redes a partir de telecentros.
} 


\section{Poder público}

Atualmente é bastante discutido o papel do Estado e das políticas governamentais com relação às ações ligadas a chamada inclusão digital. Há quem defenda que cabe aos governos responsabilizarem-se pelo combate à brecha digital. Há, por outro lado, quem acredite que, neste contexto como em outros, eles são os atores principais que não conseguem, não podem e nem devem atuar sem coadjuvantes. Raros são os que acham que o poder público não deve assumir postura alguma em relação à questão. Pelo menos em boa parte dos discursos, acadêmicos e leigos, o Estado tem sido intimado a ser propositivo e executivo, tem sido cobrado quando ausente ou quando suas ações se inserem em perspectivas meramente assistencialistas, paternalistas ou mesmo autoritárias. "Pelo menos o discurso não tem separado nitidamente as forças políticas quando se trata de discutir a inclusão digital. [...] As divergências ideológicas se manifestam nas opções e prioridades da implementação de propostas de universalização do acesso às tecnologias da inteligência” (SILVEIRA, 2001, p.32). Ainda que em outro sentido, Servon (2002, p.106) alerta para a mesma questão: “embora o suporte público seja inquestionavelmente vital no tratamento da disparidade tecnológica, a questão de qual, especificamente, deveria ser o papel apropriado do governo com relação a este problema permanece em aberto."25

São muitos os projetos envolvendo TIC criados pela administração pública no mundo todo, tanto nos países considerados mais ricos como nos mais pobres. É fácil constatar que se trata de uma gama muito variada de ações, distintas em termos quantitativos e qualitativos, implantadas em instâncias de abrangência territorial variadas. Podem ser ações mais locais e temporárias, podem ser projetos assumidos como políticas públicas de amplo alcance e duração, ou mesmo estarem associadas a investigações, levantamentos e pesquisas que buscam aferir sobre o estado vigente da chamada brecha digital em uma determinada localidade. Um dos aspectos que caracterizam as políticas públicas

25 Tradução da autora. No original: "Although public support is unquestionably vital to addressing the technology gap, the question of what, specifically, should be the appropriate role of government with respect to this problem remains an open one." 
consideradas de inclusão digital é a garantia de gratuidade no acesso a diferentes recursos digitais. Esta garantia pode ser permanente em alguns projetos, e temporária em outros, principalmente quando se prevê ações futuras de sustentabilidade. ${ }^{26}$ No primeiro caso, porém, a gratuidade dos serviços pode ser interrompida por um gestor com diferente postura política, que, ao assumir o poder público, modifique a estrutura do projeto. É importante perceber que, por um lado, existem projetos que são criados, propostos pelo Estado, mas nem sempre totalmente financiados e administrados por ele, e que por outro, muitas vezes, estes projetos dependem e estão à mercê das colorações partidárias responsáveis temporariamente pela gestão pública. É igualmente importante destacar que um dos mais significativos problemas no campo das iniciativas governamentais é justamente essa falta de garantia de continuidade e expansão dos programas. "Políticas e programas em curso endereçados à brecha digital são frágeis e vulneráveis a reduções e eliminação em razão das vicissitudes políticas” ${ }^{27}$ (SERVON, 2002, p.104). Há que se pensar, neste contexto, que as iniciativas TIC implantadas pelo poder público devem ser criadas como instrumentos institucionais que permaneçam imunes aos humores políticos ocasionais.

Nos países onde as várias faces das desigualdades sociais se impõem de forma crônica, as ações de governo se somam às iniciativas da sociedade civil organizada e aos projetos da iniciativa privada, de forma imprescindível. Porém, em alguns desses países, incluindo o Brasil, as políticas públicas, inclusive as que estão vinculadas às TIC, estão sujeitas a entraves burocráticos e à falta de coordenação e articulação. E são, ainda, desalinhadas com a maioria das outras iniciativas implantadas por estes outros setores da sociedade. Neste contexto, instala-se um cenário onde, muitas vezes, vários agentes estão fazendo coisas muito parecidas, enfrentando as mesmas dificuldades e problemas, ou mesmo, dispondo verbas substanciais para um mesmo fim ou localidade sem necessidade, e mais grave,

\footnotetext{
${ }^{26}$ Existem projetos estruturados em diferentes fases, por exemplo, implantação, desenvolvimento e expansão. Cada uma delas tem suas estratégias próprias, e dentre essas estratégias pode estar a garantia de gratuidade, ou, pelo contrário, a contribuição financeira dos públicos envolvidos, com razões e objetivos específicos. Neste contexto se encaixam as questões de sustentabilidade, que serão tratadas adiante.

27 Tradução da autora. No original: "Current policy and programs to address the digital divide are fragile and vulnerable to reduction and elimination because of the vicissitudes of politics."
} 
onde recursos são desperdiçados, não havendo intercâmbio de informações e coordenação de ações. Há quem defenda que essa coordenação deveria ser exercida por alguma instância governamental. ${ }^{28}$ Segundo Servon (2002), a fragmentação de ações vinculadas ao uso das TIC em âmbito governamental é compreensível, dado que abarca várias esferas políticas incluindo educação, desenvolvimento econômico e bem estar social. Porém, a autora alerta que “[...] melhorar a administração das políticas públicas, seja através dos departamentos e entre diferentes níveis, é necessário a fim de tratar esta questão de forma abrangente. Para fazer repercutir políticas que tratam a disparidade da tecnologia necessita-se coordenação e colaboração"29 (SERVON, 2002, p.103).

As iniciativas propostas por governos quase sempre são pensadas como ações de grande abrangência quantitativa. Entretanto, existem as ações menores, qualitativamente relevantes, realizadas pelos governos locais e pequenos municípios. No Brasil, Solonópole ${ }^{30}$, Pirai $^{31}$ e Sud Mennucci ${ }^{32}$ são exemplos de cidades que levaram a cabo projetos significativos. ${ }^{33}$ Há que se ponderar a relação entre quantidade e qualidade nesse contexto, ainda que seja impróprio considerar que uma inviabilize a outra. Outro ponto a se destacar em iniciativas governamentais é que a execução dos projetos quase nunca é assumida integralmente pela administração pública. Podem-se citar, entre outros, dois fatores relacionados a esta questão, que possuem laços entre si. Primeiro, a especificidade dos projetos que

\footnotetext{
${ }^{28}$ No Brasil, várias são as tentativas de organizar a implantação de iniciativas envolvendo TIC por parte do governo federal na gestão atual, e mesmo passada, do presidente Luis Inácio Lula da Silva

${ }^{29}$ Tradução da autora. No original: "[...] improved management of public policy, both across departments and between different levels, is necessary in order to comprehensively address this issue. Making sound policy to deal wiyh the technology gap will require coordination an collaboration."

30 Solonópole: iniciativa do governo local da cidade do estado do Ceará, posta em prática a partir de 2001, voltada principalmente a prover infra-estrutura de acesso à internet e a criação de serviços a partir de um portal web.

31 Piraí Digital: iniciativa do governo municipal desta cidade do estado do Rio de Janeiro, voltada ao desenvolvimento local, envolvendo, entre outros, a provisão de infra-estrutura de acesso a internet.

32 Sud Mennucci - Cidade Digital: iniciativa implantada e gerida pelo governo municipal da cidade paulista, desde 2002, baseada na provisão de infra-estrutura de acesso à internet, para uso ilimitado e gratuito.

${ }^{33}$ Destaca-se também, neste cenário, a cidade de Quissamã, no estado do Rio de Janeiro, que também provê gratuitamente o acesso a internet, e inclui a implantação de telecentros e portal web.
} 
abarcam TIC requer a inserção de pessoas da comunidade nas unidades onde as ações se desenvolvem, para que se possa estimular o envolvimento de possíveis usuários. Um telecentro, por exemplo, não é como um posto de saúde ou uma escola, que as pessoas procuram com objetivos bastante claros, mas um equipamento de outra natureza. É preciso, entre outros, orientar as pessoas para o uso dos meios e instrumentos digitais ali disponíveis. ${ }^{34}$ Segundo, a grande maioria dos governos não tem estrutura administrativa exclusiva que abarque esta nova função. Também de acordo com as tendências atuais de descentralização da administração pública e de transferência para a sociedade do ônus e responsabilidade de vários serviços públicos, percebidas em muitos países, opta-se muitas vezes por alocar projetos em estruturas já institucionalizadas, ao invés de se criar mais um equipamento público, nos moldes convencionais. É o caso, por exemplo, dos inúmeros telecentros que são implantados em bibliotecas e escolas públicas.

A partir dessa perspectiva é que a grande maioria das iniciativas propostas e financiadas pelo poder público prevê nas suas estruturas organizacionais parcerias de gestão com associações comunitárias, organizações não governamentais e outras instâncias locais, que manifestam, de certa forma, interesses em relação às tecnologias digitais. "Parcerias entre agentes governamentais e outros atores serão decisivas às estratégias de sucesso. Governos de todos os níveis podem exercer um papel chave na criação de incentivos para que os atores que estão distintamente confrontando a brecha digital trabalhem juntos $^{35}$ ” (SERVON, 2002, p.227). A ênfase dessas parcerias entre o poder público e as instituições locais pode variar em muitos sentidos. Há projetos em que elas são apresentadas a partir do viés da participação comunitária, da promoção da cidadania, da adequação à realidade local. Em

\footnotetext{
${ }^{34}$ Seria importante perceber até que ponto os governos entendem a implantação de telecentros diferentemente da implantação de outros serviços. Talvez este seja o caminho para compreender porque se insiste em opções tão restritas de atividades nesses locais, como a realização de cursos e elaboração de currículos, entre outros. Poderia-se pensar a necessidade de se ter explicito, na base da formulação desses programas, a natureza diferenciadora de seus serviços.

${ }^{35}$ Tradução da autora. No original: "Partnerships between government bodies and other actors will be critical to a successful strategy.Governments at all levels can play a key role by creating incentives for the actors that are separately confronting the digital divide to work together."
} 
outros casos, assume-se que as parcerias fazem parte exclusivamente das estratégicas para viabilizar projetos, no sentido de disponibilizar meios e recursos de que o poder público não pretende ou não pode dispor, seja material ou humano. Conhecidos como recursos de contrapartida, eles são muitas vezes fundamentais para que o poder público consiga levar a cabo e manter projetos de grande abrangência. Assim, dificilmente tem-se um governo como único e exclusivo financiador. A grande maioria das iniciativas governamentais em qualquer instância agrega um conjunto de fundos que vêm de fontes variadas, como fundações e organizações sem fins lucrativos, empresas privadas, também de doações de entidades, e inclusive de diferentes órgãos do próprio governo.

Quando um projeto público prevê uma grande abrangência, com centenas ou milhares de unidades implantadas em contextos diversificados, o que se vê, com certa freqüência, são algumas unidades funcionando de acordo com o previsto e outras não. Muitas vezes, projetos muito bem concebidos e planejados, assumem, na prática, desdobramentos que ficam muito aquém do desejado. É possível que haja muitas razões para isso, dentre elas, ineficiência administrativa e falta recursos financeiros, formação deficitária dos implementadores, alguns obstáculos técnicos, entre outros. Outra questão importante diz respeito ao grau de flexibilidade que tais experiências replicáveis devem possuir. É preciso examinar as possibilidades de criar modelos a partir de estruturas flexíveis a ponto de abarcar elementos e situações particulares que dificilmente se repetem, que pertencem a contextos locais muito particulares. No geral, a solução exemplar proposta para minimizar este problema é justamente a parceria com instituições com significativa inserção na comunidade local. Ainda assim, não se ameniza o perigo de transformar projetos bem planejados em ações sem direcionamentos práticos e concretos, terminando por implantar projetos de maneira burocrática, transferindo atribuições, abrindo mão de contatos mais estreitos e diretos com as comunidades locais, o que pode levar a projetos pró-forma. É o que acontece, por exemplo, em algumas unidades de telecentros de grandes projetos brasileiros, que apesar de alardearem estar a serviço da comunidade e ter como premissa aproximar o computador da vida de donas-de-casa, trabalhadores, estudantes, desempregados, jovens, entre tantos outros usuários potenciais, têm suas unidades funcionando anonimamente como meros 
laboratórios de informática dentro de instituições de ensino ou outras organizações sem expressividade nas comunidades. A lógica que se instaura é quase sempre a mesma, os parceiros ou instituições ditas hospedeiras cumprem com os requisitos que thes foram solicitados, comprovam-nos de alguma maneira. Os proponentes financiadores dos projetos enviam-lhes os recursos previstos nos editais, sejam materiais ou de outra natureza, e passam a acreditar (e contabilizar estatisticamente) que tudo está funcionando conforme planejado, quando na verdade não está. A gestão local imprime uma conduta própria, alheia às premissas tão caras ao projeto. Neste contexto em que as avaliações são raras, parece importante que antes de disponibilizarem-se grandes investimentos governamentais em ações dessa natureza, sejam implantados pequenos projetos pilotos que testem os modelos em escalas menores. Em geral, a ausência de aferições é percebida na própria formulação e estruturação dos programas, que quase nunca incluem instâncias de avaliação qualitativa.

\section{Instituições acadêmicas}

Nas universidades, cada vez mais, tem-se estudado a questão da inclusão exclusão digital. Grande parte desta produção diz respeito a estudos teóricos, que abarcam grandes levantamentos, análises e sistematizações de informações associadas ao tema. Tem-se investido pouco, em termos proporcionais, em estudos de campo, em aplicações práticas, que possam aferir um conjunto de dados e informações fruto de experimentações.

São numerosos os trabalhos teóricos, centrados em referências diversas, que analisam as iniciativas e projetos TIC implantados em todo o mundo. Modestamente, as referências desta tese constituem uma pequena amostra destes trabalhos. Porém, podem-se citar poucos trabalhos cujo objetivo é verificar as possíveis implicações da implantação das TIC na vida cotidiana das pessoas a partir de experiências práticas. São ainda pouco numerosos os estudos centrados na influência da implantação de projetos 
envolvendo o uso das TIC em comunidades locais específicas, com acompanhamento e avaliação sistemática em diferentes estágios. É relevante o que dizem Gaved e Anderson:

Nós temos verificado que pesquisa empírica detalhada a respeito dos efeitos dessas iniciativas é rara, especialmente a longo prazo. Isto pode ser em parte porque se assumiu que seus efeitos seriam positivos, o que pode ter levado a uma relativa falta de avaliação. [...] Além disso, o direcionamento à assim chamada exclusão digital é o interesse primeiro de muitos governos e comunidades que as iniciativas foram amplamente vistas como uma das formas mais simples de atuar neste campo. Neste sentido, pode-se ter como resultado uma certa relutância em examinar seus efeitos em maiores detalhes ${ }^{36}$ (GAVED; ANDERSON, 2006).

Alguns trabalhos acadêmicos são propositivos e dão origem a importantes iniciativas vinculadas ao uso das tecnologias digitais. O estudo de caso realizado por Keith Hampton sob orientação de Barry Wellman em Toronto, Canadá, que resultou na tese Living the wired life in the wired suburb: Netville, glocalization and civil society, de 2001, é um dos trabalhos acadêmicos mais usados como referência na área. Significativos também são os estudos de Randal Pinkett, de 2002, centrados no Camfield Estates: MIT Creating Community Connections Project desenvolvido pelo Massachusetts Institute of Technology; e a pesquisa de Marcus Foth, da Queensland University of Technology, Austrália, que resultou na tese Towards a Design Methodology to Support Social Networks of Residents in Inner-City Apartment Buildings, de 2005. Destacam-se também, por um lado, o trabalho desenvolvido em Bohechio, na República Dominicana, também por pesuisadores do Massachussets Institute of Techonology, e por outro, em Blacksburg, através do Virginia Polytechnic Institute \& State University. ${ }^{37}$

\footnotetext{
${ }^{36}$ Tradução da autora. No original: "We have found that detailed empirical research into the effects of these initiatives is scarce, especially over the long term. This may be in part because it was assumed that their effects would be positive, which may have led to a relative lack of assessment. [...] Also, addressing the so-called 'digital divide' is a prime concern for many governments and community initiatives were widely seen as one of the simplest ways to do this. As a result there may have be some reluctance to examine their effects in more detail."

${ }^{37}$ Cabe ressaltar aqui o interesse particular deste estudo em tais experiências acadêmicas, que foram, inclusive, as primeiras referências do projeto Comunidades_online, e serão discutidos mais atentamente no próximo capítulo.
} 
As iniciativas acadêmicas quase sempre são concebidas como experiências únicas ou modelares. Tratase, na maioria das vezes, de projetos exemplares em teste para averiguações múltiplas e possíveis ampliações futuras. Incluem metodologia acadêmica rigorosa, em alguns casos com grupo de controle, em outros, planejamento detalhado com projeto piloto, implantação, desenvolvimento e finalização. Quase sempre o principal objetivo de uma iniciativa envolvendo TIC proposta pela universidade é a experimentação, a possibilidade de averiguar dados, de testar ações específicas, de verificar suposições. As pesquisas teóricas e, ainda mais, aquelas baseadas em estudos de caso, são demasiado importantes pois podem nortear a condução de projetos e alimentar as políticas públicas no setor das TIC. Numa área de intervenção nova como essa, principalmente para o poder público, seria importante se se pudesse guiar por estudos consistentes e significativos, tendo-se como parâmetro informações sistematizadas. Como destacado no item anterior, um dos modelos predominantes de projetos públicos de intervenção na área das TIC é o telecentro. Neste contexto, é importante que se crie e experimente modelos alternativos, que se ponha à prova novas possibilidades de ações. No projeto Comunidades_online, numa iniciativa acadêmica até então inédita no Brasil, experimentou-se as possibilidades de levar conexão para dentro da casa das pessoas, numa pequena fração de uma comunidade, de criar uma interface computacional específica de comunicação e interação, e a partir disto, buscou-se também testar a re-qualificação das atividades realizadas em telecentros.

As experimentações acadêmicas nesta área devem esmiuçar possibilidades, examinar alternativas, além de desvendar os múltiplos aspectos envolvidos. Tratam-se de estudos que investigam o presente, ações que acontecem numa velocidade espantosa, muitas vezes de difícil apreensão. Inquirir a respeito do que as tecnologias podem trazer como oportunidades para comunidades de baixa renda, quais mudanças podem favorecer, diz respeito a relações qualitativas com as TIC. Tais relações podem, muitas vezes, só ser verificadas nestes ambientes acadêmicos, porque em outras situações, como no âmbito das políticas públicas, o foco são, muitas vezes, resultados na forma de números. Interessa-se, neste último caso, pela quantidade de pessoas cadastradas como usuárias dos programas, pela quantidade das que conseguiram atingir a finalização dos cursos básicos de informática, pelo número de 
unidade implantadas, entre outros. O fato de a demanda por iniciativas envolvendo TIC ser muito grande e urgente, muitas vezes, desloca o direcionamento da questão para soluções quantitativamente significativas. Grande parte das iniciativas criadas por organizações não governamentais, e mesmo daquelas que são frutos da boa intenção de líderes comunitários, também é, muitas vezes, orientada pelas demandas numéricas, ou por necessidades muito específicas. Neste sentido, reforça-se o papel dos projetos e estudos acadêmicos preocupados em avaliar e aferir a qualidade das intervenções desta natureza. Apesar de se constituírem como saber e praxis em construção, podem já ser estruturados e estabelecidos a partir de determinadas referências.

Em todas as iniciativas TIC em que o proponente principal são as instituições acadêmicas, vê-se também a recorrência maciça às parcerias, principalmente em relação à execução dos projetos e seus financiamentos. ${ }^{38}$ De forma geral, há que se destacar que é principalmente através das parcerias com associações comunitárias locais que se pode favorecer a transferência de conhecimentos citada acima.

\section{Organizaç̄es do terceiro setor}

\footnotetext{
${ }^{38}$ Geralmente, recorre-se às grandes companhias de infra-estrutura de telecomunicações para financiar a infra-estrutura de rede dos projetos, seja para a criação de intranets ou mesmo para o acesso à internet. Em alguns casos estas companhias fornecem descontos nos serviços. É comum também os grandes fabricantes de equipamentos financiarem os projetos na forma de doações de computadores e periféricos, assim como as empresas proprietárias de software colaborarem com doações de cópias dos seus produtos.

${ }^{39}$ Algumas expressões utilizadas neste item passaram a ser muito usadas nos últimos anos, em vários contextos, e por isso assumem, em determinados casos, significados distintos. Procura-se aqui apenas delimitar os sentidos apropriados a este estudo, deixando de lado as discussões e debates a respeito da pertinência ou não de definições. Segundo Fernandes (1997, p.27) "Terceiro Setor é composto de organizações sem fins lucrativos, criadas e mantidas pela ênfase na participação voluntária, num âmbito não governamental, dando continuidade às práticas tradicionais da caridade, da filantropia e do mecenato e expandindo o seu sentido para outros domínios, graças, sobretudo, à incorporação do conceito de cidadania e de suas múltiplas manifestações na sociedade civil. [...] Sendo tantos e tão variados os componentes deste Terceiro Setor, que sentido há em agrupá-los todos sob um mesmo nome? Vejo quatro razões principais, que se manifestam não apenas na retórica, mas também,
} 
Muitas são as iniciativas patrocinadas pela sociedade civil no campo da chamada inclusão digital. ${ }^{40}$ São organizações não governamentais, entidades comunitárias e associações de naturezas diversas que se voltam à criação e manutenção de projetos ligados ao uso das TIC para a população de baixa renda. Por um lado, muitas vezes, são tentativas e ensaios de quem aprende fazendo, que se transformam em ações exemplares, modelos eventualmente replicáveis. Por outro lado, podem ser iniciativas estruturadas, mas pontuais e de pequenas dimensões, sem pretensões de ampliação e replicação. Independente das dimensões que assumem, é certo que contribuem muito, em diferentes sentidos, neste contexto. Há quem diga que tais iniciativas não devem substituir as ações do poder público. Independente disto, como já destacado, é importante dizer que a sociedade civil também não age sozinha. Quase sempre está em parceria seja com o próprio governo, com a iniciativa privada ou com outras entidades similares. Warschauer (2006, p.221) relata bem o consenso que há sobre o papel das organizações do terceiro setor neste contexto: “[...] provavelmente, o método mais eficaz para alavancar os recursos comunitários é o trabalho por meio das organizações ou dos líderes comunitários, para legitimar e administrar iniciativas comunitárias de tecnologia.” À parte as relações entre governo e organizações da sociedade civil já citadas, é preciso destacar que no contexto brasileiro, especificamente, tais relações passaram a moldar, nestes últimos anos, práticas diferentes em iniciativas vinculadas ao uso das TIC, em muitos sentidos.

No Brasil, as organizações da sociedade civil são comumente conhecidas como ONGs - Organizações Não Governamentais independentes do caráter legal que possuem efetivamente, e independente de suas estruturas administrativas. Entretanto, há uma diversidade significativa no conjunto destas entidades, em diferentes aspectos, que deve ser considerada, independente do marco legal que as regulamentam,

e talvez sobretudo, em programas e plataformas de natureza prática: faz contraponto às ações de governo; faz contraponto às ações do mercado; empresta um sentido maior aos elementos que o compõem e projeta uma visão integradora da vida pública".

40 "Sociedade Civil (Ciência Política) - O termo possui um leque amplo de definições; Norberto Bobbio apresenta uma definição abrangente, em que Sociedade Civil é a esfera das relações entre indivíduos, entre grupos, entre classes sociais, que se desenvolvem à margem das relações de poder típicas das instituições estatais” (SOCIEDADE CIVIL, 2007). 
sejam elas ONGs, OSCIPs - Organizações da Sociedade Civil de Interesse Público, OSs - Organizações Sociais, organizações da sociedade civil, fundações, organizações privadas sem fins lucrativos, entidades filantrópicas, entidades assistencialistas, associações comunitárias, entre outras. ${ }^{41}$

Aqui, especificamente, interessa examinar a diferença entre dois tipos de iniciativas ligadas ao terceiro setor. Existem as entidades, associações, instituições que têm como base comunidades locais de baixa renda que nasceram espontaneamente a partir de movimentos comunitários. São entidades que desenvolvem projetos sociais com perspectivas de atuações e perfis muito diversos, e que em determinado momento, passaram a abarcar ações envolvendo o uso das TIC nas suas atuações, e que agem em uma base local restrita. Por outro lado, existem as organizações, associações, instituições que têm por finalidade trabalhar com projetos independentes de uma base local definida. São órgãos que se constituíram a partir da intenção de por em prática ações ligando tecnologias e comunidades de baixa renda. Geralmente, desenvolvem práticas restritas a determinadas localidades, que se expandem com o passar do tempo. Tais organizações podem se transformar em grandes instituições promotoras de iniciativas vinculadas ao uso das TIC. É importante que se diferencie, neste contexto, estes dois perfis, porque eles podem dar origem e sustentar iniciativas TIC diferentes em alguns aspectos.

De um lado, estão as iniciativas que se constituem como soluções alavancadas por líderes comunitários frente a percepção dos problemas e necessidades locais. São ações que nascem em pequenas instituições comunitárias, e que independente disso, podem ou não ser viabilizadas a partir de parcerias, seja em termos financeiros ou gerenciais. "Diversas vezes um grupo comunitário único pode ser levado a gerir um projeto” (WARSCHAUER, 2006, p.222). De outro lado têm-se as iniciativas que são implantadas em determinadas comunidades por grandes organizações do terceiro setor, trata-se de intervenções destes organismos externos nas comunidades através de projetos ligados às tecnologias. 0

${ }^{41}$ Algumas das expressões citadas possuem correspondências jurídicas, referindo-se, inclusive, a títulos e qualificações dados pelo poder público. Outras são apenas formas diferentes de se aludir a associações civis sem fins lucrativos. 
CDI - Comitê para a Democratização da Informática é uma das ONGs que trabalham com TIC mais conhecidas, no Brasil e em outros países, tendo projetos implantados desde 1995. A principal ação do CDI é implantar EICs - Escolas de Informática e Cidadania em comunidades de baixa renda e em locais onde se situam minorias marginalizadas.

Gaved e Anderson (2006) diferenciam estas duas formas de iniciativas chamando-as top down e bottom up, qualificando-as como iniciativas exógenas e endógenas, embora não as contraponham em relação às organizações do terceiro setor, e sim em termos de políticas públicas e iniciativas locais, o que é também bastante pertinente. É preciso mesmo destacar que as iniciativas implantadas pelo terceiro setor em comunidade locais se parecem muito com políticas públicas. Principalmente no sentido da possibilidade de estarem menos engajadas à realidade social dos possíveis usuários, e de terem membros da comunidade agindo como meros beneficiários ou clientes. É bem mais provável que se tenha usuários envolvidos e comprometidos com a estruturação e bom desempenho dos projetos nas iniciativas que nascem dentro do terceiro setor em comunidades locais. As relações entre usuários e projeto assumem grande importância, sendo consenso a afirmação que quanto mais estreitos são os laços participativos, mais estimuladas são as interações espontâneas, assim como, quanto mais são os suportes sociais envolvidos, maiores as chances de resultados positivos (GAVED; MULHOLLAND, 2005). 0 envolvimento comunitário parece necessário tanto para dar sustentação às ações propostas, como para potencializar e promover recursos sociais. DiMaggio e Hargittai (2001) assinalam a importância dos suportes sociais para os novos usuários das TIC: “Nós pressupomos que o suporte social de todos os tipos aumenta a motivação dos usuários em usar a tecnologia e a amplia para que eles desenvolvam suas próprias competências." 42 Warschauer (2006, p.265) também destaca a importância de se ter organizado projetos onde as estruturas sociais e seus recursos estão bastante coesos: “[...] o capital social preexistente pode ter uma influência importante sobre a capacidade de indivíduos ou grupos

${ }^{42}$ Tradução da autora. No original: "We hypothesize that social support of all kinds increases users' motivation to use the technology and the extent to which they develop their own digital competence." 
utilizarem a TIC". O trabalho dos dinamizadores sócio-culturais e informáticos dos telecentros NCCs de Extremadura se dá neste sentido. São pessoas que nasceram ou vivem na localidade e cumprem a tarefa de serem guias e orientadores no processo de alfabetização tecnológica. São os animadores sócio-culturais também responsáveis por darem apoio aos usuários. Estes agentes utilizam técnicas de motivação, têm a tarefa de detectar em conversas os interesses e as necessidades das pessoas, e estão sempre abertos às demandas (EQUIPO TÉCNICO AUPEX, 2003).

Neste contexto, é preciso que se perceba alguns contra-sensos. Os discursos de muitos proponentes de iniciativas envolvendo TIC não condizem com suas ações práticas. Isto vale tanto para grande parte dos dirigentes envolvidos com a questão da chamada inclusão digital que estão no governo, na iniciativa privada, como nas organizações do terceiro setor. Alardeia-se, num plano teórico, os benefícios do engajamento com a realidade das comunidades locais, com a geração de oportunidades de emprego e renda, com o incentivo à capacitação e produção de conteúdo, o apoio a diferentes redes comunitárias, o uso de software livre, entre outros. Na prática, o que se vê, são esforços, são tentativas de implementar as ações tão abrangentes que os discursos apontam, dando origem a projetos parciais, justamente se avaliados a partir da retórica. Isso faz pensar que, concretamente, tanto a implantação como a manutenção de iniciativas TIC são processos bastante complexos, e demandam monitoramento constante, avaliações permanentes e re-planejamento. Práticas quase inexistentes em projetos desta natureza, como se verá a seguir. No caso das organizações do terceiro setor este fato é mais grave, pois muitas delas têm interesses em transformar suas ações em modelos que podem se tornar políticas públicas.

"Um dos papéis de destaque para o terceiro setor tem sido a capacitação de monitores de telecentros" (DIAS, 2003, p.91). À parte o recente debate público a respeito do papel das ONGs no Brasil, principalmente quanto às irregularidades no uso de verbas públicas, é preciso que se diga: são comuns pequenas empresas privadas que se estruturam como organizações do terceiro setor atuantes na área de inclusão digital. Quase sempre especializadas em formação, em atividades de capacitação e 
treinamento, revestem-se de princípios altruístas para oferecer seus serviços ao governo ou outras entidades, na forma de parcerias e apoios. A grande maioria destas organizações é competente e possui ações meritórias. 0 problema consiste em revestir atividades com fins lucrativos com militância política ou com voluntariado. De novo, é o discurso em contraste com prática. Não se vê problema algum em tais organizações se posicionarem como empresas de prestação de serviços ou consultoria, que agregam profissionais especialistas em questões referentes à chamada inclusão digital. Mereceria exame mais atento o fato das iniciativas vinculadas às TIC assumirem, em determinados contextos, em algumas instâncias governamentais e em muitas instâncias do terceiro setor, este caráter de causa, que determina a existência de uma militância ativa, acostumada a uma cartilha pré-estabelecida, e que, muitas vezes, se fecha às novas experiências e possibilidades.

\section{Setor privado}

É difícil dizer se o setor privado, principalmente ligado às grandes empresas de telecomunicações e tecnologia da informação, direta ou indiretamente, realiza também ações dentro da agenda da chamada inclusão digital. 0 que se vê, por um lado, são fundações ou institutos empresariais que diretamente promovem iniciativas envolvendo TIC procurando moldá-las a ações de responsabilidade social e marketing. ${ }^{43}$ Porém, tais fundações e institutos são conceitualmente considerados organizações do terceiro setor, como se viu acima. Além do que as ações de responsabilidade social podem implicar em redução de impostos, o que, no limite, equivaleria ao uso indireto de recursos públicos e não privados. Por outro lado, é comum que as empresas estejam ligadas indiretamente a iniciativas dessa

\footnotetext{
${ }^{43}$ Responsabilidade Social - Define o grau de amadurecimento de uma empresa privada em relação ao impacto social de suas atividades; abrange, em termos gerais, desenvolvimento comunitário, equilíbrio ambiental, tratamento justo aos funcionários, comunicações transparentes, retorno aos investidores, sinergia com parceiros e satisfação do consumidor (RESPONSABILIDADE SOCIAL, 2007).
} 
natureza por meio de parcerias ou apoios, patrocinando liberação de taxas de licenciamentos, manutenção de serviços, direitos de uso, doando equipamentos, entre outros.

As iniciativas inclusivas patrocinadas exclusivamente por empresas privadas se constituem, na maioria das vezes, em ações relevantes. Mas quando se trata especificamente da indústria de tecnologia da informação ou do setor de telecomunicações, agindo direta ou indiretamente em iniciativas inclusivas, tais ações parecerem assumir o caráter compensatório. Como já foi dito, grande parte das iniciativas aqui em questão buscam recursos junto a grandes empresas privadas do setor para colocar em prática suas ações. Cabe ressaltar que esta prática, muitas vezes, além de necessária, se constitui como possibilidade única de se estruturar projetos desta natureza. Este auxílio, que a primeira vista poderia parecer incoerente, é muito bem justificável no interesse das indústrias de equipamentos e software, e prestadoras de telecomunicações, em terem seus produtos e serviços utilizados, conhecidos e dirigidos ao maior número de pessoas possíveis. Mesmo que sejam pessoas que vivam em comunidades socialmente vulneráveis, de qualquer forma, significa sempre abrir novas possibilidades de mercado, e ainda a formação de consumidores para determinados bens e serviços. "Com referência ao apoio exterior, é importante levar em consideração que grupo algum participa de um projeto comunitário sem ter seus próprios interesses em mente" (WARSCHAUER, 2006, p.229). O fato é que estas grandes empresas, diretamente através das suas fundações ou institutos, e mesmo como parceiros ou apoiadores, sempre têm recursos disponibilizados para implantação de iniciativas ligadas a ações inclusivas. Incômodo porém, é alinhavar seus interesses aos propósitos, e mesmo ideais, destas ações, ainda que apenas explícitos em discursos.

A lista de parceiros financeiros de algumas iniciativas estudadas é um exemplo claro de que as principais companhias privadas ligadas ao universo das TIC, em âmbito mundial, têm interesse em participar de projetos desta natureza. O conjunto de experiências Camfield Estate - MIT Creating Community Connections Project, Making Healthy MUSIC, Information Technology Initiative, NetVille e Helsinki Virtual Village apresenta como parceiros e colaboradores: Bell Atlantic, Bell Communications 
Research, Nortel, IBM, Apple Computer, Hewlett Packard Company, Microsoft Corporation, AT\&T Research, The Intel Corporation, Panasonic, Sonera, Ericsson, Motorola, Nokia, entre muitos outros. A maioria dessas parcerias está centrada nas conveniências acima citadas, poucas são as empresas privadas que participam de iniciativas TIC com o propósito de testar novos produtos e serviços. Isso acontece em Helsinki Virtual Village e NetVille, especificamente.

Como em outros contextos, mas principalmente no setor privado, os investidores primam por resultados objetivos que devem se traduzidos em números e comprovados estatisticamente. As empresas privadas valorizam dados quantitativos. 0 mérito das suas ações está sempre relacionado a valores numéricos. Contudo, alerta Warshaurer:

[...] é importante assinalar que as contradições do mundo real surgem entre atingir 'números' e atingir 'pessoas', isto é, entre atingir quantidades maiores de pessoas de modo mais rápido e menos intensivo e atingir quantidades menores de pessoas de modo mais lento e mais extensivo. Esses são equilíbrios que qualquer tipo de projeto de desenvolvimento social deve ponderar [...] (WARSHAURER, 2006, p. 269). 


\section{OS recursos alocados nos projetos}

Uma iniciativa vinculada ao uso das TIC pode ter diferentes objetivos e neste sentido assumir diferentes propósitos, seja por meio de ações diretas, como a chamada alfabetização digital, ou indiretas, como a implantação de infra-estrutura para a provisão de canais de acesso a internet, ou mesmo por meio de práticas que reúnem estes dois tipos de ações. ${ }^{44}$ Cada iniciativa caminha, em determinado sentido, de acordo com suas finalidades e metas, sejam elas estabelecidas a curto, médio ou longo prazo, e em alguns casos, regida apenas por necessidades e demandas urgentes, sem um planejamento muito claro.

É bastante comum que uma iniciativa que tenha um objetivo mais complexo, como, por exemplo, a promoção de cidadania e capital social, ou mesmo, a geração de renda, cumpra algumas metas elementares e básicas, que são, muitas vezes, os alvos principais de outras iniciativas. É o caso, por exemplo, da provisão de acesso a equipamentos e conexão. Isto não indica que umas são mais importantes ou significativas que outras. Os objetivos e proposições de cada iniciativa devem ser considerados de acordo com os contextos nos quais são determinados e exercidos. Além dos agentes envolvidos, entre tantos outros fatores, devem ser levados em conta a diversidade de localidades, comunidades e usuários, e principalmente, as diferenças em termos de disponibilidade de infraestrutura e recursos financeiros. É muito difícil estabelecer comparações absolutas entre iniciativas envolvendo TIC, para isso teria-se que dispor de contextos e situações muito semelhantes, em vários níveis. Mesmo assim, passados já alguns anos em que as primeiras iniciativas começaram a ser constituídas, é possível, necessário e útil, que guardadas as devidas proporções, algum juízo de valor se estabeleça entre elas. As análises estabelecidas abaixo estão imbuídas de determinados critérios apreciativos e avaliativos, que ora têm-se estabelecido a partir do próprio desenvolvimento, em amplo

${ }^{44}$ As ações diretas são aquelas que envolvem necessariamente a presença de usuários. Ações indiretas são aquelas que possibilitam a execução das ações diretas, estão associadas e relacionadas, principalmente, à provisão de infra-estrutura. 
sentido, das próprias iniciativas, ora são frutos das investigações deste estudo. Se, em certos momentos, estas apreciações valorativas são consonantes com o discurso uníssono, senso comum, proferido insistentemente pelos agentes envolvidos em iniciativas desta natureza, em outros, são investigações, exercícios de repensar a respeito de consensos. Procura-se se apropriar do que já se mostrou bastante legítimo e examinar o que ainda gera incertezas.

Discorre-se, a seguir, sobre os objetivos mais comuns que as iniciativas ligadas às TIC assumem, sejam eles isolados ou associados. Procura-se destacar a relevância destes objetivos em determinados contextos, e investigar, em termos de planejamento, desenvolvimento e resultados, suas abrangências.

\section{Infra-estrutura de conexão}

Existem inúmeras iniciativas que têm por objetivo principal estabelecer a infra-estrutura necessária para que determinada localidade ou comunidade possa estar conectada à internet. Outras iniciativas põem em prática ações que buscam viabilizar o cumprimento de metas mais complexas. Independente de ser um fim em si mesmo, ou um meio, a infra-estrutura necessária para o acesso à internet é considerada, consensualmente, muito mais que um fator intrínseco e essencial às iniciativas associadas à chamada inclusão digital. ${ }^{45}$ Se num passado ainda recente, levar o acesso à rede a localidades distantes de grandes centros, muitas vezes desprovidas de outras infra-estruturas de comunicação, era considerado por muitos, um grande investimento no sentido da inclusão digital, hoje as discussões avançam em outra direção, considerando como fator inclusivo a própria qualidade de conexão. Trata-se de minimizar a presença desigual do acesso a internet de banda larga, seja entre países, localidades, e mesmo entre pessoas de status sociais diferentes. É consenso pensar que qualquer tecnologia oferecida

\footnotetext{
${ }^{45}$ É muito incomum encontrar quem defenda e proponha, hoje, ações inclusivas sem acesso à internet. Não se pode, porém, desconsiderar projetos em operação em alguns contextos onde a rede ainda não está presente, seja por motivos de carência de investimentos em infra-estrutura de telecomunicações, ou pelo fato do acesso a internet ser proibido, seja por questões morais, de restrição à liberdade, de segurança, entre outros.
} 
deve ser considerada um meio e não finalidade em si, e que a qualidade do que é ofertado contribui para a manutenção ou não de desigualdades.

As críticas que ainda recebem as iniciativas focadas na provisão de infra-estrutura de acesso à internet, e mesmo de provisão de equipamentos, é que são ações parciais, que parecem considerar a inclusão digital como uma questão de acesso físico. Como destacado oportunamente, inúmeros são os autores que colocam em xeque esta concepção, e que adotam a postura de que o acesso a equipamento e internet é pré-condição à inclusão. Hoje, como se disse, mesmo em instâncias menos especializadas, é consenso considerar que as ações de inclusão digital vão muito além do acesso físico. Mas nem por isso, as questões e problemas de falta de infra-estrutura, que afligem incontáveis comunidades ao redor do mundo, foram resolvidos. Pelo contrário, romper com esta primeira barreira em determinados contextos é um esforço enorme, e neste sentido, discursos reformulados e conceitos revistos não ajudam muito.

Assim como os serviços de internet ainda são caros, artigos de luxo para uma parcela bastante significativa da população mundial, os investimentos em infra-estrutura de conexão também são díspares, agregando e reforçando mais um elemento no contexto das desigualdades. "Em resumo, os mesmos lugares que são caracterizados por pobreza econômica também tendem a sofrerem de pobreza informacional; um modelo desenvolvido em que as desigualdades nos espaços físicos e eletrônicos mutuamente se reforçam"46 (SERVON, 2002, p.9). Presencia-se esta realidade tanto em países desenvolvidos como em desenvolvimento. Nestes últimos, as disposições para gerar ações, públicas ou privadas, de implementação de infra-estrutura em todos os níveis, de saneamento básico a comunicação e conexão à internet, são mais complexas, lentas e difíceis, além de serem agravadas pelo estado de carência em amplo sentido de determinadas parcelas da população. Se nos países

${ }^{46}$ Tradução da autora. No original: "In short, the same places that are characterized by economic poverty also tend to suffer from information poverty; a pattern has developed in which inequalities in physical and eletronic spaces mutually reinforce one another." 
desenvolvidos discutem-se formas de assegurar a todos a oportunidade de terem acesso físico à internet a partir das casas, em países em desenvolvimento o grande desafio é prover o acesso universal a partir de algum lugar, seja em casa, no trabalho, na escola, ou em telecentros (WARSCHAUER, 2006). Se, em determinados contextos, é difícil a implantação de infra-estrutura de conexão à internet seja por fios, cabos, ou wireless, por se tratar de um serviço considerado caro, e até pouco tempo, de estruturação lenta, sujeito às políticas de telecomunicações adotadas pelos governos, o que dizer da possibilidade de garantia e permanência de conexão de banda larga. 0 custo de manutenção de acesso à internet rápida requer a disposição de recursos mensais considerados altos, seja no plano doméstico como coletivo, fator que dificulta ainda mais a incorporação do acesso à rede à vida diária de grande parte da população mundial.

Um exemplo de iniciativa que se volta à provisão de infra-estrutura de conexão à internet é o programa GESAC - Governo Eletrônico - Serviço de Atendimento ao Cidadão ${ }^{47}$ do governo federal brasileiro, criado em 2003 sob coordenação do Ministério das Comunicações. Embora o programa tenha por finalidade fornecer infra-estrutura de conexão a localidades carentes, engloba também ações de implementação de telecentros. A conexão GESAC é fornecida por satélite. O programa atinge várias comunidades, e possui parceria com outros projetos de inclusão digital do governo federal.

\section{Equipamentos e conexão}

Muitas iniciativas envolvendo o uso das TIC voltadas a providenciar o chamado acesso físico são alimentadas conceitualmente por pesquisas metodologicamente centradas em valores numéricos, em dados demográficos objetivos, e em tratamentos estatísticos rigorosos, como as analisadas por

\footnotetext{
47 GESAC - Governo Eletrônico Serviço de Atendimento ao Cidadão: iniciativa de provisão de infra-estrutura de acesso à internet, também do governo federal brasileiro, em vigor desde 2003.
} 
Mossberger, Tolbert e Stanbury (2003), e demonstram, em maior ou menor grau, as dimensões quantitativas da chamada exclusão digital.

O resultado notável é que todos os três estudos baseados em diferentes levantamentos e métodos estatísticos relatam as persistentes disparidades quanto ao acesso à internet baseadas em raça, etnia, educação e renda. [...] Os dados revelam que a 'exclusão digital' em termos de acesso à tecnologia da informação é uma realidade inegável. Da mesma forma que mais Americanos adquirem computadores e reúnem-se online, a maioria das disparidades que emergiram durante a última metade dos anos 1990 permanecem ${ }^{48}$ (MOSSBERGER; TOLBERT; STANBURY, 2003, p.35).

Como visto oportunamente, é consenso que ações voltadas exclusivamente às necessidades de disponibilizar equipamentos e conexão são demasiado insuficientes para garantirem relações qualitativamente significativas com e através das tecnologias de informação e comunicação. Embora também muitos considerem que se o problema da chamada inclusão digital estivesse só relacionado à questão de acesso físico ele seria de solução menos complexa, isto não atenua o fato de que prover equipamentos e conexão à internet, não seja, por si, uma ação simples. Como se verá, inclusive, no contexto do projeto Comunidades_online.

Muitos fatores estão envolvidos em ações desta natureza, a começar pelas possibilidades de acesso físico a rede, passando pela adoção ou não de periféricos e determinados software, pela qualidade técnica dos equipamentos e conexões, até as questões de manutenção e obsolescência, entre outros. São fatores que derivam implicações que em maior ou menor grau podem ou não determinar o êxito de iniciativas TIC. Para DiMaggio e Hargittai (2001) a localização do acesso físico a internet está intimamente relacionada à questão de autonomia no uso das TIC. Quem tem acesso à rede somente nos locais de trabalho ou em locais de uso coletivo, como telecentros, cibercafés, centros comunitários de

48 Tradução da autora. No original: "The striking result is that all three studies based on different survey data and statistical methods report persistent gaps in acess to the Internet based on race, ethnicity, education, and income. [...] The data reveal that a 'digital divide' in terms of information technology acess is an undeniable reality. Even as more Americans purchase computers and flock online, most of the disparities that emerged during the latter half of the 1990s remain." 
tecnologia, entre outros, estaria sujeito a normas, limitações de horário, filtros, e outras formas de monitoramento, que moldam relações com as TIC qualitativamente diferentes das estabelecidas por aqueles que têm acesso a partir do ambiente doméstico, por exemplo, que em contrapartida, estariam sujeitos às dinâmicas familiares. Os autores supõem que quanto maior autonomia, liberdade e flexibilidade no uso das TIC maior benefícios há para os usuários. Como se vê adiante, alguns autores ressaltam que, direta ou indiretamente, o desempenho técnico dos equipamentos e conexões está diretamente associado à qualidade da relação que as pessoas estabelecem com as TIC.

Algumas iniciativas TIC voltadas a alavancar o acesso a equipamentos e dispositivos informáticos têm sido implantadas em várias partes do mundo, ora centradas na criação e produção de instrumentos informáticos de baixo custo, ora voltadas ao financiamento e incentivo à aquisição de microcomputadores convencionais por pessoas de baixa renda. O programa indiano Simputer é um dos mais conhecidos no primeiro caso ${ }^{49}$; no Brasil, o Cidadão Conectado - Computador para Todos ${ }^{50}$, lançado pelo governo federal em junho de 2005, é declarado como programa de fomento à inclusão digital das classes C e D. Este programa está baseado em incentivos fiscais aos fabricantes de microcomputadores, em isenção de impostos aos comerciantes varejistas, e no financiamento direto e indireto de máquinas com juros menores e prazos maiores que os praticados pelo mercado. 0 projeto OLPC - One Laptop Per Child ${ }^{51}$ idealizado e dirigido por Nicholas Negroponte pode ser citado também como exemplo de iniciativas voltadas a produção de equipamentos de baixo custo. Centrado na criação

\footnotetext{
${ }^{49}$ Ver Warschauer (2006, p.100).

50 Projeto Cidadão Conectado - Computador para Todos: iniciativa do governo federal brasileiro, em vigor desde 2005, voltado a facilitação do acesso a equipamentos através de financiamentos especiais.

51 OLPC - One Laptop per Child: iniciativa de uma organização do terceiro setor dirigida por pesquisadores do MIT Massachusetts Institute of Technology a partir de 2005, centrado no desenvolvimento de equipamentos informatizados portáteis de baixo custo.
} 
e produção de laptops de US\$100 para uso na educação, está sendo oferecido a governos de países em desenvolvimento de todo o mundo. ${ }^{52}$

Deve-se destacar que tanto a produção de equipamentos como a instituição de planos de acesso a internet com custos inferiores aos praticados no mercado convencional demandam uma negociação nem sempre fácil, envolvendo governos, sociedade civil e setores industriais nas áreas de microeletrônica e telecomunicações, pois se trata de administrar interesses que nem sempre caminham em direções paralelas e convergentes. Warschauer (2006) destaca no contexto de produtos de tecnologia de informação o fenômeno conhecido como dilema inovador, que diz respeito, grosso modo, à dinâmica do mercado em que empresas e companhias, quando enfrentam a saturação de mercado de determinados produtos, optam por agregar novos valores a esses produtos, ofertando-os a um mercado superior limitado, a criar novas linhas de produtos de baixo custo (tecnologias desagregadoras) para o mercado de massa.

Neste contexto de provisão de equipamentos e conexão inclui-se também todo o conjunto de práticas de reciclagem de microcomputadores, que são apresentadas muitas vezes como soluções para fomentar o acesso físico a equipamentos informáticos, e que, por sua vez, possuem também diversos matizes e propósitos. Se estas práticas foram, num primeiro momento, consideradas como forma alternativa de disponibilização de computadores para projetos ditos de inclusão digital, hoje já fazem parte do conjunto de procedimentos intrínsecos a projetos bem estabelecidos. As questões de reciclagem não estão associadas somente ao baixo custo favorecido pelo reaproveitamento de equipamentos descartados, que podem dar suporte a um rápido crescimento de redes de computadores, dado o baixo custo de máquinas, e assim, à viabilidade de criação de projetos voltados a disponibilização de acesso físico. O uso de microcomputadores de origem reciclada em projetos vinculados ao uso das TIC pode

52 Recentemente este valor foi acrescido de US\$40. O equipamento portátil produzido no âmbito deste projeto é chamado XO. Pode-se citar também, neste contexto, os equipamentos Classmate, da Intel e o Mobilis, da Encore Software. 
fazer desses projetos estimuladores da capacitação dos indivíduos, vetores de geração de renda, favorecedores da reunião de pessoas em grupos de trabalho coletivos. Assim, se por um lado, pode envolver ações de geração de trabalho e renda, e de formação profissional por meio de cooperativas, laboratórios e oficinas de reciclagem, por outro, destaca-se o importante papel em minimizar o acúmulo do chamado lixo tecnológico. Além disso, é importante que se diga que a prática da reciclagem se constitui em um instrumento importante no sentido de desmistificação da própria tecnologia, desnudando-a para que possa ser apropriada em outros moldes. Entretanto, a reciclagem de equipamentos não pode ser considerada panacéia nem para frentes de inclusão digital, nem para o lixo tecnológico. Segundo algumas organizações, em determinados contextos, o custo total de propriedade de uma máquina recondicionada pode ser maior do que um computador novo e os custos de manutenção, incluindo a vida útil curta das máquinas recondicionadas, podem torná-las desvantajosas. ${ }^{53}$ A reciclagem é também, algumas vezes, o pretexto para transferir e exportar material tecnológico em desuso dos países desenvolvidos para regiões mais pobres do planeta. 0 Casa Brasil e o Plurall $^{54}$ são exemplos de projetos que incorporam a reciclagem de equipamentos a suas ações.

Também não se pode esquecer, relacionada a provisão de equipamentos, as questões de manutenção e atualização. Um projeto cujo objetivo é ofertar o acesso equipamentos informatizados e internet não se completa quando tais dispositivos tornam-se disponíveis. A partir de então, se instaura uma demanda permanente de manutenção desses equipamentos e conexão, visando não só otimizar funcionamento, mas solucionar pequenos problemas inerentes a rotina de uso, o que requer, no mínimo, o auxílio de pessoas com conhecimentos técnicos específicos em hardware e software. A médio e longo prazo, o

\footnotetext{
${ }^{53}$ Estudo promovido pela SchoolNet Africa (SNA) em parceria com o Commonwealth of Learning e o International Institute for Communication and Development (IICD), citado especificamente em PLURALL (2007). O artigo expõe: "Além disso, a ausência de capacitação da população local para manutenção, a dependência externa e limitações técnicas e financeiras das organizações que recebem os equipamentos influem negativamente no aproveitamento dos PCs. Por fim, o desempenho destes equipamentos muitas vezes obriga à utilização de sistema operacional e softwares antigos. Mesmo assim, muitos projetos pretendem continuar trabalhando com PCs reutilizados, principalmente por falta de alternativas" (PLURALL, 2007).

54 Plurall: iniciativa de uma organização do terceiro setor, a partir de 2006, voltada ao desenvolvimento de equipamentos e solução em software de baixo custo.
} 
desafio também é vencer as barreiras da obsolescência dos equipamentos, programas, e conexão. Atualizar, ou tornar mais eficazes alguns destes itens, está associado não somente a possibilidade de elevar a qualidade dos mesmos, mas principalmente, a manter as características primeiras dos projetos. Warschauer (2006) ressalta que projetos centrados em modelos baseados em equipamento apresentam diversas falhas importantes, onde os custos dos computadores seriam apenas uma questão entre tantas outras. "Neste, incluem-se os preços dos softwares, da manutenção e dos periféricos; e, em ambientes institucionais, os preços do treinamento, do planejamento e da administração, assim como os de substituição do hardware e software, necessidade imposta devido a obsolescência planejada dos produtos" (WARSCHAUER, 2006, p.56).

A provisão de infra-estrutura de conexão e de equipamentos e conexão em si são essenciais a projetos envolvendo TIC, sem os quais estes não existiriam. Muitas iniciativas podem apenas contemplar tais ações, ou podem ter alinhadas a elas um ou mais objetivos que serão tratados nos próximos cinco itens. É muito recorrente no discurso e na prática dos projetos uma sobreposição de objetivos.

\section{Affabetizaç̧̃o dig̣tal}

Quando se tem por meta atingir objetivos inclusivos necessariamente tem que se cumprir etapas infraestruturais de conectividade e de disponibilização de equipamentos, assim como há de se considerar ações de alfabetização digital, chamadas também letramento digital, instrumentalização digital, treinamento digital, entre outros. Apresentar pessoas ao universo das TIC, propor este contato, ensinálas a usarem computadores e outros instrumentos informatizados, a acessarem a rede, seja para comunicar, obter informações ou criar conteúdos, faz parte dos objetivos da grande maioria dos projetos ligados ao uso das TIC, sendo que as dimensões que estas ações assumem podem variar bastante. Nestes casos, mais do que um passo a cumprir, trata-se das metas finais de muitas iniciativas. 
Muitos projetos estão focados no ensino formal de informática, através da administração de cursos de computação convencionais, envolvendo aspectos de hardware e software. Os usuários cumprem determinadas etapas de aprendizado voltadas simplesmente a habilitá-los ao uso operacional das tecnologias de informação e comunicação. Como em escolas convencionais, no final de cada curso recebe-se um certificado comprovando a aptidão na utilização de determinadas ferramentas. Nesta perspectiva, este aprendizado é o instrumento principal para trazer às pessoas o universo digital. ${ }^{55}$ Entretanto, é difícil encontrar, no conjunto das iniciativas em questão, principalmente brasileiras, tal objetivo descrito claramente nestes termos. Como destacado oportunamente, os discursos neste âmbito são bastante diferentes das práticas, há inúmeros projetos que funcionam como escolas de informática, acumulando metas atingidas na forma de números de usuários-alunos, em cursos rápidos e restritos, mas com pretensões e objetivos mais amplos, baseados em generalizações tipo inclusão social e promoção da cidadania, entre outros. Na grande maioria das vezes, tais objetivos são legítimos, e bem intencionados, mas se apresentam, na prática, dissociados das ações que efetivamente se desenvolvem.

Não se trata de desmerecer iniciativas centradas no oferecimento de cursos formais. Um dos problemas aqui, como já foi dito, é acreditar e, em muitos casos, se fazer acreditar, seja frente a usuários, seja a financiadores, que as ações práticas assumidas são meios para se atingir os objetivos almejados, camuflando o distanciamento, a brecha, entre os produtos reais das ações realizadas e as metas desejadas. Há um descompasso entre a ação concreta, sua amplitude, abrangência, e possibilidade, e os objetivos propostos. Há que se examinar o papel efetivo que os cursos formais assumem em iniciativas inclusivas. Tais cursos, com materiais didáticos específicos, conteúdos pré-estabelecidos, padronizados, quase sempre têm como premissa instrumentalizar, seja com relação a conhecimentos em software, seja em hardware, submetendo a interação com a tecnologia a um processo de mão única, descontextualizado. 0 aprendizado de utilização dos instrumentos técnicos parece ser um fim

\footnotetext{
${ }^{55}$ Ações desta natureza estão também voltadas a capacitação profissional e geração renda.
} 
em si mesmo, imprime à tecnologia caráter de foco único e principal do ensino e aprendizagem. Cursos com tais formatos parecem não ser meios efetivos de apropriação das TIC, principalmente se comparados com outras propostas de processos de aprendizagem.

Algumas iniciativas estão comprometidas e preocupadas em realmente ir além. Embasadas em metodologias que procuram contextualizar o aprendizado à prática diária, procuram dar competência às pessoas no sentido de sobrepor tecnologias digitais e vida cotidiana. Buscam tornar as TIC significativas, facilitadoras das ações no âmbito da vida pessoal e profissional. E para tal, promovem o ensino e uso das ferramentas tecnológicas a partir dos desejos e necessidades concretas dos usuários. Cada telecentro NCC de Extremadura, é estruturado a partir de uma metodologia chamada metodologia da participação, e constiui-se como:

[...] um espaço aberto, livre, com um educador-guia e um educando ativo que desenvolvem o caminho e os conteúdos formativos conjuntamente com os interesses e os ritmos de cada usuário/alfabetizando, partindo do desenho de um modelo de aprendizagem baseado nos interesses e necessidades dos usuários, e no desenvolvimento de experiências individuais e coletivas $^{56}$ (EQUIPO TÉCNICO AUPEX, 2003, p.27).

Neste sentido, Warschauer destaca que:

[...] letramento eletrônico é uma expressão geral, que abarca diversos outros letramentos genéricos da era da informação, incluindo aqueles por via do computador, e os letramentos informacional, multimídia e comunicacional mediados por computador. Esses novos letramentos originam-se, em parte, dos novos aspectos tecnológicos associados ao computador, mas também do cenário social mais amplo em que os computadores são usados (WARSCHAUER, 2006, p.154).

\footnotetext{
${ }^{56}$ Tradução da autora. No original: "[...] un espacio abierto, libre, com un educador-guía y um educando activo que desarrollan el intinerario y los contenidos formativos conjuntamente com los intereses y los ritmos de cada usuario/alfabetizando partiendo del diseño de um modelo de aprendizaje basado em los intereses y necesidades de l@s usuari@s y el desarrollo de experiencias individuales y colectivas."
} 
0 autor apresenta então quatro formas de letramento, sendo que o primeiro deles diz respeito ao conhecimento específico de computação. Afirma que conforto e fluência com hardware, software e sistemas operacionais não devem ser fins em si mesmos, são importantes componentes quando a finalidade é uma ampla aprendizagem, e devem ser tratados como tais. Assinala também o letramento em multimeios, que se instaura como possibilidade de resgate da comunicação audiovisual e o letramento que está relacionado às maneiras e habilidades de comunicar online e a netiqueta ${ }^{57}$. 0 autor define, por fim, o letramento informacional que diz respeito à capacidade de localizar, avaliar e usar informação (WARSCHAUER, 2006).

Muitos outros autores descrevem a alfabetização digital também como um processo complexo, que requer muito mais que a habilidade em manusear computadores, estar na internet e operar editores de texto, planilhas eletrônicas, entre outros.

Tecnologia da informação requer um conjunto de habilidades específicas em computação que podemos chamar de competências técnicas, mas muitos usos da internet também demandam mais informações gerais e conhecimentos, arraigados na alfabetização básica. A proliferação de websites oferecendo informações [...] requer habilidades para localizar, ler, compreender e avaliar informação (em relação a conteúdos e fontes) ${ }^{58}$ (MOSSBERGER; TOLBERT; STANBURY, 2003, p. 54).

Entre cursos convencionais e outras metodologias de ensino-aprendizagem, é importante destacar que existe uma gama de projetos associadas à educação formal, em diversos países, que são parte de políticas públicas na área inclusiva, mas que não fazem parte desta análise. São projetos voltados a

\footnotetext{
${ }^{57}$ Conjunto de normas de comportamento na internet, reflete condutas de boas maneiras, boas práticas ou de bom senso à comunicação e interação neste ambiente.

58 Tradução da autora. No original: "Information technology requires a set of computer-specifc skills that we call technical competencies, but many uses of the Internetalso demand more general information literacy, rooted in basic literacy. [...] The proliferation of websites offering information [...] requires the ability to locate, read, comprehend, and evaluate information (both its content and its source)."
} 
implantação de laboratórios de informática nas escolas públicas, por exemplo. Enquanto algumas destas ações estão a tal modo imbricadas a outras ações educacionais que se tornam, muitas vezes, difícil diferenciá-las, outras se restringem à provisão de equipamentos às escolas, acompanhados ou não de acesso a internet.

\section{Capacitação profissional e geração de renda ${ }^{59}$}

Muitos projetos envolvendo o uso das TIC têm por objetivo contribuir para a formação para o mercado de trabalho, principalmente de jovens e desempregados, através dos cursos na área de informática, sejam eles profissionalizantes ou não. Espera-se que os cursos se constituam como aperfeiçoamento nos conhecimentos exigidos pelo mercado de trabalho formal, ou sejam caminhos abertos para o trabalho autônomo. Aprender a usar computadores e determinados software específicos seriam, neste caso, garantias de criação de novas oportunidades de trabalho e emprego.

É indiscutível que o mercado de trabalho, no geral, acompanhando as tendências de informatização cada vez mais acelerada de importantes instâncias da vida cotidiana, requeira profissionais que estejam em consonância a esta realidade. Neste sentido é pertinente que muitas iniciativas TIC estejam focadas não só nos cursos profissionalizantes na área de informática, mas na formação para o mercado de trabalho e em serviços oferecidos a pequenos empreendedores. 0 que parece ser descabido, porém, é que se alimente a idéia fantasiosa de que conhecimentos básicos em informática é a garantia de entrada para o mercado de trabalho formal, e mesmo fonte certa de geração de renda para aqueles que queiram se estabelecer como profissionais autônomos.

\footnotetext{
${ }^{59}$ No terreno da chamada inclusão digital é bastante comum o uso indiscriminado do verbo capacitar, seja referindo-se a usuários de projetos, como a gestores, monitores, animadores e tantos outros. Este termo, porém, pode adquirir, dependendo do contexto, conotações pejorativas, como se estivesse se tratando de pessoas incapazes em algum sentido. Ressalta-se que aqui se utiliza capacitação como atribuição de novas competências, como possibilidade de assimilação de novos saberes, sem valoração ou hierarquização alguma.
} 
O trabalho e a empregabilidade no mundo atual são fatores complexos, cercados de incertezas, sujeitos a determinantes de naturezas distintas, alvos de intermináveis análises e debates, consensos e dissensos. Castells (2000, p. 285) ressalta que “[...] embora a tecnologia em si não gere nem elimine empregos, ela, na verdade, transforma profundamente a natureza do trabalho e a organização da produção". 0 autor destaca que a tecnologia de informação está redefinindo os processos de trabalho e os trabalhadores e, portanto, o emprego e a estrutura ocupacional. Muitos empregos são eliminados pela automação na indústria e serviços, muitos empregos estão mudando sua exigência de qualificação, os atributos educacionais exigidos segregam, a mão-de-obra é desvalorizada em cargos iniciais e temporários para atividades de baixa qualificação realizadas por minorias. Castells (2000) também alerta que os padrões de trabalho e a polarização da mão-de-obra são determinados socialmente e projetados administrativamente no processo de reestruturação capitalista, que ocorre com a ajuda do processo de transformação tecnológica. Este imbricado contexto, por si, põe por terra perspectivas afirmativas e deterministas de garantia de obtenção de emprego e trabalho a partir de qualquer ação específica. ${ }^{60}$

Seria pertinente às iniciativas TIC voltadas especificamente a objetivos de capacitação profissional e geração de renda que complementassem suas ações com a busca efetiva de alternativas de trabalho

\footnotetext{
${ }^{60}$ Neste sentido, pode-se tomar como exemplo a inapropriação das informações a respeito de um determinado programa voltado à inclusão digital do governo federal brasileiro: "O programa de inclusão digital do Ministério da Ciência e Tecnologia pode ser resumido em: oferta de instrumentos, meios e facilidades, para os menos favorecidos, facilitando o acesso às oportunidades de emprego, geração de renda ou melhoria da renda através da melhor qualificação profissional e com isto transformar cidadãos brasileiros, hoje à margem, em participantes ativos do processo de desenvolvimento econômico e social" (BRASIL, 2006). As ações referentes a este programa são descritas vagamente, em termos gerais que podem assumir, qualitativamente, status muito diferentes: "[...] principais ações e atividades: apoiar a instalação de telecentros em escolas e bibliotecas públicas ou em instituições públicas dos próprios estados e municípios; apoiar a implantação de laboratórios de informática em escolas públicas; treinar e capacitar monitores e professores em tecnologia da informação para telecentros públicos; implantar núcleos de informática, dotados de biblioteca virtual, sala de teleconferência e de treinamento; apoiar projetos voltados para a difusão e acesso à tecnologia da informação para a população carente; apoiar projetos de capacitação e qualificação de mão-de-obra em tecnologia da informação; apoiar projetos de difusão e acesso à tecnologia da informação e comunicação voltados para as pessoas com deficiência ou com mobilidade reduzida; apoiar projetos de capacitação e qualificação de mão-de-obra e Tecnologia Assistiva." (FOMENTO, 2006).
} 
para aqueles que capacitam, ou mesmo que propusessem ações paralelas concretas de geração de renda.

No Centro de Profissionalização de Adolescentes Padre Bello (CPA), que agrega uma série de iniciativas profissionalizantes, inclusive ligadas às TIC, sabe-se que o investimento em formação não é suficiente para que os jovens se incorporem ao mercado de trabalho. Depois de estabelecerem parcerias com empresas de setores produtivos específicos, investiram na CooperJovem, uma cooperativa de serviços para o mercado, composta de jovens técnicos. A cooperativa faz reciclagem de computadores doados por empresas e os comercializa, dá suporte a usuários de informática, monta e oferece manutenção em estruturas de rede. Trata-se da criação concreta de uma alternativa de geração de renda. Os telecentros voltados aos negócios, focados em capacitação tecnológica e treinamento empresarial, são um outro exemplo de iniciativa exclusivamente focada no aprimoramento profissional, no caso, de pequenos e médios empresários. Os TIN Telecentros de Informação e Negócios do Ministério do Desenvolvimento da Indústria e Comércio Exterior brasileiro são um exemplo.

\section{Informaç̄os e serviços}

A internet reúne e disponibiliza livremente hoje um conjunto de informações até então inimaginável, em amplitude planetária. É inerente à internet disponibilizar tanto informações das mais variadas naturezas, como formas específicas de comunicação e serviços, sendo que toda iniciativa envolvendo o uso das TIC que prevê, no mínimo, acesso livre a rede, está implementando o oferecimento de informações, comunicação e serviços. Neste item procura-se examinar iniciativas que se prestam ao oferecimento de informações ou serviços específicos. Cabe ressaltar que serviços incluem, necessariamente, ações interativas ou trocas informacionais. É comum ver algumas iniciativas considerarem serviço a disponibilização de informações úteis, por exemplo. 
Embora excluídas desta pesquisa, as iniciativas relativas a e-governo (e-gov) ou governo eletrônico, ou ainda portais cívicos segundo Musgrave (2005), estariam aqui alocadas. Trata-se de iniciativas e projetos web desenvolvidos por instâncias governamentais na forma de serviços públicos prestados a população através da internet, do oferecimento de informações, principalmente ligadas a administração pública e a todos os outros setores públicos. São programas e projetos que apresentam características bastante diferentes, que possuem também qualidades e abrangências bastante distintas e que são, por si, um recorte específico dentro das iniciativas envolvendo TIC, muito estudado e avaliado em áreas disciplinares distintas. Neste contexto, é preciso apenas destacar que as discussões em torno da relação ente governo eletrônico e a chamada inclusão digital não são unânimes. Muitos acreditam que ter serviços públicos disponíveis na rede é direito dos cidadãos, e portanto obrigatoriedade dos governos. Outros acreditam que as ações de e-gov, como são chamadas, se inserem no escopo das ações convencionais de inclusão digital.

Como sublinhado no início, grosso modo, as experiências que têm como premissa proporcionar apenas o acesso livre a internet, com ou sem oferecimento de apoio técnico, também se encaixariam nos propósitos de prover informações e serviços. Neste caso, trata-se das informações e serviços disponíveis na rede de modo geral, não associados a comunidades, localidades ou conteúdos específicos. Tais iniciativas privilegiam a liberdade, o não direcionamento na apropriação das TIC, e em geral, se constituem como espaços coletivos com computadores para acesso gratuito e livre à internet. 0 programa Acessa São Paulo, do Governo do Estado de São Paulo, é uma iniciativa baseada neste moldelo, embora busque agregar outras atividades. ${ }^{61}$ É difícil, porém, diferenciar as iniciativas centradas exclusivamente no acesso livre de ações voltadas a promover o acesso físico, discutidas acima. Nas primeiras há a intencionalidade em garantir uma certa autonomia aos usuários, a postura de não tolher as possibilidades nos usos das TIC, sendo oferecido opcionalmente meios de obtenção de

\footnotetext{
${ }^{61}$ Acessa São Paulo: projeto implantado pelo do governo do Estado de São Paulo a partir de 2001, centrado em telecentros de acesso livre à internet.
} 
informações específicas sobre informática, ou mesmo suporte para o desenvolvimento de atividades, o que as segundas, muitas vezes, não contemplam. Também difícil é medir, até que ponto, a liberdade requerida no acesso livre se sustenta, dado que a estrutura de acesso coletivo é, por si, limitadora, seja em termos de tempo, conteúdo, e em outros aspectos. Trata-se, no mínimo, de um paradoxo. Ainda assim, as iniciativas que carregam apenas a bandeira do acesso livre assumem conceitualmente que cabe aos usuários a busca pelo acesso qualitativamente significativo, enquanto que nas iniciativas centradas no acesso físico esta questão é, na maioria das vezes, ignorada; o foco são os equipamentos. Nos dois casos, porém, parece haver a total desconsideração de que para além dos aparatos físicos existem níveis convenientes de habilidades para processar e utilizar informação, ou seja, de capacidade cognitiva. Warschauer (2006, p.157) descreve que o processo de letramento informacional abarca "[...] tanto o conhecimento específico do uso do computador (por exemplo, domínio do programa de navegação e das ferramentas de busca) como habilidades de letramento crítico mais amplas (por exemplo, análise e avaliação das fontes de informação)." Tendo como parâmetro as habilidades críticas e não só operacionais, difícil é mensurar o nível de resultados que se pode esperar destas práticas. DiMaggio e Hargittai (2001) destacam inclusive importância de se dar atenção e investigar o aspecto de busca de conteúdo na internet, "Nós conhecemos muito pouco sobre o que explica a desigualdade na capacidade ou competência necessária para encontrar informações online.”62

Em outro sentido, as iniciativas que se voltam especificamente a provisão de serviços e informações o fazem, na grande maioria das vezes, por meio de interfaces web especialmente criadas para tal fim, tendo como meta, inclusive, promover o desenvolvimento de determinadas comunidades de base local, seja no plano econômico, educacional, social, de saúde, entre outros. Geralmente são criados sistemas web, na forma de portais, com páginas informativas e, eventualmente links que oferecem determinados serviços relacionados a educação e cultura, consumo, saúde, entretenimento, direito,

${ }^{62}$ Tradução da autora. No original: "We know very little about what explains inequality in the know-how or competence needed to find information on-line." 
entre outros. Podem ter também como objetivo mobilizar a ação coletiva, facilitando a troca de informações e comunicação ampla entre moradores e instâncias comunitárias locais. Um exemplo que pode bem ilustrar este modelo de projetos centrados na provisão de informações e serviços é Blacksburg Electronic Village. Trata-se de uma iniciativa inicialmente voltada a aumentar o acesso a internet banda larga de toda a região de Blacksburg com o interesse de superar o isolamento rural e a exclusão digital baseada em geografia. O objetivo principal era promover o desenvolvimento econômico, oportunidades educacionais e de saúde, e também a troca de informações e comunicação na comunidade. A iniciativa está centrada no oferecimento de serviços comunitários e conteúdos informativos a partir de um web portal comunitário, que oferece, entre outros, ferramentas como

fórum e chats. ${ }^{63}$ É muito comum que iniciativas TIC ligadas a provisão de informações e serviços deste tipo agreguem às suas metas a produção e publicação de conteúdos locais na rede e a promoção de interações sociais comunitárias, sejam on-line, presenciais, ou ambas. Em parte significativa das iniciativas TIC estudadas, estes objetivos estão entrelaçados, como se verá a seguir.

\section{Produç̧̃ã e publicaçăo de contéidos}

A produção e publicação de conteúdos são considerados desafios a serem enfrentados em muitas iniciativas vinculadas ao uso das TIC. São ações muito valorizadas neste âmbito, e abrangem um conjunto de aspectos, que podem ser agrupados em contextos distintos, nos quais destacam-se, por um lado, a ausência de conteúdo na rede destinada às classes consideradas de baixa renda, e por outro, as questões relativas à cognição em geral. Servon (2002) ressalta que os centros comunitários de tecnologias (CTCs) norte-americanos que enfatizam conteúdo possuem propósitos distintos, ligados geralmente a criação de material específico para os membros da comunidade; ao ensino de criação de

\footnotetext{
${ }^{63}$ Os impactos das TIC nesta comunidade foram objeto de muitos estudos acadêmicos. Ver: KAVANAUGH, A.L.; PATTERSON, S.J. (2003). The Impact of Community Computer Networks on Social Capital and Community Involvement in Blacksburg. In: WELLMAN, B.; HAYTHORNTHWAITE, C. (Ed.). The Internet in Everyday Life. Malden: Blackwell Publishing.
} 
conteúdos por esses próprios membros e por fim, ao auxílio na busca de informações importantes que já existem na rede. Acredita-se que a experiência de produzir conteúdos e colocá-los online é importante para a formação de uma capacidade de avaliar criticamente o que está disponível na rede. Em outras palavras, a mesma propriedade crítica que é essencial à busca de conteúdos na internet seria importante também a produção e publicação neste meio.

Atento às questões relativas a qualidade e quantidade do material digital, do conteúdo, disponível na internet vinculado a realidade sócio-cultural do público da maioria das iniciativas inclusivas, Sorj revela que:

em termos gerais, pode-se afirmar que tanto nos países em desenvolvimento, quanto nos países centrais boa parte dos conteúdos da Internet se orientam para os usuários de classe média, principal mercado consumidor com potencial de gerar direta ou indiretamente receitas [...]. A destinação ao usuário de classe média se dá tanto pelo conteúdo como pela forma, pois a maioria dos sites supõe que o internauta possui um nível educacional relativamente alto. [...] Mas igualmente dramática é a falta de sites dedicados aos setores urbanos mais pobres da população, cujo principal ponto de acesso são os telecentros, para os quais é limitada a produção de conteúdo que leve em consideração suas necessidades culturais e socioeconômicas (SORJ, 2003, p.71).

A inadequação de conteúdos a contextos específicos, principalmente relacionados a minorias e grupos de baixa renda não é exclusivo a internet, e sim extensível às mídias em geral. É uma prática recorrente, e bastante perversa, a exclusiva veiculação de informações de aspectos negativos destes grupos e comunidades nos grandes meios de comunicação. Criam-se, muitas vezes, imagens depreciativas, generalizando o que por ora é parcial e restrito. Acredita-se que este quadro pode ser revertido e requalificado positivamente através da internet. Warschaurer (2006, p.124) afirma que “[...] as publicações on-line podem proporcionar uma mídia excelente para o compartilhamento de conteúdo comunitário localmente desenvolvido e podem com frequiência contribuir para a preservação 
da língua e da cultura das minorias". Servon (2002) parece destacar a importância do protagonismo na rede:

Aqueles CTCs que ativamente fomentam a criação de novos conteúdos aceitam como verdadeiro que as pessoas não deveriam ser consumidoras passivas de informação, mas antes deveriam ativamente moldar a internet por meio da produção de conteúdos que refletem e representam as comunidades desprivilegiadas $^{64}$ (SERVON, 2002, p.66).

O projeto Viva Favela, da ONG Viva Rio, nasce com o objetivo de produzir informação sobre a realidade social e cultural das favelas do Rio de Janeiro para os meios de comunicação, não focando restritamente a violência, como de praxe. Com a instituição do portal vivafavela.com passa-se a oferecer uma gama bastante variada de serviços e informações aos moradores daquelas comunidades, que o acessam principalmente nos telecentros. Embora apenas uma parte do conteúdo disponível no portal seja produzido exclusivamente por pessoas das próprias comunidades, chamadas correspondentes comunitários, a iniciativa agrega uma série de outros projetos que juntos constituem um significativo material sobre as comunidades cariocas faveladas. ${ }^{65}$

As ações de produção e publicação de conteúdos na internet estão intimamente ligadas às habilidades cognitivas das pessoas de forma geral, e especificamente, às suas capacidades em manipularem os dispositivos informáticos, seja hardware ou software. À parte a barreira legítima das dificuldades no uso das ferramentas informatizadas, o que se faz premente, é a inadequação do nível de escolaridade e alfabetização de grande parte do público dos projetos TIC, que afeta diretamente ações amplas de produção de conteúdo. A questão principal é que, neste cenário, tais ações não acontecem de forma espontânea, precisam ser sustentadas, dirigidas.

\footnotetext{
${ }^{64}$ Tradução da autora. No original: "Those CTCs that actively foster the creation of new content believe that people should not only be passive consumers of information but rather actively shape the Internet by producing content that reflects and represents disenfranchised communities."

${ }^{65}$ Sobre os projetos Cambito, Favela Tem Memória e Nordeste Aqui, e sobre o Viva Favela em geral, ver Sorj (2003).
} 
Parece que a forma mais de adequada de por em prática ações de produção de conteúdo são as atividades voltadas exclusivamente a este fim, nas quais os dispositivos informáticos são apenas instrumentos, meios. Tais atividades se estruturam a partir das demandas, dos interesses próprios, seja de uma pessoa, grupo ou comunidade. Quando a produção de conteúdo é a meta, os produtores, agora protagonistas, emergem, e devem ser estimulados a buscar os recursos que necessitam para por em prática seus objetivos, inclusive os recursos tecnológicos. Neste sentido, as ações de produção de conteúdo se alinham às ações de alfabetização digital, especificamente àquelas que se estruturam a partir de metodologias diferentes das empregadas nos cursos tradicionais de informática, que privilegiam a experimentação e a inovação. A referência aqui também são as atividades realizadas nos $t$ NCCs de Extremadura, em implantação desde 1999, que já se mostraram bastantes satisfatórias e relevantes. Para a estruturação destas atividades parte-se de um diagnóstico participativo, que ajuda a descobrir potenciais projetos junto à comunidade, que os elegem e os assumem. Os tipos de atividades desenvolvidas em tais projetos se adaptam a demanda permanente dos participantes, e podem estar ligados, por exemplo, a recuperação cultural e envolver festas, gastronomia; a divulgar informação e comunicação, e envolver rádio e jornal; a assistência a saúde, educação, trabalho; a promoção associativa, e então voltar-se a vizinhos, mulheres, entre outros. Tem-se como premissa construir um site ou páginas web a partir das atividades e projetos, que reúnam textos, áudios, fotografias, frases, entrevistas, entre outros. As ações de upload na rede são resultados de um processo de produção de conteúdo e da publicação destes conteúdos (EQUIPO TÉCNICO AUPEX, 2003).

Quanto à produção e publicação de conteúdos há que se mencionar também outros aspectos importantes. Ferramentas de publicação de conteúdos na web foram criadas, e são constantemente aprimoradas, para facilitar aos usuários não especialistas em programação a inserção de conteúdos na internet; os blogs são um exemplo, como se vê adiante. Os recursos multimídia deveriam ser mais explorados, em diferentes interfaces, pois possibilitam a utilização de linguagens alternativas à verbal escrita. As imagens, estáticas ou em movimento, os sons, são possibilidades outras de expressão para pessoas com alfabetização precária, também para aquelas portadoras de necessidades especiais. 0 
protagonismo na produção de conteúdo pode ir se ampliando gradativamente, incluindo a possibilidade de intervenção mesma na tecnologia. Em muitas iniciativas envolvendo TIC, as atitudes de criação, de re-apropriação de informações e conhecimento, podem se estender a intervenções nos próprios suportes tecnológicos. Em oficinas de reciclagem de computadores é possível fazer experimentações com hardware, a utilização de software livre e aberto possibilita incursões no campo da programação.

É sabido que grande parte do conteúdo da internet é produzido na língua inglesa, o que implica também em uma série de dificuldades para aqueles que falam outras línguas, e que não possuem competências e habilidades necessárias para compreendê-la. É importante destacar que este fato, por si, independente das suas implicações conjunturais amplas, é fator limitante de acesso ao conteúdo da internet, e que se soma aos outros acima citados. Por este conjunto de aspectos, as ações de produção e publicação de conteúdos parecem imprescindíveis aos projetos ligados às TIC, e fazem, cada vez mais, parte dos seus objetivos. É importante destacar que tais ações estão, em grande parte, também associadas a práticas de fomento das interações online e presenciais, e da disponibilização de informações e serviços.

\section{Interaçōes sociais onlinee face-a-face}

Não são muitos os projetos que declaradamente possuem como objetivo principal alavancar as interações online e presenciais de comunidades geograficamente referenciadas. Existem, porém, ações propostas em determinadas iniciativas envolvendo TIC que, na prática, têm como conseqüência a promoção do capital social e o incremento das relações entre os atores sociais da localidade. Mesmo que indiretamente, são ações que agilizam o fluxo de informações e comunicação naquele contexto e estimulam o desenvolvimento qualitativo das relações sociais, além de promoverem o interesse pelas questões de caráter público e coletivo. 
Como destacado oportunamente, é característico às iniciativas vinculadas a experiências acadêmicas o interesse em examinar e avaliar as interações sociais online e face-a-face a partir da introdução das TIC em determinadas localidades. As ações de produção e publicação de conteúdos, e mesmo de disponibilização de informações e serviços podem estar agregadas também a objetivos de desenvolvimento comunitário a partir do incremento da comunicação centrada em ambientes virtuais. Como se vê adiante, alguns estudos mostram a pertinência da busca de fortalecimento de aspectos da vida comunitária em localidades a partir do potencial de comunicação e de troca de conteúdos e informação nos ambientes de interação online.

É importante considerar que os exames dos fenômenos dos relacionamentos sociais na internet estão sujeitos a especificidades e variações tal qual as iniciativas a eles associados. A iniciativa The Intercom Ontario Trial, conhecida como NetVille, apontou que a internet constrói capital social, tanto à distância como em âmbito local, a experiência The HomeNet Project mostrou que os efeitos da internet nas relações sociais dependem das maneiras específicas de como a rede é usada. Os aprofundamentos nos resultados ou conclusões vinculados a esses projetos fazem parte das discussões do próximo capítulo. Aqui cabe ressaltar que existem diferentes formas de promover as interações online e face-a-face em comunidades de base local. Parece pertinente supor que para tal é preciso dispor algumas ações e dispositivos voltados exclusivamente a este fim. Apenas a conexão a rede não é garantia de que as interações sociais em instâncias locais serão incrementadas. Outros exemplos de iniciativas, como Camfield Estate e Making Healthy MUSIC, confirmam que as interações online e face-a-face são potencializadas quando se dispõem de instrumentos online e offline especificamente planejados para criar conexões entre pessoas, e outras instâncias locais. É preciso que se ofereçam meios que possibilitem o engajamento comunitário via tecnologia digital. 


\subsection{Aspectos estruturais de iniciativas envolvendo IIC}

Destacam-se aqui aspectos distintos relacionados à estrutura de implementação de iniciativas envolvendo TIC. Discorre-se, a princípio, sobre as especificidades dos instrumentos tecnológicos, e sobre questões relativas a conectividade, hardware e software. Depois se volta aos meios disponíveis de apreender a realidade socioeconômica e cultural das comunidades locais sujeitas às ações de iniciativas desta natureza. Como se disse, trata-se de uma de suas feições metodológicas. Por último, discute-se neste contexto avaliações, sustentabilidade e interfaces.

\subsection{Instrumentos tecnologicos}

Alguns pesquisadores consideram que hoje, de certa forma, a tecnologia não oferece mais empecilho algum aos projetos vinculados às TIC. “[...] os obstáculos para a difusão de tal tecnologia não são tecnológicos, mas sociais, econômicos e políticos” (WARSCHAUER, 2006, p.110). Segundo o autor, estes projetos estão sujeitos à vontade política de incentivar tecnologias voltadas às necessidades das populações de baixa renda, que são apenas mercado potencial e não mercado existente. Neste contexto, tecnologia diz respeito especificamente aos meios técnicos necessários para fazer uso pleno das possibilidades apresentadas pela chamada sociedade da informação. Envolve toda a infra-estrutura de conexão a internet; os equipamentos informatizados que permitem o acesso a rede e a produção de informação e conhecimento, o hardware; além dos sistemas lógicos, os software. 
Procura-se, aqui, tratar de algumas especificidades dos instrumentos tecnológicos que de uma forma, ou de outra, podem influenciar aspectos das iniciativas e projetos, discutir a respeito das possíveis relações existentes entre características e qualidades de equipamentos, conexões e programas, e a apropriação devida ou indevida das TIC. Trata-se de demarcar, se possível, as coerências entre os meios disponíveis, seja conexão, hardware ou software, e os desempenhos pretendidos. É importante assinalar, neste contexto, que para além da disponibilização desses recursos materiais, o suporte técnico e operacional assume papel primordial. É comum o relato de projetos que permanecem inoperantes por determinado período de tempo por falta de assistência técnica especializada. É preciso que se tenha estratégias de manutenção e suporte técnicos constantes e permanentes, do contrário, corre-se o risco de atenuar qualquer prática de planejamento, a curto, médio ou longo prazo.

\section{Conectividade}

Gaved e Mulholland (2005) relatam o comentário de um dos usuários dos projetos que estudam: "se o computador está offline ele é somente $10 \%$ da máquina que é quando está online.”66 Oportunamente já se discutiu a importância atribuída hoje a qualidade de conexão a internet, que contribui para a manutenção ou não de desigualdades. Também foi dito que o desempenho técnico dos equipamentos e conexões está diretamente associado à qualidade da relação que as pessoas estabelecem com as TIC. É presumível que a experiência de uma pessoa que acessa internet banda larga seja diferente daquela que acessa numa velocidade de transmissão de dados considerada lenta. Para Castells (apud SERVON, 2002, p.xviii) "banda larga é essencial para se usar realmente as possibilidades da internet como um meio de comunicação e um sistema de informação". ${ }^{67}$ Silveira (2005b) destaca que as decisões a

\footnotetext{
${ }^{66}$ Tradução da autora. No original: "One user commented that 'if the computer is offline it's only $10 \%$ of the machine it is when it's online"'.

67 Tradução da autora. No original: "Broadband is essential to really use the possibilities of Internet as a communication medium and as an information system."
} 
respeito de equipamentos e conexões podem determinar o sucesso ou não de uma iniciativa envolvendo TIC. DiMaggio e Hargittai (2001) também alertam para o fato de que equipamentos e conexões inferiores tecnicamente podem reduzir direta ou indiretamente os benefícios que os usuários podem ganhar da internet.

Primeiro, usuários com conexões lentas, software desatualizados, e hardware obsoletos são simplesmente incapazes de acessarem determinados sites. Segundo, porque sua experiência na web é menos gratificante, eles provavelmente usam a internet menos e adquirem menos as habilidades que possibilitam os usuários obterem todos os benefícios que o acesso pode prover ${ }^{68}$ (DiMAGGIO; HARGITTAI, 2001).

É oportuno destacar, neste contexto, as considerações apresentadas no trabalho de Gaved e Anderson (2006) que enfatizam que os propósitos sociais que se desejam alcançar em uma iniciativa TIC é que devem definir os requerimentos físicos e aparatos técnicos necessários, não o contrário.

\section{Hardwaree periféricos}

A importância que a disponibilização de hardware possui em iniciativas inclusivas já foi mencionada, especificamente em relação às soluções de produção de equipamentos de baixo custo e às políticas de fomento a aquisição de computadores. Pretende-se destacar aqui a relação entre as iniciativas TIC e equipamentos do ponto de vista da experiência do usuário. Uma questão recorrente neste contexto é que os projetos vinculados à chamada inclusão digital, principalmente os financiados pelo governo, devem beneficiar a comunidade e não o indivíduo em particular. Adotam-se posturas em que a aquisição de habilidades básicas para o uso das tecnologias deve ser exercida a favor dos interesses

\footnotetext{
${ }^{68}$ Tradução da autora. No original: "First, users with slow connections, older software, and old hardware are simply unable to access certain sites. Second, because their experience on the Web is less gratfying, they are likely to use the Internet less and acquire fewer of the skills that enable users to derive the full benefits that access can provide."
} 
comunitários, em primeiro lugar, e depois, se possível, das necessidades particulares, individuais. 0 foco, a meta, deve ser o que se considera de interesse público, comum, e não pessoal. Isto seria pertinente se em determinadas situações não limitasse a qualidade da experiência com TIC dos usuários.

É certo que equipamentos e conexões mais potentes, com melhores configurações, abrem portas ao desenvolvimento de possibilidades e experiências mais ricas com as tecnologias, sendo que o contrário também parece verdadeiro. A adoção de terminais thin client, em rede, pela grande maioria dos projetos inclusivos centrados em telecentros parece pertinente. ${ }^{69}$ Além de mais baratos, facilitam a manutenção, pois não necessitam de upgrade, não correm o risco de sofrer ataques de vírus, entre outros. Mas estes equipamentos, muitas vezes, estão desprovidos de drivers de disquetes e CD-ROM, e de saídas tipo USB, o que impossibilita ações básicas aos usuários, como a gravação de cópias dos resultados de seus trabalhos, ou a utilização dos conteúdos digitais por eles desenvolvidos, inclusive a partir de outros dispositivos como telefones celulares, impondo limites às suas ações. Trata-se de elementos básicos que configuram os microcomputadores, cuja ausência não deveria se justificar pelo fato de se tratar de projetos coletivos, ou ainda pela falta de recursos financeiros.

A questão é que a riqueza das experiências e possibilidades que as tecnologias podem proporcionar também depende, em maior ou menor grau, da qualidade dos equipamentos disponíveis. Ter a disposição não só hardware de qualidade, mas uma diversidade de dispositivos, como câmeras fotográficas e filmadoras digitais, web câmeras, impressoras, scaners, equipamentos de áudio, pode ampliar de forma significativa as possibilidades de ações com TIC. ${ }^{70}$ Principalmente porque a produção

\footnotetext{
${ }^{69}$ Thin-clients são máquinas dotadas de arquiteturas de hardware que possuem baixa capacidade de processamento e pouca memória, têm poucos (ou nenhum) aplicativos instalados, e dependem de uma rede e de um servidor central para o processamento de atividades.

${ }^{70}$ É importante destacar que iniciativas envolvendo TIC deveriam considerar, cada vez mais, a utilização de dispositivos móveis que têm se tornado bastante acessíveis a uma camada cada vez maior da população. Estes equipamentos têm permitido outras
} 
de conteúdos, principalmente daqueles que iniciam seus contatos com as tecnologias digitais e possuem dificuldades inclusive com a linguagem verbal escrita, deve contemplar outras formas de expressão, a utilização de linguagens outras, que os equipamentos multimídia podem oferecer. Em alguns casos, os recursos multimídia parecem se tornar elementos fundamentais de iniciativas TIC, porque constituem

peças chaves para a inserção dessas tecnologias nas narrativas cotidianas das pessoas. Pode-se dizer que no caso da alfabetização tecnológica realizada pelos telecentros NCCs de Extremadura, estruturada a partir de projetos e atividades, tais equipamentos são fundamentais. Fazem parte dos equipamentos básicos desses um telecentros computadores com acessórios como microfones, caixas de som, e webcam, scaner, câmera fotográfica digital, gravador de áudio digital, e impressora. Para uso comum nos NCCs se tem disponível datashow, gravadora de CD-ROM, câmera digital de vídeo, e ainda uma equipe que auxilia a realização de videoconferências (EQUIPO TÉCNICO AUPEX, 2001).

\section{Software}

A questão central quando se trata da relação entre software e iniciativas envolvendo o uso das TIC é a adoção ou não de software livre. É difícil, porém, situar esta questão apenas como sendo de caráter técnico, porque ela é, antes de tudo, assumida como ideológica.

A preferência pelos programas livres e abertos, baseados quase exclusivamente no sistema operacional GNU/Linux, está centrada não apenas na ausência de pagamento de licenças de uso, mas no fato de 
que possuem código-fonte aberto, o que possibilita utilizá-los, adaptá-los, alterá-los e aperfeiçoá-los de acordo com necessidades específicas, e distribuí-los livremente. ${ }^{71}$

A essência do software livre reside em quatro liberdades que seus usuários devem exercer: Liberdade de executar o programa para qualquer propósito. Liberdade para estudar o programa e adaptá-lo às suas próprias necessidades, ter acesso a seu código-fonte. Liberdade de redistribuir suas cópias originais ou alteradas. Liberdade para aperfeiçoar o programa e liberá-lo para benefício da comunidade (SILVEIRA, 2001, p.38).

É irrefutável que tais características estão diretamente associadas a democratização em amplo sentido que as iniciativas baseadas na chamada inclusão digital pressupõe e estão vinculadas. A hegemonia e monopólio de mercado exercidos pela Microsoft, por exemplo, não deveriam se sustentar neste cenário, embora haja ainda iniciativas inclusivas que utilizam exclusivamente seus programas.

Assim como o modelo de distribuição gratuita do software livre não pressupõe gratuidade em todos os sentidos $^{72}$, o argumento que defende o uso de software proprietário, ainda o mais utilizado proporcionalmente em diferentes ambientes de trabalho, baseado num suposto favorecimento da empregabilidade pode ser contestado. Já foi dito, oportunamente, que o conhecimento em informática, de maneira geral, não é garantia de emprego. Mesmo assim, é preciso considerar que, cada vez mais, os sistemas operacionais e demais software, proprietários e livres, utilizam-se do mesmo modelo conceitual, inclusive de usabilidade, o que faz com que a utilização deste ou daquele seja muito parecida. As tão alegadas dificuldades de utilização por não especialistas do software livre, considerados não "amigáveis”, não existem mais, e os problemas relacionados a integração de sistemas

\footnotetext{
${ }^{71}$ Estes programas estão disponíveis a partir da GPL - General Public License (Licença Pública Genérica). Criada pela Free Software Foundation a GPL permite aos autores de software distribuírem livremente seus códigos com a garantia de que os desenvolvedores que os utilizarem manterão códigos modificados em GPL também, ou seja, irão mantê-los aberto.

72 "O software livre não é necessariamente um software gratuito" (SILVEIRA, 2001, p.38). A fonte de receita dos desenvolvedores destes programas é a prestação de serviços de suporte, e não a comercialização de licenças de uso.
} 
operacionais e a compatibilização de plataformas tecnológicas heterogêneas estão cada vez mais sendo solucionados.

É sabido que grande parte dos usuários domésticos, pelo menos no Brasil, usa cópias de programas que possuem direitos reservados sem pagar algum tipo de licença de uso. Esta prática, segundo os defensores do software livre, é de interesse do mercado de software proprietário, porque induz ao uso massivo de seus produtos. De forma direta e espontânea, as pessoas são treinadas, habilitadas, capacitadas, a serem usuárias de determinados programas. 0 que alimentaria um contexto permanente de subordinação tecnológica. O compartilhamento de códigos, possibilitados pelo software livre, associado a práticas de treinamento e capacitação de desenvolvedores, ao contrário, estaria associado a idéia de protagonismo, tão cara ao contexto inclusivo.

É preciso considerar também que, se por um lado, a implementação de software livre pode baratear os custos de implantação e manutenção de programas e sistemas em iniciativas inclusivas, por outro, ainda há a dificuldade de disponibilização de mão-de-obra técnica especializada nesta área. 0 desenvolvimento e aplicabilidade do software livre dependem igualmente da formação dos chamados desenvolvedores, e também da capacitação de pessoas voltadas à manutenção. Muitos defendem a transferência de dinheiro gasto com patentes para a formação dessas pessoas. À comunidade daqueles que trabalham com programação de software livre e aberto de forma colaborativa contrapõem-se a dos utilizadores, que são os usuários comuns não interessados em serem programadores ou se ocuparem em desenvolver software, que em certo sentido, precisam de auxílio técnico, nem sempre tão disponível.

Hoje, a opção pelo não uso de software livre em iniciativas envolvendo TIC não se sustenta mais por motivos técnicos. Já é bastante aceito que o software livre possui diversas qualidades técnicas e econômicas, além de ser socialmente justo. "Tecnicamente o software livre é superior. É mais robusto, mais flexível, menos sujeito a invasões e vírus. Mas o software proprietário também funciona de forma adequada na maioria dos casos, e a discussão mais interessante sobre vantagens e desvantagens passa 
somente tangencialmente pela questão puramente técnica" (CAMPOS, 2005). 0 que parece fundamental destacar é que este contexto é ainda bastante complexo, permeado por uma realidade bastante desafiadora, que inclui as questões relativas a migração entre sistemas, a posicionamentos políticos e de governo, a direitos autorais, entre outros. De qualquer modo, é um cenário permeado por discursos ideológicos de um lado e preconceitos do outro, onde estudos e avaliações aprofundados, embasados conceitualmente, isentos de qualquer interesse específico, poderiam ser de grande auxílio.

\subsubsection{Aproximaçōes com o contexto sócio-econômico-cultural}

Um dos pontos mais importantes em iniciativas TIC diz respeito ao contexto sócio-econômico-cultural envolvido nos projetos. Identificar as principais características dos potenciais usuários ${ }^{73}$ desses projetos, assim como das localidades e comunidades as quais pertencem, é tarefa primordial, que pode determinar uma série de aspectos que os molduram.

O conjunto de usuários, muitas vezes denominados população-alvo, pode ser definido, descrito e delimitado a partir de vários fatores, de acordo com a natureza da iniciativa em questão. Em projetos centrados em localidades físicas, por exemplo, podem ser os moradores de determinados conjuntos habitacionais, comunidades, bairros, e até cidades; em projetos acadêmicos, os usuários são definidos a partir de recortes em determinadas amostragens, como por exemplo, os dezessete alunos portadores

\footnotetext{
${ }^{73}$ É importante destacar que a adequação dos termos empregados para nomear as pessoas envolvidas nessas iniciativas não é consensual. Poderia-se elencar inúmeras apropriações e inconveniências neste contexto, o que levaria a discussões, embora pertinentes, bastante paralelas.
} 
de diferentes necessidades especiais em pesquisa realizada na Unesp Presidente Prudente. ${ }^{74}$ Os usuários podem, então, variar tanto quantitativamente, como podem adquirir, qualitativamente, status diferenciado. Podem ser definidos segundo categorias, a partir de características etárias, étnicas, de gênero, nível de escolaridade, classe social e renda, portabilidade de necessidades especiais, entre outros; ou mesmo a partir de estruturas determinadas pelo formato familiar, por grupos sociais específicos (desempregados, pequenos empresários, donas-de-casa, etc.), por organizações sociais (associações comunitárias, instituições públicas, etc), entre outros. No projeto Making Healthy MUSIC, desenvolvido pelo Media Lab do Massachussets Institute of Techonology, os participantes deveriam ter crianças atendidas em uma determinada escola primária e serem residentes de um determinado conjunto habitacional. Os NCCs de Extremadura se destinam a todos os âmbitos de atividades e setores sociais e profissionais da região de Extremadura, Espanha: empresários, trabalhadores, desempregados, mulheres, adultos, jovens, organizações sociais e culturais e, em geral, a toda a população, principalmente com menores possibilidades de acesso as TIC.

Hoje, são comuns tanto iniciativas destinadas a públicos muito abrangentes como a públicos muito específicos, fato que, por si, envolve diferentes implicações, seja com relação a proposições, financiamentos, objetivos, instrumentos tecnológicos, estrutura, entre outros. Avaliar as diferenças e similaridades entre projetos voltados especialmente a jovens, desempregados, mulheres, portadores de necessidades especiais, entre outros e estabelecer paralelismos entre si e com projetos que compreendem usuários não determinados por uma ou mais características específicas seria pertinente, um trabalho exaustivo de grande valor, mas que ultrapassa os objetivos deste estudo. A tarefa que se faz premente aqui, principalmente pelo recorte temático da pesquisa, é pensar nos caminhos disponíveis que podem levar a aproximação e apreensão das realidades nas quais estão imersas as

\footnotetext{
${ }^{74}$ Trata-se de pesquisa do grupo Ambientes Potencializadores para Inclusão, do Grupo de Pesquisa e Suporte em Educação e Tecnologia, da Faculdade de Ciências e Tecnologia. Ver SPIGAROLI, A. et al. As Tecnologias de Informação e Comunicação (TIC) como ferramentas potencializadoras para a inclusão: um desafio para a sociedade. In: PELLANDA, N.; SCHLÜNZEN, E.; SCHLÜNZEN JR., K. (Org). (2005). Inclusão digital: tecendo redes afetivas / cognitivas. Rio de Janeiro, DP\&A.
} 
comunidades, e conseqüentemente, os possíveis usuários, alvos de iniciativas voltadas a população em situação de vulnerabilidade social.

\section{Agências oficiais, dados numericos}

Pode parecer óbvio pensar que se deva levar em conta o contexto sócio-econômico-cultural dos usuários na implantação de projetos desta natureza, mas no momento primeiro que se desenha um programa que se pretenda reprodutível ou expansível este fator ganha pesos e dimensões próprios. A obviedade parece vir da constatação de que contextos diferentes exigem conformações diferentes. E aí é que se coloca a questão: como deve se estruturar um projeto abrangente para que possa acomodar diversidades locais? Quais aspectos podem se manter imutáveis e quais podem variar de acordo com o contexto local? Ainda assim, mesmo em projetos únicos é preciso considerar, especificamente, a natureza do perfil sócio-economico-cultural da comunidade, e é preciso saber como conhecer os contornos da comunidade na qual vai se intervir. O objetivo maior é ter as conformações locais como parâmetro, para ter em mãos dados e informações a partir dos quais é possível concretizar as propostas inclusivas.

Trata-se, em primeiro plano, das configurações dos padrões sociais, econômicos e culturais de vida, de comportamento, de organização de uma determinada população, por meio de uma integração de variáveis múltiplas. Estas variáveis englobam aspectos demográficos, como estrutura etária, gênero e composição familiar; informações sobre migração; aspectos relacionados ao trabalho, como a oferta de empregos, desemprego e subemprego; características educacionais, como analfabetismo e defasagem escolar, também englobam informações sobre questões de saúde, previdência social, programas sociais compensatórios, segurança e justiça, condições de habitação e saneamento básico, infra-estrutura de telecomunicações, entre outras. Saber identificar como foram feitas avaliações e levantamentos de 
dados a respeito dos usuários finais em uma determinada iniciativa faz-se importante. Possibilita, no limite, tecer considerações sobre as possibilidades dos níveis de adequação aos recursos que estarão sendo oferecidos e disponibilizados. Há uma diferença significativa entre basear estudos sobre um determinado contexto em dados estatísticos e por meio de levantamentos específicos, pontuais, e direcionados.

Embora os dados estatísticos estejam, em certa medida, na maioria dos países, disponíveis a partir das diversas agências governamentais especializadas em coletas e análises sistemáticas de dados, e do fato de que a seleção e agrupamento de alguns indicadores poder gerar classificações bastante fiéis quanto à estrutura social, econômica e cultural de uma determinada região geográfica, nem sempre a imersão em dados objetivos, baseados em levantamentos estatísticos confiáveis, é o caminho mais apropriado para traçar o perfil de uma comunidade. Estes dados fornecem informações preciosas, pelo menos num primeiro momento, a projetos de grande porte, seriáveis, onde é preciso definir pontos de intervenção, localidades, dentro de grandes áreas. São os projetos que se estabelecem como políticas públicas federais, ou mesmo regionais. São projetos modulares, aplicáveis a determinadas localidades que são justamente definidas a partir de alguns de padrões demográficos e/ou socioculturais determinados por dados e índices estatísticos. O projeto Casa Brasil, por exemplo, tem como critério "funcionar em áreas de exclusão social, com baixo Índice de Desenvolvimento Humano - IDH, de grande densidade populacional e com fácil acesso à população do entorno; e ser instalada e mantida em espaços laicos" (CASA BRASIL, 2007). E se implanta territorialmente a partir da seguinte lógica:

As capitais que possuem população acima de um milhão e duzentos mil habitantes poderão ser contempladas com até 3 (três) unidades do Projeto Casa Brasil. As capitais que possuem população de setecentos mil e um até um milhão e duzentos mil habitantes poderão ser contempladas com até 2 (duas) unidades do Projeto Casa Brasil. As capitais que possuem população até setecentos mil habitantes poderão ser contempladas com 1 (uma) unidade do Projeto Casa Brasil. Excluídas as capitais, 6 (seis) cidades na região Centro-Oeste e 7 (sete) 
cidades nas demais regiões do país sendo distribuídas pela ordem de maior população visando atingir um maior número de Estados por região, ressalvadas as cidades de população inferior a 50.000 mil habitantes. Na hipótese de não haver candidato para as cidades relacionadas, será selecionada a cidade de maior população no respectivo estado entre as relacionadas nas tabelas de localidades suplementares (CASA BRASIL, 2007).

A definição de aspectos dos projetos vinculados às TIC tendo por base regras fechadas e normas préestabelecidas, determinadas por instrumentos criados por uma gestão com excesso de formalidades, pode levar a realizações concretas diferentes das planejadas, a incertezas de se estar agindo da forma desejada junto àqueles que realmente se quer atingir. Ter como referência dados estatísticos é um aspecto importante no rol dos múltiplos aspectos que tecem a implantação de projetos de grande abrangência, principalmente quantitativa, entretanto, apresenta implicações que merecem ser consideradas. Rizek (2007) alerta para o fato de que narrativas e comentários, obtidos principalmente através de questionários e entrevistas, podem publicizar algumas dimensões, ainda que mesmo parciais que, freqüentemente estão ocultas em mapas e estatísticas, em índices objetivos, em leituras de quantidades, em expressões em números.

\section{Recortes locais, açöes participativas}

Existem outros meios de aproximação do contexto de uma comunidade local, também metodologicamente aceitos, que privilegiam contatos diretos, e se constituem importantes ferramentas, principalmente quando o objetivo é a formulação de diagnósticos. Observação participativa, etnografia, entrevistas, aplicação de questionários, consultas de impressões, representações construídas pelas pessoas pertencentes à comunidade, são importantes instrumentos de coleta de dados, e podem se sobrepor às informações geradas pelos indicadores de natureza estatística citados acima. Um diagnóstico gerado a partir da própria comunidade, contando com a colaboração dos diversos agentes sociais presentes na vida diária da localidade, ou seja, as instituições públicas e 
privadas, organizações não-governamentais e associações comunitárias, pode ter a capacidade de deixar transparecer particularidades da comunidade, e de desenhar com mais precisão a estrutura social a qual se está vinculado. Segundo Warschauer,

[...] todos os níveis de análise (organizacional, institucional e da sociedade) social se sobrepõem. Cada um aponta para o papel crítico das estruturas sociais na moldagem de como a tecnologia se propaga, e para a correspondente importância da análise social e dos objetivos sociais no planejamento dos projetos de desenvolvimento da TIC (WARSHAURER, 2006, p. 282).

É importante destacar que, em geral, grande parte dos projetos baseados em ações que visam prover acesso físico a equipamentos e internet levam em conta indicadores na forma de números. Poderia se indagar se este fato influi na qualidade das propostas desta natureza. Acredita-se que os projetos que visam uma proximidade na relação com usuários finais, e uma maior inserção significativa das TIC à realidade dessas pessoas, deveriam levar em conta informações geradas a partir da própria comunidade. DiMaggio e Hargittai (2001) destacam que a possibilidade dos usuários usarem a internet de acordo com os propósitos que eles mesmos escolheram estaria ligada a satisfação desses usuários; quando não se percebe razão para o uso da tecnologia, ela pode ser descartada como irrelevante.

Como destacado, para uma aproximação com as potencialidades, necessidades e desejos dos usuários, no sentido de conhecer o contexto local, perceber demandas, elaborar planos de ações a longo prazo, ou mesmo projetos pontuais a serem postos em prática por um curto período, deve-se contar com o apoio das lideranças locais, das suas instituições e organizações. É o que faz os dinamizadores sociais dos NCCs de Extremadura. Em Camfield States utiliza-se a ferramenta metodológica Asset-Based Community Development ( $A B C D)$, apresentada adiante, para identificar recursos comunitários relevantes, para desenhar as estratégias de organização da própria experiência (PINKETT, 2002). É um exemplo, entre outros, de aproximação com a vida comunitária através do levantamento de suas potencialidades, de suas qualidades e não apenas de suas necessidades, carências e demandas. 


\subsubsection{Estrutura de implementação}

Como se viu, uma iniciativa envolvendo TIC pode assumir conformações múltiplas, pode estruturar-se de diferentes maneiras. Trata-se aqui de três aspectos fundamentais que tais iniciativas podem ou não abarcar, e das implicações decorrentes de se incluir ou não ações mais amplas dentre os seus propósitos. Discute-se, em específico, o papel das avaliações, da chamada sustentabilidade e das interfaces computacionais no escopo desses projetos.

\section{Avaliaç̃os e monitoramentos}

Muitas das experiências apresentadas aqui foram implantadas durante a década de 1990 e o início da década de 2000. Boa parte dessas experiências já terminou, boa parte está em curso. Nota-se, a este respeito, implicações importantes no campo das pesquisas, análises e aferição de dados e resultados. Muitas iniciativas vinculadas a pesquisas acadêmicas, com temática relacionada à sociabilidade a partir da internet, foram realizadas em diferentes momentos, dentro deste curto período de tempo, o que, ainda assim, pode significar contextos e estágios distintos de desenvolvimento das TIC. Fato que pode inviabilizar comparações e paralelismos entre estes estudos (GAVED; ANDERSON, 2006). O contexto das TIC possui vínculos muito estreitos com o desenvolvimento tecnológico, seja em hardware, software e outros, que faz com que muitos dispositivos se tornem obsoletos numa rapidez estrondosa, e que surjam de forma constante novas possibilidades técnicas. Esta quase instantaneidade de alterações, que abrange outros níveis também, como o crescente número de usuários da internet, aliada à característica da própria construção do meio através do uso, das ações concretas e não previstas de antemão, implicam limitações às avaliações. Estas limitações se apresentam principalmente nas dificuldades quanto às comparações, principalmente em relação a métodos, e a aferição de resultados, 
e possibilidade de proceder a afirmações gerais e conclusões definitivas. DiMaggio e Hargittai (2001) alertam para o fato: “[...] nós acreditamos que as questões e métodos de pesquisa apropriados para elucidar as questões de igualdade [de acesso] são diferentes agora em relação do que eram nos primeiros estágios de difusão da internet."75

Mesmo tendo como horizonte este contexto de difícil apreensão, as avaliações de iniciativas ligadas às TIC são imprescindíveis, porque estão relacionadas a perspectivas de realimentação dos projetos, porque a partir delas se pode criar parâmetros consensuais, por exemplo, em relação ao que significam resultados positivos nesta área. Parâmetros para o que se pode considerar fundamental e secundário, para o que se pode ou não chamar de boas práticas, ou mesmo, para o que se considera como iniciativas bem sucedidas. Como destacado oportunamente, são as avaliações que permitem também as experimentações, a adoção e criação de novas possibilidades. Mesmo assim, ainda são poucas as iniciativas que dedicam a devida atenção às questões avaliativas, exceto às que possuem fortes vínculos com instituições acadêmicas. É quase impossível aferir sobre a qualidade das ações desta natureza porque falta desenvolver metodologias específicas de monitoramento e avaliação que considerem, entre outros, a necessidade de se estabelecer parâmetros de comparação entre ações específicas. A avaliação em projetos voltados à chamada inclusão digital não é uma rotina. Faltam indicadores comuns para avaliar os projetos como um todo, e mesmo questões específicas, como por exemplo, as vantagens econômicas e sociais que as TIC eventualmente trazem às comunidades locais, os efeitos nas interações sociais, a relação entre TIC e empregabilidade, a satisfação dos usuários, entre tantos outros.

Em algumas iniciativas há a preocupação em se criar instrumentos de aferição de resultados com relação aos próprios objetivos e metas, o que é relevante dentro deste contexto. 0 perigo é que tais

75 Tradução da autora. No original: "But we believe that the research questions and methods appropriate for illuminating distributive issues are different now than they were at an earlier stage of the Internet's diffusion." 
instrumentos, sendo parciais e exclusivos a determinados projetos, podem levar a uma certa tautologia, a um caminhar em círculos, e não a um avanço. Como destacado, tanto a implantação como a manutenção de iniciativas envolvendo TIC são processos bastante complexos, e deveriam demandar monitoramento constante, avaliações permanentes e ações de re-planejamento, quase inexistentes em projetos desta natureza. O cenário aqui é a estruturação de ações ligadas a questões que são, ao mesmo tempo, muito novas e urgentes, e que requerem um conjunto eficiente de atuações coordenadas. Um sistema de monitoramento e avaliação adequado pode ser o caminho mais curto para concretizar tais ações de forma satisfatória, isto se inserido e adotado como prática permanente, inerente a estas iniciativas.

\section{Sustentabilidade ${ }^{76}$}

Gaved e Anderson (2006) citando Farr e Papandrea (2004 apud GAVED; ANDERSON, 2006) ${ }^{77}$ definem três estruturas chave independentes para o estabelecimento e sustentabilidade de iniciativas envolvendo TIC: (1) recursos financeiros, (2) empoderamento comunitário ${ }^{78}$ e impacto socioeconômico, e (3)

\footnotetext{
${ }^{76}$ Sustentabilidade é um destes termos que estão na ordem do dia. Entretanto, o conceito de sustentabilidade é utilizado quase sempre de forma inapropriada, porque implica necessariamente múltiplas dimensões e diversas matrizes discursivas: social, econômica, ecológica, política, entre outras. Grosso modo, neste contexto, sustentabilidade pode ser pensada como uma idéia relacionada à continuidade de aspectos econômicos, sociais e culturais. No âmbito econômico, diz respeito aos aportes financeiros de determinados projetos para que possam funcionar de forma efetiva depois que uma presumida assistência financeira externa acaba.

77 FARR, P; PAPANDREA, F. (2004). Achieving sustainable community online access centres. Connecting societies and markets: communication technology, policy and impacts: ITS 15th Biennial Conference Berlin, Germany, Sep., 2004. Berlin: Elsevier.

${ }^{78}$ Termo também de uso trivial, tradução livre do inglês empowerment, em voga principalmente nos contextos ligados às áreas de desenvolvimento social. "[...] o empoderamento como um objetivo operacional é atualmente muito evidente nas políticas e nos programas das ONGs nacionais e internacionais. Também já começa a ter influência crescente nas agências de desenvolvimento bilaterais e multilaterais. Apesar disso, continua sendo um termo complexo que não se define facilmente e que está aberto a uma variedade de interpretações. [...] Quando falamos de processo de 'empoderamento', nos referimos à posições relativas ao poder formal e informal desfrutado por diferentes grupos socioeconômicos, e às conseqüências dos grandes desequilíbrios na distribuição desse poder. Um processo de empoderamento busca intervir nestes desequilíbrios e ajudar a
} 
operações eficientes e sistemas de suporte. À parte a complexidade que o conceito sustentabilidade abarca, sabe-se que nesse plano ela estaria associada não só a estabilidade financeira, mas também a estabilidade social, o envolvimento comunitário, aspectos tão caros a projetos desta natureza.

Porém, é a auto-sustentabilidade relacionada a recursos financeiros uma das questões mais polêmicas quanto se trata de iniciativas inclusivas. ${ }^{79}$ Principalmente quando o modelo adotado é o do telecentro. Neste contexto, há quem defenda de forma incisiva o acesso universal e gratuito como responsabilidade do poder público e se posicione contra toda e qualquer forma de remuneração em relação às ações desenvolvidas em centros considerados de inclusão digital. Para os defensores de políticas públicas, o acesso aos benefícios que os meios digitais proporcionam são direitos básicos dos cidadãos como também o direito à moradia, saneamento básico, assistência à saúde, educação, entre outros. Nesses casos a ausência de qualquer tipo de investimentos por parte dos usuários nestes projetos é considerada essencial, ponto pacífico. Por outro lado, há quem acredite que a auto-sustentabilidade está relacionada a medidas necessárias que podem se reverter em caminhos alternativos e benéficos aos projetos inclusivos. Neste sentido, é vista como política de redução de danos, ou como caminho único e estratégico de viabilidade, e mesmo como a única possibilidade de um projeto garantir a sua continuidade. Para muitos projetos que dependem do setor público, seria também uma forma de se precaverem da sujeição às vicissitudes políticas.

Tem-se discutido muito, principalmente nos países em desenvolvimento, não só sobre o papel do governo como financiador permanente de benefícios envolvendo TIC, como os modelos de sustentabilidade financeira para tal iniciativas. Na concepção de alguns, a continuidade dos projetos propostos e implantados pelo governo deveria, depois de um certo tempo, ser assumida pelos próprios

aumentar o poder daqueles grupos 'desprovidos de poder', relativamente aos que se beneficiam do acesso e uso do poder formal e informal” (OAKLEY; CLAYTON, 2003).

79 "Auto-Sustentação: estado alcançado por uma organização quando consegue gerar - por meio de suas próprias atividades as receitas necessárias para garantir o financiamento de todos os seus programas e projetos” (AUTO-SUSTENTAÇÃO, 2007). 
usuários ou comunidades beneficiadas, através, por exemplo, da cobrança de serviços. 0 projeto Casa Brasil do governo federal brasileiro, por exemplo, foi concebido para ser administrado por instituições hospedeiras que devem implantar um programa de sustentabilidade para suas unidades a partir de um ano de funcionamento, de acordo com as suas potencialidades. O governo, teoricamente, assumiria os gastos de implantação e funcionamento da unidade por um ano, e daria suporte administrativo durante este mesmo período. Depois deste tempo, o conselho gestor das unidades seria responsável por colocar em prática o plano de sustentabilidade criado e pré-aprovado.

\section{Interfaces computacionais ${ }^{80}$}

As questões relacionadas à estruturação das chamadas interfaces computacionais em iniciativas ligadas ao uso das TIC comumente não recebe devida importância. Grande parte das iniciativas estudadas que objetivam especificamente a criação de ambientes virtuais de interação social para comunidades locais se apropria do modelo de interface gráfica de tela tipo portal web, composto de uma série de menus e links, uma porção significativa de informações textuais, às vezes permeadas por imagens, agregando, em alguns casos, algumas ferramentas de trocas de mensagens tipo chat ou fórum. ${ }^{81} \mathrm{Um}$ dos principais argumentos para justificar a utilização deste modelo como padrão tem sido a rápida apreensão e a facilidade de interação. Trata-se, supostamente, de uma interface fácil de ser manipulada pelos usuários. Pode-se dizer que esta característica está associada, grosso modo, a reprodução que os portais apresentam de uma lógica de estruturação informacional de outros meios de comunicação, como o jornal impresso, por exemplo. Parece que a opção foi transpor para o meio eletrônico a linguagem de uma mídia já conhecida pelos usuários, a qual estejam acostumados. E neste sentido,

\footnotetext{
${ }^{80}$ O capítulo 3 desta tese trata especificamente do tema interfaces computacionais. Aqui cabe pontuar algumas poucas questões desse assunto no contexto das iniciativas estudadas.

${ }^{81}$ Ver, no Apêndice A, as iniciativas NetVille, Blacksburg Electronic Village, Camfield Estate, Helsinki Virtual Village, Solonópole, entre outras.
} 
coloca-se de lado a exploração dos recursos potenciais oferecidos pelo meio digital, inclusive a internet, minimizando suas características peculiares, minando possibilidades de exploração de novas linguagens. Outra característica também comum à maioria dessas interfaces é a estruturação a partir de metáforas, de várias naturezas. O risco que se corre com a utilização destes recursos é também negligenciar novas potencialidades criativas.

As interfaces computacionais parecem receber atenção no contexto de projetos envolvendo TIC quando estão voltadas a um público particular, seja de não alfabetizados, de pessoas pertencentes a comunidades iletradas que possuem grande tradição oral, quando se trata de portadores de necessidades especiais, entre outros. Nestes casos ganha status de elemento central no processo dito de inclusão digital. 0 uso de aplicativos, em alguns casos de hardware, especialmente desenvolvidos é considerado, neste contexto, os instrumentos potenciais para superar ou minimizar as barreiras com o mundo físico e social. 0 desenvolvimento de interfaces se destaca nas experiências de VAN Bohechio, na República Dominicana, SARI, na Índia, Making Healthy MUSIC, nos Estados Unidos, e, em certo sentido, em Pantin, na França. Estes projetos apresentam interfaces que, embora restritas às telas, se propõem a trabalhar linguagens alternativas, a explorar potencialidades dos meios, ou mesmo a desenvolver conteúdos específicos para as comunidades as quais se destinam. O CKS - Community Knowledge Sharing desenvolvido para VAN Bohechio e o ambiente virtual de Les Courtillières de Pantin são bons exemplos de adequação entre os potenciais usuários, as linguagens e conteúdos oferecidos. 


\subsection{Iniciativas envolvendo IC: universo dos possiveis}

\section{Instâncias privadas, coletivas e virtuais}

Em geral, as práticas ligadas às TIC em comunidades de base local, ou seja, em espaços territoriais delimitados, podem se dar em três frentes de ações. Uma primeira envolve diretamente os espaços privados dos indivíduos e famílias, uma segunda envolve os espaços comunitários, dos grupos, e por fim, uma terceira envolve apenas instâncias virtuais. São ações centradas na provisão de equipamentos e conexão nas moradias, na implantação de telecentros, e no desenvolvimento de plataformas web, respectivamente. Nada impede, porém, que muitas dessas iniciativas se estruturem a partir de combinações dessas ações. Nas experiências estudadas, especificamente em NetVille, Making Healthy MUSIC, Blacksburg Electronic Village, The HomeNet Project, e Helsinki Virtual Village, as pessoas circunscritas em determinadas territorialidades têm acesso a computadores e internet a partir de suas próprias casas. Nas experiências Les Courtillières de Pantin, Information Technology Initiative, VAN Bohechio, NCC-Extremadura e SARI, o acesso se dá por meio de instâncias comunitárias, em telecentros. ${ }^{82}$ Em Camfield Estate, como no projeto Comunidades_online, a intervenção se faz através dessas duas instâncias, privada e coletiva. Se, por um lado, os projetos que visam prover as pessoas diretamente com computadores e conexão disponibilizando-os nas suas moradias são geralmente mais dispendiosos do que aqueles que se centram apenas no fornecimento desses dispositivos via instâncias coletivas, como os telecentros, por outro, permitem aferir de forma mais direta possíveis transformações na vida das pessoas. Não por acaso, no rol dos projetos estudados em questão, todos possuem vínculos com instâncias acadêmicas. O fato de estarem localizados em países considerados ricos, como Estados Unidos, Finlândia e Canadá, pode atestar então a necessidade de facilidades financeiras e verbas substanciosas para esta determinada forma de estruturação. 0

\footnotetext{
${ }^{82}$ Em Pantin, porém, houve estímulo ao acesso domiciliar como conseqüência da implementação do telecentro.
} 
Comunidades_online aparece como exceção neste conjunto, reafirmando seu caráter de experimentação, como se verá, dado que grande parte das experiências realizadas em países considerados pobres ou em desenvolvimento, como República Dominicana, Índia e Brasil, por exemplo, é centrada apenas em telecentros. ${ }^{83}$

\section{Açōes conjuntas}

Um aspecto importante a se reafirmar neste contexto é o fato de que muitas iniciativas envolvendo TIC são estruturadas de forma a abarcar várias ações em conjunto. Os TeleKiosks do projeto SARI estão associados a uma ampla política de sustentabilidade regional, vinculada a diferentes instituições. A experiência de VAN Bohechio, patrocinada por um consórcio de parceiros, abarca a implantação de infra-estrutura wireless de acesso à internet associada a um projeto especial de interface. Helsinki Virtual Village é um laboratório onde estão sendo testados desde equipamentos de vários tipos a parcerias de diversas naturezas, passando por novas experiências também no campo das interações sociais e do planejamento urbano. NetVille abarcou estudos tecnológicos de empresas privadas e investigação acadêmica, assim como o planejamento de uma rede intranet, de configuração específica.

A reflexão sobre o universo das iniciativas envolvendo TIC requer a conformação de suas dimensões e complexidades. 0 exercício de investigação realizado aqui foi importante porque deixou perceber essa amplitude, que foi também experimentada na vivência do projeto Comunidades_online. Foi importante no sentido de possibilitar uma compreensão desse universo. Pode-se entender que tal complexidade reflete as interdependências e subordinações de aspectos e contextos distintos, principalmente

\footnotetext{
${ }^{83}$ O que não significa, entretanto, que nestes países não se desenvolvam experiências baseadas em outros modelos.
} 
econômicos e políticos, e também aqueles próprios da pluralidade de desafios e inovações constantemente apresentados no contexto das tecnologias de informação e comunicação.

As experiências apresentadas acima possuem diferenças de estruturação, métodos, objetivos, contextos sócio-econômico-culturais, entretanto algumas representaram, e outras ainda representam, uma evidente oportunidade de inserir as TIC na vida das pessoas. O contexto das TIC mudou durante estes anos de pesquisa. Assistiu-se, principalmente em relação à situação brasileira, um aumento das ações da iniciativa privada, principalmente tornando mais disponíveis e baratos equipamentos e conexões, e alguns resultados dos programas do governo voltados a disponibilização de acesso a equipamentos e conexão. Percebe, em certo sentido, que essas ações de acesso estão sendo resolvidas, tornando a questão da apropriação qualitativa das TIC mais imperativa.

Neste sentido, a partir dos estudos realizados, seria importante sublinhar algumas questões importantes. Os projetos envolvendo TIC alocados em comunidades locais deveriam ter como objetivo principal a produção de conteúdos e a publicação na internet, dando ênfase àqueles relacionados à realidade local. É importante que todos se vejam na rede, em iguais condições. Num segundo plano também podem fomentar, quando possível, ações de formação profissional, capacitação e geração de renda. Para o bom desempenho dessas iniciativas é imprescindível o envolvimento da comunidade local, seja por meio de meio de parcerias com organizações, associações ou instituições que estejam fortemente comprometidas com o desenvolvimento e aprimoramento da comunidade. Trata-se de adensar os suportes sociais, perceber demandas para traçar as qualidades das intervenções, utilizando, se possível, ferramentas metodológicas apropriadas, principalmente em projetos top-down. Neste sentido, é importante a formação de animadores locais que trabalhem aspectos de incentivo e estímulo, e dos multiplicadores que podem garantir, em certo sentido, a continuidade dos projetos. As ações com TIC não acontecem de forma espontânea, precisam ser sustentadas e dirigidas, e ao mesmo tempo, estimuladoras e criativas, no sentido de enfrentamento dos problemas de cognição, e de fomentação de capacidade crítica. Estas ações devem ser desenhadas de forma a abarcar, nas 
comunidades locais, relações face-a-face e online. As avaliações e monitoramento são igualmente importantes, em vários sentidos. No plano micro, para re-alimentar os projetos locais, ajudar cumprir demandas, no plano macro, para conhecer natureza do objeto em questão, criar parâmetros de aferição, criar um modus operandi, ainda que mínimo.

As parcerias, como visto, são fundamentais. Instância alguma consegue trabalhar sozinha, tanto no desenvolvimento do contato e vínculo com as pessoas, como na disponibilização de recursos materiais e humanos, passando pela capacidade de reflexão e avaliação. A auto-sustentabilidade é questão polêmica. Entretanto, parece razoável considerar que a comunidade não deveria assumir sozinha o ônus da continuidade de um projeto envolvendo TIC, principalmente em termos financeiros. Poderia, quando muito, partilhar desta responsabilidade. O Estado ou outros mantenedores devem prover os recursos básicos de manutenção de conexão a internet e equipamentos. Por sua vez, a conexão é imperativa, e deve ser de banda larga. Sabe-se que a qualidade dos aparatos tecnológicos molda e influencia as experiências do usuário. São mais uma variável no jogo entre manter ou romper desigualdades. 0 uso software livre é igualmente importante nos projetos TIC, tanto em termos de construção de viabilidade financeira, como de liberdade de uso, de possibilidade de formação de desenvolvedores.

Os agentes governamentais devem ter consciência de que as iniciativas envolvendo TIC requerem políticas públicas de natureza diferente das que comumente fazem, devem se precaver dos problemas de cumprir metas apenas quantitativas. As iniciativas devem ser preservadas dos males da fragmentação e da falta de flexibilidade. Devem ainda ter como pressupostos a continuidade, ainda que soprem os ventos dos humores partidários. Tais agentes devem achar a medida da coordenação, e se abster dos contra sensos entre discurso e ação, evitando favorecer o primeiro. Os estudos acadêmicos devem encontrar a justa medida entre o propositivo, prático, e o teórico. Devem, entretanto, pautar ambos na experimentação. Depois se deve publicizar seus resultados. 
As interfaces computacionais merecem atenção cuidadosa. Pouco exploradas em iniciativas envolvendo TIC, principalmente voltadas a comunidades de base local, são os meios, os instrumentos que possibilitam as interações na e através da internet. Mas como se verá adiante, podem ser também outras coisas, para além da telas, dispositivos que atraem ou repelem.

Parece evidente que a realização de projetos envolvendo TIC está vinculada não só ao estabelecimento de objetivos claros, mas mais precisamente, a consideração de um conjunto de variáveis que as ações desta natureza pressupõem e da interdependência entre elas. Entretanto parece difícil ter iniciativas e projetos que abarquem satisfatoriamente todas essas variáveis, inclusive porque tais variáveis se imbricam a contextos externos de naturezas bastante distintas. ${ }^{84}$ Trata-se de uma justa dificuldade em se avançar em várias frentes ao mesmo tempo, instaurando um certo grau de restrição. Diz-se respeito a limitações de certa forma intrínsecas à implantação dessas ações e práticas, e não simplesmente exigências que não se cumprem. As limitações, neste caso, não assumem conotações negativas. São contenções ao universo do que é possível ser realizado, às condições próprias do que é, pela própria natureza desses projetos, factível. O que impossibilita, em certo sentido, atestar especificamente sobre o grau de sucesso, ou de plena realização, de iniciativas inclusivas. Tudo isso reafirma o caráter ainda em construção desse universo, nos planos práticos e também teóricos. Se, por um lado, como se viu, é inapropriado considerar que cada projeto desta natureza é em si responsável pela transposição das barreiras da exclusão digital, por outro parece claro o seu caráter imprescindível, como bem resume Santos (2006, p.138): “contudo, mesmo em suas concretizações mais tímidas, a inclusão digital, representa um ganho social."

A inclusão digital é entendida neste trabalho como um processo que tem como horizonte a qualidade das experiências das pessoas, grupos e comunidades locais com o uso das TIC. Um processo que

\footnotetext{
${ }^{84}$ Sabe-se, por exemplo, que inserção das TIC na sociedade depende de alguns fatores que vão da oscilação da economia mundial à vontade política dos governantes, passando pela mobilização social em amplo sentido.
} 
objetiva tornar estas experiências parte das suas narrativas cotidianas. Como se verá no capítulo 4, a experiência em Cidade Tiradentes mostra a importância de uma iniciativa inclusiva ser construída a partir de ações de viés cultural. As ações dessa natureza, agregadas ao uso das TIC, parecem favorecer caminhos para a ampliação das aspirações e perspectivas sócio-culturais das pessoas, no sentido de expandir e adensar visões de mundo, formar de sujeitos críticos, que podem, por exemplo, produzir conteúdos e postá-los na internet, e também saber distingui-los e diferenciá-los. Neste sentido, a inclusão digital deve ser configurada a partir de práticas e atividades de cunho cultural que tendem a explorar as potencialidades do uso das TIC com vistas a transformações no âmbito dos indivíduos e comunidade, como se verá mais adiante.

A seguir examina-se mais atentamente como se dá a inserção das TIC na vida cotidiana de comunidades de base local e qual o caráter específico das transformações que estariam a elas associadas. 

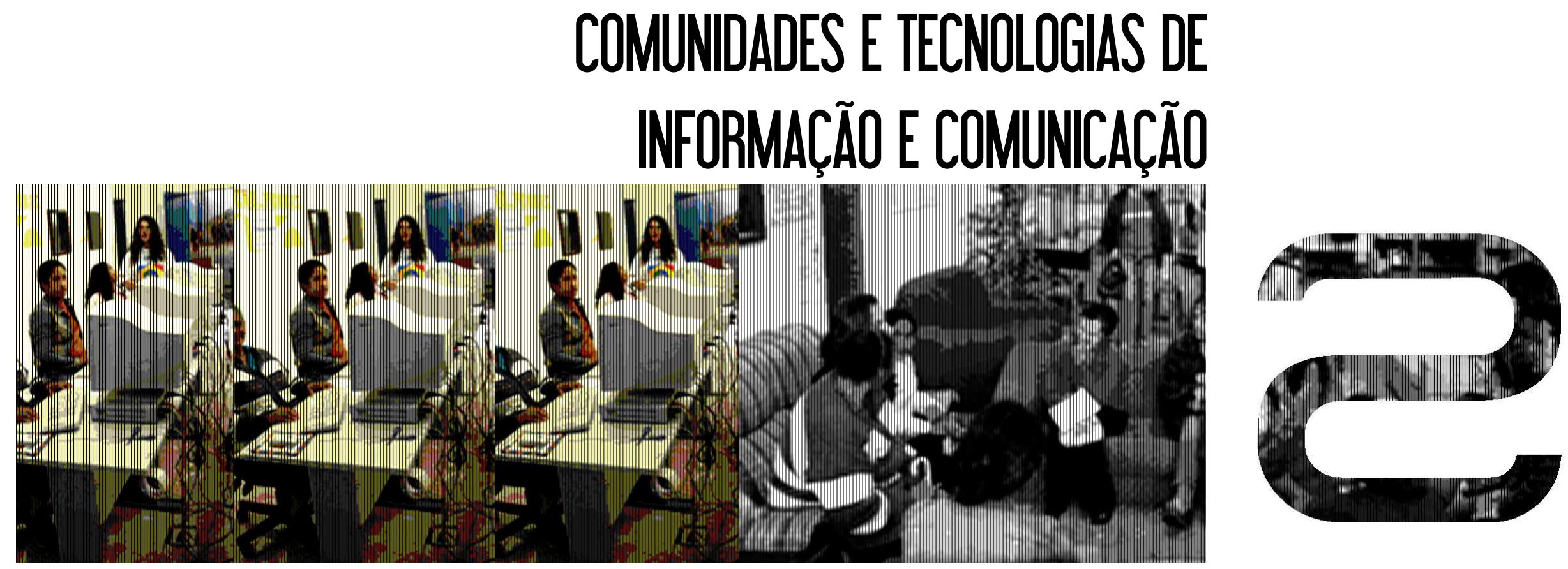
Este capítulo investiga a natureza da comunidade na contemporaneidade, considerando os aportes teóricos das Ciências Sociais que buscam estabelecer as bases para o entendimento da comunidade também a partir dos efeitos da introdução das tecnologias de informação e comunicação na vida cotidiana. Procura-se, num primeiro momento, apresentar as definições de comunidade, para depois delimitar, quando possível, as especificidades e abrangências de suas porções física e virtual, e dos aspectos mais significativos da constituição de cada uma delas. Um dos objetivos é dar subsídios ao entendimento da conformação dos espaços híbridos a partir da comunidade.

Em seguida, apresentam-se alguns conceitos e abordagens relacionados a parâmetros de desenvolvimento comunitário, amplamente utilizados e aceitos, que servem de referências para delimitações de padrões de condições e qualidade de vida em comunidades geograficamente referenciadas. Trata-se de alguns indicadores de desenvolvimento e bem estar social, cujas alterações em termos positivos, no contexto das iniciativas envolvendo TIC, se tornam objetivos e resultados almejados. Propõe-se um aprofundamento no entendimento e uma demarcação dos conceitos de transformação social, capital social, empoderamento, e ainda de algumas abordagens metodológicas relacionadas a propósitos de mobilização de recursos sociais, seja no plano individual ou coletivo, para depois averiguar suas relações com a introdução das TIC, principalmente através do estabelecimento de instâncias virtuais de comunicação e interação em comunidades locais, no âmbito de alguns projetos. Neste sentido, reafirma-se, por um lado, o pressuposto de que nesses projetos a tecnologia não é um fim em si mesma, e por outro, que quando se estabelece que o resultado final de uma iniciativa envolvendo TIC é a resolução de um problema na comunidade ou a provisão de benefícios para as pessoas envolvidas, é importante que isso não fique vago, ou seja, há necessidade de se definir de forma clara o que se quer atingir, como bem pontua Beamish (2001). 


\section{Interação, interação social}

De maneira elementar, interação significa a ação recíproca entre duas ou mais entidades. Numa perspectiva da Ciência Física, estas entidades podem ser especificamente partículas, corpos, campos quânticos, entre outros. Na Sociologia, interação pode ser definida, de forma rasa, como as relações e ações entre as pessoas membros de um grupo ou entre grupos de uma comunidade, ou sociedade. É um processo que resulta do contato e comunicação, e que pressupõe modificação de comportamento dos agentes sociais envolvidos. Segundo Lakatos (1995, p.83) "Interação social é a ação social, mutuamente orientada, de dois ou mais indivíduos em contato. [...] a interação é a reciprocidade de ações sociais." É precisamente a esta interação que se refere neste capítulo, ou seja, às ações e relações entre membros de um grupo ou comunidade, que podem ser as pessoas ou ainda as instituições constituintes desse grupo, ou ambas.

Ignora-se aqui, momentaneamente, as especificidades dos suportes e meios que possibilitam a criação das instâncias virtuais de comunicação e interação social, e volta-se à qualidade das relações sociais estabelecidas em uma comunidade local a partir da efetivação de espaços híbridos. No próximo capítulo, entretanto, o olhar se volta à diversidade das interfaces computacionais como meios que dão suporte às interações sociais online ou nos espaços híbridos, e averiguam-se suas implicações na estruturação dessas interações. 0 foco volta-se mais para a interação entre os indivíduos e as próprias interfaces, ou ainda, entre indivíduos através da interface, acentuando o através, que é o meio, o suporte que sustenta a interação. Mais que um recurso metodológico, trata-se de um esforço de separar, de desagregar, um objeto uno, a fim de apreendê-lo em sua natureza complexa. A interatividade na rede e através dela depende, talvez na mesma medida, dos meios físicos e materiais que a suportam como das estruturas das redes sociais a qual se vinculam. Como um auxílio a estruturação e ao entendimento das questões que o tema propõe, vislumbra-se duas maneiras de olhar para um objeto, uma separação fugaz de uma entidade que sozinha não tem significação. 


\section{Definiç̧̄es e conceituaçōes de comunidade}

Nas Ciências Sociais são inúmeras as definições que se aplicam ao termo comunidade, e mais precisamente, aos objetos que este termo potencialmente poderia aludir. Consciente de que as proposições teóricas e conceituais em torno do tema não são consensuais, interessa aqui apresentar algumas concepções de comunidade, dando especial atenção àquelas que as relacionam ao universo de transformações vivenciadas a partir das TIC.

Em geral, a idéia de comunidade é ampla, diversificada, e ao mesmo tempo, um tanto imprecisa. A noção ordinária, e tradicional, de comunidade está associada a idéia de um grupo de pessoas que interagem principalmente por meio de contatos face-a-face, que apresentam comportamentos parecidos, que compartilham valores, de maneira informal, ou seja, não institucionalizada, e expressam interesses em comum e uma identidade compartilhada. É também bastante comum associar à comunidade um componente territorial, ou seja, uma base local, um espaço físico limitado, unidades geográficas de vizinhança, e também um sentimento de pertencimento, uma tendência à cooperação e solidariedade. A despeito da idéia de comunidade envolta, muitas vezes, a uma aura nostálgica e romantizada, alguns estudos realizados nos últimos anos buscam discuti-la a partir de uma perspectiva que inclui, de maneira geral, as implicações contemporâneas do processo amplamente conhecido como globalização, e de forma específica, as mais novas transformações tecnológicas relacionadas aos processos de comunicação. Estes estudos são significativos na medida que abarcam os fenômenos das comunidades desvinculadas de espaços territoriais e presenças físicas, alinhando-os justamente às possibilidades de interação que vem com os meios de comunicação digitais, que por sua vez, impulsionam a revisão dos conceitos mais clássicos de comunidade. 


\subsubsection{Comunidade: um conceito antigo}

Os estudos do alemão Ferdinand Tönnies, realizados entre meados do século XIX e início do XX, situamse entre as principais referências na conceituação de comunidades no âmbito das Ciências Sociais. Seu trabalho foi pioneiro no sentido de estabelecer as primeiras idéias em relação às estruturas sociais a partir de agrupamentos humanos, ainda que alheio às metodologias estruturadas que viriam compor a disciplina sociológica alguns anos depois. Tönnies estabeleceu um modelo teórico baseado em duas categorias analíticas representadas nas palavras alemãs Gemeinschaft e Gesellschaft, usualmente traduzidas como comunidade e sociedade.

Para Tönnies uma comunidade seria um agrupamento humano unido em torno de um território físico, e unido também por interesses comuns, pelo senso recíproco de pertencimento, por semelhanças culturais. Trata-se de um tipo de associação em que o reconhecimento grupal está centrado no uso dos mesmos códigos, e na convivência entre pares. Cada indivíduo se reconhece no outro e no grupo. Uma comunidade implica vontade e desejo coletivos, relações duradouras baseadas em normas de funcionamento incorporadas e reconhecidas nas ações cotidianas. 0 paradigma é o universo rural, préindustrial (SÁ FILHO, 2006). Na comunidade a economia é familiar, e a estrutura de trabalho baseada no artesanato. Por sua vez, a sociedade, para Tönnies, está ligada ao modelo urbano, racional, formal e hierarquizado, em que pesam as relações em favor do individualismo, da intimidade e da vida particular, em detrimento às ações e vontades coletivas. As relações entre os indivíduos estão centradas nas aparências, impessoalidade, nos interesses utilitários, nos conflitos e tendência ao anonimato. Os mecanismos que regem a sociedade seriam abstratos, o patrimônio cultural padronizado, nivelado, baseado em códigos impostos por grupos dominantes. Trata-se dos agrupamentos da era industrial, regidos pelos interesses monetários, capitalistas, que possuem intrincada divisão de trabalho (SÁ FILHO, 2006). 
Segundo Gurney e Aguirre (1980) Tönnies distingue os dois tipos de grupos de acordo com o tipo de vontade dominante:

Gemeinschaft está embasada no que se chama vontade natural (wesenwille). Nela as relações se valoram por razões dela mesma. Os nexos sociais são intensos, têm valor intrínseco e não dependem de nenhum propósito exterior e ulterior a eles mesmos. Em Gesellschaft, pelo contrário, a diferenciação de meios e fins nas relações sociais se completa e a ação social obedece a vontade racional e se motiva por fins exteriores (zwechrational). 0 tipo de vontade que impera na sociedade é o fator determinante e prioritário nas relações sociais. As pessoas na Gemeinschaft, percebem o grupo como uma entidade natural e durável criada por forças ou seres sobrenaturais, enquanto que na Gesellschaft o grupo é percebido como entidade artificial e mutável e supeditado aos interesses individuais (kurwille) ${ }^{1}$ (GURNEY; AGUIRRE, 1980).

As categorias analíticas dicotômicas de Tönnies se contrapõem, e em certo sentido, parecem sugerir juízos de valor que, segundo alguns autores, privilegiariam um modelo comunitário frente ao societário. Mais importante, porém é destacar que o autor considera que os agrupamentos, na prática, possuem características de ambos os modelos teóricos, comunidade e sociedade.

Esta ressalva se faz necessária pois assim se pode compreender que padrões de sociabilidade comunitária continuam a existir na sociedade urbana e capitalista, marginal e residualmente na maioria dos casos segundo esta perspectiva, e possibilitando a articulação até mesmo de outras sociabilidades híbridas. [...] Aliás, ainda que seu esquema seja amarrado em um agrupamento dual de conceitos contrastantes, de modo algum Tönnies os pensava de maneira estanque, isolada e estática, e sim apontando as dinâmicas de longo prazo que eles representavam, isto é, o desenvolvimento da sociedade de seu tempo (BRANCALEONE, 2006).

\footnotetext{
1 Tradução da autora. No original: "Gemeinschaft esta basada en lo que el llama voluntad natural. (wesenwille). En ella las relaciones se valoran por razon de ellas mismas. Los nexos sociales son intensos, tienen valor intrinseco y no dependen de ningun propósito exterior y ulterior a ellos mismos. En Gesellschaft, por el contrario, la diferenciacion de medios y fines en las relaciones sociales se completa y la accion social obedece a la voluntad rational y se motiva por fines exteriores. (zwechrational). El tipo de voluntad que impera en la sociedad es el factor determinante y prioritario en las relaciones sociales. Las personas en Gemeinschaft, perciben el grupo como una entidad natural y durable creada por fuerzas o seres sobrenaturales, mientras que en Gesellschaft el grupo es percibido como entidad artificial y cambiable supeditado a los intereses individuales (kurwille)."
} 
Ainda assim, parece difícil transpor diretamente para a atualidade esses arranjos de sociabilidade ${ }^{2}$, dada a complexidade da sociedade contemporânea, e a distância histórica em que foram definidos. Contudo, Brancaleone (2006) destaca as potencialidades descritivas do modelo comunidade-sociedade, se se admite a relevância de "como, onde e sob quais condições por excelência estes se manifestam e se reproduzem enquanto tal."

Wellman (1999a) diz que muitos autores compartilharam a visão de Tönnies do enfraquecimento dos vínculos comunitários e seus prejuízos, ainda que lançassem algumas vantagens advindas dos novos contornos impostos pela sociedade industrializada. Contudo, diferentes caminhos foram estabelecidos nos estudos dos agrupamentos humanos a partir das análises pioneiras de Tönnies. Diversos pesquisadores, alocados em áreas disciplinares distintas, procuraram (e ainda procuram) delimitar os conceitos de comunidade, de sociedade, na medida em que as feições do mundo se tornam mais complexas e exigem novos aportes teóricos que sejam condizentes à realidade empírica.

\subsubsection{Comunidade na contemporaneidade: as redes sociais}

Durante a segunda metade do século passado, precisamente durante os anos 1960, no campo da teoria sociológica, algumas abordagens lançam novas perspectivas às análises da estrutura social. Trata-se de princípios que possibilitam pensar e re-pensar a estrutura social, princípios capazes de descrever a complexidade das interações sociais nos agrupamentos humanos, partindo da constatação da ineficácia das ferramentas teóricas até então disponíveis. O fato de compartilhar uma localidade, de ter sentimentos de pertencimento, parece não ser bases sólidas e suficientes para se compreender as interações sociais entre indivíduos. Parece claro que para novos fenômenos tem-se que lançar mão de

\footnotetext{
${ }^{2}$ A sociabilidade é entendida neste trabalho a partir das redes sociais, como sendo a forma como diferentes atores sociais estabelecem laços, ligações e relações entre si. Trata-se das maneiras de estabelecimento de redes sociais, que assumem, então, diferentes combinações, manifestações e padrões.
} 
novos conceitos, ou ainda re-pensar princípios previamente estabelecidos. Tem sido assim com a comunidade, que a despeito daqueles que acreditavam no seu desaparecimento, na sua falência, ressurge com outras roupagens, a partir tanto dos estudos dos sistemas de redes de relações sociais, como de novas pesquisas, algumas delas baseadas em novas técnicas de coletas de dados, mais consistentes. Segundo Santos,

[...] se respeitarmos o conceito tradicional de comunidade, elas nem estariam completamente condenadas nas sociedades industriais, e tampouco seriam encontradas em abundância nas sociedades pré-industriais. 0 que os recentes analistas de redes apontam é para a necessidade de uma mudança no modo como se compreende o conceito de comunidade: novas formas de comunidade surgiram, o que tornou mais complexa nossa relação com as antigas formas (SANTOS, 2005, p.239).

Neste contexto situam-se as abordagens teóricas das redes sociais, conhecidas também como análise das redes sociais, em inglês, Social Network Analysis. ${ }^{3}$ Estes novos quadros conceituais têm sido delineados nas Ciências Sociais de forma intimamente atrelada a referenciais teóricos desenvolvidos em outros campos disciplinares e científicos, que simultaneamente estão a explorar a capacidade descritiva e explicativa do conceito de rede, voltado aos mais variados objetos e fenômenos. "Nas ciências sociais, a análise das redes tem sido sempre um campo, por excelência, de interdisciplinaridade"4 (PORTUGAL, 2007).

O conceito de rede social, no sentido analítico proposto por Barry Wellman, está associado a uma vertente de abordagem estruturalista, mais voltada à questão da relação como unidade básica da estrutura social. “A análise estrutural americana fez escola sobretudo com os estudos sobre as redes

\footnotetext{
${ }^{3}$ Em inglês também chamadas science of networks, social network paradigm e structural analysis.

${ }^{4}$ As chamadas ciências das redes buscam apreender as interconexões do mundo contemporâneo, e para tal lançam mão de conhecimentos interdisciplinares. "Autores como Duncan J. Watts (sociólogo, doutorado em matemática aplicada), Mark Buchanan ou Albert-László Barabási (ambos físicos) têm cruzado conhecimentos das ciências sociais, da matemática, da física, da engenharia, da medicina, da biologia na defesa de uma visão do mundo em que tudo está ligado" (PORTUGAL, 2007).
} 
sociais enquanto fonte de suporte social" (PORTUGAL, 2007). Existem, entretanto, outras abordagens, desenvolvidas por diferentes autores, que fazem da social network analysis uma teoria multifacetada. ${ }^{5}$

Os agrupamentos humanos, nesta perspectiva, seriam concebidos a partir das relações sociais, a partir do modelo de redes sociais. Estas, por sua vez, são compostas por conjuntos de nós e conjuntos de laços interconectatos, por um conjunto de relações interligadas. Os nós podem ser unidades sociais, indivíduos, associações, organizações, grupos, paises, ou outras coletividades, assim como os laços são tomados como fluxos de recursos, ou quaisquer relações estruturadas entre os nós, como transmissão de informações, trocas de bens, entre outros. Os laços apresentam diferentes atributos. Assim, nem pessoas reunidas em grupos limitados, nem em torno de determinadas áreas geográficas, nem vínculos de solidariedade seriam padrões suficientes para pensar a respeito das comunidades.

Uma análise de redes de comunidade considera como ponto de partida de pesquisa as ligações e os fluxos de recursos. Somente então se investiga a distribuição espacial e os sentimentos de solidariedade associados com as ligações observadas. Com uma abordagem em grande medida independente do estudo de comunidade centrados em princípios espaciais e normativos. Isso torna possível a descoberta de comunidades baseadas em redes que não são nem vinculadas a uma vizinhança nem a uma instância de sentimentos de solidariedade ${ }^{6}$ (WELLMAN; LEIGHTON, 1979).

Segundo Portugal (2007) Wellman aborda a relação entre os comportamentos individuais e as características das redes de relações. Sua preocupação é com as redes enquanto fonte de suporte social, por isso se volta às implicações entre diferentes estruturas de redes e os efeitos na mobilização de recursos e na construção de oportunidades para seus membros. "Tendo em conta os contextos macroestruturais nos quais estão inseridas as redes pessoais, o autor analisa a influência das formas das

\footnotetext{
${ }^{5}$ Existe um grande leque de autores que trabalham também na linha da network analysis, entre eles Claude Fischer, Mark Granovetter, Nan Lin, Bruno Latour, entre tantos outros (PORTUGAL, 2007).

${ }^{6}$ Tradução da autora. No original: "A network analysis of community takes as its starting point the search for social linkages and flows of resources. Only then does it enquire into the spatial distribution and solidary sentiments associated with the observed linkages. Such an approach largely frees the study of community from spatial and normative bases. It makes possible the discovery of network-based communities which are neither linked to a particular neighborhood nor to a set of solidary sentiments."
} 
redes nas mudanças das situações individuais e na integração nos sistemas macrossociais" (PORTUGAL, 2007).

As descrições e estudos da estrutura social realizados por Wellman e pelos teóricos da network analysis não excluem a noção de comunidade, mas a coloca em outros termos. Demonstram que as comunidades têm sido transformadas, mas não desapareceram ou se perderam. Tais estudos

[...] têm mostrado a permanente abundância e vitalidade dos relacionamentos interpessoais tanto quanto eles têm sido afetados pelo capitalismo, socialismo, urbanização, industrialização, burocratização, e novos transportes e tecnologias de comunicação. Novas formas de comunidade têm sido constituídas substituindo as velhas. A demonstração da penetrabilidade e importância das comunidades pessoais tem refutado argumentações que as transformações em grande escala têm produzido comumente o isolamento social em uma "sociedade de massas" (e.g., Kornhauser 1959). Se as análises focam em laços e sistemas de recursos informais ao invés de pessoas vivendo em vizinhanças e povoados, a comunidade pode ser percebida ${ }^{7}$ (WELLMAN, 1999a).

Assim, as comunidades são abordadas como uma forma específica de relação social, que pressupõe companheirismo e ajuda, que rompe com os limites geográficos de vizinhança (PORTUGAL, 2007). Para Wellman (1999b) o que se está vivendo atualmente é uma profunda mudança paradigmática, principalmente no modo como a sociedade é organizada. Segundo o autor, vive-se hoje em sociedades em rede - networked societies. Na sociedade baseada em grupos, em little boxes, conforme metáfora usada pelo autor, as pessoas se relacionam com poucos membros de cada grupo dos quais participam, confinadas de acordo com uma estrutura precisa, com limites para inclusão e exclusão, e hierarquias profundas. Já nas sociedades em rede, as interações são mais diversas, as hierarquias mais rasas, os

\footnotetext{
${ }^{7}$ Tradução da autora. No original: "[...] have shown the continuing abundance and vitality of interpersonal relationships even as they have been affected by capitalism, socialism, urbanization, industrialization, bureaucratization, and new transportation and communication technology. New forms of community have come into being to replace older ones. The demonstration of the pervasiveness and importance of personal communities has rebutted contentions that large-scale social transformations have produced widespread social isolation in an alienated "mass society" (e.g., Kornhauser 1959). If analysts focus on social ties and systems of informal resource exchange than on people living in neighborhoods and villages, community can be seen." KORNHAUSER, W. (1959). The Politics of Mass Society. New York: Free Press.
} 
limites mais permeáveis. Em casa, no trabalho, e em outras instâncias, as trocas acontecem entre redes múltiplas. O viver em redes pressupõe, segundo Wellmam (1999b), o aumento das habilidades para conectar muitos ambientes sociais e a diminuição do controle que estes ambientes têm sobre as pessoas. Também pressupõe interações baseadas nas características das pessoas, no seu estilo de vida, seu pensamento e interesses, substituindo critérios como idade, gênero, raça e etnia; cria vínculos indiretos ao invés de isolamento, amplia a possibilidade de escolhas e reduz a identificação e a pressão de se pertencer a grupos, aumentando oportunidades.

Isso nos remete a uma transmutação do conceito de "comunidade" em "rede social". Se solidariedade, vizinhança e parentesco eram aspectos predominantes quando se procurava definir uma comunidade, hoje eles são apenas alguns dentre os muitos padrões possíveis das redes sociais. Atualmente, o que os analistas estruturais procuram avaliar são as formas nas quais padrões estruturais alternativos afetam o fluxo de recursos entre os membros de uma rede social. Estamos diante de novas formas de associação, imersos numa complexidade chamada rede social, com muitas dimensões, e que mobiliza o fluxo de recursos entre inúmeros indivíduos distribuídos segundo padrões variáveis (SANTOS, 2005, p.239).

A natureza da comunidade na contemporaneidade ultrapassa a sociabilidade baseada em limites geográficos, em relações face-a-face, estende-se para além das instâncias onde valores e interesses são partilhados, onde se presencia a sensação de pertencimento, se alinha aos fenômenos das associações humanas no ciberespaço. 


\subsection{As chamadas comunidades virtuais}

Wellman, Boase e Chen (2002) dizem que as "as comunidades começaram a mudar de grupos para redes bem antes do advento da Internet" ${ }^{8}$ e Santos (2005) salienta que as reflexões sobre a estrutura da sociedade, sobre os formatos das interações humanas aconteceram "[...] ao mesmo tempo em que se desencadeava uma profunda revolução nos meios de comunicação”(SANTOS, 2005). A despeito da cronologia exata e precisa, a comunidade pensada em dimensão reticular está hoje intimamente atrelada aos estudos dos padrões de sociabilidade possibilitados pelas tecnologias de comunicação digital. Seja porque estes novos formatos de interação social são constituintes das sociedades contemporâneas, seja porque seus pressupostos prescindem de vínculos territoriais, presenciais, e se voltam exclusivamente às análises dos espaços relacionais das interações sociais.

Keith Hampton (2001) em sua pesquisa sobre os efeitos da internet numa comunidade local, ou mais precisamente, sobre o desenvolvimento de redes sociais ancoradas na comunicação mediada por computador, adota concepções teóricas que apresentam comunidades claramente como redes que não são nitidamente organizadas dentro de vizinhanças delimitadas no espaço físico. Ao indagar-se a respeito dos efeitos da comunicação informatizada nas relações sociais, Hampton (2002) destaca o debate, ainda presente nas instâncias acadêmicas, entre aqueles que denomina não-utopistas e os chamados utopistas tecnológicos. Os primeiros acreditam que na sociedade contemporânea, na qual trabalho, lazer e vida social ocorrem também em grande parte em ambientes virtuais, as pessoas podem rejeitar as relações sociais centradas em vínculos baseados em localizações físicas e contatos face-a-face. Por outro lado, os segundos acreditam que a internet criou uma forma totalmente nova de comunidade, que libertou o indivíduo das restrições geográficas, e das amarras das características sociais como gênero, raça e etnia. Segundo o autor, este debate não reconhece que, perdida ou recriada, a comunidade já foi libertada da geografia, do lugar físico, e que as TIC podem, por um lado,

\footnotetext{
${ }^{8}$ Tradução da autora. No original: "Communities started changing from groups to networks well before the advent of the Internet."
} 
assegurar a promessa de reencontro das comunidades baseadas em lugares físicos, ou por outro, libertá-las definitivamente. Assim, comunidades se definem como redes compostas de vínculos sociais de intensidade variáveis em múltiplos ambientes sociais, incluindo àqueles estabelecidos em instâncias virtuais.

Comunidades consistem em parentescos extensos, ambiente de trabalho, grupo de interesse e vínculos de vizinhança, que, juntos, formam uma rede social que provê ajuda, apoio, controle social e outras conexões para ambientes múltiplos. Dentro destas comunidades pessoais os indivíduos usam múltiplos métodos de comunicação: contato pessoal direto, telefone, correio postal, e mais recentemente fax, e-mail, chats, e grupos de discussão via e-mail. Procurar pelo lugar da comunidade antes (seja em vizinhanças ou no ciberespaço) é um meio inadequado de revelar relações comunitárias de apoio"9 (HAMPTON, 2002).

Para diversos autores o entendimento do fenômeno das comunidades virtuais estaria intimamente associado a este conceito amplo de comunidade. Meneses (2004) ressalta que a tendência dos estudos sobre comunidades virtuais se situa num universo de visão moderada:

[...] tem ganhado força as posturas intermediárias, mais moderadas, onde se concebe a possibilidade de entender as comunidades como entidades que se ocultam, com uma definição mais pragmática onde a comunidade virtual não seja vista como algo substituto da comunidade local, onde o pertencimento se derive da própria participação e a interação com o espaço virtual, entendida a interação de uma forma mais ampla ao redefinir o que significam os grupos em um contexto não presencial, e desprendido do espaço físico como elemento constitutivo ${ }^{10}$ (MENESES, 2004).

\footnotetext{
${ }^{9}$ Tradução da autora. No original: "Communities consist of far-flung kinship, workplace, interest group and neighborhood ties that together form a social network that provides aid, support, social control and links to multiple milieus. Within these personal communities people use multiple methods of communication: direct in-person contact, telephone, postal mail, and more recently fax, email, chats, and email discussion groups. Looking for community in one place at one time (be it in neighborhoods or in cyberspace) is an inadequate means of revealing supportive community relations."

10 Tradução da autora. No original: "[...] han cobrado fuerza las posturas intermedias, más moderadas, donde se concede la posibilidad de entender las comunidades como entidades que se solapan, con una definición más pragmática donde la comunidad virtual no sea vista como algo sustitutivo de la comunidad local, donde la pertenencia se derive de la propia
} 
O autor ressalta que a tendência é buscar definir comunidade a partir do conceito de função e não de localização geográfica, da distinção entre laços sociais fracos e fortes ${ }^{11}$, e "dentro da tradição que alguns autores chamam de privatização da sociabilidade em direção ao individualismo em rede [...]"12 (MENESES, 2004). As comunidades virtuais seriam um dos instrumentos disponíveis na sociedade da informação que expressariam a privatização da sociabilidade que caminha para o individualismo em rede. O olhar, agora, estaria focado nas redes pessoais, ou seja, são as pessoas que comandam suas próprias interações, por meio de comunidades pessoais, e não mais a família, o grupo ou a comunidade local.

Segundo Castells (2003) o individualismo em rede corresponde a um padrão social e não a um acúmulo de pessoas isoladas, é uma estrutura social que abarca redes individuais, sejam elas online e/ou offline, com base em interesses, valores, afinidades e projetos. ${ }^{13}$ Padrão que se alinha à abordagem de Wellman das estruturas sociais em rede, especificamente do que chama comunidades pessoais ou redes pessoais. Para este autor, trata-se de pessoas conectadas em redes sociais, não em grupos,

participación y la interacción en el espacio virtual, entendida la interacción de una forma más amplia al redefinir lo que significan los grupos en un contexto no presencial, y desprendida del espacio físico como elemento constitutivo."

${ }^{11}$ Mark Granovetter, um dos principais estudiosos da social network theory, em The Strength of Weak Ties, define dois tipos de laços sociais e suas implicações. Os laços fortes seriam aqueles caracterizados por um alto grau de intimidade, proximidade, reciprocidade, que envolveriam grandes comprometimentos durante períodos de tempo grandes. Os laços fortes constituem redes de interação mais estáveis. Por sua vez, os laços fracos se caracterizariam por relações mais soltas, mutáveis, por contatos indiretos, e também como canais através dos quais se acessa idéias, influências e informações situadas em outros meios sociais. "Do ponto de vista individual, então, laços fracos são um importante recurso que faz possível a mobilidade de oportunidades" (GRANOVETTER, 1973).

Tradução da autora. No original: "From the individual's point of view, then, weak ties are an important resource in making possible mobility opportunity."

${ }^{12}$ Tradução da autora. No original: "[...] dentro de la tradición de lo que algunos autores llaman la privatización de la sociabilidad hacia el individualismo en red [...]"

${ }^{13}$ Para Castells (2003) a rede seria especificamente uma forma central de organizar a interação baseada em escolhas e estratégias de atores sociais (indivíduos, famílias ou grupos sociais). Não haveria mais um compartilhamento baseado em valores e organização social. O individualismo em rede, como padrão social, estaria intimamente associado à configuração atual da família nuclear, que possui como características predominantes a autonomia dos seus membros e a perda da autoridade absoluta dos pais. Também poderia ser associado a um novo formato familiar: o das pessoas vivendo sós. 
comunicando entre si pessoalmente ou mediadas por computador, integradas em comunidades caracterizadas por uma prática personalizada de encontro com outras pessoas.

[...] o mundo wireless permite verdadeiramente comunidades pessoais que provêm suporte, sociabilidade, informação, e um senso de pertencimento separadamente para cada indivíduo. É o indivíduo, e não a família ou o grupo, que é a unidade primeira da conectividade. [...] Este é um tempo para indivíduos e suas redes, não para grupos. A coletividade toda abraçada (Parsons 1951; Braga and Menosky 1999) tem se tornado uma rede personalizada, fragmentada. Autonomia, oportunidade, e incerteza determinam o jogo comunitário de hoje ${ }^{14}$ (WELLMAN, 2001).

Assim, as comunidades virtuais estariam inseridas no contexto dos processos de transformações da própria noção de sociabilidade, da reestruturação da participação em grupos, e da medida do capital social $^{15}$ (MENESES, 2004). Neste sentido, as comunidades virtuais podem ser tomadas como redes sociais.

Por causa da flexibilidade e do poder de comunicação da Internet, a interação social on-line desempenha crescente papel na organização social como um todo. As redes on-line, quando se estabilizam em sua prática, podem formar comunidades, comunidades virtuais, diferentes das físicas, mas não necessariamente menos intensas ou menos eficazes na criação de laços e na mobilização (CASTELLS, 2003, p.109).

Para Castells (2000) a comunicação mediada por computador não cria novas redes de sociabilidade, reforça os padrões sociais preexistentes, expande o alcance das redes sociais, da mesma forma que não substitui outros meios de comunicação. Lévy (2000, p.128) também atesta: “[...] é raro que a

\footnotetext{
14 Tradução da autora. No original: "[...] wireless world affords truly personal communities that supply support, sociability, information, and a sense of belonging separately to each individual. It is the individual, and neither the household nor the group, that is the primary unit of connectivity. [...JThis is a time for individuals and their networks, not for groups. The all-embracing collectivity (Parsons 1951; Braga and Menosky 1999) has become a fragmented, personalized network. Autonomy, opportunity, and uncertainty rule today's community game."
}

PARSONS, T. (Ed.). (1951). The Social System. Glencoe, IL: Free Press.

BRAGA, B.; MENOSKY, J. (1999). Dark Frontier: Seven of Nine Goes Home. Star Trek Voyager, February 17. UPN Network.

${ }^{15}$ Sobre capital social, ver o próximo item deste capítulo. 
comunicação por meio de redes de computadores substitua pura e simplesmente os encontros físicos: na maior parte do tempo, é um complemento ou um adicional."

A história das comunidades virtuais começou muito antes da chegada da world wide web. Pode-se dizer que a origem da internet e a origem das comunidades virtuais estão profundamente atreladas. Howard Rheingold, responsável não só por cunhar o termo comunidade virtual, mas pelas primeiras análises sobre o fenômeno atesta:

A maioria das pessoas não tem consciência que as comunidades virtuais realmente se voltam exatamente ao começo da Arpanet (uma precursora da Internet) e antes com o projeto PLATO, portanto há pelo menos 30 anos atrás. [...] E naturalmente, a Arpanet foi construída por uma comunidade. [...] E contrário ao mito comum, a Arpanet não foi criada como um sistema de comunicações à prova de bomba nuclear. Ela foi criada para conectar esta comunidade e habilitála a compartilhar dados de um computador para outro e conectar diferentes resultados de pesquisa. [...] A primeira lista de e-mail começou quando os primeiros nós da Arpanet estavam terminando. Assim a comunidade virtual no sentido de comunicação muitos-para-muitos, pessoaa-pessoa volta exatamente ao começo das redes de computadores e tem impulsionado seu crescimento deste então. Eu imagino que isto é provavelmente a peça mais importante da história ${ }^{16}$ (RHEINGOLD apud POWAZEK, 2002, p.286).

Os termos comunidade virtual e comunidade online têm sido empregados ${ }^{17}$, de forma ampla, para designar as interações sociais na internet de diferentes naturezas, que são, hoje, realizadas a partir de ferramentas distintas, como se verá adiante. Rheingold disseminou esses termos a partir de 1993, com

\footnotetext{
${ }^{16}$ Tradução da autora. No original: "Most people are unaware that virtual communities really go back to the very beginning of the Arpanet (a precursor to the Internet) and before whith the PLATO project, so they're at least 30 years old. [...] And of course, the Arpanet was build by a community. [...] And contrary to the usual myth, the Arpanet was not created as a nuclear bomb-proof communications system. It was created to connect to this community and enable them to share data to another and connect different research efforts. [...] The first email lists started when the first Arpanet nodes were up. So virtual community in the sense of many-to-many, person-to-person communications goes back to the very beginning to computer networks and has driven the growth of it ever since. I think that's probably the most important piece of history."

${ }^{17}$ Em inglês encontram-se diferentes denominações para o fenômeno, entre elas, online communities, virtual communities, computer-mediated communities, electronic communities, tele-communities, cyber-communities, techno-communities, technosociality.
} 
a publicação do livro The Virtual Community: Homesteading on the Electronic Frontier, que descreve e reflete suas experiências durante anos na WELL (Whole Earth' Lectronic Link), uma das primeiras comunidades online. Esta obra se tornou referência clássica ao tema, expondo de forma otimista, características e promessas das comunidades virtuais, que permitiriam o estabelecimento de atividades comunitárias sem fronteiras. Nesta obra, o autor define: “Comunidades virtuais são agregados sociais que emergem na Rede, quando pessoas o bastante conduzem discussões públicas por um tempo adequado, com sentimentos humanos suficientes, para formar redes de relações pessoais no ciberespaço”"18 (RHEINGOLD, 1993).

Para Lévy (2000, p.127) "Uma Comunidade Virtual é construída sobre as afinidades de interesses, de conhecimentos, sobre projetos mútuos, em um processo de cooperação ou de troca, tudo isso independentemente das proximidades geográficas e das filiações institucionais". Para o autor "O desenvolvimento das comunidades virtuais acompanha, em geral, contatos e interações de todos os tipos” (LÉVY, 2000, p.129). De acordo com sua concepção de virtual, atesta que se pode sustentar que as chamadas comunidades virtuais “[...] realizam de fato uma verdadeira atualização (no sentido da criação de um contato efetivo) de grupos humanos que eram apenas potenciais antes do surgimento do ciberespaço" (LÉVY, 2000, p.130).

Existem inúmeras noções de comunidades virtuais disponíveis em literatura acadêmica e leiga tanto quanto existem de comunidades, e também consensos e dissensos a respeito. Considera-se aqui, como se viu, a noção de comunidade virtual como rede social online, numa matriz da Social Network Analysis, a partir de Wellman e Castells. Neste sentido, comunidade virtual poderia ser assumida como uma rede social cujos nós são pessoas que se comunicam e interagem através de meios digitais de forma a estabelecer laços e trocas, constituindo relações sociais. Trata-se de redes com tamanhos, composições e qualidades variáveis, onde se estabelece algum tipo de sociabilidade. O próprio

\footnotetext{
${ }^{18}$ Tradução da autora. No original: "Virtual communities are social aggregations that emerge from the Net when enough people carry on those public discussions long enough, with sufficient human feeling, to form webs of personal relationships in cyberspace."
} 
Rheingold pondera, na mesma entrevista a Powazek, citada acima, passado oito anos de publicação de The Virtual Community, que o fenômeno das comunidades virtuais é mais amplo e complexo do que supunha, destacando a importância das descobertas da Social Network Analysis, as redefinições das noções senso comum de comunidade, e seu envolvimento com as mudanças dos meios de comunicação. “Comunidades virtuais são um subconjunto das redes sociais online” ${ }^{19}$ (RHEINGOLD apud POWAZEK, 2002, p.290).

Meneses (2004), ao analisar especificamente o Orkut.com, uma das chamadas comunidades virtuais de relacionamentos mais conhecidas atualmente, principalmente no Brasil, chega a citar possíveis diferenças entre as tradicionais comunidades virtuais de interesse e as comunidades pessoais do individualismo em rede. ${ }^{20}$ Baseado em Rheingold, o autor cita como tradicionais às comunidades virtuais as noções de debate e discussão em torno de temáticas e interesses comuns, a geração de valores compartilhados e do próprio sentimento de pertencimento. No Orkut existe uma infinidade de comunidades estabelecidas a partir de temas muito diversificados, dispostos a partir de categorias, podendo ser consideradas grupos de interesses comuns. Os indivíduos optam por criar ou fazer parte destas comunidades, automaticamente as têm agregadas a seus perfis na rede, o que não significa que efetivamente estabeleçam interações efetivas nestes ambientes, contrariando as premissas de Rheingold de debate e discussões. Segundo Meneses (2004), pertencer a uma comunidade de interesse no Orkut cumpriria mais um papel na composição do perfil dos indivíduos, ou seja, na definição de identidades, do que propriamente de interação social. Segundo o autor, este seria um exemplo significativo do uso social de uma determinada tecnologia, ou ferramenta, atestando sua própria configuração. No Orkut.com o estabelecimento de uma comunidade pessoal estaria acima da criação de

\footnotetext{
${ }^{19}$ Tradução da autora. No original: "Virtual communities are a subset of online social networks."

${ }^{20}$ Segundo Meneses (2004), trata-se de uma rede de acesso restrito, gratuita, da qual pode-se participar a partir do convite de algum integrante. Ela disponibiliza informações a respeito do indivíduo tanto na esfera pessoal, como social e de trabalho, que são visíveis para outros membros de acordo com alguns critérios. A comunicação entre os membros da rede se dá basicamente por envio de e-mails pessoais [abertos- scrapbook, ou em caixa fechada] e através de fóruns de discussões estabelecidos em comunidades específicas. O Orkut.com se insere na linha de desenvolvimento de software para a formação de redes sociais do grupo Google.
} 
redes de interações baseadas em interesses. Porém, Meneses assume na sua análise que o Orkut.com articula comunidades pessoais, associadas mais aos conceitos do individualismo em rede proposto por Wellman e Castells como forma dominante de sociabilidade na atualidade, com as tradicionais comunidades virtuais de interesse, criando uma rede de redes. Para o autor, este "novo modelo de interação online oferece um passo além do disponível no cotidiano presencial, permitindo que a interconexão e a interação social através da rede seja não mais algo desejável ou futuro, senão uma realidade e com diversas caras"21 (MENESES, 2004).

Os agrupamentos formados no ciberespaço são um conjunto heterogêneo de fenômenos sociais constituídos a partir trocas comunicacionais. A comunicação mediada por dispositivos digitais, incluindo a comunicação mediada por computador $^{22}$, não necessariamente pressupõe a existência de comunidades virtuais. Ou seja, a existência desse meio de comunicação não é um pressuposto para a existência das comunidades virtuais. Existem as trocas de mensagens privadas um-para-um, a comunicação sem possibilidades de interlocução do tipo um-para-todos, práticas peer-to-peer, e muitas outras ações comunicacionais, estabelecidas a partir de diferentes ferramentas no ciberespaço, alheias a constituição de comunidades virtuais. Segundo Jones:

A literatura a respeito das comunidades virtuais é insistente no sentido de que a comunicação interativa é uma condição necessária para uma série de mensagens CMC demonstrar a existência de uma comunidade virtual. [...] A exigência de um nível mínimo de interatividade nos permite excluir uma variedade de classes de CMC da categoria de comunidade virtual. Por exemplo, uma lista de email aonde assinantes recebem notícias e informações mas não são capazes de conduzir

\footnotetext{
${ }^{21}$ Tradução da autora. No original: "[...] nuevo modelo de interacción online se ofrece un paso más allá de lo disponible en la presencialidad cotidiana, permitiendo que la interconexión y la interacción social a través de la red sean no ya algo deseable o un futurible, sino una realidad y con diversas caras".

22 É comum encontrar em textos acadêmicos dos últimos anos da década 1990 a expressão CMC, acrônimo de comunicação mediada por computador (em inglês computer mediated communication), referindo a forma de comunicação por excelência em meios digitais. Hoje está em desuso, pelo fato do computador ser apenas um entre os vários equipamentos de suporte das TIC.
} 
discussões interativas com colegas assinantes não poderia ser classificada aqui como uma comunidade virtual ${ }^{23}$ (JONES, 1997).

Além da comunicação interativa, o que mais determinaria uma comunidade virtual? As comunidades virtuais geralmente são caracterizadas a partir de alguns pressupostos como interação, sentimento de pertencimento, compartilhamento de interesses, afinidades e objetivos, tendência à cooperação, variedade de membros e a estabilidade e permanência desses membros durante um determinado período de tempo, contrapondo-se a efemeridade nas relações. ${ }^{24}$ Também podem ser pensadas a partir de algumas dinâmicas, que envolvem a sinergia entre variáveis técnicas e sociais (RIBEIRO, 2001). Segundo este autor, “[...] a técnica fornece um elemento essencial para o estabelecimento do dinamismo social dentro das comunidades virtuais" (RIBEIRO, 2001). Neste mesmo sentido, Lemos atesta:

O ciberespaço é, enquanto forma técnica, ao mesmo tempo, limite e potência dessa estrutura social de conexões tácteis que são as comunidades virtuais (chats, muds e outras agregações eletrônicas). Em um mundo saturado de objetos técnicos será nessa forma técnica que a vida social vai impor o seu vitalismo e reestruturá-la. [...] A forma técnica molda-se ao conteúdo social, não sem conflitos (LEMOS, 1997).

$\mathrm{Na}$ verdade, a noção de comunidade virtual abarca multiplicidades e diferenciações, fluidez e flexibilizações, tanto quanto são possíveis tipos diferentes de interações no ciberespaço, espécies de associações de pessoas em ambientes de comunicação digitais. A generalização de qualidades ou entendimentos se torna, neste contexto, inviável.

\footnotetext{
${ }^{23}$ Tradução da autora. No original: "The literature regarding virtual communities is insistent that interactive communication is a necessary condition for a series of CMC messages to demonstrate the existence of a virtual community. [...]. The requirement for a minimum level of interactivity allows us to exclude a variety of classes of CMC from the category virtual community. For example, an email list where subscribers receive news and information but are not able to conduct interactive discussions with fellow subscribers would not be classified here as a virtual community."

${ }^{24}$ Diversos autores, entre eles Rheingold e Castells, destacam a relação direta entre a criação da internet, imbuída de espírito de comunitarismo, de cooperação, de experimentação, de exploração de possibilidade e recursos tecnológicos, e a constituição das comunidades virtuais.
} 
Hoje, comunidades virtuais se estabelecem a partir de uma variedade de infra-estruturas tecnológicas, de espaços digitais, de diferentes formatos de comunicação digital disponíveis, ou seja, a partir de redes múltiplas usadas como suporte de interações sociais, seja listas de discussões, fórum de debates, comunicadores instantâneos, ambientes gráficos de chats, blogs, jogos online, entre tantas outras. ${ }^{25} \mathrm{Se}$ a princípio, nos anos 1970 e 1980, a interação nas comunidades virtuais era conduzida predominantemente através de textos escritos, nos BBS (Bulletin Board Services) e MUDs (Mult-User Domains), hoje se dá cada vez mais por meio de sons e imagens. A tendência é que se expandam para ambientes digitas com outros formatos, a partir da sofisticação das tecnologias ubíquas, de realidade virtual, entre outras. ${ }^{26}$

Existem diferentes abordagens nos estudos de comunidades virtuais, desde análises de sociabilidade a partir de ferramentas específicas, como a realizada por Meneses, citada acima, passando pela particularidade dos aspectos comunicacionais, de criação e manutenção de ferramentas de suporte, de mediação, e ainda pela questão de gênero, raça, etnia, ordem e controle social, classe e status socioeconômico, entre tantos outros. Assim como, existem análises focadas em comunidades virtuais de aprendizagem, comunidades virtuais de relacionamento, comunidades virtuais de prática ${ }^{27}$,

\footnotetext{
25 Jones (1997) define estes suportes tecnológicos como virtual settlement, algo próximo a estabelecimento virtual ou assentamento virtual, que seria o lugar, a base das comunidades virtuais no ciberespaço, ou dentro da qual uma comunidade virtual opera. "A existência de um virtual settlement é a prova da existência de uma comunidade virtual associada" (JONES, 1997). Segundo o autor, para o estabelecimento de um virtual settlement são necessárias algumas condições, que justamente 0 diferencia em qualidade de um ciberespaço qualquer. São condições: (1) um nível mínimo de interatividade, concebida como trocas comunicacionais e não como característica dos meios; (2) um número variado de comunicadores, ou seja, mais que dois indivíduos interagindo; (3) um espaço público comum onde uma porção significativa de um grupo que realiza comunicação mediada por computador de forma interativa ocorre; e (4) um nível mínimo de quantidade de membros de sustentação, relacionada à interatividade, densidade e estabilidade das trocas comunicacionais. Para Jones, uma comunidade virtual não é equivalente a um virtual settlement, "uma comunidade virtual é uma forma de relação social forjada via um virtual settlement" (JONES, 1997)

Nessa nota, tradução da autora, no original: "The existence of a virtual settlement is proof of the existence of a related virtual community" "e "...] a virtual community is a set of social relationships forged via a virtual settlement".

${ }^{26}$ Como já destacado, no próximo capítulo trata-se das diferentes ferramentas disponíveis na internet, das interfaces de modo geral, e das possibilidades de interação.

${ }^{27}$ Ver, a respeito, WENGER, E.; McDERMOTT, R.; SNYDER, W.M. (2002). Cultivating Communities of Practice. Boston: Harvard Business School Press.
} 
comunidades virtuais de lazer, comunidades virtuais de conhecimento, comunidades virtuais de interesse. Quanto à sociabilidade, geralmente as discussões giram em torno de algumas características principais, que são a independência do espaço geográfico, as possibilidades e impossibilidades de anonimato e de trocas sensoriais, de romper ou manter isolamentos, de criar, manter ou ocultar identidades, e das capacidades de escolhas.

Há quem destaque, a partir deste emaranhado de características, focos positivos ou negativos, ou perspectivas restritivas ou emancipatórias, muito embora existam, como se viu, comunidades e comunidades. É a práxis quem dita se um recurso é libertador ou uma armadilha, se é inofensivo ou perigoso. E ainda assim, estes extremos dicotômicos nem sempre exprimem de forma apropriada os processos que ocorrem nas comunidades virtuais. Kollock e Smith (1999), editores de Communities and Cyberspace, afirmam logo na introdução do livro que os diferentes autores compartilham do "[...] entendimento comum de que os tipos de interações e instituições que estão emergindo no ciberespaço são mais complicadas do que podem ser parcialmente capturados em termos de utopias e antiutopias"28 (KOLLOCK; SMITH, 1999, p.4). Para os autores, não se trata de indagar se a interação online é boa ou ruim, o importante é descrever e analisar modelos, padrões de organizações e interações sociais online da forma que existem.

Estes fatos corroboram a idéia de que as análises de comunidades virtuais estão em construção, não são generalizáveis, e tendem, cada vez mais, a estar concentradas em comunidades determinadas, detentoras de particularidades não extensíveis a outras. Fato que explica, como se disse, certa dificuldade e prudência na caracterização dos elementos constituintes das comunidades virtuais.

${ }^{28}$ Tradução da autora. No original: "[...] a common understanding that the kinds of interactions and institutions that are emerging in cyberspace are more complicated than can be captured in one-sided utopian or dystopian terms". 


\subsubsection{Comunidades em espaços hibridos}

Ainda que a comunidade seja mais bem caracterizada, nos dias de hoje, a partir das redes sociais, não se pode ignorar por completo o componente territorial dos agrupamentos humanos. Milani, quando voltado à questão do desenvolvimento local, destaca:

A análise do local do desenvolvimento pode ganhar força com a expansão da globalização econômica, porquanto o desenvolvimento local seria o contraponto do contexto e da diversidade frente ao temor da uniformização de meios e conteúdos. O local pode ser emancipatório, tornarse fonte de novas utopias e apresentar potencial transformador. [...] O local é, nesse sentido, construído social e territorialmente; é delimitado pela permanência de um campo estável de interação entre atores sociais, econômicos e políticos (MILANI, 2004).

Castells, em sua ampla análise da sociedade dos últimos anos do século XX, mostra que:

[...] juntamente com a revolução tecnológica, a transformação do capitalismo e a derrocada do estatismo, vivenciamos no último quarto do século o avanço de expressões poderosas de identidade coletiva que desafiam a globalização e o cosmopolitismo em função da singularidade cultural e do controle das pessoas sobre as suas próprias vidas e ambientes (CASTELLS, 2002, p.18).

Dentre essas expressões de identidade coletiva destacam-se o fundamentalismo religioso, o nacionalismo, a identidade étnica, e a identidade territorial. Interessa aqui, particularmente, esta última forma de identidade relacionada ao âmbito espacial, que pode ser relacionada às comunidades locais. O autor chama atenção para o complexo campo onde atuam variáveis de espaço e cultura, e destacando perspectivas conflitantes a respeito, declara que as pessoas se sociabilizam e interagem em seu ambiente local e formam redes sociais, ou seja, as identidades locais entram em intersecção com outras fontes de reconhecimento social, criando um padrão diversificado de interações, como postula Wellman. Neste sentido, afirma: 
[...] não creio que seja impreciso afirmar que ambientes locais, per se, não induzam um padrão específico de comportamento ou, ainda, justamente por isso, uma identidade distintiva. [...] as pessoas resistem ao processo de individualização e atomização, tendendo a agrupa-se em organizações comunitárias que, ao longo do tempo, geram um sentimento de pertença e, em última análise, em muitos casos, uma identidade cultural, comunal (CASTELLS, 2002, p.79).

Destaca, assim, o território como sendo a fonte mais imediata de auto-reconhecimento e organização autônoma. Por fim salienta que

[...] as comunidades locais, construídas por meio da ação coletiva e preservadas pela memória coletiva, constituem fontes especificas de identidades. Essas identidades, no entanto, consistem em reações defensivas contra as condições impostas pela desordem global e pelas transformações, incontroláveis e em ritmo acelerado. Elas constroem abrigos, mas não paraísos (CASTELLS, 2002, p.84).

A análise de Castells dá destaque às comunidades locais, e não descarta o fato que a territorialidade em si seja capaz de produzir determinados padrões de interação social, ao mesmo tempo em que estabelece a possibilidade de agregar a esta outras redes sociais de interação. Assim, os agrupamentos humanos podem ser considerados de uma perspectiva que abarca tanto os componentes territoriais, como os componentes das redes sociais que prescindem das limitações espaciais e temporais, como visto acima. É neste sentido que se pode falar em comunidades estabelecidas a partir de espaços híbridos, como redes de pessoas que sobrepõem às interações sociais vinculadas a um determinado recorte territorial, a um espaço geográfico limitado, as interações estabelecidas no ciberespaço.

As redes sociais locais, as comunidades geograficamente referenciadas, as comunidades de base local, ou simplesmente as comunidades, no sentido mais tradicional do termo, "são por definição limitadas no tempo e espaço." (SANTOS, 2005, p.247). O ciberespaço constitui um novo locus de expansão para estas comunidades, de superação destas limitações. A hibridação espacial, no plano das comunidades, se dá quando os laços sociais forjados a partir do território, do espaço físico, das redes de interação local, reverberam no ciberespaço, assim como quando os vínculos, os laços, as interações sociais 
criadas em ambientes virtuais são transpostas para os espaços concretos delimitados. Uma comunidade instaurada em espaços híbridos seria então estabelecida por redes sociais constituídas a partir da sinergia da comunicação e interação em ambientes físicos e virtuais.

Gaved e Mulholland (2005) chamam comunidade híbrida (hybrid community) uma comunidade que consiste em pessoas que interagem socialmente usando ambos os meios de comunicação online e offline. Além da comunicação entre moradores e do suporte à interação social, estes meios são utilizados para reunir e estocar informação. Trata-se de uma comunidade que é suportada e possibilitada através do uso de canais múltiplos de comunicação, inclusive por ferramentas e serviços baseados na internet, mas não exclusivamente.

Estas comunidades híbridas podem superar as dificuldades apresentadas pelas comunidades puramente virtuais, usando mecanismos de confiança inerentes a agrupamentos sociais face-aface, enquanto por sua vez a comunidade física deve beneficiar-se de recursos adicionais oferecidos por uma infra-estrutura de rede e ferramentas online $e^{29}$ (GAVED; MULHOLLAND, 2005).

Para os autores o uso dos canais online e offline pode variar, sendo possível o estabelecimento de comunicação primeiramente tanto através de ferramentas digitais como por meios tradicionais. Contudo, os autores estão interessados nas práticas de inserção de infra-estruturas tecnológicas em comunidades com existência física ${ }^{30}$, e, portanto entendem o termo comunidade híbrida como comunidades onde a interação física é estendida ao virtual, e não vice-versa. Há que se considerar aqui uma certa impropriedade nesta nomenclatura, pois híbrido é o espaço comunicacional da comunidade, e não ela em si. Gaved e Mulholland (2005) dizem que essas comunidades podem ser frutos de estudos exploratórios desenvolvidos pela academia e governos, de testes de mercado de organizações comerciais, ou ainda iniciativas das próprias comunidades, seja em função da ausência de recursos

\footnotetext{
${ }^{29}$ Tradução da autora. No original: "These hybrid communities may overcome the difficulties faced by purely virtual communities, using the trust mechanisms inherent within face to face social groupings, while in turn the physical community may benefit from the additional affordances offered by a network infrastructure and online tools."

${ }^{30}$ Os autores usam, neste estudo, o termo comunidade de localidade (community of locality) para descrever uma comunidade geográfica onde algum nível de interação social e ligação emocional existem, ou de capital social, nos termos de Putnam.
} 
externos, seja acionadas pela idéia da vizinhança conectada. Esses autores se voltam aos projetos iniciados pelas próprias comunidades locais, nomeadas grassroots initiated networked communities, procurando investigar estas ações como soluções sustentáveis de superação da exclusão digital. ${ }^{31} \mathrm{~A}$ hipótese é que estas comunidades iniciadas pelos próprios moradores locais podem oferecer soluções sustentáveis para as múltiplas desigualdades entre aqueles que estão potencialmente conectados.

Nós supomos que uma solução potencial é conduzir os indivíduos online como parte de suas comunidades locais, que adicionando uma infra-estrutura de rede e ferramentas online para a comunidade tanto indivíduos como comunidade irão se beneficiar. Esta comunidade híbrida, permite comunicar e armazenar informação usando ambos os canais de comunicação online e offline, pode oferecer um método sustentável para superar a exclusão digital e informar o discurso ao redor das comunidades virtuais utilizadas dentro de um ambiente social ${ }^{32}$ (GAVED; MULHOLLAND, 2005).

Etzioni e Etzioni (1999) fazem uma análise comparativa entre o que chamam comunidades face-a-face (f2f) e comunidades mediadas por computador (CMC), usando diferentes parâmetros: o acesso a interlocutores, a amplitude do conhecimento interpessoal, as possibilidades de difusão de interação, de reagrupamento, de efetuar mecanismos de distanciamento e civilidade, e compartilhamento da memória, ligado a história, identidade, experiências e rituais. Os autores definem comunidade a partir de dois atributos, os laços, associado a rede de relações carregadas de sentimento que cercam um grupo de indivíduos, e a cultura, relativo ao compartilhamento de valores, tradições e costumes, propósitos, e identidade histórica. Laços e cultura seriam atributos contínuos de uma comunidade e não variáveis dicotômicas. Segundo Etzioni e Etzioni (1999) as comunidades que combinariam os sistemas de

31 Tais autores criticam a noção de digital divide constituída em termos dicotômicos de acesso. Consideram a questão da desigualdade no universo digital a partir de vários fatores, de acordo com DiMaggio e Hargittai (2001).

${ }^{32}$ Tradução da autora. No original: "We hypothesise a potential solution is to bring individuals online as part of their local community; that by adding a network infrastructure and online tools to a community both individuals and the community itself will benefit. This hybrid community, enabled to communicate and store information using both online and offline channels of communication, may offer a sustainable method to overcoming the digital divide and inform the discourse surrounding virtual communities utilised within a social environment." 
comunicação face-a-face e CMC, ou seja, estabelecidas a partir de um sistema híbrido (hybrid system), possuem uma melhor capacidade de união, de estabelecer laços entre as pessoas, e uma forma mais eficaz de compartilhar valores. Os autores sugerem que "ambos os sistemas face-a-face e CMC possuem forças e fraquezas, e que sua peculiar combinação promete reunir em maior quantidade os prérequisitos de comunidade do que qualquer um deles poderia separadamente"33 (ETZIONI; ETZIONI, 1999). Estes sistemas mistos seriam, portanto, mais eficazes à prática de constituição de comunidades.

Para Castells (2003) existe um padrão de interação entre redes online e offline, que se estabelece por excelência a partir da comunicação híbrida. “[...] o que observamos em nossas sociedades é o desenvolvimento de uma comunicação híbrida que reúne lugar físico e ciber lugar (para usar uma terminologia de Wellman) para atuar como suporte material do individualismo em rede" (CASTELLS, 2003, p.109). Nardi e O'Day (2000), em sua análise de Pueblo, um ambiente virtual de aprendizagem criado para estudantes de uma escola secundária em Phoenix, Estados Unidos, destacam seu arraigamento na comunidade, em ambos os mundos virtual e físico, como uma de suas qualidades primeiras. "Puebo não é estritamente virtual nem estritamente físico - é um novo tipo de lugar híbrido, estendendo-se sobre ambos os locais, físico e virtual"34 (NARDI; O'DAY, 2000, p.132).

Blanchard e Horan (2000), ao estudarem comunidades virtuais, destacam a importância de distinguir entre dois diferentes tipos: a comunidade virtual de interesse, geograficamente dispersa, e a physically based virtual community (comunidade virtual de base física), que diz respeito à comunidade tradicional, territorialmente delimitada, acrescida de recursos eletrônicos para uso dos indivíduos. Os autores destacam que esta distinção se faz importante pelo fato da relação entre estes dois tipos de comunidade virtual ser pouco conhecida, havendo indícios que estas duas formas possam estar competindo entre si, ou mesmo que os laços em comunidades virtuais sejam mais fortes quando

\footnotetext{
${ }^{33}$ Tradução da autora. No original: "[...] both $f 2 f$ and CMC systems have strengths and weaknesses of their own, and that their proper combination promises to meet more of the prerequisites of community than either of them could separately."

${ }^{34}$ Tradução da autora. No original: "Pueblo is neither strictly virtual nor strictly phisical -it is a new kind of hybrid place, stretching across both physical and virtual locales."
} 
estabelecidos a partir da comunicação face-a-face e mediada por computador. A distinção parece necessária também quando se assume que as comunidades virtuais fortalecem as relações face-a-face em comunidades geográficas:

[...] é possível aqui efeitos diferentes na participação como membros nesses dois tipos de comunidades em relação ao capital social e ao engajamento cívico. Tanto as comunidades virtuais dispersas como as comunidades de base física podem ter potencial para aumentar capital social, mas nas comunidades de base física pode ser mais provável o aumento do engajamento cívico (especialmente sendo membro em um grupo face-a-face) desde que esta comunidade esteja já associada a um centro cívico por assim dizer ${ }^{35}$ (BLANCHARD; HORAN, 2000).

Esta comunidade virtual de base física, definida por Blanchard e Horan se aproxima conceitualmente da comunidade instituída a partir de espaços híbridos, aqui considerada, assim como da idéia por trás do termo glocalization (glocalização), usado por Wellman e Hampton ${ }^{36}$ (HAMPTON, 2001). Glocal expressaria para estes autores a combinação da conectividade global e local facilitada pela comunicação mediada por computador. Segundo Hampton,

o desenvolvimento das redes sociais suportadas por computador assegura a perspectiva de alavanca para ambas as comunidades, local e não-local (global). A conectividade da comunicação mediada por computador provê acesso à pessoa localizada à distância, mas ao mesmo tempo a localização da tecnologia na moradia facilita o acesso às relações locais. [...] Se a nova tecnologia de comunicação pode expandir e aumentar o acesso a membros de nossas redes sociais, tanto à

\footnotetext{
${ }^{35}$ Tradução da autora. No original: "[...] there may different effects of member participation in these two types of communities in regards to social capital and civic engagement. Both dispersed virtual communities and physically based communities may have the potential to increase social capital, but physically based communities may be more likely to increase civic engagement (especially membership in a FtF group) since this community is already associated with a civic center so to speak."

${ }^{36}$ Segundo Hampton (2001) a expressão glocalization também aparece em vários artigos dos anos 1990, referindo-se aos processos sociais, econômicos e políticos relacionados aos efeitos locais dos fenômenos globais.
} 
distância como com aqueles encerrados à mão, potencialmente aumenta o acesso ao capital social $^{37}$ (HAMPTON, 2001,p.31).

A comunidade instituída a partir de espaços híbridos expressa o entrelaçamento de uma comunidade geograficamente referenciada e uma comunidade virtual agregada a ela. Expressa também a sobreposição de redes sociais construídas presencialmente e redes sociais implementadas em ambientes virtuais, ambas estabelecidas a partir de referências territoriais. Pode-se dizer que a comunidade em espaço híbrido é um outro lugar, uma outra instância, constituída a partir da ampliação ou potencialização da comunidade de base local pela associação de duas instâncias comunicacionais de interação, as estabelecidas no plano físico, concreto, das relações presenciais e as fundadas em ambientes virtuais, suportadas por meios digitais. ${ }^{38}$

\subsection{Consideraçōes sobre transformaç̄es a partir das IT}

Uma das questões centrais à criação de espaços online de interação social voltados a comunidades geograficamente delimitadas é: o que leva as pessoas a interagirem nesses ambientes virtuais? Ou seja, como e porque as pessoas incluiriam instâncias virtuais de comunicação e interação no seu cotidiano? Estas perguntas, em maior ou menor grau, relacionam-se aos objetivos e finalidades de muitas iniciativas envolvendo TIC e comunidades locais, que quase sempre, estão direcionadas a fomentar

\footnotetext{
37 Tradução da autora. No original: "The development of computer-supported social networks holds the prospect of enhancing both non-local (global) and very local communities. The connectivity of computer-mediated communication provides access to people located at a distance, but at the same time the location of the technology in the home facilitates access to local relationships. [...]lf new communication technology can expand and increase access to members of our social networks, both at a distance as well as with those close at hand, it potentially increases access to social capital. "

38 É importante que se diga aqui que, embora não seja interesse desta pesquisa, é possível estabelecer relações entre a abordagem de comunidades em espaços híbridos e o escopo das investigações da chamada cidade virtual.
} 
ganhos e melhorias na qualidade de vida das pessoas, seja nas suas dimensões sociais, econômicas, ou em ambas. Outras questões que se fazem prementes neste contexto são: qual natureza dessas melhorias? Como fazer com que as pessoas percebam estas possibilidades e perspectivas?

Neste item procura-se mostrar alguns parâmetros e estruturas teóricas que orientam diferentes práticas e ações que têm como objetivo o desenvolvimento de uma comunidade local. Considera-se aqui desenvolvimento como qualquer processo de alteração de uma determinada realidade, material ou imaterial, qualificado como positivo. Qualquer forma de transformação das condições sociais, econômicas ou políticas, ou ainda especificamente das dimensões educacionais, culturais, e outras, que agregue ganhos na qualidade de vida das pessoas, seja no plano individual ou coletivo. Parte-se do princípio de que uma situação-problema em uma comunidade pode ser enfrentada a partir de determinadas ações direcionadas a estabelecer impulsos e perspectivas para a mudança do estado considerado indesejável. Interessa a este trabalho as possíveis mudanças em âmbito comunitário a partir da introdução dos meios de comunicação mediados por tecnologias digitais, portanto reuniram-se aqui parâmetros e conceitos chaves selecionados a partir de trabalhos que se voltam aos efeitos das TIC na vida cotidiana de comunidades de base local. Trata-se de uma reunião de diferentes conceitos e abordagens que se relacionam, e que figuram como metas, objetivos ou ainda como resultados almejados de inúmeras iniciativas envolvendo o uso das TIC. Todos, invariavelmente, estão relacionados ao fomento de ganhos e melhorias na qualidade de vida das pessoas.

É importante que se diga que existe uma infinidade de indicadores sociais, criados pelos mais variados órgãos de pesquisa e voltados a interesses distintos, que procuram medir de forma sistematizada e parametrizada diferentes aspectos das condições de vida, como por exemplo, autonomia, qualidade, desenvolvimento, eqüidade, entre tantos outros. O interesse aqui não é apresentar e discutir especificamente métodos acabados de aferição de condições de vida, nem tampouco se aventurar na discussão a respeito de mensuração de qualquer natureza, e sim demarcar alguns conceitos e procedimentos metodológicos que são significativos no contexto das iniciativas envolvendo o uso das TIC, principalmente àquelas ancoradas territorialmente. 
Primeiro apresentam-se os conceitos de transformação social, capital social e empoderamento. Ainda que não exclusivos ao universo das iniciativas que envolvem TIC, são citados como propósitos na maioria dos projetos pertencentes ao rol das ações ditas de inclusão digital. Se alinham à superação de dificuldades, e à disposição de benefícios e recursos, quando se trata das comunidades em espaços híbridos. Depois se apresentam algumas estratégias metodológicas, também citadas neste contexto, que buscam estruturar caminhos que levem as mudanças almejadas.

\subsubsection{Transformação social}

A transformação social é hoje o ponto focal, objetivo primeiro, de diferentes ações no âmbito das políticas públicas de forma geral, das agências de desenvolvimento nacionais e internacionais, de organizações não governamentais, independente de escalas e amplitudes. Ainda que a expressão transformação social seja invariavelmente associada a um caráter positivo, a uma noção de melhorias qualitativas ou quantitativas de pelo menos algum aspecto da vida das pessoas ou grupos, também agrega uma dimensão de imprecisão, um sentido nebuloso, vinculando-se, muitas vezes, a outras noções como cidadania, emancipação, igualdade e justiça social.

$\mathrm{Na}$ Sociologia clássica a transformação social é vista como um processo, e é concebida de forma diferente por autores como Karl Marx, Ėmile Durkheim e Max Weber. Silva apresenta uma síntese das teorias e análises destes três pensadores com relação a esta questão:

[...] para Marx, o processo de transformação social se encontra estreitamente relacionado com as contradições que ocorrem na base material da sociedade: com as contradições que se manifestam entre as forças produtivas e as relações de produção e com as lutas classes. Em cada contexto histórico, a classe dominada da época seria o agente da transformação social na medida em que adquirisse consciência das contradições sociais e na medida em que se organizasse para a conquista do poder político enquanto instrumento promotor das mudanças. [...] para Durkheim, a 
evolução social ocorre conforme se expandem a divisão e a especialização do trabalho. Com a divisão do trabalho ocorre o enfraquecimento da consciência coletiva; o nascimento e desenvolvimento das individualidades, mas nem por isso, a sociedade se desintegra. Se antes as semelhanças que havia entre os membros da coletividade os mantinham, mecanicamente, integrados, agora, é a divisão do trabalho que, ao torná-los diferentes e dependentes uns dos outros, os mantém organicamente integrados entre si. Weber, por sua vez, explica a transformação social pelas lutas que ocorrem entre as diversas visões de mundo. Quer dizer, para Weber, a transformação social ocorre na medida em que uma dada visão de mundo encontra adeptos com interesses ideais e materiais afins e se implanta no mundo tendo em vista a sua conservação ou a sua transformação (SILVA, 2004).

Estas três visões relacionam a transformação social a processos complexos, com variáveis que perpassam diferentes campos de estruturação da vida social. Entretanto, a idéia de transformação social que parece estar por trás das práticas contemporâneas desenvolvidas no âmbito dos governos ou da sociedade civil organizada está longe de um sentido ligado a uma mudança de estruturas da sociedade, de seus paradigmas fundadores, ou mesmo de um caráter revolucionário. 0 sentido que assume no contexto destas ações está vinculado a mudanças graduais planejáveis, a possibilidades de alteração de estados de desigualdade ou falta de autonomia que podem levar a uma sociedade mais justa, porém nos moldes vigentes. Trata-se de um conceito que parece ter como horizonte a exeqüibilidade de uma sociedade mais horizontalizada e igualitária.

Ainda que alheia a uma perspectiva de alteração das estruturas sociais amplas, a transformação social engendrada em contextos sociais específicos e realidades locais é de grande importância, e não menos complexa. Está vinculada a processos de participação social, de desenvolvimento local, a mudanças significativas de diferentes setores da vida social, ao acesso, ampliação, e distribuição de bens culturais, e também de consumo, e ainda a estratégias de combate à exclusão social e diminuição da pobreza, nos termos apresentados no capítulo anterior. 
Os processos de transformação social compreendidos a partir da ótica do desenvolvimento local não são simples, envolvem uma multiplicidade de fatores, também situados nos campos sociais, culturais, políticos e econômicos. Ainda que não sejam regulados somente pelo sistema de mercado, não são também frutos de assistencialismo, situam-se nos entremeios das questões de descentralização, governança local, participação, da emergência da sociedade civil, do fortalecimento do capital social, entre outros.

Neste projeto de transformação social, há significativo grau de interdependência entre os diversos segmentos que compõem a sociedade (âmbitos político, legal, educacional, econômico, ambiental, tecnológico e cultural) e os agentes presentes em diferentes escalas econômicas e políticas (do local ao global). É fundamental pensar o desenvolvimento local enquanto projeto integrado no mercado, mas não somente: o desenvolvimento local é também fruto de relações de conflito, competição, cooperação e reciprocidade entre atores, interesses e projetos de natureza social, política e cultural (MILANI, 2004).

No âmbito das iniciativas e projetos envolvendo o uso das TIC, e neste trabalho, a transformação social se estabelece a partir desta perspectiva de busca de eqüidades, e se reverbera em mudanças em diferentes níveis. Seja na formação de um sujeito mais crítico, autônomo, consciente de seu lugar no mundo, seja nas alterações das situações de penúria a que estão sujeitos determinados grupos.

\subsection{Capital Social: as redes sociais potencializam a mobilização de recursos}

O conceito de capital social é demasiado importante no contexto dos trabalhos que investigam comunidades. Possui uma relação explícita não só com as concepções de redes sociais, mas também com desenvolvimento local e transformação social. Trata-se de um conceito que começou a circular nos ambientes acadêmicos mais intensamente partir de meados dos anos 1990, e que hoje é amplamente divulgado e utilizado tanto nas pesquisas acadêmicas das Ciências Sociais, como em áreas disciplinares 
distintas como Economia, Administração, Política e Educação. A apropriação do conceito de capital social se entendeu a diferentes agendas e campos de discussão, também nos circuitos leigos, que a despeito da credibilidade também variada, envolve agentes diferentes como dirigentes políticos, organizações não governamentais, organizações internacionais de auxílio, entre outros (MILANI, 2004; PORTUGAL, 2007).

A extensão da apropriação do conceito de capital social, em todos estes contextos, parece explicitar ainda mais a diversidade de definições que o termo abarca, as controvérsias, ambigüidades e amplitudes por trás da idéia, a falta de consenso entre seus principais formuladores, acentuando a dificuldade, por um lado, de sua operacionalização, tanto teórica quanto empírica, e por outro de atestar sua capacidade heurística. A despeito disso, concebido como fonte de benefícios, o conceito vem se instrumentalizando em políticas e práticas de desenvolvimento local, no sentido de identificar suas potencialidades em comunidades em diferentes contextos. "Ele implica ampliar a perspectiva a aspectos não econômicos da vida social, tais como o capital de confiança e conviviabilidade, de capacidade coletiva de viver e agir juntos de maneira eficaz" (MILANI, 2004).

Vários autores, no campo das Ciências Sociais, têm abordado a noção de capital social, derivando diferentes vertentes e abordagens, entre eles, Pierre Bourdieu, Robert Putnam, James Coleman, Nan Lin, Mark Granovetter, Francis Fukuyama, Henk Flapp, Roland Burt, Alejandro Portes, Christian Grootaert, John Durston, David Robinson, Deepa Narayan, e outros (FONTES; EICHNER, 2004; MILANI, 2004; PORTUGAL, 2007; SANTOS, 2005).

O interesse aqui é destacar alguns poucos conceitos de capital social que se constroem vinculados às concepções de redes sociais. Quando se pensa as redes sociais como provedoras de recursos, como o faz Wellman, ai percebe-se o capital social. Este conceito alinha às redes sociais, comunicação, apoio e cooperação, e pode ser estabelecido no sentido de direcionar a criação e reprodução de práticas inclusivas. 
Redes de relações propiciam o fluxo e o intercâmbio de informações; criam espaços nos quais a comunicação pode ter lugar, o que é uma função-chave para sistemas sociais ricos em capital social, uma vez que abrem acesso à informação e permitem que opiniões e conhecimentos sejam compartilhados. O sentimento de pertencer ao grupo (identidade de grupo) é fundamental na definição do capital social [...] (MILANI, 2004).

O capital social se constitui como um capital, uma riqueza, um valor, um fundo, um estoque, que é apreendido nas relações sociais, pondo em evidência alguns recursos advindos das próprias relações e conexões entre indivíduos, disponíveis através das redes sociais.

Existem evidências de que o capital social pode ser usado para promover a redução da pobreza, o desenvolvimento e o bem-estar social, o que aproximaria os interesses da sociologia e da economia nesse campo. [...] No entanto, sua mensuração é problemática e, embora ele possa ser associado ao desenvolvimento, especialmente local, sua promoção não é trivial, ou seja, como ele está incrustado nas redes de relações sociais, não é evidente, do ponto de vista das pesquisas na área de econômia, como a sua expansão ou modificação pode afetar o bem-estar de seus componentes (MARTELETO; OLIVEIRA E SILVA, 2004, p.45).

Nan Lin apresenta quatro fatores que explicariam a disponibilização desses recursos a partir dos laços sociais: o fluxo de informação facilitado, a influência de agentes importantes, os laços sociais como credenciais, e o reforço de identidade e reconhecimento (PORTUGAL, 2007).

Bourdieu é comumente considerado pioneiro no estudo sobre capital social (FORNI; SILES; BARREIRO, 2004). O capital social é para este autor o conjunto de recursos, efetivos ou potenciais, relacionados às relações e redes sociais, que podem ser mobilizadas efetivamente para beneficiar o indivíduo ou sua classe social. Trata-se de redes duráveis, mais ou menos institucionalizadas, construídas através de estratégias de investimento nas relações sociais, passíveis de serem utilizadas como fontes de benefícios (MILANI, 2004; PORTUGAL, 2007).

Coleman trabalha com o conceito de capital social em uma dimensão individual, e também o localiza nas redes de contatos sociais. O autor destaca a capacidade de relacionamento do indivíduo, e as 
expectativas de reciprocidade e comportamento confiáveis que emergem desta rede de conexões, que juntas ajudariam na eficiência individual (PORTUGAL, 2007; RATTNER, 2003). Para Coleman o capital social no plano coletivo:

ajudaria a manter a coesão social, pela obediência às normas e leis; a negociação em situação de conflito e a prevalência da cooperação sobre a competição, tanto nas escolas quanto na vida pública, o que resultaria em um estilo de vida baseado na associação espontânea, no comportamento cívico, enfim, numa sociedade mais aberta e democrática (RATTNER, 2003).

Os estudos de Putnam, bastante conhecidos, ao contrário dos de Bourdieu e Coleman, chamam atenção para as análises de capital social em âmbito das estruturas sociais macro, para o âmbito coletivo, não individual (PORTUGAL, 2007; RATTNER, 2003). Para Putnam, o capital social está relacionado a aspectos da organização social, principalmente uma dimensão normativa e de confiança existente entre os diversos atores sociais. Refere-se ao grau de associativismo e de acatamento às normas de comportamento cívico como facilitadoras de coordenação e cooperação para benefício comum (MILANI, 2004; RATTNER, 2003). Os trabalhos de Putnam estão ligados a uma dimensão política, e ressaltam a intensidade da vida associativa, a estruturação da sociedade civil e sua relação com o exercício da democracia. Sobre o conceito em Putnam, Rattner escreve:

[...] o capital social se fundamenta nas relações entre os atores sociais que estabelecem obrigações e expectativas mútuas, estimulam a confiabilidade nas relações sociais e agilizam o fluxo de informações, internas e externas. Em vez de controles e relações de dominação patrimonialistas, o capital social favorece o funcionamento de normas e sanções consentidas, ressaltando os interesses públicos coletivos. Enquanto as vias convencionais de formar capital humano estimulam o individualismo, a construção de capital social repercute favoravelmente na coesão da família, da comunidade e na sociedade (RATTNER, 2003).

As análises sobre capital social elaboradas por Milani (2004) e Portugal (2007) chamam a atenção para o fato de se associar a idéia de capital social somente com um efeito positivo. Ainda que aqui somente estes efeitos interessem, é bom que se saiba que os mecanismos que possibilitam o fluxo de capital 
social podem excluir os que estão fora dos grupos, podem impedir a iniciativa individual, restringir a liberdade individual e reduzir expectativas pessoais (MARTELETO; OLIVEIRA E SILVA, 2004; PORTES, 1998 apud PORTUGAL, 2007). ${ }^{39}$

\subsubsection{Empoderamento}

É importante destacar que paralelo aos objetivos de transformação social e aumento de capital social nos diferentes projetos que buscam, no limite, alavancar a qualidade de vida das pessoas, seja no contexto das TIC ou não, se alinham as metas de empoderamento. 0 empoderamento também não é um conceito simples. Abordado a partir de diferentes perspectivas, envolve componentes individuais e coletivos. Surgido nos anos 1970, vem sendo discutido desde então. Segundo Oakley e Clayton (2003) empoderamento diz respeito aos desequilíbrios na distribuição de poder, seja formal ou informal. Segundo os autores, o empoderamento, foco de muitas intervenções para a promoção do desenvolvimento social e humano, reconhece as habilidades e conhecimentos das pessoas e comunidades, e:

[...] tem sido instrumentalizado por meio de metodologias práticas de projetos, e quanto ao seu efeito e impacto, começa a ser traduzido em medidas observáveis. De forma concreta, o empoderamento pode se manifestar em três grandes áreas: (1) o poder como maior confiança na capacidade pessoal para levar adiante algumas formas de ação; (2) o poder como aumento das relações efetivas que as pessoas desprovidas de poder podem estabelecer com outras organizações; e (3) o poder como resultado da ampliação do acesso aos recursos econômicos, tais como crédito e insumos (OAKLEY; CLAYTON, 2003).

De acordo com Costa (2004) “empoderamento é o mecanismo pelo qual as pessoas, as organizações, as comunidades tomam controle de seus próprios assuntos, de sua própria vida, de seu destino, tomam

${ }^{39}$ PORTES, A. (1998). Social Capital: Its Origins and Applications in Modern Sociology, Annual Review of Sociology, n. 24, p.11-24. 
consciência da sua habilidade e competência para produzir, criar e gerir. "Seja no plano das mudanças individuais ou coletivas, de acordo com Stromquist (1997 apud COSTA 2004) ${ }^{40}$, os parâmetros do empoderamento são (1) construção de uma auto-imagem e confiança positiva; (2) desenvolvimento da habilidade para pensar criticamente; (3) a construção da coesão de grupo; (4) a promoção da tomada de decisões; e (5) a ação.

A transformação social, o empoderamento e o capital social interessam aqui quando relacionados no plano coletivo às comunidades geograficamente demarcadas, e às comunidades em espaços híbridos, justamente onde se operam a instrumentalização destes conceitos, através de diferentes iniciativas e projetos. Nesse contexto tais comunidades são tomadas como públicos-alvo, o que deriva alguns reveses. Rizek (2007) faz uma análise em que apresenta a questão dessas comunidades locais como instrumento de gestão e de controle da pobreza. Levados a cabo por diversos atores, que atuam no “[...] mercado de verbas públicas e privadas que financiam os programas contemporâneos de inclusão social, [...] que instituem uma face ou uma configuração nova para a chamada 'questão social' [...]", na condição muitas vezes de assessorias técnicas, realizam-se intervenções de várias naturezas nas comunidades, instaurando uma “[...] forma de encenar e figurar as formas de desigualdade assimiladas como inevitáveis, como objeto de gestão e administração” (RIZEK, 2007). Segunda a autora:

No trato coletivo com grupos organizados como "comunidades", o conflito, os embates acabam por ser paulatinamente substituídos por um saber difuso que se aproxima de uma tecnologia social ou mesmo de uma tecnologia do social, produzindo novas práticas, freqüentemente pedagogizadas, novos saberes, novos empreendimentos e toda uma indústria de premiações nacionais e internacionais (RIZEK, 2007).

É importante pensar que sob esta perspectiva as mudanças e emancipações pretendidas parecem minorar. Instaura-se uma lógica do fazer institucionalizado voltado a si próprio, análogo às práticas que concebem a tecnologia com um fim em si mesma.

${ }^{40}$ STROMQUIST, N. (1997). La busqueda del empoderamiento: en qué puede contribuir el campo de la educación. In LEON, M. Poder y Empoderamiento de las mujeres. Santafé de Bogotá. TM Editores. 


\subsubsection{0s recursos locais: Asset-Based Community Development}

Outra crítica que recebem determinados programas e iniciativas que se voltam a promoção do desenvolvimento local, e ao combate a pobreza de forma geral, diz respeito a predisposição que apresentam em transformar as pessoas e as comunidades em clientes, em beneficiários passivos e permanentes. Tais programas são, muitas vezes, chamados assistencialistas, de forma pejorativa. Geralmente se justificam a partir de necessidades e carências, enfatizam as deficiências e problemas que imperam nessas comunidades.

Os pesquisadores norte-americanos John P. Kretzmann e John L. McKnight da Universidade Northwestern, preocupados com a temática do desenvolvimento comunitário, elaboraram o Asset-Based Community Development ${ }^{41}(\mathrm{ABCD})$, um instrumento que dispõe uma série de princípios e práticas que buscam fomentar o desenvolvimento de comunidades, seja no plano econômico como no social, tendo como base os recursos relevantes, os bens, disponíveis nas próprias comunidades.

Kretzmann e McKnight partem do princípio que existem duas formas de intervenção em comunidades locais, ou duas abordagens quando se quer a revitalização destas comunidades, uma baseada em necessidades e outra focada em capacidades. A primeira, centrada no que é ausente na comunidade, está intimamente relacionada aos modelos de ações tipo top-down, que envolve pesados esforços de agentes externos à comunidade, que se prestam a desenvolver serviços a fim de construir as capacidades locais. Neste modelo os indivíduos são percebidos como clientes passivos dependentes dos serviços sociais prestados.

O fato é que a orientação deficiente representada pelo mapa de necessidades que constitui nosso único guia a vizinhanças de baixa renda tem trazido consequiências danosas aos residentes. Nós temos já notado uma entre as mais trágicas - que é os próprios residentes começarem a aceitar

\footnotetext{
${ }^{41}$ Desenvolvimento Comunitário Baseado em Ativos. Traduz-se aqui asset como ativo, recurso, ou bem.
} 
este mapa como o único guia para a realidade de suas vidas. Eles concebem a si próprios e suas vizinhanças como fundamentalmente deficientes, vítimas incapazes de encarregar-se de suas vidas e do futuro de suas comunidades ${ }^{42}$ (KRETZMANN; MCKNIGHT, 1993).

O segundo modelo de ação está centrado no reconhecimento das capacidades, habilidades, talentos e dons dos membros da comunidade local, sejam indivíduos, associações e instituições locais, na valorização do que está presente naquela determinada territorialidade, ou vizinhança, como chamam. Nesta perspectiva, volta-se a processos de direcionamento e desenvolvimento de capacidades, aos esforços de agentes internos, trabalha-se com o mapeamento de bens, ou recursos locais, para engendrar mudanças que sejam auto-sustentáveis. Segundo os autores, um processo de desenvolvimento que leva a transformações deve ter como ponto de partida não o mapa das carências e necessidades das comunidades locais e sim o mapa das capacidades e recursos existentes nessas comunidades:

[...] a evidência histórica indica que um desenvolvimento comunitário significante ocorre somente quando as pessoas da comunidade local estão comprometidas a investirem elas mesmas e seus recursos nesta realização. Esta observação explica porque comunidades nunca são construídas de cima para baixo, ou de fora para dentro. [...] A segunda razão para enfatizar o desenvolvimento de recursos internos de vizinhanças urbanas locais é que o prospecto de ajuda externa é de fato desanimador. [...] o foco intenso na auto-consciência interna não é pretendido para minimizar seja o papel que as forças externas tem desempenhado em ajudar a criar as condições irremediáveis das vizinhanças de baixa renda, seja a necessidade de atrair recursos adicionais para estas comunidades. Ao invés disso este foco interno forte é pretendido simplesmente para

\footnotetext{
42 Tradução da autora. No original: "The fact that the deficiency orientation represented by the needs map constitutes our only guide to lower income neighborhoods has devastating consequences for residents. We have already noted one of the most tragic--that is, residents themselves begin to accept that map as the only guide to the reality of their lives. They think of themselves and their neighbors as fundamentally deficient, victims incapable of taking charge of their lives and of their community's future."
} 
enfatizar a primazia da exposição, investimento, criatividade, esperança e controle locais $^{43}$ (KRETZMANN; MCKNIGHT, 1993).

O processo de construção e desenvolvimento comunitário a partir dos recursos e forças da comunidade local, segundo o modelo proposto, apresenta então três características ou princípios ${ }^{44}$. Primeiro, é baseado nos recursos locais, segundo, é focado internamente, terceiro, é impulsionado pelas relações. Neste sentido, a mobilização comunitária se daria então a partir do mapeamento dos recursos locais, da construção das relações internas, da mobilização de recursos comunitários para desenvolvimento econômico e compartilhamento de informações, da construção de um plano ou uma imagem comunitária, e do estabelecimento de conexões externas que possam dar suporte ao desenvolvimento definido localmente (KRETZMANN; MCKNIGHT, 1993).

Como um modelo de ação, uma abordagem que busca permitir o desenvolvimento de uma comunidade local através da potencialização de seus diferentes recursos, pode-se dizer que o Desenvolvimento Comunitário Baseado em Ativos está diretamente associado ao fomento de capital social e empoderamento.

O foco nos recursos locais redireciona a atenção para o vasto capital social das comunidades. [...] As capacidades individuais dos residentes são os blocos básicos da construção de qualquer comunidade. Como as pessoas exercitam estas capacidades, elas freqüentemente encontram o

\footnotetext{
${ }^{43}$ Tradução da autora. No original: "[...] the historic evidence indicates that significant community development takes place only when local community people are committed to investing themselves and their resources in the effort. This observation explains why communities are never built from the top down, or from the outside in. [...] The second reason for emphasizing the development of the internal assets of local urban neighborhoods is that the prospect for outside help is bleak indeed. [...] Again, this intense and self-conscious internal focus is not intended to minimize either the role external forces have played in helping to create the desperate conditions of lower income neighborhoods, nor the need to attract additional resources to these communities. Rather this strong internal focus is intended simply to stress the primacy of local definition, investment, creativity, hope and control."

${ }^{44}$ Existem cinco categorias de recursos comunitários que, identificados e interligados entre si, dão sustentação a um processo de desenvolvimento comunitário voltado às habilidades locais: (1) os que dizem respeito aos residentes locais, suas habilidades, experiências e capacidades (2) os que estão ligados às associações voluntárias, clubes e redes locais, atuantes nas áreas culturais, esportivas e sociais, (3) àqueles agregados às instituições locais, sejam públicas, comerciais ou sem fins lucrativos, (4) os recursos físicos, que envolve terras, construções, infra-estrutura, transportes e (5) os recursos econômicos, ligados a produção, consumo, trocas informais (KRETZMANN et al., 2005).
} 
que necessitam nos talentos de outros em seus empreendimentos. Esta conduta os une com outros indivíduos com quem irão trabalhar a fim de uma meta comum. Quando eles fazem isto, combinam seus próprios talentos com as capacidades de outros para formar uma associação e dar suporte a instituições locais que podem criar contribuições vastas e valiosas para sua comunidade $^{45}$ (TURNER-LEE; PINKETT, 2004, p.172).

\subsection{Participação: a metodolog̣ia de Extremadura}

$\mathrm{Na}$ comunidade autônoma de Extremadura, na Espanha, desde o final dos anos 1990, está sendo implementada uma ação estratégica pela Junta de Extremadura, através do Conselho de Educação, Ciência e Tecnologia e da Associação das Universidades Populares de Extremadura (AUPEX), com colaborações de municípios e outras entidades. Trata-se de um projeto coletivo de mudança social, econômica e cultural, da articulação de um modelo de desenvolvimento socioeconômico e cultural, que envolve as TIC em todos os setores de atividade, incluindo aí a implantação dos telecentros NCCs, já citados oportunamente neste trabalho. Interessa destacar aqui a amplitude desta iniciativa, que parte de uma estratégia regional vislumbrando a possibilidade de transformação social, nos planos pessoal e coletivo, e especificamente a Metodologia da Participação que estrutura os planos de alfabetização tecnológica desenvolvidos nos telecentros. Em Extremadura, a alfabetização tecnológica é concebida como um instrumento de mudança, é operacionalizada através dessa metodologia participativa, que se baseia justamente nos componentes suscetíveis de transformações sociais, que possibilitem um

\footnotetext{
45 Tradução da autora. No original: "The focus on local assets redirects attention to the extensive social capital of communities. [...] The individual capacities of residents are the basic building blocks of any community. As people exercise these capacities, they often find they need the talents of others in their enterprises. This leads them to join with other individuals who will work with them toward a common goal. When they do this, individuals combine their own talents with the capacities of others to form associations and support local institutions that can make extensive and valuable contributions to their community."
} 
processo de desenvolvimento da região e sua incursão no que chamam sociedade da informação e comunicação.

O foco das preocupações dos centros de alfabetização tecnológica não recai na formação pela formação, senão em mudar a cultura e a percepção que têm os cidadãos de si mesmos e de seu contexto. Trata-se de indagar e extrair boas práticas de uma dinamização para a mudança, pressupondo esta uma mudança de estilo, do estado de ânimo das organizações e das pessoas, nas formas de fazer, para provocar o crescimento e a materialização das potencialidades que se encontram ocultas na sociedade extremenha. [...] Pretende-se uma imersão coletiva em um processo de ação-reflexão para despertar a consciência crítica sobre os fatos e nossas formas de vida, pondo em contato inquietudes, idéias e iniciativas da sociedade extremenha ${ }^{46}$ (EQUIPO TÉCNICO AUPEX, 2003, p.8).

A Metodologia da Participação parte, então, da identificação de atitudes e aptidões suscetíveis a mudanças sociais, que são (1) as práticas, costumes ou ações desenvolvidas na vida diária, (2) os equipamentos, ferramentas, objetos, vestimentas, utilizados habitualmente, (3) as narrativas, interpretações ligadas ao povo da região, nos planos individual e coletivo, (4) os símbolos, ligados a liderança como referência, (5) a identidade, associada às peculiaridades da comunidade, (6) as relações, ou seja, as redes de colaboração estabelecidas e a estabelecer e (7) o estado de ânimo, que diz respeito aos valores positivos ligados a resolução de conflitos, e a percepção de oportunidades (EQUIPO TÉCNICO AUPEX, 2003, p.41). Estes componentes, por sua vez, são utilizados nos processos de motivação, capacitação e organização que são os pilares da Metodologia da Participação.

\footnotetext{
${ }^{46}$ Tradução da autora. No original: "El foco de las preocupaciones de los centros de alfabetización tecnológica no recae em la formación por la formación, sino em cambiar la cultura y la percepción que tienen los ciudadanos de si mismos y de su contexto. Se trata de indagar e extraer buenas prácticas de uma dinamización para el cambio pressuponiendo ésta um cambio de estilo, del estado de ánimo em las organizaciones y em las personas, em las formas de hacer, para provocar el crescimiento y materialización de las potencialidades que se encuentran ocultas em la sociedad extremeña. [...] Se pretende uma inmersión colectiva em um proceso de acción-reflexión para despertar la consciência crítica sobre los hechos y nuestras formas de vida poniendo em contacto inquietudes, idéias e iniciativas de la sociedade extremeña [...]".
} 


\section{Motivação}

A motivação tem por objetivo conduzir as pessoas e organizações para além do uso instrumental de computadores e da internet, e também dos interesses pessoais, visando o comprometimento com o coletivo. As técnicas de motivação fazem parte de um processo de animação sociocultural realizado pelos dinamizadores, cuja tarefa é a decifração do imaginário coletivo. Estes são responsáveis por detectar os interesses e necessidades dos participantes. Neste sentido, o processo de motivação se alinha a um diagnóstico participativo da localidade e de suas organizações. As conversações são os elementos chaves do processo de motivação, a estratégia mais importante, permitem descobrir problemas, interesses, necessidades de cidadãos e organizações. Permitem estruturar as atividades moldadas às demandas a cada momento.

\section{Capacitação}

O processo de capacitação começa com a proposta de atividades, que parte da demanda dos paricipantes, alinhada ao treinamento no uso das ferramentas tecnológicas. 0 objetivo aqui é formar para transformar, e para tal, concebe-se esta formação contínua do uso das TIC como expressão das aptidões e atitudes criativas, da participação em projetos de interesse geral voltado a cidadania. Porém, o educador guia, orienta um processo de autoformação, na qual o educando é ativo. Juntos desenvolvem conteúdos formativos, de acordo com interesses, necessidades e ritmos próprios do educando. 0 processo de capacitação estabelece a conexão entre necessidade de aprender, a realidade vivida e a realidade desconhecida.

\section{Organização}

O processo de organização visa não reproduzir formas existentes, mas buscar novas formas complementares de se organizar em rede. 0 objetivo é criar projetos coletivos na rede, a partir de reuniões e intercâmbios presenciais e virtuais. A organização dos NCCs, em parte espontânea e livre, 
em parte induzida pelos dinamizadores, tem como base a comunicação e o diálogo, através de conversas e acordos por consenso.

Embora o discurso proferido pelos agentes implementadores desse projeto pareça estar, algumas vezes, envolto a um espírito demasiado panfletário, as ações postas em prática em Extremadura atestam a validação da metodologia adotada e dos resultados almejados, ainda que não em toda a expressividade pretendida. Trata-se de uma iniciativa envolvendo TIC que coloca o fator humano em primeiro plano e a partir dele desenha as transformações sociais desejadas.

\subsection{Animação sociocultural}

As metodologias de animação sociocultural possuem extensos aportes conceituais e teóricos que também devem ser examinados, no sentido de orientarem as práticas a serem implementadas e incentivadas no âmbito de iniciativas e projetos envolvendo TIC que almejam transformações sociais. Dizem respeito às garantias, responsabilidades, e importâncias da participação da comunidade nessas iniciativas e projetos. Augustin e Gillet (2006) apresentam a animação sociocultural como herdeira da educação popular e de valores como o acesso igualitário à cultura. Situam-na assim:

Ao relacionar-se com os fenômenos de crises dos laços sociais, com a perda das certezas culturais do passado, se apresenta, antes de qualquer coisa, como um método de adaptação, integração e transformação sociais. Método que tem a intenção de estimular as expressões múltiplas, e especialmente as dos meios populares locais. Neste sentido, a animação é a continuação do projeto de educação popular que, sem a ilusão de suprir as desigualdades sócio-espaciais, imagina 
em troca uma estratégia de promoção dos valores diferenciais de indivíduos, grupos e espaços ${ }^{47}$ (AUGUSTIN; GILLET, 2006, p.19).

Trabalhando a partir de uma proposta de consideração de atores menos sujeitos a projetos assistencialistas e mais favoráveis a mudança, os animadores socioculturais atuam em diversas áreas da vida social e cultural, em diferentes projetos de intervenção ligados a grupos e comunidades locais, em equipamentos sociais ou outras organizações. Presentes em Extremadura, esses agentes parecem ser peças chaves em intervenções que demandam a valorização das interações sociais, sejam elas face-aface ou online.

Foth (2006a), nos seus estudos sobre as redes sociais em comunidades locais e sobre o design de sistemas online de suporte para estas redes, adotou uma metodologia que agrega várias abordagens de pesquisa em desenvolvimento comunitário e redes comunitárias, entre elas a animação sociocultural e o Desenvolvimento Comunitário Baseado em Ativos. Chamada de PAD: Participation, Animation, Design, a metodologia combina princípios de participação, animação e design. 0 autor destaca que "os princípios que estas influências metodológicas provêem atuam a favor da estrutura de uma abordagem dupla que integra as atribuições técnicas de design e implementação de uma rede comunitária, com as atribuições sociais de animação e sustentação de rede comunitária entre os residentes de uma vizinhança”"48 (FOTH, 2006a). A metodologia proposta por Foth abarca os vários estágios de um projeto envolvendo TIC, nos moldes de implementação de uma comunidade em espaço híbrido:

\footnotetext{
${ }^{47}$ Tradução da autora. No original: "Al estar relacionada com los fenômenos de crisis del lazo social, com la perdida de las certezas culturales del pasado, se apresenta, antes que nada, como um método de adaptación, integración y transformación sociales. Dicho método intenta estimular las múltiples expressiones, y especialmente las de médios populares localizados. Em este sentido, la animación es la continuación del proyecto de la educación popular que, sin la ilusión de suprimir las desigualdades socio-espaciales, imagina em cambio uma estratégia de promoción de los valores diferenciales de indivíduos, grupos y espacios.

48 Tradução da autora. No original: "The common ground that these methodological influences provide advocates a dual approach that integrates the technical task of designing and implementing a community network with the social task of animating and sustaining community networking among residents of the neighbourhood."
} 
Depois da fase inicial de imersão [na comunidade local] no estágio I, o modelo integra o design de sistemas [...] com os esforços de construção comunitária [...] nos estágios II e III. Métodos de design participativo são utilizados para criar a infra-estrutura técnica, para prover acesso à informação e para assegurar a usabilidade dentro de um contexto da interação homemcomputador e de sistemas de design centrados em humanos, enquanto que a animação sociocultural é empregada para povoar a rede, fazer uso da informação e cultivar a sociabilidade dentro de um contexto de vínculos sociais e redes humanas peer-to-peer. 0 estágio IV adapta princípios de marketing viral para manter e formar uma massa crítica de usuários ativos e para estabelecer uma cultura de vizinhança que fortalece a rede comunitária online [...]. Ainda que o processo progressivo de investigação crítica, reflexão e ação dentro do paradigma da pesquisa ação já incorpore um progressivo envolvimento de avaliação dentro de cada estágio, este ponto da pesquisa modelar se fecha com uma avaliação final do projeto no estágio $V^{49}$ (FOTH, 2006a).

Em iniciativas envolvendo o uso das TIC, inclusive de implantação de comunidades em espaços híbridos, o caminho que se percorre do desejo de transformação e mudança, ao resultado das ações implementadas, é demasiado tortuoso. Demanda, como foi visto no capítulo anterior, a execução harmônica e concomitante de diferentes práticas. Entretanto, é preciso que estejam claros, neste percurso, os objetivos a serem atendidos. Estes objetivos devem ser desenhados e definidos de tal forma que sejam os moldes, os parâmetros das ações realizadas. Embora sejam outputs, neste contexto funcionam como inputs. São os insumos, as matérias-primas sob as quais se devem trabalhar. Beamish (2001) chama a atenção tanto para o problema da falta de clareza nas metas como para a suposição, subjacente a muitos projetos envolvendo TIC em comunidades locais de baixa renda, de que a

\footnotetext{
49 Tradução da autora. No original: "After the initial phase of immersion in Stage I, the model integrates systems design (indicated on the left) with community building efforts (on the right) in Stages II and III. Participatory design methods are utilised to create the technical infrastructure, to provide access to information and to ensure usability within the context of human-computer interaction and human-centred systems design, whereas sociocultural animation is employed to populate the network, make use of information and to improve sociability within the context of social ties and human peer-to-peer networks. Stage IV adapts principles of viral marketing to maintain and build upon a critical mass of active users and to establish a neighbourhood culture that strengthens the online community network, [...]. Although the ongoing process of critical inquiry, reflection and action within the action research paradigm already incorporates an ongoing commitment to evaluation within each stage, the research aspect of the model closes with a final project evaluation in Stage V."
} 
tecnologia automaticamente melhora a vida das pessoas e lugares. “[...] posto que igualdade de acesso é indiscutivelmente importante, nós estamos freqüentemente incertos sobre o porque as comunidades de baixa renda deveriam ter acesso. Elas poderiam usá-lo para trazer mudança social? Mobilização política? Empregos? Educação?"50 (BEAMISH, 2001, p.364).

\section{Reflexões sobre comunidades em espaços hibridos}

Busca-se aqui o exame mais detalhado dos efeitos que as tecnologias de informação e comunicação podem imprimir na vida de indivíduos e comunidades geograficamente referenciadas. Trata-se da reunião de alguns resultados e reflexões a respeito dos aspectos sociais da internet, a partir de diferentes estudos, que atestam ser possíveis a transformação social, a elevação de capital social, o empoderamento de comunidades locais e seus atores, a partir do uso das TIC. O objetivo também é entender como se estabelece a dinâmica das relações entre as dimensões concretas e virtuais de comunidades locais, é perceber qual o caráter e estrutura que essa dinâmica, é desvendar em que resulta o estabelecimento de uma outra instância comunicacional em uma comunidade local, a partir dos ambientes de interações sociais no ciberespaço. Para tal examina-se, também, o estabelecimento de uma agenda de pesquisa que parece voltar-se a estas questões.

É importante considerar que qualquer investigação dos efeitos das TIC em geral, ou dos fenômenos sociais na internet em particular, estão sujeitos a especificidades e variações de diferentes ordens. Sejam aquelas ligadas as exclusivamente as características técnicas, que se alteram e transmutam

\footnotetext{
${ }^{50}$ Tradução da autora. No original: "[...] even though access is inarguably important, we are often unclear about why low-income communitues should have access. Could they use it to bring about social change? Political mobilization? Employment? Education?"
} 
constantemente, a modelos diferentes de ambientes virtuais de interação, como se verá no capítulo três desta tese, sejam às associadas ao rol dos diferentes aspectos que possuem as iniciativas e projetos, como visto no capítulo um. Ainda é preciso considerar que se inscreverem num universo amplo de investigações que têm não só pontos de partidas e recortes diversos, mas metodologias e premissas distintas.

\subsection{Uma nova agenda de pesquisa}

Segundo Castells (2003), a internet nasceu para a maioria das pessoas em 1995, o que engloba a sociedade em geral, excluindo apenas instâncias diretamente relacionadas ao universo computacional. ${ }^{51}$ Pode-se pensar, então, que a sociabilidade na e com a internet é fenômeno novo, cuja origem é extremamente recente. Guardadas as devidas proporções, para um conjunto cada vez mais significativo da sociedade contemporânea, apenas há uma década é possível vislumbrar instâncias de sociabilidade a partir de ambientes virtuais. É, portanto, neste contexto que se instauram os estudos das transformações das interações sociais na sociedade da informação, usando a denominação do próprio Castells.

Segundo Dornelles (2004, p.242), "é cada vez mais comum e compreensível que seja possível bater papo, conhecer pessoas, fazer amigos e até mesmo namorar via computador / internet”. Porém, a familiarização com os fenômenos dos relacionamentos sociais na internet não excluem especificidades, principalmente quando se aventura no campo analítico. É importante destacar algumas implicações que se fazem presentes neste contexto na área metodológica. Por um lado, ainda que seja curto o período de tempo de existência da internet, diferentes momentos podem significar estágios distintos de sua

\footnotetext{
51 Sabe-se, como se verá, que o uso de redes de computadores como meio de comunicação data do final da década de 1960. Sabe-se também que os usos dessas redes a partir de então foram fundamentais na conformação atual da internet e de suas diferentes ferramentas de comunicação.
} 
configuração; por outro, o desenvolvimento tecnológico, seja em hardware e software, torna muitos instrumentos e ferramentas comunicacionais obsoletos na mesma medida em que se apresentam configurações mais aprimoradas, tudo isso com uma rapidez estrondosa. Estes fatos alinhados podem, de certa forma, inviabilizarem comparações entre os resultados de algumas pesquisas, tornando-os bastante circunscritos a determinados contextos. Esta quase instantaneidade de alterações, que abrange outros níveis e variáveis também, como se verá, implica algumas limitações metodológicas a essas pesquisas. Estas restrições se convergem na impossibilidade de se estabelecer afirmações gerais e conclusões definitivas sobre os efeitos das TIC sobre as relações sociais, o que de forma alguma diminui a importância desses estudos. 0 interesse crescente nesta área de pesquisa aliado a constatação empírica do uso cada vez mais acelerado de instrumentos digitais na comunicação atestam neste sentido.

A busca pelo entendimento das relações entre internet e vida cotidiana, das relações entre comunicação e interações sociais em instâncias virtuais e híbridas, tem dado origem a novas agendas de pesquisa. Há especificamente uma agenda recente que procura relacionar comunidades locais e TIC, e vem recebendo inúmeras denominações na literatura acadêmica internacional.

Gaved e Anderson (2006) apresentam alguns exemplos de termos usados, no inglês, para descrever iniciativas que igualmente procuram relacionar comunidades territorialmente delimitadas e o uso das TIC: community network, network community, networked community, place based community network, place based virtual network, community-based ICT initiatives e local net. Arnold (2004) fala do estudo empírico do uso doméstico das TIC dentro de campo de pesquisa chamado community networking. Nesta pesquisa deparou-se ainda, em diferentes momentos, com estudos que apresentavam as seguintes nomeações para este campo de estudo: community-based ICT projects, 
electronic community networking, community-based technologies, community technology, ou ainda projects ICT. Além de community computing e community informatics que aparecem logo abaixo. ${ }^{52}$

É importante destacar que à parte as diferentes denominações, as vezes com diferenças bastantes sutis entre si, o interesse final das pesquisas parece ser sempre o entrelaçamento das tecnologias digitais no plano das comunidades locais. As referências utilizadas são também coincidentes em muitas áreas disciplinares, porém as abordagens metodológicas apresentam significativa variação. Há, em alguns casos, a intencionalidade de definir precisamente mais que um nome, e sim uma agenda, com princípios e amplitudes. Porém, por enquanto, é difícil prever se haverá no futuro um consenso em torno deste ou daquele termo ou expressão, e ainda mais sobre seus temários e recortes.

Beamish (2001) fala das diferentes acepções que termo community computing, traduzida aqui como computação comunitária, têm assumido ao entrelaçar comunidade e tecnologia. Cita o sentido de provisão de acesso a internet e informações a comunidades locais que assumiu primeiramente, depois destaca aquele que relaciona redes comunitárias públicas de acesso a computadores e conexão para grupos locais, e por fim, destaca o sentido de provisão de conteúdos online relevantes para grupos de baixa renda para incentivar uso das TIC. Citando Morino, a autora acredita que a melhor definição para o termo community technology, que agrega em si uma variedade de projetos, seria a de um processo que serve a comunidades de bases geográficas, que responde às suas necessidades e constrói soluções para seus problemas, usando comunicação eletrônica (MORINO,1994 apud BEAMISH, 2001)..$^{53}$

Também Carroll (2005) situa seus estudos a partir da experiência Blacksburg Electronic Village, sobre a qual se fala adiante, dentro do escopo da community computing. Segundo o autor trata-se de uma

\footnotetext{
${ }^{52} \mathrm{Na}$ literatura acadêmica brasileira consultada percebe-se o uso da expressão inclusão digital para qualificar as iniciativas, projetos e experiências desta natureza, e quando pertinente, faz-se menção ao vínculo com comunidades geograficamente referenciadas. Conforme apresentado no capítulo anterior, preferiu-se neste trabalho não utilizar nenhuma expressão específica que pudesse implicar recortes rígidos, ou ainda construções conceituais ou teóricas próprias, optando-se por termos mais genéricos, dado que no trabalho como um todo faz-se referências a iniciativas envolvendo o uso das TIC muito diferentes em si.

${ }^{53}$ MORINO, M. (1994). Assessment and Revolution of Community Networking. Paper presented at Ties That Bind, at Apple Computer, Cupertino CA.
} 
instância que une, por um lado, uma prática e, por outro, a pesquisa em ciências sociais e em ciências da computação; e que também:

pode ser um instrumento e uma ferramenta para oportunidades econômicas, educação e instrução, auto-expressão e lazer, e desenvolvimento social e político. Pode ser um teste e laboratório para o estudo de questões que se estendem da usabilidade de computadores e redes à criação de capital social em democracia participativa"54 (CARROLL, 2005, p.59).

Destacando sua composição que confronta propósitos e interesses, o autor diz que para serem bem sucedidas, as ações de community computing requerem uma perspectiva conciliadora, de participação de diferentes grupos. Devem ainda abraçar diferentes tensões, entre as quais destaca: (1) aquela estabelecida de forma inerente nas relações entre desenvolvimento comunitário e o desenvolvimento tecnológico, (2) aquela que se situa entre a necessidade da infra-estrutura que vem quase sempre da imposição de agentes externos e o desenvolvimento criativo das redes comunitárias e (3) aquela que diz respeito aos atritos entre as motivações cívicas e as motivações econômicas. Para Carroll (2005) a tecnologia tem que estar voltada a aplicações para o desenvolvimento comunitário, sendo este desenvolvimento facilitado quando a tecnologia de suporte é eficaz.

Day e Schuler (2004a) apresentam a community informatics, traduzida aqui como informática comunitária, campo emergente dentro da pesquisa de tecnologia da comunicação comunitária, como um conjunto de princípios e práticas ligadas ao uso e apropriação das TIC em comunidades com fins de desenvolvimento, seja social, pessoal, econômico ou cultural. Defendem que este conjunto de princípios deva integrar práticas, políticas e pesquisas a favor do desenvolvimento comunitário. Segundos estes autores, o planejamento, implementação e desenvolvimento de sistemas de comunicação digital em comunidades locais deveriam estar atrelados, em âmbito local, às redes sociais e ao capital social. "Eles deveriam ser considerados elementos integrantes da infra-estrutura

54 Tradução da autora. No original: "It can be an engine and a tool for economic opportunity, education and training, selfexpression and leisure, and social and political development. It can be a testbed and laboratory for studying issues ranging from the usability of computers and networks to the creation of social capital in participatory democracy." 
comunitária tanto quanto o são, da mesma maneira, as bibliotecas públicas" 55 (DAY; SCHULER, 2004b, p.217). Para Gurstein (2004), que teria cunhado o termo informática comunitária, esta abordagem estabelece o design e o sistema de implementação das TIC em seus contextos comunitário e social, e:

[...] provê de forma mais proveitosa uma base conceitual e metodológica do design para o uso eficaz. [...] inclui: (1) um comprometimento para a universalização da tecnologia - possibilita oportunidades que incluem os desfavorecidos; (2) um reconhecimento que a 'vida da comunidade física' é o verdadeiro centro do bem estar - econômico, político e cultural - tanto familiar como individual; (3) uma convicção que esta vida comunitária pode ser melhorada através do uso criterioso das TIC; (4) um entendimento sofisticado da tecnologia da informação focado no usuário; e (5) a aplicação de liderança social, empreendedorismo, e criatividade ${ }^{56}$ (GURSTEIN, 2004).

Ainda neste contexto de pesquisas que buscam investigar as benesses das TIC em comunidades locais se situam as pesquisas agrupadas em torno dos chamados social software (software sociais), que se voltam ao desenvolvimento de programas de interação social, de ferramentas de suporte à sociabilidade online, abordados, neste trabalho, mais atentamente, no próximo capítulo. É, portanto, dentro desta agenda com contornos bastante permeáveis que se situam os estudos das comunidades constituídas a partir dos espaços híbridos.

\footnotetext{
55 Tradução da autora. No original: "They must be considered as integral elements of the community infrastructure, in much the same ways as public libraries are."

56 Tradução da autora. No original: "[...] most usefully provides a conceptual and methodological foundation for designing for effective use.[...] include: • a commitment to universality of technology-enabled opportunity which includes the disadvantaged; • a recognition that the "lived physical community" is at the very center of individual and family well-being - economic, political, and cultural; • a belief that this lived community can be enhanced through the judicious use of ICTs; • a sophisticated user-focused understanding of information technology; and • applied social leadership, entrepreneurship, and creativity."
} 


\subsubsection{A complementaridade da sociabilidade onlinee offline}

Como já se disse, os estudos dos efeitos das TIC em diferentes campos se constroem, pelo menos num primeiro momento, de forma dicotômica, entre posturas entusiastas e desgostosas, para depois posicionarem em patamares mais moderados, serenos. No contexto específico da sociabilidade, alguns autores destacavam que as redes de interação virtuais poderiam tanto construir, incentivar e alavancar como mascarar, destituir e minar o envolvimento pessoal, as relações e interações sociais face-a-face, e assim, o capital social, ou mesmo provocar isolamento social e o agravamento dos estados de depressão e solidão. Também existiam àquelas precavidas ao extremo, que ignoravam alterações significativas nos vínculos sociais.

Como se viu, as pesquisas sobre interações sociais associadas à internet se inscrevem num universo amplo de investigações. E neste universo existem não só pontos de partidas e recortes diversos, mas premissas distintas. Muitas pesquisas consideram as formas de comunicação na internet análogas a outras formas de comunicação tradicionais e interações interpessoais, e faz suas análises a partir das ferramentas teóricas utilizadas em trabalhos que investigam práticas de sociabilidade baseadas em interações face-a-face. Outros estudos buscam discutir as formas de sociabilidade online, e mesmo a noção de comunidade virtual, exclusivamente a partir de uma perspectiva que inclui, de maneira geral, as implicações contemporâneas do processo amplamente conhecido como globalização, e de forma específica, as transformações tecnológicas relacionadas à comunicação. Neste sentido, muitos apontam

a impropriedade de se trabalhar com analogias e alertam para a necessidade de se criar novos instrumentais de pesquisa.

Não é demais, porém, sublinhar o contexto de controvérsias que envolvem os estudos e pesquisas sobre os padrões de sociabilidade a partir do uso da internet e de outras tecnologias digitais de comunicação. Se a sociabilidade online é uma realidade na vida cotidiana de uma parcela crescente da população cada vez mais difícil de contestar, o que ela efetivamente provoca ou provocará na estrutura da 
sociedade contemporânea e futura, de forma geral, é considerado ainda questão em aberto. Segundo Meneses (2004), os cientistas sociais têm conseguido demonstrar que o uso social das tecnologias de informação e comunicação não compete com outros tempos de uso social, ou seja, a conexão não prejudica fontes de interações presenciais, e pode ser inclusive fonte para novos vínculos - que podem se transformar em vínculos presenciais, e ainda mais, a conexão aumenta as relações com familiares e amigos. Mas o autor pontua também a grande euforia que alimenta os caminhos que levam a distinção destes usos da internet na atividade social. Ressalta que a sociedade em geral, e também os círculos científicos, confundem as possibilidades de socialização para desconectados de uma comunidade local com promessas de realização de atividades comunitárias sem fronteiras, a partir da criação de vínculos pessoais estáveis não mais centrados em localização geográfica, ou em indicadores de raça, idade e gênero.

Castells (1999), ao indagar-se a respeito das implicações do uso maciço da internet como meio de comunicação, ressalta várias questões. Primeiramente, destaca que a rede é um veículo que não é facilmente controlável técnica ou politicamente, fato que abranda os efeitos nocivos dos tradicionais sistemas de comunicação de massa. Afirma que a universalização da rede não implica no aparecimento de uma sociedade virtual que substituiria o que ele chama de "sociedade real" e cita os trabalhos de Barry Wellmam, já apresentados aqui, que mostram que as redes sociais mediadas por computador são largamente associadas às práticas sociais das pessoas nas suas já existentes redes sociais, destacando que as comunidades eletrônicas não são menos reais ou menos significativas que as comunidades territoriais. ${ }^{57}$ Como se viu, a internet ampliaria as cadeias sociais fixadas espacialmente, ao invés de deslocá-las.

\footnotetext{
${ }^{57}$ Castells faz referência especificamente a WELLMAN, B. et al. (1996). Computer networks as social networks: collaborative work, telework and virtual community, Annual Reviews of Sociology, n.22 e WELLMAN, B., GULIA, M. Net surfers don't ride alone: virtual communities as communities. In: WELLMAN, B. (Ed.) (1998). Networks in the global village. Boulder: Westview Press.
} 
Castells (2003, p.100) destaca que "contrariando alegações de que a Internet seria ou uma fonte de comunitarismo renovado ou uma causa de alienação do mundo real [sic], a interação social na Internet não parece ter um efeito direto sobre a configuração da vida cotidiana em geral, exceto por adicionar interação on-line às relações sociais existentes". Para o autor, além da correta formulação de questões, "o estudo da sociabilidade na/sobre/com a Internet deve ser situado no contexto da transformação dos padrões de sociabilidade em nossa sociedade", o que significa "inserir seus efeitos específicos na evolução geral dos padrões de interação social e em sua relação com os suportes materiais dessa interação: espaço, organizações e tecnologias da comunicação" (CASTELLS, 2003, p.105). Castells (1999) ainda chama atenção para o fato de que o uso compartilhado da internet se dá em situações de interesses profissionais e pessoais, e para isso são criadas redes com propósitos específicos, através de afinidades, valores e interesses. Cita também estudos psicológicos que apontam que o canal induz personalidades flexíveis e identidades mutáveis, mas que são livres de constrangimentos e individualizadas no seu modo de interação. Por fim, afirma que a sociabilidade na internet pode ser forte ou fraca, na acepção de Granovetter (1973), dependendo das pessoas e do conteúdo das suas relações.

\subsection{Resultados a partir de alguns estudos}

Os três trabalhos citados abaixo estão inseridos dentro da agenda de pesquisa que se volta à relação entre internet e vida cotidiana, de forma geral, e especificamente à inserção das TIC em comunidade locais nos moldes de criação de comunidades em espaços híbridos, ainda que possuam características distintas entre si e diferentes escopos, não necessariamente demarcados aqui. Tais trabalhos possuem em comum o fato de terem sido realizados na forma de uma intervenção prática, envolvendo uma pesquisa de campo, e neste sentido se diferem daqueles de cunho mais teórico, apresentados quando se discutiu aqui comunidades em espaços híbridos. 
Estes estudos foram selecionados dentro de um rol bastante restrito de projetos que envolvem a criação de comunidades em espaços híbridos a partir do acesso privado a internet, ou seja, que privilegia a disponibilização das tecnologias digitais de comunicação a partir das casas das pessoas. 0 acesso privado é fundamental porque permite autonomia e liberdade, como pontua DiMaggio e Hargittai (2001), e portanto, uma aferição mais consistente sobre o uso e as implicações das TIC no cotidiano das pessoas. ${ }^{58}$ Assim, dentro deste conjunto pouco numeroso, optou-se por apresentar aqui as intervenções que foram estudadas de forma mais exaustiva e que possuem um conjunto razoável de publicações a respeito. ${ }^{59}$ Os resultados a eles vinculados devem ser considerados, no conjunto, segundo as delimitações próprias a estes estudos apresentadas acima.

\section{The Intercom Ontario Trial _ NetVille}

NetVille é a iniciativa mais conhecida, e os estudos a seu respeito os mais citados, no âmbito das pesquisas de natureza aqui abordada. Foi uma experiência inovadora, implantada na periferia de Toronto, Canadá, a partir de meados dos anos 1990, em um conjunto residencial de pouco mais de setenta casas, objeto de estudo de pesquisadores da Universidade de Toronto e de um consórcio de empresas de telecomunicações. A interação social e o monitoramento do comportamento comunicacional dos moradores de um conjunto de casas equipadas com conexão rápida à internet integrava também uma instância de comunicação online, através de uma rede local tipo intranet, instituída a partir de uma interface computacional gráfica especialmente desenhada para tal fim.

\footnotetext{
${ }^{58}$ É importante considerar que até pouco tempo se considerava que a universalização ideal do acesso as TIC seria aquela que possibilitaria o acesso a internet partir dos ambientes domésticos. Hoje, com as possibilidades das tecnologias móveis, este ideal talvez esteja em xeque. Há que se pensar também no indivíduo conectado.

${ }^{59}$ Fazem parte também deste conjunto, por exemplo, os trabalhos já citados Making Healthy MUSIC - Multi-User Sessions In Community e The HomeNet. Também os estudos de Michael Arnold da Universidade de Melbourne, sobre a intervenção, a partir de 1999, no conjunto residencial Williams Bay, em Melbourne, na Austrália, onde foi implantada uma intranet, e os de Marcus Foth em Brisbane, também Austrália, a partir de um conjunto de moradias para estudantes, Southbank Campus Apartments, desde o final de 2002.
} 
Assim, o projeto fornecia, por um lado, acesso à internet banda larga, com acesso a web e uso de $e$ mail, e por outro, conteúdos e ações específicas da comunidade através da rede intranet, que dispunha de lista de e-mail, fórum de discussões, videophone, entre outros. Os moradores de NetVille ${ }^{60}$ consentiram em ser objetos de estudo, tendo sua lista de discussão via e-mail pesquisada. Esta lista era a instância principal que os moradores usavam para comunicarem entre si exclusivamente, e tornou-se a forma privilegiada pela qual eram discutidas as questões referentes ao conjunto, ao bairro, à vizinhança, além de importante meio de divulgação de informações sobre a comunidade e seus membros. Essa experiência tinha-se como objetivo primeiro investigar os efeitos do uso da internet nas redes sociais, no capital social e no envolvimento comunitário.

A realização de NetVille foi sistematicamente planejada, avaliada e analisada. Interessa particularmente aqui, o que Keith Hampton e Barry Wellman, seus os principais estudiosos, sugerem. Hampton revela, a partir de NetVille, que as TIC incentivaram uma comunidade no nível menos esperado, o de vizinhança local.

Contrária a visão de que a Internet é especificamente uma tecnologia global, uma das mais interessantes descobertas deste estudo refere-se a como o acesso à CMC [comunicação mediada por computador] afeta as relações sociais em um nível local. Especificamente, o uso da CMC favorece a participação pública, o crescimento de redes sociais locais, a conectividade de vínculos sociais locais, e a dissipação espacial de redes locais ${ }^{61}$ (HAMPTON, 2001, p.170).

Isto porque, na verdade, se se der oportunidade para as pessoas interagirem e trocarem informações num determinado local, é mais provável a formação de vínculos sociais locais fortes. As TIC então facilitariam a troca de informação, comunicação e outros recursos ao nível de vizinhança, incentivando

\footnotetext{
${ }^{60}$ Em sua maioria famílias nucleares, de classe média-baixa.

${ }^{61}$ Tradução da autora. No original: "Contrary to the view that the Internet is specifically a global technology, some of the most interesting findings from this study relate to how access to CMC affects social relations at the local level. Specifically, that the use of CMC encourages public participation, the growth of local social networks, the connectivity of local social ties, and the spatial dispersion of local networks."
} 
o estabelecimento de comunidades baseadas no espaço físico, ou seja, a oportunidade de interação social local é a responsável pelo aumento do envolvimento comunitário local.

Não é que a internet seja especial na habilidade em manter vínculos sociais. Antes, a internet é mais um meio de comunicação usado junto com os meios existentes. Quando a distância torna a comunicação pessoal ou por telefone difícil, a comunicação mediada por computador tem o potencial de preencher este espaço. A fricção de tempo e espaço tem tradicionalmente limitado o contato social com os membros mais distantes de nossas redes sociais. Onde o contato pode facilitar a troca de suportes, a CMC media o efeito da distância, aumentando as trocas de suporte com aqueles que estavam previamente então fora de alcance. A despeito da habilidade da internet em conectar pessoas à distância, seu potencial em conectar pessoas no nível da vizinhança local pode ser mais significante ${ }^{62}$ (HAMPTON, 2001, p.101).

A internet facilita contatos, possibilita trocas de suportes e recursos, portanto constrói capital social, tanto à distância como em âmbito local. Isto pode ser válido tanto para os vínculos sociais locais como para um aumento de participação pública. 0 estudo de NetVille leva a crer que projetar comunicações mediatizadas por computadores para facilitar a troca de comunicação e informação, em bases locais, pode melhorar o fluxo de informação e ampliar redes sociais locais, aumentando a rapidez de envolvimento comunitário.

Quando a internet engaja as pessoas principalmente em atividades não sociais, então se parece mais com a televisão, sua imersibilidade pode tornar as pessoas ausentes da comunidade, dos envolvimentos organizacionais e políticos, e da vida doméstica. Ao contrário, quando as pessoas usam a internet para comunicar e interligar com amigos, parentes, e organizações - próximos e

\footnotetext{
62 Tradução da autora. No original: "It is not that the Internet is special in its ability to maintain social ties. Rather, the Internet is another means of communication used along with existing media. When distance makes in-person or telephone communication difficult, computer-mediated communication has the potential to fill the gap. Friction of time and space has traditionally limited social contact with the most distant members of our social networks. Where contact can facilitate the exchange of support, CMC mediates the effect of distance, increasing supportive exchanges with those who were previously just out of reach. Despite the Internet's ability to connect people across distance, its potential to connect people at the local neighbourhood level may be more significant."
} 
distantes - então ela é uma ferramenta de construção e manutenção de capital social. Nossa pesquisa tem mostrado que não há um único efeito da internet ${ }^{63}$ (WELLMAN et al., 2001).

Assim, a partir de NetVille, é possível afirmar que quando as relações sociais são examinadas em termos de redes e não de grupos ou de territorialidades apenas, e quando a internet não é tratada como um sistema único, e sim como meio que abarca diferentes fins, encontra-se que comunicação a partir dela pode dar suporte ao crescimento de redes sociais, capital social e bem estar comunitário (HAMPTON, 2001).

\section{Camfield Estates - MT Creating Community Connections Project}

A intervenção na comunidade de baixa renda centrada na área residencial de Camfield Estates, em Boston, Estados Unidos, e seu entorno, a partir do ano 2000, acompanhada pelo pesquisador Randall Pinkett, objetivava:

[...] estabelecer Camfield como um modelo para outras comunidades manifesto de duas maneiras. Primeiro, como uma metodologia que pode informar o trabalho sendo feito em outras comunidades para o fortalecimento das capacidades dos residentes, organizações e negócios em suas vizinhanças. Segundo, como um exemplo que demonstra as possibilidades ilimitadas quando os membros da comunidade estão engajados como agentes ativos de mudança e produtores ativos de informação e conteúdo ${ }^{64}$ (PINKETT, 2002, p.324).

\footnotetext{
${ }^{63}$ Tradução da autora. No original: "When the Internet engages people primarily in asocial activities, then even more than television, its immersiveness can turn people away from community, organizational and political involvement, and domestic life. By contrast, when people use the Internet to communicate and coordinate with friends, relatives, and organizations-near and far-then it is a tool for building and maintaining social capital. Our research has shown that there are no single Internet effects."

${ }^{64}$ Tradução da autora. No original: "[...] to establish Camfield as a model for other communities manifests itself in two ways. First, as a methodology that can inform the work being done in other communities to strengthen the capacity of residents, organizations, and businesses in their neighborhood. Second, as an example that demonstrates the limitless possibilities when community members are engaged as active agents of change and active producers of information and content."
} 
O projeto instalou computadores conectados nas moradias das pessoas de um conjunto habitacional, criou um telecentro na localidade, implantou um sistema web comunitário que reuniu um significativo banco de dados dos recursos da comunidade local e ferramentas de comunicação online, como fóruns de discussões, listas de e-mail, e chats. ${ }^{65}$ Buscou investigar como indivíduos, famílias e comunidade podem se tornar agentes ativos de mudanças, especificamente ao apropriarem-se das TIC como produtores ativos de conteúdos. Para tal estabeleceu suas bases metodológicas a partir da interação entre Sociocultural Constructionism e Asset-Based Community Development, a primeira relacionada à tecnologia comunitária, e a segunda, a construção comunitária, já citada neste trabalho. ${ }^{66}$

São numerosas as lições aprendidas a partir do projeto Camfield Estates ${ }^{67}$, entretanto, interessa destacar aqui os primeiros resultados do projeto, apresentados por Turner-Lee e Pinkett (2004): (1) os participantes fortaleceram suas conexões pessoais com os membros da família, e amigos locais, (2) os participante estão fazendo melhor uso dos recursos comunitários como um resultado do aumento na percepção desses recursos, (3) os participantes estão melhor informados sobre o que está acontecendo localmente e há uma melhoria na circulação de informação e comunicação com vistas ao desenvolvimento, (4) os participantes têm sido inspirados a partir do uso da internet a permanecerem informados localmente, nacionalmente e internacionalmente, (5) os participantes estão usando a

\footnotetext{
65 Tratava-se de um modelo convencional de web site. Apresentava os objetivos do projeto, links para sites das instituições parceiras, o perfil dos residentes, um sistema informação com mapas geográficos (GIS), calendários de eventos, notícias e anúncios, espaço de estocagem de arquivos e espaço para pesquisa no próprio site sobre organizações e instituições ligadas a diversas áreas localizadas na vizinhança do conjunto residencial, mas não oferecia serviços propriamente ditos (CAMFIELD ESTATES, 2005).

CAMFIELD ESTATES. Site oficial da comunidade. Apresenta ambientes de interação e link para documentos sobre o projeto, assim como para instituições parceiras. Disponível em <http://www.camfieldestates.net>. Acesso em 17 mar. 2005.

${ }^{66}$ Ver, a respeito, PINKETT, R. (2000). Bridging the Digital Divide: Sociocultural Constructionism and an Asset-Based Approach to Community Technology and Community Building. Annual Meeting of the American Educational Research Association (AERA). New Orleans: AERA.

67 Pinkett (2002) cita inúmeras recomendações no capítulo final de sua tese para futuros projetos dessa natureza, entre elas, procurar entender os ambientes social e cultural, assim como os indivíduos, famílias e comunidade; alcançar recursos através de esforços coordenados; demonstrar claramente as relevâncias do projeto, alargar os custos com tecnologia; integrar ações online e offline; engajar residentes como participantes ativos; dar suporte a processos e produtos, entre outros.
} 
internet para reunir informações que podem ajudá-los a dedicarem-se aos seus interesses e necessidades básicas, e (6) os residentes têm cultivado uma meta-competência, uma renovada confiança neles mesmos e em suas habilidades para aprender.

Quanto ao capital social, especificamente, Pinkett (2002) revela que, numa perspectiva individual, houve casos particulares de pessoas que se beneficiaram da expansão dos vínculos em âmbito local e mesmo global. Em uma perspectiva coletiva, porém, foram percebidas mudanças até então superficiais. Houve uma percepção melhor dos bens e recursos comunitários que poderia ser traduzida no uso significativo deles, e houve a aquisição de novos conhecimentos, habilidades, que podem ser transpostos entre os relacionamentos mais significativos. Quanto ao capital cultural, foi impulsionado em dois sentidos. "Primeiro, nós temos ajudado a facilitar um aumento no fluxo das comunicações e informações. Segundo, nós temos dado poder aos participantes para ver grandes possibilidades igualmente neles mesmos e em suas comunidades, e acredito que é aqui onde nossos esforços têm feito grande contribuição"68 (PINKETT, 2002, p.307).

\section{Blacksburg Electronic Village _BEV}

Quando os pesquisadores norte-americanos da Virginia Polytechnic Institute \& State University (Virginia Tech), no início dos anos 1990, começaram a planejar ações envolvendo TIC para a cidade de Blacksburg, que abriga a universidade e tem cerca de 40.000 habitantes, o objetivo principal era promover o acesso a internet, a fim de minorar a exclusão digital, tanto a centrada no acesso em si, como também em geografia, dado que se trata de uma localidade em meio rural. A partir de então, as metas foram sendo expandidas para a criação de uma comunidade virtual, que se agregasse em torno de um portal web, que pudesse promover o desenvolvimento econômico, oportunidades educacionais,

\footnotetext{
${ }^{68}$ Tradução da autora. No original: "First, we have helped facilitate an improved communications and information flow. Second, we have empowered participants to see even greater possibilities for themselves and their community, and I believe it is here that our efforts have made the greatest contribution."
} 
de saúde e bem estar para a comunidade, que pudesse facilitar a troca de informações e comunicação, mobilizando a ação coletiva. Em sete anos de projeto Blacksburg tinha $87 \%$ de seus habitantes utilizando a internet, o que representava o maior uso de internet per capita no mundo (COHILL, 2000). A questão que guiava as ações neste momento era: Quais as implicações tangíveis na qualidade de vida em uma comunidade geograficamente delimitada quando é adicionado um outro padrão de comunicação baseado em redes computacionais? (KAVANAUGH; PATTERSON, 2003).

Ainda que as expectativas dos pesquisadores em relação a um aumento geral e significativo no envolvimento e vínculo comunitário não tenham se cumprido até então, a iniciativa em Blacksburg mostra algumas evidências importantes sobre o papel da internet e das redes computacionais comunitárias. A mais significativa delas é que as pessoas usam a internet para atividades de construção de capital social:

[...] quanto mais pessoas têm sido conectadas a internet, mais provavelmente elas estão usando a rede para construir capital social, e para aumentar o envolvimento nas comunidades locais e suas questões. Uma extensão lógica desta conclusão é que se as atividades de construção de capital social ocorrem na comunidade, o envolvimento e vínculo aumentariam e a qualidade de vida melhoraria. [...] Se a rede comunitária computacional é um novo tipo de associação voluntária, ou um caminho eficiente de extensão das tradicionais associações para novas audiências, os usuários desta rede são engajados na comunicação com os membros de sua comunidade. Está é a questão, então o capital social construído entre os membros da comunidade que fortalece as redes sociais e a confiança social, e ajuda a conduzir o envolvimento comunitário e uma qualidade de vida superior $^{69}$ (KAVANAUGH; PATTERSON, 2003, p.339).

\footnotetext{
${ }^{69}$ Tradução da autora. No original: "[...] that the longer people have been connected to the Internet, the more likely they are to use the networked to built social capital, and to increase involvement in local community and issues. One logical extension of this conclusion is that if social capital building activities occur in the community, involvement and attachment should increase and quality of life should improve.[...] Whether the community computer network is a new kind of voluntary association or an efficient way of extending traditional associations to new audiences, network users are engaging in communication with their community members. It is this talk or social capital building among community members that strengthens social networks and social trust, and helps lead to community incolvement and higher quality of life."
} 
Muitas discussões chamaram a atenção dos pesquisadores a partir desses resultados, e estão sendo investigadas, entre elas: haveria já altos níveis de capital social na comunidade? Já se sabe, porém, que a internet capitalizaria as redes sociais existentes ao mesmo tempo em que atingiria pessoas já predispostas a serem mais ativas.

[...] interação online freqüentemente ocorre entre pessoas que pertencem a determinadas redes sociais e grupos formais e informais que existem offline, e portanto, que também se vêem em ambientes face-a-face. Ser membros dessas outras redes sociais proporciona, de forma intrínseca, normas de reciprocidade, regras, e papéis que transportam para as comunidades online. Pessoas com participações em dois ou mais grupos (formando 'pontes' ou vínculos sociais fracos entre eles) são mais ativas e envolvidas na comunidade, e têm mais vínculos sociais e fortes ligações com a comunidade. [...] estas diferenças enfatizam os aspectos sociais na comunidade que são reforçados e fortalecidos não somente por uma maior interação face-a-face mas também por uma maior interação online ${ }^{70}$ (KAVANAUGH et al., 2005).

Os resultados mostram que as atividades no âmbito desta experiência têm habilitado grupos a interagir de forma nova e sem sacrificar os tecidos sociais comunitários existentes. Grupos sociais que normalmente têm contatos limitados entre si podem interagir e se expressar numa arena pública. E para além dos aspectos sociais, os serviços online do governo local disponibilizados através do web site agora efetuam funções administrativas mais eficientes. As empresas locais provêem seus produtos e serviços para o público em geral mais facilmente e com mais rentabilidade. Esta é, inclusive, uma característica singular desta iniciativa: sua implementação esteve motivada em dois sentidos, em igual proporção, o cívico, que busca criar capital social e alavancar a ação coletiva; e o econômico, que possibilita incentivar as atividades de comércio e o turismo (CARROLL, 2005).

\footnotetext{
70 Tradução da autora. No original: "[..] online interaction often occurs among people who belong to corresponding social networks and formal and informal groups that exist offline, and therefore, who also see each other in face-to-face settings. Being members of each other's social networks provides built-in norms of reciprocity, rules, and roles that carry over into the online community. People with two or more group memberships (forming 'bridging' or weak social ties across groups) are more active and involved in the community, and have more social ties and stronger community attachment. [...] All of these differences emphasize the social aspects in the community that are reinforced and strengthened not only by more face-to-face interaction but also by more online interaction."
} 
Estes estudos empíricos parecem corroborar o que os trabalhos teóricos apresentados oportunamente aqui buscam demonstrar, ou seja, que há uma grande possibilidade de aumento capital social mas comunidades locais quando se sobrepõem novas instâncias de interação e comunicação às já existentes. E com isso, há possibilidade de se operar transformações em variados aspectos da vida da comunidade e indivíduos.

\subsection{As redes sociais e os espacos hibridos: recursos e transformaçōes}

Não são só as dicotomias dos estudos de Tönnies que parecem não se encaixarem nas conformações dilatadas da sociabilidade contemporânea. Bem mais recentes, os primeiros estudos sobre as implicações das tecnologias de informação e comunicação na sociabilidade alimentaram uma série de impropriedades que, neste caso, foram superadas rapidamente, principalmente aquelas centradas exclusivamente nas questões das perdas e substituições. As relações sociais estabelecidas através da presença física não se perderam ou deixaram de existir em função das relações sociais estabelecidas no ciberespaço, e ao contrário do que se supunha, elas podem ser incrementadas a partir destas porções online. É o que dizem alguns estudos teóricos mais recentes e o que mostram certas experiências empíricas, conforme apresentado. Hoje é possível constatar de que as interações nas redes sociais podem se estabelecer em um outro espaço - o espaço híbrido, que se constrói a partir do entrelaçamento das instâncias comunicacionais presenciais, estabelecidas a partir da existência física, concreta, face-a-face, e virtuais, instituídas em determinados ambientes em redes de comunicação digitais. 
Assim, as comunidades devem ser entendidas principalmente como redes sociais, independentemente dos lugares ou das instâncias em que se alocam. As comunidades locais são redes sociais cujos laços, ou relações estruturadas, se dão, a princípio, em função de um componente territorial, ou geografia delimitada. As comunidades virtuais são redes sociais com relações estruturadas em ambientes virtuais, que se estabelecem a partir de diferentes atributos. Quando as comunidades locais estendem e estabelecem seus laços e interações, seja para transmissão de informações, para trocas de bens, ou fluxo de recursos, também a partir de ambientes virtuais, pode-se dizer que configuram comunidades em espaços híbridos. 0 individualismo em rede, ou as redes pessoais, são uma nova unidade, um novo padrão social preponderante nessas redes sociais, centrado no indivíduo, inserido neste contexto.

O capital social é o recurso próprio às redes sociais, independente se estas estão alocadas em espaços online, offline ou em ambos. Trata-se dos bens advindos do fluxo de informações e das trocas de recursos intrínsecos às relações sociais. Como se viu, as tecnologias de informação e comunicação favorecem e incrementam as redes sociais que se estabelecem a partir de bases locais, porque ao instaurarem outros espaços comunicacionais, possibilitam a criação de outros laços, de outras relações efetivas, portanto favorecem o incremento do capital social. A ampliação do acesso a diferentes recursos, a promoção de capacidades, a construção de confiança e de uma auto-imagem positiva, o fortalecimento dos vínculos entre redes, podem derivar transformações sociais. Estas caminham sempre no sentido de trazer para pessoas e comunidades mudanças de caráter positivo, e de minorar desigualdades.

Ainda que os estudos demonstrem que a comunicação em instâncias virtuais possibilita o incremento das interações sociais, o fortalecendo das redes sociais em si, e portanto transformações em comunidades locais, parece claro que isso não acontece de forma espontânea. A disponibilização da internet em uma comunidade local não significa a sua apropriação como uma outra instância de interação social. Por ora, esse desenvolvimento de comunidades em espaços híbridos, com um sentido claro de potencial transformador, ainda que centrada somente em aspectos sociais, parece depender de forças indutivas. Forças que se estabelecem em diferentes planos, que são de naturezas distintas, 
porém, que estão entrelaçadas. A partir do reconhecimento dos recursos e bens alocados nestas redes sociais, ações participativas e de animação sociocultural parecem que, juntas, podem impelir e incitar pessoas e coletividades a se voltarem à complementaridade dos espaços online e offline. Há, entretanto, na maioria dos projetos envolvendo TIC voltados a estas questões, um vazio na atenção a estes suportes que são capazes de realizar o diálogo entre as porções físicas e virtuais de uma comunidade local.

As pessoas, além de aprenderem o uso de instrumentos informatizados, de ferramentas que possibilitam a manipulação de informações digitais ou o acesso ao ciberespaço, precisam se apropriar das possibilidades mesmas de ampliação de instâncias de comunicação, de produção de conteúdo, de troca de recursos que as TIC proporcionam. É sabido que só as tarefas direcionadas a simples instrumentalização para o uso operacional da tecnologia não são suficientes para dotar de significado as incursões e interações em ambientes virtuais, seja em âmbito pessoal ou coletivo. É neste sentido que se torna importante em projetos de estruturação de comunidades em espaços híbridos a promoção de atividades de estímulo e motivação, ancoradas em práticas cotidianas, que relacionadas a realidade e ao contexto local da comunidade, indicam as perspectivas e oportunidades de se apropriar das TIC para promover mudanças positivas em âmbito pessoal e coletivo. As demandas, estabelecidas a partir de intervenções participativas, devem orientar a qualidade das ações a serem desenvolvidas nos ambientes das redes sociais. Deve-se considerar que estas atividades possam assumir o caráter de ações de animação sóciocultural direcionadas ao desenvolvimento colaborativo da instância virtual, fazendo com que os próprios usuários participem ativamente da construção e estruturação desse outro locus de interação comunitária.

Assim, a transformação social parece poder derivar de um conjunto de ações que buscam desenvolver e potencializar uma série de recursos e capacidades próprias às pessoas e seus grupos. 0 capital social parece ser o bem disponível mais sujeito às intervenções no âmbito das iniciativas comunitárias envolvendo TIC. Indubitavelmente é o mais almejado e citado, engloba um conjunto amplo de benesses, que de certa forma estão ligadas também aos processos de empoderamento. Os modelos de 
ação apresentados, como Desenvolvimento Comunitário Baseado em Ativos, a Metodologia de Participação, e a Animação Sociocultural, se estabelecem como possíveis caminhos para trabalhar estes recursos no sentido da transformação social.

Quando as questões do entrelaçamento das tecnologias digitais no plano das comunidades locais se apresentam à prática, às iniciativas e aos projetos a serem implementados, emerge então um conjunto de estudos de campo, de investigações empíricas, e uma agenda de pesquisa que buscam, ao mesmo tempo, conhecer quais são seus contornos e amplitudes. Há um consenso de que se trata de processos que buscam responder às necessidades, à construção de soluções e oportunidades, no âmbito das comunidades locais. Servem a fins de desenvolvimento, seja social, pessoal, econômico ou de educação e cultura. É uma agenda que conforma, por um lado, as questões relacionadas ao campo disciplinar das Ciências Sociais, e por outro, da Ciência da Computação, como bem diz Carroll (2005), mas que envolve também questões amplas de design. As especificidades das interfaces computacionais, os suportes lógicos e físicos que possibilitam a comunicação e interação em ambientes virtuais também determinam a qualidade, o caráter e a conformação distintiva de espaços híbridos. É isto que se examina com mais atenção no capítulo a seguir.

Os espaços virtuais de interação com base em redes sociais locais são construídos, assim como os espaços híbridos em si. E seus arquitetos devem dispor de um conjunto de princípios conceituais coerentes com os modos de vida daqueles que devem se apropriar desses espaços. Aqui, continuando e reafirmando a analogia, se esteve debruçado no entendimento desses modos de vida, das suas naturezas e perspectivas. Buscou-se perceber outros significados para a construção desses espaços para além da simples necessidade de abrigo, e que caminhasse em direção às possibilidades transformadoras do contexto em que se inserem. A seguir, no próximo capítulo, o olhar se volta aos sistemas estruturais e construtivos que vão dar suporte a presença humana nestes espaços. Assim, nesta pesquisa, segue-se investigando a respeito das questões de design dos espaços virtuais agregadas a questões de design de redes sociais, segue-se investigando a constituição do espaço híbrido em fragmentos urbanos. 


\section{INTERFACES COMPUTACIONAIS DE INTERAÇÃO COMUNTIÁBIA}
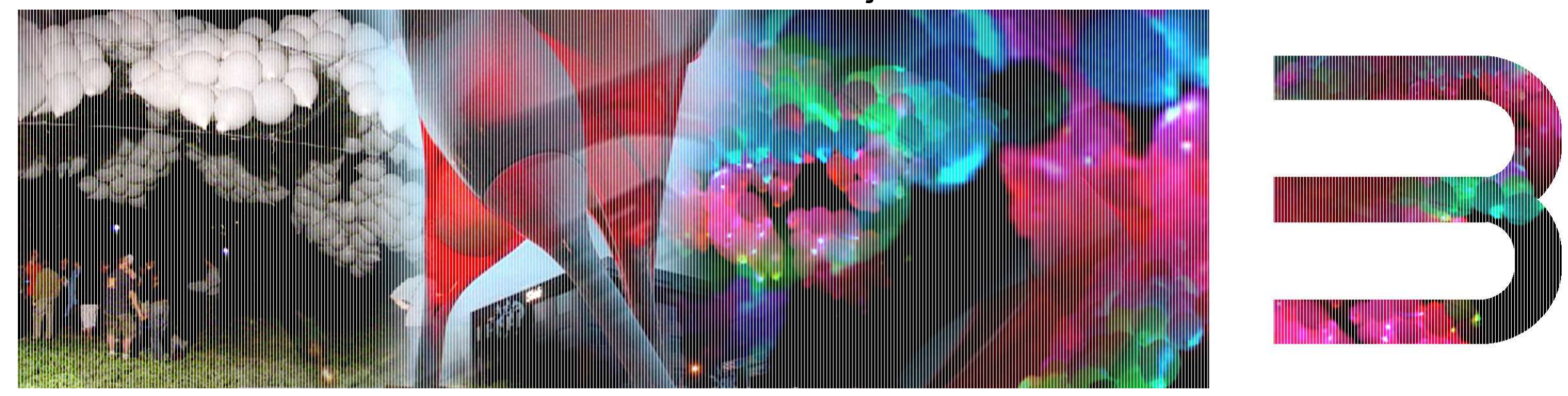
O exame das tecnologias de processamento de informação e comunicação digitais é, na contemporaneidade, de grande importância, frente ao papel imprescindível que desempenham não só como suporte de imensuráveis fluxos informacionais, mas também de interações sociais. Neste contexto, o computador pessoal e a internet ainda são parte de um sistema central. Entretanto, cada vez mais o estudo de diferentes interfaces e protocolos de redes é tomado como parâmetro para medir as possibilidades e alcance dessas tecnologias, inclusive como instâncias simbólicas, por excelência, do momento histórico atual. Souza e Silva (2001) diz que "o modo como o espaço digital é pensado (através da interface) determina também como se dá a presença humana neste novo lugar de sociabilidade". No mesmo sentido Johnson (2001, p.21) afirma a relevância cultural do design de interface, destacando que "o modo como escolhemos imaginar essas novas comunidades on-line é obviamente uma questão de grande significação social e política”.

Considerando-se o entendimento da constituição de ambientes virtuais fundamental a esta pesquisa, este capítulo expõe uma visão ampla do que seriam as interfaces desses ambientes virtuais, tendo como parâmetro a escala da comunidade e do fragmento urbano. 0 objetivo é verificar a infraestrutura material, os suportes tecnológicos lógicos e físicos possíveis de dotar uma comunidade local de um locus híbrido, adensando esferas de comunicação e interação. Trata-se de uma incursão nas qualidades das interfaces como meios, como canais, através dos quais as relações inter-pessoais também podem se estabelecer. Trata-se de um olhar direcionado às características e potencialidades dessas interfaces.

Em meio à profusão de significados e definições que a palavra interface possui no contexto das tecnologias de informação e comunicação, é bastante comum em instâncias não acadêmicas, e mesmo em instâncias disciplinares não envolvidas com esta questão, tomá-la como interface gráfica disposta em telas. É importante que se diga de antemão que, neste trabalho, interface não está restrita a elementos gráficos e a telas. A interação a que se refere o título deste capítulo diz respeito às ações e relações estabelecidas entre membros de uma comunidade, no mesmo sentido apresentado no capítulo 
anterior. Porém, o foco aqui são as interfaces computacionais que podem mediar essas interações e, neste sentido, se apresenta um novo conjunto de ações e relações específicas, próprias ao domínio das interfaces. São as interações intrínsecas ordenadas através dos artefatos computacionais e digitais, e também com estes artefatos. Trata-se de um outro âmbito de interação, particular ao campo disciplinar das interfaces computacionais, como se vê adiante. Grosso modo, pode-se dizer que no capítulo anterior, abordaram-se as interações mediadas por interfaces computacionais com foco na qualidade das relações estabelecidas entre indivíduos e, em certo sentido, nos seus desdobramentos, tendo como principal referencial teórico os aportes das Ciências Sociais. Aqui se volta aos requisitos tecnológicos, lógicos e físicos, necessários para dar suporte a essas relações, ao seu modus operandi, a partir de estudos de diferentes áreas disciplinares. Essas duas abordagens reforçam, por um lado, o caráter interdisciplinar dessa pesquisa, e, por outro, decorrem de um dos seus principais pressupostos, que relaciona a qualidade das experiências mediadas por interfaces computacionais com as próprias características e configurações dessas interfaces. Sendo, neste sentido, possível afirmar que esta divisão é um recurso estritamente metodológico.

Nos primeiros tópicos deste capítulo discorre-se sobre as principais questões que envolvem hoje tecnologias computacionais e digitais, e investiga-se a colaboratividade, dando destaque às ações de produção de conteúdo. Depois, abordam-se, neste campo, os paradigmas de interação e os próprios conceitos de interface. Sinaliza-se, ao mesmo tempo em que se justifica, a importância da investigação de modelos alternativos para a constituição de interfaces para ambientes virtuais de interação comunitária, que podem ser pensados a partir do design para a experiência e da chamada digital art ou art media, da qual faz parte, por exemplo a interface D-Tower desenvolvida por Lars Spuybroek e Q. S. Serafijn, do V2 LAB e NOX-Architekten. No tópico final, a questão central é a especificidade dos estudos correntes de ambientes virtuais de interação social. 

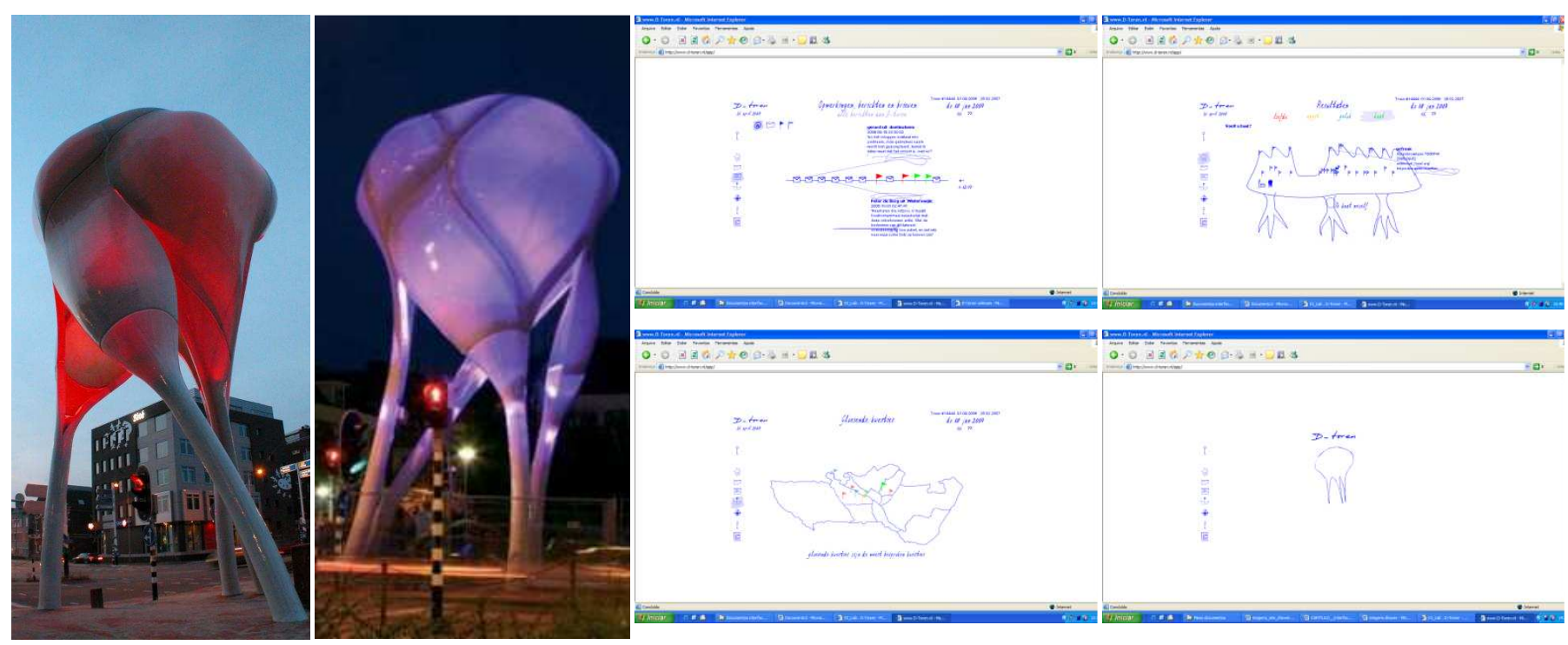

Fig. 1 - 2. D-Tower: objeto. Fonte: D-TOWER (2004).

Fig.3 - 6. D-Tower: web site. Fonte: D-TOWER DELINCHIN (2008).

D-Tower (Lars SPUYBROEK, Q. S. SERAFIJN, V2 LAB e NOX-Architekten; Doetinchem, Holanda, 2003/2008).

Consiste em um sistema informático composto de três partes: um objeto físico de 12 metros de altura, um website e um questionário, que juntos, mapeiam e comunicam o estado emocional dos habitantes da cidade de Doetinchem. O objeto é implantado no espaço urbano, enquanto o website reúne sistematicamente, através de um conjunto de perguntas dispostas no questionário online, informações a respeito do estado de espírito dos habitantes da cidade, que estão cadastrados no site. Tais informações são expressas diariamente, de forma automática, pelo objeto, na forma de representações gráficas, com movimentos e cores, e no site por um conjunto de bandeirinhas que se dispõem em um mapa da cidade. Cada emoção é representada por uma cor: vermelho para amor, azul para felicidade, amarelo para medo e verde para ódio. Trata-se de uma interface que representa, tanto através do objeto como do site, o humor, o estado afetivo dos habitantes de um determinado lugar. "D-Tower é um híbrido coerente de diferentes meios, onde a arquitetura é apenas uma parte de um grande sistema de relações interativas. É um projeto onde o intensivo (sentimentos e qualidades) e o extensivo (espaço e números) começam trocando papéis, em que a ação humana, cor, dinheiro, valor e sentimentos tornam-se todos entidades em rede"1 (DTOWER, 2004).

${ }^{1}$ Tradução da autora. No original: "D-Tower is a coherent hybrid of different media, where architecture is only part of a larger interactive system of relationships. It is a project where the intensive (feelings and qualia) and the extensive (space and numbers) start exchanging roles, in which human action, color, money, value and feelings all become networked entities." 


\subsection{Propriedades do digital}

Busca-se, a seguir, examinar algumas conformações importantes dos instrumentos tecnológicos de comunicação e informação e questões que se destacam no momento atual, como convergência e recombinações. Não se trata de mais uma investigação dos contrapontos e continuidades entre as estruturas digitais e as bases analógicas, e sim de um rápido exame dos principais conceitos presentes na configuração do universo digital hoje, como base para as discussões que se seguem.

\subsubsection{A natureza das mídias digitais'}

As mídias digitais assumem hoje diferentes formatos. Porém, em comum, apresentam algumas características primordiais. 0 ponto fundamental a considerar é que pressupõem conectividade em rede. Ainda que, como destaca Pinheiro (2007, p.17), o paradigma das redes ocupe "lugar central no pensamento contemporâneo: na vida, na comunicação, na sociedade, na política, na economia e nas ciências. [...] e compreender o funcionamento das redes torna-se o ponto comum das mais diversas áreas de conhecimento", interessa aqui acentuar sua característica no âmbito físico também, para além

\footnotetext{
${ }^{1}$ Mídia é uma palavra aportuguesada do inglês Media, cuja pronúncia é justamente mídia. Media vem do latim e significa meios, no plural. O singular deste termo em latim é medium (meio). Optou-se aqui por usar a palavra mídia preferencialmente no plural, ainda que muitos vejam nisso redundância, por indicar a variedade e a multiplicidade de significados que abrange, e também porque é amplamente empregada no meio acadêmico. Trata-se de um termo que assume várias definições e sentidos dependendo do contexto de atividades ao qual é empregado, seja no campo da comunicação, da publicidade, entre tantos outros. Nesse trabalho usa-se o termo mídias digitais e novas mídias como sinônimos, com o sentido amplo ligado à área das tecnologias e instrumentos de comunicação digitais, e em oposição aos canais de comunicação tradicionais. Tratam-se dos suportes, instrumentos, meios, canais, veículos, linguagens, recursos e técnicas de comunicação baseados em tecnologias digitais.
} 
dos aspectos estruturais, sistêmicos e simbólicos. Quando a tecnologia dos computadores e a tecnologia dos sistemas de comunicações se unem, dão origem às redes. "Esta é a base de todas as infraestruturas de informação" (DERTOUZOS, 1998, p.401). Segundo Lemos (2005) o princípio da conexão em rede, ou conectividade generalizada,

começa com a transformação do PC (computador pessoal, início da microinformática em 1970) em CC (computador coletivo, com o surgimento da internet e sua popularização nos anos 80 e 90 ), e o atual CC móvel (computador coletivo móvel, a era da ubiqüidade e da computação pervasiva desse início de século XXI com a explosão dos celulares e das redes Wi-Fi). Tudo comunica e tudo está em rede: pessoas, máquinas, objetos, monumentos, cidades (LEMOS, 2005).

\section{Multimidia}

Manovich (2002) diz que as novas mídias, ao sintetizarem a convergência de duas trajetórias históricas separadas, da computação e das tecnologias das mídias, fazem a tradução de todas as mídias existentes para dados numéricos acessíveis através de computadores. É neste sentido que se deve olhar para as tecnologias digitais e seus sistemas de hardware e software capazes de representar e armazenar quaisquer informações no formato digital. Possibilitando, inclusive, que as informações se estruturem de maneira multi-sensorial, através da associação e coordenação de diferentes meios combinados, dispondo sons, imagens estáticas e em movimento, textos, formas, texturas. Nas Ciências da Computação chamam-se multimídia estes sistemas múltiplos em combinação, que envolvem mais de um dos sentidos humanos, utilizados para representar, apresentar, armazenar, transmitir e processar informações digitalmente. Existem, entretanto, outras significações para multimídia que não restritas a este campo. 


\section{Hipertexto e hipermidia}

A origem do que se chama hoje hipertexto está relacionada a uma preocupação em criar mecanismos e ferramentas que refletissem a mente humana e em aproximar da sua capacidade de pensar, ou seja, de armazenar e recuperar informações, e construir conhecimento. O Memex, uma espécie de máquinabiblioteca proposto em 1945 por Vannevar Bush, descrito em seu artigo As We May Think, discute esta questão. Ted Nelson, às voltas com o sistema Xanadu, cria o termo hipertexto em 1962, concebido como expressão de uma nova forma de permitir a escrita e a leitura não-linear, baseada em indexações e associações de idéias. Douglas Engelbart, em 1962, também começou a trabalhar o desenvolvendo de um sistema informático, o NLS oN-Line System, que potencializava a capacidade e produtividade humana ao armazenar dados em arquivos compartilhados e fazer referências cruzadas, estabelecendo conexões entre eles. Segundo Pratschke (2002, p.29) a origem do hipertexto está associada a estas duas concepções, uma mais associativa representada por Nelson, e uma mais conectiva, representada por Engelbart.

Enquanto para Nelson o hipertexto constitui uma ferramenta individual de criatividade, para Engelbart, é a capacidade necessária de um sistema, projetada para melhorar a comunicação. São, em princípio, duas concepções opostas de design e de exploração pelo usuário. 0 que elas têm em comum, é que todos os sistemas de hipertexto possibilitam o acesso não-linear à informação, ainda que se baseiem em diferentes definições. [...] De acordo com a primeira categoria, o hipertexto associa mais do que indexa as informações. Seria um formato nãoseqüencial de representação de idéias, abolindo os tradicionais representação e processamento lineares das informações. No não-linear e dinâmico hipertexto, o conteúdo não se encontra fixado a uma estrutura e uma organização rígidas. Na segunda categoria, a hipermídia seria um estilo de sistemas para representação de informações e organização em torno de uma rede de nós conectados através de links. O hipertexto pode, segundo esta ótica, ser visto como uma forma de documento eletrônico, uma abordagem do gerenciamento de informações na qual os dados são 
estocados em uma rede de nós e de links, visualizado em browsers interativos e manipulado através de editores de estrutura (PRATSCHKE, 2002, p.30).

Ainda que considerando estas diferenciações, pode-se tomar o hipertexto como um texto que possui dimensões múltiplas, não acessíveis diretamente à percepção, um texto que não possui uma seqüência linear definidora da ordem na qual deve ser lido. Trata-se, então, de um texto não seqüencial, que pressupõe a participação do leitor na escolha de um percurso de leitura, ampliando possibilidades de interpretação. Constitui-se como rede, envolto por diversas conexões e nós, permitindo inúmeras leituras e associações múltiplas. Texto em que o leitor aparece como co-criador e produtor, frente a múltiplas possibilidades na construção de sucessões temporais. Apresenta fragmentos importantes em relação ao todo, e também a sincronização de linguagens e recursos. ${ }^{2}$

A hipermídia é geralmente tratada como uma expansão do conceito de hipertexto por incluir outras mídias, quando se toma o hipertexto restrito a documentos de linguagem oral escrita. Hipermídia são os ambientes informacionais estruturados de maneira não-linear a partir de recursos multimídia. Os sistemas de hipermídia unem recursos visuais, sonoros, táteis e outros quaisquer para criar narrativas interativas, estabelecidas a partir de interconexões em uma rede de informações. Os ambientes de hipermídia também são construídos a partir de relações entre os objetos que o compõem, a partir de informações vinculadas. Como no hipertexto, trata-se de uma escritura complexa porque se constrói de forma relacional, permite interações, possibilita ao leitor diferentes percursos de leitura. ${ }^{3}$

Interessa destacar aqui o uso dos recursos de multimídia e hipertextuais nos processos de comunicação e interação nas mídias digitais, e principalmente, como estruturadores da world wide web.

\footnotetext{
${ }^{2} \mathrm{O}$ hipertexto é comumente associado a recursos computacionais, mas sua constituição não está exclusivamente ligada a formatos eletrônicos, podendo aparecer em textos impressos, por exemplo.

${ }^{3}$ Existe uma problematização com relação a apropriação e uso dos termos hipertexto e hipermídia como sinônimos ou não. Contudo a abordagem desta questão não cabe aqui.
} 
O hipertexto da World Wide Web conduz o leitor de um texto a outro, ad infinitum. Contrário às imagens populares dos meios computadorizados como restringindo toda cultura humana dentro de uma única biblioteca gigante (que sugere a existência de algum sistema ordenado), ou num único livro gigante (que sugere uma progressão narrativa), é talvez mais correto pensar a cultura das novas mídias como uma infinita superfície horizontal onde textos individuais são colocados sem nenhuma ordem em particular, [... $]^{4}$ (MANOVICH, 2002, p.77).

O uso apropriado dos recursos de multimídia e hipertexto pode significar muito mais que a plena apreensão e exploração dos potenciais que as novas mídias oferecem como meio de comunicação e interação, como ambiente informacional e simbólico da cultura digital. Segundo Rezende (2004), podese supor que influenciem a maneira de organizar e articular o pensamento através da indução de um processo mental de argumentação analítica, dialética, de prova e contra-prova. A mente humana estaria estruturada segundo uma rede de informações que se interconectam segundo uma lógica de associações, próxima a um formato de hipertexto. De acordo com este autor, o ambiente hipertextual presente na web possibilitaria extravasar este impulso associativo, e exercitar um instrumental de busca, seleção, análise, e síntese. Tudo isso sob o filtro de um determinado contexto, associado à realidade daquele que interage.

A proliferação crescente de instrumentos, ferramentas e aplicativos que facilitam a criação hipermidiática por parte daqueles considerados não especialistas, presenciada hoje na internet, como se verá adiante, pode indicar uma progressiva extinção de objetos na rede estruturados ainda exclusivamente nos limites da linguagem verbal escrita e da estruturação textual seqüencial, estática e linear. Ainda que seja impossível apresentar dados estatisticamente apropriados, era fácil observar, há alguns poucos anos atrás, que uma parcela significativa das páginas web não explorava de maneira

\footnotetext{
${ }^{4}$ Tradução da autora. No original: "The hypertext of the World Wide Web leads the reader from one text to another, ad infinitum. Contrary to popular images of computer media as collapsing all human culture into a single giant library (which implies the existence of some odering system), or a single giant book (whtch implies a narrative progression), it is perhaps more accurate to think of the new media culture as an infinite flat surface where individual texts are placed in no particular order, [...]"
} 
significativa todas as possibilidades que o meio possibilitava, seja em termos de criação de mensagens informacionais hipertextuais, seja de composição de conteúdos a partir de sons e de imagens em movimento, por exemplo. E isto mesmo levando em consideração, em alguns contextos, a constante melhoria na qualidade da conectividade, que favorece muito a exploração e uso desses recursos. Se parece intrínseco aos weblogs, ferramentas de interação recentes na rede, uma certa estruturação e configuração hipertextual, também neste caso, existem ainda inúmeros exemplos significativos de pouca exploração criativa desses recursos na elaboração de aplicativos neste formato.

Há que se destacar as qualidades emancipatórias do hipertexto, principalmente quando instaura uma nova relação entre redatores e leitores, e a possibilidade de uma escrita construída coletivamente. "O hipertexto, de fato, sugere uma nova gramática de possibilidades, uma nova maneira de escrever e narrar. [...] Como a palavra sugere, um link -um elo, ou vínculo-, é uma maneira de traçar conexões entre coisas, uma maneira de forjar relações semânticas” (JOHNSON, 2001, p.83). Contudo, “a Web deveria ser uma maneira de ver novas relações, de conectar coisas que de outro modo ficariam separadas" alerta Johnson (2001, p.92), referindo-se à rigidez dos sistemas de links, que não possibilitam aos usuários a criação de trilhas associativas próprias, ainda que se percebam hoje possibilidades crescentes na criação flexível de conexões voltadas a interesses específicos com as diferentes ferramentas e aplicativos da chamada web colaborativa. Esta preocupação também parece rondar os pesquisadores Alex Primo e Ricardo Araújo, da Universidade Federal do Rio Grande do Sul, cuja equipe concebeu e programou uma ferramenta chamada Co-link, que procura justamente romper com os links estáticos, fechados e unidirecionais. O objetivo da ferramenta é "permitir que qualquer interagente possa criar novos links associativos em um texto pré-existente e/ou acrescentar novos destinos a um link já criado" (CO-LINK, 2008), ou seja, permitir que num dado hipertexto a leitura criativa e associativa pessoal repercuta sobre o próprio texto, rompendo com a determinação inicial programada no aplicativo. Este projeto sugere "uma nova possibilidade tecnológica que possa favorecer a escrita coletiva de hipertextos" (CO-LINK, 2008). Lévy também destaca a possibilidade da escrita coletiva a partir de hipertextos: "Quando o sistema de visualização em tempo real da estrutura do 
hipertexto (ou sua cartografia dinâmica) é bem concebido, ou quando a navegação pode ser efetuada de forma natural e intuitiva, os hiperdocumentos abertos accessíveis por meio de uma rede de computadores são poderosos instrumentos de escrita-leitura coletiva” (LÉVY, 2000, p.57).

\subsection{Reconfiguraç̄ōes e recombinaç̄öes}

André Lemos (2005) diz que a cibercultura caracteriza-se por três princípios que estariam na base da lógica da remixagem, ou do potencial recombinante das tecnologias digitais ${ }^{5}$. Seriam eles: (1) a liberação do pólo de emissão, que diz respeito a ruptura das conexões entre autor ${ }^{6}$, obra e original, (2) a conectividade generalizada, e (3) a reconfiguração de formatos midiáticos e práticas sociais.

Na cibercultura, novos critérios de criação, criatividade e obra emergem consolidando, a partir das últimas décadas do século $\mathrm{XX}$, essa cultura remix. Por remix compreendemos as possibilidades de apropriação, desvios e criação livre [...] a partir de outros formatos, modalidades ou tecnologias, potencializados pelas características das ferramentas digitais e pela dinâmica da sociedade contemporânea (LEMOS, 2005).

O autor destaca o vínculo das práticas recombinantes com uma forma de cultura contemporânea que chama pós-modernismo, e sua atual abrangência: “A novidade não é a recombinação em si mas o seu alcance. A recombinação e a re-mixagem têm dominado a cultura ocidental pelo menos desde a segunda metade do século XX, mas adquirem aspectos planetários nesse começo de século XXI” (LEMOS,

\footnotetext{
${ }^{5}$ Remixar significa em português mixar novamente, alterando o que foi feito antes. Mixar, no sentido que interessa aqui, diz respeito a combinar e ajustar. Remix, em inglês, é a união do prefixo re, designando reiteração, ao verbo to mix, que significa misturar, mesclar, amalgamar, combinar, unir, embaralhar. (Cf. http://michaelis.uol.com.br).

${ }^{6} \mathrm{O}$ autor de bens culturais seria agora uma mescla de autor / usuário / espectador.
} 
2005). Como prática de reconfiguração midiática cita o podcasting ${ }^{7}$, os blogs, os sistemas P2P, software livres e obras artísticas.

No mesmo sentido, Manovich diz que:

hoje, muitas das arenas culturais e de estilo de vida - música, moda, design, arte, aplicações web, meios criados por usuários, comida - são governados por remixes, fusões, colagens, ou mash-ups. Se o pós-modernismo definiu os anos 1980, definitivamente o remix domina os anos 2000, e provavelmente continuará a determinar a próxima década também ${ }^{8}$ (MANOVICH, 2007b).

Este mesmo autor fala do uso difuso que o termo remix passou a assumir, do estrito uso nas práticas de mixagem na área da gravação de áudios ao uso generalizado aplicado hoje a qualquer meio, assumindo o sentido de se retrabalhar a partir de elementos culturais existentes ${ }^{9}$. A world wide web, redefinindo os documentos eletrônicos como uma mistura de outros documentos, trouxe definitivamente a cultura e a prática remix, que hoje se estende para além da cultura e internet (MANOVICH, 2007b). "Remixability praticamente tornou-se uma característica embutida ao universo das redes de mídias digitais" 10 (MANOVICH, 2005).

Tanto Lemos como Manovich, ao definirem as práticas amplas de recombinações, que se aplicam a tecnologias, conteúdos, aplicativos, e dispositivos digitais, como constituintes e fundamentais à cibercultura, alertam para o aparecimento, em paralelo, de mecanismos que buscam reprimi-las. As

\footnotetext{
${ }^{7}$ Forma de circular arquivos de som em MP3 pela internet por meio de ferramentas de assinatura. Este e os outros exemplos citados por Lemos são abordados neste capítulo no item ferramentas e práticas colaborativas.

${ }^{8}$ Tradução da autora. No original: "Today, many of cultural and lifestyle arenas - music, fashion, design, art, web applications, user created media, food - are governed by remixes, fusions, collages, or mash-ups. If post-modernism defined 1980s, remix definitely dominates 2000s, and it will probably continue to rule the next decade as well."

${ }^{9}$ Manovich (2007b) indica também a inadequação do uso dos conceitos de apropriação, citação, colagem e montagem como também definidores de remix.

${ }^{10}$ Tradução da autora. No original: "Remixability becomes practically a built-in feature of digital networked media universe."
} 
licenças Creative Commons e dos software livres, a Foundation for a Free Information Infraestructure, lutam bravamente contra as grandes corporações que representam as leis do copyright e patentes.

\subsubsection{Convergência digital}

O termo convergência assume, hoje, diferentes significados dependendo da área em que for aplicado, seja tecnológica, comunicacional, mercadológica, cultural ou social. Interessa destacar aqui alguns aspectos no entendimento da convergência associada às tecnologias digitais que ajudam a moldar as ações e experiências no universo da cibercultura.

Grosso modo, convergência tecnológica diz respeito à reunião de diferentes tecnologias capazes de compartilhar recursos entre si. Diferentes conectividades, mídias, hardware e software, em sinergia, poderiam ser combinados para a realização de uma função ou de ações em comum, e mesmo utilizados em diferentes contextos. Quando se rompem os limites das funções convencionais, entra-se no terreno da convergência, em diferentes proporções e escalas. Segundo Zuffo,

[...] há pelo menos dez anos que especialistas em ciências e tecnologias da informação (TIs) prevêem, face à crescente complexidade dos circuitos integrados, a convergência das diferentes tecnologias, no sentido em que redes de comunicação de dados, computadores, radiodifusão e televisão difusora, radiocomunicação, telefonia fixa e celular, sistemas de gravação e reprodução de vídeo e som tenderiam, e tendem, a serem combinadas e colocadas em um único, ou mesmo distribuídas, em poucos tipos de equipamentos. Essa visão, um tanto simplista por estar baseada em apenas uma área das Tls, tornou-se não só realidade, como vem trazendo implicações mercadológicas e sociais que dificilmente poderiam ser previstas, há pouco tempo, pelos mais argutos economistas e sociólogos (ZUFFO, 2005, p.72). 
É extensa a lista de exemplos que comprovam a tendência marcante da convergência digital seja no campo das tecnologias de comunicação, dos dispositivos informáticos, das mídias digitais, já implantados e ou em implantação, no sentido de interoperabilidade universal. ${ }^{11}$

Henry Jenkins (2006) propõe um alargamento do conceito de convergência, para além do seu entendimento como um processo tecnológico envolvendo aplicações multimídias e dispositivos informáticos. Convergência, para o autor, é uma palavra que descreve as mudanças da maneira de circulação das mídias dentro da nossa cultura, mudanças de âmbito tecnológica, industrial, cultural e social. Convergência refere-se a co-existência de múltiplos sistemas de mídias por onde fluem conteúdos midiáticos (JENKINS, 2006). Trata-se de um processo em andamento, uma série de intersecções estabelecidas entre estes diferentes sistemas, que incluem uma interação mais complexa entre velhas e novas mídias. O fluxo de conteúdos através de múltiplas plataformas, a cooperação entre várias indústrias de mídias e o comportamento migratório da audiência em busca de experiências de entretenimento também são entendidos como processos associados à convergência. Interessa destacar que na acepção de Jenkins os efeitos da convergência na maneira de produzir e utilizar mídias implicam uma perspectiva em que a audiência "está demandando o direito de participar da cultura" (JENKINS, 2006, p.24), instaurando uma nova cultura participativa e a inteligência coletiva, nos termos de Lévy ${ }^{12}$.

[...] a cultura da convergência representa uma mudança nos modos como nós pensamos sobre nossas relações com as mídias, que nos fazem mudar primeiro por completo nossa relação com a

\footnotetext{
${ }^{11}$ Pode-se citar a telefonia fixa que possibilita a conexão à internet banda larga, a telefonia celular digital que oferece serviços de internet e TV, os padrões de comunicação sem fio, como Blue-Tooth, Wi-Fi e Wi-Max, o desenvolvimento das técnicas de compressão e descompressão de áudio e de vídeo, voz e vídeo sobre protocolo internet, televisão e rádio digitais, entre tantos outros.

12 Para o filósofo francês Pierre Lévy, inteligência coletiva "é uma inteligência variada, distribuída por todos os lugares, constantemente valorizada, colocada em sinergia em tempo real, que engendra uma mobilização otimizada das competências. [...] a finalidade da inteligência coletiva é colocar os recursos de grandes coletividades a serviço das pessoas e dos pequenos grupos -e não o contrário" (LÉVY, 2000, p.199)
} 
cultura popular, as habilidades que adquirimos direto através do divertimento pode ter implicações em como nós aprendemos, trabalhamos, participamos no processo político, e conectamos com outras pessoas ao redor do mundo ${ }^{13}$ (JENKINS, 2006, p.22).

Independentemente da ênfase adotada nas análises sobre convergência, há um consenso em se considerar o diálogo e as hibridações entre as tecnologias móveis e a web um dos elementos mais significativos deste processo. Para Jenkins (2006) as tecnologias digitais têm se tornado centrais ao processo de convergência midiática. "A tendência para a mobilidade e para o uso muito intenso da internet é avassaladora” (ZUFFO, 2005, p.76).

\subsection{Consideraç̣̄es sobre a internet ${ }^{14}$}

As tecnologias de informação e comunicação instauraram novos paradigmas em uma das estruturas constituintes básicas do ser humano, a comunicação. A internet, porém, não deve ser considerada um meio homogêneo de comunicação, que possui características determinadas e estanques, como por exemplo ainda o são o rádio e o jornal impresso. Trata-se de um meio que abrange formas diferentes de comunicação associadas a variáveis de naturezas distintas, que englobam desde a disponibilidade de suportes tecnológicos de hardware e software, como uma diversidade de protocolos, códigos e linguagens, objetos de alterações constantes.

\footnotetext{
${ }^{13}$ Tradução da autora. No original: "[...] convergence culture represents a shift in the ways we think about our relations to media, that we are making that shift first through our relations with popular culture, but that the skills we acquire through play may have implications for how we learn, work, participate in the political process, and connect with other people around the world".

${ }^{14} \mathrm{~A}$ internet é tratada aqui como a rede de interconexão mundial dos computadores, e também como meio de comunicação, e neste sentido, pode ser apreendida como constituinte ciberespaço, na concepção proposta por Lévy, apresentada na introdução deste trabalho.
} 
Comunicar através da internet pressupõe a escolha de ferramentas específicas que foram sendo estabelecidas e moldadas ao longo da sua própria constituição, e que de certa forma, ou foram institucionalizadas a partir de características e possibilidades distintas, ou descartadas. A internet, no contexto do seu desenvolvimento, assume configurações diversas, em momentos distintos. Há, para períodos específicos, variações quantitativas e qualitativas quanto à disponibilização e favorecimento de práticas comunicacionais, perfis de usuários, características de conteúdos, entre outros. As ações e práticas a partir da internet estão sujeitas a processos de alterações permanentes, a reconfigurações, seja em termos tecnológicos como conceituais ou de conteúdos. Trata-se de transformações rápidas e constantes, e portanto, de difícil apreensão. Tanto as investigações jornalísticas como as pesquisas realizadas em instâncias acadêmicas devem, portanto, levar em conta este contexto de elasticidade, e considerar como válidas no presente suas apreciações sobre a rede. Isto implica uma impossibilidade de afirmações contundentes e categóricas, como generalizações amplas, a respeito da rede. Os sistemas de comunicação na internet incluem-se neste contexto em que aplicações emergentes convivem com velhas práticas, num continuum avesso a rupturas abruptas. Acredita-se que as diferentes possibilidades de trocas informacionais na internet tende a moldar interações sociais de caráter distinto, possibilitando, como se vê adiante, a conformação de relações sociais em diversos níveis. Neste sentido, no contexto da internet, é sempre mais apropriado pensar plural. Sincronismos e assincronismos não precisam ser mutuamente excludentes em determinadas aplicações, os atos comunicacionais podem também ser estabelecidos a partir de lógicas combinadas de um para um, um para muitos e muitos para muitos. Pólos emissores e receptores são flexíveis, novos protocolos indicam novas possibilidades de comunicação.

É comum aos trabalhos que abordam a internet o resgate de sua genealogia. Ao traçar sistematicamente a origem e desenvolvimento da rede, busca-se contextualizá-la historicamente. Em meio a siglas, datas e referências notáveis destaca-se quase sempre exclusivamente o aspecto da sua origem militar, obedecendo a mesma seqüência ilustrativa e panorâmica, ligada ao Departamento de Defesa dos Estados Unidos e à sua agência de pesquisas - a ARPA Advanced Research Projects Agency, 
que deram forma à Arpanet, um sistema aberto de comunicação por computador, descentralizado e flexível, que seria como uma primeira versão da internet. Associado a este fato, sublinha-se também que, em meados dos anos 1960, o contexto das pesquisas científicas na área de computação estava em grande parte voltado à questão da interação e que diversos pesquisadores e centros de pesquisas, não só norte-americanos, buscavam investigar tanto a comutação por pacotes, o compartilhar online tempo de computação, e conseqüentemente, a formação de redes de computadores. Assim, procura-se salientar que várias pesquisas contribuíram para o desenvolvimento da internet, num ambiente favorável a disponibilização de informações entre pesquisadores. É importante considerar que esta emersão se dá no bojo dos chamados movimentos de contracultura, que certamente a influenciou. Castells (2003, p.13) diz que mais importante do que narrar a história, "parece ser a lição crítica que podemos destilar dos processos que levaram à formação da internet". Tais processos moldam seu contexto e seus atuais usos. Destaca que associado aos possíveis objetivos voltados às estratégias militares estiveram pesquisas e investigações científicas desenvolvidas com um imenso caráter de autonomia, e por isso mesmo, imersas num contexto de grande inventividade e liberdade de pensamento. A internet surgiu envolta a instituições governamentais e ambientes acadêmicos, estes últimos responsáveis pelo desenvolvimento de outras redes alternativas de comunicação por computadores, ora de caráter científico, estudantil ou mesmo comunitário, que viriam a influenciar usos e serviços que se fizeram disponíveis mais tarde. A internet esteve, desde o princípio, ligada a estruturas abertas, tanto em termos tecnológicos como institucionais e sociais. A flexibilidade de protocolos, a descentralização de redes, a interconexão ilimitada, a tradição de acesso aos códigos fontes de software, a instituição de grupos cooperativos, corroboram estas afirmações.

É sabido que o uso de uma determinada tecnologia atesta sua própria configuração. Com a internet não foi, e continua não sendo, diferente. Da produção e do processo de aprendizagem pelo uso derivam, em partes, sua difusão em grandes proporções e seu próprio aperfeiçoamento. Neste sentido, os processos e usos das redes de computadores, nas suas origens, constituíram o que Castells (2003) chama de cultura comunitária, que está ligada à própria formação autônoma de redes e à publicação 
independente, que deram forma à diversidade das comunidades virtuais. Consenso, produção colaborativa, processos abertos, espírito de liberdade, autonomia, descentralização, informalidade, diversidade, prazer em criar, comunicação livre e horizontal, prática da livre expressão, distribuição democrática, estiveram e estão vinculados à essência do processo de produção da tecnologia da interconexão de computadores, estendida agora a dimensões planetárias. Não se pode, porém, ignorar que fazem parte do contexto de desenvolvimento da rede tanto os usos comerciais, que também a moldaram e continuam moldando, sendo importantes propulsores da sua expansão, como também os lobbies e cartéis a favor de interesses específicos e privados, que em momentos e instâncias específicas, tentam interferir nos seus processos de gestão.

Interessa destacar aqui a possibilidade de que muitas práticas comunicacionais e interativas, mesmo culturais e sociais, econômicas e políticas, que estão sendo estruturadas e impulsionadas através da internet, possam ter, como base, alguns de seus atributos constituintes, como, colaboratividade e experiência participativa, comunicação não hierarquizada, liberdade de expressão, autonomia e diversidade. Estes atributos poderiam contribuir no estabelecimento de padrões de comportamento na rede, que transferidos para o domínio social, poderiam moldar as formas de interações sociais na rede, e talvez fora dela. O horizonte, porém, é considerar o ciberespaço como suporte apropriado com características distintivas à estruturação de diferentes formas de sociabilidade.

\subsection{Em comum: ferramentas e práticas colaborativas}

Socialização, comunicação e interação através das mídias digitais pressupõem conexão e ferramentas apropriadas. Judith Donath, uma das principais pesquisadoras do Sociable Media Group, do Media Lab do MIT, vem explorando no desenvolvimento de interfaces computacionais justamente as qualidades e 
parâmetros desta apropriação. A interface Visual Who é um dos primeiros trabalhos de Donath neste sentido.
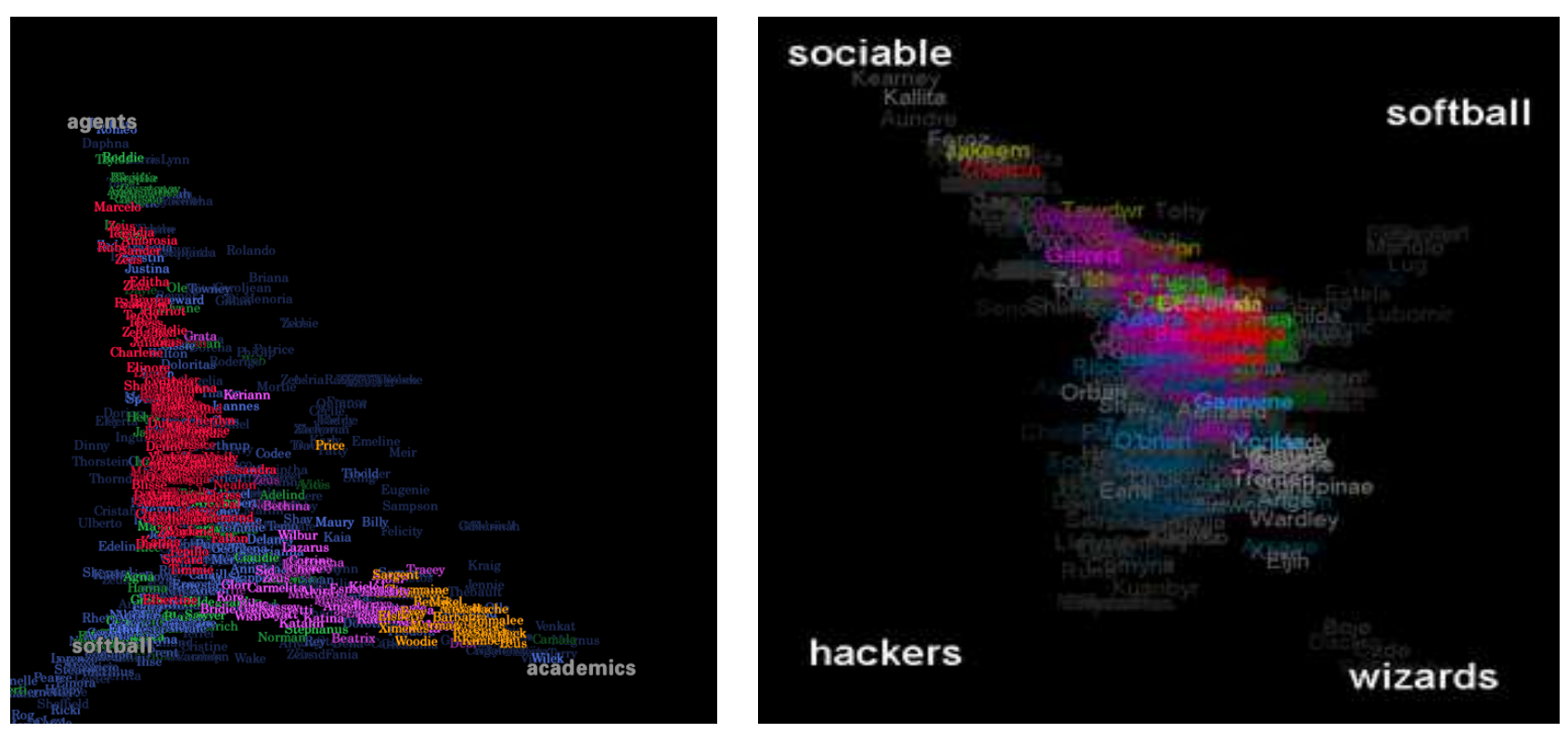

Fig.7-8 Visual Who Fonte: DONATH (1996)

Visual Who (Judith DONATH, MIT Media Lab / Sociable Media Group, 1995)

Interface que possibilita a visualização de determinadas relações entre as pessoas de uma comunidade, a partir, por exemplo, de interesses em comum. Busca expressar padrões de associações interativas de comunidades online através de representações gráficas que envolvem o nome das pessoas, e elementos como movimento, cor e brilho, tendo com base listas de e-mails. O objetivo é encontrar maneiras perceptíveis e legíveis para o entendimento das relações sociais de uma comunidade complexa (DONATH, 1995, 1996).

Quando se fala na qualidade das conversações e trocas entre pessoas, e grupos de pessoas, através de dispositivos digitais conectados à internet costuma-se usar um termo específico: colaboração. Neste contexto trata-se de uma expressão amplamente empregada que agrega significados muito mais abrangentes do que sua estrita denotação. Muitos estudos procuram compreender as relações de colaboração estabelecidas na internet a partir das perspectivas sociológicas e econômicas. Conceitos e 
teorias em torno da economia das doações e da cultura das dádivas são exemplos, entre outros ${ }^{15}$. Colaborar e cooperar aqui significa muito mais que comunicar e participar ${ }^{16}$. Entende-se colaboração como sendo um processo de contribuição mútua, centrado nas competências dos indivíduos e/ou grupos. Na colaboração, pessoas estão juntas, num senso de pertencimento, como um grupo cujos componentes interagem entre pares, com um mesmo objetivo, havendo espaço para autonomia, igualdade, respeito mútuo, e uma postura de tolerância com diferenças e divergências. Um processo colaborativo nem sempre é definido de forma fechada e organizada, há espaço para discussão e negociação, não pressupõe um escopo pré-estabelecido. Implica, pois, na busca de conhecimento, de informação, de um resultado novo, que depende das relações estabelecidas entre os indivíduos e o grupo, e que só se constrói a partir delas.

\subsection{Já história?}

Há, como já foi visto, uma relação intrínseca entre alguns aspectos da internet e práticas colaborativas. Nos primeiros anos do desenvolvimento de redes de comunicação que utilizavam computadores, já estava presente a idéia de colaboração. Allen (2004), em seu artigo Tracing the Evolution of Social Software, apresenta uma possível genealogia do desenvolvimento de programas voltados à aplicação social, que começa com as idéias de Vannevar Bush, passam pela Arpanet, pelo NLS de Engelbart, pela implementação, nos anos 1970, de um programa colaborativo, o Electronic

${ }^{15}$ Ver, a respeito, APGAUA, R. (2004). O Linux e a perspectiva da dádiva. Horizontes Antropológicos, Porto Alegre, v.10, n.21, p.221-240, jan./jun. e KOLLOCK, P. (1999). The economies of online cooperation: gift and public goods in cyberspace. In SMITH, M.A.; KOLLOCK, P. (Ed.) Communities in Cyberspace. London, Routledge.

${ }^{16}$ Não interessa a este trabalho discorrer sobre os possíveis discernimentos entre colaboração e cooperação, presentes principalmente nos estudos relacionados a ambientes digitais de aprendizagem. Muitos autores tratam estes termos como sinônimos, outros os diferenciam. Alheio a semelhanças e discordâncias, e mesmo a possíveis fusões de significados, opta-se aqui por caracterizar colaboração a partir da ótica da comunicação mediada de forma geral. 
Information Exchange System (EIES), precursor do que viria a ser o Bulletin Board System (BBS), que mais tarde deu suporte à criação da WELL (Whole Earth 'Letronic Link).

Tendo a cooperação como meta, empresas e fundações emprestaram fundos para o desenvolvimento do Electronic Information Exchange System (EIES), o primeiro software para comunicação coletiva de grande escala, lançado em 1972. Entre as suas principais aplicações estavam: preservar o anonimato dos participantes, organizar a comunicação de grandes audiências e facilitar o contato entre pessoas independente da distância física e das limitações de tempo de cada um. Isso demonstra a tentativa de usar conhecimentos da psicologia para entender a dinâmica dos relacionamentos em grupo, o que levou à criação de soluções tecnológicas adotadas até hoje em softwares como fóruns e programas de e-mail (SPYER, 2007, p.24).

Nos estudos acadêmicos os programas de suporte para as relações em grupo são comumente chamados social software, além de outros termos que também são usados, tais como groupware e CSCW, acrônimo de Computer Supported Cooperative Work. Entretanto, parece difícil estabelecer um consenso em relação a uma terminologia exclusiva, dado que o desenvolvimento de ferramentas para a interação online em grupo está relacionado a diferentes disciplinas, tecnológicas e humanas, que investigam os processos de apoio e auxílio a cooperação. O próprio termo social software explicita esta relação entre componentes sociais e instrumentos técnicos.

É importante perceber que, desde o começo da expansão da internet para um grande público, nos anos 1990, as práticas de compartilhamento de informações, os ambientes colaborativos, as plataformas de interação e interlocução grupal se desenvolvem e se estabeleceram cada vez mais, principalmente a partir de uma simplificação que visa a utilização por usuários não especialistas, e a gratuidade. 0 termo Web 2.0, cunhado em 2004 pelo editor norte-americano Tim O'Reilly, buscava nomear aplicativos e sites estruturados a partir de práticas chamadas bottom-up (de baixo para cima), ou seja, a partir de conteúdos produzidos através da interação dos usuários, chamados User Generated Content (UGT). Hoje, ainda envolto em controvérsias, dado sua ligação com interesses corporativos e 
mercadológicos, o termo é amplamente difundido e empregado em círculos especializados e leigos para definir, ainda que grosso modo, o conjunto de práticas colaborativas implementadas na rede. Trata-se da necessidade de caracterizar tanto as diferentes ferramentas e aplicações que objetivam a criação de redes sociais em ambientes digitais, como a própria internet como uma plataforma que disponibiliza um conjunto de programas de gestão de informações.

Nesta nova Web a rede digital deixa de ser uma simples vitrine de conteúdos multimídia para converter-se em uma plataforma aberta, construída sobre uma arquitetura baseada na participação dos usuários. Ao redor do conceito Web 2.0 gira uma série de termos-satélites que retroalimentam sua evolução. Software social, arquitetura da participação, conteúdos gerados por usuários, rich Internet applications, etiquetas, sindicação de conteúdos e redes sociais, são somente alguns na larga lista de conceitos que enriquecem este fenômeno ${ }^{17}$ (COBO ROMANí; PARDO KUKLINSKI, 2007, p.15).

Os desdobramentos culturais e sociais, e até mesmo econômicos, desta web colaborativa suscitam tanto interesse quanto seus desenvolvimentos e transformações de caráter tecnológico. A questão não é mais disponibilizar informações e sim interagir de diferentes formas e amplitudes com estas informações. Potencializar compartilhamento, participação e colaboração caminha no sentido de propiciar às pessoas, usuários não especialistas, poder não só para produzir conteúdos, mas para manipular, organizar e gerir tais conteúdos publicados de forma viral na internet. 0 usuário agora pode criar, editar, selecionar, classificar, hierarquizar, moderar, avaliar, divulgar e disseminar idéias, informações e conhecimento por meio das redes sociais, seja na forma de textos, sons, imagens e vídeos, ou a partir de combinações entre eles.

\footnotetext{
17 Tradução da autora. No original: "En esta nueva Web la red digital deja de ser una simple vidriera de contenidos multimedia para convertirse en una plataforma abierta, construida sobre una arquitectura basada en la participación de los usuarios. Alrededor del concepto Web 2.0 giran una serie de términos-satélite que retroalimentan su evolución. Software social, arquitectura de la participación, contenidos generados por el usuario, rich Internet applications, etiquetas, sindicación de contenidos y redes sociales, son sólo algunos en la larga lista de conceptos que enriquecen este fenômeno."
} 
A nova dinâmica técnico-social da cibercultura instaura assim, não uma novidade, mas uma radicalidade: uma estrutura midiática ímpar na história da humanidade onde, pela primeira vez, qualquer indivíduo pode, a priori, emitir e receber informação em tempo real, sob diversos formatos e modulações, para qualquer lugar do planeta e alterar, adicionar e colaborar com pedaços de informação criados por outros (LEMOS, 2005).

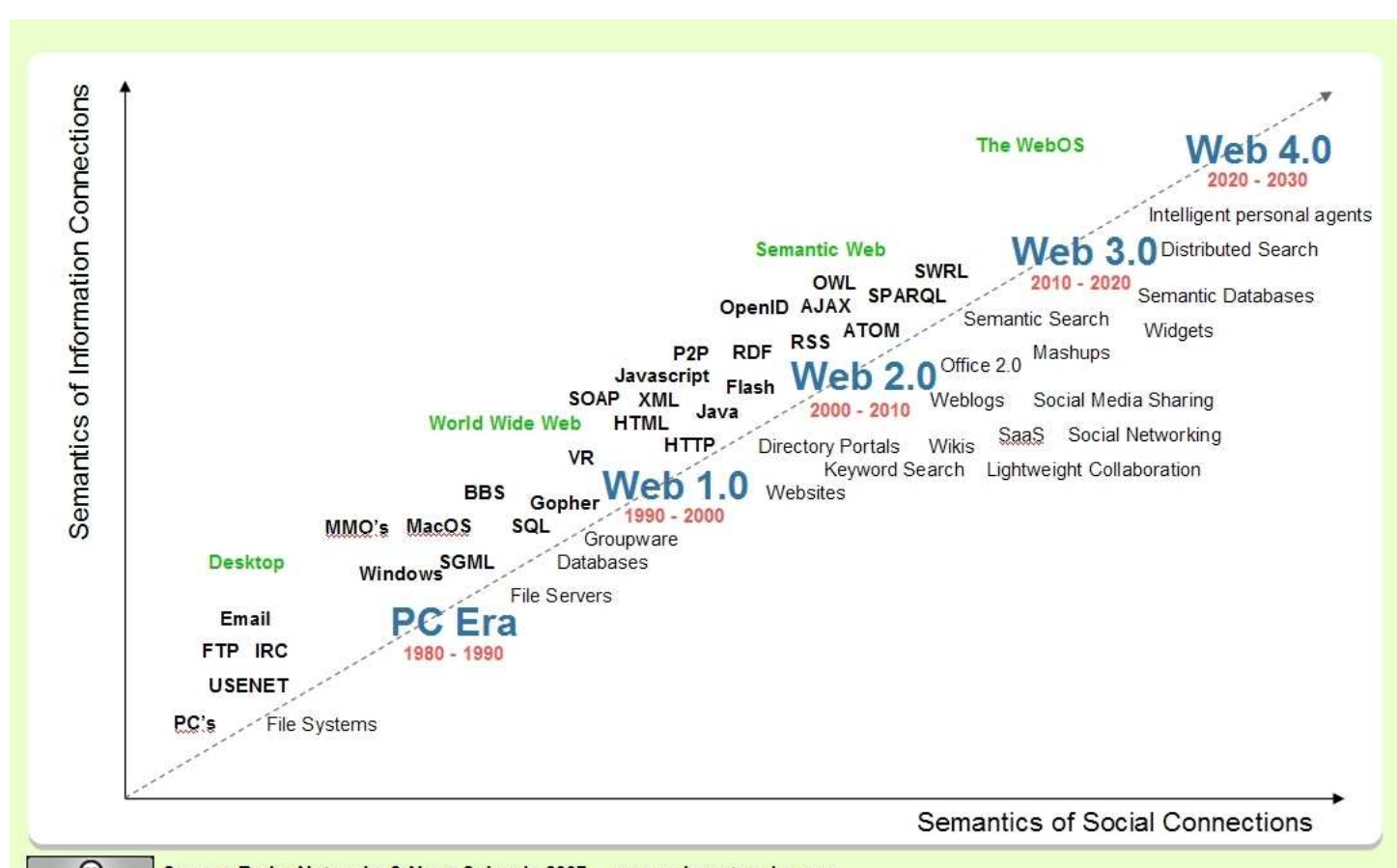

Fig.9 Fases da internet Fonte: INTERNET (2008)

Há quem já vislumbre além das possibilidades da rede dos processos colaborativos de hoje. Outras novas ondas de desenvolvimento de tecnologias voltadas a web e também centradas nos usuários estariam a caminho, acompanhadas de um conjunto de terminologias também passíveis de controvérsias. A chamada web inteligente (web 3.0), chamada ainda de web semântica, estaria envolta 
a mecanismos de busca mais inteligentes que procurariam dar sentido e contexto às informações disponíveis na rede, gerando organizações e usos de conteúdos mais eficientes. A web 4.0 integraria todos os serviços e software necessários a todas as ações do dia-a-dia. Seria um enorme sistema operacional, uma enorme plataforma, agregando agentes pessoais inteligentes. Mas tudo isso ainda é futuro.

Ainda que se saiba que as redes sociais online existem para além da web, a partir de outros protocolos da internet e mesmo nas intranets, apresentam-se, a seguir, algumas tecnologias, plataformas, ferramentas e práticas que se constituem hoje como mecanismos que buscam implementar a colaboratividade nesta rede e/ou a partir dela, seja para a comunicação e interação em busca da troca de informações, compartilhamento de idéias e experiências, e produção de conhecimento, seja para o trabalho, entretenimento ou para o estabelecimento de sociabilidades. O objetivo é entender as dimensões desses mecanismos, seus fundamentos gerais, sejam eles consagrados pelo uso, ou ainda experimentais. Busca-se vislumbrar tendências ou possibilidades em relação ao estabelecimento dos processos colaborativos na fase atual da internet. Entretanto, como Cobo Romaní e Pardo Kuklinski, se está também consciente:

[...] de que todo esforço de sistematizar ou organizar os recursos existentes na Rede se reduz a um intento de êxito parcial [...]. Tentar depurar, classificar e organizar o universo digital é uma tarefa sem fim e, por tanto, uma espécie de harakiri acadêmico, cuja missão nunca se alcançará plenamente. Isto se intensifica se se entende a rede de redes como um sistema aberto, vivo e em permanente mutação, onde muito do que hoje se aponta no papel amanhã evolui ou se funde e deixa de vigorar ${ }^{18}$ (COBO ROMANÍ; PARDO KUKLINSKI, 2007, p.62).

\footnotetext{
${ }^{18}$ Tradução da autora. No original: "[...] de que todo esfuerzo de sistematizar u organizar los recursos existentes en la Red se reduce a un intento de éxito parcial [...]. Intentar depurar, clasificar y organizar el universo digital es una tarea sin fin y, por tanto, una especie de harakiri académico, cuya misión nunca se alcanzará plenamente. Esto se intensifica si se entiende la red de redes como un sistema abierto, vivo y en permanente mutación, donde mucho de lo que hoy se apunta en el papel mañana evoluciona o se fusiona y pierde vigência."
} 
A seleção das ferramentas colaborativas teve como foco a produção e compartilhamento de conteúdo, e da própria rede. ${ }^{19}$ A classificação também aqui é um recurso metodológico, dado que grande parte das ferramentas combina diferentes características. As especificidades das redes sociais estão dispostas no próximo tópico, em separado, dada a sua importância neste trabalho. É possível vislumbrar outras formas de estruturação desse conteúdo, como a organização a partir da divisão das ferramentas colaborativas de tipos síncronas e assíncronas, e dos programas que auxiliam o gerenciamento dos fluxos informacionais, adotada por Spyer (2007). Preece, Rogers e Sharp (2005), mais preocupadas com o projeto de sistemas de colaboração e comunicação mediada por computador (CMC), propõem uma forma de classificação também em termos de comunicação síncrona e assíncrona, e incluem uma categoria em que combinam CMC com outras atividades colaborativas. Cobo Romaní e Pardo Kuklinski (2007) propõem uma ordenação do que chamam de arquitetura da web 2.0 a partir de quatro eixos: (1) redes sociais, (2) conteúdos, (3) organização social e inteligência da informação, e (4) aplicações e serviços.

\subsubsection{A questão da produção de conteúdo na rede}

Uma das principais características do atual estágio da internet é a facilidade de produção e publicação de conteúdos. É bastante provável que um usuário com conhecimentos básicos em internet, munido de um computador conectado e motivado, consiga criar e adicionar informações na rede. É possível também que consiga interagir com pessoas de diferentes maneiras. A facilidade de utilização das diversas ferramentas disponíveis traz à cena o protagonismo do usuário comum. A internet, em boa

\footnotetext{
${ }^{19}$ Ficaram de fora desta seleção ferramentas e plataformas voltadas especificamente a organização, coordenação e gestão de projetos na web também conhecidas como tecnologias colaborativas. E também os buscadores convencionais, reprodutores e agregadres de música, os processadores de textos, planilhas e slides disponíveis online, e sites de armazenamento, por estarem todos relacionados ainda com ações desenvolvidas no plano pessoal, não necessariamente envolvendo trocas coletivas.
} 
parte, não é mais construída e comandada apenas por profissionais especialistas privilegiados. Amadores, sem formação específica, acadêmica ou prática, na área de produção de sites e páginas, de jornalismo ou publicação de forma geral, sem conhecimentos avançados linguagens de programação, sem o auxílio de equipes especializadas de computação e serviços de hospedagem em servidores, agora podem ser geradores de conteúdos. Podem criar de forma autônoma e gratuitamente seus próprios meios de expressão na rede.

\section{Conteídos produzidos pelos usuários}

\section{A blogosfera}

A possibilidade de formação de redes sociais colaborativas a partir de conexões de blogs é facilmente verificável empiricamente. Estas redes são possíveis tanto quanto são possíveis as criações de interesses específicos em torno de determinados assuntos, pessoas ou grupos de pessoas. Blogs são cada vez mais usados de forma profissional ou pessoal, para discutir e apresentar assuntos gerais e específicos, para fazer cobertura de eventos, publicar e comentar notícias:

[...] não se entende os weblogs sem seu sentido de comunidade. Quem escreve um weblog acaba rodeado por uma comunidade fiel de leitores muito deles também bloggers, que os lê assiduamente. Escrever um weblog é como cozinhar para um grupo e nunca comer sozinho. Quem encara um weblog tem presente que está ao mesmo nível de seu interlocutor. Pode-se iniciar um diálogo com seu autor, porque estão sentados à mesma mesa, rebater seus argumentos e aportar seus próprios ${ }^{20}$ (ESTALELLA, 2005).

\footnotetext{
${ }^{20}$ Tradução da autora. No original: "Porque no se entienden los weblogs sin su sentido de comunidad. Quien escribe un weblog acaba rodeado por una comunidad fiel de lectores, muchos de ellos también bloggers, que lo leen asiduamente. Escribir un weblog es como cocinar para un grupo y nunca comer sólo. Quien encara un weblog tiene presente que está al mismo nivel que su interlocutor. Puede entablar un diálogo con su autor, porque están sentados a la misma mesa, rebatir sus argumentos y aportar los propios."
} 
Cobo Romaní e Pardo Kuklinski (2007) destacam que se trata de um formato que favorece a troca de conteúdos, a criação coletiva de conhecimento, e que explora novas formas de organizar e compartilhar informações:

[...] o universo dos blog está embasado na idéia de que qualquer um pode escrever online e construir um espaço conversacional que contribua para reforçar as relações sociais. [...] a criação e o consumo de conteúdos se transformam em um processo unipessoal e coletivo, onde todos os atores alimentam esta cadeia como um círculo virtuoso que potencializa o social com o tecnológico, e vice-versa ${ }^{21}$ (COBO ROMANÍ; PARDO KUKLINSKI, 2007, p.66).

Para Spyer (2007) a força dos blogs como ferramentas colaborativas também está intimamente relacionada à rede de interlocutores e às interligações entre si. Para o autor, blogs não fariam sentido sem a blogosfera, e esses conjuntos comunitários ou colaborativos merecem relevância porque agregam vários usuários que participam publicando conjuntamente, seja um grupo restrito de pessoas ou milhares delas.

Reafirmando a importância e a aceitação deste formato, seja como um novo meio de comunicação, de interlocução entre pares, de distribuição de conteúdo, novas aplicações e formatos estão sendo testados pelas comunidades de bloggers. A ampla utilização do YouTube e do Flickr atesta esta aceitação. É significativo também o desenvolvimento de ferramentas que otimizam e enriquecem o uso dos blogs com diferentes recursos que ajudam a apresentação e organização dos seus conteúdos, e também auxiliam a estruturação da blogosgera, como sua difusão e indexação. ${ }^{22}$

\footnotetext{
${ }^{21}$ Tradução da autora. No original: "[...] el universo de las blog está basado en la idea de que cualquiera puede escribir en línea y construir un espacio conversacional que contribuya a reforzar las relaciones sociales. [...] la creación y el consumo de contenidos se transforman en um proceso unipersonal y colectivo, donde todos los actores alimentan esta cadena como um círculo virtuoso que potencia lo social con lo tecnológico, y viceversa".

22 Um bom exemplo é o Technorati um serviço gratuito de internet que oferece, além da possibilidade de criação de blogs, um sistema de busca e indexação de conteúdo por meio de tags (etiquetas), e informações constantes sobre o crescimento da blogosfera, entre outras funcionalidades. [http://technorati.com/]
} 
Os chamados microblogs ou nanoblogs possibilitam a troca rápida de textos pequenos, com caracteres limitados, a integração com outras ferramentas e aplicações, e também outros dispositivos, como o telefone móvel ${ }^{23}$. É certo que exploram a convergência digital de modo geral, nos moldes já discutidos, mas em particular privilegiam a união entre celular e web. Embora já usados para flashmobs, como se verá, para ler notícias, comentar e divulgar palestras e eventos, ou mesmo para simplesmente saber o que pessoas estão fazendo ${ }^{24}$ ou onde irão, os desdobramentos culturais e sociais dos microblogs ainda estão no campo especulativo. "Tudo indica que sua utilidade é grande para grupos sociais que precisam estar o tempo todo conectados" (SILVEIRA, 2007a, p.42).

\section{A nanomidia}

Há hoje uma grande discussão acerca da relação dos blogs com o jornalismo praticado nos veículos de comunicação tradicionais. Vários termos são adotados para dar nome a está prática: nanomídia, micromídia, We Medi, jornalismo em rede, networkjornalismo, jornalismo cidadão, jornalismo colaborativo (ESTALELLA, 2005). Como de praxe, quando o assunto são desdobramentos a partir das TIC, coexistem céticos e deslumbrados. Os primeiros ignoram o valor dos blogs e dos sites de notícias alimentados por usuários na internet frente às mídias tradicionais, os segundos acreditam que tudo caminha para a extinção dos veículos convencionais. O que parece ser mais coerente é a complementaridade e a simbiose entre os formatos (ESTALELLA, 2005; SPYER, 2007). Lemos (2005) associa esta questão ao fenômeno da cibercultura de reconfiguração da indústria midiática e de suas práticas de produção de informação.

O jornalismo digital feito pelos próprios leitores, a reportagem e editoração autônoma, livre de controle ideológico e amarras publicitárias, que começou com o site Slashdot, voltado para o público

\footnotetext{
${ }^{23}$ Há quem chame moblog os blogs que podem ser atualizados a partir de dispositivos móveis como telefones celulares, laptops, PDAs e outros.

24 "O que você está fazendo?" é a pergunta estampada na página principal do Twitter, um dos sistemas de microblogging mais conhecidos hoje.
} 
com maior conhecimento técnico de computação, hoje tem o site de notícias Digg.com como exemplar significativo. Sem moderação, milhares de pessoas buscam, enviam, revisam e escrevem notícias na rede sobre tudo. Os paradigmas são outros, rompe-se com as funções estáticas de redator, editor e leitor, todos podem desempenhar tais papéis de forma colaborativa, a estrutura é a comunicação viral.

Wikis

Wikis são ferramentas construídas a partir de software abertos que possibilitam a redação colaborativa na internet. Pode-se pensá-las como com processadores de informações agregados a navegadores web que permitem publicação, ampliação, enriquecimento e modificação de conteúdos, arquivos e links de diferentes formatos reunidos em páginas. Isso de forma rápida e fácil porque utiliza linguagem de marcação simplificada ${ }^{25}$. Trata-se do princípio remix por excelência (LEMOS, 2005). A Wikipedia, a enciclopédia livre cujo conteúdo está sendo desenvolvido colaborativamente, é o maior projeto centrado em wiki conhecido. E não por acaso, embora comporte outras aplicações, "[...] a função natural do wiki, o motivo pelo qual e a partir do qual a ferramenta vem se desenvolvendo, é a formação de comunidades para a redação colaborativa” (SPYER, 2007, p. 59).

\section{Conteúdos recombinados}

Mash ou mash up é uma palavra inglesa cujo significado mais trivial é mistura. No universo da internet, mashup remete às combinações de algumas aplicações web, ou conteúdos de sites distintos, que derivam outros serviços ou websites. Trata-se de reunir dados e ferramentas de várias fontes, misturar diversos sistemas, geralmente oriundos de portais especializados, e dispô-los em um único lugar de acordo com interesses específicos, criando funções customizadas. Hoje já existem alguns construtores

\footnotetext{
${ }^{25}$ Markup Language, conjunto de códigos utilizados para controlar o layout e a aparência dos textos.
} 
de mashups relativamente simples de serem trabalhados, que permitem que as pessoas com conhecimentos técnicos mínimos criem seus próprios serviços online. ${ }^{26}$

A criação de ferramentas híbridas, frutos da integração de várias tecnologias online mixadas, só é possível graças à disponibilização de algumas companhias em abrirem parte dos códigos de seus software. Contudo, o êxito desta prática está ligado ao crescimento das comunidades de amadores que criam e compartilham seus projetos, transformando o mashup em um conceito cujas qualidades principais são participação, abertura e redes de colaboração. Neste caso, o compartilhamento de projetos favorece a replicação para outros usos, e também inovações criativas. "Geralmente são iniciativas baratas e desenvolvidas nas horas vagas por motivos particulares e que acabam sendo adotadas por outros usuários" (SPYER, 2007, p.244).

\section{Conteúdos classificados e compartilhados pelos usuários}

Folksonomia é o termo aportuguesado derivado de folksonomy, um neologismo atribuído ao arquiteto da informação Thomas Vander Wal, que vem da junção de folk (gente, povo) e taxonomy (taxonomia, ciência da classificação). Trata-se de ferramenta que possibilita a classificação e organização de conteúdos e informações da internet realizada pelos próprios usuários, através de palavras-chave ou tags, que são etiquetas digitais. A idéia é dar aos usuários o poder de "representar e recuperar a informação através de sua própria linguagem” (PAVAN et al., 2007, p.83). ${ }^{27}$ Segundo esses autores, "folksonomia caracteriza-se por ser uma classificação social, ou seja, um trabalho realizado coletivamente por usuários das ferramentas ou sites, que organizam as informações atribuindo

\footnotetext{
${ }^{26}$ A disponibilidade de APIs Application Programming Interface (ou Interface de Programação de Aplicativos) que possibilita a utilização de funcionalidades de um programa por outros programas aplicativos, e métodos de codificação de conteúdo, como web feeds e javascript possibilitam mashups relativamente simples de projetar.

${ }^{27}$ Entre os sites que utilizam tags, ou etiquetagem eletrônica, estão os conhecidos Flickr, YouTube e Tecknorati.
} 
palavras-chave a textos, artigos, livros, fotografias, vídeos, músicas, links, entre outros, disponíveis na internet” (PAVAN et al., 2007, p.83). As chamadas nuvens de tags (tags clouds) são recursos gráficos utilizados para apresentar as tags mais freqüentes e importantes em um determinado universo, permitindo uma forma rápida de visualização.

A idéia de classificação de conteúdos pelos usuários se desenvolveu em paralelo à de compartilhamento de listas de sites preferidos, e evoluiu para a classificação de qualquer recurso web (SPYER, 2007). Hoje há inúmeros serviços disponíveis na internet que oferecem ferramentas de compartilhamento e gerenciamento público de listas de links favoritos, chamados social bookmarks, ou marcadores sociais de favoritos. Tais links podem levar a sites, blogs, fotos, vídeos, músicas, audiocasts, matérias, entrevistas, documentos em geral, e podem ser acessadas de qualquer lugar, de forma gratuita.

E, além da vantagem individual, o compartilhamento de milhares de listas possibilita o cruzamento desses dados indicando quais usuários têm interesses em comum por visitarem o mesmo site, registrarem as mesmas páginas, usarem as mesmas etiquetas ou procurarem pelos mesmos assuntos. Por isso, participantes de sites como o del.icio.us aumentam sua capacidade de encontrar conteúdo relacionado a seus interesses observando a relação de favoritos de pessoas com as quais ele se identifica (SPYER, 2007, p.67).

Hammond et al. (2005 apud PAVAN et al., 2007, p.81) destaca que "quando os links são etiquetados, gerenciados, comentados e publicados na Internet, passam a representar a biblioteca particular do usuário colocada em espaço público. Quando agregada com as bibliotecas de outros usuários, possibilitará o estabelecimento de redes sociais."28

Apesar de todas as limitações apontadas por especialistas na área das Ciências da Informação, a etiquetagem, classificação, hierarquização, ordenação, e arquivamento de conteúdos de forma

${ }^{28}$ HAMMOND, T. et al. (2005). Social bookmarking tools: a general review. D-Lib Magazine, Reston, v.11, n.4, Apr. Disponível em: <http://www.dlib.org/dlib/april05/hammond/04hammond.html>. Acesso em: 9 jul. 2006. 
descentralizada, realizadas por usuários, destacam-se por possibilitar a auto-expressão e a organização coletiva da informação na rede. "Sua arquitetura está desenhada sob a idéia da coletivização do conhecimento e permite recolher as opiniões de todos os que participam, atribuindo maior relevância aos conteúdos mais populares"29 (COBO ROMANÍ; PARDO KUKLINSKI, 2007, p.78).

Paralelamente à questão de categorização de conteúdos em meios colaborativos, situam-se outras ligadas a instâncias de gerência. Mecanismos de coordenação, envolvendo regras, procedimentos e convenções; de moderação ou automoderação, e que medem participação e feedback, projetados e implantados como parte da arquitetura dos sistemas em algumas aplicações, são exemplos significativos da necessidade de administrar ambientes colaborativos.

Um dos dilemas com que as pessoas envolvidas no desenvolvimento de tecnologias colaborativas se deparam é saber quanto de controle implementar e quanto deixar para que os próprios usuários configurem. [...] Quando se trabalha com estas questões referentes ao design, é importante considerar o que ocorre se muito ou pouco controle é implementado na tecnologia colaborativa (PREECE; ROGERS; SHARP, 2005, p.155).

Conceder privilégios, estabelecer critérios de permissões e diferenciações entre usuários, ou permitir aos usuários que decidam as próprias convenções e regulamentações, regras de controle, é determinar, de certa forma, os limites não só entre compartilhamento e colaboração e o desestímulo a cooperação, ajuda e trabalho em comum, mas também pode significar filtrar ruídos, evitar entropia, garantir um determinado status de comunicabilidade, gerenciar fluxos de informação, administrar disputas e conflitos.

${ }^{29}$ Tradução da autora. No original: "Su arquitectura está diseñada bajo la idea de la colectivización del conocimiento y permite recoger las opiniones de todos los que participan, atribuyendo mayor relevancia a los contenidos más populares." 


\section{Conteídos selecionados chegam aos usuários}

Sindicar significa, em português, tomar informações sobre algo por ordem superior, inquirir, investigar (HOUAISS, 2002). Sindicação, no universo da internet, significa distribuição de conteúdo por assinatura. ${ }^{30}$ Ainda que receber e dar informações pareçam ser ações antagônicas, fazem parte de um mesmo processo. Neste universo, através das ferramentas de sindicação, os usuários da rede podem receber automaticamente e periodicamente pequenos resumos enviados pelos sites de seu interesse a respeito dos novos conteúdos disponíveis. De um lado estão as ferramentas que funcionam como disponibilizadores de conteúdos, que estão alocadas em sites ou páginas e podem ser acionadas (ou assinadas) pelos usuários, e do outro aquelas que trabalham como agregadores (ou captadores) desses conteúdos selecionados, que podem estar online ou instalados nos computadores dos usuários. São ferramentas conhecidas como feeds ${ }^{31}$ e agregadores ou leitores de feeds, respectivamente. Estas últimas consultam periodicamente os feeds dos sites ou páginas selecionadas pelo usuário em busca de conteúdos renovados e caso encontre, organiza-os. Pode-se ainda receber feeds por e-mail, filtrá-los a partir de temas específicos, procurá-los a partir de determinados buscadores e ainda compartilhá-los por meio de listas.

Estes mecanismos simples e gratuitos ajudam as pessoas a estabelecer ordenadamente suas próprias fontes de informação na rede. Criam um tipo de navegação personalizada e otimizada, baseada em interesses específicos, que ajudam as práticas de busca de conteúdos na internet. Há uma certa aproximação entre as práticas de sindicação e mashup, as duas possibilitam a reunião e a colagem de conteúdos de acordo com interesses específicos, e mais, trabalham a favor das necessidades e desejos das pessoas, da autonomia. Primo (2005a) destaca que, ao lado da aproximação entre redatores e

\footnotetext{
${ }^{30}$ Segundo Spyer (2007, p.62) a origem deste sentido vem do o próprio significado do termo content syndication (sindicar conteúdo) em inglês: "utilizar o serviço de uma empresa para distribuir um produto de um autor para diversos meios de comunicação."

${ }^{31}$ Feeds (em inglês, alimentar) são baseados na linguagem XML e possuem diferentes formatos, sendo os mais conhecidos RSS (Really Simple Syndication) e Atom.
} 
leitores gerada por estes aplicativos em determinados casos, se dá, na mesma proporção, um distanciamento, derivado da perda de contextualização das informações, comprometendo o debate e as trocas que contribuem para a formação das comunidades online.

\subsection{Infra-estrutura compartilhada}

A fluidez de conteúdos na internet só é possível graças a um conjunto de tecnologias que funcionam associadas, formando e compondo camadas que agregam combinações de protocolos de comunicação, plataformas e software.

\section{As redes peer-to-peer}

P2P é uma grafia utilizada para o termo peer-to-peer, que em português significa par-a-par. Trata-se de uma tecnologia, mais precisamente de um protocolo de aplicação, que permite a criação de redes de compartilhamento de conteúdos de modo distribuído, baseada na concepção de que todos os dispositivos, geralmente computadores convencionais, podem desempenhar papéis de servidores e clientes. ${ }^{32}$ Nas arquiteturas de redes convencionais as máquinas servidores são aquelas que fornecem dados e as clientes aquelas que recebem, nas arquiteturas de redes de pares puras cada computador atua ao mesmo tempo como servidor e cliente, favorecendo o compartilhamento tanto de recursos, como de conteúdos oferecidos pela rede, sem necessidade de passar por nenhuma entidade intermediária. Assim, as tecnologias peer-to-peer permitem a comunicação direta entre nós, estabelecendo-se como um meio bastante utilizado de compartilhamento de arquivos pela internet em qualquer formato, de software a conteúdos multimídias, voz sobre IP, entre outros. As redes P2P são

${ }^{32}$ O programa Napster, de compartilhamento de arquivos de áudio MP3, de 1999, é considerado o marco primeiro nesta tecnologia, ainda que tenha usado uma rede peer-to-peer não pura. 
importantes porque promovem a comunicação horizontal, com participantes usando recursos próprios para compartilhar informações, distribuindo inclusive os custos das transferências de dados. Fundam-se na auto-organização, descentralização e autonomia. "Vemos aqui mais uma forma de reconfiguração midiática, de liberação do pólo da emissão e do princípio em rede, colocando arquivos em circulação para diversas formas de apropriação e criação" (LEMOS, 2005).

O protocolo de compartilhamento P2P denominado BitTorrent, criado por Bram Cohen em 2003, destaca-se não só por permitir a transferência arquivos considerados grandes, como músicas, vídeos e programas, de forma rápida, eficiente e estável, mas por apresentar alguns conceitos inovadores. 0 BitTorrent possui recursos associados a sistemas de sindicação chamados broadcatching ${ }^{33}$, que facilitam a distribuição, possibilitando inclusive download de arquivos à medida que são disponibilizados. 0 BitTorrent também possui um sistema que reafirma a colaboração entre os pares, ou seja, trabalha no sentido de privilegiar o compartilhamento, na medida em que traça a equivalência entre taxas de velocidades para download e upload de arquivos ponto torrent de um usuário, instaurando literalmente a prática do "é dando que se recebe".

Primo coloca em dúvida se as redes P2P criam situações ligadas diretamente à formação de comunidades virtuais, dado que "a rigor, não existe uma verdadeira interação entre os participantes" (PRIMO, 2005a), e sim uma normatização automatizada, e também tendo em vista o absoluto anonimato dos envolvidos nesse tipo de compartilhamento. Entretanto, o autor reconhece a intenção cooperativa por traz dessas práticas. Outra questão importante envolta na análise dessas redes diz respeito ao copyright. Muitos defensores do direito autoral classificam esta tecnologia como facilitadora de acesso a conteúdos considerados ilegais, justamente aqueles protegidos por direitos autorais. Há ainda outra questão controversa. As redes P2P podem sofrer restrições quando adotadas

33 "A distribuição por assinatura de arquivos Torrent recebeu o nome de 'broadcatching' -formado pelo jogo das palavras broadcasting ('difusão') e do verbo to catch ('receber')" (SPYER, 2007, p.65). 
ações de administração de banda pelos provedores de acesso à internet, com o objetivo de reduzir a velocidade de trocas de arquivos dessas redes. Trata-se de traffic shaping, modelagem de tráfego, uma tecnologia que trabalha reprimindo largura de banda, inclusive para algumas aplicações específicas, e no limite, alterando a experiência do usuário final e violando o princípio de neutralidade da internet, que prediz que todo conteúdo na internet deve ser tratado igualmente.

\section{A colaboração Wi-Fi" Fi $^{34}$ redes criadas por usuários}

O compartilhamento chega ao acesso à internet através de práticas que envolvem a iniciativa dos próprios usuários, criando conectividades abertas e gratuitas, antes só possíveis por meio de algumas poucas ações realizadas em instâncias públicas locais. Começa a ganhar corpo experiências que objetivam criar redes de acesso sem-fio (wireless) à internet a partir de comunidades cujos participantes estejam dispostos a dividir, e a tornar aberto e grátis o acesso a internet que possuem, criando pontos de acesso (hotspots) para que outros possam conectar. A idéia é muito semelhante aos princípios de programas peer-to-peer, e também pode se alargar através da telefonia celular, que começa a ser testada sem a centralidade das empresas operadoras.

A rede FON, criada no final de 2005 na Espanha em torno do movimento de mesmo nome é a mais significativa rede Wi-Fi nestes moldes. Trata-se de uma comunidade internacional de pessoas com conexão sem-fio que compartilham o acesso à internet. Com a instalação de um equipamento roteador compatível e programa especial, cada usuário abre a partir da sua conexão banda larga, um canal Wi-Fi público seguro, separado do seu privado, através do qual pode compartilhar conexão com outros usuários.

${ }^{34} \mathrm{Wi}$-Fi é a sigla de Wireless Fidelity, uma tecnologia de rede sem fios de qualquer tipo que usa o protocolo IEEE 802.11, que dita como deve ser a transmissão de informações usando as ondas radioelétricas em faixas não-regulamentadas do espectro. 
As redes de conexão física wireless tipo mesh (malha), nomeada também multi-hop (múltiplos saltos), podem ser mais um exemplo de criação de sistemas que buscam criar caminhos diferentes para interconexões. "Ela tenta criar no terreno da conexão física o mesmo princípio de comunicação lógica da Internet” (SILVEIRA, 2007b). Diversas tecnologias e equipamentos (desktops ou notebooks, telefones móveis e PDAs), juntos, podem permitir o estabelecimento de uma rede wireless que busca tráfegos mais eficientes para as transmissões de dados.

Ao dotar a infra-estrutura de conexão à internet dos mesmos princípios de compartilhamento, abertura e gratuidade que inundam suas aplicações, potencializa-se ainda mais o acesso à rede, a comunicação digital e, de forma indireta, o espírito da colaboração no ciberespaço.

\subsection{Designcolaborativo, Softwarelivre e Participatory Design}

Muitos são os enfoques que se pode dar à questão envolvendo software livres, como se viu. Um merece especial atenção aqui. 0 desenvolvimento de programas abertos é uma das práticas mais significativas de colaboratividade na rede. Seu sistema de desenvolvimento, a partir da comunidade de software livre distribuída mundo afora, inspira e molda a maior parte dos aplicativos apresentados acima ${ }^{35}$. A questão do uso das tecnologias colaborativas de produção e compartilhamento de conteúdo disponíveis na internet está intimamente associada à forma em que estas ferramentas são criadas e desenvolvidas, ou seja, a partir de suportes abertos. "A geração destes canais de participação se consolidam, em alguma medida, como herança da cultura hacker de compartilhar saber sob estruturas abertas e

\footnotetext{
${ }^{35}$ Poderia citar aqui uma lista longa de programas significativos, de sistemas operacionais como o GNU/Linux, às aplicações Ajax, tecnologias usadas para criar aplicativos interativos para a web, aos sistemas de gestão de conteúdos Drupal e WordPress.
} 
horizontais que promovem a inter-criatividade e a inteligência coletiva, em benefício da comunidade" 36 (COBO ROMANÍ; PARDO KUKLINSKI, 2007, p.56). Silveira (2005a) também mostra este vínculo: “Da prática hacker de compartilhamento de códigos-fonte de softwares, a comunidade de software livre inspirou o surgimento de uma ação similar em outras áreas, tais como na música, com o Creative Commons e na consolidação de repositórios públicos de conhecimento, como a Wikipedia, entre outros tantos exemplos".

Os programas abertos são desenvolvidos envolvendo diferentes arranjos de comunidades de especialistas em programação, que mesmo diferenciando entre si de forma significativa em relação a níveis de qualificação formal, adotam estruturas de trabalho horizontais, não hierárquicas, baseadas em capacidade e envolvimento, tendo como suporte o interesse comum em aprimorar-se, e mais, em compartilhar e manter o livre acesso ao conhecimento criado. Fischer (2002) referindo-se ao sucesso dos programas open source como modelos de design colaborativos apresenta três princípios que têm caracterizado seus desenvolvimentos: “(1) na cultura da doação, o status social é determinado não pelo que você controla mas que você doa, (2) o prestígio é um bom caminho para atrair atenção e cooperação dos outros, e (3) a utilização é a forma mais sincera de louvor" (FISCHER, 2002). ${ }^{37}$ Estas seriam também as bases sob as quais se sustenta a colaboração na internet.

O modelo de colaboração em que são produzidos os programas livres estão, em certo sentido, em consonância com determinados atributos do chamado design participativo, e de todas as abordagens em design que procuram envolver usuários nos seus processos de desenvolvimento, em diferentes

\footnotetext{
${ }^{36}$ Tradução da autora. No original: "La generación de estos canales de participación se consolidan, en alguna medida, como herencia de la cultura hacker de compartir el saber bajo estructuras abiertas y horizontales que promuevan la intercreatividad y la inteligencia colectiva, en beneficio de la comunidad."

${ }^{37}$ Tradução da autora. No original: "[...] (1) in gift cultures, social status is determined not by what you control but by what you give away, (2) prestige is a good way to attract attention and cooperation from others, and (3) utilization is the sincerest form of flattery."
} 
gradações, estabelecendo processos menos impositivos, tipo bottom-up. ${ }^{38}$ Contudo, os usuários envolvidos no design de software livres são um tipo particular de usuários, àqueles que possuem necessariamente conhecimentos e habilidades técnicas, e são comumente conhecidos como desenvolvedores. ${ }^{39}$

O design participativo busca envolver usuários ativamente no desenvolvimento de produtos. Designers e usuários projetam em cooperação e parceria (PREECE; ROGERS; SHARP, 2005). Mas aqui os usuários são leigos, são as próprias pessoas em função das quais os produtos são criados. Os projetos participativos de sistemas de software buscam, através de determinadas técnicas e metodologias, alcançarem facilidade de acesso e utilização pelos usuários através do engajamento destes durante as diferentes fases dos ciclos de seus desenvolvimentos. Parte-se da premissa de que usuários aceitarão novos sistemas mais facilmente quando envolvidos em seus projetos. Contudo Preece, Rogers e Sharp (2005, p.326) alertam: “envolver usuários em decisões de design não é tarefa simples”. Pratschke (2002, p.27) destaca outro aspecto da questão: “[...] a necessidade de validar-se através de decisões consensuais pode acabar levando a uma perda de qualidade."

\subsubsection{Colaboração em questão}

Existem exemplos suficientes que evidenciam por que o desenvolvimento da Web 2.0 não é somente tecnológico e sim principalmente de ordem social. Dito de outro modo, a Web 2.0 não inventa a colaboração entre as pessoas, mas sim oferece um enorme leque de possibilidades para

\footnotetext{
${ }^{38}$ Entre eles situam-se os chamados User-Centered Design, Meta-Design, Contextual Design, entre tantos outros.

${ }^{39}$ É importante destacar aqui uma questão considerada polêmica. Muitos argumentos em torno da adoção dos software livres enaltecem a possibilidade dos usuários criarem suas próprias ferramentas, à maneira que lhes convier e de acordo com suas necessidades e interesses, entretanto, usuários comuns, leigos, não são habilitados a modificarem ou mesmo participarem do processo de produção destas aplicações simplesmente porque para tal exige-se conhecimentos técnicos muito específicos.
} 
facilitar o intercâmbio e a cooperação entre indivíduos ${ }^{40}$ (COBO ROMANÍ; PARDO KUKLINSKI, 2007, p. 56).

Entretanto, nesse universo, não pesam só pontos positivos. A vida comunitária na internet contém percalços como também o tem a vida fora dela. Primo (2005a) ressalta esses entraves sem contudo invalidar a colaboração, colocando-os como parte do próprio processo de interação em ambientes de diversidade:

Reveladas as tensões, os choques de idéias e os desequilíbrios sóciocognitivos mediados pelo computador, sugere-se que seja adotada uma visão desencantada da cooperação, vendo-a não como uma seqüência cumulativa de ações altruístas, mas como um laboroso processo de interação a partir de diferenças. Ou seja, os embates a partir do contraditório não são obstáculos à cooperação, nem são os desequilíbrios uma barreira ao desenvolvimento intelectual e à comunicação. Pelo contrário, são a própria condição que faz mover tais processos (PRIMO, 2005a).

Ainda assim, visões que quebram a euforia em torno do espírito de colaboração e da explosão de conteúdos produzidos por usuários na web atual são importantes porque, além de permitem análises mais equilibradas do fenômeno, podem direcioná-los a usos significativos, para além do entretenimento e da exposição gratuita que muitas vezes permeia algumas aplicações e ferramentas. Não se trata de estabelecer juízos de valores, mas justamente de considerar que a diversidade de propósitos em torno da idéia de desenvolver coisas em comum na rede tende a ser enriquecedora. Tem-se, muitas vezes, em alguns circuitos específicos, em nome de uma postura libertária e aberta, desestimulado as discussões a respeito da qualidade relacionada à produção de conteúdo na internet, como se toda e qualquer ação que busque dar algum direcionamento a essa abundância de possibilidades de trocas fosse questão de imposição cultural e cerceamento de liberdade, contrapondo-se ao estado de independência da internet.

40 Tradução da autora. No original: "Existen suficientes ejemplos que evidencian por qué el desarrollo de la Web 2.0 no es sólo tecnológico sino que principalmente de orden social. Dicho de otro modo, la Web 2.0 no inventa la colaboración entre las personas, pero sí ofrece un enorme abanico de posibilidades para facilitar el intercambio y cooperación entre indivíduos." 
Pensar que tudo que se produz na rede é bom, por ser fruto de tecnologias que se apóiam em compartilhamento de informações e processos colaborativos, é um grande equívoco. As possibilidades estão abertas à produção e compartilhamento, como visto acima, os usos das ferramentas se intensificam, mas não se pode ignorar que existem inúmeros desafios a serem vencidos, tanto em relação ao reconhecimento mesmo dessas possibilidades pelos usuários para além da recreação, diga-se também legítima, como no campo da produção qualitativa, visando o crescimento e desenvolvimento intelectual, a autonomia, a consciência crítica, e a tão desejada criação de conhecimento. Por exemplo, a Wikipedia não é explorada em todas as suas possibilidades se usada só como mais um site de pesquisa. 0 caminho para rever tal situação, num contexto de privações como o brasileiro, parece ser o das ações contextualizadas, centradas em demandas, principalmente com vieses cultural e educativo, como já indicado.

Não é só a qualidade das ações de produção de conteúdo que podem limitar os potenciais e benefícios dos processos colaborativos das redes digitais. 0 avanço das idéias de propriedade sobre as tecnologias envolvidas na comunicação digital, sejam códigos, protocolos ou padrões, leva à concentração de poder, e pode também controlar a expansão desses processos de compartilhamento na medida em que coloca em risco a conectividade generalizada e aberta. Esta é uma batalha estabelecida pela cultura digital e só pode ser vencida a partir de seu ambiente natural, a própria rede. 


\subsection{Paradigmas de interaç̆̃o}

Interação, interativo, interatividade são termos hoje empregados em diferentes campos disciplinares, como se viu, mas recebem qualificações particularmente valorizadas quando se trata de artefatos computacionais e digitais. Porém, se significações imprecisas são atribuídas a estes termos nas esferas leigas, no âmbito acadêmico, uma multiplicidade de enfoques demonstra a necessidade de entendê-los melhor:

O discurso agora ubíquo sobre interatividade pode parecer ter surgido repentinamente e muito recentemente. A chamada 'mídia interativa', para dizer nulidades como 'compras interativas' e 'entretenimento interativo', era raramente usada antes dos anos 1990. Revistas com 'interatividade' em seus títulos tem aparecido somente muito recentemente. É, todavia, importante ver que o 'culto da interatividade' tem estado em formação por um longo tempo ${ }^{41}$ (HUHTAMO, 2000, p.109).

A partir dos anos 1970, o termo interação começa a figurar no cenário da Ciência da Computação para designar a ação conjunta humano-computador. Findava o tempo em que a manipulação dos computadores era realizada de forma mais direta, por meio de chaves e cabos, visores, cartões, apenas por especialistas. Com as novas interfaces de estações de trabalho, monitores, teclados, mouses, scanners, facilita-se e, ao mesmo tempo, torna-se complexa a questão de como operar computadores. A noção de interação passa a ser alvo das atenções neste contexto, e parece ser o caminho para equalizar este aparente paradoxo.

${ }^{41}$ Tradução da autora. No original: "The catchword 'interactive media', to say nothing of 'interactive shopping' and 'interactive entertainment', was seldom used before the 1990s. Magazines with 'interactivity' in their title have begun to appear only very recently. It is, howeever, important to see thet the "cult of interactivity" has been in the making for a long time." 
A interatividade, desde então, tem merecido destaque em inúmeros trabalhos, tanto teóricos como práticos. Há um consenso, pelo menos nos primeiros, de que se trata de um conceito, no mínimo, nebuloso, uma noção problemática, de difícil significação (LÉVY, 2000; PRIMO, 2005b; SHEDROFF, 2005). Grande parte desses estudos situa a interação no contexto das diferentes teorias da informação e da comunicação, apontando propriedades e incongruências frente ao desenvolvimento de artefatos multimídias, de diferentes interfaces, e novos potenciais de transmissão e conexão. "A interatividade assinala muito mais um problema, a necessidade de um novo trabalho de observação e de avaliação dos modos de comunicação, do que uma característica simples e unívoca atribuível a um sistema específico" (LÉVY, 2000, p.82).

As principais indagações presentes nestes estudos dizem respeito às propriedades da interação, e à sua condição frente às estratégias tipo ação-reação, ou mesmo emissor-receptor. A passividade seria o contraponto à interatividade? Utilizar ocuparia uma posição eqüidistante oposta a interagir, numa escala de ações em ambientes informatizados? Pode-se pensar que o aprimoramento constante e a ampla difusão das interfaces midiáticas digitais faz com que certas características consideradas interativas hoje sejam amanhã atribuídas como ações passivas?

Interessa aqui mostrar alguns conceitos de interação, considerando, como se verá, interface e interação indissociáveis, partes integrantes de um elemento uno, impossíveis de existência em separado. Em estudos ligados à disciplina $\mathrm{HCl}$ - Human-Computer Interaction, procura-se identificar classificações de estilos, tipos, técnicas e modos de interação, como o fazem também com as interfaces. É relevante considerar que diferentes interfaces agregadas a diferentes estruturas de interação geram diferentes meios, numa rica e abundante combinação de possibilidades. Pensar na relação entre estes possíveis diferentes suportes de comunicação mediada e a qualidade das experiências dos interlocutores é um importante desafio, que de certa forma também impele este trabalho. 


\subsubsection{HCl - Human-Computer Interaction}

O Human-Computer Interaction (acrônimo $\mathrm{HCl})^{42}$ é um campo extenso do conhecimento centrado nos estudos da interação entre homem e computador. Trata-se de uma área multidisciplinar, que envolve disciplinas como Ciências da Computação, Engenharia de Software, Psicologia Cognitiva, Ergonomia, Lingüística, Ciências Sociais (Sociologia e Antropologia), Design, entre outras. Está voltada à implementação e avaliação de sistemas computacionais para uso humano e aos fenômenos de interação, ao design de interfaces, e a busca de explicações e previsões desses sistemas (PREECE; ROGERS; SHARP, 2005; DE SOUZA et al., 1999). "O objetivo da $\mathrm{HCl}$ é o de construir um mecanismo que permita ao usuário comunicar-se com a aplicação desejada. $\mathrm{HCl}$ é o conector entre uma aplicação e o usuário. A maioria das ferramentas utiliza $\mathrm{HCl}$, de uma forma ou de outra” (PRATSCHKE, 2002, p.12).

Os estudos de $\mathrm{HCl}$ nascem justamente nos anos 1970, a partir das inquietações dos profissionais de computação em relação à questão de como as pessoas não especialistas interagiriam com computadores e programas. A princípio, a disciplina esteve voltada de forma exclusiva ao projeto de sistemas para um usuário sentado em frente a um computador. A partir da tradição da ergonomia, buscavam-se aspectos empíricos mensuráveis da interação, destacando habilidades motoras e perceptivas, cujo parâmetro era a produtividade. Depois veio a noção do design centrado no usuário, ou seja, de sistemas que deveriam ir de encontro às necessidades dos usuários, o usuário e o sistema são identificados como os dois focos de interesses principais. Nos anos 1980 e 1990 os especialistas em $\mathrm{HCl}$ começam a olhar para múltiplos usuários, e os contextos em que operam (BOLTER; GROMALA, 2003; PREECE; ROGERS; SHARP, 2005).

${ }^{42}$ Em português Interação Humano-Computador (acrônimo IHC). Por ser comum o uso do acrônimo $\mathrm{HCl}$, mesmo em português, optou-se por usá-lo neste trabalho. 
Os estudos de $\mathrm{HCl}$ colocam em um mesmo patamar técnica, usuário, funcionalidade e design, e se voltam, principalmente, às necessidades de usabilidade, aplicabilidade e comunicabilidade. Pressupõem metodologias estruturadas, a partir de entrevistas, observações, testes, construção de modelos e simulações, processos de demonstrações, algumas vezes design participativo, além de sistematizações contínuas de avaliações e verificações. Para o $\mathrm{HCl}$, a interação “é um processo que engloba as ações do usuário sobre a interface de um sistema, e suas interpretações sobre as respostas reveladas por esta interface” (DE SOUZA et al., 1999). Sendo, para a mesma autora, o termo interface:

[...] aplicado normalmente àquilo que interliga dois sistemas. Tradicionalmente, considera-se que uma interface homem-máquina é a parte de um artefato que permite a um usuário controlar e avaliar o funcionamento deste artefato através de dispositivos sensíveis às suas ações e capazes de estimular sua percepção. No processo de interação usuário-sistema a interface é o combinado de software e hardware necessário para viabilizar e facilitar os processos de comunicação entre o usuário e a aplicação. [...] Vemos, pois, que a interface é tanto um meio para a interação usuáriosistema, quanto uma ferramenta que oferece os instrumentos para este processo comunicativo. Desta forma a interface é um sistema de comunicação (DE SOUZA et al., 1999).

A usabilidade, um dos principais parâmetros e instrumentos da $\mathrm{HCl}$, "é um conceito que se refere à qualidade da interação de sistemas com os usuários e depende de vários aspectos, entre ele, facilidade de aprendizado [...], facilidade de uso [...], satisfação do usuário [...], flexibilidade [...], e produtividade" (DE SOUZA et al., 1999).

Independentemente dos focos, pesos e interesses dado a uma ou outra disciplina, e do tipo de aplicação, o importante a destacar é que nas abordagens mais tradicionais de $\mathrm{HCl}$ a interação está associada a aspectos funcionais e técnicos, e o usuário é, de certa forma, pré-definido, através de métodos rigorosos que aferem sobre suas necessidades e características. Segundo Pratschke (2002) exige-se da $\mathrm{HCl}$ uma perfeita performance, uma capacidade de resposta cada vez mais veloz, uma 
margem de erro desprezível, interfaces cada vez mais transparentes ${ }^{43}$ e com crescente possibilidade de interatividade. Geralmente, mesmo envolvidas com disciplinas das Ciências Sociais, as abordagens de $\mathrm{HCl}$ viesam a consideração de parâmetros contextuais e humanísticos, incluindo as relações entre o ser humano e o computador, sob o peso do seu comprometimento com métodos pragmáticos. É importante notar que a interação em $\mathrm{HCl}$ diz respeito a ações e interpretações a partir de uma interface, que mesmo definida como um sistema de comunicação, é descrita como um combinado de software e hardware. Mais grave do que restringir tais definições é se apropriar delas como tal.

O momento atual revela-se extremamente propício à revisão das relações entre o ser humano e o computador, em função de novas necessidades e novos comportamentos expressos pela sociedade, mas também de novas potencialidades técnicas. A simples categorização em usuários iniciantes, intermediários e freqüentes, como é de praxe nas práticas de design de interfaces Usuário FinalComputador, é suficiente para impedir a livre reflexão sobre estas relações (PRATSCHKE, 2002, p.24).

É com o propósito de justamente expandir as reflexões sobre estas relações que se apresentam, a seguir, outros aportes discursivos a respeito da noção de interação.

\subsubsection{Interação, interatividade: outras reflexões}

Um pensamento primeiro, em relação à interatividade, é que ela seria uma gradação entre um mínimo que já está garantido na constituição mesmo das interfaces, e um crescente que significa, antes de tudo, um ganho em qualidade. 0 mínimo pode significar quase uma passividade, uma interação onde as

\footnotetext{
${ }^{43}$ Bolter e Gromala (2003), cujos estudos são apresentados adiante, destacam justamente que os estudos da $\mathrm{HCl}$ e usabilidade quase sempre assumem que transparência deveria ser a meta de todos os artefatos digitais, e caso isso não aconteça, aí residiria um erro.
} 
ações dos interagentes estariam somente configuradas no universo da necessidade operacional, a partir de normas e regras pré-estabelecidas. No outro extremo estariam ações de participação ativa e criativa. Ou seja, a tal qualidade seria o estabelecimento de espaços não só de operação e acesso, mas de engendrar informação, em vários níveis.

Shedroff (2005), atento a exemplos e experiências concretas ${ }^{44}$, dá forma a sua concepção de interação a partir de uma premissa bastante parecida com a citada acima. Entende que as modalidades passivo e interativo se encontram em um continuum. A interatividade de uma experiência se situa em um espectro que vai do passivo ao interativo, sem que se saiba exatamente a demarcação entre eles. Neste sentido, não seria possível dizer se determinadas experiências são ou não interativas, e sim, se são mais ou menos interativas. Segundo o autor, a interatividade compreende muitos atributos, entre eles: a capacidade de resposta e realimentação; o grau de controle das pessoas sobre suas experiências; as possibilidades de criatividade e produtividade, que servem para as pessoas repensarem suas experiências ou ajudá-las a revivê-las; e as práticas de comunicação e adaptabilidade (SHEDROFF, 2005).

Diferentemente de Shedroff, Lévy (2001) é categórico ao afirmar que um receptor de informação nunca é passivo. E da mesma forma que este, discorre sobre a possibilidade de se medir o grau de interatividade de uma mídia ou de um dispositivo de comunicação. Em eixos diferentes estariam dispostas as possibilidades de apropriação e de personalização da mensagem recebida; a reciprocidade da comunicação; a virtualidade, no sentido da possibilidade de cálculo computacional; a implicação da imagem dos participantes nas mensagens, e a telepresença.

Primo e Cassol (2005), imbuídos pelos estudos da comunicação e por uma perspectiva cognitiva, sugerem a interação como uma qualidade da relação que emerge da ação entre interagentes, definindo dois modelos de interação, a mútua e a reativa.

\footnotetext{
${ }^{44}$ Nathan Shedroff é um designer especializado em projetos de inovação relacionados à tecnologia de informação estando mais ligado ao campo prático do que acadêmico. Porém, sua produção teórica tem sido uma referência importante nesta área.
} 
A interação mútua se dá de forma negociada, que acontece entre agentes, de forma aberta, através de um processo de negociação, com ações interdependentes que geram interpretações, possuem fluxo dinâmico e cuja relação se dá através da construção negociada. A interação reativa dá-se em um sistema fechado, num processo de estímulo-resposta, com fluxo linear e determinado, relação causal e baseada no objetivismo (PRIMO apud RECUERO, 2001). ${ }^{45}$

Os dois conceitos de interação, mútua e reativa, podem ser discutidos a partir de diferentes dimensões não excludentes, variáveis e agregáveis entre si, tais como: o conjunto de objetos ou entidades que se inter-relacionam formando um todo, os acontecimentos que apresentam mudanças no tempo, a relação entre a ação e a transformação, o curso ou seqüência da relação, o que se passa entre a decodificação e a codificação, o encontro, a conexão, as trocas entre elementos ou sub-sistemas, e a interface, tomada como superfície de contato, agenciamento de articulação, interpretação e tradução (PRIMO; CASSOL, 2005).

Segundo Lemos,

podemos compreender a interatividade digital como um diálogo entre homens e máquinas (baseadas no princípio da micro-eletrônica), através de uma 'zona de contato' chamada de 'interfaces gráficas', em tempo real. A tecnologia digital, possibilita ao usuário interagir, não mais apenas com o objeto (a máquina ou a ferramenta), mas com a informação, isto é, com o 'conteúdo' (LEMOS, 1997).

Neste texto o autor concebe interatividade em três níveis não excludentes: técnico "analógicomecânico", técnico "eletrônico-digital” e "social” (ou simplesmente interação).

Para Huhtamo (2000, p.106), “idealmente, um sistema interativo é caracterizado por uma relação em tempo real entre o humano e o sistema, ou, como Andy Lippman do MIT Media Lab coloca, pela

45 PRIMO, A. (1998). Interação Mútua e Interação Reativa: Uma Proposta de Estudo. 404NotFound, n. 45. Disponível em: <http://www.psico.ufrgs.br/ aprimo/pb/intera.htm >. Acesso em: 31 dez. 2005. 
'atividade mutua e simultânea por parte de ambos os participantes, usualmente trabalhando através de alguma meta, mas não necessariamente’”. No exercício de mapear interatividade contemporânea, o autor traça alguns dos caminhos em que seus princípios tem sido formados, através de algumas manifestações do encontro homem-máquina: mecanização, automação, e cibernética, por exemplo. “Interatividade é parte de um desenvolvimento gradual do computador a partir de idéias que primeiro foram discutidas em conexão com automação - um fenômeno que a primeira vista pode parecer ser seu pólo oposto" (HUHTAMO, 2000). Entretanto, Huhtamo fala da importância em resistir a apresentar toda a história da relação homem-máquina direcionada à idéia presente de interação; segundo ele, uma ilusão criada pela observação posterior.

\subsubsection{Designde Interação}

0 Design de Interação ${ }^{46}$ emergiu do campo do $\mathrm{HCl}^{47}$. Trata-se de "uma disciplina voltada exclusivamente à interatividade entre uma experiência e sua audiência. [...] e está interessada em explorar a complexidade das experiências reais [sic] no sentido de criar novas interações que se comparem a estas em riqueza e complexidade, e não somente a traços”48 (SHEDROFF, 2005, p.134).

\footnotetext{
${ }^{46}$ Em inglês Interaction Design, também citado, às vezes, como user-based e user-oriented design.

47 Há entre o Design de Interação e a $\mathrm{HCl}$ muitos aspectos em comum, pode-se dizer que são modalidades centradas nos mesmos fundamentos. Às vezes torna-se difícil diferenciar estas duas abordagens. Para Preece, Rogers e Sharp (2005) o Design de Interação busca ampliar o escopo de $\mathrm{HCl}$, visando sua aplicação em contextos diversos. Pinheiro (2008) destaca que a "disseminação da computação favoreceu o amadurecimento de uma disciplina focada no design de mídias interativas, dentro da qual existem atualmente diversas especialidades relativas a diferentes etapas do projeto de sistemas computacionais". Ver PINHEIRO, M. Do design de interface ao design da experiência. Revista Design em Foco (Salvador), 2008. Artigo aceito para publicação.

48 Tradução da autora. No original: "Interaction design is a discipline that specifically focuses on the interactivity between an experience and its audience. [...] and are interested in exploring the complexity of real experiences in order to create new interactions that compare in richness and complexity, not merely in features."
} 
Para Preece, Rogers e Sharp (2005) trata-se do design de produtos interativos que dão suporte às atividades cotidianas das pessoas, com objetivo de criar experiências que melhoram e complementam a maneira como trabalham, se comunicam e interagem. O Design de Interação é uma abordagem de desenvolvimento centrada no usuário, suas principais características são, além do foco no usuário, trabalhar com critérios de usabilidade específicos e considerar a iteração. É baseado em uma metodologia, tal qual $\mathrm{HCl}$, que pressupõe identificar necessidades e estabelecer requisitos, trabalhar em sub-atividades que envolvem design conceitual e design físico, avaliações, entre outros (PREECE; ROGERS; SHARP, 2005). De acordo com essas autoras, no Design de Interação a interação de uma dada aplicação deve ser criada de forma flexível, ou híbrida, a partir de modelos conceituais baseados em atividades ou em objetos, de acordo com a natureza da atividade a receber suporte. Os primeiros estão voltados às atividades dos usuários ao interagirem, e podem ser modelos baseados em instrução, quando o usuário fornece instruções de diferentes maneiras e o sistema obedece a ordens, em conversação, quando o sistema assume papel de parceiro, em manipulação e navegação, quando utiliza-se do conhecimento dos usuários a respeito do mundo físico e da manipulação direta, e em exploração e pesquisa, quando baseado experiência com mídias existentes. Os segundos modelos conceituais, centrados em objetos, são baseados em analogias com o mundo físico, com a forma que um certo objeto é utilizado em um determinado contexto.

O Design de Interação, segundo Shedroff (2005), deve ser pautado nas pessoas servidas pela tecnologia, e não nela mesma. Dar aos usuários, ou participantes, como prefere o autor, um certo grau de controle sobre suas experiências, criatividade e produtividade na medida certa, possibilidades de personalização e expressão de si mesmos, ainda que finitas e controláveis, permitem satisfação e realização, além de abrirem portas para repensar ou ainda reviver experiências. Preece, Rogers e Sharp (2005) colocam o Design de Interação, por um lado, diretamente associado a metas de usabilidade computacional, e por outro, a metas decorrentes da experiência do usuário, ou seja, preocupado com a criação de sistemas que sejam também satisfatórios, agradáveis, divertidos, interessantes, úteis, motivadores, 
esteticamente apreciáveis, incentivadores de criatividade, compensadores e emocionalmente adequados.

Shedroff (2005) diz que a usabilidade tem sido usada erroneamente, do ponto de vista dos seus interesses, processos e resultados. 0 interesse por facilidade de uso de um produto ou experiência, uma qualidade positiva, tem cedido lugar a interesses por tabelas, orçamentos, e eventualmente aparência. Seu potencial como ponto de partida de inovações tem sucumbido a reforçar o status quo.

Ainda que dito de formas distintas, cada qual acentuando o tom de acordo com interesses específicos, os estudos de Shedroff e Preece, Rogers e Sharp apresentam o Design de Interação cercado por uma metodologia estruturada que busca investigar usuários e atividades, que está a procura de um objetivo específico, funcional e previsível. Parece claro que no âmbito do Design de Interação, e também do $\mathrm{HCl}$, é considerada a melhor interface aquela que responde às qualificações de serem claras e simples, assim como a melhor interação seria aquela pautada no uso eficiente e produtivo da aplicação, e quando possível, criativo.

\subsubsection{Designpara a Experiência}

Experiência parece ser o conceito na ordem do dia. Está presente no trabalho de muitos autores que examinam o design de e com tecnologia digital de um modo geral, assumindo conceituações e amplitudes muito variadas, também de acordo com os aportes teóricos explorados. Neste emaranhado de princípios, chama a atenção o Design para a Experiência, uma proposta de design que é caracterizada mais como uma prática que passou a ser recorrente nos últimos anos, investigada em grandes centros de pesquisa e que, justamente, parece não possuir modelos teóricos com contornos 
bem definidos se comparada a outras. As propostas vinculadas ao Design para a Experiência interessam aqui porque tratam a questão da interação como elemento essencial, tomada como exploração de novas formas de apropriação do objeto pelo indivíduo. Tais propostas objetivam a exploração de experiências a partir da apropriação dos artefatos em geral, incluindo os associados à tecnologia digital, e situam a interação como caminho principal para fomentar estas experiências.

[...] o design para a experiência propõe uma participação menos passiva e maior liberdade do indivíduo frente às possibilidades dadas pelo objeto. Nessa postura conceptiva, a relação com o objeto é pensada de forma a fomentar experiências no cotidiano. A interação surge como elemento essencial a ser explorado pelo projeto, trabalhando como catalisador nessas relações (NARDELLI, 2007, p.61).

Segundo os estudos realizados no Nomads.usp ${ }^{49}$, as abordagens de design que colocam a experiência como central têm suas raízes nos trabalhos do filósofo John Dewey, que estabelece uma base teórica abrangente e profunda acerca da experiência, considerando-a um processo com começo e fim, uma seqüência de eventos interconectados, que pode provocar sentimento de satisfação ou insatisfação, também do psicólogo Mihaly Csikszentmihalyi, que "formulou o conceito flow, entendo-o como uma forma de experiência completa, intensa e emocionalmente positiva" (NARDELLI, 2007, p.134), e dos economistas Joseph Pine e James H. Gilmore. ${ }^{50}$

O Design para a Experiência é abrangente, busca ampliar e enriquecer as experiências da vida cotidiana, considerando aspectos culturais e contextuais na relação indivíduo objeto, em oposição a focar-se na realização de roteiros pré-estabelecidos dentro de um espectro limitado de tarefas. Procura resgatar o cotidiano como espaço de reflexão e o caráter transformador da experiência. (MANZINI;

\footnotetext{
${ }^{49}$ Principalmente pelos pesquisadores Prof. Dr. Marcelo Tramontano, MSc. Nilton Nardelli e mestranda Cynthia Nojimoto.
}

${ }^{50}$ Em Experience Economy: Work Is Theatre \& Every Business a Stage, de 1989, os autores apresentam a economia como divida em quatro estágios de desenvolvimento: o agrário, o industrial, o de serviços e o de experiências. Esta última seria a economia do consumidor, que pressupõe que sucesso econômico esteja hoje relacionado a proporcionar experiências, ao favorecimento e desempenho de experiências (MANOVICH, 2007a). 
MERONI, 2005). “Certeau [1996] oferece uma possibilidade de leitura do design para a experiência que permite verificar um potencial transformador embutido nas práticas cotidianas de relação com o objeto, ainda que mantidas as relações tradicionais do design com o consumo e o mercado" (NARDELLI, 2007, p.84) ${ }^{51}$. Dentre os conceitos norteadores desta abordagem pode-se destacar a espontaneidade, imprevisibilidade, expressividade, a exploração do humor e ironia, e do o contexto formal do objeto para além da ótica estético-funcionalista. O Design para a Experiência busca promover a realização de experiências e não apenas circunscrevê-las em roteiros fechados, minuciosamente pré-estabelecidos e limitados. Trata-se de fornecer meios para que as experiências se realizem. 0 designer se responsabiliza pela criação do objeto e pelas possibilidades de interações especificamente potenciais do indivíduo sobre mesmo, visando propiciar a experiência, que abarca a interação efetiva do indivíduo e as respectivas relações simbólicas. Neste sentido, torna-se apropriado falar de design para a experiência e não de um design da experiência (MANZINI; MERONI, 2005).

\footnotetext{
${ }^{51}$ CERTEAU, M. (1996). A Invenção do Cotidiano: Artes de Fazer. Petrópolis: Vozes.
} 

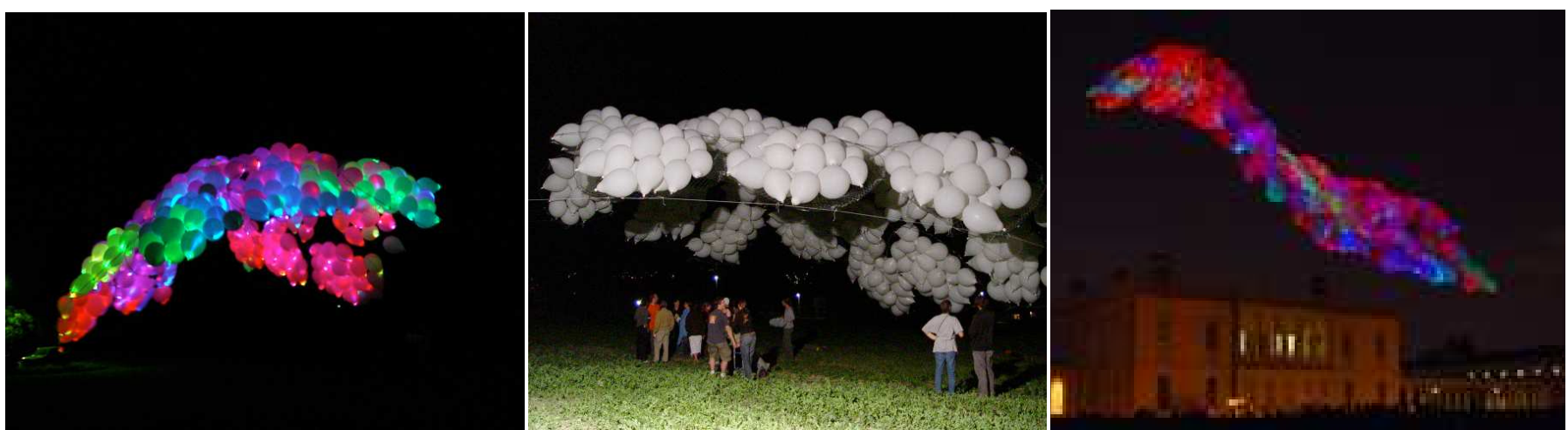

Fig.10-12 Sky Ear Fonte: SKY EAR (2004)

Sky Ear (Usman HAQUE; Fribourg e Londres, 2004)

Experimento de sistema interativo composto por uma nuvem de fibra de carbono flutuante, formada por balões de hélio, sensores eletromagnéticos e telefones celulares. A nuvem é um sistema sensor e agente, porque responde a ondas eletromagnéticas geradas por chamadas de telefones celulares, os inputs das pessoas, e também produz campos magnéticos. O objetivo desse experimento é investigar um tipo de interação construtiva e contínua, que segundo o autor, "depende da criatividade da pessoa e da máquina enquanto negociam por intermédio de uma interface, e é essa criatividade 'conversacional', [...], que torna essas interações as mais interessantes” (HAQUE, 2006, p.70). Há, neste trabalho, a premissa de levar os observadores à participação colaborativa.

Ainda que pareça razoável pensar que para as mídias digitais, que necessariamente envolvem programações, simulações e controle, este processo de design seja inadequado, isto não é verdade porque está se pensando aqui em sistemas mais amplos que abarcam instâncias não programadas, como os aspectos subjetivos, imprevisíveis, ligados ao sujeito, e mesmo ao contexto. O experimento Sky Ear, proposto por Usman Haque, parece apropriado para corroborar esta idéia.

Dessa forma, as mídias digitais participam da experiência projetada pelo designer, potencializando um conjunto de relações envolvendo instâncias da realidade, tanto originais e concretas, quanto simuladas e virtuais, propondo uma complementaridade a cerca das mesmas e, dessa maneira, promovendo uma valorização dos aspectos que dão forma à vida social e ao mundo em que vivemos. A utilização de mídias digitais surge como um instrumento importante no resgate de aspectos do âmbito social por meio do fomento de experiências (NARDELLI, 2007, p.94). 
Manovich também destaca o papel da experiência no design contemporâneo, e sua forte relação com a interação:

[...] utilizar dispositivos de informação pessoal é agora algo concebido como uma experiência orquestrada cuidadosamente, ao invés de um meio para um fim. A interação explicitamente chama a atenção para si. A interface engaja o usuário em uma espécie de jogo. 0 usuário é solicitado a empregar significativos recursos emocionais, perceptuais e cognitivos ao próprio ato de operar o dispositivo (MANOVICH, 2007a).

Este autor também destaca que o conceito de experiência da economia, formulado por Pine e Gilmore, funciona para explicar como a interação se tornou palco para proporcionar experiências sensoriais ricas e sedutoras (MANOVICH, 2007a).

Shedroff apresenta a sua abordagem de design como Experience design, a qual chama-se aqui design da experiência $^{52}$. Embora seus estudos também se vinculem às teorias de J. Dewey e dêem ênfase na criação de experiências atrativas, possui fortes vínculos com as abordagens mais tradicionais do design de interação e seus derivados ${ }^{53}$. Para o autor, "o design de experiências não é algo diferente da recognição de experiências"54 (SHEDROFF, 2005, p.2). Segundo o autor, trata-se de uma disciplina em formação, fruto da combinação de muitas outras, cuja definição ainda está em curso. Esta abordagem situa a experiência como fundação de todos os eventos da vida, sejam elas tradicionais, físicas, digitais. Segundo Shedroff, os elementos que contribuem para experiências superiores são

\footnotetext{
${ }^{52}$ Neste ponto convém perguntar: existe diferença entre design de interação e design da experiência? Parece não haver uma resposta fácil. Os termos são utilizados indistintamente com sentido semelhante por muitos profissionais do mercado. A diferença parece existir mais na concepção que alguns têm de seu trabalho, o que implica abraçar um ou outro termo, do que propriamente em características distintas (PINHEIRO, 2008). Parece haver consenso na noção de que design de interação está diretamente relacionado com mídias interativas, com os meios digitais. Quando se fala em design da experiência, no entanto, é possível ampliar o universo de atuação, não se limitando aos sistemas computacionais.

53 Shedroff aborda em seu texto, além de Experience design e Interaction design, Information Design, Interface Design e Sensorial Design.

${ }^{54}$ Tradução da autora. No original: "The design of experiences isn't any newer than the recognition of experiences."
} 
reconhecíveis e reproduzíveis, o que as fazem desenháveis, projetáveis. Para este autor, uma experiência digital pode ser bem estruturada e ao mesmo tempo privilegiar uma interação criativa com o usuário. A experiência pode ser decomposta em três diferentes momentos: atração, onde se lançam sinais para os sentidos, engajamento, sendo a própria experiência, precisa ser suficientemente diferente do ambiente circundante, e conclusão, que deve levar a resolução (SHEDROFF, 2005).

Segundo Pinheiro (2008), "no design da experiência leva-se em conta não só as características dos 'objetos' criados, mas as características dos usuários, o contexto de uso dos sistemas, as ações e reações possíveis, valorizando a experiência de uso e a interação ao longo do tempo." Pinheiro também atesta:

Se antes o trabalho dos designers se encerrava com a fabricação dos objetos que projetavam, quando o foco passa a ser o projeto de uma "experiência", planeja-se um processo cujos limites nem sempre são fáceis de perceber, o que implica dizer que nem sempre há um marco que delimite o fim do projeto, podendo este ser constantemente revisto, atualizado (PINHEIRO, 2008). ${ }^{55}$

Bolter e Gromala vinculam seus estudos aos de Shedroff. Para estes autores, no design de experiência "a interação entre designer e usuário através da tecnologia é que dá à experiência seu significado" 56 (BOLTER; GROMALA, 2003, p.25). Esta abordagem, segundo suas visões, possui relação com as primeiras formas de mídia, envolvendo múltiplas formas delas, é design corporificado e contextual, posto que entende importância contexto cultural e econômico em que funciona. Para os referidos autores, levando em conta estas dimensões, seria possível encontrar o ritmo apropriado entre atributos de transparência e reflexibilidade, como se verá a seguir. Aqui acentua-se a questão do potencial

\footnotetext{
${ }^{55}$ PINHEIRO, Mauro. Do design de interface ao design da experiência. Design em Foco, Salvador,, 2008. Artigo aceito para publicação.

56 Tradução da autora. No original: "The interaction between designer and user throught the technology is what gives the experience its meaning."
} 
transformador do design: "Qualquer artefato digital- uma ferramenta de produtividade, um web site, ou mesmo um jogo de computador- é predisposto a mudar alguma coisa na relação do usuário com seu ambiente físico e cultural"57 (BOLTER; GROMALA, 2003, p.140).

\subsubsection{Como pensar o díálogo?}

Apresentaram-se aqui posturas diferentes quanto à interação. De um lado situam-se as abordagens preocupadas com a otimização da interação a partir de parâmetros funcionais, mensuráveis e objetivos, ligadas a $\mathrm{HCl}$. De outro lado se coloca a interação a favor da experiência, portanto não utilitária, não relacionada à tarefa específica, que inclui princípios de imprecisão, indefinição, subjetividade. De um lado tem-se o controle, as regras, os roteiros específicos, um conjunto limitado de opções, e de outro, o não-programável, as predisposições, as tendências, o inusitado, o aberto; muito embora se saiba difícil que a interação se estabeleça em quaisquer desses termos absolutos, dado sua complexidade. Parece pertinente considerar que a interatividade deva ser concebida como portadora de atributos que possuem características dessas duas naturezas, que devem ser pensadas não como antagônicas, e sim em termos de equilíbrio, em função do fator que mais pesa, o humano.

Destaca-se também neste contexto a recorrência de pelo menos dois atributos importantes das interações: as trocas comunicacionais e a individualização dos interagentes. Ainda que intrincada às configurações da interface, portanto difícil de se medir e comparar, a qualidade da interação está também sujeita a outras variáveis, tais como a velocidade de conexão e processamento, e as habilidades cognitivas e físicas dos interagentes.

\footnotetext{
${ }^{57}$ Tradução da autora. No original: "Any digital artifact -a productivity tool, a Web site, or even a computer game -is meant to cgange something in the user's relationship to her physical and cultural environment."
} 
Como se verá, a interface pode ser assumida como uma instância técnica, cultural, signica e comunicacional, que permite, entre outros, que sinais eletrônicos tornem-se informação para os seres humanos. Uma instância ampla que possibilita a interatividade, ou seja, a movimentação, a ação, o diálogo através e com dados digitais. A interface é o set da interatividade. A interatividade seria uma espécie de diálogo específico e particular que se estabelece através e com as interfaces, e que possui um papel importante na construção das redes sociais online que possibilitam a estruturação de braços de comunidades locais no ciberespaço.

\subsection{Interfaces: conceitos}

Como destacado acima, a comunicação entre seres humanos através e com meios computacionais e digitais envolve dois importantes aspectos indissociáveis, interface e interação. A interatividade se processa na esfera da interface, e neste sentido, interfaces e interações são intrínsecas. De certo modo, gravitam em torno dos mesmos referenciais e reportam-se à mesma história.

\subsubsection{Para além das telas}

A complexidade e a amplitude do design de interface estão refletidas na multiplicidade de definições que o próprio termo interface assume. 0 emaranhado de concepções que gravitam em torno do tema reafirma que as interfaces do universo digital pertencem ao campo da interdisciplinaridade, e fazem 
parte dos interesses da engenharia de software, da análise de sistemas, do design de informações, da psicologia cognitiva, da sociologia, da antropologia e etnografia, do design, da arquitetura, entre outros. As interfaces despertam tamanho interesse pelo fato de serem os elementos chaves para que o mundo virtual associado às informações e comunicações digitais se represente, para que possa ser acionado seu caráter de atualização (Lévy, 2000). É natural que campos disciplinares distintos procurem demarcá-las a partir de seus referenciais, o que deriva um conjunto heterogêneo e bastante significativo de definições.

Neste sentido, procura-se aqui reunir um grupo limitado, contudo representativo, de conceituações de interface, ou relativo ao design de interface, que apresenta subsídios teóricos distintos. É importante que se diga, de antemão, que as diferentes conceituações não são excludentes, e, em alguns casos, são complementares umas às outras, contribuindo para a formação de uma idéia bastante abrangente a respeito de interface. Esta revisão é significativa porque inclui aportes advindos do campo artístico. Incomuns, as abordagens provenientes das teorias e discussões estéticas e formais estabelecem contrapontos, indicam possibilidades e limitações. Isto porque são intrínsecos à arena artística as experimentações e explorações, e o descompromisso utilitário. Os artistas estabelecem relações com as tecnologias de informação e comunicação no sentido de examinar suas significações, potencialidades, efeitos, e também para atestar sobre sua natureza e limites.

Opta-se aqui por lançar conceitos e definições, ora complementares, ora discordantes, esquivando-se de contextualizar em detalhes a história das interfaces humano computador, já bastante conhecida e difundida. ${ }^{58}$ Pode-se dizer, grosso modo, que o desenvolvimento dos computadores se dá a partir de

\footnotetext{
${ }^{58}$ Muitos trabalhos podem ser consultados a respeito. Johnson (2001) cita dois em particular: Tools for Thought de Howard Rheingold e Insanely Great de Steven Levy.
} 
meados dos anos $1940^{59}$. Contudo, o desenrolar das interfaces torna-se significativo nos anos 1960 e 1970, com o advento do microprocessador e do computador pessoal e das linguagens visuais para a informação, que originaram as primeiras interfaces gráficas. Tais interfaces começam a ser estruturadas, mais precisamente, a partir de 1968, quando Douglas Engelbart demonstrou a necessidade de criação de guias de informação, derivando a idéia do mapeamento de bits e a concepção do espaço-informação. ${ }^{60} \mathrm{Na}$ mesma época, outro passo importante da história das interfaces foi a introdução das metáforas, a partir das pesquisas da Xerox PARC [acrônimo de Palo Alto Research Center]. ${ }^{61} \mathrm{Na}$ década de 1980 popularizou-se o uso dos computadores com interfaces gráficas. As chamadas de Graphical User Interfaces - GUls "[...] transformaram para sempre as interações conversacionais entre usuários e computadores” (PRATSCHKE, 2002, p.21).

A interface esteve, a princípio, intimamente associada a artefatos específicos, como a tela, o teclado e o mouse, e também a uma determinada forma de representação na tela, a linguagem visual gráfica. Por esta razão, hoje ainda é comum a associação direta de interface seja com a própria tela de computador, seja com um determinado modo de representar informação, através de um design gráfico de telas, com ícones, janelas e menus. “A própria palavra interface evoca imagens de desenho animado de ícones coloridos e lixeiras que se mexem, bem como os inevitáveis clichês da acessibilidade ao usuário" (JOHNSON, 2001, p.18). Sem dúvidas, o conjunto destes elementos representou uma mudança radical na forma de representar a informação digital (DERTOUZOS, 1998). "Desde o surgimento das

\footnotetext{
${ }^{59}$ Os primeiros computadores possuíam uso altamente especializado. Não apresentavam monitores e teclados (consoles), toda interação ocorria através de painéis, leds e cartões perfurados, não existiam também linguagens de programação nem sistemas operacionais.

60 Engelbart, um dos pesquisadores mais importantes da história da informática, realizava pesquisas que concebiam os computadores como meios que poderiam auxiliar o ser humano na resolução de problemas. Acreditava que bons dispositivos de computação seriam providos por um conjunto de ferramentas (toolkit) correto. Foi o responsável pelo desenvolvimento do sistema de hipertexto NLS/Augment, como se viu, pelo projeto do primeiro mouse, e entre outros, idealizou um processador de textos. Na mesma década, Ivan Shuttherland, outro pesquisador importante, projetou um sistema para manipular imagens visuais em uma tela [SketchPad].

${ }^{61}$ Destaca-se, neste contexto, o pesquisador Alan Kay.
} 
janelas, nenhuma outra grande revolução nas interfaces gráficas aconteceu de maneira massiva" (VELASCO, 2006). Entretanto, desde então, paralelas ao aprimoramento específico de interfaces com tal configuração, outras possibilidades foram e estão sendo abertas no desenvolvimento de interfaces, seja em centros acadêmicos, através de laboratórios multidisciplinares de pesquisa em tecnologias digitais, seja no âmbito das organizações voltadas ao mercado e consumo, ou ao uso militar, e também em ambientes exclusivo de produção estética e artística. Neste contexto, o destaque é dado aos objetos e aportes conceituais advindos da arte digital ${ }^{62}$. Buscam-se diferentes possibilidades de se fazer transparecer, apresentar, representar e refletir o universo da informação e comunicação digital, como mostra, por exemplo, o trabalho Under Scan de Rafael Lozano-Hemmer. "Os artistas que trabalham na nova área aberta com as tecnologias interativas desenvolvem trabalhos de grande importância para a criação de novas interfaces que possibilitem um uso mais criativo da tecnologia digital [...]" (VELASCO, 2006).

\footnotetext{
${ }^{62}$ Arte digital, mídia arte, arte interativa, web arte, net art, workart, são, entre outros, os nomes que a arte que lida com o universo digital recebe hoje. Possuem, em comum, uma natureza voltada a exploração da questão da virtualidade, do ciberespaço, da interação.
} 

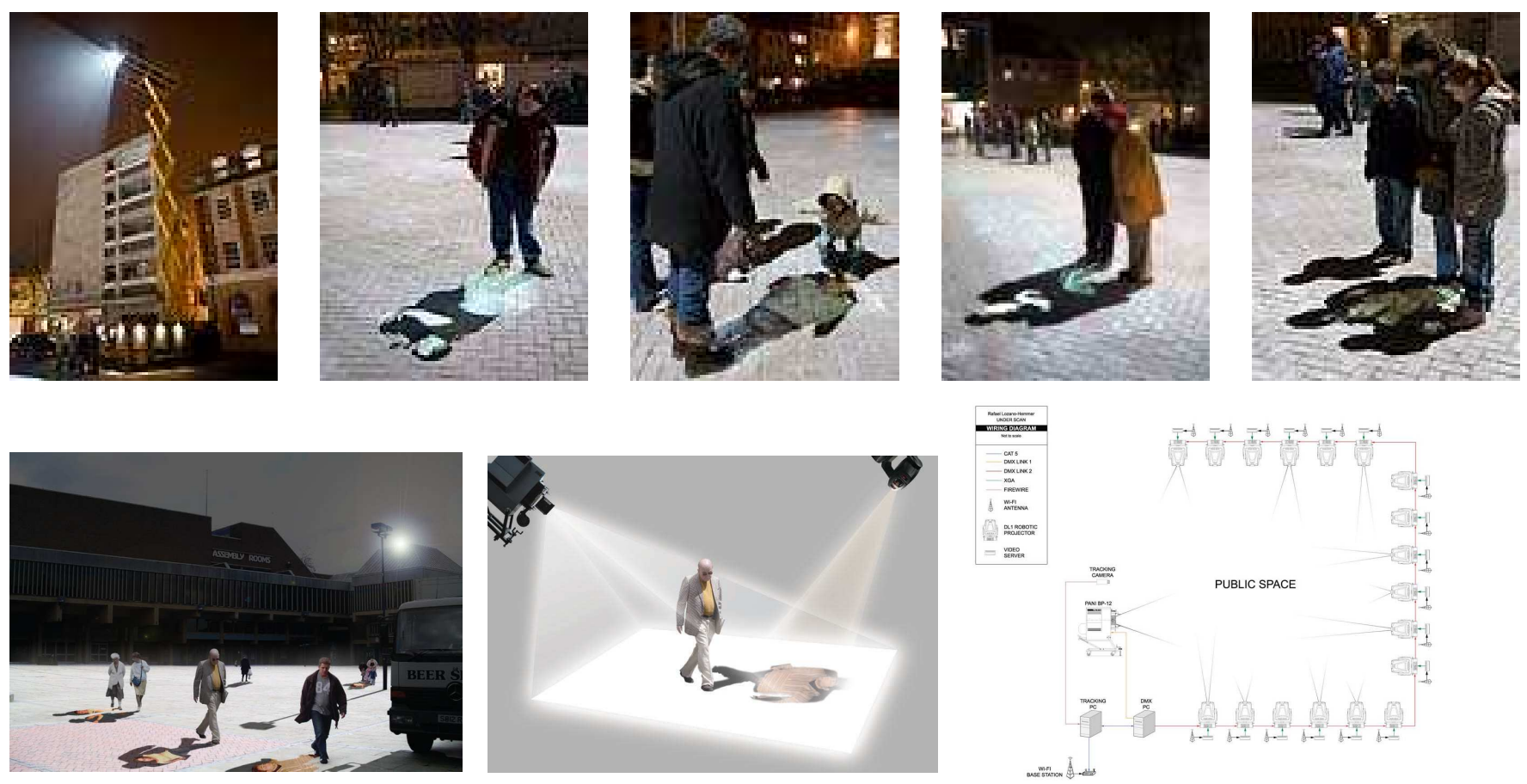

Fig.13-20 Under Scan Fonte: UNDER SCAN $(2005,2008)$

Under Scan. Arquitectura relacional 11. (Rafael LOZANO-HEMMER; East Midlands Development Agency, Inglaterra, Northampton, 3-12 fevereiro 2006).

Objeto de arte pública desenvolvido com tecnologias digitais. Trata-se de vídeo-retratos filmados na cidade e posteriormente projetados em ruas e praças. As imagens são reveladas a medida em que as sombras das pessoas as descobrem e passam a interagir com elas. O artista busca nesta série de trabalhos chamados "arquitetura relacional" re-conectar, de diferentes formas, a esfera pública frente ao que chama de crescente alienação da condição urbana. "As peças são normalmente intervenções efêmeras designadas para estabelecer relações arquitetônicas e sociais nas quais comportamentos imprevisíveis podem emergir"1 (LOZANO-HEMMER, 2002).

${ }^{1}$ Tradução da autora. No original: "The pieces are usually ephemeral interventions designed to establish architectural and social relationships where unpredicted behaviours may emerge." 


\subsubsection{Infra-estruturas técnicas}

Dertouzos (1998) apresenta a interface como um conjunto de equipamentos e técnicas, vinculando-o ao relacionamento entre pessoas e máquinas. “As interfaces são importantes, pois nos colocam em contato com as máquinas do Mercado de Informação, ou, numa abordagem mais filosófica, porque são o ponto de encontro entre o humanismo e a tecnologia" ${ }^{63}$ (DERTOUZOS, 1998, p.85). Ao lado das linhas fornecidas pelos transmissores mundiais de informações e dos instrumentos universalmente compartilhados (novos software), as interfaces seriam parte das três camadas que compõem uma infraestrutura de informação.

[...] a interface homem-máquina 'definitiva' é aquela capaz de reunir os tipos adequados de comunicação, o hardware e o software corretos - todos preparados para aceitar os conceitos do que deve ser a comunicação entre pessoas e máquinas. [...] 0 que realmente importa é que o ser humano estará tentando enviar ou absorver um conceito. E todos os equipamentos sensacionais têm a obrigação de ajudá-lo a fazer exatamente isso (DERTOUZOS, 1998, p.113).

Nesta perspectiva exclusivamente técnica, parece fazer sentido associar à interface atributos de eficiência. Segundo o autor, a interação entre humanos e máquinas seria tão mais eficaz à medida que mais se aproximaria da comunicação entre humanos (DERTOUZOS, 1998).

Lévy (2001), apesar de ampliar a noção de interface, como se verá a seguir, também apresenta uma conceituação de interface a partir da informática, que inclui até mesmo relações máquina-máquina:

Enquanto vocábulo especializado, a palavra 'interface' designa um dispositivo que garante a comunicação entre dois sistemas informáticos distintos ou um sistema informático e uma rede de

\footnotetext{
${ }^{63}$ Dertouzos (1998, p.31) apresenta nesta obra uma definição detalhada do que chama Mercado de Informação. Grosso modo, seria um modelo que abrange "todas as atividades que podemos esperar e imaginar no novo universo da informação".
} 
comunicação. Nesta acepção do termo, a interface efetua essencialmente operações de transcodificação e de administração dos fluxos de informação. (LÉVY, 2001, p.176).

Entretanto, o elemento de tradução tão caro ao autor, como se verá, já está presente ai.

\subsubsection{Perspectiva cuttural e simbolica}

Johnson diz que,

em seu sentido mais simples, a palavra [interface] se refere a softwares que dão forma à interação entre usuário e computador. A interface atua como uma espécie de tradutor, mediando entre duas partes, tornando uma sensível para a outra. Em outras palavras, a relação governada pela interface é uma relação semântica, caracterizada por significado e expressão [...] (JOHNSON, 2001, p.17).

As interfaces aparecem aqui como software, e assim, também como um aparato técnico. Porém, além do destaque da interação usuário computador como parte constituinte das interfaces, ganha força nesta definição o caráter de mediação e tradução. Para Johnson (2001, p.17) “[...] um computador deve também representar-se a si mesmo ao usuário, numa linguagem que este compreenda". As interfaces constituem-se como instâncias que dão sentido às informações que estão sob a forma de zeros e uns aos usuários, ou seja, representam a informação para os usuários, além de ajudarem na sua organização, filtragem e classificação. São elementos de comunicação com uma determinada finalidade. E nesse sentido, uma das questões centrais que as envolvem diz respeito à tradução de toda informação digital [composta de bits e bytes] em uma linguagem que seja compreensível ao usuário.

A interface é a mediadora entre o que se vê e/ou manipula e a ação efetiva realizada pelo computador. Remete a um encadeamento comunicacional, de associações e conexões, que, na maioria das vezes, é 
desconhecido e invisível, e que se dá nos suportes micro-eletrônicos. Tudo parece simples, enquanto a apreensão perceptiva do universo digital se revela através do design de interface. Este fato por si corrobora a importância das interfaces como um espaço fecundo de significação, inclusive social e política, que vai além de um programa de necessidades e de requisitos de usabilidade, como muitas vezes faz acreditar a disciplina $\mathrm{HCl}$. Johnson dá destaque também à relevância cultural e simbólica do design de interface. "A ágora do século XX pode perfeitamente se deslocar para o ciberespaço, mas não irá muito longe sem arquitetos de interfaces que desenhem os projetos” (JOHNSON, 2001, p.20). Através deste paralelo com a arquitetura, revela que ao espaço, seja físico ou virtual, estão associadas questões mais amplas como um conjunto de valores, pressupostos a cerca da sociedade, visões de mundo.

A descoberta do espaço-informação pode engendrar uma transformação social tão ampla e variada como a que acompanhou a maravilhosa revolução de Alberti. E é por isso que é tão essencial reconhecermos a riqueza e a complexidade do meio, seu âmbito de expressão e significação cultural. [...] 0 espaço-informação é a grande realização simbólica do nosso tempo (JOHNSON, 2001, p.156).

Como se disse, Lévy, em algumas circunstâncias, define interface tendo como parâmetro o campo dos instrumentos digitais e os diferentes modos de comunicação da informação. "Usamos aqui o termo 'interfaces' para todos os aparatos materiais que permitem a interação entre o universo da informação digital e o mundo ordinário" (LÉVY, 2000, p.37). Em outra obra sentencia: “Uma interface homem/máquina designa o conjunto de programas e aparelhos materiais que permitem a comunicação entre um sistema informático e seus usuários humanos” (LÉVY, 2001, p.176). Entretanto, este autor apresenta também uma conceituação mais ampla, associando interface a operações de contato, tradução, passagem, transformação:

A noção de interface pode estender-se ainda para além do domínio dos artefatos. Esta é, por sinal, sua vocação, já que interface é uma superfície de contato, de tradução, de articulação, 
entre dois espaços, duas espécies, duas ordens de realidades diferentes: de um código para outro, do analógico para o digital, do mecânico para o humano...Tudo aquilo que é tradução, transformação, passagem, é da ordem da interface (LÉVY, 2001, p.181).

\subsubsection{As ideias que chegam com os téricos da arte digital}

Interessados nas implicações culturais da revolução digital, Bolter e Gromala (2003, p.87) ${ }^{64}$ assinalam que "o computador não é um espaço neutro de informação: ele molda a informação que carrega e por sua vez é moldado pelos mundos físicos e culturais em que funciona"65. Entendem que a arte digital pode ser vista como uma forma de design de interface, e demarcam as vantagens em conceber interface a partir deste fazer artístico:

A parte mais visível, e de certa forma a mais importante, de qualquer dispositivo digital é sua interface - a face que o dispositivo apresenta para seus usuários. E a arte digital é toda interface, definida plenamente pela experiência de sua observação ou uso. É por isso que a arte digital pode proporcionar como que um exame claro das possibilidades e restrições do design digital: ela falha ou tem sucesso inequivocamente pelo poder de sua interface ${ }^{66}$ (BOLTER; GROMALA, 2003, p.11).

\footnotetext{
${ }^{64}$ Neste livro os autores examinam diversos aspectos relacionados ao design de interfaces a partir dos trabalhos de arte digital presentes no Art Gallery do International Conference on Computer Graphics and Interactive Techniques de 2000.

65 Tradução da autora. No original "The computer is not a neutral information space: it shapes the information it conveys and is shaped in turn by the physical and cultural worlds in which it functions."

${ }^{66}$ Tradução da autora. No original "The most visible, and in some ways the most important, part of any digital application is its interface - the face that the application presents to its users. And digital art is all interface, defined entirely by the experience of its viewing ou use. That is why digital art can provide such a clear test of the possibilities and constraints of digital design: it fails or succeeds unequivocally on the strenght of its interface."
} 
Ao relacionar a arte digital e o design de interface, os autores postulam uma forma mais pura de design experimental, e neste sentido, a relação entre arte digital e inovação pode se estender à prática do design de interfaces. Bolter e Gromala apresentam uma a idéia importante à cerca da visibilidade da interface, a partir de uma crítica à maneira como algumas disciplinas mais técnicas e alguns especialistas em usabilidade supõem e acreditam ser a melhor interface: sempre clara, simples, natural $^{67}$ e invisível ${ }^{68}$, no sentido de favorecer de maneira eficaz a comunicação no universo de informações digitais. São categóricos ao afirmar que o design digital não deveria tentar ser invisível, e que os artefatos digitais necessitam ser janelas e espelhos. ${ }^{69}$ As interfaces, segundo Bolter e Gromala, são janelas quando se esquece delas, quando se tornam transparentes, quando se olha através delas para o mundo de informação, e são espelhos quando se olha para elas, para a realização de sua função, quando reflete o interagente, seu contexto, e a sua relação com o computador. Nesta perspectiva, boas interfaces seriam aquelas que combinam, que harmonizam estas duas estratégias. "As interfaces deveriam oscilar de maneira controlada entre transparência e reflexibilidade"70 (BOLTER; GROMALA, 2003, p.68).

Lev Manovich (2002), em seu The Language of New Media, usa o termo cultural interface para descrever as maneiras em que os computadores apresentam dados culturais e permitem interagir com eles. Por interação entende a gramática de ações significativas que o usuário pode realizar. Segundo o

\footnotetext{
${ }^{67}$ Associada à natural interface, que, grosso modo, permite a interação pelo movimento e com manipulação direta.

68 Invisível aqui no sentido de não chamar atenção para si, de se fazer imperceptível.

69 Bolter e Gromala referenciam a idéia de computador invisível a partir das concepções de Donald Norman, bastante conhecidas, apresentadas em The Invisible Computer. Norman (1999) apresenta um novo paradigma de design através de um método que chama information appliances. Centrado no usuário, trata-se de uma tecnologia humana de aplicações onde a tecnologia do computador desaparece. Ou seja, deve ser invisível, escondida da visão, permitindo que a concentração se volte exclusivamente às atividades humanas, alheias a situações de complexidade e frustração. Nesses processos de design, primeiro viriam as necessidades humanas, depois a tecnologia, gerando produtos que primam pela simplicidade, versatilidade $e$ prazer. Algumas teorias em torno da computação ubíqua, apresentada abaixo, também compartilham, de certa forma, a idéia de tornar os computadores imperceptíveis.

${ }^{70}$ Tradução da autora. No original "Interfaces should oscillate in a controlled way between transparency and reflectivity."
} 
autor, numa perspectiva semiótica, a interface computacional atua como um código que carrega mensagens culturais, e como tal não é neutro, agrega em si modelos de mundo, sistemas lógicos ou ideologias. Assim, está-se sempre impondo uma determinada lógica ao organizar os dados num computador de determinada forma, posto que há inúmeras maneiras em que estes dados poderiam ser apresentados.

[...] a interface provê modelos distintos de mundo. Por exemplo, um sistema de hierarquia de arquivos assume que o mundo pode ser organizado em uma hierarquia lógica de múltiplos níveis. Em contraste, o modelo de hipertexto da World Wide Web organiza o mundo como um sistema não hierárquico regulamentado pela metonímia ${ }^{71}$ (MANOVICH, 2002, p.65).

Manovich (2002) diz que toda linguagem apresenta uma gramática de ações que estrutura, no espaço e no tempo, a experiência humana de acesso à informação. Para o autor, a linguagem das interfaces culturais é composta de elementos de outras linguagens, de formas culturais já familiares, e neste sentido haveria continuidades entre as interfaces computacionais e velhas formas culturais, linguagens e convenções. 0 cinema, a palavra impressa e os princípios da interface humano-computador ${ }^{72}$ moldam interfaces culturais, que têm a tela como elemento central. "A linguagem das interfaces culturais são um híbrido. É uma singular, muitas vezes inadequada mistura entre as convenções das formas culturais tradicionais e convenções de $\mathrm{HCl}$ - entre um ambiente imersivo e um lugar de controles, entre estandardização e originalidade"73 (MANOVICH, 2002, p.91).

\footnotetext{
${ }^{71}$ Tradução da autora. No original "[...], the interface provides distinct models of the world. For instance, a hierachial fise system assumes that the world can be organized in a logical multilevel hierarchy. In contrast, a hypertext model of the World Wide Web arranges the world as a nonhierarchical system ruled by metonymy."

72 Manovich (2002) utiliza o termo $\mathrm{HCl}$ como acrônimo de human-computer interface, que reuniria dispositivos físicos de entrada e saída, metáforas de organização de dados de computador, e modos de manipular dados. Neste trabalho, porém, utiliza-se HCl como acrônimo de human-computer interaction.

${ }^{73} \mathrm{O}$ ambiente imersivo a que se refere aqui está relacionado ao cinema. Tradução da autora. No original: "The language of cultural interfaces is a hybrid. It is a strange, often awkward mix between the conventions of traditional cultural forms and the conventions of $\mathrm{HCl}$ - betweens an immersive environment and a set of controls, between stardardization and originality."
} 
Num estudo voltado à tendência que chama "estética das ferramentas da informação", Manovich (2007a) diz que um dispositivo típico de informação e comunicação digital tem dois tipos de interface, uma física e uma interface da mídia. Estes dois tipos de interface estariam sujeitos a um novo paradigma de interação. Este paradigma situa a interação como um evento estético ou uma experiência estética e significativa ${ }^{74}$. Deixa para trás, no design de interface, a ênfase na eficiência e funcionalidade, na usabilidade, e todo o pensamento de que a interface deveria ser invisível. Essas novas referências e critérios partem do pressuposto de que a interação é um evento em si, uma experiência estética explícita. A estetização das ferramentas de informação e comunicação digitais está associada não só à beleza, mas ao apelo e ao estímulo dos sentidos, a uma interface sensual e distraída, uma interface experiência.

Como qualquer outra interação, a interação com dispositivos informacionais se tornou uma 'experiência de design'. [...] Dado que o processo de 'estetização' de ferramentas da informação começou a menos de uma década atrás, estou certo de que o que temos visto até o momento são apenas tímidos passos iniciais. Mais efeitos selvagens e experiências que nem podemos imaginar hoje nos aguardam no futuro (MANOVICH, 2007a).

Apresentam-se aqui duas abordagens de Manovich. Uma primeira que situa as interfaces das mídias digitais como linguagem, que carregam em si componentes culturais, e se alinha, de certa forma, ao pensamento de Johnson. E uma outra mais voltada a entender as atuais configurações dessas interfaces e seus correspondentes paradigmas de interação a partir do design, aproximando-se, neste sentido, das idéias aqui expostas de Bolter e Gromala.

\footnotetext{
${ }^{74}$ Manovich faz um paralelo entre as experiências agora valorizadas no design de interfaces e na economia, a partir da obra de Pine e Gilmore Experience Economy: Work Is Theatre \& Every Business a Stage, já citada.
} 


\subsubsection{Ideia em aberto}

As interfaces das mídias digitais são peças fundamentais na configuração do mundo atual. É claro que a importância que assumem está além da simples necessidade de estabelecer o diálogo e a relação homem-computador. Mas talvez justamente por conta disso, seu universo de significação seja tão amplo. Embora os autores apresentados ampliem suas noções de interface, atribuam a ela diferentes sentidos, suas caracterizações e análises se voltam constantemente aos aparatos técnicos do universo digital, seja os tradicionais hardware e software ou outros. Atestando, desta forma, que é só a partir de uma determinada materialidade, de um elo com o mundo físico, que se consegue pensar interface. Johnson (2001) centra a maior parte de suas análises nos componentes das interfaces gráficas de tela, a partir dos programas. Lévy (2000) apresenta a interface também como parte da infra-estrutura técnica do universo virtual digital ao lado dos programas, destacando a diversidade de máquinas e aparelhos de entrada no ciberespaço. Manovich (2007a), tomando o telefone celular como exemplo, fala da estética e da interação física a partir dos objetos tecnológicos, e neste sentido, destaca capas, telas, teclados, botões. Bolter e Gromala desenvolvem seus argumentos a partir de obras da arte mídia como, por exemplo, a obra Text Rain de Camille Utterback e Romy Achituv, que se constrói a partir de telas, programas e projetores. 

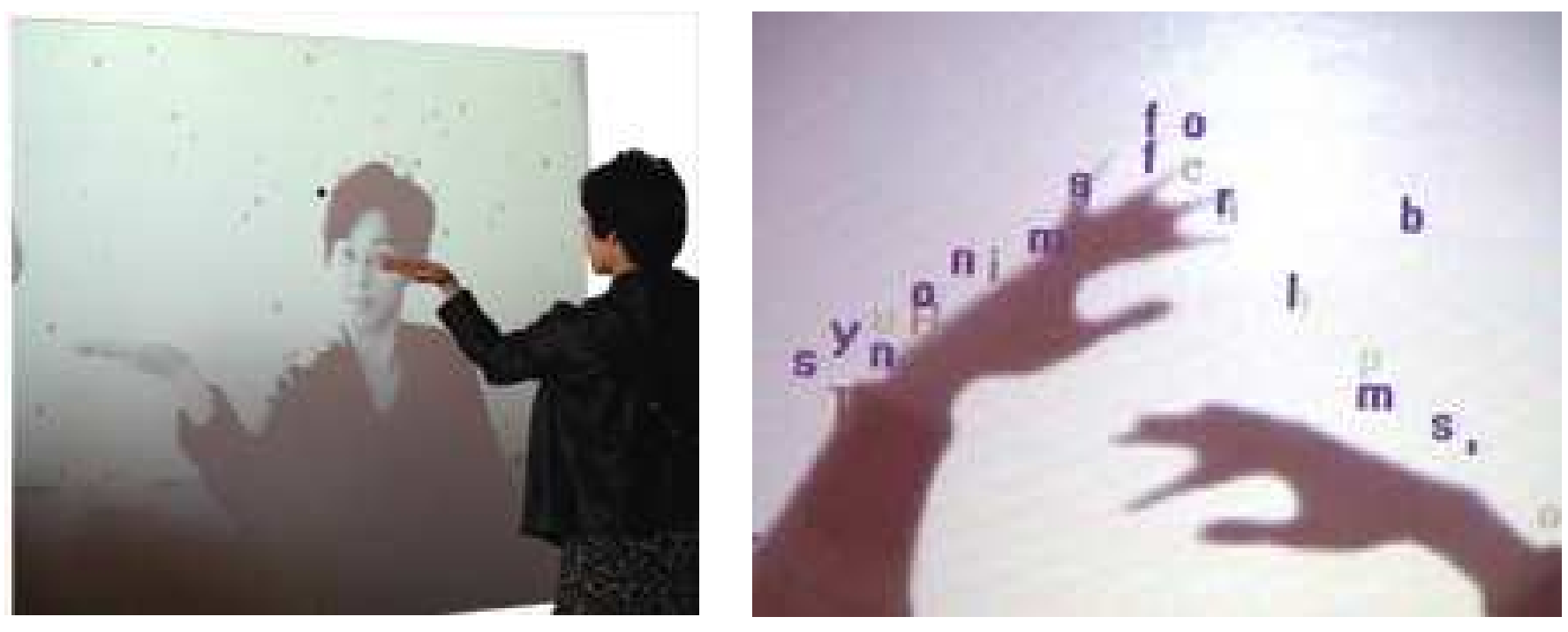

Fig. 21-22 Text Rain Fonte:TEXT RAIN (2008)

Text Rain (Camille UTTERBACK e Romy ACHITUV, New York University , 1999).

Trata-se de uma instalação interativa em que a imagem do ambiente em que os participantes estão é capturada e reproduzida em tempo real em uma grande tela de projeção. Nesta projeção há uma animação na forma de chuva de letras coloridas, e os participantes, que aparecem em preto e branco, podem usar seu corpo ou qualquer outro instrumento para interagir com as letras que caem. As letras respondem às ações dos participantes. Elas são linhas de um poema sobre corpos e linguagem. Segundo Utterback, ler as frases na instalação requer um esforço tanto físico quanto mental (BOLTER; GROMALA, 2003; TEXT RAIN, 2008).

O conceito de interface é de natureza multidisciplinar. Assume diferentes contornos dependendo da área que se considere, do peso que se deposita em um determinado foco. A construção de uma visão fechada, uma definição una, não se aplica aqui. Trata-se de um conceito em aberto, que se molda a partir de diferentes perspectivas. Para este trabalho, este entendimento múltiplo parece ser conveniente, seu escopo leva a considerá-la a partir da materialidade, e também de um ponto de vista de superfície de contato, de ambiente de comunicação, de objeto simbólico, de suporte de linguagens.

Parece óbvio que não se possa fugir a certa materialidade, mas não tão óbvio assim aonde as interfaces, indo além das telas, estruturando-se como elementos simbólicos e culturais, como 
linguagem, como superfícies de tradução, transformação, passagem, como janelas e espelhos, podem chegar. Para Otto Rössler, cientista estudioso de interfaces, criador de uma área de pesquisa chamada Endophysics, onde a interface entre a mente humana e o mundo representa papel central, surpreende ao dizer:

A noção "interface" é uma das mais difíceis noções de se entender da história. Por exemplo, o Agora é pura interface. 0 mundo é pura interface. Somente consciência é mais (substância pura). Mas dentro dos seus limites sombrios, não temos nada além de interface. A matéria é quase igualmente difícil de entender, sendo -como um exo ${ }^{75}$ - um esforço de entender o mundo - quase absurdo. Mas dentro do precário "universo" material, de novo nada além de uma interface espera $^{76}$ (RÖSSLER, 2001).

\subsection{Ambientes interativos digitais: instantâneos}

Como se viu, a interatividade se dá nos espaços concebidos das, nas e para as interfaces. Interface e interação são intrínsecas; geram, a partir das possibilidades combinatórias e permutações de suas variantes, inúmeros arranjos bastante distintos. A seguir apresenta-se uma categorização de diferentes interfaces e os principais modelos de interação associados a elas. É importante dizer que esta disposição favorece os interesses específicos deste trabalho, que envolve aportes multidisciplinares, e não necessariamente se alinha ao rigor das taxionomias desenvolvidas em áreas disciplinares específicas

\footnotetext{
${ }^{75} \mathrm{Na}$ teoria de Röessler exo é caracterizado pela objetivação, e exteriorização.

76 Tradução da autora. No original "The notion interface' is one of the most difficult to understand notions of history. For example, the Now is pure interface. The world is pure interface. Only consciousness is more (pure substance). But within its shadowy [sombrio] recesses, we have nothing but interface. Matter is about equally hard to understand, being - as an exoattempt to understand the world- almost ridiculous. But within that material "universe", again nothing but an interface waits."
} 
ligadas às ciências computacionais. Nestes últimos 25 anos, uma infinidade de estudos sobre interfaces vem sendo desenvolvidos, em centros de pesquisas mundo afora. Uma classificação de categorias, que demarcaria os parâmetros conceituais deste conjunto heterogêneo parece ser uma tarefa hercúlea, principalmente porque as interfaces podem ser isto e aquilo, estarem situadas num entre avesso a determinações em absoluto, como se viu. A preocupação aqui é examinar algumas possibilidades de interfaces que sejam apropriadas como elementos midiáticos de uma determinada comunidade ancorada em um fragmento urbano. Esta é a escala, o parâmetro. ${ }^{77}$ Suas configurações são importantes à medida que revelam capacidades e potencialidades em explorar, em conjunto ou isoladamente, a interação de um com um, de um com muitos, de muitos com um e de muitos com muitos, as possibilidades e facilidades diversas de expressão e representação, de visibilidade permanentemente atualizada, as características de não-linearidade ou hipertextualidade, o auxílio a processos de aquisição de autonomia e capacidade cognitiva, de colaboração, entre outros.

Apresenta-se primeiro um conjunto de interfaces ligadas ao modelo WIMP (acrônimo inglês de Windows Icons Menus and Pointer ${ }^{78}$, em português janelas, ícones, menus e apontadores) apoiado em tecnologias de interfaces gráficas GUI (Graphical User Interface, Interface Gráfica do Usuário) e em ferramentas específicas, que geralmente ainda são associadas às telas e, mais, aos computadores de mesa e laptops. Depois a atenção se volta às interfaces relacionadas a outros contornos, que estão agrupadas, em alguns casos, em torno de idéias semelhantes e complementares. Trata-se de modelos que exploram o emprego da computação para além das telas dos computadores pessoais. Interessa mostrar aqui não os aportes técnicos, e sim as possibilidades das TIC se alojarem em dispositivos, aparatos, e

\footnotetext{
${ }^{77}$ Não interessa aqui os sistemas interativos que envolvem exclusivamente máquina e homem, e, máquina e máquina, sem interlocução com outras pessoas, como àqueles de realidade ou inteligência artificial.

${ }^{78}$ Ou Windows Icons Mouse and Pull-down menus.
} 
objetos que possam estar integrados aos espaços das comunidades locais, à sua vida cotidiana, ampliando esferas de comunicação e interação coletiva. ${ }^{79}$

\subsubsection{Telas: padrões Gil / WIMP}

Busca-se apresentar aqui algumas qualidades distintivas das ferramentas mais utilizadas e conhecidas de comunicação mediada na internet, através das interfaces gráficas do usuário, conhecidas também como interfaces de tela, por terem as camadas de apresentação de software dispostas neste formato. Uma descrição mais específica sobre cada uma delas está disposta no Anexo $B$ desta tese. É pertinente dizer, grosso modo, que estas ferramentas podem ser implementadas em dispositivos tradicionais como os computadores pessoais de mesa e televisores digitais, mas também em dispositivos portáteis, móveis, como notebooks e laptops, telefones celulares convencionais ou smartphones, PDAs, entre outros. Cada um destes dispositivos apresenta um caráter próprio, que associado a uma ferramenta, ou a uma combinação delas, deriva uma forma diferente de mediação, o que vale dizer que a cada arranjo de ferramentas e dispositivos cria-se uma interface diferente. Os limites são imprecisos e tênues. Como bem destaca Lévy:

Não é possivel deduzir nenhum efeito social ou cultural da informatização baseando-se em uma definição pretensamente estável dos autômatas digitais. Basta que seja conectada uma nova interface (a tela catódica, o mouse, uma nova linguagem de programação, uma redução de tamanho) à rede de interfaces que constitui o computador no instante $t$, e no instante $\mathrm{t}+1$ se terá obtido um outro coletivo, uma outra sociedade de microdispositivos, que entrará em novos arranjos sócio-técnicos, mediatizará outras relações, etc. (LÉVY, 2001, p.177).

79 Há que se destacar que, por hora, determinadas interfaces das tecnologias digitais, como os sistemas de segurança, vigilância e controle, desempenham, nesta escala da cidade, os papéis mais importantes. 
A World Wide Web e o correio eletrônico são as ferramentas mais conhecidas de comunicação na rede. As listas de discussão via correio eletrônico e os fóruns de discussão, embora tenham surgido junto com a internet, e sejam anteriores à web, são ainda também bastante utilizados, mantendo suas roupagens bem parecidas durante estes anos. Os chats, diferentemente, parecem ter se alterado de acordo com o desenvolvimento da rede, mudando de formato à medida que se agregam tanto recursos lógicos mais sofisticados como diferentes usos, sofrendo o impacto das demandas impostas por usuários mais exigentes e integrados ao meio. Mais recentes, os blogs e comunicadores instantâneos já estão incorporados à cultura comunicacional da internet, e como se verá, trouxeram incorporados a si importantes recursos. Os SMS (Short Message Service), próprios aos dispositivos móveis, apresentam alguns aspectos relevantes distintos, para além de ser uma alternativa, e produto, de baixo custo para o uso da rede de telefonia móvel. Já a videoconferência e a voz sobre protocolo internet, parecem ainda restritos a universos e grupos específicos.

Não demorou muito para que as caixas de textos dos chats convencionais dessem lugar aos ambientes gráficos em duas e três dimensões, com recursos multimídia que permitem uma outra percepção da interação em tempo real. Hoje, na maioria dos chats, são ambientes em grande parte figurativos, ou seja, baseados em metáforas e simulações do espaço físico, em que um grupo de pessoas, por meio de avatares, interagem e estabelecem conversas coletivas simultâneas. Às trocas baseadas na linguagem verbal escrita podem adicionar-se alguns recursos gráficos e sonoros. Estes chats são comumente chamados ambientes virtuais, dos quais também fazem parte os jogos tipo MUDs e MMOs. ${ }^{80}$ Estruturado a partir de plataformas GMUK (Graphic Multiple User Conversation), o The Palace foi o primeiro chat 2D, criado em 1995 por Mark Jeffries. Hoje o mais conhecido é o 3D Second Life, que tem tido um crescimento expressivo em termos de usuários no âmbito de diferentes países ao redor do planeta, e se

${ }^{80}$ Trata-se de jogos online que permitem a comunicação síncrona em diferentes ambientes e reúnem em torno de si uma rede de jogadores, chamadas também comunidades virtuais de jogadores. MUD significa Multi-User Domain, e é uma versão online de um jogo eletrônico dos anos 1970 chamado Dungeons ou Dragons, por isso MUD também pode ser acrônimo de Multi-User Dungeons ou Multi-User Dragons. MMO significa Massive Multiplayers On Line, um tipo de MUD com características reconfiguráveis e colaborativas, e abrange o MMORPG, Massive Multiplayer Online Role Playing Games. 
constitui, cada vez mais, como objeto de estudo de pesquisadores de diferentes áreas disciplinares. Interessam-se pelo Second Life, por exemplo, estudiosos que se voltam às questões das interações sociais em instâncias online e também às possibilidades de etnografias nesses ambientes, e ainda pesquisadores que se interessam pelo design de interfaces, especialmente, pelas representações de espaços, pessoas e redes sociais nos chamados mundos virtuais. Os estudos The Projects e Information Spaces / Avatars se incluem neste último grupo.

Em paralelo a interação simultânea, algumas chats possibilitam conversas reservadas, sem o caráter público e grupal. Uma característica marcante nesses ambientes é que os interagentes geralmente são pessoas desconhecidas entre si. Isto fez do chat um espaço inseguro e sujeito a intencionalidades duvidosas, principalmente frente a aplicativos que possuem funcionalidades mais apropriadas à promoção de relacionamentos e interações interpessoais, como àquelas que exigem alguma forma de identificação (SPYER, 2007). 

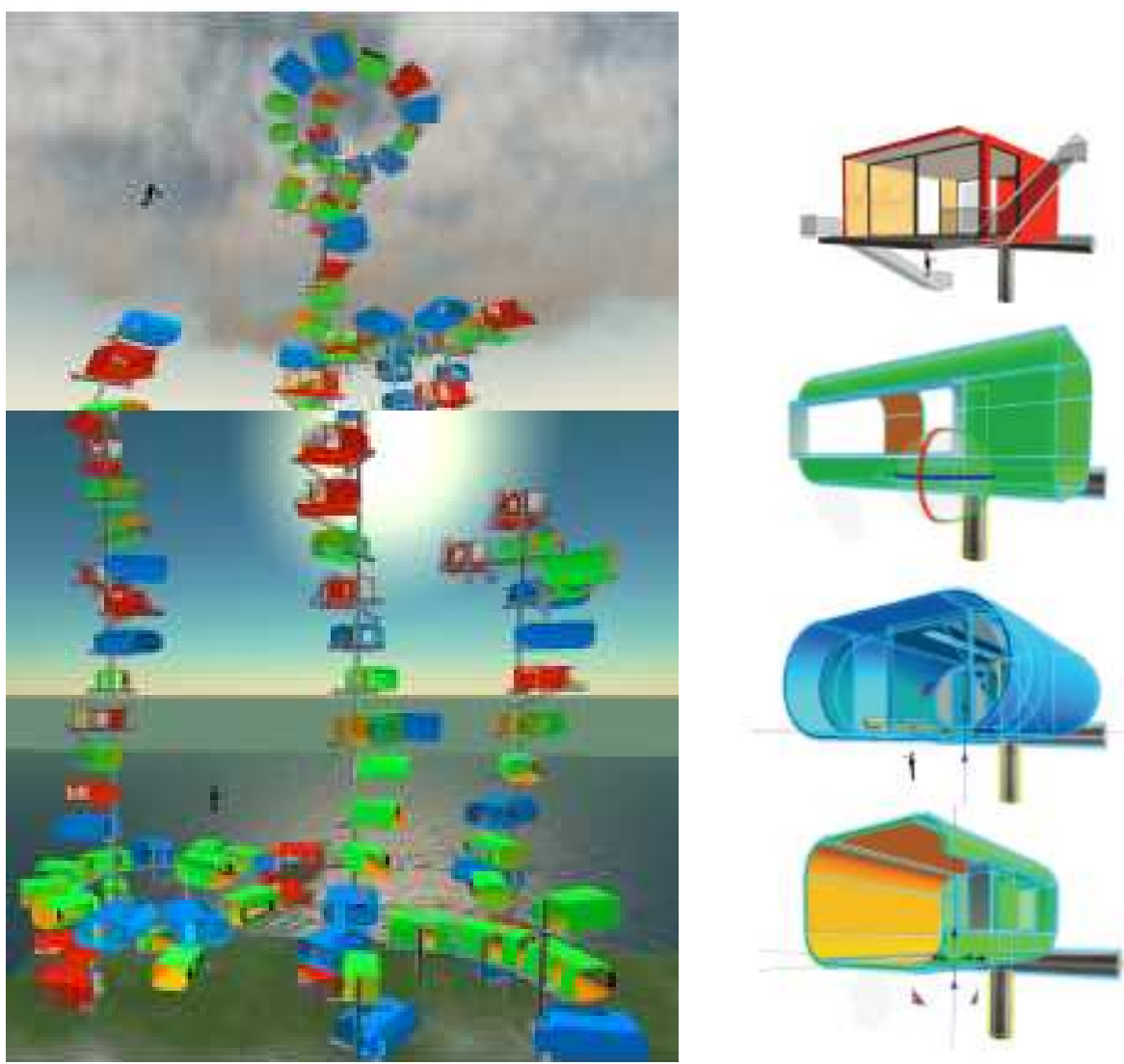

Fig.23-24 The Projects Fonte:THE PROJECTS (2008)

The Projects (Drew HARRY, Dietmar OFFENHUBER; MIT Media Lab / Sociable Media Group, 2007)

Estudos de arranjos espaciais para o Second Life. Trata-se de uma arquitetura social modular inspirada nos exemplos do PlugIn City, trabalho desenvolvido nos anos 1960 pelo grupo de arquitetura inglês Archigram. O objetivo é a construção de espaços socialmente significativos em ambientes virtuais. Acredita-se no uso da espacialidade na criação de um novo vocabulário social, na criação de espaços sociais atrativos (HARRY; OFFENHUBER; DONATH, 2007; THE PROJECTS, 2008). 

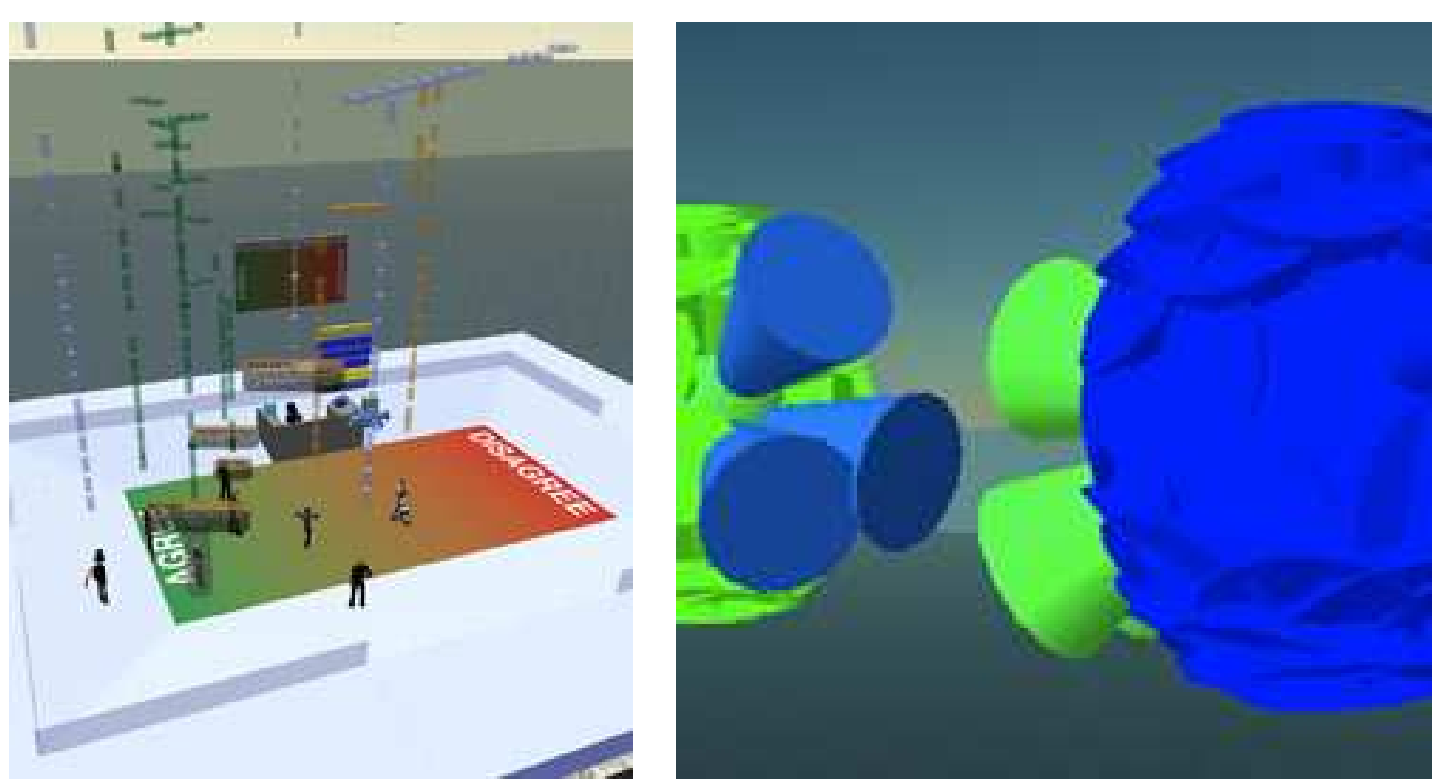

Fig.25-26 Information Spaces / Avatars Fonte: INFORMATION SPACES (2008) e AVATARS (2008)

Information Spaces / Avatars (Drew HARRY; MIT Media Lab / Sociable Media Group, 2007).

Estudos de aplicativos de representações de espaços e pessoas em ambientes gráficos de mediação e interação social. Tratase de criar alternativas às representações literais. Information Spaces reconfigura e dota de significação espaços de encontros no Second Life. Avatars estabelece expressão gráfica de avatares a partir da percepção da presença de outros no Second Life (AVATARS, 2008; INFORMATION SPACES, 2008).

Os SMS estão intimamente relacionados com o surgimento de fenômenos conhecidos como smart mob e flash mob, que são performances muito rápidas, de caráter político e crítico, ou lúdico, feitas por grupos de pessoas, planejadas e programadas seja através das próprias mensagens SMS via telefonia móvel, e-mail ou de sistemas de microblogging. Importante destacar neste contexto a exploração das possibilidades das TIC de mobilização e articulação rápida de pessoas desconhecidas, e as relações estabelecidas entre comunicação no ciberespaço, tecnologias móveis e ações concretas no plano físico. Rheingold (2002) define smart mob de forma ampla, decrevendo-o como uma nova forma de envolvimento social, de organização de interações e trocas. Tratam-se de mobilizações, cooperações e 
ações coletivas constituídas a partir da disponibilidade de dispositivos móveis com capacidade combinada de comunicação e computação.

As potencialidades dos dispositivos móveis têm sido exploradas de forma intensa, tanto no âmbito dos desenvolvimentos acadêmicos quanto comerciais. Há um consenso geral de se trata de peças chaves às tecnologias digitais num futuro próximo, por razões bastante distintas, algumas já mencionadas oportunamente. 0 RadioActive é uma ferramenta que se insere dentro deste contexto.

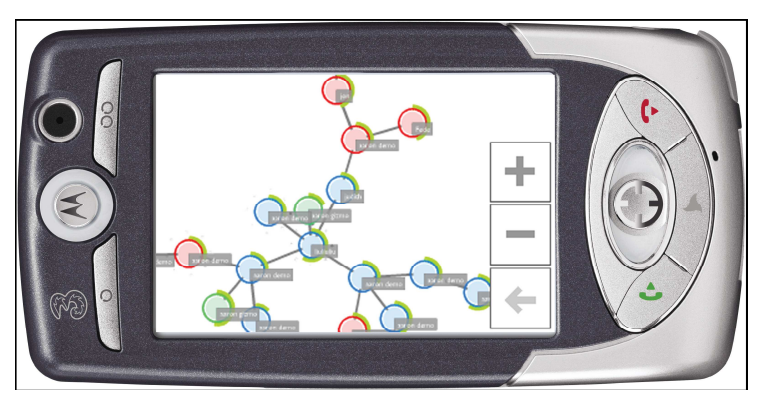

Fig.27 RadioActive Fonte: RADIOACTIVE. (2008)

RadioActive (Aaron ZINMAN, Judith DONATH; MIT Media Lab / Sociable Media Group, 2006).

Ferramenta de fórum para dispositivos móveis. Cria estratégias de navegação e estruturação para o estabelecimento de amplas discussões assíncronas em áudio. Ou seja, possibilita amplas trocas de mensagens através de gravação e audição de posts, e do uso de um dispositivo gráfico nos moldes GUI. Trata-se de uma interface que busca dar suporte à comunicação em grupo dentro de um contexto de mobilidade, no espaço urbano (ZINMAN, 2006; ZINMAN; DONATH, 2007; RADIOACTIVE, 2008).

Como se viu, o blog é a ferramenta que hoje mais se destaca no cenário da web pelo fato de estar estruturada em um sistema que simplifica de forma expressiva a produção e publicação de conteúdos na internet por pessoas não especialistas na área de informática. O conceito de blog foi se transformando a partir da idéia primeira de publicação de diários pessoais para um tipo de página a 
partir da qual se estabelecem interações através do registro de comentários, chamados posts (do inglês post, postar), que são um conjunto de informações sobre um ou vários assuntos tratados.

O gênero de cada weblog varia tanto quanto seus conteúdos. Há autores que contam com todo detalhe seus devaneios amorosos, outros que o usa para narrar em detalhes suas ações no trabalho ou como plataforma de seu trabalho acadêmico, há quem o escreve enquanto está viajando e querem fazer de seu weblog um autêntico relato novelesco e têm autores (bloggers) focados nas análises da atualidade noticiosa $[\ldots]^{81}$ (ESTALELLA, 2005).

A importância dos blogs de se estruturarem em sistemas que exigem um esforço mínimo dos usuários na interação a partir das camadas de apresentação se iguala à capacidade de potencializarem redes sociais amplas, como citado anteriormente.

\subsubsection{Alem telas}

\section{Ambientes virtuais imersivos}

As interfaces para aplicações computacionais que possuem uma relação com o espaço físico tridimensional e com experimentações sensoriais podem ser denominadas ambientes virtuais imersivos. ${ }^{82}$ Trata-se de ambientes tridimensionais gerados por computador, a partir de projeções em

\footnotetext{
${ }^{81}$ Tradução da autora. No original: "El género de cada weblog varía tanto como sus contenidos. Hay autores que cuentan con todo detalle sus devaneos amorosos, otros que lo usan para narrar sus en el trabajo o como plataforma de su labor académica, hay quien lo escribe mientras está de viaje y quien hace de su weblog un auténtico relato novelado y hay autores (bloggers) enfocados hacia el análisis de la actualidad noticiosa [...]"

82 No campo disciplinar das Ciências da Computação estes ambientes são denominados e conhecidos como Realidade Virtual (VR: Virtual Reality). O que leva muitos autores, mesmo não sendo da área, a utilizarem estes termos como sinônimos. Entretanto, esta nomenclatura parece equivocada dada à amplitude que a expressão realidade virtual abarca. Além de utilizada de forma indiscriminada para denominar tanto aplicativos em três dimensões não-imersivos para telas convencionais, ou seja, interfaces gráficas 3D, como caves (Cave Automatic Virtual Environment) construídas com tecnologias de última geração em centros avançados de pesquisa, suscita também imprecisão quando pensada em contraposição a outras possíveis formas de realidade, questão que não cabe aqui ser discutida.
} 
telas, onde pessoas podem interagir usando dispositivos multisensoriais como luvas, óculos e capacetes especiais, entre outros. "Nesta abordagem das interfaces, o humano é convidado a passar do outro lado da tela e a interagir de forma sensório-motora com modelos digitais" (LÉVY, 2000, p.38). Esta forma de interface envolve três fundamentos: interação, imersão e experimentação. A experiência imersiva em ambientes interativos se baseia em imagens gráficas em três dimensões geradas em tempo-real pelo computador, geralmente baseada em alto grau de realismo frente ao mundo concreto. Trata-se de interfaces que diferem entre si a partir do nível de imersão e de interatividade que proporcionam, e que apresentam uma variação significativa quanto à sofisticação das tecnologias empregadas.

Pratschke (2002), procurando evitar conceituações apenas de natureza tecnológica, se volta a estes ambientes como uma nova interface de comunicação, a partir dos conceitos de simulação, interação, imersão, telepresença e comunicação em rede. Destacando suas qualidades multiforme e multidisciplinar, poderiam ser definidos como uma "experiência da presença em um ambiente virtual, potencializado em meio de comunicação, em uma situação de complementaridade entre virtualidade e concretude, [...]" (PRATSCHKE, 2002, p.51). Enquanto Lévy (2000) aborda esta interface em termos de interação humano-máquina, interessa, pois, sua possibilidade de mediar relações entre indivíduos, como um novo meio de estar e tocar não só em informações, mas em pessoas. Pratschke (2002, p.77) coloca que todas as aplicações destes ambientes "são aplicações de comunicação porque envolvem, por um lado, a comunicação usuário/computador, por outro, a comunicação usuário-usuário”. Dertouzos (1998, p.101) também afirma: “As novas experiências podem vir em diferentes formatos. A realidade virtual mergulha a pessoa numa situação determinada. Pode também colocar pessoas distantes em contato." Já Bolter e Gromala (2003) mostram que, apesar de freqüentemente seguirem o modelo de interface transparente, que parece eliminar o computador, há uma possível singularidade nas aplicações criativas de ambientes virtuais, alegando que sempre se leva a própria vivência, a própria experiência corporificada ao ciberespaço, ainda que se junte ao mundo do computador. "Aplicações de 
realidade virtual criativas não procuram escapar do nosso mundo corporal; realidade virtual pode ser uma tecnologia para explorar a corporificação"83 (BOLTER; GROMALA, 2003, p.126).

Em seu trabalho sobre touching art, Huhtamo (2007, p.72), estudioso das mídias interativas, fala das situações mediadas tecnologicamente onde a interação acontece via uma interface com "um complexo hardware-software desenhado com este propósito" ${ }^{84}$. Aproxima arte tátil, arte interativa e mídia interativa: todas requerem a ação do usuário para funcionarem, e o desenvolvimento de uma conversa entre usuário e a obra ${ }^{85}$. Neste sentido, mostra que "uma rica variação de modos de toque tem sido proposto por artistas das novas mídias"86 (HUHTAMO, 2007, p.88), seja usando interfaces padrão e usuais (com mouse, teclado, e outras), seja criando as próprias interfaces, essenciais às próprias obras. Destaca que os usos da tatilidade na arte mídia contemporânea explora o estágio atual das tecnologias digitais e novos elos entre humanos e máquinas, e que alguns artistas podem, através destes, explorar experiências sensoriais, discursos, e imaginários (HUHTAMO, 2007).

\section{Realidade Aumentada}

Realidade aumentada e realidade expandida são termos, grosso modo, equivalentes, que significam a sobreposição de informações digitais sobre o ambiente físico. ${ }^{87}$ Trata-se da ampliação informacional de um dado ambiente ou objeto, através de dispositivos que permitem a projeção e a composição de

\footnotetext{
${ }^{83}$ Tradução da autora. No original: "Creative VR applications do not seek escape from our embodied world; virtual reality can be a technology for exploring embodiment."

84 Tradução da autora. No original: "p.72 um complexo hardware-software desenhado com este propósito ........"

${ }^{85}$ Dentre estas interfaces imersivas também situam-se as chamadas haptic interfaces. O termo haptica vem do grego haptesthai e está relacionado à sensibilidade ao toque. Trata-se de dispositivos que provém interação física em ambientes virtuais.

${ }^{86}$ Tradução da autora. No original: "p.88... uma rica variação de modos de toque tem sido proposto por artistas das novas mídias", .."

${ }^{87}$ Estes termos, embora também remetam a outras possíveis formas de realidade, o que implica imprecisões, são usados de maneira precisa, referindo sempre a este tipo específico de interface.
} 
camadas de informações digitais, geralmente informações visuais. É uma área de pesquisa associada diretamente com os estudos de ambientes virtuais imersivos, e que possui vínculos também com a chamada computação ubíqua. Segundo Milgram e Kishino (1994) “[...] um ambiente de Realidade Mesclada, então, é tal que o mundo real e objetos do mundo virtual estão presentes juntos dentro de um simples display, que está, em qualquer lugar entre os extremos de um virtuality continuum ${ }^{88}$ (MILGRAM; KISHINO,1994).

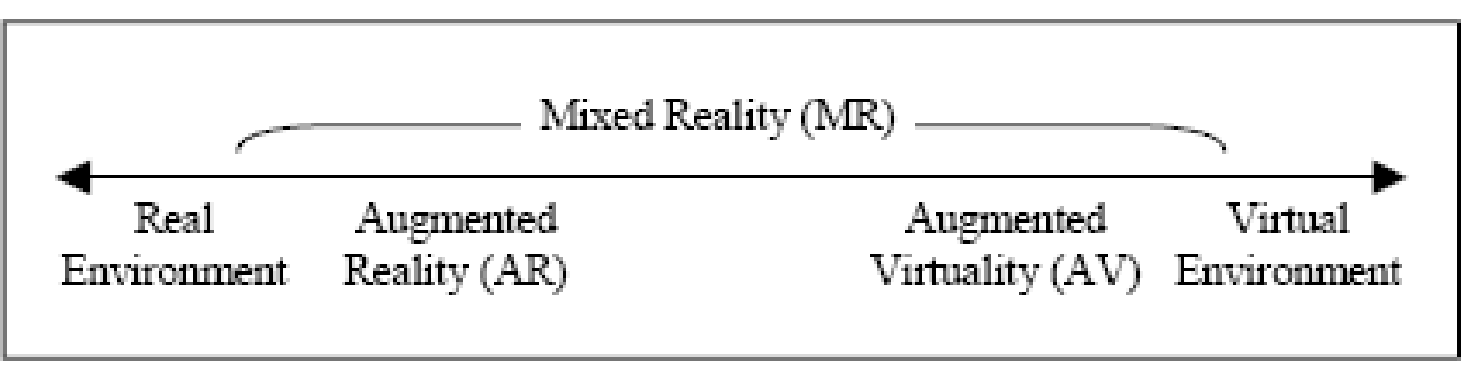

Fig.28: Representação de virtuality continuum Fonte: MILGRAM; KISHINO (1994)

As aplicações de realidade aumentada permitem às pessoas uma visão enriquecida e ampliada, o aprimoramento das experiências concretas a partir da complementaridade das informações advindas do mundo virtual. São aplicações geralmente vinculadas à necessidade de precisão na identificação de pequenas áreas de operação, ao rastreamento e visibilidade dos objetos no espaço, à interação em espaços públicos ou semi-públicos, e à criação de smart spaces em geral, que vão das formas mais sofisticadas às mais simples. 0 sistema Hear\&There é uma experiência no sentido de acrescentar uma dimensão informacional sonora a uma determinada localidade.

\footnotetext{
${ }^{88}$ Tradução da autora. No original: "[...] Mixed Reality environment, therefore, is one in which real world and virtual world objects are presented together within a single display, that is, anywhere between the extrema of the virtuality continuum."
} 

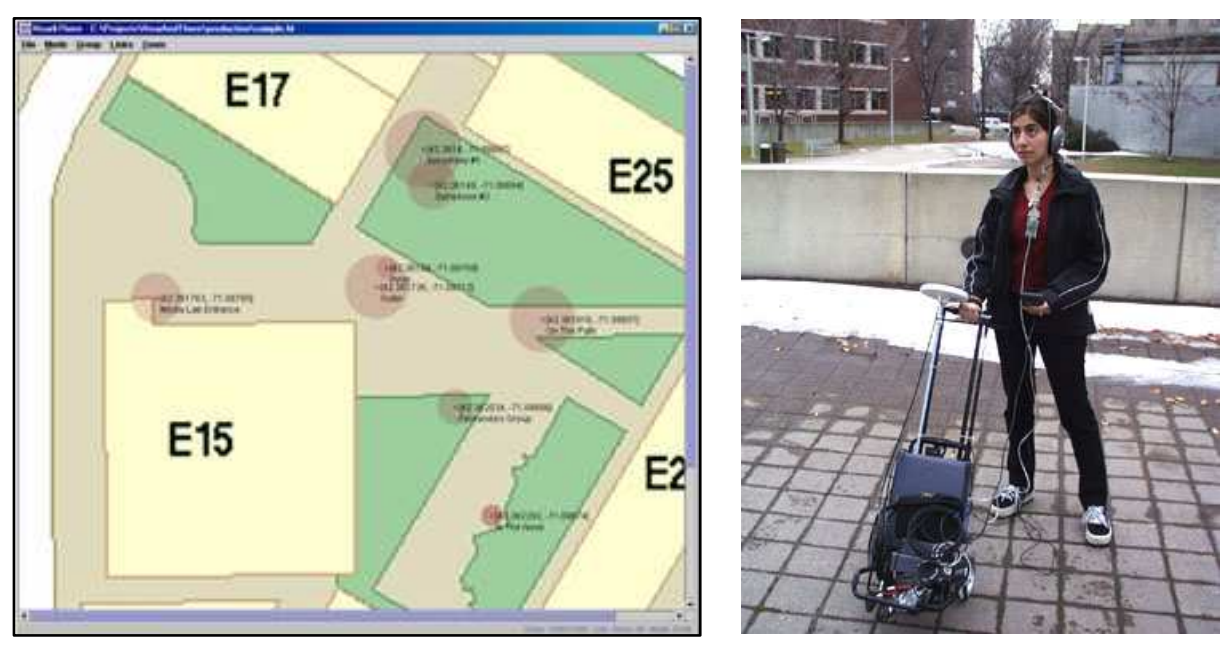

Fig.29-30 Hear\&There Fonte: ROZIER; KARAHALIOS; DONATH (2000)

Hear\&There (ROZIER, Joseph; KARAHALIOS, Karrie; DONATH, Judith, Sociable Media Group - MIT Media Lab, 2000)

Trata-se de um sistema de realidade ampliada que inclui uma interface de simulação padrão GUI [Graphical User Interface]. Tem como finalidade promover a identidade de um grupo de indivíduos através da impressão de sons, de modo que se possa construir um senso de comunidade numa localização física e fazer com que os lugares sejam sentidos com mais vida. Busca valorizar a dimensão sonora de uma determinada localidade. Os usuários do sistema podem deixar suas próprias impressões sonoras associadas a um local particular, em um espaço físico aberto. Tais impressões consistem em vários layers de música, efeitos de sons, ou vozes gravadas. Usando um componente de navegação, os usuários podem ouvir os sons caminhando pela área ocupada com tais impressões, que também podem ser conectadas, direcionando usuários dentro de da área, assim como podem ser recuperadas através da interface GUI (ROZIER, 1999; ROZIER; KARAHALIOS; DONATH, 2000). 


\section{Computação Ubiqua}

Computação ubíqua, ubicomp, computação pervasiva ${ }^{89}$, computação embarcada, virtualidade incorporada $^{90}$, e mesmo computação móvel, são termos freqüentemente usados como sinônimos, embora conceitualmente diferentes. Associados a princípios de invisibilidade e onipresença, a idéia central é que a computação move-se para fora das estações de trabalho e computadores pessoais e torna-se integrada à vida cotidiana, em objetos e espaços, permitindo que as pessoas usufruam as tecnologias digitais onde e sempre que quiserem, ainda que não as conheça, ou mesmo que não as perceba. Trata-se da computação que está em toda parte ao mesmo tempo, das interfaces que se encontram integradas aos ambientes em torno das pessoas.

Em linguagem simples, computação ubíqua é uma abordagem que procura introduzir computadores no mundo que nos rodeia. Os computadores serão embutidos [...], tão integrados aos ambientes que ninguém perceberá que são computadores. [..] Portanto, devemos olhar tudo que cerca as pessoas como um candidato a tais interfaces" (DERTOUZOS, 1998, p.98).

Araújo (2003) define computação ubíqua como uma junção da computação pervasiva e da computação móvel. A primeira pressupõe o computador embutido no ambiente de forma invisível, e a capacidade de obter informação deste para controlar, configurar e ajustar uma aplicação para dispositivos ou usuários. 0 ambiente também seria capaz de detectar outros dispositivos. Trata-se uma integração total de tecnologias. A computação móvel diz respeito à capacidade de mover fisicamente serviços computacionais, uma independência de localização ligada a acesso. A computação ubíqua, inserida no ambiente, agrega a mobilidade à funcionalidade da computação pervasiva, um alto grau de dispositivos embarcados e de mobilidade, e então “[...] qualquer dispositivo computacional, enquanto em

\footnotetext{
${ }^{89}$ Adaptação livre do vocábulo inglês pervasive. [Em inlgês: pervasive adj 1 penetrante, infiltrador. 2 difundido, espalhado, difuso. 3 Philos universal. Disponível em: <http://michaelis.uol.com.br/ > Acesso em 19 jan 2008] Não possui definição específica em português.

${ }^{90}$ Em inglês embodied virtuality. E ainda outros nomes: Invisible Computing, Calm Technology, Context Aware Computing. Intelligent Ambience, Reactive Environment.
} 
movimento conosco, pode construir, dinamicamente, modelos computacionais dos ambientes nos quais nos movemos e configurar seus serviços dependendo da necessidade” (ARAÚJO, 2003, p.50). Para a autora, computação ubíqua pressupõe diversidade, descentralização e conectividade. Computadores embutidos nos objetos do dia-a-dia implicam em muitos requisitos e desafios, seja pela grande variedade e heterogeneidade de dispositivos, embarcados e/ou de acesso à informação ${ }^{91}$, ou de protocolos e padrões de comunicação.

Mark Weiser, um dos pioneiros da pesquisa nesta área, diz que se deve aprender a conviver com os computadores e não apenas a interagir com eles. "O desafio é criar um novo tipo de relacionamento das pessoas com os computadores, no qual o computador assumiria a liderança em se tornar imensamente melhor no fazer as coisas de modo que as pessoas pudessem simplesmente dar andamento as suas vidas"92 (WEISER, 1993). A abordagem da computação ubíqua pressupõe o foco na tarefa e não na computação, é a primeira que deveria monopolizar atenção usuário e não a segunda. Fala-se aqui em interação natural e interfaces naturais, aplicações e artefatos sensíveis ao contexto e com um mínimo de impacto para sua utilização. A computacao ubíqua é cada vez mais possibilitada dada as disponibilidades técnicas e econômicas que tornam os tamanhos e preços dos microprocessadores e outros componentes eletrônicos cada vez menores.

Bolter e Gromala (2003) destacam as aplicações de computação ubíqua, e também de realidade ampliada, como cientes do contexto em que estão inseridas, reconhecedoras da diversidade e divergência, e então dizem, que neste sentido, elas tendem a serem reflexivas, porque o usuário vê uma combinação de ambiente físico e camadas geradas por computador. A interface Echologue,

91 Uma grande variedade de dispositivos podem ser embarcados em quiosques, mobiliários, eletro-domésticos em uma infinidade de objetos que nos cercam. Os dispositivos portáteis de acesso a informação, que também realizam a comunicação entre usuários disponíveis hoje são: computadores de mão, handhelds ou assistentes pessoais digitais (PDAs - Personal Digital Assistent); telefones celulares; telefones inteligentes (SmartPhones); screenphones, entre outros.

92 Tradução da autora. No original: The challenge is to create a new kind of relationship of people to computers, one in which the computer would have to take the lead in becoming vastly better at getting out of the way so people could just go about their lives." 
desenvolvida por Orkan Telhan, explora justamente esta característica de entrelaçamento de ambientes presenciais e informações digitais. Bolter e Gromala (2003) falam também desses tipos de aplicações como sendo um novo paradigma para o design de interface, para o design digital. Trata-se do contextual design, que explora a relação entre o físico e o virtual, que reconhece o conjunto de condições em que os artefatos digitais operam, que nada mais é do que o mundo de vida da experiência humana. "O que não quer dizer que aplicações digitais simplesmente devam adaptar-se às condições existentes do mundo dos usuários. O bom design digital, como a arte digital, pode remodelar seus contextos assim como responderem a eles"93 (BOLTER; GROMALA, 2003, p.140).

Ainda que considerando o contexto, a computação ubíqua pressupõe que os computadores devam se juntar ao mundo de forma invisível, transparente. E neste sentido estariam mais para janelas do que para espelhos, na concepção de Bolter e Gromala. Esses autores consideram isto um erro, e destacam que as aplicações da computação ubíqua que mais interessam são às que funcionam sob a forma de mídia ubíqua, como câmeras e telefones celulares, e ainda a web, que representam o mundo para os usuários e enviam estas representações de um lado a outro, sempre sob a sua estreita supervisão. Neste caso, então, mais que uma contradição, trata-se da reafirmação da necessidade da oscilação entre transparência e reflexibilidade.

93 Tradução da autora. No original: "That is not to say that digital applications must simply adapt themselves to the existing conditions of the user's world. Good digital design, like digitl art, can reshape its contexts as well as respond to them." 

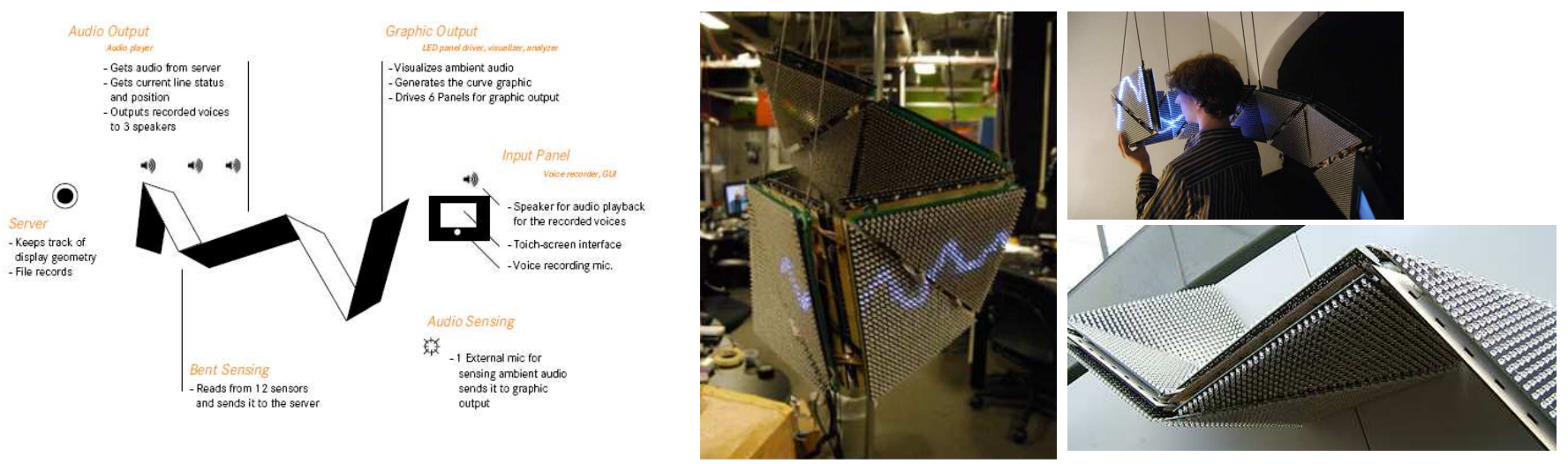

Fig.31-34 Echologue Fonte:TELHAN (2007)

Echologue (Orkan TELHAN, Judith DONATH; MIT Media Lab / Sociable Media Group, 2007).

Interface que reflete os ambientes a partir de suas feições sonoras. Funciona como um sensor e expositor de características e identidades socioculturais de um local a partir do aspecto sonoro em particular. Trata-se de uma interface que busca contribuir para a percepção de lugares sociais no espaço público (TELHAN, 2007; ECHOLOGUE, 2008).

\section{Computação vestivel}

Alguns autores situam a computação vestível como uma parte da computação ubíqua (ARAÚJO, 2003), outros a situam ao lado desta (STARNER et al., 1997), ou ainda complementar a esta (DERTOUZOS, 1998). A computação vestível diz respeito a equipamentos computadorizados usados no corpo humano ou em peças de vestuário, ou acessórios embutidos (cintos, óculos, pulseiras, fones de ouvido, entre outros), com diferentes aplicabilidades, desempenhando e auxiliando ações do dia-a-dia ${ }^{94}$. Dertouzos (1998) chama os dispositivos da computação vestível de bodynets, redes pessoais compostas de vários equipamentos distribuídos pelo corpo, interfaces capazes de acompanhar uma pessoa aonde ela vá, que podem ter utilidade como periféricos numa série de aplicações.

\footnotetext{
${ }^{94}$ Intelligent clothing pode ser considerado uma forma de wearable computer. Está mais associado aos tecidos com dispositivos informáticos. Ver: Nørstebø, C. A. Intelligent textiles, soft products. Disponível em: <http://design.ntnu.no/fag/PD9/2003/artikkel/Norstebo.pdf>. Acesso em 22 jan 2008.
} 
Trata-se de uma incorporação de sistemas eletrônicos que tende a ser discreta. Componentes e dispositivos interagem com o usuário a partir do contexto ou situação, como se fossem extensões do corpo humano. A interface The Hug Shirt, que vai além do utilitarismo prático e funcional, coloca-se justamente à disposição da comunicação afetiva corporal.

$\mathrm{Na}$ abordagem da computação vestível, o corpo funciona como plataforma, podendo ser um meio para trocas de informação ou uma fonte em si mesma. Estes dispositivos de processamento para comunicação podem atuar como um assistente inteligente, ou também como host de outros dispositivos. Starner et al. (1997) diz que os computadores vestíveis são mais privados e discretos, inclusive que telefones celulares e PDAs. "O usuário pode concentrar-se na realidade física mas ter acesso imediato ao virtual se necessário" 95 (STARNER et al.1997). Neste sentido, uma característica importante das interfaces de computação vestível é que, inseridas no espaço pessoal dos usuários, controladas por estes, estão constantemente disponíveis, sempre ligadas e sempre acessíveis, e sendo utilizadas ao mesmo tempo em que se está realizado outras atividades (MANN, 1998).
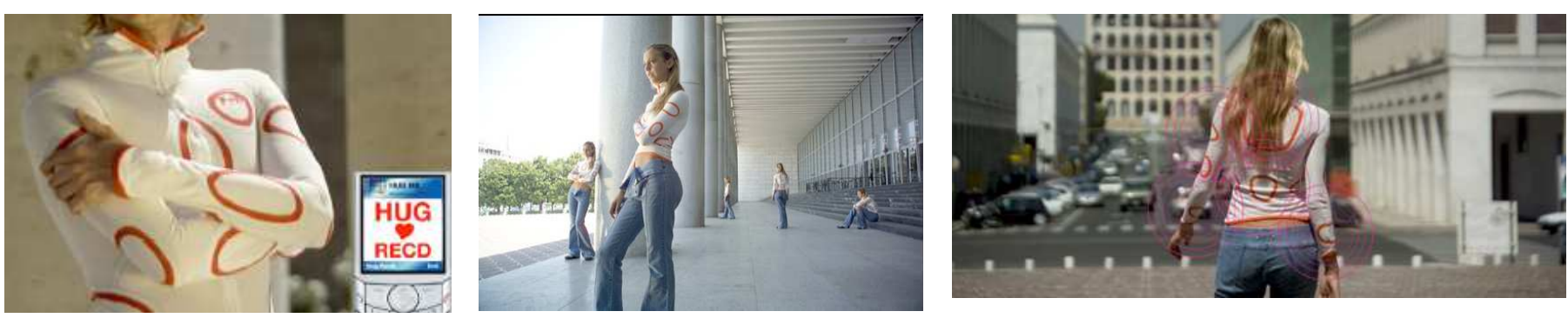

Fig.35-37 The Hug Shirt Fonte: THE HUG SHIRT (2008)

The Hug Shirt (CuteCircuit LCC, Inglaterra, 2004)

Linha de roupas desenvolvidas em lycra envolta por micro-sensores que transmitem sensações físicas. Tais sensores recebem informações emitidas a distância através do bluetooth de telefones celulares, e são capazes de reproduzir a sensação de toque de maneira personalizada, por vibrações, intensidade, temperatura, entre outros (THE HUG SHIRT, 2008).

\footnotetext{
${ }^{95}$ Tradução da autora. No original: "The user can concentrate on physical reality but have immediate access to the virtual if needed."
} 


\section{Bitstangiveis}

Consideradas mais uma variante da computação ubíqua, mas também vinculadas às idéias de realidade aumentada, bits tangíveis ou tangible bits são interfaces que privilegiam a manipulação de informações digitais através da operação de objetos físicos. Há aqui uma tentativa de acoplar bits e átomos, transformando superfícies físicas em interfaces ativas entre o mundo concreto e o digital. Trata-se de estabelecer forma física para informações digitais, contrapondo às interfaces padrão GUI interfaces tangíveis, que, entre outros atributos, são capazes de alterar a percepção dos objetos. Ishii e Ullmer (1997) destacam três caminhos principais na condução das experiências de união entre ciberespaço e ambiente físico: transformar as superfícies dos espaços arquitetônicos em superfícies de interação entre ambientes físicos e digitais; juntar bits e átomos em objetos do cotidiano, ou seja, imprimindo informações digitais aos objetos, e por fim criar ambientes mídias, que tornem usuários conscientes, nos seus planos de ações, das informações presentes nos ambientes periféricos. "A transição suave dos focos de atenção dos usuários entre fundo e frente usando mídia ambiente e objetos comprimidos é um desafio chave para Bits Tangíveis"96 (ISHII; ULLMER,1997).

Também associados à computação ubíqua e pervasiva, os ambientes atentos (Attentive Environments) e a computação transparente (Transparent Computing) são abordagens que procuram explorar ambientes e computadores que analisam o usuário e contexto, que os percebem e buscam atender às suas necessidades, como um caminho importante para aumentar a interação humano-computador, entre outros. O computador antecipa as ações do usuário, por avaliar o contexto, passando usuário então a realizar um controle não expresso claramente.

${ }^{96}$ Tradução da autora. No original: "The smooth transition of users' focus of attention between background and foreground using ambient media and graspable objects is a key challenge of Tangible Bits." 
Neste sentido, o modo de interação está muito mais implícito: as interfaces dos computadores respondem às expressões e aos gestos do usuário. Os ambientes ricos em sensores são utilizados para detectar o estado atual dele. [...] 0 projeto BlueEyes da IBM está desenvolvendo vários dispositivos compuracionais que utilizam tecnologia de sensoriamento não-perceptível, incluindo vídeos e microfones que rastreiam e identificam as ações dos usuários (PREECE; ROGERS; SHARP, 2005, p.84).

A Physical Computing está relacionada à utilização de sistemas informatizados de interação com o ambiente, o contexto, e é também baseado em sensores, para captura e envio de informações digitais. o Arduíno, uma plataforma simples de micro-controladores baseada em um circuito de entradas e saídas, conhecida por ser de fonte aberta, se encaixa também neste contexto, porque pode funcionar como a interface entre ambiente e computador.

\subsubsection{Panorama}

O panorama apresentado acima mostra como está estruturada hoje a comunicação e interação no universo das mídias digitais. Ainda que não seja possível saber se absolutamente todas as possibilidades de interfaces computacionais de interação comunitária estão expressas aí, corrobora-se a idéia de uma grande diversidade de caminhos possíveis para se pensar a construção e suporte do diálogo mediado pelas TIC. Também as tendências de reconfigurações e convergência, nos sentidos discutidos anteriormente, são claramente reafirmadas aqui. Muitos destes suportes são amplamente utilizados, outros ainda carecem de aplicabilidade prática no sentido de possibilitar a construção de espaços híbridos em comunidades locais, a partir do adensamento de diálogos e interações, e da sobreposição de camadas comunicacionais extras, a fim de potencializar experiências coletivas de outra ordem. Há disposição, como bem diz Mann (1996) ainda que se referindo aos vestíveis, “[...], o uso ubíquo de 
'roupa inteligente' poderia ter o potencial de tornar o mundo dentro de uma comunidade provinciana uma aldeia global com barreiras de tempo e espaços caídas."

\subsection{Estruturas para as redes sociais online}

As comunidades virtuais, concebidas como redes sociais online, são estruturadas a partir de diferentes suportes tecnológicos, chamados por alguns de instrumentos de social networking ${ }^{98}$. Grande parte das interfaces e ferramentas apresentadas acima se enquadra neste contexto, e podem ser consideradas bases sob as quais é possível o estabelecimento de redes de interações sociais online, ou seja, meios, lugares e ambientes para interações sociais no ciberespaço. A interface Comment Flow explora a representação da estrutura dessas redes sociais que têm como locus principal os ambientes virtuais, imprimindo-lhe uma certa materialidade ainda que sob as mesmas bases digitais.

\footnotetext{
97 Tradução da autora. No original: "[...], ubiquitous use of 'smart clothing' might have the potential to turn the world into a smalltown community - a global village asbarriers of time and space fall."

${ }^{98}$ Networking é uma palavra da língua inglesa que significa a prática de encontro entre pessoas envolvidas num mesmo tipo de trabalho, para compartilhar informação e diferentes formas de apoio. (Longman Dictionary of Contemporary English. Longman Dictionary of Contemporary English. Editora: Longman - 3 ed.,1995).
} 

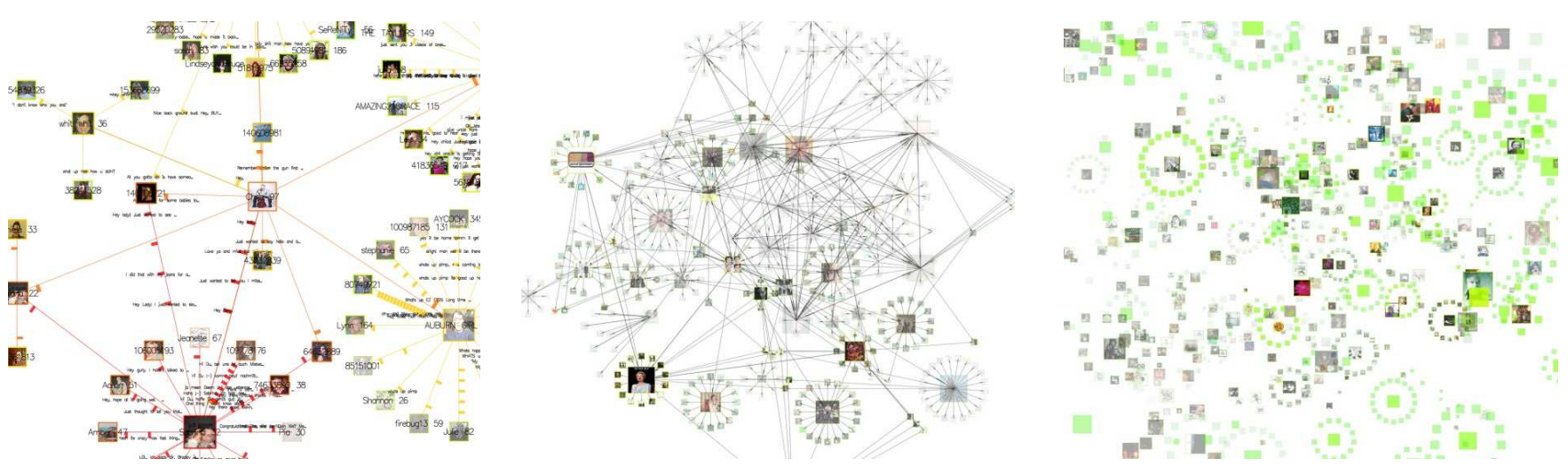

Fig.38-40 Comment Flow Fonte: COMMENT FLOW (2008)

Comment Flow (Dietmar OFFENHUBER, Judith DONATH; MIT Media Lab / Sociable Media Group)

Ferramenta de representação de uma rede social. Trata-se da exploração e visualização significativas da estrutura de uma comunidade online, de um retrato mais elaborado da vida social online, tendo como base o site myspace (COMMENT FLOW, 2008).

Gotved (2002) investiga as comunidades online especificamente a partir das suas dimensões espaciais. Segundo a autora existiriam três diferentes níveis nos espaços compartilhados online, de igual importância: o que diz respeito ao protocolo base, àquele relativo a experiência social em si, e por fim, o pertinente à linguagem utilizada para a compreensão das redes virtuais em termos espaciais. No trabalho de Gotved, estes níveis correspondem a tipologias analíticas. "A tipologia consiste de três dimensões diferentes do espaço online e a proposta é que todo tipo de comunidade online tem sua dispersão própria dentro dessas dimensões. As dimensões são interpretadas simultaneamente no processo de interação, [...]" "99 (GOTVED, 2002, p.409). A dimensão que chama espaço da interface corresponde ao lugar da reunião, onde são estabelecidas, visivelmente e materialmente, a comunicação. Este espaço pode ser mais ou menos sofisticado, e é definido pelo conjunto software e hardware. Também é variável, podendo apresentar um design muito simples, ou mais elaborado. Já o

\footnotetext{
99 Tradução da autora. No original: "The typology consists of three different dimensions of online space, and the claim is that every type of online community has its own dispersion within these dimensions. The dimensions are interpreted simultaneously in the interaction process, [...]."
} 
espaço social é constituído pelas interações humanas em si, no nível da interpretação dos significados sociais. É fluido e de difícil definição, porém é o principal aspecto de uma comunidade online. Já o espaço metafórico, sobreposto aos demais, é aquele que estabelece analogias com os espaços offline, que cria as conexões com estes espaços.

Assim, a tipologia pode ser aplicada para todo tipo de reunião online, determinando em que grau o espaço da interface facilita a ascensão de uma comunidade, e como o espaço visível facilita as interações; em que grau o espaço social existe como uma percepção (mais ou menos) compartilhada daquela comunidade, e como poderia evocar emoções fortes; e em que grau o espaço metafórico está provendo a comunidade com um tipo de espacialidade formulada e conexões para o espaço offline ${ }^{100}$ (GOTVED, 2002, p.412).

Interessa destacar aqui que o trabalho de Gotved explicita uma relação, uma conexão, entre a conformação e configuração das interfaces e a qualidade das relações sociais e trocas as quais dão suporte. Outros estudos atestam neste sentido. Ren, Kraut e Kiesler (2007) argúem que “[...] as restrições e oportunidades inerentes ao design das comunidades online influenciam como as pessoas se vinculam à comunidade e se elas estão dispostas a despender esforços em seu interesse". ${ }^{101}$ Preece (2001b) revela que:

[...] desenvolvedores de software desenham software, acreditando que estão desenhando comunidades. Enquanto, com olhos acurados, sociólogos reflexivos descrevem a emergência de comunidades. Mas comunidades não são desenhadas nem apenas emergem. A maneira que os software são desenhados afeta o desenvolvimento da comunidade justamente como a arquitetura de uma casa afeta aqueles que vivem nela. A maneira das pessoas interagirem em uma

\footnotetext{
100 Tradução da autora. No original: "Hence, the typology may be applied to every kind of online gathering, determining to which degree the interface space supports the rise of community and how the visible space facilitates the interactions, to which degree the social space exists as a (more or less) shared perception of that community and how strong emotions it might evoke, and to which degree the metaphorical space is providing the community with a kind of formulated spatiality and connections to offline space."

101 Tradução da autora. No original: "[...] the constraints and opportunities inherent in online community design influence how people become attached to the community and whether they are willing to expend effort on its behalf."
} 
comunidade molda sua evolução a longo prazo. E ainda que o comportamento das pessoas não possa ser controlado, pode ser influenciado. 0 comportamento social é complexo, quer ocorra onou offline ${ }^{102}$ (PREECE, 2001b, p.6).

No mesmo sentido, Primo (2005a) diz que "os meios não são tubos de pura transmissão [...], sem ruído ou qualquer repercussão no processo comunicacional". ${ }^{103}$ Parece haver um consenso sobre o vínculo entre o design das estruturas de suporte das redes sociais online e as relações sociais estabelecidas a partir destes suportes, pelo menos no sentido de que o primeiro influencia e afeta, de certo modo, o segundo. Da mesma forma, seria pertinente pensar a possibilidade do design desses suportes virem também a refletir e expressar os modos de conceber estas relações, igualmente como de praxe no fazer arquitetônico.

Para Souza e Silva (2000), “não apenas a máquina precisaria se representar para o usuário, como também cada um necessita se representar para o outro. 0 problema do design de interfaces passou a ser construir ambientes online que facilitem essa interação." É importante destacar que os diferentes ambientes que se constituem locus interação virtual apresentam diferentes recursos de representação. Tais recursos podem ser criados através de metáforas em geral, de simulacros e mimeses, e também podem ser pensados usando outras instâncias de significação, menos associadas ao repertório de senso comum. Porém, na configuração de interfaces, é usual a utilização de elementos figurativos e metáforas do ambiente concreto, presencial. Grande parte das interfaces de tela, além de bastante centradas em discursos verbais escritos, associa a ele imagens e outros códigos com elementos significativos referenciados no universo físico ordinário, das relações face-a-face. Pode-se dizer isto

102 Tradução da autora. No original: "[...] software developers design software, believong they are designing communities. Meanwhile, keen-eyed, reflective sociologists decscribe the emergence of communities. But communities are neither designed nor do they just emerge. How software is designed affects community development just as the architecture of a house affects those who live in it. How people interact in a commmunity shapes its long-term evolution. And though people's behavior connot be controlled, it can be influenced. Social behavior is complex, whether it occurs on- or offline.

${ }^{103}$ Esta problemática está ligada também à questão de que os meios, quaisquer que sejam, não são neutros, na qual se insere, por sua vez, a discussão de Marshall McLuhan expressa na máxima "o meio é a mensagem". 
tanto em relação aos primeiros MUDs, aos tradicionais chat em duas ou três dimensões, a alguns web sites. Parece que a utilização de recursos abstratos, não imitativos, está ainda ligada apenas a trabalhos, pesquisas e experimentações associadas à produção acadêmica e dos mídia-artistas, e não necessariamente a constituição pragmática de aplicativos voltados a uma grande audiência. A validação da metáfora do desktop parece reverberar nas instâncias de interações sociais online, especificamente em direção às construções figurativas de espaços e de pessoas. Por um lado, é pertinente supor que um rompimento gradual neste sentido poderia significar ganhos qualitativos das interações, tanto com as interfaces como através delas, que pudessem levar a uma apreensão simbólica e cognitiva mais criativa nesse universo. Por outro lado, reafirma-se o caráter ainda experimental que envolve o design de interfaces, um campo de investigação exploratório, onde convenções e inovações podem ora estar alinhadas, ora revelarem-se como horizontes distintos.

\subsubsection{Requisitos projetuais e tecnologicos para redes sociais online}

Existem na web portais e sites voltados a muitos tipos de comunidades, sejam ou não de base local. Musgrave (2005) descreve dois modelos distintos de web sites específicos de comunidades de base territorial, Community Portal (portal comunitário) e Civic Portal (portal cívico).

A categorização de Portal Comunitário é vista agora como aqueles exemplos de portais desenvolvidos por ativistas (i. e. conduzido de baixo para cima) dentro de uma rede comunitária, que pertence e é gerido por uma organização não governamental (normalmente um grupo de vizinhança geográfica sub-regional). 0 termo Portal Cívico então refere-se a portais de patrocínio 
governamental (nacional, regional, ou governo local), (conduzido de cima para baixo), dentro de um escopo do que é chamado por rede cívica ${ }^{104}$ (MUSGRAVE, 2005, p.33).

Independentemente se frutos de iniciativas bottom-up ou top-down, comerciais ou não, os portais e sites de comunidades locais são muitas vezes considerados instrumentos que promovem a comunicação e favorecem a interação social nessas comunidades, e que, eventualmente, alavancam o desenvolvimento local, a construção de cidadania, o senso de identidade, o capital social. Entretanto, é importante observar que a estruturação desses ambientes web de base local, chamados em inglês place-based websites, muito comuns, obedece a um formato tradicional de web sites, geralmente não conformando comunidades online como se concebe aqui, pelo fato de estarem focados em outros objetivos e propósitos. Constituem-se mais como sites cujo interesse primeiro é a reunião de um conjunto de informações sobre uma determinada localidade, ora de caráter oficial, quando ligado aos poderes administrativos, ora comercial, quando fruto de iniciativas privadas, ainda que ofereçam, em alguns casos, ferramentas de comunicação interpessoal. ${ }^{105}$ Poderia se considerar estes sites como loci virtuais de determinadas comunidades locais nos casos em que tais ferramentas sejam suficientemente apropriadas pela comunidade, de tal forma que se instaurem como uma outra esfera de comunicação com base naquela territorialidade. Os requisitos para tal apropriação são de ordens diferentes, como se viu oportunamente. Aqui cabe perguntar quais seriam as condições necessárias no âmbito da interface para que ocorra esta apropriação. Ou o que especificamente da interface implica na qualidade das interações sociais estabelecidas nesta instância virtual que as tornam suficientemente significativa. Quais são os pressupostos projetuais e tecnológicos para se criar uma rede social online?

\footnotetext{
104 Tradução da autora. No original: "The categorisation of Community Portal is now viewed as those portal instances developed by activists (i.e. bottom-up driven) within a community network, owned and operated by a non-governmental organisation (typically a sub-regional geographic neighbourhood group). The term Civic Portal then refers to government sponsored (top-down driven) portals (national, regional, or local government), within the scope of what is termed a civic network."

105 Trata-se de um conjunto de páginas web que dispõe informações em diferentes formatos, às vezes associadas a algumas ferramentas de comunicação, como fóruns, e-mails e blogs. São sites que possuem uma identidade visual que obedece a padrões de layout muito comuns, como por exemplo, a página principal dividida em diferentes seções, informações dispostas a partir de grade retangular, hierarquia a partir de tamanho de letras e imagens, ou pelo uso de determinadas cores, entre outros.
} 
Donath (1996), sobre a possibilidade de desenvolvimento de comunidades online, diz que o ambiente, que seria a infra-estrutura técnica e a interface do usuário, deveria prover meios para a comunicação e a visualização de indicadores sociais, revelando os padrões sociais constituídos a partir de um vocabulário cultural. Para Donath (2006), o fato de a comunicação online se dar em ambientes totalmente construídos, em contextos inventados, faz com que as decisões de design afetem de forma profunda todos os seus aspectos, determinando, entre outros, graus de fidelidade nas interações sociais. Para a autora, e-mails, blogs, e outros ambientes, suportam “[...] um diferente ecossistema de identidades, índices, e signos; cada qual produz uma cultura diferente” ${ }^{106}$ (DONATH, 2006). Certos designs resultariam certos tipos de interação, e design atrativos levariam a espaços novos de sucesso. Donath apresenta então as decisões de design relacionadas diretamente a composição de diferentes ambientes de interação social. Os estudos em torno da interface Chit Chat Club expressam a exploração desta idéia.

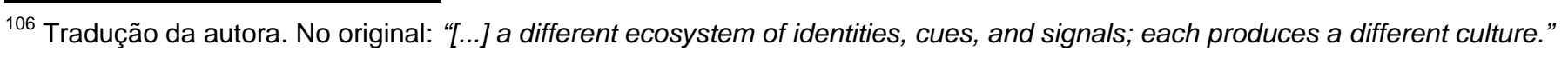




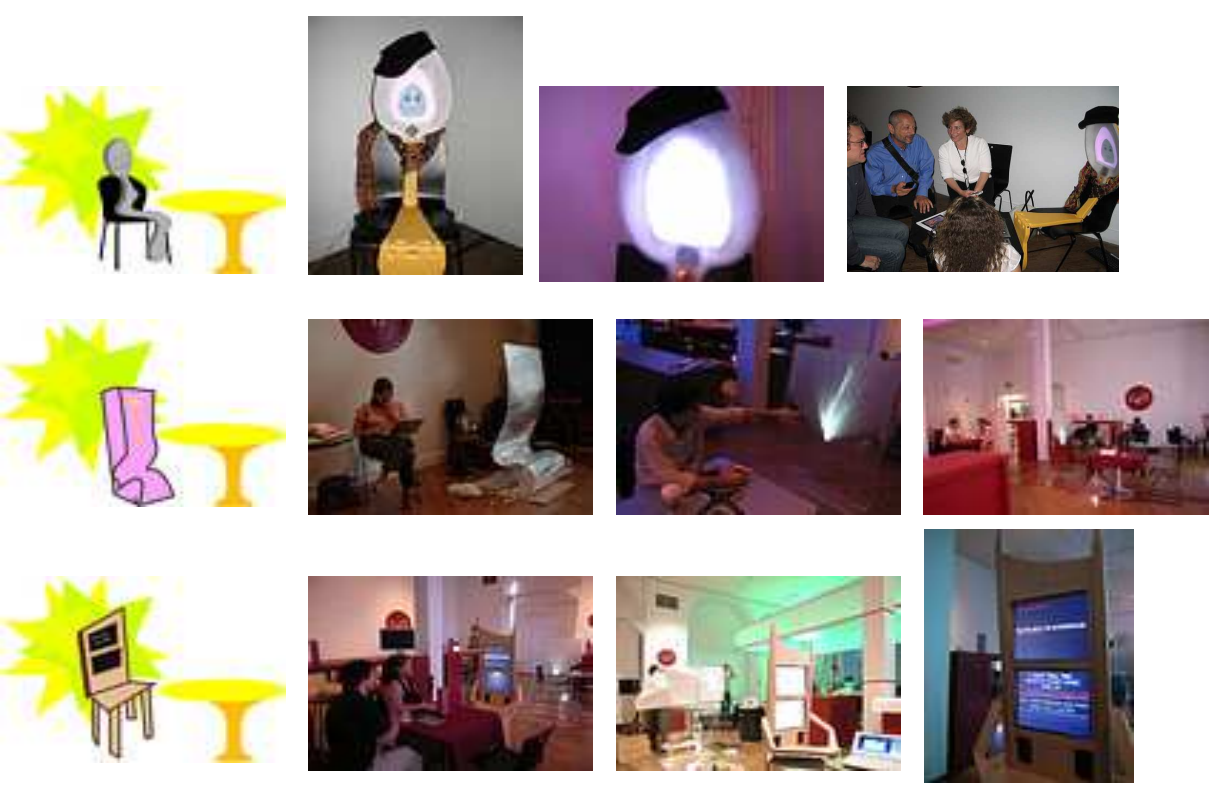

Fig.41-52 Chit Chat Club: (1) sculptural spoon, (2) chair: abstracted graphics e (3) chair: instant messaging Fonte: CHIT CHAT CLUB (2008)

Chit Chat Club (Karrie KARAHALIOS, Judith DONATH; MIT Media Lab / Sociable Media Group; Social Space Group, University of Illinois at Urbana-Champaign, e ISEA Inter-Society for the Electronic Arts, 2004 / 2008).

Interfaces de conexões de espaços públicos. Trata-se de uma ampla pesquisa que busca criar catalisadores sociais, a partir de novas formas de conversação e interação física dentro de espaços híbridos. São experimentações de design que visam incorporar a comunicação mediada entre espaços públicos físicos e online. Utiliza uma plataforma web e ferramentas de comunicação instantânea (CHIT CHAT CLUB, 2006; KARAHALIOS, 2004).

Mitchell (2000) diz que há determinadas condições para que um lugar virtual tenha sucesso. 0 simples uso de tecnologia de networking e software sofisticados não garantem habitabilidade e visitabilidade. 0 autor apresenta algumas condições necessárias para que um determinado espaço virtual não falhe frente aos objetivos de serem apropriados pelos usuários. Em primeiro lugar, deve ser acessível aos usuários potenciais. Isto envolve uma série de questões: o planejamento da quantidade de sites intermediários e hiperlinks a serem acessados antes de chegar ao destino final, a qualidade das vizinhanças, ou seja, dos sites aos quais são ligados, a disponibilidade de acesso por meio de buscadores, além da adequação às tecnologias de largura de banda e capacidade do servidor. Um 
ambiente virtual também deve chamar atenção, ser visível, atrativo. Para tal, Mitchell destaca algumas estratégias que podem ser desenvolvidas, seja junto às ferramentas de busca na web, a partir da criação de contadores que atestam a popularidade do site, e da localização e rearranjo de signos no espaço virtual, respondendo a mudanças de necessidades e condições. Por fim, o autor chama a atenção para o fato da persistência no retorno a determinados espaços virtuais estar relacionada à elementos como motivação, customização, confiança e respeito. Mitchell cita a qualidade dos ambientes virtuais que se tornam familiares, partes de uma história: “[...] eles podem sustentar comunidades proporcionando um pouco de valor cultural e emocional para copartilhar"107 (MITCHELL, 2000, p.127).

Powazek (2002) apresenta os aspectos de design diretamente relacionados à criação de comunidades online a partir da análise de inúmeros exemplos práticos. De antemão os designers devem, segundo o autor, conhecer a audiência, garantir a participação através de ferramentas apropriadas, e estabelecer conteúdos significativos. 0 autor destaca também que o design de comunidades online, centradas na comunicação direta, pública e instantânea, deve ser flexível, simples, legível e bonito, além de voltado às experiências dos usuários, com começo, meio e fim. Discorre sobre a questão das regras, da moderação, da intimidade, e das barreiras nesses ambientes, efêmeros na maioria dos casos, sujeitos a uma inerente falta de controle, porque apropriados e construídos pelos próprios usuários. 0 design visual do espaço comunitário deve considerar, segundo o autor, a escolha criteriosa de seus elementos, como cores, formas e padrões, ilustrações e fotografias. Contudo, ressalta: "Penso que é difícil quantificar exatamente o quanto o design visual de um espaço contribui para a qualidade das contribuições, sendo impossível negar que um influencia diretamente o outro" (POWAZEK, 2002, p.59). ${ }^{108}$

\footnotetext{
107 Tradução da autora. No original: "[...] they can sustain communities by providing something of cultural and emotional value to hold in common."

108 Tradução da autora. No original: "And thouhg it's hard to quantify exactly how much the visual design of a community space contributes to quality of the contributions, it's impossible to deny that one directly influences the other.
} 
Shedroff (2005) diz que hoje é dada grande atenção à criação de comunidades online, entretanto o foco está mais voltado a questões de venda de produtos e serviços, do que às considerações sobre o que levaria pessoas a fazerem parte dessas comunidades. Para o autor, as comunidades online bem sucedidas distinguem-se a partir de quatro pontos:

A habilidade dos membros em criar identidades duradouras. Formas apropriadas de comunicação com outros. Tópicos significativos [seja conteúdo ou contexto] em torno dos quais se pode reunir e interagir. A habilidade dos membros em compartilhar verdadeiramente na criação e expansão da comunidade, no mínimo ajudando a gerar o conteúdo para a comunidade ${ }^{109}$ (SHEDROFF, 2005, p.190).

O autor ainda apresenta como importante ao processo de estabelecimento dessas comunidades a criação de identidade, seja com os outros participantes, seja com seus os criadores, relacionada ao senso de envolvimento e à expressão pessoal. Importante também é o fato dos membros sentirem algum senso de propriedade da comunidade, que se estende à criação dos principais conteúdos em torno do qual a comunidade se reúne. O conteúdo é, segundo Shedroff, essencial à maioria das comunidades, serve para estimular as discussões.

Para Preece (2001a, 2001b), pesquisadora de $\mathrm{HCl}$, a avaliação de comunidades online pode se dar a partir de métodos quantitativos e qualitativos. Os primeiros, objetos de estudo da autora, dizem respeito a parâmetros métricos de sociabilidade e usabilidade, conectados e mutuamente impactantes. Os segundos se dão a partir de estudos etnográficos. "O foco de usabilidade é então a interação através da interface humano-computador. O foco da sociabilidade é a interação humano-humano suportada pela tecnologia" (PREECE, 2001a). Relacionada com o desenvolvimento de software, uma sociabilidade

\footnotetext{
109 Tradução da autora. No original: "The ability of members to create persistent identities. Appropriate ways of communicating with others. Meaningful topics (whether content or context) around which to congregate and interact. The ability of members to actually shere in the creation and expansion of the community, at the very least by helping to gerate the content for the community."
} 
online considerada boa deve ser estabelecida a partir propósitos em comum; pessoas, que assumem diferentes papéis; e políticas, relacionadas às linguagens e protocolos e a governança. Os determinantes, que indicam sucesso de sociabilidade incluem medidas como número de participantes em uma comunidade, número de mensagens ou unidade de tempo, satisfação dos membros, e medidas menos obvias como soma de reciprocidade, número de mensagens por tópico, fidelidade, e outros. A usabilidade, relacionada à facilidade dos indivíduos em aprenderem a usar e interagir com um produto, neste contexto diz respeito ao suporte do diálogo e da interação social, ao design da informação, a navegação e ao acesso, centrando-se nos números de erros, velocidade de aprendizagem, produtividade, satisfação dos usuários e outros. "Na prática, a sociabilidade e a usabilidade estão densamente relacionadas. 0 entendimento da interação social informa diretamente o planejamento da sociabilidade e indiretamente influencia em grande parte o design de usabilidade"110 (PREECE, 2001b, p. 394).

As abordagens acima citadas buscam estabelecer a natureza, o caráter e os limites da comunicação e interação online. Para os diferentes autores é ponto pacífico a conexão entre a configuração dos ambientes online e a qualidade interlocução estabelecida a partir deles. Contudo, demonstram não haver consenso quanto a especificidade dos elementos desta configuração que seriam determinantes na constituição desta ou daquela característica de interação, e mesmo de um espaço social online fecundo. Embora alguns pressupostos projetuais sejam recorrentes, como a necessidade de uma efetiva identificação dos interagentes e de regras de procedimentos claras, as lições práticas e as investigações acadêmicas parecem demonstrar que não ha relações causais, e sim estabelecidas a partir de um emaranhado de pontos a considerar dependendo do contexto.

\footnotetext{
110 Tradução da autora. No original: "In practice, sociability and usability are closely related. Knowledge of social interaction directly informs sociability planning and indirectly influences much usability design."
} 
Poder-se-ia discutir aqui outras especificidades dos ambientes virtuais, ou possíveis feições das redes sociais as quais dão suporte. Ou seja, poder-se-ia alinhar as interações sociais mediadas por computador e as características estruturais dos canais, suas imposições e condicionamentos. Destacando, caso a caso, as questões tecnológicas que favorecem e/ou dificultam processos de cooperação, de trocas sociais. Contudo, ainda que devidamente embasados, seja em etnografias, seja em estudos midiáticos e tecnológicos, por mais abrangente que se pudesse ser, estar-se-ia trabalhando em um universo restrito e específico, dado o contexto mutável e as impossibilidades comparativas frente às inúmeras variáveis que o estabelecimento de ambientes virtuais envolve. Apresenta-se a seguir, uma breve incursão desta natureza, complementando e finalizando as discussões a respeito desta temática.

\subsection{Interaçōes sociais e algumas ferramentas especificas}

Como já foi dito, um dos caminhos para verificar o caráter das novas formas de interação social a partir da internet é examiná-las tendo em conta algumas de suas ferramentas de comunicação específicas. Os chats são descritos como um espaço social público, de encontro, ocupado por indivíduos que buscam conversar, conhecer pessoas, trocar idéias, criar amizade, paquerar, e combater sentimentos de solidão. Buscam-se também, por um lado, relacionamentos amorosos mais consistentes, envolvendo namoro e sexo, e por outro, experimentar o sentimento de grupo, de turma. As intencionalidades e propósitos dos freqüentadores dos chats textuais, por exemplo, sejam estes regulares ou eventuais, variam na proporção das diferentes salas temáticas disponíveis, que, no limite, podem indicar a busca de vínculos afetivos ou relações mais efêmeras. Os perfis dos freqüentadores também estão intimamente ligados às suas respectivas condições sociais offline, que determinam suas próprias condições de estarem conectados à rede (DORNELLES, 2004). Além disso, analisar a interação nos chats significa também se debruçar sobre as ações requeridas na comunicação, e nos próprios ambientes 
gráficos, ou seja, nas camadas de apresentação das interfaces, permeadas de metáforas e simulações. A interação nestes ambientes possui lógica própria, estruturada numa dinâmica de conversação, caótica aos menos avisados, que envolve, entre outros, a habilidade e velocidade em teclar e a alternância entre se mostrar e esconder.

Segundo Opazo (2002), nos chats exclusivamente textuais, faltam informações do contexto social comum aos sujeitos envolvidos na interação e não há possibilidades de transmitir ou evidenciar pautas não verbais envolvidas na comunicação, assim como, de estruturar e elaborar discursos. ${ }^{111}$ Estes fatos os diferenciam das interações presenciais, embora sejam comuns a outras formas de comunicação. Por outro lado, a autora assinala que as relações nesses chats obedecem a uma nova forma de reunir sujeitos. Sujeitos que são essencialmente heterogêneos, que possuem uma diversidade cultural, de lugares, e de ideologias, e que interatuam e conhecem outras pessoas com os quais não teriam a possibilidade de fazê-lo em nenhum outro meio direto de comunicação.

Pesquisas indicam ser comum, para grupos mais ou menos estruturados de freqüentadores de chats, a associação entre a vivência online e offline, ou seja, os encontros virtuais freqüentemente podem se alternar com encontros presenciais. Barreira (2004), analisando o universo dos chats, alerta para o vínculo entre os ambientes concretos e virtuais: "as regras, a dinâmica e o tipo de interatividade encontrados na rede são derivados, portanto, da cultura existente fora dela: apresentando suas particularidades, nutre-se sobretudo da existência off-line, estando essencialmente a ela entrelaçada" (BARREIRA, 2004, p.76).

Hoje as ferramentas de chat tridimensionais tornam a comunicação nestes ambientes mais elaboradas. Chamadas, como se viu, de mundos virtuais, permitem interação não só textuais, mas por voz e através

\footnotetext{
111 A ausência de acesso à informação contextual do outro, através de inflexão de voz, dos gestos e posturas, tentam ser supridas com recursos alternativos, como os chamados emoticons, ou mesmo com o emprego de onomatopéias, caracteres que buscam representar expressões faciais, ações físicas e estados de espírito (BARREIRA, 2004; OPAZO, 2002).
} 
da criação objetos e imagens 3D. O Second Life, criado e mantido pela Linden Lab desde 2003, já citado, é uma mistura de jogo, de redes de relacionamentos e de comércio virtual.

Assim como os chats, os comunicadores instantâneos possibilitam a comunicação síncrona, sendo possível ao usuário ser notificado tanto da presença de outros usuários online como da recepção de mensagens em tempo real. Mas diferentemente dos chats, as ferramentas tipo messenger constituemse como espaços privados de interação social na internet, onde prevalece a esfera individual, e cujo objetivo central é mais reforçar relações sociais já estabelecidas ao invés de criar novas relações. Tais sistemas favorecem os encontros entre amigos e familiares, pertencentes a diferentes esferas de interação do indivíduo, mas sempre restritos a um grupo de pessoas autorizadas e selecionadas por ele. De acordo com Gomes e Delfa (2004), as salas de chat têm sido relegadas a um segundo plano no espaço virtual, constituindo-se como meros lugares em que se entra em contato com indivíduos desconhecidos para, posteriormente, em ocasiões próximas, se passar à interação através das ferramentas tipo messenger. Segundo os autores, essas ferramentas permitem certa personalização, através de intervenções dos usuários nos espaços de interação nas interfaces gráficas e mesmo através das modificações das formas de expressão individual, envolvendo nickname, imagem e perfil. Os comunicadores instantâneos estariam menos sujeitos aos fenômenos de interações sociais baseadas em identidades falsas e representações de papéis, mais ligados à configuração de identidades estáveis, embora também possibilitem a criação de identidades múltiplas. Spyer (2007, p.42) compartilha da mesma opinião: "o Orkut e os comunicadores instantâneos tomaram o posto do chat como promotor de relacionamentos, de amizade, de encontro de turmas e também de busca por companhia íntima."

De um modo geral, o que se pode ver é a construção permanente de caminhos para o estabelecimento da sociabilidade na internet baseada na flexibilidade de articulação das relações, espelhadas nas condutas sociais contemporâneas, e no uso social da rede a partir de diferentes ferramentas. 0 permanente desenvolvimento e o aprimoramento das ferramentas de interatividade e interlocução na internet, como se viu, parecem apontar para o caminho contrário ao que leva à falência da vida social 
e ao isolamento. Pelo menos por enquanto, nada indica que a interação social na internet seja responsável por um possível abandono das relações face-a-face em ambientes concretos. Uma tendência acentuada de uso de instrumentos como o e-mail e os comunicadores instantâneos poderia talvez atestar uma certa tendência à interação interpessoal de caráter mais privado, mas o êxito dos blogs e do orkut.com pode contrariar esta tendência, ao privilegiarem as trocas envolvendo um conjunto maior de interlocutores, e a constituição de comunidades. Também um certo isolamento social, e as identidades falsas e representações de papéis parecem minimizadas pelos muitos relatos da articulação entre interação online e física. As interações na internet são parte de redes sociais, instauram-se nos comportamentos e subjetividades da vida cotidiana, alimentando-a, espelhando-a, e transformando-a. Certamente inúmeras respostas neste campo ainda estão por ser dadas, enquanto também muitas questões ainda estão por ser articuladas.

\subsection{Interfaces computacionais de interaçăo comunitaria: um elemento do espaço hibrido}

A conformação de informações em linguagem digital possibilita a criação de uma representação sígnica que pode ser disponibilizada a partir de diferentes suportes, que estão, cada vez mais, integrados. A instalação Suspensión Amodal criada por Rafael Lozano-Hemmer expressa de forma exemplar essa integração. 

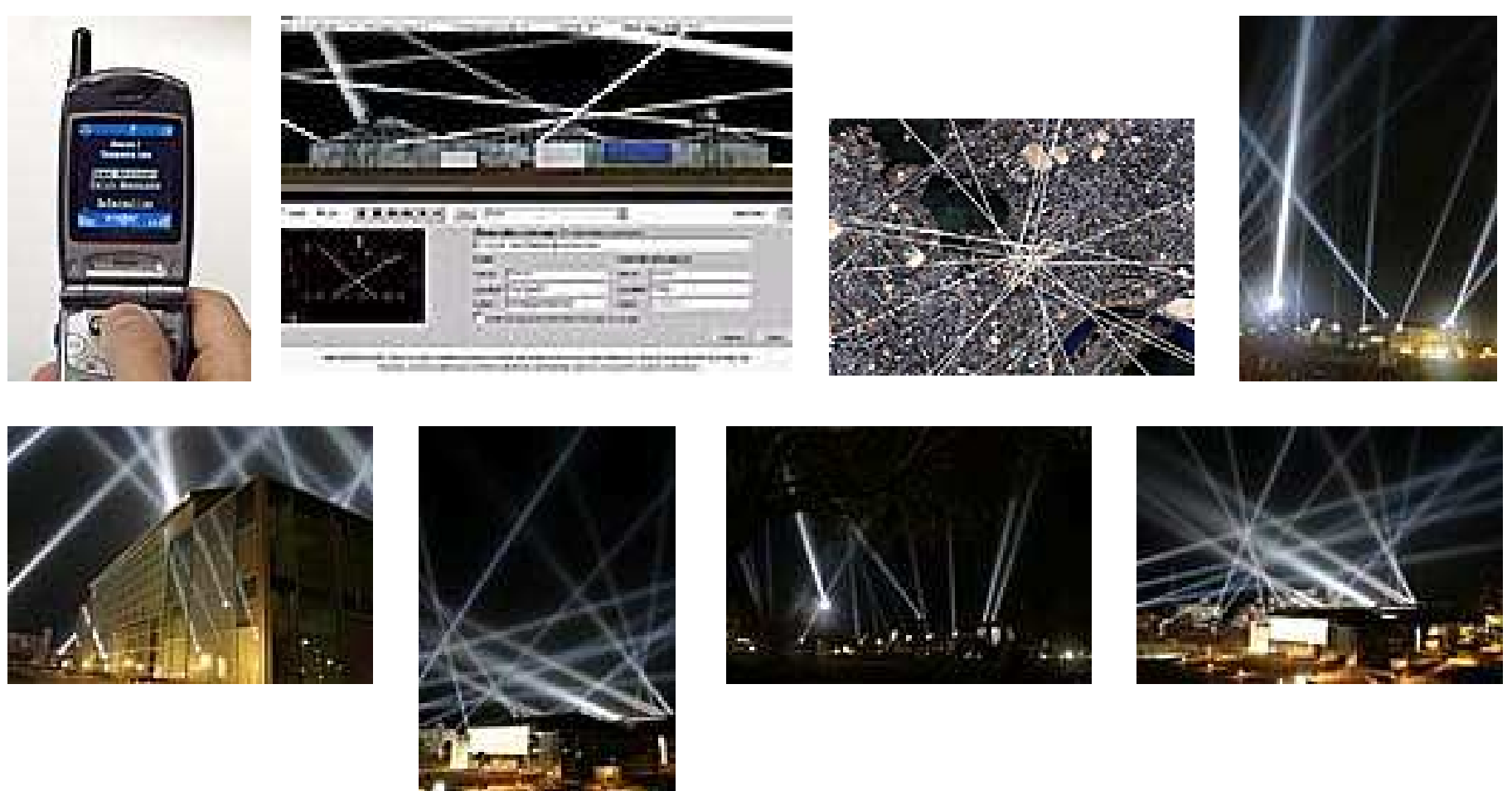

Fig.53-60 Suspensión Amodal Fonte: SUSPENSIÓN AMODAL (2008a, 2008b)

Suspensión Amodal - Arquitectura relacional 8. (Rafael LOZANO-HEMMER; Yamaguchi Center for Art and Media, Japão 2003)

Instalação interativa. Os participantes enviam mensagens curtas pela internet, telefones móveis ou terminais locais que são codificadas em seqüência de luzes projetadas por canhões no céu. A intensidade das luzes é modulada representando diferentes caracteres de texto. As mensagens ficam no céu até que alguém as leia pelo celular ou internet, e assim, são projetadas em um edifício na cidade e se mostram também no site da internet. Segundo o autor, a instalação "[...] criou uma malha interativa de luz sobre a cidade, uma nuvem flutuante de dados que podia ser escrita e lida. A peça era provida de uma plataforma conectada em que residentes locais e participantes remotos de diferentes regiões e países poderiam estabelecer relações ad hoc. Embora tornasse visível o tráfego de informação em uma escala urbana, a peça também foi planejada como um desvio da assumida transparência da comunicação eletrônica"1 (SUSPENSIÓN AMODAL, 2008b).

${ }^{1}$ Tradução da autora. No original: "[...] created an interactive mesh of light over the city, a floating cloud of data that could be written to and read. The piece provided a connective platform in which local residents and remote participants from different regions and countries could establish ad hoc relationships. While visualizing the traffic of information on an urban scale, the piece was also intended as a deviation from the assumed transparency of electronic communication." 
O campo das tecnologias digitais está sujeito a constantes mudanças, como se viu. Impondo, especificamente, uma lógica restritiva ao seu universo analítico. Durante esta pesquisa presenciou-se, por exemplo, a afirmação do cenário da convergência digital, da tendência à mobilidade a partir de diferentes dispositivos, assim como o nascimento do YouTube, a explosão dos blogs e Orkut, sob o pano de fundo das discussões a respeito da implementação da TV digital no Brasil. Estas mudanças implicam diferentes posturas não só no campo das idéias, tornando-se imperativo também nas esferas práticas, como se verá adiante no âmbito do projeto Comunidades_online. 0 exercício realizado aqui de ampliação da visão das interfaces de mediação do universo das TIC é, ainda que um registro instantâneo, de grande valia. Apresenta a dimensão do alcance das interfaces, daquilo que elas são, ou que podem ser. Embora se saiba que, nos projetos e iniciativas práticas, se consiga utilizar, efetivamente, um conjunto de recursos bastante restrito, é importante que se tenha uma noção ampla dos parâmetros norteadores de constituição dessas interfaces, principalmente como auxílio às tomadas de decisões.

As interfaces computacionais de interação comunitária são meios, lugares de contato, estruturados por sistemas lógicos e físicos que não são neutros. Socialmente construídas, carregam em si concepções de mundo, posturas ideológicas, agregam acepções culturais. Interfaces que são apenas janelas estariam associadas a uma crença de que a tecnologia pode desaparecer, e mais ainda, que pode colocar pessoas em contato com a realidade. "O perigo da transparência é que a interface irá mascarar a operação do sistema exatamente quando o usuário necessita ver e entender o que o sistema está fazendo"112 (BOLTER; GROMALA, 2003, p.55). A importância da reflexibilidade residiria na capacidade de fazer os usuários perceberem as maneiras em que as interfaces moldam as experiências, de torná-los conscientes de seus contextos e de potencializar a redefinição dos mesmos.

\footnotetext{
112 Tradução da autora. No original: "The danger of transparency is that the interface will mask the operation of the system exactly when the user needs to see and understand what the system is doing.
} 
É possível perceber, no plano teórico, que as características e configurações das interfaces alteram a qualidade das experiências realizadas a partir delas, enquanto no plano prático, parece difícil que se estabeleça a medida em que isto efetivamente ocorre, e sob quais bases. Sabe-se, por exemplo, que a disponibilidade de banda de conexão à internet determina em grande medida o alcance das experiências que se pode ter a partir das interfaces. Mas há, ainda, um grande caminho a ser percorrido no sentido de se estabelecer parâmetros para as infra-estruturas e as configurações necessárias à sustentação da sociabilidade online. Talvez fosse mais prudente, enquanto um conjunto de evidências empíricas não salte aos olhos, dizer que apenas se pode suspeitar que as interfaces em si exerçam um dos papéis primordiais na constituição de ambientes online de interação social, e que contribuam, de forma significativa, em última instância, para a transformação de indivíduos e coletividade.

Ainda que interfaces e interatividade sejam fundamentais para o estabelecimento de instâncias comunicacionais online, o uso é que determina, atesta e valida este estabelecimento. A busca para que as tecnologias alcancem dimensões socialmente relevantes se dá pelas constantes experimentações e inovações, e também pela consciência de que este processo é guiado, em grande parte, pelas necessidades e desejos das pessoas que se apropriam dessas tecnologias. A tecnologia não tem poder em si, possibilita ou restringe, favorece ou cria obstáculos. Assim, a apropriação de um ambiente virtual comunitário com vínculos estreitos com espaços geográficos delimitados não depende exclusivamente de um design correto, mas também de outras variáveis, entre as quais situam-se as ações de estímulo e incentivo. Uma comunidade online de base local tem como característica distintiva a possibilidade de proximidade física, concreta dos seus membros. Possui uma dimensão offline, de contato face-a-face que não pode, nem deve, ser ignorada. Mais que um simples dado de design, seria pertinente investigar a possibilidade dessas ações presenciais serem constituintes mesmas das interfaces dessa natureza. Seria possível ampliar a noção de interfaces destinadas à interação comunitária local, e assim considerar podem ser estruturadas a partir de ações também realizadas nos espaços concretos (SANTOS; TRAMONTANO, 2006). Uma interface computacional de interação 
comunitária deve ter estrutura aberta e flexível para ser delineada pelos usuários, para abrigar e incorporar conteúdos produzidos a partir de estímulos e ações presentes nos planos offline e online. As trocas entre estes universos são constituintes da construção dos espaços híbridos em fragmentos urbanos. 


\section{EXPERIÊNCIA EM CIDADE TIRADENTES:}

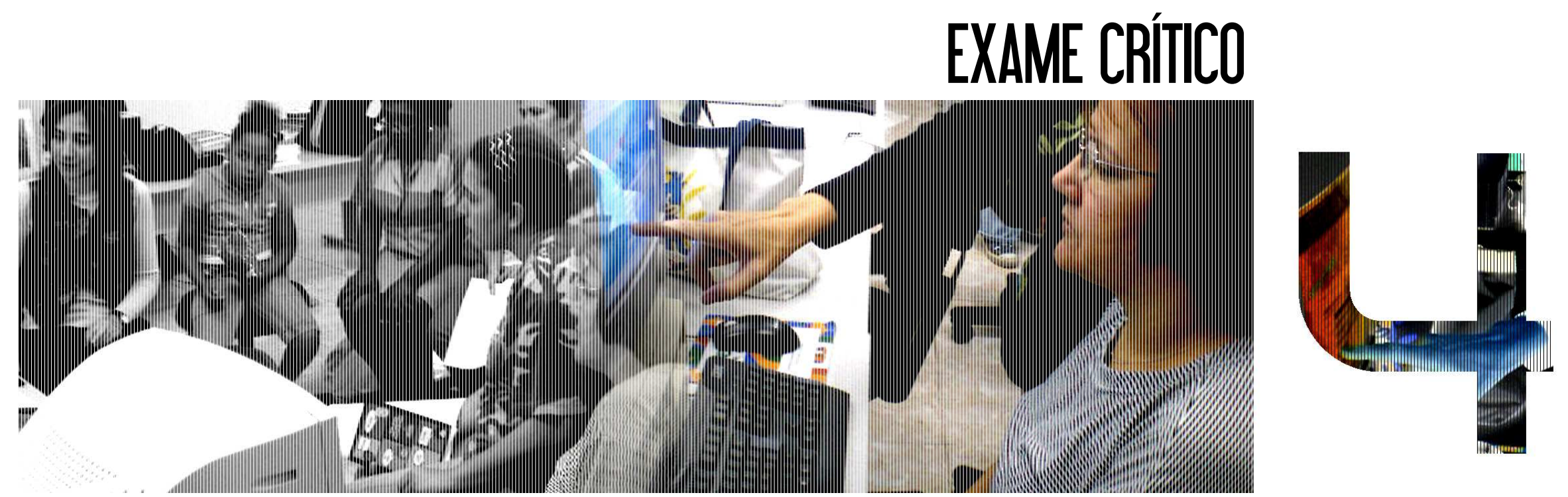


Este capítulo pretende investigar a concepção, desenvolvimento, implantação e resultados da experiência em Cidade Tiradentes, a partir dos recortes temáticos e aportes teóricos apresentados nos capítulos 1, 2, e 3 desta tese ${ }^{1}$. Trata-se da elaboração de um exame crítico, de reflexões sobre a o projeto Comunidades_online, incluindo grande parte do seu percurso, da concepção aos resultados obtidos, tendo como referência o horizonte teórico desenvolvido nas diferentes etapas desta pesquisa.

Apesar de perpassarem esta tese como um todo, as reflexões e análises sobre a experiência em Cidade Tiradentes estão sistematizadas neste capítulo. 0 projeto Comunidades_online: domesticidade $e$ sociabilidade em políticas públicas para inclusão digital, aqui tratado ora como projeto Comunidades_online, ora como projeto COL, se constitui, desde sua concepção, como uma ação abrangente, nasce multidisciplinar, e dentro dele várias frentes procuram se estabelecer. Durante seu desenvolvimento assume diferentes configurações, espelhando avanços e amadurecimentos, alterações sofridas, e mesmo as novas conformações que as tecnologias digitais vinham apresentando.

Como se apresenta na introdução desta tese, as reflexões aqui apresentadas são fruto de estudos teóricos e da participação da autora nas atividades práticas realizadas no âmbito do projeto Comunidades_online. É importante destacar que este projeto foi estruturado como uma pesquisa exploratória de caráter eminentemente executivo e propositivo. Mesmo que dotado de uma instância reflexiva, foi na sua instância executiva, de caráter extremamente prático, que residiram seus desafios e riquezas, e concentram-se basicamente suas atividades. De fato, ainda que muitos resultados desta pesquisa doutoral contribuíram diretamente para traçar os contornos do horizonte teórico do projeto Comunidades_online, como se viu, é importante afirmar que este projeto é muito mais abrangente do que aparece aqui. Um dos principais objetivos do projeto Comunidades_online seria a formulação de políticas públicas. Entretanto, este projeto incluía e priorizava a concepção, produção e teste de

${ }^{1}$ Consideram-se aqui, em especial, as categorias analíticas estabelecidas no capítulo 1 como um pano de fundo para se pensar as diversas questões envolvidas no projeto Comunidades_online, ainda que se apresente sob uma estrutura distinta. 
equipamentos informatizados distintos do computador convencional, o design de infra-estrutura de redes e de conexões concebidas como alternativa a modelos usuais, o projeto de interfaces computacionais para uso comunitário, a renovação de procedimentos metodológicos avaliativos, entre outros, visando justamente a proposição de políticas públicas para o setor habitacional, com estratégias de inclusão digital. Parte dessas questões não é tratada e aprofundada aqui porque se refere a conteúdos que estão além do foco e objetivos desta pesquisa doutoral. Mesmo assim, algumas delas aparecem indiretamente entrelaçadas às questões centrais tratadas aqui, justamente pela natureza de variáveis imbricadas das iniciativas envolvendo o uso das TIC.

As discussões aqui estabelecidas não têm a pretensão de esgotar a análise do projeto Comunidades_online. É uma leitura deste projeto, entre muitas possíveis, que privilegia, em alguns momentos, enxergar os vínculos entre os diferentes aspectos que o envolvem, e, em outros, tratar de algumas questões particulares. Este capítulo está estruturado em duas partes. Uma primeira, que corresponde ao próximo item, tem caráter mais abrangente, busca tecer considerações gerais a cerca do projeto Comunidade_online, envolvendo concepção, estrutura, desenvolvimento, ajustes, e implementação. Uma segunda parte, que corresponde aos dois outros itens do capítulo, estabelece abordagens focadas em aspectos mais específicos. Trata-se, em particular, das questões relativas às parcerias e interfaces, e de estabelecer análises mais conclusivas acerca do projeto. A perspectiva aqui não é retomar na integra todas as discussões estabelecidas nos capítulos anteriores, mas justamente remeter-se a elas no contexto da análise deste projeto em específico, e quando pertinente, apresentar as principais referências de suporte às discussões mencionadas.

Quer-se também proporcionar uma visão panorâmica sobre uma iniciativa envolvendo o uso das TIC, que justamente falta a muitas análises desta natureza. Busca-se, em certo sentido, estabelecer um olhar para diferentes direções, enxergar o todo. Como se disse, a arquitetura é uma disciplina que requer esta habilidade. Requisita exercícios constantes de entrelaçar visões de mundo, modos de vida, comportamentos, diferentes disponibilidades materiais e possibilidade técnicas, na amplitude mesma 
que estas questões podem significar. A construção do espaço, seja ele concreto, virtual ou híbrido, exige esta qualidade.

\subsection{0 projeto Comunidades_online}

O projeto Comunidades_online começou a ser delineado nos primeiros meses do ano de 2003. Busca-se aqui tecer considerações gerais a cerca desse projeto, e dos percursos que trilhou desde a sua concepção, abrangendo suas diferentes fases de desenvolvimento, até sua etapa conclusiva no segundo semestre de 2007. Adota-se, assim, neste trabalho, este período como limite de análise. Ele corresponde ao encerramento de determinadas ações e atividades, de acordo com o planejamento estabelecido junto à FAPESP, sua principal financiadora. Ainda que a experiência continue em curso em Cidade Tiradentes, nesta fase em específico houve, como nos primeiros meses de 2006, o encerramento conclusivo de algumas ações dentro do projeto que, por um lado, possibilitaram a execução de determinadas práticas e, por outro, despontavam em direção a um delineamento de ações futuras.

Não se trata aqui, porém, de tecer um relato minucioso de caráter meramente descritivo. 0 objetivo é construir um exame mais crítico e contextualizado a partir das discussões estabelecidas nos capítulos anteriores dessa tese, que deverão ser aprofundadas nos próximos itens deste capítulo a partir de questões mais específicas. Trata-se de estabelecer uma visão geral sobre este projeto, entretanto circunscrita ao recorte temático desta pesquisa. É importante que se diga que outras reflexões e análises envolvendo este projeto foram e vem sendo realizadas em outras frentes de pesquisas, que se desenvolvem paralelamente em áreas disciplinares distintas. Portanto, estabelece-se aqui algumas reflexões de caráter limitado frente a amplitude de questões que o projeto Comunidades_online suscita 
e envolve O COL reuniu algumas pesquisas de doutorado e mestrado, e várias pesquisas de iniciação científica, alocados em diferentes grupos da Universidade de São Paulo que, juntos, levaram a cabo o projeto. Além do Nomads.usp da Escola de Engenharia de São Carlos, principal idealizador e responsável pelo projeto Comunidades_online, participaram também o LSI - Laboratório de Sistemas Integráveis da Escola Politécnica, o NUTAU - Núcleo de Pesquisa em Tecnologia da Arquitetura e Urbanismo da Faculdade de Arquitetura e Urbanismo, e o Intermídia do Instituto de Ciências Matemáticas e de Computação.

\subsection{Concepç̧̃o do projeto}

O projeto Comunidades_online foi idealizado por pesquisadores acadêmicos, para ser desenvolvido a partir de diferentes parcerias. Nasce, entretanto, no âmbito disciplinar da Arquitetura e Urbanismo, tendo como um dos seus objetivos principais verificar as possíveis transformações a partir da introdução de instâncias virtuais de comunicação e interação na vida cotidiana de comunidades locais, observando o alcance das implicações espaciais, no domínio das habitações e seus entornos, e na sociabilidade. Teve também, desde o início, como meta, ser uma experiência voltada à inclusão digital, no sentido aqui considerado. Propostas de realização de uma experiência prática em uma comunidade de baixa renda, com um campo de experimentação de inclusão digital, envolvendo uma equipe multidisciplinar de pesquisadores, foram informalmente formuladas com grupos de pesquisas de áreas distintas da Arquitetura que tinham interesses em montar um projeto conjunto. Dentre outras, havia premissas de testar equipamentos informatizados inovadores de baixo custo, interfaces gráficas colaborativas e de testar e aplicar novos métodos avaliativos.

O escopo do projeto se concretizou em um plano de pesquisa incorporado na linha de políticas públicas da FAPESP, considerada um dos principais órgãos de fomento à pesquisa do Brasil, e veio de encontro 
ao interesse explícito do projeto de se estruturar no formato de uma política pública que pudesse ser adotada e replicada em âmbito governamental. ${ }^{2} 0$ projeto Comunidades_online estruturou-se como uma pesquisa acadêmica que deveria se desdobrar em uma prática de política pública, e neste sentido, além da universidade, existiam outras instâncias governamentais envolvidas com a sua execução e futuros desdobramentos. ${ }^{3}$

Desde o início trabalhou-se, nesse projeto, a partir da hipótese de que a inserção e uso das tecnologias de informação e comunicação na vida cotidiana das pessoas em uma comunidade, a partir do espaço doméstico, cria e altera níveis de sociabilidade e, provoca modificações na apropriação dos espaços concretos, sejam eles privados ou coletivos. Pretendia-se entender as implicações da implantação de uma esfera de comunicação virtual em um certo recorte de espaço físico, refletindo como este outro locus de sociabilidade poderia alterar comportamentos, e assim, os espaços de habitar. Para a verificação desta proposição buscou-se utilizar uma série de mecanismos metodológicos, sendo o principal deles a realização de uma experiência prática, ou seja, uma pesquisa de campo, empírica, com a implantação de uma instância virtual de comunicação e interação em uma pequena parcela do distrito paulistano Cidade Tiradentes. ${ }^{4}$

\footnotetext{
${ }^{2}$ É preciso salientar que o projeto Comunidades_online nasce formalmente sob a influência direta de seu principal órgão de fomento, a FAPESP, e que seu desenvolvimento esteve, muitas vezes, atrelado às requisições deste órgão.

${ }^{3}$ A COHAB-SP Companhia Metropolitana de Habitação de São Paulo, que tem como uma de suas principais atividades o projeto e implantação de habitações de interesse social na cidade de São Paulo e a CGE - Coordenadoria do Governo Eletrônico da Prefeitura de São Paulo, que atuava na implantação de telecentros, figuraram entre os diversos parceiros do projeto Comunidades_online. (Inclusive, nesta época inicial, estas duas entidades mantinham uma parceria para a implantação de telecentros.) A idéia primeira do projeto era pensar na possibilidade de uma política pública voltada ao oferecimento de equipamentos computadorizados de baixo custo que disponibilizassem o acesso à internet a partir das moradias. Tais custos seriam embutidos no financiamento habitacional, distribuindo o pagamento por um período de, pelo menos, quinze anos. A perspectiva era considerar o acesso à informação uma necessidade de importância equivalente ao abastecimento de água e conexão a redes de esgoto.

${ }^{4}$ Fazia parte do quadro metodológico do projeto Comunidades_online também a consulta a fontes de dados secundárias, através de revisões bibliográficas para uma gama extensa de temas correlacionados, associados a áreas disciplinares distintas;
} 
O projeto Comunidades_online possui uma natureza bastante complexa porque procurou abarcar, em uma só iniciativa, várias frentes e ações de promoção do uso das tecnologias digitais. Esta característica o diferencia de um número significativo de projetos e iniciativas envolvendo o uso das TIC, principalmente daquelas voltadas a impulsionar a inclusão digital. Como se viu no capítulo 1 desta tese, é comum que iniciativas desta natureza estejam centradas em alguns aspectos específicos, como por exemplo, na provisão de acesso físico a equipamentos e conexão a internet, ou no ensino do uso de aplicativos e programas (MOSSBERGER; TOLBERT; STANBURY, 2003; SERVON, 2002; WARSCHAUER, 2006). Desde sua concepção, o projeto Comunidades_online pretendia se estabelecer como uma ação abrangente. Assumia igual importância no âmbito deste projeto o acesso domiciliar as TIC a partir de interfaces computacionais apropriadas a realidade socioeconômica em questão, a qualidade dos recursos a serem disponibilizados, e as maneiras de envolvimento das pessoas e comunidade na construção dessa experiência. Neste sentido, os instrumentos tecnológicos lógicos e físicos deveriam ser repensados frente às soluções comumente adotadas, e os recursos associados às TIC deveriam romper a barreira da instumentalização para o uso e estarem inseridos na vida cotidiana das pessoas e comunidade, fazendo parte de suas narrativas, associados a uma melhoria na qualidade de vida.

Durante os anos de desenvolvimento e implantação do projeto Comunidades_online, como se vê a seguir, seus objetivos não mudaram. Entretanto, na medida em que o projeto tomava corpo, e que se revelava sua real amplitude, impunham-se algumas limitações em relação aos alcances possíveis das verificações propostas. Durante o período aqui considerado não foi possível tecer reflexões específicas a respeito dos efeitos das TIC nos espaços concretos da comunidade, e também a respeito da sociabilidade no recorte local definido. Entretanto, consolidava-se, com o passar do tempo, entre outros, as evidências quanto as qualidades das ações necessárias junto à comunidade para povoar ambientes virtuais e trazer a realidade das TIC ao seu cotidiano, a complexidade e implicações da

a consulta a fontes de dados primárias, a partir de contatos e visitas a outros projetos e iniciativas similares; e o desenvolvimento de uma interface computacional a ser utilizada como suporte para o ambiente virtual, entre outros. 
construção de uma interface computacional, e a certeza de que é pertinente considerar que a construção de espaços híbridos também faz parte do escopo das atribuições dos arquitetos, como aponta a parte conclusiva dessa tese.

\section{Cidade Tiradentes}

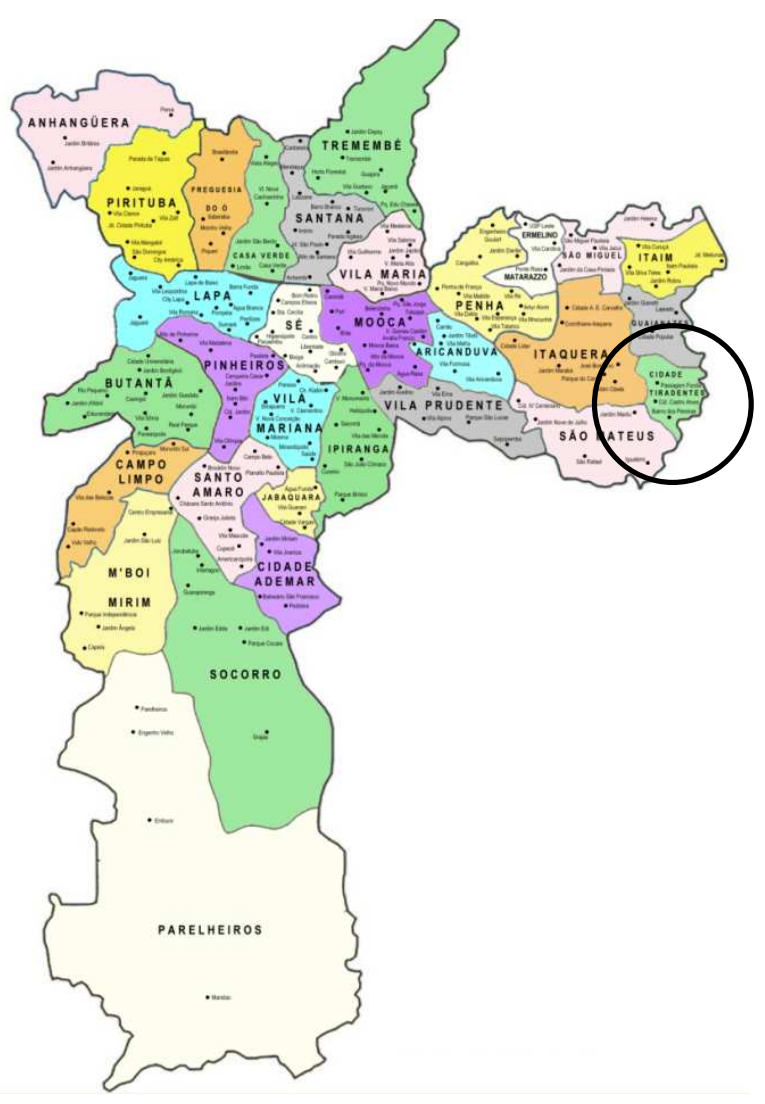

Fig. 1 Divisão política do município de São Paulo Fonte: DIVISÃO (2008) 
A área de intervenção do projeto COL é o distrito de Cidade Tiradentes, que fica no extremo leste da cidade de São Paulo, como indica o mapa acima, e que tem sido alvo das atenções do governo municipal há pelo menos duas gestões ${ }^{5}$ por apresentar indicadores socioeconômicos críticos, como um dos menores IDH - Índice de Desenvolvimento Humano ${ }^{6}$ da cidade. Trata-se de uma região que apresenta um grau extremo de exclusão socioeconômica, e carências também em duas frentes, habitacional e urbana (PEDROSO, 2003; USINA, 2003). Estes governos, cada qual a seu modo, têm buscado consolidar uma nova perspectiva de ação pública no distrito. Durante estes anos de pesquisa se presenciou, no entorno da área de intervenção do projeto Comunidades_online, por exemplo, a implantação de alguns equipamentos públicos, a ocupação de espaços vazios com praças e parques, e uma melhoria no acesso a transportes públicos. ${ }^{7}$

Local escolhido para a implantação do primeiro telecentro da cidade de São Paulo, o distrito de Cidade Tiradentes concentra um grande complexo de conjuntos habitacionais. Sua ocupação formal se deu a partir dos anos 1970, com a construção gradativa pelo Estado e 40 mil unidades habitacionais. ${ }^{8}$ Por trás de uma aparente homogeneidade, o distrito possui uma diversidade no campo habitacional. Encontramse no local, além dos diversos conjuntos patrocinados pelo poder público, a ocupação informal, com favelas e loteamentos clandestinos e irregulares. Caracterizam também Cidade Tiradentes as grandes áreas vazias remanescentes em meio ao ambiente construído impróprias para ocupação habitacional, a maioria delas pertencentes ao poder público. Sua situação geográfica determina, em conjunto com

\footnotetext{
${ }^{5}$ Primeiro com a gestão da prefeita Marta Suplicy, entre 2001 a 2004, depois com a atual gestão, que teve à frente José Serra do início de 2005 a maio de 2006, e Gilberto Kassab desde então.

${ }^{6}$ Índice definido pela ONU, cuja referência maior é 1. Em 2000, o índice de Cidade Tiradentes era 0,68 (PEDROSO, 2003).

${ }^{7}$ Não se sabe, porém, se tais ações aconteceram também em outras áreas do distrito, e mesmo quais os desdobramentos frente a este contexto de amplas carências. Neste período, na região próxima a área de intervenção do projeto Comunidades_online foram implantados um CEU - Centro Educacional Unificado, o Hospital Municipal Cidade Tiradentes e a Escola Técnica de Saúde Pública Cidade Tiradentes. Notou-se também a abertura de inúmeros estabelecimentos voltados ao comércio e prestação de serviços.

${ }^{8}$ Possui uma população estimada em 220 mil habitantes, com predominância de jovens de até 24 anos, e ocupa uma área de 15 $\mathrm{km}^{2}$. Só a população estimada que habita os conjuntos habitacionais é de 150 mil pessoas (USINA, 2003).
} 
outros fatores, seu aspecto de bairro dormitório, com uma população que submete-se à dinâmica de deslocamentos diários para outras regiões da cidade, ainda que privada de ligação própria com transportes de massa, como trem e metrô.

A situação da falta de emprego local é expressiva, e em parte, fruto da constituição do distrito como bairro-dormitório, sendo marcante a pouca quantidade de estabelecimentos industriais, comerciais, e de serviços na área. Em Cidade Tiradentes a maioria das atividades comercias possui caráter informal e programas sociais governamentais de complementação de renda atingem uma porção significativa da população. Os números sobre o distrito, sejam eles relativos à área da saúde, educação ou segurança, por exemplo, ou relacionados à renda e analfabetismo, demonstram o grau de precariedade dos serviços oferecidos à população, reafirmando a baixa qualidade de vida a qual seus moradores estão submetidos (USINA, 2003). Destaca-se a presença de uma centena de entidades e associações, patrocinadoras de projetos de diversas naturezas, que muitas vezes, de forma assistencialista, buscam minimizar a ausência da atuação do poder público na região, ainda muito marcante. A violência e a insegurança fazem parte do cotidiano da população, como de praxe em toda região carente em amplo sentido. É certo que o estigma de bairro violento, alimentado muitas vezes pela mídia, instaura mais um revés na vida cotidiana de seus moradores.

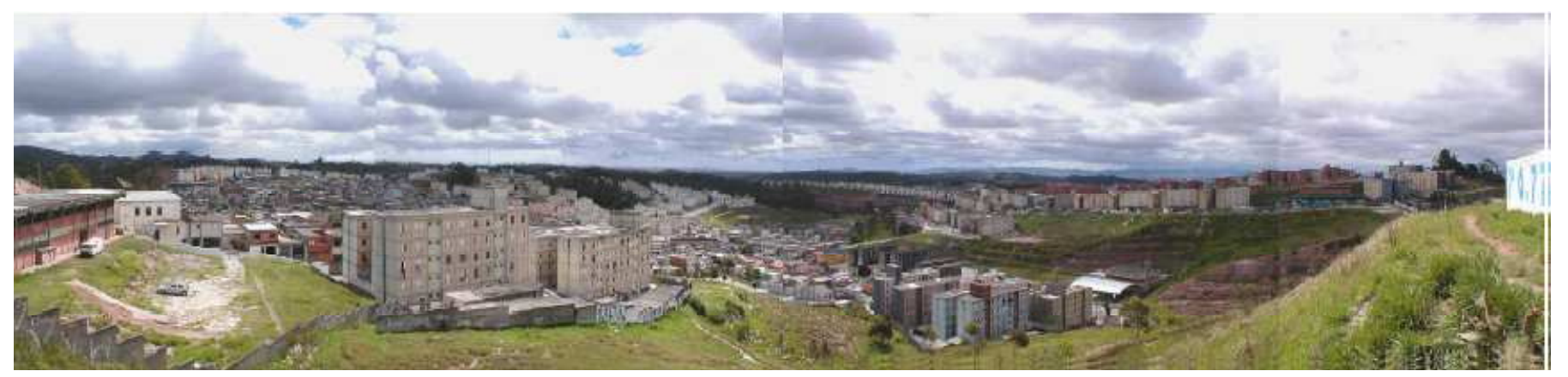

Fig. 2 Vista de Cidade Tiradentes Fonte: USINA (2003) 


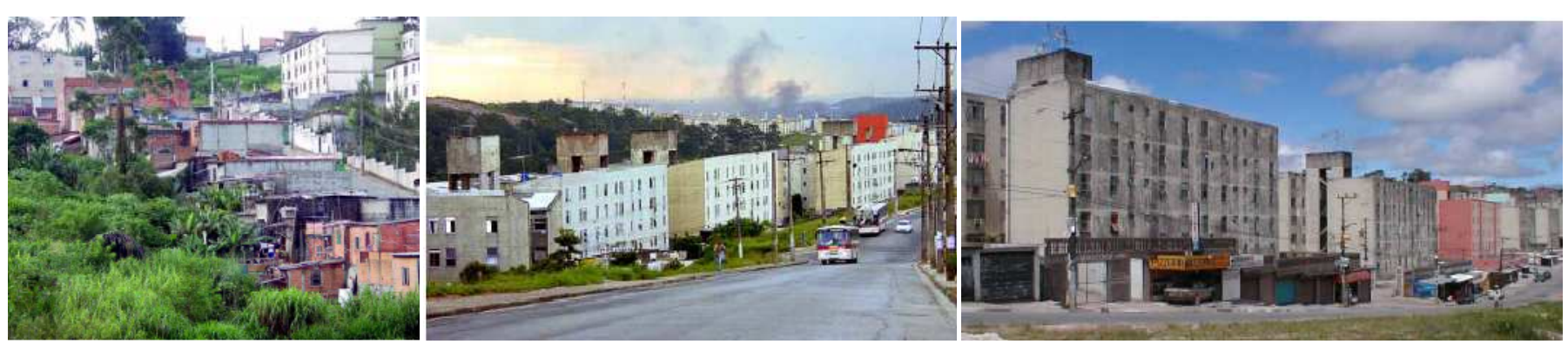

Fig. 3-5 Vistas de Cidade Tiradentes Fonte: USINA (2003)

Alguns aspectos revelados a partir da caracterização realizada no projeto Comunidade_online, citada a seguir, reafirmam estes dados, destacando, por exemplo, que a ampla maioria dos entrevistados tem, na área de intervenção do projeto, renda mensal entre um e cinco salários mínimos.

\section{Proposiç̄es, objetivos e disponibilizaç̄oo de recursos envolvendo IC}

Uma das principais questões que envolveram o projeto Comunidades_online desde a sua concepção foi qual seria a configuração da instância virtual a ser implantada, ou seja, como se conformaria o ambiente virtual a ser disponibilizado em Cidade Tiradentes. Para além do oferecimento de equipamentos e conexão, o cerne do projeto COL era fornecer meios que possibilitassem e permitissem a estruturação de um espaço virtual de comunicação em uma parcela de Cidade Tiradentes, no qual as pessoas também pudessem interagir. 0 objetivo do projeto Comunidades_online era dar às pessoas residentes na área de intervenção da pesquisa a possibilidade de interagirem também a partir de numa instância virtual e assim ampliar seus horizontes de interação social.

A princípio, pretendeu-se organizar e articular uma instância virtual em Cidade Tiradentes sob a forma de uma rede que integraria diferentes atores, ações e conteúdos. Chamou-se rede ao conjunto de recursos que seriam dispostos, ou seja, a forma de estabelecimento de conteúdos e práticas 
comunicacionais no ambiente virtual. Sabia-se, desde o início, que se queria evitar o formato que grande parte das experiências e projetos TIC adotavam até então, que era estruturar a instância virtual da comunidade a partir de um web site tipo portal comunitário, com o oferecimento de informações, alguns serviços específicos e ferramentas de comunicação como fóruns de discussão, chats, lista de $e$ mails. ${ }^{9}$ o desejo era testar outras possibilidades, principalmente no sentido do estabelecimento de práticas colaborativas de produção de conteúdo.

É importante que se diga que em 2003 a produção de conteúdo no contexto da internet brasileira era ainda possível somente para aqueles que tinham conhecimentos avançados na área de informática. Ferramentas como blogs eram pouco conhecidas e utilizadas. Estava-se também em um outro estágio de desenvolvimento da internet com relação a velocidade do tráfego de informações. As conexões discadas (dial-up) continuavam a ser substituídas por conexões banda larga tipo $\operatorname{ADSL}^{10}$ ou wireless, para um público cada vez maior, mas ainda muito restrito.

A configuração e elaboração da rede do projeto COL envolvia um desenvolvimento conceitual agregado à compatibilização dos dispositivos físicos e lógicos também em discussão. Isso incluia, entre outros, a arquitetura de software, o design específico das camadas de apresentação, e todos os requisitos operacionais do ambiente virtual, incluindo aí a configuração do terminal de acesso a ser utilizado, as conexões disponíveis. Assim, o desenvolvimento da rede acontecia entrelaçado a tomadas de decisões quanto a configuração dos equipamentos, dos software e conexão a serem utilizados em Cidade Tiradentes. Neste sentido, a concepção da rede do projeto Comunidades_online se estabelecia na discussão da própria constituição da interface que daria suporte ao ambiente virtual, que se transforma a medida que a pesquisa avançava em qualquer uma dessas diferentes frentes de ações.

\footnotetext{
${ }^{9}$ Como o fazem, por exemplo, os projetos de Camfield Estate; Blacksburg Electronic Village e Helsinki Virtual Village.

${ }^{10}$ ADSL (Assymetrical Digital Subscriber Line) é uma tecnologia que utiliza linha telefônica digital para tráfego de dados em banda larga, ou seja, com capacidade de transmitir grande quantidade de informação durante uma unidade de tempo.
} 
No início da pesquisa não estava claro que as discussões em torno do que na época chamava-se rede também era uma discussão sobre interface. Há aqui duas questões. Primeiro, uma concepção ampla de interface não estava ainda amadurecida no âmbito do projeto, tal qual se apresenta nas reflexões do capítulo anterior, considerando-a, entre outros, a partir de uma determinada materialidade, e também de um ponto de vista de superfície de contato, de ambiente múltiplo de comunicação, de suporte de linguagens com atribuições simbólicas (BOLTER; GROMALA, 2003; JOHNSON, 2001; LÉVY, 2001; MANOVICH, 2002). Segundo, naquele momento, e também em outros como se verá, havia uma fragmentação de atribuições de aspectos que envolviam a criação do ambiente virtual. Trabalhava-se, em separado, nos diferentes grupos de pesquisa, no desenvolvimento de equipamentos, dos software e na concepção dos recursos a serem disponibilizados, ainda que se tivesse consciência da natureza de independência destas ações. Minimizar esta dificuldade, em parte característica ao trabalho interdisciplinar, foi um dos principais desafios do projeto $\mathrm{COL}$, sob o qual se debruça mais atentamente adiante.

Podem-se delimitar diferentes versões para a constituição dos requisitos da interface de suporte ao ambiente virtual de interação de Cidade Tiradentes, instituídas em estágios e fases distintas de desenvolvimento do projeto Comunidades_online.

\subsection{Diferentes momentos do projeto Comunidades_online}

O que se apresenta abaixo é uma síntese das principais questões envolvidas no processo de constituição das diferentes fases do projeto COL. O objetivo é considerar a natureza das alterações que se processaram até se chegar às ações implantadas em Cidade Tiradentes. 


\section{As primeiras idéias e atividades}

A primeira versão para a interface do projeto COL fundamentava-se nas interações existentes na vida cotidiana das pessoas da comunidade. 0 foco, naquele momento, esteve voltado a conhecer a comunidade local, suas características e particularidades, a fim de adequar o formato da interface às necessidades identificadas como importantes. Os atores principais seriam os residentes da área de intervenção, os estabelecimentos comerciais, as instituições públicas e associações locais. Buscava-se acrescentar facilidades ao dia-a-dia e criar novas ferramentas de diálogo na comunidade, estendendoas a um universo amplo de interlocutores, envolvendo também o adensamento de fluxos de informação, impossíveis através de outros meios. A interface do projeto Comunidades_online deveria contemplar a integração de diversas bases de dados pertencentes a várias instâncias participativas das pessoas no seu universo cotidiano, entre outras, aquelas voltadas a saúde, educação, direitos, cultura, lazer. Pretendia-se criar para as pessoas uma nova possibilidade de apreensão de sua realidade, de forma que todas as camadas de interações no universo cotidiano fossem reunidas em um ambiente virtual específico. A interface do projeto $\mathrm{COL}$, neste momento, era estruturada como uma interface integradora de bases de dados, com informações e serviços a serem disponibilizados. ${ }^{11}$ Era concebida a partir do indivíduo, se estruturava a partir de identidades pessoais. Deveria ser customizável ${ }^{12}$, proporcionar a visualização das redes de interação de cada pessoa no ambiente virtual e também oferecer possibilidades de geração de renda.

Neste momento pensava-se que a participação nesta instância virtual de interação deveria estar vinculada à utilidade, para que depois se situasse na criação e na troca de conteúdos, e também, se

\footnotetext{
11 Ou seja, os conteúdos e alguns serviços propostos estariam vinculados ou disponíveis a partir de bancos de dados pertencentes a instituições públicas, associações não governamentais e estabelecimentos comerciais que atuam na área de intervenção da pesquisa, podendo alguns dos serviços propostos serem acessados por meio de links.

${ }^{12}$ Customizar é um termo que não aparece ainda nos dicionários oficiais da língua portuguesa, e significa, grosso modo, alterar segundo especificações individuais. Trata-se de um aportuguesamento, que tem como origem o termo inglês customer, que significa cliente.
} 
possível, na geração de renda. As pessoas é que traçariam seus perfis de interação e gerariam seus padrões de relacionamento nessa comunidade virtual de base local. Estes poderiam ter um caráter mais funcional e público, ou seja, estariam ancorados principalmente nos serviços oferecidos e nas possibilidades de geração de renda, e poderiam também estar mais ligados à vida íntima, privada, ou ao entretenimento e lazer.

Percebe-se aqui uma nítida intenção de ancorar as diversas atividades cotidianas das pessoas no ambiente virtual, como um caminho para que este ambiente alcance dimensões socialmente relevantes e seja apropriado. De forma gradativa, como se verá, esta idéia foi sendo descartada por diferentes motivos, entre eles pelas dificuldades técnicas e mesmo burocráticas de se reunir e conectar diferentes bancos de dados pertencentes a instituições diferentes, pelo porte dos equipamentos e conexão a internet necessários para se manipular ambientes com estas características, pelo esforço enorme que geraria em termos de tempo de programação, ultrapassando o período previsto para tal, entre outros. Entretanto, percebe-se agora, que figuram entre as principais razões deste abandono a constatação de que, tal qual as instâncias presenciais de interação, não se tem reunido em um único lugar todas as dimensões da vida, e ainda mais, que era importante garantir um outro espaço comunicacional. Este espaço de trocas em si traria as possibilidades de provisão de recursos, as benesses e as transformações pretendidas.

\section{Telecentro, equipamentos e conexão}

No âmbito do projeto Comunidades_online as questões relacionadas aos equipamentos e à conexão a internet foram pensadas de forma ampliada, em conjunto com outras frentes e ações. A provisão de equipamentos e conexão banda larga para acesso privado nas habitações era um dos objetivos da pesquisa, assim como repensar e redesenhar o papel do telecentro como estrutura de acesso coletivo as 
TIC. Buscava-se também, por um lado, rediscutir a primazia do computador entre os equipamentos informatizados destinados a ações inclusivas de populações de baixa renda, através de pesquisas, testes e utilização de terminais de acesso de baixo custo tipo set-top box. Tais equipamentos estavam sendo projetados em alguns centros de pesquisa, inclusive no LSI, parceiro no projeto COL, principalmente visando a implementação da TV digital no Brasil que viria acontecer poucos anos depois do início do projeto, em 2007. ${ }^{13}$ Por outro lado, a idéia era que o telecentro funcionasse como provedor de acesso a internet para as moradias da área de intervenção que recebessem os equipamentos informatizados, além de ser o local onde se estabeleceriam as relações presenciais entre os possíveis interagentes da instância virtual, e também onde deveriam ser realizadas atividades voltadas a aprendizagem de uso das tecnologias digitais. ${ }^{14} 0$ telecentro sempre foi pensado como âncora para as ações que deveriam ser estabelecidas no ambiente virtual.

Paralela às discussões sobre as especificações dos equipamentos, a qualidade técnica da infra-estrutura que estenderia a conexão da internet do telecentro às moradias, uma segunda versão da interface foi estabelecida, a partir de um desdobramento da primeira. Mantidas as mesmas características acima assinaladas, operou-se uma sistematização e sintetização de funções. A interface passou a ser pensada a partir de três planos de atuações: [1] o cidadão online, [2] informações permanentes e temporárias e [3] lugares de comunicação. Ou seja, espelharia os contextos diversos da vida diária das pessoas, seria um novo locus de comunicação, estaria disponível por meio de uma interface integradora de banco de dados, customizável, e que possibilitasse as pessoas a perceberem a si mesmas no âmbito da comunidade.

\footnotetext{
${ }^{13}$ A pesquisa realizada pelo LSI sobre os terminais de acesso procurava conjugar esforços para atingir um duplo objetivo: produzir os terminais necessários ao projeto Comunidades_online e definir o padrão do terminal de tipo 'inclusão digital' , previsto no projeto brasileiro de TV Digital. Esse projeto mobilizou, como se sabe, diversas equipes em várias universidades brasileiras, trabalhando em consórcios, ligadas a empresas com evidentes interesses comerciais.

${ }^{14}$ O telecentro vinculado ao projeto Comunidades_online é, desde 2006, o do projeto Casa Brasil, do Governo Federal, que está alocado em Cidade Tiradentes no Centro Cultural Arte em Construção do Instituto Pombas Urbanas, parceiro do projeto. No início, entretanto, a idéia era trabalhar com o Telecentro Cidade Tiradentes, o primeiro telecentro implantado pelo Governo Eletrônico da Prefeitura Municipal de São Paulo.
} 
O que se chama aqui de terceira versão da interface nada mais foi do que uma tentativa de verificação de possibilidades e definição de estratégias, a partir da junção de um conjunto resumido dos requisitos anteriormente definidos, com os pressupostos de hardware e software pré-estabelecidos até então. Seriam implementadas ações em instâncias virtuais a partir de quatro ambientes, ou funcionalidades. Uma primeira, pessoal, relativa a esfera de sociabilidade entre as pessoas, a comunicação síncrona, ao espaço de diálogo a partir de diferentes identidades. Trata-se de uma instância de encontros onde os interagentes deveriam perceber-se como parte de uma rede social. A segunda contemplava as necessidades de comércio eletrônico, através da comunicação assíncrona e disponibilização de aplicativos. A terceira buscava prover serviços de interesse comunitário, através de comunicação assíncrona e acesso a banco de dados. A quarta era focada na comunidade, em ações no telecentro instituído como espaço de convívio e estímulo às atividades coletivas a partir de oficinas com a população local e ações de upload. Queria-se testar e verificar preliminarmente quais os desempenhos desta interface, redimensionar, se necessário, requisitos, equipamentos e conexões. Tratava-se de uma etapa de trabalho intermediária, cujo objetivo era testar diversas idéias em relação a diferentes aspectos da interface, e do projeto, ou seja, da arquitetura do sistema, princípios de interação, às necessidades da infra-estrutura de conexão, à configuração e desempenho dos terminais de acesso, passando pelas atividades presenciais no telecentro. A idéia era realizar essa fase de testes, incluindo discussões a respeito de questões de viabilidade técnica e de custos. Por uma série de motivos esta verificação não foi possível. Entretanto, algumas das idéias aqui formuladas foram incorporadas nos ajustes e alterações que o projeto sofreu em relação às suas propostas iniciais, a partir dos primeiros meses de 2006.

\section{djustes e alteraçōes}

As alterações sofridas no âmbito do projeto Comunidades_online explicam-se principalmente em função de acontecimentos externos que foram enviesando seus objetivos, fora da alçada deste próprio. Foram 
acontecimentos que ocorreram sobretudo nas esferas políticas municipal e federal, causando o esfriamento da relação com a COHAB-SP e a Coordenadoria do Governo Eletrônico, parceiros iniciais do projeto, e a diminuição do interesse público pelo projeto do terminal de acesso (set-top box), respectivamente. ${ }^{15}$ Ainda que representassem contratempos, o desafio não-previsto de superá-los ajudou a consolidar alguns aspectos importantes do próprio projeto, como se vê a seguir. É importante lembrar que essas alterações não foram estanques, mas encontraram-se inter-relacionadas, afetando-se umas às outras. Ficou claro, neste momento do projeto, que a constituição de políticas públicas devem independer das afiliações partidárias que se tornam responsáveis temporariamente pela gestão pública. Deve-se precaver das vicissitudes políticas, como destacado oportunamente.

O projeto Comunidades_online, a partir de então, passa a configurar-se de forma diferente, espelhando os avanços e amadurecimento da pesquisa, e também as novas configurações que a comunicação via internet vinha apresentando durante aquele período. 0 requisito primeiro para a interface era que se estruturasse como um repositório de conteúdos. A partir de alguns contextos propostos, que funcionariam como espaços temáticos, todas as informações e conteúdos seriam inseridas pelos usuários. Abandona-se a idéia de trabalhar com banco de dados, de gerenciar informações a respeito das pessoas nos seus diversos campos de atuação cotidiana, para somente propor que se crie um ambiente de upload e dowload de informações e documentos criados pelos próprios usuários, de acordo com seus desejos e necessidades. Trata-se de uma mudança significativa, uma aparente simplificação que opera um avanço exemplar. Procura-se dar voz direta aos potenciais usuários e abrir-lhes a possibilidade de construção de um ambiente virtual de interação de forma ainda mais colaborativa. A

\footnotetext{
${ }^{15}$ A produção dos terminais de acesso estava ligada ao desenvolvimento do padrão de referência (protocolo) brasileiro de TV digital, ou Sistema Brasileiro de TV Digital (SBTVD). A decisão do governo federal de designar o padrão japonês como prioritário para a exploração da TV digital no Brasil, e sua manifestação em seguida também em favor do padrão europeu, esvaziou em muito o interesse sobre a pesquisa brasileira de terminais de acesso. A equipe do projeto Comunidades_online, e em particular, do LSI, viram-se diante de uma grande e repentina dificuldade: encontrar parceiros interessados em produzir a grande quantidade de terminais prevista no projeto, arcando com seus custos. A Intel, parceira possivelmente disponível, encontrava-se agora com outros interesses.
} 
estrutura, até então proposta, pressupunha o oferecimento de algo pronto a ser utilizado, um modelo pré-estabelecido e estratificado no qual os usuários teriam que encaixar sua interação virtual.

A partir do exame de outras experiências envolvendo o uso das TIC, principalmente do projeto exemplar de alfabetização digital desenvolvido nos Novos Centros de Conhecimento de Extremadura, apresentado em diferentes partes desta tese, passou-se a discutir, de forma aprofundada, a respeito da natureza dos vínculos pretendidos e possíveis entre as pessoas da comunidade local e o ambiente virtual a ser criado. Trilhando um caminho parecido ao da experiência espanhola, a idéia era fazer com que as tecnologias de informação e comunicação fizessem parte das narrativas cotidianas das pessoas, desse voz direta a essas pessoas, criasse espaços para que a própria comunidade se manifestasse de acordo com suas demandas.

Tendo como horizonte as diretrizes acima destacadas, estabeleceu-se como requisito para a interface do projeto COL que esta não deveria ser estruturada a priori, isto é, que seria importante não direcionar conteúdos, e sim propiciar meios para que a comunidade pudesse produzir os conteúdos que lhe conviesse, que espelhassem seus interesses, sem uma intervenção muito impositiva. Abdicou-se da postura de porta-vozes para dar voz direta aos cidadãos da comunidade. Como foi dito, para que as primeiras ações na rede não ficassem soltas, houve a sugestão de criar no ambiente virtual alguns contextos temáticos como aglutinadores dos conteúdos produzidos, que poderiam ser mantidos, substituídos ou excluídos. Está se propondo neste momento no projeto Comunidades_online a criação do ambiente virtual que funcione como repositório de conteúdo, com alguns contextos préestabelecidos, a partir de uma interface amplamente flexível que permita expressar um outtro espaço da comunidade, o virtual, gerado a partir dos conteúdos criados por esta própria comunidade. Ofereceria-se agora uma base, uma estrutura.

Algumas idéias desenvolvidas nos modelos anteriores de interface deveriam se manter, como as possibilidades de customização, ou seja, cada usuário teria no seu ambiente virtual elementos que 
expressem somente a sua interação, que é diferente da dos demais. Isto seria possível pelo uso personalizado de ferramentas de dowload e da ativação ou não de determinados contextos no seu ambiente de interação, entre outros. A idéia de que cada usuário perceba a si mesmo na totalidade da rede, que perceba quem ele é dentro da comunidade, permanece, como proposto desde o início do projeto, e seria buscado pelo design gráfico das camadas de apresentação dos sistemas implementados.

Destaca-se, nesta fase de desenvolvimento da interface, uma mudança significativa que dizia respeito a ausência de ferramentas tradicionais específicas para comunicação, seja síncronas ou assíncronas. Alguns estudos demonstraram, neste período, que membros da comunidade, possíveis usuários da rede, já usavam ferramentas tradicionais de comunicação oferecidas pela internet. ${ }^{16} \mathrm{~A}$ idéia preponderante era que não haveria necessidade de se criar ferramentas específicas de comunicação no ambiente virtual a ser implementado. Seria uma sobreposição desnecessária, que poderia gerar conflito com as outras instâncias virtuais espontaneamente já estruturadas em Cidade Tiradentes a partir das ferramentas disponíveis na web. Neste momento havia uma grande difusão do uso de diferentes ferramentas de comunicação a partir da internet e dos telefones móveis. Os membros da comunidade de Cidade Tiradentes que já possuíam, de alguma forma, acesso a rede, estavam fazendo uso delas.

Outros aspectos importantes merecem ainda ser considerados. O fato de que a criação do espaço virtual seja tarefa de quem atua nele, sendo os próprios usuários os definidores do caráter que este espaço deveria assumir, não implicaria um descomprometimento frente a sua configuração por parte daqueles que estão propondo a sua criação. Pelo contrário. A implementação do ambiente virtual de interação social do projeto Comunidades_online deveria ser estimulada e patrocinada por atividades a serem desenvolvidas de forma colaborativa com as pessoas da comunidade da área de intervenção. Várias ações que incluiriam oficinas e o desenvolvimento de atividades e projetos específicos seriam

${ }^{16}$ Os estudos do Intermídia sobre as comunidades relacionadas a Cidade Tiradentes no Orkut e as informações obtidas a partir dos grupos focais realizados com moradores da área foram fontes importantes a este respeito. 
realizadas, no sentido de promover a interação com as tecnologias de informação e comunicação de forma contextualizada e criativa. ${ }^{17}$

A interface passaria a ser construída a partir de inúmeras atividades presenciais a partir do telecentro. Essas atividades possuiriam o duplo papel de estímulo e aprendizagem do uso das TIC. A idéia era que a partir dessas atividades presenciais, contextualizadas à realidade e demanda dos usuários, estes estariam capacitados também a fazer uso das TIC a partir das suas habitações, e que seriam estimulados a interagir no ambiente virtual criado para a comunidade. Desta forma pretendia-se estimular a criação de uma comunidade em espaço híbrido nos moldes discutidos no capítulo 2 (BLANCHARD; HORAN, 2000; CASTELLS, 2003; ETZIONI; ETZIONI, 1999; GAVED; MULHOLLAND, 2005; NARDI; O'DAY, 2000; HAMPTON, 2001).

Desta forma também, buscava-se enfrentar uma série de dificuldades, que já tinham sido detectadas como recorrentes em projetos desta natureza, como se viu em detalhes no capítulo 1 desta tese. A primeira delas seria promover a alfabetização digital para além da instrumentalização operacional, muitas vezes estabelecida com os tradicionais cursos de informática (EQUIPO TÉCNICO AUPEX, 2003; MOSSBERGER; TOLBERT; STANBURY, 2003; WARSCHAUER, 2006). Outra seria a disponibilização de conteúdos, que envolve um conjunto de aspectos, entre eles as questões de cognição e justamente a ausência dos mesmos na internet quando se trata da realidade sociocultural dos usuários em questão (SORJ, 2003; WARSCHAUER, 2006). Seria fundamental que as pessoas da comunidade de Cidade Tiradentes, assim como tantas outras que se encontram na mesma situação de exclusão, pudessem se expressar na internet, pudessem se enxergar e se encontrar, e mais, pudessem (re) estabelecer laços, e instâncias de trocas, abrindo o caminho para possíveis transformações, em diferentes dimensões, como mostra o capítulo 2 (MILANI, 2004; RATTNER, 2003; OAKLEY; CLAYTON, 2003). Estar-se-ia assim

\footnotetext{
${ }^{17}$ Neste momento entende-se que o objetivo é capacitar os moradores acrescentando a essa capacitação um sentido mais próximo da vivência de cada grupo social, através de um registro pessoal ou de um aspecto de sua visão do bairro na rede de interação online.
} 
enfrentando também uma outra dificuldade que diz respeito ao envolvimento comunitário necessário tanto para dar sustentação às ações propostas, como para potencializar e promover os recursos atribuídos às redes sociais.

Nesta fase do projeto, o exame de modelos de arquitetura de sistemas, também avançava. Buscava-se um modelo que pudesse agregar os requisitos delineados, entre diversos exemplos analisados. O Google Earth configura-se como uma estrutura base, com algumas ferramentas de uso facilitado, que permitem a intervenção dos usuários em vários sentidos, e chamou a atenção principalmente na forma facilitada de disponibilização de conteúdos. 0 estudo sistemático desta ferramenta permitiu perceber as possibilidades do desenvolvimento de uma interface cuja estrutura principal permitiria aos usuários a troca de conteúdos, por meios de ações de dowload e upload facilitadas, e mais, que permitiria o acesso à esses conteúdos a partir de vários pontos. Ou seja, cada conteúdo disponibilizado poderia estar agregado a vários outros conteúdos, permitindo uma interação associativa. É importante que se diga, que neste momento, as práticas de mashup, ou seja, de integração de várias aplicativos online mixadas, ainda não eram comuns e tão facilitadas, como são hoje.

\section{Micro-computadores, reciclagemem e nova área de intervenção}

Nesta etapa de implantação do projeto, descartou-se por definitivo o uso de terminais de acesso tipo set-top boxes e passou-se a considerar o uso de microcomputadores pelos moradores da área de intervenção, resultado de processos de reciclagem de máquinas inservíveis doadas. ${ }^{18} \mathrm{~A}$ inclusão do uso de microcomputadores de origem reciclada no projeto $\mathrm{COL}$ foi vista como uma alternativa viável que se

\footnotetext{
${ }^{18}$ A troca da utilização de terminais de acesso tipo set-top boxes por micro-computadores oriundos de processo de reciclagem envolveu, além dos aspectos já levantadas, também uma questão de custo. Seria necessário agora prover os equipamentos necessários ao projeto com seus próprios recursos. Esta alteração derivou ainda uma significativa redução no número de apartamentos, estabelecimentos comerciais, prédios públicos e associações a serem contemplados.
} 
encaixava de forma considerável no escopo do projeto. ${ }^{19}$ A reciclagem, feita por uma cooperativa, foi vista como uma ação que estimularia a capacitação de pessoas e o trabalho coletivo em grupos, e atuaria também como um vetor de geração de renda. Também era considerada a possibilidade de que esta ação poderia dar suporte ao rápido crescimento do ambiente virtual a ser implantado ${ }^{20}$, principalmente quando se pensava que esta prática poderia se estender com a implantação de uma oficina de reciclagem no telecentro base do projeto. A reciclagem de equipamentos informatizados, como sei viu no capítulo 1 , também pode fazer as pessoas entenderem que a estrutura e 0 funcionamento do computador são relativamente simples, e que é possível e necessário desmistificá-lo para melhor aproveitá-lo. É nesse momento também que o telelentro de referência do projeto passava a ser o telecentro Casa Brasil, alocado no Centro Cultural Arte em Construção do Instituto Pombas Urbanas, e o próprio Instituto, passava a ser um dos parceiros mais importantes do projeto $\mathrm{COL}^{21} \mathrm{O}$ projeto Casa Brasil pretendia instalar uma oficina de reciclagem junto a essa unidade de telecentro, fato que ratificava as decisões sobre o uso de microcomputadores no projeto Comunidades_online.

Houve então, nesse momento, a substituição das parcerias que envolviam o telecentro de referência do projeto. A troca do telecentro municipal pelo telecentro do Instituto Pombas Urbanas implicou na escolha de novos edifícios de apartamentos para a área de intervenção do projeto. A nova área de

\footnotetext{
${ }^{19}$ Estes micro-computadores seriam produzidos por meio de parceria com a CooperJovem, uma cooperativa de trabalho, nas proximidades de Cidade Tiradentes, que reúne jovens e adolescentes que foram capacitados em cursos do CPA - Centro de Profissionalização de Adolescentes Padre Bello, em torno de atividades como reciclagem de computadores, concepção, instalação e manutenção de redes, manutenção de equipamentos de informática, software livre, entre outros. As máquinas inservíveis utilizadas pela CooperJovem para atender às necessidades do projeto COL seriam fornecidas gratuitamente pelo ICMC - Instituto de Ciências Matemáticas e da Computação da USP.

${ }^{20}$ Uma referência aqui era a experiência da CooperJovem, que destina a quase totalidade de sua produção de computadores aos moradores da vizinhança do CPA - Centro de Profissionalização de Adolescentes, no bairro de São Mateus. As máquinas são vendidas por preços muito baixos e seu valor é parcelado, estimulando a compra mesmo por famílias muito pobres.

${ }^{21} \mathrm{O}$ Instituto Pombas Urbanas desenvolve diferentes projetos e programas culturais. Foi instituído a partir do grupo teatral Pombas Urbanas, formado em 1989 pelo diretor Lino Rojas com jovens de São Miguel Paulista, zona leste de São Paulo, tornando-se uma OSCIP - Organização da Sociedade Civil de Interesse Público em 2002. Desenvolve, desde 2004, a estruturação do Centro Cultural Arte em Construção em Cidade Tiradentes num galpão cedido pela Cohab - SP, no qual sedia um telecentro do projeto Casa Brasil, implantado a partir dos últimos meses de 2006.
} 
intervenção, próxima à anterior, faz parte de uma mesma vizinhança dentro do bairro, e de um mesmo conjunto habitacional da COHAB-SP (Santa Etelvina III-A).$^{22}$ Compõe-se de três blocos de habitações, em frente ao Instituto Pombas Urbanas, totalizando 144 apartamentos, conforme mostram as imagens a seguir:
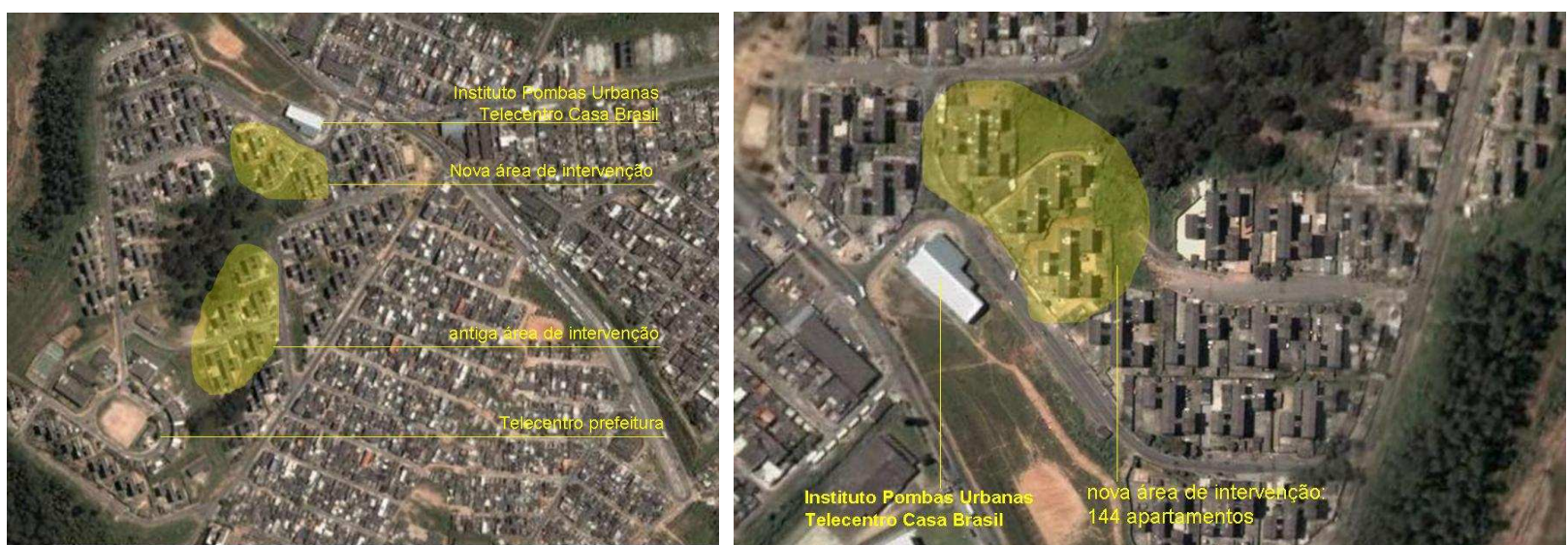

Fig. 6-7 Áreas de intervenção do projeto COL: Instituto Pombas Urbanas e telecentro Casa Brasil Fonte: NOMADS.USP (2006)
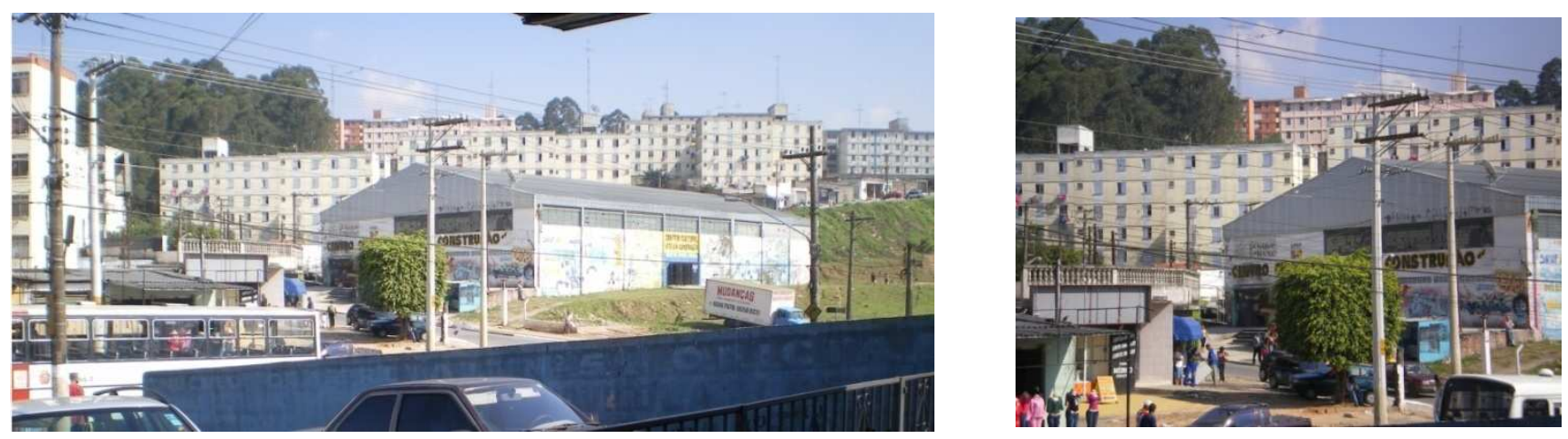

Fig. 8-9 Área de intervenção: Centro Cultural Arte em Construção, ao fundo os edifícios Fonte: SANTOS (2007)

22 Toda a caracterização da comunidade já tinha sido feita, e ainda que os resultados mostrassem uma realidade bastante homogênea, procedeu-se a realização de nova uma consulta nos apartamentos agora em questão, em agosto e setembro de 2006. Todos os edifícios já consultados nas avaliações anteriores passariam a fazer parte do grupo de controle. No geral, contanto essas duas fases da pesquisa, foram contatadas e caracterizadas 295 famílias e seus domicílios, 219 na primeira fase e 74 na segunda. 
Esta troca trouxe para o projeto Comunidades_online vários aspectos positivos. 0 principal deles foi o fato do novo telelecentro alojar-se em uma estrutura de ação comunitária consolidada muito antes de sua implementação. Como destacado nos capítulos 1 e 2 desta tese, é de extrema importância que as iniciativas envolvendo o uso das TIC em comunidades locais estejam permeadas por um amplo envolvimento comunitário que dê sustentação às ações propostas, de forma potencializar e promover os recursos sociais (AUGUSTIN; GILLET, 2006; EQUIPO TÉCNICO AUPEX, 2003; FOTH, 2006; KRETZMANN; McKNIGHT, 1993). O Instituto Pombas Urbanas, entidade de interesse público, sediada em Cidade Tiradentes ao lado da área de intervenção, têm diversos programas de ação social visando a comunidade local, e mais importante, possui uma relação estável cultivada com esta comunidade. Os cursos e atividades oferecidos à comunidade pelo Instituto são vários, e prioritariamente de cunho cultural. Incluem teatro, circo, dança, música, graffiti, rádio e a partir de 2006 o telecentro, dentro de uma programação mensal com apresentações de espetáculos e exibição de filmes, uma biblioteca comunitária, encontros e debates. ${ }^{23}$ Os interesses e objetivos do Instituto Pombas Urbanas e do projeto COL se alinhavam em vários aspectos, entre eles, no sentido de que ambos buscavam a criação de estratégias de inclusão social voltadas não apenas para a capacitação profissional e geração de renda mas para a integralidade da pessoa e sua conscientização como cidadão e parte de um coletivo maior.

\section{Caracterização}

O trabalho de caracterização das famílias e de seus domicílios pertencentes a área de intervenção possibilitou um conhecimento bastante amplo sobre as características da comunidade, seus problemas, aspirações e necessidades, tornando seus contornos mais visíveis. ${ }^{24}$ Conhecer a comunidade, para além

\footnotetext{
${ }^{23} \mathrm{O}$ Instituto Pombas Urbanas recebe regularmente financiamento através de programas da prefeitura municipal de São Paulo, da Secretaria de Estado da Cultura, além de captar recursos com base na Lei Rouanet e de institutos privados.

${ }^{24}$ É importante destacar que os princípios metodológicos de levantamento de dados e avaliações mereceram especial atenção no âmbito do projeto Comunidades_online. Foram delineados em trabalhos conjuntos do Nomads.usp e do Nutau. Entretanto,
} 
dos dados estatísticos, bastante disponíveis, parece fundamental em projetos da natureza do Comunidades_online, como discutido no capítulo 1 (RIZEK, 2007; WARSCHAUER, 2006). Neste caso em específico, permitiu um grau de aproximação com a comunidade que foi fundamental para a delimitação das atividades propostas. Na medida que as relações com o Instituto Pombas Urbanas se fortaleciam, as informações trazidas por ele eram somadas aos resultados já obtidos na caracterização, o que auxiliou em muito nas leituras dos dados. Na mesma medida, o projeto ajudou o Instituto Pombas Urbanas a compreender de forma concreta percepções sobre a comunidade que eram ainda intuitivas para eles. Esse conjunto de informações foi importante também na definição dos requisitos da interface computacional e no o planejamento das oficinas realizadas no telecentro. ${ }^{25}$

Alguns aspectos revelados a partir desta caracterização merecem ser destacados aqui para entender o conjunto das ações levadas a cabo no âmbito do projeto Comunidades_online. Na área de intervenção $75 \%$ dos entrevistados declararam já usar o computador e em 33,33\% dos casos, ao menos um dos moradores utilizam a internet, uma a duas vezes por semana. Esse uso se dá a partir de sua casa ou de um telecentro. A grande maioria dos moradores da área de intervenção afirmou perceber a importância do uso das TIC a partir de telecentros, principalmente, como possibilidade de inserção no mercado de trabalho, contato com amigos e parentes, o acesso a serviços públicos e em seguida para lazer; e $46 \%$ dos entrevistados afirmaram existir pelo menos um morador do apartamento que participe das atividades desenvolvidas no Instituto Pombas Urbanas. Dentre aqueles que participam dessas atividades, as crianças são a maioria. ${ }^{26}$

tanto as discussões das técnicas adotadas, de questionários aplicados presencialmente, a aplicação remota de ferramentas para a obtenção de informações, assim como os procedimentos avaliativos adotados em diferentes momentos da pesquisa, não são discutidos aqui. A quantidade de informações e diversidade de mecanismos utilizados para sua apresentação resultou em um volume documental rico e significativo.

${ }^{25}$ Além disso, forneceu informações e foi um dos critérios adotados para a definição da amostra de famílias moradoras dos apartamentos que seriam convidados a participar ativamente da pesquisa a partir do recebimento dos computadores.

${ }^{26}$ Assistir a peças de teatro e filmes são as atividades mais realizadas por aqueles que freqüentam o Centro Cultural, seguidos pelo item 'lazer'; os cursos e a biblioteca são pouco freqüentados pelos moradores dos referidos apartamentos. 
Ainda que esta caracterização tenha sido essencial ao projeto COL em diferentes aspectos, entre eles, na alimentação das discussões sobre encaminhamento de atividades e no auxílio nas definições e critérios para eleição da amostra para distribuição dos computadores nos apartamentos, não revelou muito sobre as redes sociais locais, suas características, assim como as trocas de recursos presentes nessas redes, a qualidade dos laços e relações. Há que considerar que se propunha investigar estas redes através de ferramentas que pudessem estar online em um outro estágio da pesquisa, que como se verá, foi impossibilitado de se concretizar. ${ }^{27}$ Tal impossibilidade derivou-se da maior dificuldade enfrentada neste projeto, a conexão a internet.

\section{A dificuldade de conexão}

Desde a concepção do projeto Comunidades_online, o estabelecimento da conexão que possibilitaria a construção do ambiente de interação virtual a ser disponibilizado em Cidade Tiradentes estava centrada na utilização do telecentro como provedor de acesso a internet, a partir da possibilidade de uma ampliação da banda suficiente para abarcar os equipamentos a serem disponibilizados nos apartamentos da área de intervenção. Esta idéia permaneceu inalterada apesar da mudança do telecentro de referência para o projeto, e da nova área de intervenção, conforme apresentado. Seria mantida a infra-estrutura de conexão através de cobertura wireless da área de intervenção, com a utilização de antena instalada no telecentro.

Em um primeiro momento, estudou-se várias alternativas para a infra-estrutura de conexão da rede a ser implementada, fosse wireless com ou sem mesh, fosse com cabos, incluindo os custos de materiais e serviços de execução. Nesse momento também foram feitas inúmeras tentativas para viabilizar a

${ }^{27}$ A idéia era que a partir do uso sistemático do ambiente virtual se realizassem diferentes consultas aos usuários que pudessem caracterizar as suas redes sociais antes e depois da implantação do ambiente virtual de interação. 
ampliação da largura de banda da conexão que viria a ser oferecida ao telecentro, pensando inclusive em outras alternativas para a provisão da conexão. Investigou-se insistentemente junto a vários técnicos e gestores dos programas governamentais envolvidos - Casa Brasil e GESAC ${ }^{28}$ - as reais possibilidades de ampliação da banda para a incorporação dos computadores do projeto Comunidades_online ${ }^{29}$. As respostas recebidas de todos os consultados sempre foram positivas, embora nada de concreto tenha sido, em momento algum, encaminhado. Também foi aventada a possibilidade de se obter conexão gratuita, através de patrocínios e apoio financeiro de fundações ou empresas ligadas ao setor de telecomunicações, mas também não houve resultados. Neste dado período de implantação do projeto, no início de 2007, mesmo com a antena instalada e a conexão disponível, o telecentro funcionava muito aquém da sua capacidade porque tinha sofrido um assalto, em que terminais tipo thin-clients e servidores disponibllizados pelo Casa Brasil foram roubados. Apesar de a conexão declarada ser de $256 \mathrm{kbps}$, a nominal oscilava bastante, e mantinha-se em patamares muito inferiores a esta, o que acontece até hoje.

Diante da impossibilidade de se conseguir a conexão através do poder público e instituições, partiu-se para a realização de estudos que verificassem a viabilidade de provisão do serviço através de operadoras de telecomunicações privadas. É importante que se diga que o contato com essas empresas foi difícil, mesmo quando se sugeria a possibilidade de aquisição do serviço. Isso fez crer que havia pouco interesse, por parte do setor privado, em atender às demandas de projetos de cunho social, como o Comunidades_online, voltados para classes de baixa renda, menos consumidoras de serviços oferecidos através da rede. Ainda assim, verificou-se que a tecnologia mais viável e disponível no bairro, depois de um levantamento realizado, seria a ADSL. Entretanto, essa conexão não estava

${ }^{28}$ É o programa GESAC, citado oportunamente, que fornece a conexão, via satélite, aos telecentros da rede Casa Brasil.

${ }^{29}$ Personalidades do universo nacional da inclusão digital, que reconheciam a relevância do projeto Comunidades_online, também ajudaram nas tentativas de ampliação de largura de banda, ou mesmo no fornecimento alternativo de conexão. Realizaram solicitações neste sentido a altos executivos do setor das telecomunicações, assim como a ministros das pastas das Comunicações e Cultura, estes últimos detentores de grande poder decisório. Infelizmente, e surpreendentemente, tais investidas também não produziram resultados. 
disponível para setenta por cento dos endereços consultados da área de intervenção. Portanto, não haveria naquele momento, possibilidade de se conseguir a conexão através deste meio. ${ }^{30}$

Diante da dificuldade em conectar os apartamentos, seja a partir do telecentro, seja por meio das operadoras comerciais, aventou-se a possibilidade de execução de uma rede intranet conectando as residências. Pelo menos durante o período inicial, isso permitiria que os moradores comunicassem entre si, e postassem conteúdos na rede, ainda que esta não fosse visível na internet, sendo que a conexão com a internet se daria no momento em que um link fosse disponibilizado. Esta solução, por mais que fosse passivel de se implementar, não era favorável do ponto de vista da interface computacional que estava sendo desenhada. Alguns requisitos de programação são específicos aos sistemas web e dispensáveis aos sistemas destinados ao uso offline, como uma intranet. Neste sentido, a adaptação de um mesmo aplicativo a esses dois ambientes, principalmente quando se trata de colocá-los online posteriormente, é complexa, de tal maneira que mostrou-se inviável para este projeto. ${ }^{31} \mathrm{~A}$ solução intranet também requereria dispositivos - placas e antenas, por exemplo - que ao serem agregados aos equipamentos reciclados, tornariam esses equipamentos quase tão caros quanto aqueles oferecidos pelo mercado convencional de computadores naquele momento.

Assim, depois de esgotadas todas as possibilidades, nos últimos meses de vigência do projeto, admitiuse que não seria possível efetivar a conexão nos apartamentos, a menos que houvesse patrocínio do Estado ou caso os voluntários arcassem individualmente com as despesas, possibilidade que nunca foi ponderada, levando em conta a faixa de renda da população evolvida na pesquisa. Entretanto, os levantamentos realizados na área de intervenção, já citados, mostravam a existência de conexões

\footnotetext{
${ }^{30}$ Entretanto, os levantamentos realizados na área de intervenção mostravam a existência de conexões domiciliares, tanto ADSL como discadas, em diversos apartamentos visitados. Tal fato indicava que, após disponibilização dos equipamentos, os moradores talvez buscassem espontaneamente soluções para a efetivação da conexão por iniciativa própria.

${ }^{31}$ Uma conexão em banda estreita é insuficiente para 'rodar' satisfatoriamente diversos aplicativos, desestimulando de forma considerável o uso da rede, seja em casa ou no telecentro, justamente quando esse contato deveria constituir uma experiência positiva para qualquer usuário.
} 
domiciliares, tanto ADSL como discadas, em diversos apartamentos visitados. Tal fato indicava que, se fossem disponibilizados os equipamentos, os moradores talvez buscassem espontaneamente soluções para a efetivação da conexão por iniciativa própria.

Se, por um lado, sabia-se ser bastante recorrente a prática de instalações clandestinas, tanto de telefonia como de conexão à internet, por outro, parecia pertinente pensar na solução dos principais problemas relacionados à provisão de acesso à internet em um futuro próximo. Dentro das suas estratégias de negócios, as operadoras desse serviço têm procurado facilitar cada vez mais a contratação de conexão à internet, por exemplo através da oferta de produtos diferenciados e associados a outros serviços, como TV por assinatura.

Tais perspectivas, em conjunto, validaram o empréstimo dos computadores do projeto Comunidades_online aos voluntários da comunidade, mesmo diante da impossibilidade de se viabilizar a conexão em seus apartamentos. Foram ainda testados vários caminhos alternativos que pudessem contornar a ausência de conexão. 0 mais importante deles era a inclusão de um equipamento tipo pen drive de gravação de arquivo, voz e de reprodução de mp3 que seria emprestado junto com cada computador. Essa ação poderia garantir que produtos gravados em arquivos pudessem ser transportados e disseminados com facilidade. Ao mesmo tempo poderia auxiliar ou mesmo enriquecer atividades de cursos e oficinas oferecidas no Centro Cultural.

Acreditava-se que assim, na medida em as experiências com o uso das TIC fossem consolidadas, uma maior aproximação da comunidade com o Centro Cultual fosse induzida. As relações de sociabilidade seriam então ampliadas a partir da instância virtual de interação, que neste momento, estava alocada a partir do telelento. 
O esgotamento de possibilidades para a provisão de conexão à internet no âmbito do projeto Comunidades_online leva a concluir que a conexão à internet de residências de famílias de baixa renda é um dos principais entraves, embates e desafios em iniciativas envolvendo o uso das TIC com um viés de inclusão digital. Parece não existir, por parte das empresas privadas, interesse em prover infraestrutura para conexão de banda larga em regiões pobres da periferia, onde residem populações com pequena capacidade de endividamento. Assim, muitas vezes, a conexão discada acaba se configurando como única opção para acesso à internet, comprometendo, como se viu no capítulo 1, a qualidade da experiência que se pode ter na rede, principalmente neste momento em que cada vez mais as informações estão dispostas no formato de imagens e movimento e sons (Castells apud SERVON, 2002; DiMAGGIO; HARGITTAI, 2001; SILVEIRA, 2005b).

Por um lado, mostra-se o importante papel do Estado. Através de suas esferas federal, estadual e municipal, caberia a este agente a tarefa de provisão de acesso banda larga à rede para as classes populares, incapazes de fazê-lo por si. Reafirma-se aqui que se trata de uma tarefa que deveria ser entendida como a provisão de um serviço público, como discutido anteriormente. Por outro lado, acentua-se aqui que ainda que as ações voltadas a inclusão digital não devam se reduzir a disponibilização de equipamentos e conexão, sem estes porém, tais ações são inevitavelmente fadadas a se constituírem como ações bastante parciais. Percebe-se aqui aquelas restrições citadas no capítulo 1 como sendo próprias às iniciativas desta natureza. Entretanto, neste caso, trata-se sim de uma exigência básica que não se cumpriu, de infra-estrutura, atribuída a uma explícita ausência do Estado, seja como executor, seja como gestor. 0 universo do possível aqui alinha as perspectivas disponíveis de inclusão digital das periferias brasileiras a um cenário bastante preocupante, principalmente quando se pensa que sem conexão à internet está-se, sim, numa situação de quase pré-inclusão quando o horizonte é um processo que valoriza a qualidade das experiências das pessoas, grupos e comunidades locais a partir do uso das TIC. 


\section{OS computadores nos apartamentos}

Foram produzidos, com verbas do próprio projeto, 35 computadores com peças reaproveitadas para a realização das atividades da pesquisa correspondentes à formação do ambiente virtual de interação, que a partir de então exigiria ainda mais ações conjuntas entre atividades realizadas nas moradias da área de intervenção e no telecentro. ${ }^{32}$ Estas máquinas foram alocadas nas moradias de acordo com um conjunto de critérios estabelecidos, envolvendo inúmeros quesitos, como por exemplo, a de se possuir linha fixa de telefone instalado na unidade habitacional, e a aceitação dos moradores dos apartamentos selecionados ao convite de participar do projeto como voluntários.

Infelizmente não houve tempo suficiente entre a implantação dos computadores e a etapa conclusiva do projeto, nos últimos meses de 2007, para que fosse verificadas uma série de questões relacionadas a apropriação das tecnologias digitais pelos moradores, e observar suas ações no espaço virtual criado para ser apropriado pela comunidade local. Ainda devido à ausência de conexão, etapas previstas como as ações de estímulo e familiarização, oficinas em que os participantes postariam conteúdo a partir de seus apartamentos, assim como o treinamento de usuários com multiplicadores e monitores, haviam sido realizadas apenas parcialmente no telecentro, até o período aqui considerado.

Num projeto de tal complexidade, envolvendo diversas ações e agentes entrelaçados, é pouco provável que não se tenha atrasos. O tempo despendido nas tentativas de se viabilizar a conexão nos apartamentos constituiu-se num problema. Houve também atrasos na entrega das máquinas recicladas aos voluntários em função da demora na doação de máquinas pelo ICMC - USP, além de sucessivos atrasos do programa Casa Brasil em relação ao funcionamento pleno do telecentro e sua conexão. E

\footnotetext{
${ }^{32}$ Este número 35 é fruto de diferentes acordos e ajustes que se fizeram necessários durante desenvolvimento final do projeto Trata-se de número bastante reduzido, principalmente em relação ao que havia sido planejado inicialmente, e mesmo ainda depois dos ajustes que o projeto sofreu.
} 
aqui há que se mencionar, mais uma vez, o episódio do roubo dos equipamentos do telecentro, que prorrogou ainda mais início de suas atividades.

\section{Resultados das oficinas no telecentro}

A realização de oficinas no telecentro no âmbito do projeto COL buscou, por um lado, promover a relação entre pessoas da comunidade local de Cidade Tiradentes e as tecnologias de informação e comunicação, produzindo uma experiência positiva, e por outro, estimular as narrativas pessoais, incluindo ai experiências intermediadas pelo computador, através da interface do projeto Comunidades_online. ${ }^{33}$ Foram atividades importantes no sentido de alterar, para algumas pessoas, a percepção em relação à vizinhança local, geralmente permeada pelo medo e de desconfiança, convidando-as a mudarem seus olhares para uma visão mais positiva sobre o bairro, estimulando ambas as relações, face-a-face e virtual.

Os adultos, que se aproximavam pela primeira vez de um computador e da internet, entenderam através das oficinas que as limitações no uso destes instrumentos podem ser facilmente superados e que o ambiente virtual pode enriquecer seus cotidianos, trazendo informações e possibilidades de solidarizarem-se com outros habitantes locais que tenham interesses parecidos ou complementares, assim permitindo criar laços dentro e fora do ambiente virtual.

As oficinas com as alunas do curso de artesanato foram um exemplo claro. Nelas, o primeiro desafio, que é elevar a confiança dos participantes em suas próprias capacidades para lidar com um meio com o

${ }^{33}$ Estas oficinas foram sistematicamente planejadas e avaliadas, não cabe aqui, entretanto, discuti-las a partir de uma perspectiva metodológica. 
qual a maioria não tinha familiaridade, foi logo vencido através do foco no objetivo maior de poder organizar a produção artesanal no ambiente virtual. A possibilidade de poder publicizar um trabalho contribui para a superação das inabilidades, medos e preconceitos frente ao meio digital, e deve ser vivenciado como um horizonte de novas interlocuções.

As oficinas realizadas no telecentro, no âmbito do projeto Comunidades_online, corroboraram proposições estabelecidas a partir dos estudos teóricos desta pesquisa, apresentados nos capítulos anteriores. Primeiro, em relação a necessidade de vínculos com a realidade de vida das pessoas, com aquilo que para elas fazem sentido e é importante. Assim, as atividades do telecentro de estímulo ao uso das TIC, em particular do ambiente virtual criado para a comunidade, têm que estar associadas às práticas e demandas da comunidade, e não o contrário. Segundo, em relação a importância das atividades presenciais para estimular as interações em espaços híbridos. As oficinas, ainda que de forma pouco expressiva em termos quantitativos, mostraram ser possível favorecer e estimular renovações no padrão se sociabilidade entre os habitantes do fragmento urbano alvo do projeto e também entre estes e outros usuários do Centro Cultural. Isto aconteceria através do fortalecimento das redes sociais através das ações presenciais vinculadas ao uso dirigido das tecnologias digitais, para num estágio seguinte, transpor estas relações para ambientes virtuais. É importante que se diga que participaram de algumas dessas oficinas os professores dos diferentes cursos oferecidos no Centro Cultural, além da bibliotecária e monitores do telecentro. São eles os multiplicadores que darão continuidade as ações de inserção do uso das TIC nesta parcela da comunidade de Cidade Tiradentes incorporando-as a suas atividades diárias, inserindo-as de forma contextualizada no cotidiano das pessoas da comunidade, através de suas ações no Centro Cultural.

Da mesma forma aqui, o tempo entre a realização das primeiras oficinas no telecentro e o término do Comunidades_online foi insuficiente. Não foi possível medir a qualidade das ações com o uso das TIC inseridas nos diferentes cursos oferecidos pelo Centro Cultural, e de que forma estas ações, juntas com 
as realizações específicas do telecentro, iriam se reverberar no uso das TIC e do ambiente virtual disponibilizado através da interface criada pelo projeto COL nesta parcela da comunidade.

\subsection{Olhares analiticos e conclusivos: parcerias e interface}

Estabelecida esta visão geral sobre o projeto, procura-se aqui agregar algumas reflexões no contexto particular de algumas discussões e conceituações estabelecidas nos capítulos anteriores desta tese. Trata-se do exame de duas questões em específico, parcerias e interfaces, tendo como referência o status da experiência em Cidade Tiradentes nos últimos meses de 2007. As parecerias são centrais nos projetos desta natureza, e revelam muito sobre seus propósitos, suas estruturas, e possibilidades de realização. As interfaces computacionais são uma de suas faces que ainda não recebem a devida atenção, ao considerar-se este universo em termos qualitativos ou quantitativos. São tratadas, quando são, muitas vezes em termos só técnicos, ou ainda pertencentem à esfera exclusiva do design gráfico de informações, que, por sua vez, é entendido de forma limitada. ${ }^{34}$ Como apresentado no capítulo 2 desta tese, há entretanto, uma agenda de pesquisa em construção que reafirma a importância do entrelaçamento das tecnologias digitais no plano das comunidades locais, e que situam as questões das tecnologias digitais, computacionais, a partir de uma perspectiva também social, de desenvolvimento e transformações para as pessoas em comunidades locais (BEAMISH, 2001; CARROLL, 2005; DAY; SCHULER, 2004; GAVED; ANDERSON, 2006; GURSTEIN, 2004).

\footnotetext{
${ }^{34}$ Para uma visão mais extensa sobre a disciplina information design ver Shedroff (2005).
} 
É importante que se diga que aqui também se estabelece um recorte analítico, dentre muitos outros que seriam possíveis, que faz sentido no escopo específico desta pesquisa de doutorado. Como se viu, o projeto $\mathrm{COL}$ envolve um conjunto muito grande de questões, e ainda que se estabeleça neste trabalho um esforço para apresentar a amplitude de sua abrangência, isto se faz dentro de determinadas limitações.

\subsubsection{As parcerias no âmbito do projeto Comunidades_online}

Um projeto envolvendo TIC requer o estabelecimento de inúmeras parcerias. Como se viu, são parcerias em diferentes níveis que dão suporte a execução, gestão e financiamento. 0 projeto Comunidades_online nasce em âmbito acadêmico, com quatro grupos de pesquisa, é em termos financeiros, sustentado principalmente pela FAPESP, ainda que se considere os aportes indiretos através da parceria com o Instituto Pombas Urbanas. É, em termos práticos, gerido e executado pelo Nomads.usp em conjunto com o Instituto Pombas Urbanas. Destacam-se aqui as diferentes parcerias que se construíram no âmbito do projeto, com o objetivo de explicitar a importância deste aspecto dentro de iniciativas desta natureza, em relação a possibilidade mesma de as por em prática, e ainda mais, de perceber que se trata de relações nem sempre fáceis de se estabelecerem, dado a dificuldade de romper as diferentes barreiras que existem naturalmente na reunião de indivíduos, grupos e instituições com interesses diversos para alcançar objetivos comuns, em diferentes níveis.

\section{O projeto Comunidades_onlinee o Instituto Pombas Urbanas}

A aproximação com o Instituto Pombas Urbanas se deu em um momento bastante especial do desenvolvimento do projeto Comunidades_online em que vários ajustes e alterações estavam se 
processando, como foi mostrado no item anterior. 0 estabelecimento de um vínculo com este Instituto se inclui nesse conjunto de reformulações, sendo difícil precisar a medida em que derivou ou foi fruto de muitas delas. Para o projeto $\mathrm{COL}$ o interesse em estabelecer um trabalho em conjunto com este Instituto foi alimentado, a princípio, pelo o fato deste estar sediado ao lado da área de intervenção do projeto e desenvolver diversos programas de ação social visando a comunidade local e também pelo fato de ser uma instituição hospedeira de uma unidade do programa Casa Brasil que inclui em sua estrutura modular um telecentro. A preocupação do Comunidades_online com a formulação de políticas públicas, ia também de encontro à natureza mesma do Instituto, uma entidade de interesse público, financiada majoritariamente com recursos públicos, e capaz de tornar-se implementadora de políticas públicas. Por outro lado, o Instituto tinha interesse em incluir ações envolvendo o uso das TIC no cotidiano de suas práticas em Cidade Tiradentes, mas não sabia exatamente de que forma isto poderia acontecer. Faltavam-lhe os suportes adequados, principalmente, voltados ao espírito do trabalho desenvolvido pelo Instituto, que é pautado, nas palavras de seus coordenadores, no “[...] fortalecimento da identidade cultural local e na compreensão dos indivíduos sobre suas necessidades e potencialidades para que possam ampliar suas capacidades humanas, organizacionais e criativas e solucionar problemas comuns de forma coletiva" (INSTITUTO POMBAS URBANAS, 2006). Os direcionamentos vindos do programa Casa Brasil se mostravam insuficientes na visão dos componentes do Instituto, permeados, muitas vezes a uma estrutura burocrática, que não indicavam e favoreciam desdobramentos práticos. Os aportes do projeto Comunidades_online, que pressupunham uma prática de ação cotidiana envolvendo o uso das TIC a partir de uma forma de atuação particular de telecentro, pareceram convenientes e interessantes ao Instituto ${ }^{35}$. Assim, o Instituto Pombas Urbanas interessou-se pela parceria com o Nomads.usp e por participar do projeto Comunidades_online por entender também que o telecentro não deve ser unicamente um lugar de busca de informação individualizada, mas pode

\footnotetext{
${ }^{35}$ Tanto a parceria entre o Nomads.usp e o Instituto Pombas Urbanas, como também entre o Nomads.usp e o Intermídia, se estenderam a outros projetos depois do Comunidades_online.
} 
constituir um espaço de troca de informações, de convívio social, que o uso das tecnologias de informação e comunicação em princípio poderia enriquecer.

Desta forma, como se viu, os interesses do Instituto e projeto COL mostraram-se complementares, ambos buscavam uma forma apropriada de inserção das TIC na vida das pessoas e comunidade de modo que pudessem favorecer processos de transformação social, no sentido já discutido neste trabalho. Pode-se dizer que esta foi a proximidade que sustentou esta parceria, que na prática se construiu através de diferentes ações, entre as quais se destacam: o estabelecimento dos princípios de funcionamento do telecentro ${ }^{36}$; o uso de micro-computadores reciclados no telecentro, biblioteca e administração do Centro Cultural $^{37}$; a reestruturação dos espaços físicos, tanto do telecentro como do Centro Cultural, a realização das primeiras oficinas modelos no telecentro, incluindo também aquelas com professores e monitores dos cursos oferecidos no Centro Cultural, e as de testes com a interface computacional do projeto Comunidades_online. Esta parceria foi e é fundamental para o projeto pois alimenta as perspectivas da sua continuidade, com o incentivo e estímulo constantes ao uso das TIC e do ambiente virtual criado para a comunidade de forma contextualizada à realidade e cotidiano da própria comunidade. Ao Instituto é fundamental porque dá sustentação à incorporação das TIC nas suas atividades, ampliando o espectro das benesses que essas ações podem trazer. Assim, são nas ações com TIC desenvolvidas tanto no âmbito dos diferentes cursos oferecidos no Centro Cultural, como em oficinas realizadas no próprio telecentro, que se busca inserir as tecnologias digitais no cotidiano da comunidade local, e favorecer também o uso do ambiente virtual criado para ela. Não se sabe, porém, se o que foi realizado até o período considerado neste trabalho foi suficiente para que estas ações se concretizem durante um tempo significativo. 0 que se sabe é que através desta parceria pode-se desenhar um caminho bastante adequado tanto para a inserção das TIC na comunidade local como para

\footnotetext{
${ }^{36}$ Que de alguma forma também contou com aportes do Casa Brasil.

${ }^{37}$ Ainda que não previsto, principalmente no escopo do projeto COL, o uso dos equipamentos reciclados pela CooperJovem no âmbito desse projeto foram também alocados no Centro Cultural devido ao roubo dos equipamentos do telecentro, já mencionado.
} 
a apropriação do espaço virtual a ser estabelecido para esta comunidade. O Instituto Pombas Urbanas funciona como os animados socioculturais aos quais se referem oportunamente neste trabalho, através do trabalho que desenvolve no Centro Cultural tem todas as qualificações para dar suporte social adequado às pessoas que se iniciam no universo das TIC. Trata-se de um trabalho totalmente imerso na realidade que o circunda, física, socioeconômica e cultural, possuidor de um envolvimento cuidadoso e respeitoso com a comunidade.

A relação entre o Instituto Pombas Urbanas e o projeto Comunidades_online na figura de seu principal proponente e executor, o Nomads.usp, se deu de forma direta, com a presença de alguns embates que puderam ser manifestos e resolvidos da mesma maneira, livre de trâmites de sistemas burocráticos, e hierárquicos. Esta situação parece qualificar de forma positiva esta relação em particular, e outras desta natureza, porque agrega também o poder decisório sobre determinadas ações nas mãos daqueles que irão executá-las e concluí-las. Em estruturas mais rígidas isto fica mais difícil, dispendioso e requer necessariamente mais tempo. Ainda que esteja se falando de relações pautadas em um grau de afinidade muito grande, quando estas envolvem instituições públicas ou grandes organizações privadas as ações tendem a ficar estacionadas bastante nos papéis e nos discursos. A parceria entre o projeto COL e o Instituto Pombas Urbanas esteve firmada no terreno da autonomia.

O Comunidades_online entra nas práticas do Instituto Pombas Urbanas também por algumas frestas deixadas pelo programa Casa Brasil, cumprindo justamente algumas exigências que este programa, neste caso em específico, não contemplou. ${ }^{38} 0$ programa não dispôs satisfatoriamente de auxílios para a estruturação das atividades diárias a serem realizadas no telecentro de acordo com a natureza das ações desenvolvidas pelo Instituto. Isso poderia ser considerado uma questão até supérflua, frente àquela da disponibilização dos equipamentos roubados, que até o período considerado, não havia sido

\footnotetext{
${ }^{38}$ É importante que se diga que todas as análises do Casa Brasil dizem respeito aqui exclusivamente à unidade deste programa alocada no Centro Cultural do Instituto Pombas Urbanas.
} 
resolvida. Interessa aqui aventar a possibilidade de que se a atuação do programa Casa Brasil fosse satisfatória frente aos olhos do Pombas Urbanas a parceria deste com o Comunidades_online pudesse ter se estabelecido em outros patamares. Ou ainda, por outro lado, se o Casa Brasil tivesse uma estrutura demasiado fechada, estabelecida a partir de regras rigorosas, talvez não houvesse abertura para as ações do projeto Comunidades_online. Retoma-se esta questão no próximo item. Aqui é importante destacar, por fim, que a relação com o Instituto Pombas Urbanas cumpre o papel do apoio das lideranças locais, das suas instituições e organizações tão caro às iniciativas envolvendo o uso das TIC como apresentado no capítulo 1, justamente por favorecer uma aproximação com as potencialidades, necessidades e desejos dos usuários dessas iniciativas. É também um meio para conhecer de uma forma mais direta a realidade local, perceber demandas, elaborar planos de ações a curto ou longo prazo (DiMAGGIO; HARGITTAI, 2001; EQUIPO TÉCNICO AUPEX, 2003; GAVED; MULHOLLAND, 2005; WARSCHAUER, 2006).

\section{O projeto Comunidades_onlinee os diferentes grupos de pesquisa}

Outra parceria que merece atenção é aquela instituída entre os pesquisadores dos diferentes grupos de pesquisa da Universidade de São Paulo. Tratam-se de parcerias de certa forma comuns no ambiente acadêmico e muito consideradas dado reconhecimento da necessidade de realizar a integração entre as disciplinas, de se combater a compartimentalização excessiva do saber, as visões fragmentadas. A interdisciplinaridade é ainda mais considerada nos estudos voltados para as tecnologias de informação e comunicação e suas implicações no mundo contemporâneo, por ser este um campo de pesquisa relativamente novo que requer inúmeras ferramentas para sua apreensão, além de possuir uma característica peculiar de mudanças constantes, como se viu oportunamente neste trabalho. No âmbito do projeto $\mathrm{COL}$ buscou-se a interdisciplinatidade integrando pesquisas desenvolvidas em diferentes áreas e disciplinas a partir de diferentes grupos e pesquisadores. O Nomads.usp, principal idealizador, executor e responsável pelo projeto Comunidades_online, que têm como pesquisadores arquitetos, se 
volta às investigações sobre diferentes espacialidades, entre elas as espacialidades híbridas, centro dos interesses deste projeto, como se viu na introdução desta tese. Participou do projeto COL também o LSI - Laboratório de Sistemas Integráveis da Escola Politécnica que há vários anos tem dedicado esforços na pesquisa e desenvolvimento na área de sistemas computacionais integrados. O LSI-USP desenvolve pesquisa em algumas áreas estratégicas enfocando desde processos necessários ao desenvolvimento de microestruturas, até o processamento de alto desempenho, e o processamento visual distribuído. ${ }^{39}$ A relação entre o LSI e o projeto Comunidades_online se dava na área de testes e aplicabilidade prática de equipamentos informatizados de baixo custo, os já citados set-top boxes, e em relação as soluções tecnológicas que poderiam viabilizar a interconexão comunicacional das habitações da área escolhida com o telecentro provedor de acesso a internet. As preocupações do NUTAU - Núcleo de Pesquisa em Tecnologia da Arquitetura e Urbanismo da Faculdade de Arquitetura e Urbanismo são as diversas áreas abrangidas pela tecnologia da Arquitetura e do Urbanismo, nos campos da APO - Avaliação Pós-Ocupação, do desempenho do ambiente construído, da acessibilidade, das inovações tecnológicas, sustentabilidade e meio ambiente e gerenciamento de obras, e também das técnicas da construção, do conforto ambiental, assim como das metodologias de planejamento urbano e regional, da representação dos objetos, dos modelos e da simulação. ${ }^{40}$ Ao Comunidades_online interessava no escopo das pesquisas do Nutau sua experiência em desenvolvimento e aplicação de métodos e técnicas avaliativas, ao Nutau interessava testar novas ferramentas avaliativas, inclusive aquelas que poderiam ser dispostas por meios digitais, como por exemplo, os questionários online. Interessava-se também por fornecer subsídios para a aferição das alterações nos espaços construídos a partir da inserção de outras esferas comunicacionais. O Intermídia do Instituto de Ciências Matemáticas e de Computação trabalha com atividades de modelagem e construção de ambientes de software colaborativos, incluindo as correspondentes bases de dados e interfaces com os usuários. 0 Intermídia

\footnotetext{
${ }^{39}$ Destacam-se os trabalhos recentes no estudo e caracterização de redes ATM, as aplicações em TV a Cabo Digital Interativa, os trabalhos desenvolvidos em computação de alto desempenho e sistemas distribuídos, e industrializados, os trabalhos de Telemedicina. Ver LSI. Site. Disponível em : <http://www.lsi.usp.br>. Acesso em: 13 ago. 2004.

${ }^{40}$ Ver NUTAU. Site. Disponível em http://www.usp.br/nutau >. Acesso em: 06 jan. 2008.
} 
tem também se dedicado à construção de infra-estruturas de software abertas e de impacto principalmente no ambiente educacional. É essa experiência que o grupo traria na sua atuação em conjunto com os outros pesquisadores do projeto Comunidades_online, para a construção do espaço virtual de interação em Cidade Tiradentes.

Entretanto, o projeto $\mathrm{COL}$ esteve a maior parte do tempo sendo conduzido e direcionado pelo Nomads.usp. A parceria com o LSI se arrefeceu quando o interesse do grupo pelo desenvolvimento dos terminais tipo set-top box também foi alterado pelos rumos dado ao setor, com as políticas da TV digital adorada pelo governo federal brasileiro. O interesse do LSI no projeto Comunidades_online parece não ter transposto seu interesse no desenvolvimento deste equipamento, e não alcançou o devido comprometimento com a investigação do projeto COL como um todo. Com o ICMC os desencontros foram de outra ordem. Foram vários os pesquisadores alocados no projeto Comunidades_online por este grupo, sendo esta equipe bastante alterada durante os trabalhos de desenvolvimento da interface do projeto, por diferentes motivos, o que prejudicou bastante o andamento dos trabalhos dessa interface. Foram os alunos graduandos do curso de Ciências da Computação que, sob a responsabilidade dos pesquisadores do Nomads.usp e Intermídia, desenvolveram a parte técnica de computação da interface do projeto. Estes alunos, entretanto, entendiam a sua participação no projeto como um trabalho sob encomenda e não como uma pesquisa. Não havia prioridade para esta função, e neste sentido, não havia um esforço de intelecção do projeto como um todo, exigindo do Nomads.usp algumas vezes habilidades para investigar até onde iam as possibilidades e dificuldades técnicas. Muitas vezes as discussões não alcançavam a amplitude que deveriam porque o os interesses desses participantes eram somente as propostas e soluções técnicas de acordo com o que havia sido sugerido a eles, permanecendo no plano do que poderia ou não poderia ser feito, no que daria ou não daria certo em termos técnicos.

Com o Nutau foi diferente, havia envolvimento e as equipes de trabalho estiveram em sintonia em diferentes momentos da pesquisa, entretanto, pela própria parcialidade na implantação do projeto, 
com o término do projeto, no período em questão, quase simultâneo à implantação da interface em Cidade Tiradentes, suas ações estiveram mais focadas na caracterização da área de intervenção e não na coleta, sistematização e análise dos dados pós-implantação, como era previsto. 0 desenvolvimento do COL no âmbito do Nomads.usp também não esteve livre de percalços. Neste grupo não havia uma equipe de trabalho dedicada exclusivamente a este projeto, que conseguisse manter uma regularidade nos trabalhos e ações referentes a ele. Há que se citar aqui a distância entre Cidade Tiradentes e São Carlos, onde está sediado o Nomads.usp. Em determinados momentos este afastamento dificultou as ações conjuntas entre o Instituto Pombas Urbanas e este grupo.

Há algumas questões a serem consideradas com relação a estas parcerias. Primeiro parece que nenhum dos três grupos - LSI, Nutau e Intermídia - conseguiu, comparado ao Nomads.usp, se envolver com os diferentes aspectos do projeto Comunidades_online que não os específicos a sua área. Embora houvesse um esforço, boa vontade e predisposição, parece que o interesse maior eram as atribuições da própria disciplina em questão em si mesmas, e não a contribuição e os insumos que os resultados do projeto poderia trazer para suas áreas. Parece não ter havido a transposição necessária, a disponibilidade e versatilidade para explorar os limites que uma pesquisa desta natureza poderia trazer. Há que se destacar que a formação dos arquitetos, que em si abrange disciplinas humanas, exatas e artísticas parece conferir-lhes uma natural acomodação no trato com conteúdos de diferentes matérias, como já destacado. Os trabalhos do Nomads.usp apresentam, em si, um perfil mais generalista, e coincidentemente ou não, é o único grupo que não está diretamente interessado em estudos técnicos de forma isolada. Outra questão importante é enfrentar uma pesquisa construída a partir de embates. À exceção do Nomads.usp, pareceu difícil aos outros conseguir permanecer em terrenos movediços, envolto a muitas dúvidas e poucas certezas. O Nomads.usp tirou grandes lições de seu envolvimento nesta pesquisa, conseguiu avançar nos seus estudos, e principalmente conseguiu corroborar a idéia de que as espacialidades híbridas constituem a atual matéria prima da arquitetura e do design e são também atribuições dos arquitetos, como destaca-se nas conclusões desta tese. À exceção do Nomads.usp, que conseguiu trazer para os produtos do projeto COL construídos sob suas 
responsabilidade, a integração de diferentes áreas disciplinares, como se verá a seguir em relação à interface, sob a ótica dos outros grupos parceiros caberia indagar se realmente houve interdisciplinaridade no âmbito do projeto Comunidades_online.

\section{Outras parcerias}

As parcerias entre o projeto Comunidades_online, a COHAB-SP e a Coordenadoria do Governo Eletrônico da Prefeitura de São Paulo, já citadas, não foram levadas a cabo em função da mudança de gestão na prefeitura de São Paulo, em 2005, que gerou mudanças de orientação política e de objetivos na ação social dessas instituições. Reverberando, pelo lado do Governo Eletrônico, em uma nova orientação no telecentro no distrito de Cidade Tiradentes, com um funcionamento rígido e sem possibilidade de questionamento, o que o distanciava dos objetivos co projeto COL, e pelo lado da $\mathrm{COHAB}$, um declarado desinteresse em relação ao projeto, ainda que permanecesse como razoável para o Comunidades_online a idéia de incluir o valor do equipamento de acesso à internet na mensalidade dos mutuários, financiando-o por períodos longos. Parece claro que a constituição de políticas públicas deve independer das alternâncias dos partidos políticos na gestão administrativa dos órgãos públicos, ou que ainda os partidos devam deixar de lado suas hostilidades em favor do estabelecimento de ações consistentes que consigam vencer a barreira de permanecerem ativas por mais de quatro anos.

A parceria entre o projeto Comunidades_online e o ICMC Instituto de Ciências Matemáticas e da Computação foi estabelecida também para a doação de máquinas inservíveis tornou possível a produção dos computadores que foram emprestados à comunidade de Cidade Tiradentes e alocados no Centro Cultural. Esteve sujeita a uma série de trâmites burocráticos que trouxeram alguns atrasos ao projeto, 
que entretanto são menores frente a perspectivas que abriram de possibilidade de ampliação da rede a ser construída em Cidade Tiradentes e de servir de exemplo para outras ações desta natureza. ${ }^{41}$

A relação entre o projeto Comunidades_online e a FAPESP, seu principal órgão financiador, chama atenção por um aspecto em específico. A FAPESP trabalha dentro de uma rigidez tanto na gestão dos recursos que disponibiliza, como nas exigências de apresentação dos resultados esperados nas pesquisas que financia, que dá a esta agência de fomento uma credibilidade incontestável. Entretanto, esta Fundação foi aberta e flexível suficiente para acolher o projeto COL e entender a elasticidade da execução das tarefas estabelecidas nos cronograma, reconhecer os re-direcionamentos da pesquisa que se impuseram, e conceder a alocação de verbas quando necessário. A FAPESP, nas pessoas dos seus assessores ad hoc, entendeu a natureza experimental do projeto Comunidades_online, tornando possível suas realizações. Talvez financiadores preocupados com resultados demasiadamente palpáveis e em termos estritamente práticos não seriam adequados a experiências desta natureza.

\subsection{A interface do projeto Comunidades_online}

Dentre os objetivos principais do projeto Comunidades_online, apresentados no seu plano de pesquisa, figurava a criação de um sistema informacional de suporte para um ambiente virtual comunitário para uma parcela da população do distrito paulistano Cidade Tiradentes. Tal sistema se configuraria, a princípio como uma rede de informações, comunicações e serviços, como se viu. 0 foco principal seria prover espaços online de trocas de informações e diálogo para uso comunitário. Estava previsto que a modelagem desse ambiente fosse baseado em programas livres, tanto com relação a bases de dados

\footnotetext{
${ }^{41} \mathrm{O}$ Governo Federal brasileiro tem um programa específico destinado a reciclagem, trata-se do Projeto Computadores para Inclusão que implanta os Centros de Recondicionamento de Computadores (CRCs), coordenada pela Secretaria de Logística e Tecnologia da Informação do Ministério do Planejamento.
} 
como nas camadas de apresentação. Seria importante que a construção deste ambiente virtual tanto se desse a partir de modelos alternativos aos comumente utilizados nos campos do design de interfaces para comunidades locais, como explorasse as diferentes possibilidades de interação que o meio digital oferece. Como foi dito anteriormente, as questões quanto a estruturação das interfaces computacionais de ambientes virtuais em projetos envolvendo o uso das TIC com ações em várias frentes comumente não recebem a devida importância. Grande parte das experiências com comunidades virtuais ligadas a comunidades locais vista durante a realização deste trabalho se apropria do modelo de interface tipo portal web. Coloca-se de lado a exploração dos recursos potenciais oferecidos pelo meio, minimizando suas características peculiares, minando possibilidades de exploração de suas potencialidades. A grande maioria dessas interfaces, até pouco tempo atrás, também dificultava e mesmo impossibilita a produção de conteúdo pelos usuários. Este cenário vem mudando em função das diferentes ferramentas facilitadoras dessas ações disponíveis na internet, como se viu no capítulo 3, isso mesmo durante o desenvolvimento da interface do Comunidades_online (COBO ROMANÍ; PARDO KUKLINSKI, 2007; ESTALELLA, 2005; LEMOS, 2005; SPYER, 2007).

\section{Primeiros estudos}

O processo de concepção e os requisitos funcionais detalhados que originaram a produção da interface do projeto Comunidades_online implementada nos primeiros meses de 2007, foram apresentados em parte no item anterior. 0 que se pretendia, como se viu, era possibilitar a cada um dos usuários a percepção de si na totalidade de uma rede montada por meio de associações entre os próprios usuários e conteúdos dessa rede. Os estudos realizados nos primeiros meses de 2006 resultaram na analogia entre o ambiente virtual a ser criado para a comunidade e um céu estrelado. Como mostram as figuras abaixo, neste céu, cada estrela representaria um conteúdo e seu tamanho determinaria o número de 
associações feitas a ele. ${ }^{42}$ Nesta fase do trabalho, já estava definido que a principal função da interface seria fornecer meios para que os usuários percebessem a si mesmos como atores da rede. ${ }^{43}$
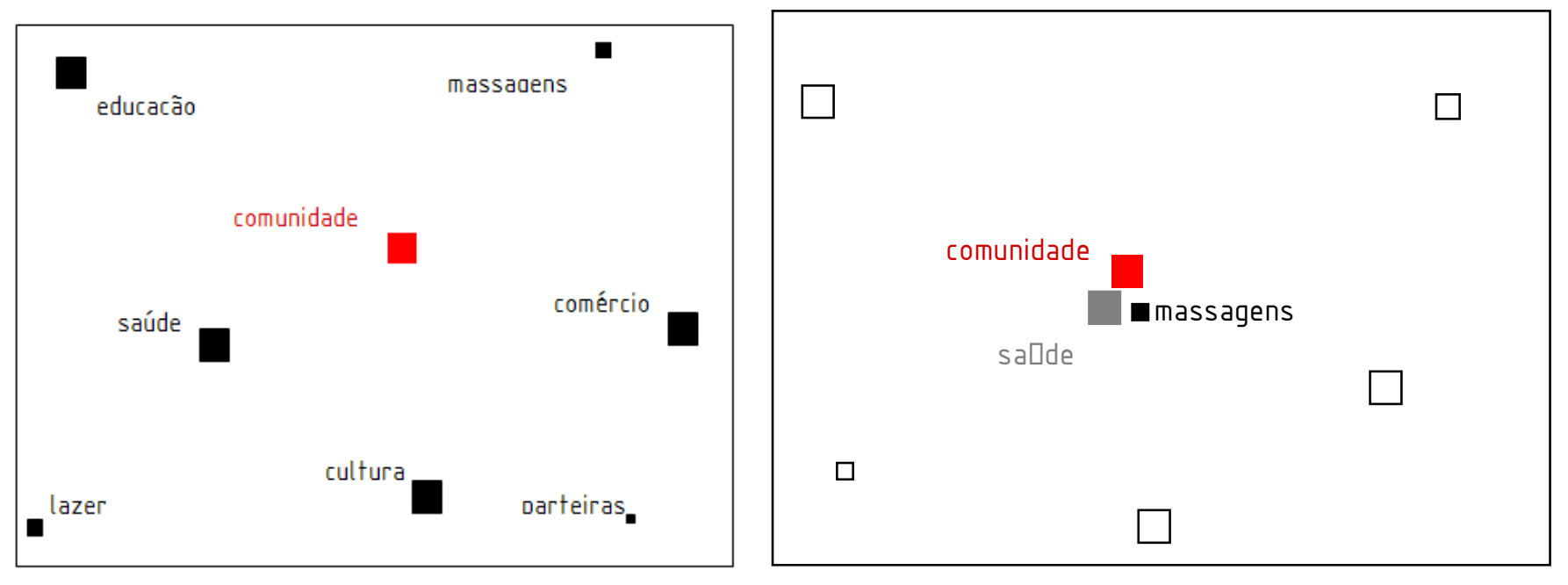

Fig. 10 Interface: estudos 1 Analogia da rede de conteúdos da comunidade ao céu estrelado.

Fig. 11 Interface: estudos 2 Conteúdos.

Fonte: NOMADS.USP (2006)

Fonte: NOMADS.USP (2006)

\footnotetext{
${ }^{42}$ Ao selecionar um determinado conteúdo, os assuntos a ele relacionados dentro da rede seriam evidenciados, e a seleção de um usuário também possibilitaria a visualização das associações entre ele e os assuntos da rede.

43 Tal percepção seria proporcionada tanto por um perfil criado para cada usuário contendo seus dados relevantes, como também pelo uso de ferramentas que permitiriam a eles executarem funções de inserção e associação de conteúdos. Deveriam estar garantido a todos tanto o acesso aos conteúdos como às relações de conteúdos existentes na rede.
} 


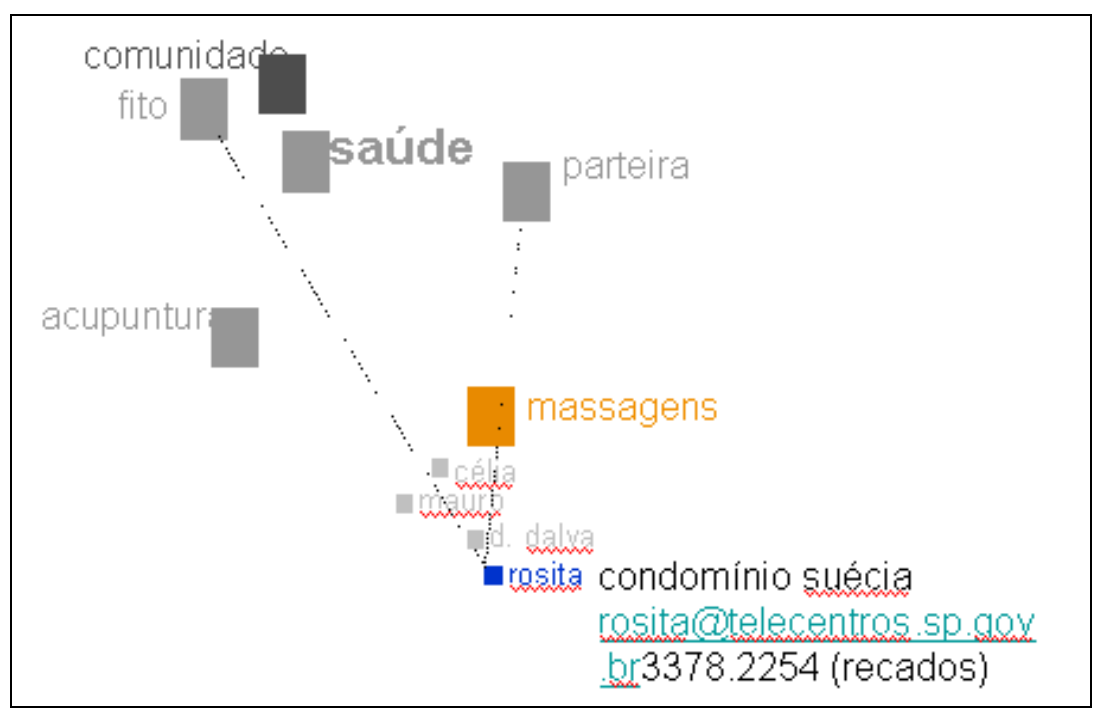

Fig. 12 Interface: estudos 3 Seleção de um usuário na rede: associação com conteúdos. Fonte: NOMADS.USP (2006)

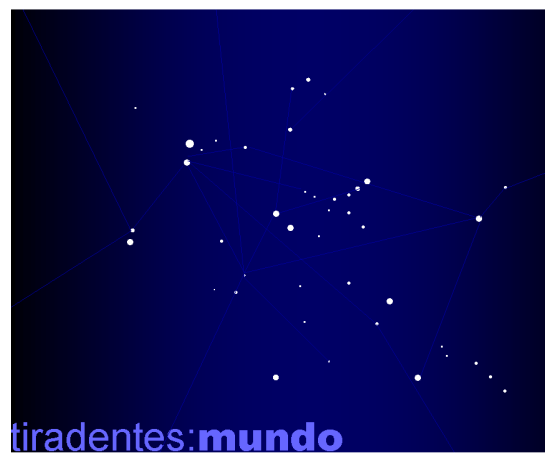

Fig. 13 Estudo gráfico Fonte: NOMADS.USP (2007)

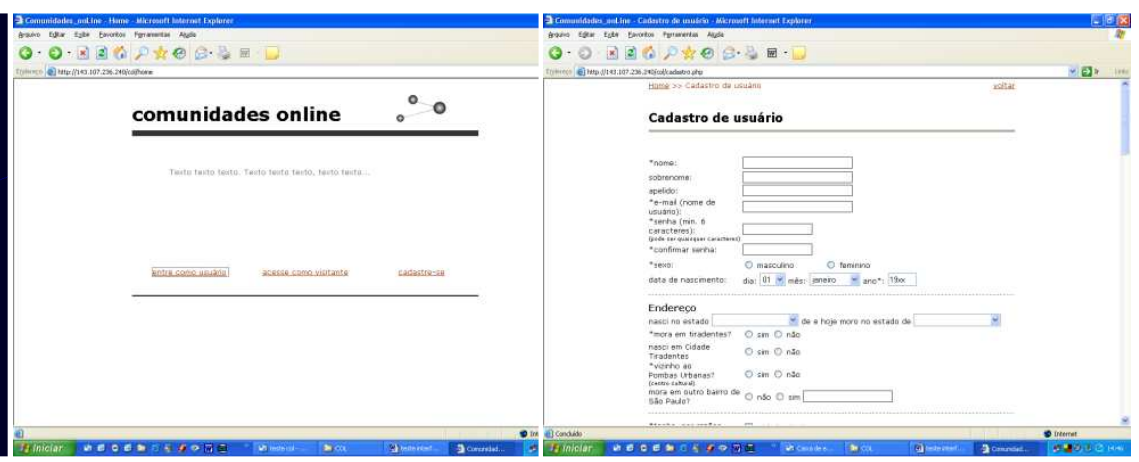

Fig. 14 Design da página inicial Fonte: SANTOS (2007)
Fig. 15 Cadastro:sofreu vários ajustes no conteúdo e

Fonte: SANTOS (2007)

A interface do projeto Comunidades_online foi desenvolvida considerando as configurações dos computadores e a conexão à internet que poderiam ser disponibilizadas no contexto do projeto 
Comunidades_online. 0 “céu estrelado" seria então um applet, aplicativo em linguagem Java possível de ser visualizado em navegadores de qualquer sistema operacional ${ }^{44}$.

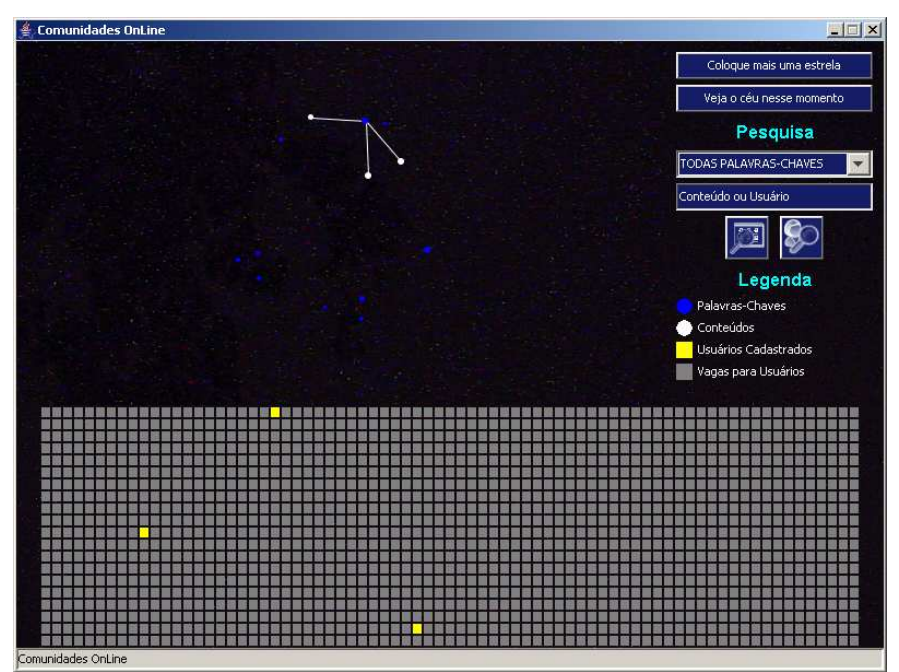

Fig. 16 Design da página principal do applet: primeira versão Fonte: SANTOS (2007)

O protótipo da interface do projeto $\mathrm{COL}$ foi finalizado após testes realizados pela equipe de pesquisadores do Nomads.usp e pelos membros parceiros do Instituto Pombas Urbanas. A realização das primeiras oficinas no telecentro priorizariam o uso e manipulação das ferramentas mais básicas da interface. ${ }^{45}$

\footnotetext{
${ }^{44}$ Optou-se por desenvolver um aplicativo web que tivesse sua camada de persistência (correspondente ao banco de dados, sistema gerenciador que armazena dados arrumados sob forma de tabelas ou matrizes) estruturada em MySQL e a camada de visualização centrada na linguagem Java. Como já foi dito, a configuração da interface a parir destes programas e linguagens derivou de estudos e investigações que buscavam uma melhor adequação às necessidades em relação a diversas características e propósitos do projeto. Várias pesquisas foram feitas no site www.prefuse.org, que dispõe uma biblioteca de visualizações criadas em Java, na busca de um framework, de uma estrutura, arquitetura modelo a partir da qual pudesse ser configurada a interface, e que pudesse abarcar todos os seus requisitos. O applet busca na base de dados os conteúdos necessários às interações. Porém, a camada de apresentação do cadastro seria feita em html e php.

${ }^{45}$ Neste sentido, os testes com a interface centraram-se primeiramente nas avaliações do preenchimento do cadastro, nas telas das informações dos usuários que estariam disponíveis a todos, ou seja, nos 'perfis', na operacionalidade da ferramenta cadastro de conteúdos (botão coloque uma estrela), e do design dos seus elementos correspondentes, na disponibilização das funcionalidades busca por conteúdo e usuário, e na ferramenta refresh (botão veja o céu neste momento).
} 


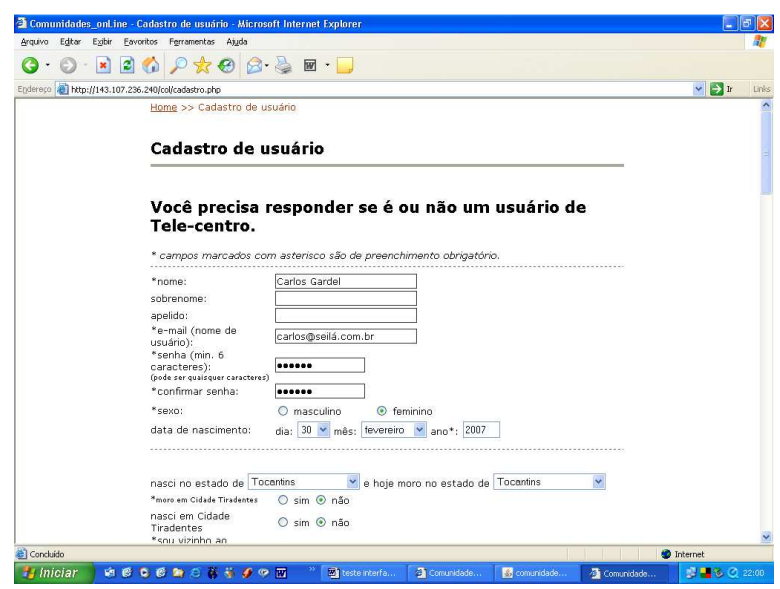

Fig. 17 Exemplo de uma página gerada durante os testes com o cadastro Fonte: SANTOS (2007)
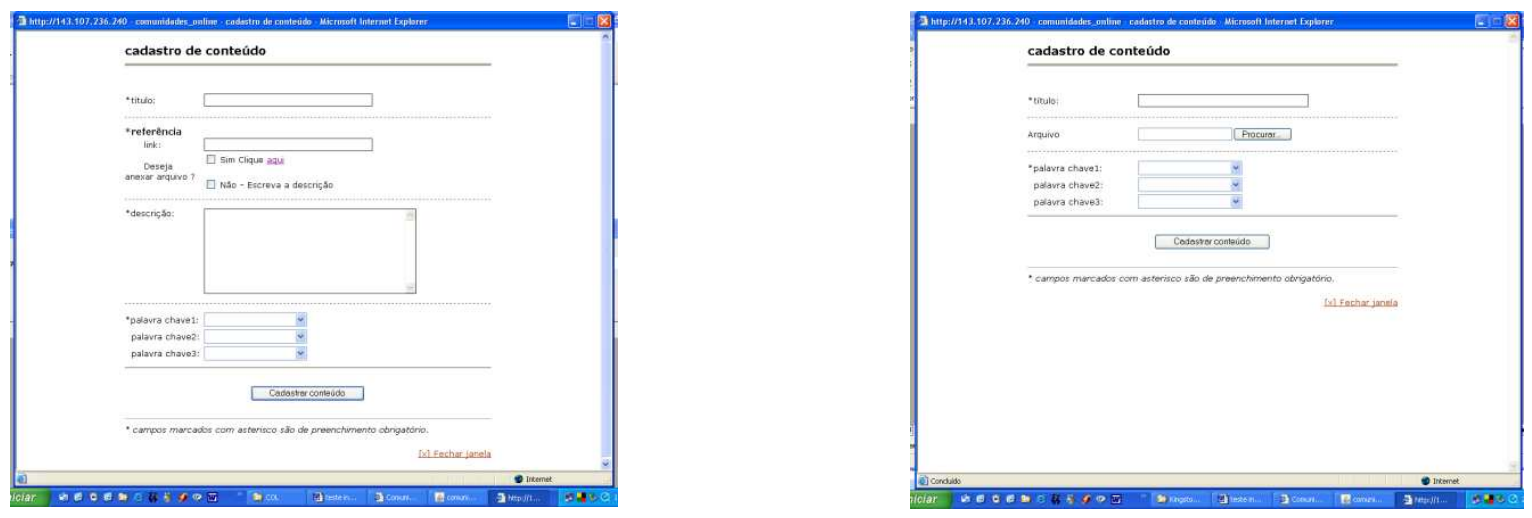

Fig. 18-19 Primeiros designs das páginas de upload Fonte: SANTOS (2007)

A partir de então a interface foi revisada, avaliada e aprimorada. Além da implementação de funcionalidades já concebidas, cada oficina realizada forneceu novos insumos e demandas para o desenvolvimento de outras ferramentas de interação, e também em relação ao aperfeiçoamento da parte gráfica e de conteúdo. Desde a concepção interface do projeto Comunidades_online esteve presente a idéia de que a interface se configuraria como um sistema em aberto, que poderia ser 
complementado, aprimorado e re-configurado tanto pelos seus desenvolvedores primeiros, como pelos seus usuários, a partir de possibilidades de inclusão de conteúdos, por exemplo.

\section{Interface cév estrelado em meados de 2007: http://433.107.236.240}

O sistema informacional de suporte do ambiente virtual criado para a comunidade Cidade Tiradentes poderia ser descrito e analisado em duas partes: uma primeira, enfocando o sistema que agrega algumas páginas relacionadas ao projeto Comunidades_online, com informações sobre o Centro Cultural, o telecentro, entre outros, e também alguns links para os sites do Nomads.usp, Instituto Pombas Urbanas, entre outros, e uma segunda, chamada de interface céu estrelado que corresponde ao ambiente de suporte da rede social propriamente dito, onde estão alocados informações sobre os usuários, conteúdos e ferramentas de diálogo, onde afinal se interage. As páginas de introdução foram desenvolvida a partir de critérios de navegação diferentes daqueles aplicados na interface céu estrelado, sendo menos associativa e mais descritiva. 0 desenho e estruturação assumem um aspecto de portal, cujos links estão dispostos de forma direta e objetiva. ${ }^{46}$

${ }^{46}$ Não interessa aqui o exame desta parte da interface, construída com o intuito de apenas contextualizar o aplicativo de interação. 

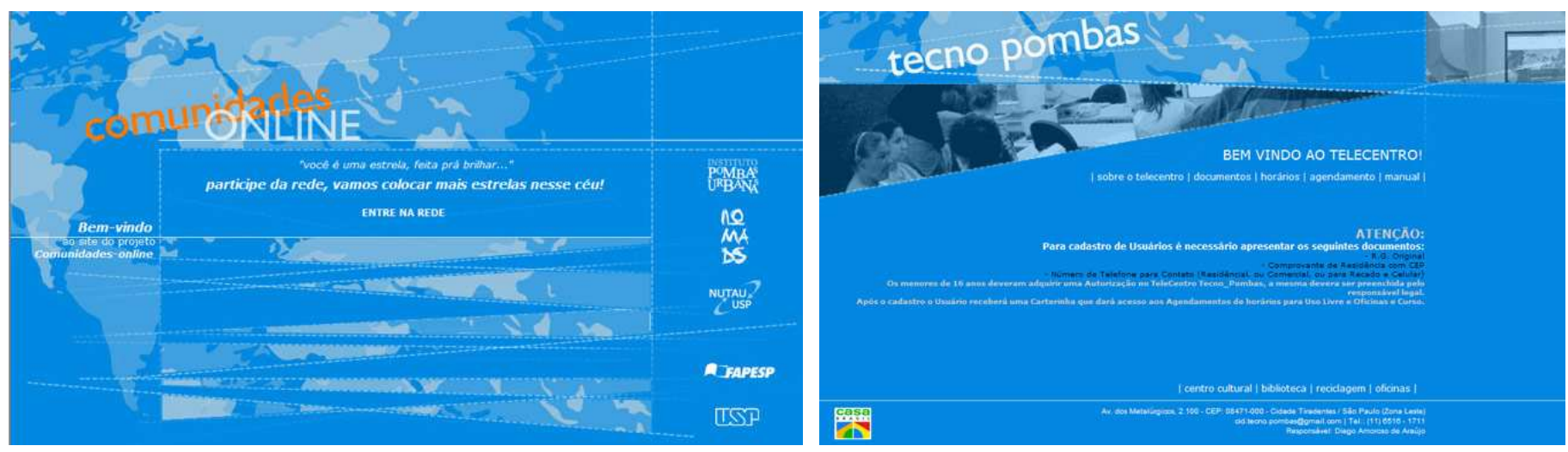

Fig. 20-21 Página inicial e página do telecentro Fonte: NOMADS.USP (2007)

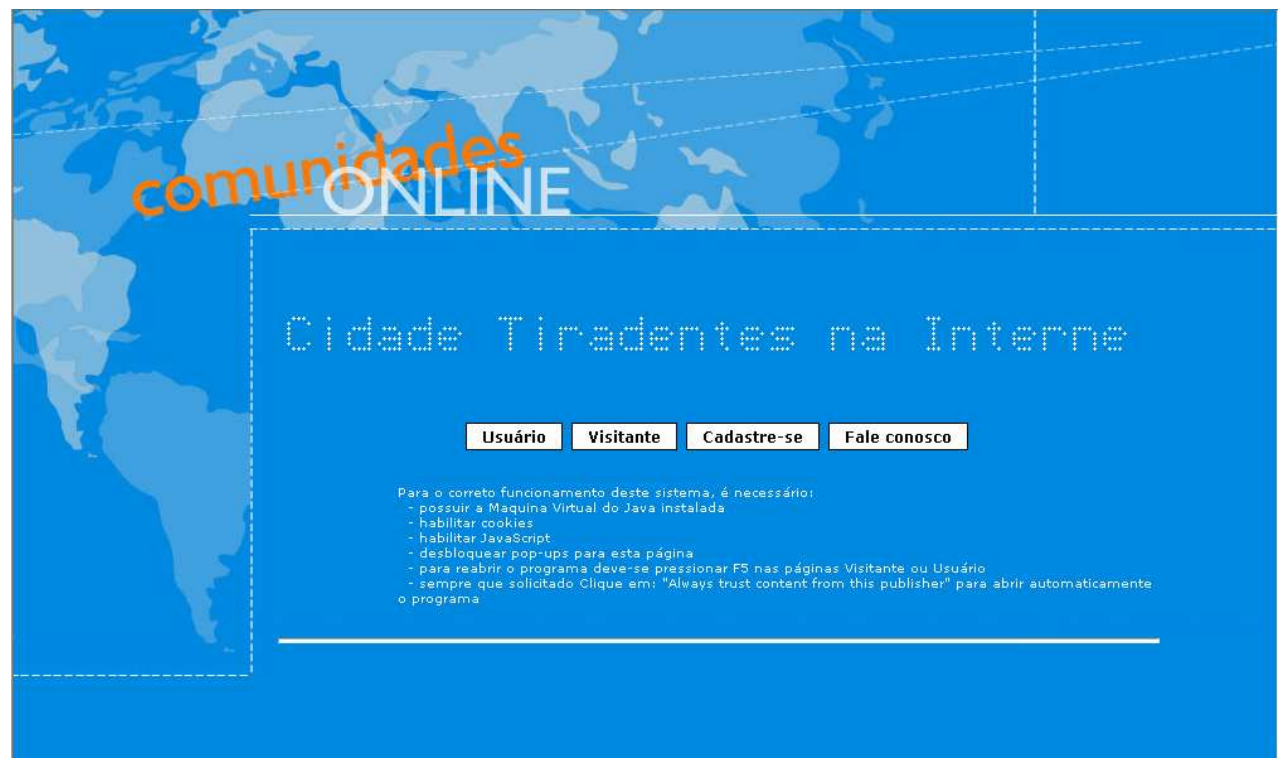

Fig. 22 Página inicial da interface céu estrelado Fonte: SANTOS (2007)

A página inicial da interface céu estrelado acompanha o mesmo design gráfico das páginas de introdução, com a imagem simplificada do mapa-múndi e a composição de regiões tonais em azul, porém numa estrutura mais ortogonal. A dinamicidade gráfica desta página se dá através da frase 
Cidade Tiradentes na Internet em movimento horizontal constante. Optou-se também aqui por privilegiar ainda um formato mais tradicional de disposição das informações em plataformas web, sendo grande parte delas apresentadas e requeridas (no preenchimento do cadastro e login, por exemplo) a partir de textos verbais escritos. ${ }^{47}$ As opções de entrada para o applet são apresentadas na página inicial através dos botões usuário, visitante e cadastre-se. 0 primeiro é destinado aos usuários já cadastrados, que apenas necessitam efetuar login, o segundo àqueles que queiram estar imersos mas sem todas as possibilidades de interação, considerados então visitantes, e o terceiro botão é destinado àqueles que queiram se cadastrar pela primeira vez ou com outras identidades. 0 acesso como visitante impossibilita o upload de conteúdos e o recebimento de mensagens, porém as outras ferramentas de interação do applet ficam disponíveis, inclusive o envio de mensagens aos autores de conteúdos. É importante perceber que, através deste instrumento, se garante às pessoas a interação no ambiente virtual criado sem a obrigatoriedade de identificação, o que é característico à internet. Ao mesmo tempo, para se expressar no ambiente coletivo da comunidade, seja colocando conteúdos online, ou estabelecendo diálogos a partir deles, as pessoas são induzidas a identificarem-se. Mesmo não significando, necessariamente, identificarem-se segundo os padrões e regras dos ambientes presenciais, é importante garantir que as interações e os diálogos estabelecidos no ambiente virtual possam se estabelecer como interlocução, um processo que garanta espaço para a alternância permanente entre produtores e receptores de mensagens. O objetivo, a perspectiva, é que o diálogo, a comunicação entre as pessoas a partir da rede, possa se fortalecer e se estender aos ambientes presenciais.

\footnotetext{
${ }^{47}$ Nesta página inicial se instrui os usuários em relação ao correto funcionamento do sistema, destacando a necessidade de se ter instalado no equipamento usado a Máquina Virtual do Java, de se desbloquear pop-ups, entre outros. Também aqui está a disponível a ferramenta fale conosco que oferece aos usuários a possibilidade de falar com os administradores responsáveis pelo sistema, seja para o envio opiniões, sugestões de qualquer natureza.
} 


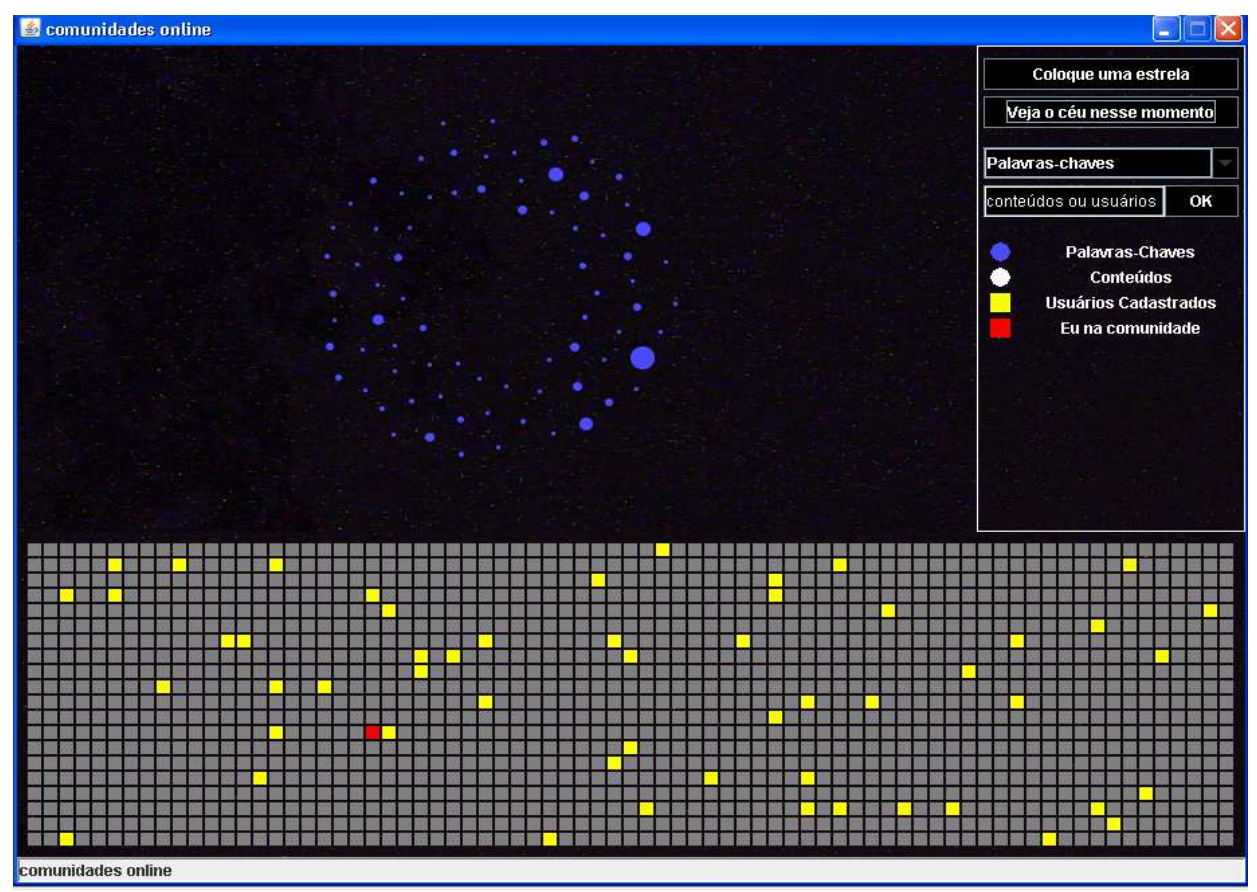

Fig. 23 Página de visualização do applet Usuário “logado" em destaque - quadrado vermelho inferior. Fonte: SANTOS (2007)

O applet é área central da interface criada para a comunidade Cidade Tiradentes. Acessada a partir da página inicial, seja como visitante ou usuário, nela estão alocados os principais conteúdos informacionais da rede, e disponíveis as ferramentas de interação e diálogo. É na camada de visualização do applet que se apresentam os usuários da rede em construção na comunidade, e também os conteúdos criados e postados por eles. O design gráfico e de interação deste aplicativo procura fugir aos padrões mais utilizados em dispositivos desta natureza na internet. Como proposto desde o início do projeto Comunidades_online, buscou-se privilegiar a disposição de informações por meio de elementos gráficos e não só textuais. Assim usuários e conteúdos aparecem primeiramente no formato de quadrados e círculos, respectivamente. É só passando o mouse por estes elementos que se tem acesso às informações textuais correspondentes. 
Acredita-se que estes e outros elementos gráficos presentes na camada de visualização do applet podem gerar interações associativas no sistema, além de possibilitarem leituras e apreensões nãolineares dos conteúdos informacionais disponíveis, o que é próprio à natureza do meio. 0 computador possibilita a estruturação de linguagens hipertextuais, e seus aplicativos devem explorar estas potencialidades, como visto no capítulo 3 desta tese (JOHNSON, 2001; LÉVY, 2000; MANOVICH, 2002; PRATSCHKE, 2002). A conexão à internet potencializa e enriquece esta característica de forma substancial. Nesta interface do projeto COL, estes aspectos foram levados em consideração principalmente aqui, no design do applet. E é particularmente nesta característica que reside um dos seus maiores diferenciais, principalmente se comparado a outros projetos com escopo parecido. Ao criar um ambiente virtual para a comunidade, ousou-se fugir ao modelo portal comunitário, tão comumente empregado, e explorar caminhos alternativos à configuração de espaços virtuais comunitários Buscou-se experimentar as novas possibilidades próprias ao meio e não reproduzir estruturas de outras mídias, dando destaque às interações informacionais associativas e não descritivas. Procura-se proporcionar ao usuário uma nova experiência. Determinados elementos adotados no design gráfico e de interação privilegiaram menos a objetividade e legibilidade tanto com relação à apresentação das informações, como na indicação de caminhos para a realização de ações no ambiente virtual, visto no capítulo 3 (BOLTER; GROMALA, 2003; MANOVICH, 2007; NARDELLI, 2007; PREECE; ROGERS; SHARP, 2005; PRIMO; CASSOL, 2005; SHEDROFF, 2005).

Reconhece-se, mesmo com um uso ainda relativamente pequeno, que o resultado conseguido corresponde a uma interface considerada, para muitos, de difícil entendimento e apreensão, que exige grande potencial de abstração, ou mesmo, explicações claras e diretas a respeito do seu funcionamento ${ }^{48}$. Uma das questões que se coloca aqui é a necessidade de se saber em que grau esta dificuldade poderia comprometer a apropriação do ambiente virtual, ou então, se ela foi sentida de

\footnotetext{
48 Já na fase de testes questionou-se, por exemplo, a opção de representar as palavras-chaves por meio dos círculos azuis e não por textos, considerando que havia uma considerável perda de legibilidade. Entretanto, naquele momento, a natureza dos trabalhos já desenvolvidos e em andamento impossibilitara alterações neste sentido.
} 
forma mais contundente apenas com relação àqueles que possuiam poucas destrezas no uso dos computadores. Não houve, até o período considerado neste trabalho, avaliações sistemáticas que pudessem indicar que esta dificuldade percebida ultrapassa os limites do primeiro contato com o ambiente, que seria, segundo os critérios do projeto Comunidades_online sempre guiado. Sabe-se entretanto que se esta dificuldade se mostrar persistente, causar desestímulos, os pressupostos da interface e soluções de design adotados precisariam ser revistos.

Aos elementos gráficos que compõem o applet podem ser lidos a partir de determinadas analogias, entre elas, trata-se do céu estrelado com suas respectivas estrelas e constelações (círculos azuis e brancos sob fundo predominantemente preto), sob o skyline noturno de Cidade Tiradentes (faixa horizontal composta de quadrados predominantemente cinzas, onde se destacam "iluminados" quadrados amarelos), onde residem os moradores da comunidade. As estrelas que brilham sob a comunidade são repositórios de sua cultura, da sua história, da sua riqueza cotidiana, das suas trocas e interações. Chama atenção na paisagem, no contexto daquela comunidade, aqueles que se interessam em fazer parte dela.

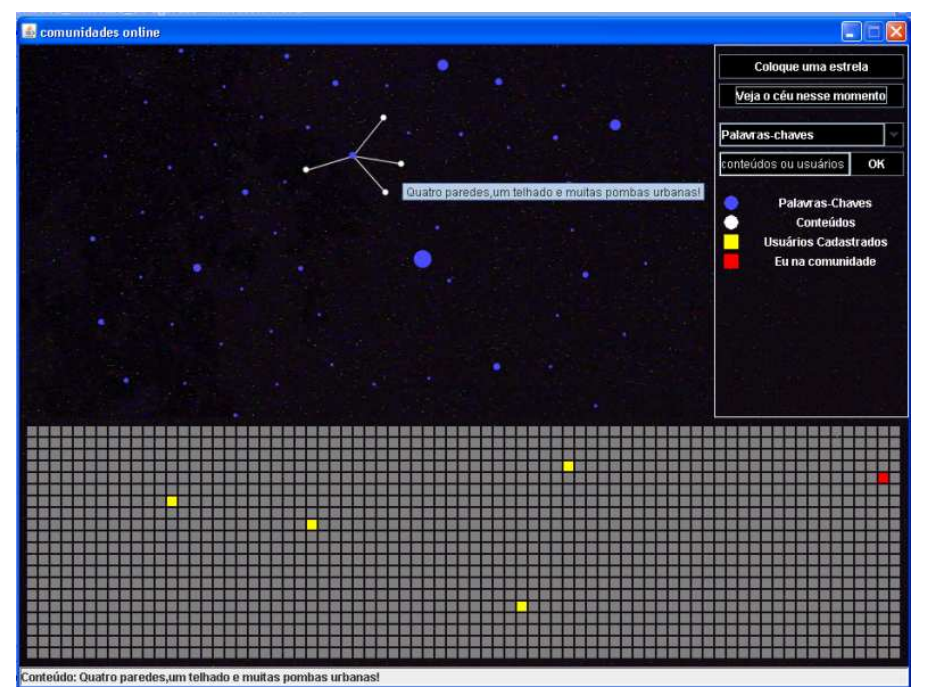

Fig. 24 Apresentação dos conteúdos associados a uma palavra-chave Em destaque o nome de um deles. Fonte: SANTOS (2007) 


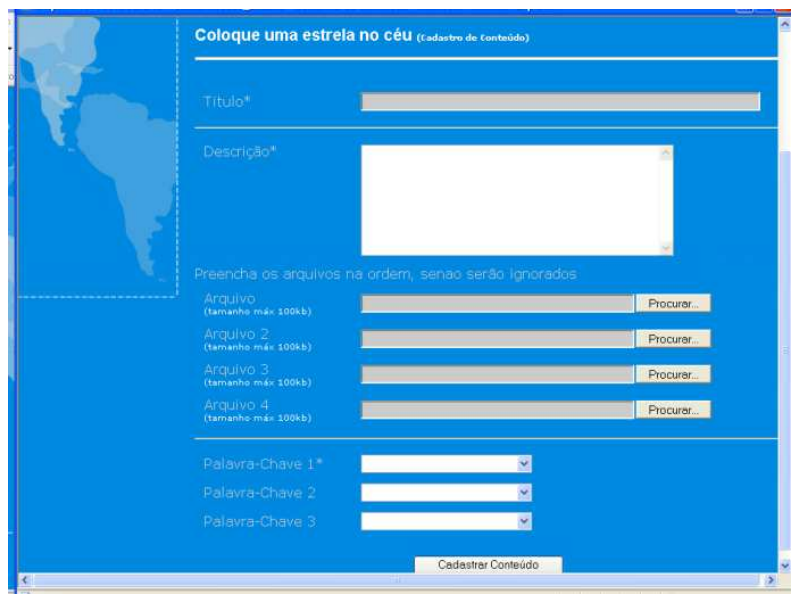

Fig. 25 Página de cadastro de conteúdo

Fonte: SANTOS (2007)

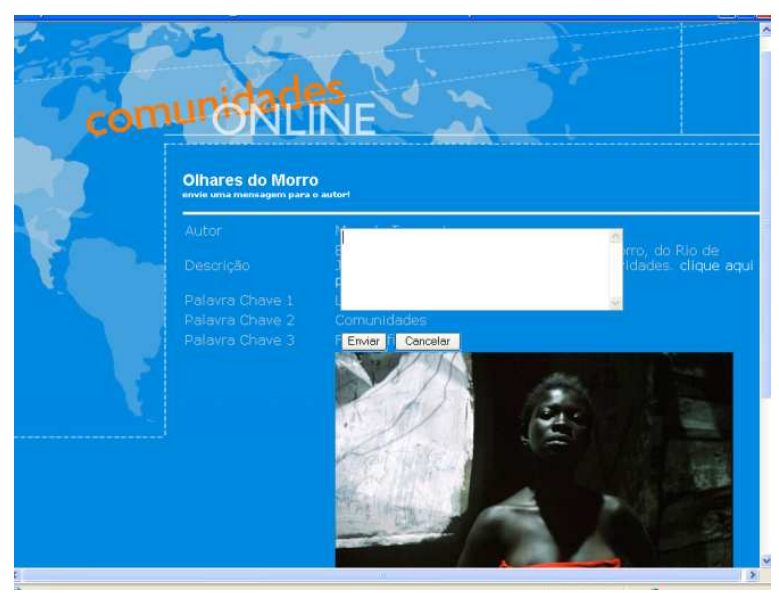

Fig. 26 Dispositivo de envio de mensagens

Fonte: SANTOS (2007)

Como se disse, toda a estruturação deste sistema foi pensada, desde o início, para se adequar aos thinclients que estariam disponíveis no telecentro como às configurações dos computadores reciclados que seriam alocados nos apartamentos. Mas, frente à realidade da conexão disponível no telecentro, houve a necessidade de abrir mão de algumas características que se queriam para a interface. Para o apllet não ficar pesado, ou seja, poder ser executado de forma satisfatória com os dispositivos do projeto, a possibilidade de se oferecer ferramentas de suporte multi-usuários em tempo real, não seria possível, assim como a customização de ambientes. Mas como se queria, no applet tem-se uma interface predominantemente gráfica. A possibilidade de navegação mais intuitiva, através destes elementos gráficos, ou mais objetiva e textual, através dos dispositivos situados à direita, na tela principal, dão, cada qual à sua maneira, acesso a diferentes níveis de informação e interatividade, podendo atender a diversos propósitos e perfis de usuários. 


\section{Aspectos do uso da interface do projeto Comunidades_online no telecentro}

As atividades realizadas nas oficinas, citadas acima, apontaram que, muitas vezes, as dificuldades iniciais no uso da interface do projeto Comunidades_online poderiam estar relacionadas mais ao nível de escolaridade dos usuários do que a uma possível falta de habilidade em lidar com os equipamentos e aplicativo. Neste sentido, a alfabetização digital situa-se como um processo complexo, que requer outras habilidades, como as ligadas a capacidade cognitiva, indo além daquelas requeridas para manusear computadores, como visto no capítulo 1 (MOSSBERGER; TOLBERT; STANBURY, 2003). Os usuários iniciantes, que não possuíam experiência alguma com computadores, parecem se sentirem bem ao verem seus perfís na interface. Além de fruto do grande esforço em dominar o mouse, digitar palavras, existe o valor simbólico de estar na internet. Isto também aconteceu com as pessoas que expuseram seus trabalhos na rede, através da interface do projeto. As imagens pessoais, como as fotografias da família, do próprio trabalho, pareciam exercer grande atração, corroborando a idéia da importância da contextualização no uso das TIC, como discutido nos capítulos 1 e 2 desta tese (DAY; SCHULER, 2004b; EQUIPO TÉCNICO AUPEX, 2003). Usar o computador, conseguir realizar uma tarefa mesmo que simples, parece mexer com a auto-estima, principalmente das pessoas mais velhas, que geralmente parecem ter uma idéia equivocada a respeito deste equipamento e da própria internet. Muitas das pessoas adultas que participaram das oficinas relataram o medo que tinham dos computadores e suas crenças de que apenas os mais jovens possuem capacidade para aprender a utilizá-lo. 

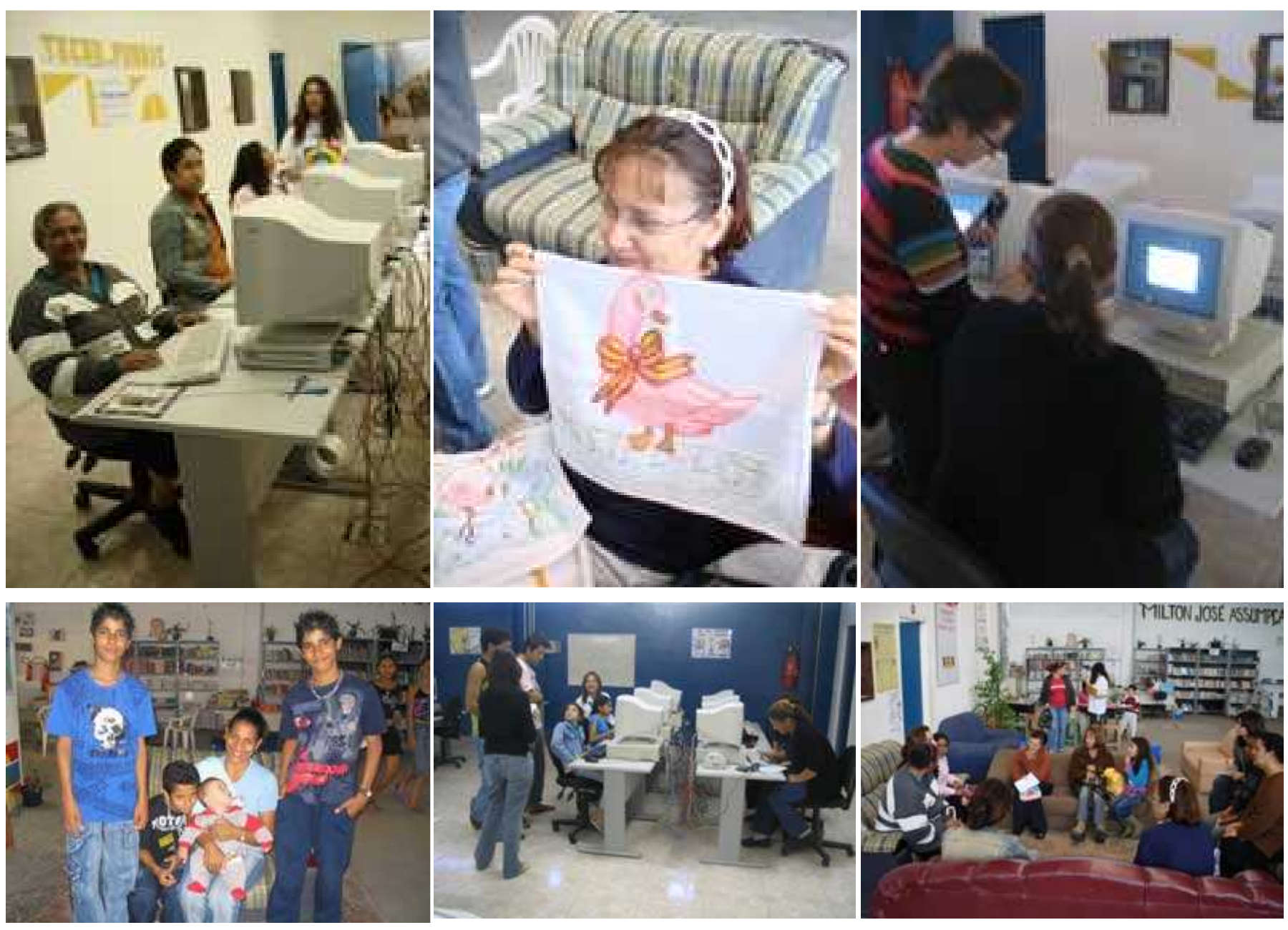

Fig. 27-32 Imagens das oficinas em Cidade Tiradentes Fonte: NOMADS.USP (2007)

O desempenho insatisfatório do conjunto conexão-equipamentos-servidor prejudicou, em muitos momentos da realização das oficinas, a operacionalização de certas funcionalidades do applet. Pode-se perceber que este fato causava algum desestímulo nos usuários. Como destacado no capítulo 1 , o desenpenho técnico dos equipamentos e conexões a internet implicam na qualidade das experiências das pessoas com as TIC (DiMAGGIO; HARGITTAI, 2001). Ainda que se tenha projetado a interface do projeto Comunidades_online tendo como parâmetro os equipamentos e conexões que poderiam ser 
disponibilizados, seus desempenhos reais foram aquém do previsto. Em algumas oficinas não se experimentou de forma exaustiva todas as potencialidades da interface, seja pela restrição de habilidades dos usuários, que demanda um tempo excessivo para a realização de determinadas tarefas, seja pelo desempenho do conjunto conexão-equipamentos-servidor, que de certa forma, dificulta também as atividades a serem realizadas durante um tempo estipulado. O conjunto disponível no telecentro teria que ser suficiente para rodar satisfatoriamente aplicativos web, caso contrário, desestimula-se de forma considerável o uso não só da interface do projeto, mas da internet de forma geral.

Como previsto, percebeu-se uma dificuldade de apreensão da interface do projeto Comunidade_online por parte dos usuários. Não se pode medir ainda em que grau exato esta dificuldade se estabelece. Porém, é possível perceber de forma clara, que a grande maioria das atividades nela centradas não requerem grandes habilidades prévias em lidar com o computador. Ainda assim é preciso que se pergunte qual o pré-requisito com relação às habilidades dos usuários que o design da interface assume (GAVED; MULHOLLAND, 2005). Durante o tempo de realização de uma oficina, pessoas que nunca tinham usado computador, com alguma orientação, conseguiam realizar algumas tarefas a partir da interafce do projeto. Acredita-se que isso se deva a contextualização temática, as ações de incentivo e também ao próprio design da interação. Dado o grande envolvimento que as pessoas demonstram com as atividades realizadas a partir da interface nas oficinas, parece imprescindível que se alimente este contato com outras atividades, até que elas se sintam estimuladas a vencer desafios sozinhas. 


\subsection{Consideraçōes sobre projeto Comunidades_online}

Neste trabalho buscou-se delinear os principais desafios que envolvem introduzir as tecnologias de informação e comunicação no cotidiano de pessoas pertencentes a comunidades locais, de modo a tornar essas tecnologias vetores importantes na melhoria da qualidade de vida. Neste momento, ainda com um olhar atento na experiência empírica de Cidade Tiradentes, reafirma-se que esta é uma iniciativa que depende de diferentes frentes de ações e variáveis de naturezas bastante distintas. Entretanto, ao lado dos desafios previstos e daqueles não formuláveis, encontram-se também as oportunidades que se apresentam ao longo do processo de implementação das experiências com os contornos do projeto Comunidades_online. 0 desafio primeiro parece ser como tratar essa sucessão de mudanças ou de alternâncias, no sentido de concluir da melhor maneira possível o que se propôs a fazer, o que significa perceber as oportunidades que se apresentam no sentido de desviar o menos possível dos objetivos e propósitos. Outro desafio importante é o discernimento sobre as lições a serem aprendidas.

Durante a realização do projeto Comunidades_online deparou-se inúmeras vezes com a questão de como lidar com uma possível restrição de objetivos. Dado a obrigatoriedade de redução de critérios, o que se teria que garantir? Além da esperada persistência em um processo de enfrentamento dos problemas, com ações práticas, parece ter contribuído para a manutenção das rotas principais deste projeto o fato de se ter bastante clareza quanto aos objetivos que não se poderia abrir mão. No projeto Comunidades_online não se poderia abrir mão de ação cultural com mediação informatizada. Ainda que este objetivo não tenha sido formulado nestes termos nos primeiros planos do projeto, estava implícito no desejo mesmo de entrelaçar TIC e vida cotidiana de forma significativa, que pudesse gerar transformações de caráter positivo. Foi a prática em Cidade Tiradentes que mostrou que as ações culturais parecem imprescindíveis neste sentido, como se verá a seguir. 
O caráter inédito do projeto Comunidade_online no contexto brasileiro reside no fato de se estabelecer como uma iniciativa inclusiva que privilegiava ações a partir de espaços coletivos e espaços privados. 0 interesse era, por um lado, ampliar as redes sociais locais a partir do estabelecimento de um ambiente virtual que pudesse ser acessado a partir das moradias, possibilitando, entre outros, às populações de baixa renda experiências com as TIC das quais eram privadas. O telecentro, modelo de acesso que possui configurações bastante constantes, poderia assumir neste projeto outras feições, justamente porque era pensando como um lugar, entre outros, de acesso físico às TIC. O telecentro foi concebido no projeto COL como lugar de suporte às experiências com as TIC vivenciadas a partir da moradia, que como destacam DiMaggio e Hargittai (2001), permitem uma maior autonomia no uso das TIC em relação ao telecentro. Assim, nestes dois lugares estabelecem-se relações com as TIC qualitativamente diferentes, que mereceriam tratamentos também distintos. Os telecentros, da maneira como são tratados pelo projeto Comunidades_online, deveriam estar totalmente integrados a outras atividades dos espaços ao qual pertencem e estão vinculados. As ações que acontecem presencialmente nestes lugares de acesso deveriam estimular e alimentar o incremento das redes sociais locais, inclusive no ciberespaço. Ao entender que as atividades solitárias através da internet poderiam deslocar-se para o interior das residências, parecia claro que o telecentro deveria assumir um caráter de locus de práticas prioritariamente coletivas. No entanto, foi a partir do contato com o Instituto Pombas Urbanas e seu trabalho no Centro Cultural Arte em Construção que o papel do Centro Cultural como elemento de comunicação com a comunidade revelou-se importante.

No projeto COL partia-se do pressuposto que o telecentro deveria ter o caráter de um lugar de intercâmbio de idéias entre os membros da comunidade, visando a ampliação de seu horizonte sóciocultural. Os aportes teóricos desta pesquisa de doutorado levam a crer que os telecentros, segundo este modelo, seriam lugares por excelência de favorecimento das redes sociais estabelecidas em espaços híbridos, que carregam em si recursos com grande potencial de transformação social, como se 
viu no capítulo $2^{49}$ (CASTELLS, 2003; HAMPTON, 2002; MENESES, 2004; MILANI, 2004; OAKLEY; CLAYTON, 2003; RATTNER, 2003; SANTOS, 2005; WELLMAM, 1999).

Como se disse, a caracterização da população realizada pelo projeto Comunidades_online na área de intervenção permite traçar um perfil rico a respeito do grupo de pessoas ali residentes, contudo, revela muito pouco a respeito das redes sociais construídas a partir dos vínculos territoriais nessa porção de Cidade Tiradentes. Teve-se, entretanto, uma idéia a respeito da fragilidade das relações sociais nessa localidade a partir dos relatos das pessoas no Centro Cultural, em diferentes ocasiões ${ }^{50}$. 0 cenário por vezes pareceu desolador, tamanha a desestruturação dos espaços de convivialidade, resultante de um conjunto de fatores, entre eles, o medo, dado a gerência de poderes paralelos na localidade, e a falta de tempo para encontros amistosos, em função da necessidade dos grandes deslocamentos diários para o trabalho, entre outros. Essa face de Cidade Tiradentes por si alimentava a pertinência de se alojar ai instrumentos que pudessem agir sobre os padrões de sociabilidade estabelecidos, que pudessem fomentar os laços e relações sociais em âmbito local. Neste sentido, pode-se dizer que o projeto COL envolveu as questões de design de redes sociais às de design dos espaços híbridos.

\footnotetext{
49 É importante que se diga que as ações de reciclagem alocadas em paralelo às ações do telecentro seriam também importantes neste sentido. Entretanto, estas ações não são devidamente tratadas aqui. Isto porque até o período a que se refere este trabalho elas ainda não estavam estruturadas na prática, ou seja, não tinham sido implementas pelo Casa Brasil, Instituto Pombas Urbanas e Comunidades_online. O Nomads.usp entretanto já havia realizado o projeto do espaço físico da oficina e de seu mobiliário. A oficina de reciclagem deveria estar interligada fisicamente com o telecentro. Essa interligação seria importante para o usuário do telecentro na medida em que ele passa a perceber que o computador no qual ele está trabalhando é o mesmo que está sendo produzido na oficina. Seria importante que os usuários do telecentro e da oficina de reciclagem enxergassem a realização das demais atividades do Centro Cultural. Os projetos arquitetônicos desenvolvidos pelo Nomads.usp para o Centro Cultural privilegiaram esta questão.

50 Em um determinado momento do trabalho em Cidade Tiradentes, convidou-se, então por telefone, os moradores dos apartamentos selecionados a participarem do projeto Comunidades_online como voluntários. A participação nesta atividade possibilitou o contato próximo com a comunidade da área de intervenção. Apesar utilizar um roteiro pré-estabelecido, por se tratar de abordagem direta, diversas vezes teve-se a oportunidade de ouvir, por exemplo, relatos sobre a relação das pessoas com seus vizinhos, suas apreciações sobre os ambientes que circundam as suas moradias, e também, sobre as expectativas com relação as TIC, o relato das habilidades - ou da falta delas - para operar computadores e internet, entre outros.
} 
Estava previsto que as investigações a respeito das interações sociais seriam feitas através de consultas online em estágios diferentes da implantação do ambiente virtual destinado à comunidade. Entretanto, a parcialidade na implantação do projeto tolheu esta importante verificação. É pertinente que se diga aqui que os diferentes problemas que surgiram no desenvolvimento do projeto Comunidades_online não

se constituíram barreiras. Eles foram enfrentados pelos pesquisadores, encarados como parte do processo de conhecimento e reflexão sobre iniciativas desta natureza.

\subsubsection{Os equipamentos, a conexz̃o e a inclusz̃o digital}

A falta de disponibilidade de conexão com a internet foi a grande dificuldade enfrentada no projeto Comunidades_online durante os dois últimos anos de seu desenvolvimento. Esta conexão seria a responsável por prover o acesso domiciliar das pessoas ao ambiente virtual criado pelo projeto para a comunidade Cidade Tiradentes, e através da qual se instauraria uma outra esfera de comunicação e interação social na comunidade. A falta desta conexão foi a que mais prejudicou a realização plena dos objetivos primeiros do projeto, e a que menos dependia de esforços exclusivos dos seus proponentes. Parece não haver criatividade e força de vontade suficientes que superem a falta de infra-estrutura. Este problema, mais dia, menos dia, vai ser resolvido, seja pelo governo seja pelo mercado. No caso deste último, resta saber a que custo para estas populações à margem. Acredita-se que deva ser atribuição do Estado a provisão de conexão à internet, por ainda tratar-se de um bem situado no centro de disputas políticas e de mercado, que se desenrolam em um nível muito distante do alcance de organizações, e mais ainda, das comunidades.

Uma questão se coloca como central nessa pesquisa: em que medida a falta de conexão nos apartamentos exclui o projeto COL do rol das iniciativas de inclusão digital. Seguindo a argumentação 
que perpassa o capítulo 1 desta tese a resposta tenderia ser positiva. Entretanto, seguindo a mesma argumentação, parece ser razoável que não se trate as iniciativas desta natureza de forma tão maniqueísta, dadas as suas dimensões e a complexidade das variáveis a que estão sujeitas. 0 projeto Comunidades_online enquanto realidade empírica pode ser considerado uma ação de inclusão digital porque se estabeleceu como uma evidente oportunidade de inserir o uso das TIC na vida das pessoas, porque se estruturou como um processo que tem como horizonte a qualidade das experiências das pessoas, grupo e comunidade local a partir do uso das TIC. Ainda que tenha esbarrado na questão primária e imperativa do acesso físico a internet, avançou de forma significativa naquela que é considerada a mais importante hoje, a apropriação qualitativa das TIC. Cumpriu com o compromisso da produção de conteúdos e a publicação na internet contextualizadas à realidade de uma comunidade local.

Acredita-se que seria adotar uma perspectiva bastante reducionista pensar que por conta dos objetivos não alcançados, o projeto Comunidades_online não tenha se concretizado. É fato que foi implantado parcialmente, contudo isto não subtrai os seus méritos. Ainda que se tenha em muitos momentos deste trabalho criticado a parcialidade dos projetos envolvendo TIC, não se trata aqui de defendê-la no contexto deste projeto em particular. Este seria um erro imperdoável nessa pesquisa, principalmente que se choca com o caráter da abordagem metodológica adotada. 0 dever aqui parece ser estabelecer um olhar crítico em duas direções, a dos obstáculos e a das conquistas. As dificuldades que merecem atenção são justamente a falta de conexão, acima citada, e o desenvolvimento parcial da interface computacional, que em determinado momento se entrecruzam, como se viu. No sentido das conquistas, destacam-se a adequação da parceria com o Instituto Pombas Urbana, e o uso significativo das tecnologias digitais no âmbito do telecentro base do projeto, entre outros. A seguir volta-se mais uma vez a algumas destas questões. 
As questões prementes para os pesquisadores envolvidos no projeto Comunidades_online durante os testes e as primeiras oficinas com a interface computacional de suporte ao ambiente virtual de Cidade Tiradentes eram: seria mesmo necessário ter construído uma interface exclusiva para o projeto, partindo do zero, isto é, projetando o sistema como um todo, todas as suas camadas, abrindo mão do uso de ferramentas disponíveis na web? Quais implicações dessa escolha? Em que sentido uma interface especialmente desenhada nesses moldes seria um diferencial em uma iniciativa TIC centrada em comunidades locais e espaços virtuais comunitários?

Como foi visto no capítulo 3 dessa tese, de uns anos para cá, existem na internet inúmeras ferramentas prontas e diversas possibilidades de criação de aplicativos que possibilitam a comunicação, produção e postagem de conteúdos e o uso ampliado de recursos gráficos (COBO ROMANÍ; PARDO KUKLINSKI, 2007; ESTALELLA, 2005; LEMOS, 2005; MANOVICK, 2005; SPYER, 2007). Quando o projeto COL foi concebido a realidade era um pouco diferente, parecia ser mais plausível a idéia de criar uma interface, principalmente quando se tinha pressupostos tão claros como a necessidade de oferecer a possibilidade de produção e publicização de conteúdos, a importância da marcação das individualidades num contexto das redes sociais em comunidades carentes, inclusive no sentido de criar identidades positivas, e avançar nas experimentações em termos de design.

Por um lado, poder-se-ia argumentar que a interface céu estrelado é diferente das interfaces disponíveis na internet, sejam as de comunidades de relacionamento, ou mesmo aquelas tipo blogs, principalmente pelo fato de que estas são guiadas e dirigidas por administradores, são vinculadas a empresas, possuem normas e restrições. Este aspecto se chocaria com a autonomia que se quer que a comunidade tenha sobre o seu espaço virtual. Como discutido oportunamente em várias partes deste 
trabalho, a internet não é homogênea, e muito menos pode ser tomada como uma comunidade. A riqueza da interface céu estrelado estaria justamente aí, na certeza de que está vinculada a uma determinada comunidade, que a partir dela pode se ver de outras maneiras, e também na facilidade de contribuir para as trocas nos planos presenciais. Poderia-se pensar ainda, com relação a esta questão, que o desenvolvimento de uma interface específica e exclusiva para o projeto Comunidades_online objetivava rever o uso de modelo e padrões, como se disse oportunamente, experimentando novas construções para os espaços virtuais, considerando exclusivamente o uso de tecnologias não proprietárias e software de código aberto.

Por outro lado, de forma até paradoxal, a interface céu estrelado parece demasiado rígida frente ao cenário de possibilidades que se vê hoje neste campo, como mostraram as interfaces D-Tower, Sky Ear, Under Scan, RadioActive, Hear\&There, Chit Chat Club e Suspensión Amodal, citadas no capítulo anterior. É fato que a interface do projeto COL está muito presa a tela dos microcomputadores, não explora, por exemplo, recursos de conexão com sistemas de telefonia móvel, tão disponíveis também no cotidiano de populações como a de Cidade Tiradentes. Sem dúvida, dentro dos contornos do projeto Comunidades_online, esta interface poderia possuir outras profundidades, outras funcionalidades, como por exemplo, se apresentar com um grande documento na forma de links, ou ainda dispor de outras ferramentas que pudessem reforçar o hábito de comunicação no espaço virtual. Há que se considerar, independente da pertinência dos motivos, que a interface do projeto Comunidades_online perdeu bastante quando abriu mão de estabelecer possibilidades de ações colaborativas mais efetivas, como dispor de ferramentas de trabalho remoto em grupo, que poderiam muito contruir na percepção das instâncias e trocas coletivas. São justamente nessas trocas que residem os recursos transformadores, capazes de fortalecer o espírito critico. São elas que quanto mais ampliadas, mais benefícios podem trazer. Neste sentido, a interface, como um meio, é um elemento que pode ser facilitador ou inibidor, que impõe dificuldades ou abre possibilidades. Tal qual outros meios e suportes, em outras situações históricas, são essenciais, porque carregam parte do nosso arsenal de significações do mundo, neste caso, no espaço virtual. 
É importante mencionar ainda a questão da pertinência do design gráfico da interface do projeto Comunidades_online. Há que se ponderar, como se viu, em que medida as abstrações gráficas não comprometeram por demais a intelecção, principalmente tratando-se de usuários iniciantes com um grau restrito de escolaridade. Haveria a necessidade de avançar nas avaliações em paralelo com o desenvolvimento da própria interface até se encontrar a justa medida entre as inovações na proposta gráfica e no design da interação, tão louváveis neste contexto, e o favorecimento de apropriação do ambiente virtual. A proposta de novos padrões de design para ambientes virtuais de interação comunitária parecem fazer sentido desde que esteja adequada ao público e finalidade aos quais se destinam.

Outras questões com relação a interface mereceriam ser discutidas mais atentamente, entretanto, ultrapassam o escopo desta pesquisa. Por fim, cabe dizer que a interface do projeto COL se construiu dentro de um universo possível, travado em meio a diferentes embates. Foi uma idéia que evoluiu, abandonando diferentes concepções pelo caminho. Hoje parece bastante inapropriado tentar reunir todas as instâncias da vida de uma pessoa e comunidade em um único lugar, ainda que o espaço virtual possua qualificações para tal. Com esta experiência é possível perceber um pouco mais que a vida se dá em múltiplos espaços, incapazes de esgotarem em si mesmos. Aos arquitetos cabem também atribuições de design e construção desses espaços, como se vê na finalização desta tese.

\subsubsection{Além da parceria: aç̄ôs culturais e transformações}

Não se conseguiu avançar muito, no projeto Comunidades_online, em relação às questões do design participativo (PREECE; ROGERS; SHARP, 2005) do ambiente de interação virtual, tanto quanto no envolvimento participativo da comunidade nas outras ações do projeto, considerando-o em termos 
qualitativos e não quantitativos. Isto se deve principalmente às ações desenvolvidas no Centro Cultural Arte em Construção do Instituto Pombas Urbanas. Pode-se dizer que é ai que se instauram as instâncias participativas no âmbito do projeto Comunidades_online.

O fato desse projeto estar imbricado às ações do Instituto Pombas Urbanas, que por sua vez se estrutura claramente a partir de ações diretas na comunidade Cidade Tiradentes, travadas sistematicamente no dia-a-dia dessa comunidade, favorece, como se viu, um aspecto primordial numa iniciativa desta natureza: o engajamento à realidade social da comunidade e ao contexto local dos seus possíveis usuários, evitando que estes se portem como meros beneficiários ou clientes, e ainda mais, indicando as perspectivas e oportunidades de apropriação das TIC no sentido de promover mudanças positivas em âmbito pessoal e coletivo.

Como se viu em diferentes momentos deste trabalho, as relações diretas entre participantes, usuários, e projeto são importantes, quanto mais estreitos são os laços participativos, mais estimuladas são as interações espontâneas, assim como, quanto mais são os suportes sociais envolvidos, maiores as chances de resultados positivos (DiMAGGIO; HARGITTAI, 2001; EQUIPO TÉCNICO AUPEX, 2003; GAVED; MULHOLLAND, 2005; KRETZMANN; MCKNIGHT, 1993; WARSCHAUER, 2006). 0 estudo de várias experiências envolvendo TIC fez perceber que o uso dessas tecnologias tece-se mais ao cotidiano das pessoas quando passa a fazer parte de suas narrativas pessoais (EQUIPO TÉCNICO AUPEX, 2003).

A experiência prática em Cidade Tiradentes mostrou que as ações desenvolvidas no Centro Cultural pela equipe do Instituto Pombas Urbanas possuíam um diferencial em relação a outras que em determinados momentos no desenvolvimento do projeto foram cogitadas para servirem de suporte às práticas do Comunidades_online. As ações culturais apresentavam uma abertura suficiente para tocar nas demandas de uma pessoa, ou grupo social. Sua natureza envolta a tradições e valores intelectuais, morais, espirituais, também ligados aos padrões de comportamento, costumes e crenças, e ainda mais, à riqueza de conhecimentos de forma geral, estabelece um canal de proximidade privilegiado com as 
pessoas e grupos. Se comparada às ações ancoradas em aspectos específicos da vida de indivíduos e comunidade, como as ligadas a saúde ou educação formal, ou mesmo esporte ou lazer, as ações culturais parecem envolver várias faces dessa vida, ao mesmo tempo. Abraça, sem demandar grandes esforços, públicos bastante distintos, em termos etários, por exemplo, e também desejos e necessidades diferentes. Essa abertura e flexibilidade, esta extensão e amplitude, levou a crer que as ações culturais em si são primordiais para abarcar práticas envolvendo TIC.

A realidade empírica em Cidade Tiradentes faz crer que a interlocução entre as TIC e a comunidade local, em projetos da natureza do Comunidades_online, deve estar estruturada em ações sócioculturais desenvolvidas por organizações ou instituições fortemente comprometidas com o desenvolvimento e aprimoramento da comunidade. Talvez em instituições como escolas ou postos de saúde não seria possível uma abertura tão grande, dado que suas próprias demandas são, por natureza, demasiado específicas, pautadas em resultados às vezes por demais objetivos. 0 mesmo poderia ser pensado em relação aos telecentros convencionais, que podem envolver, por um lado, ações bastante rígidas e direcionadas, voltadas a instrumentalização, ou por outro, ações bastante vagas, como no caso do acesso livre, que abre não do engajamento das pessoas na comunidade, como se viu no capítulo 1 desta tese.

Aprendeu-se com a experiência em Cidade Tiradentes que para que a comunidade local entenda que, na internet, é possível encontrar e produzir conteúdos relacionados com seus interesses, a familiarização e uso da rede deve se fazer através de atividades de cunho cultural que se utilizem dos recursos informatizados. Este é um dos principais aportes que a experiência prática em Cidade Tiradentes traz para a compreensão das relações entre comunidades e as tecnologias de informação e comunicação. São as ações de cunho cultural que ajudam também na percepção de que o acesso à internet e às tecnologias que a viabilizam, e ainda aos ambientes de interação virtual voltados a comunidades locais, não são um aspecto supérfluo do mundo, mas podem tornar-se um trunfo no esforço de inserção social das pessoas dessa comunidade. Como se disse oportunamente, a partir dessas 
ações culturais agregadas a TIC é possível se contribuir para ampliar as aspirações e perspectivas sócioculturais, é possível estender os horizontes sócio-culturais das pessoas e comunidades. É possível vislumbrar desenvolvimento local, é possível vislumbrar transformações. Foi neste sentido que o projeto Comunidades_online foi concebido, como uma atividade voltada à transformação da realidade local. 


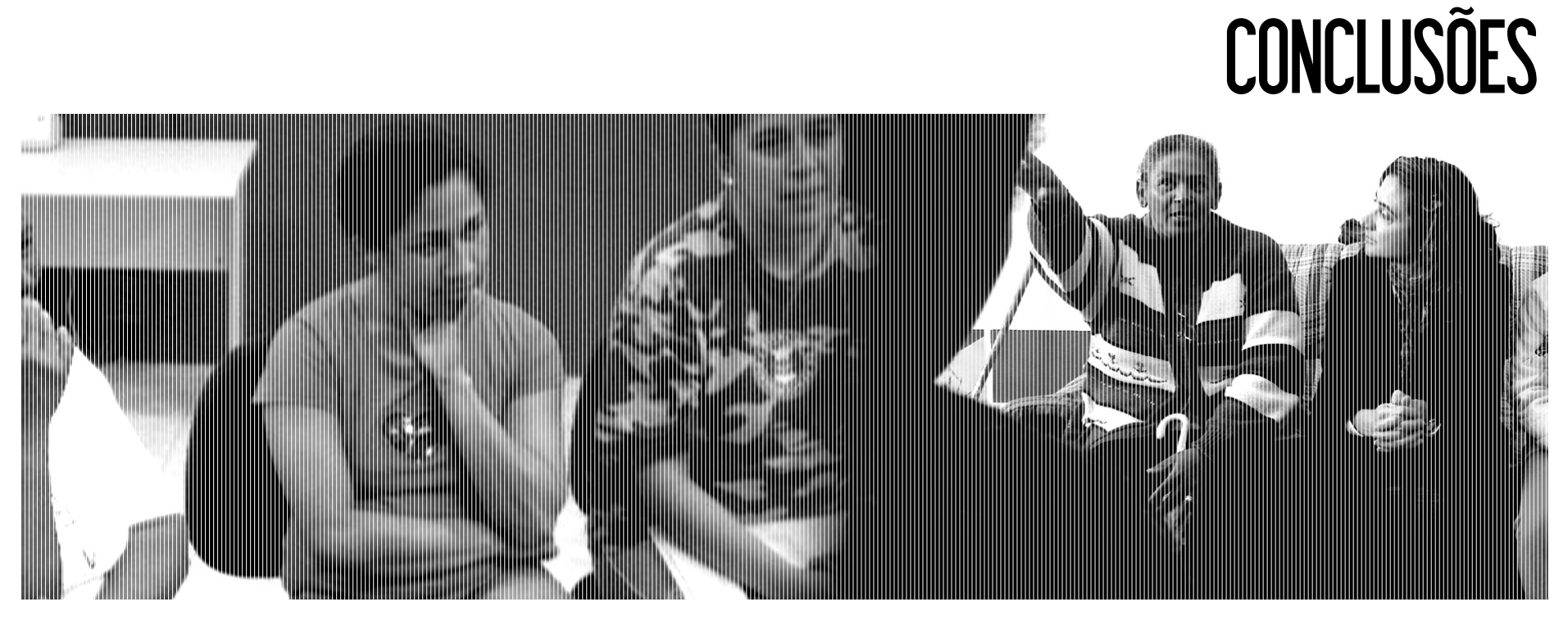




\section{Conclusões}

A seguir, busca-se destacar alguns dos resultados desta pesquisa, o que foi aprendido durante esses anos, o que pareceu bastante relevante e poderá ser útil no direcionamento de outros trabalhos. Tratase de proceder a algumas sínteses reflexivas dos conteúdos apresentados nos capítulos anteriores, de forma a sistematizá-las em duas perspectivas: as conclusões, por assim dizer, que podem ser tomadas como resultados da pesquisa, e as possibilidades de desdobramentos futuros. As questões abordadas são: tecnologias, interfaces, ações culturais e inclusão digital, o alcance das transformações, e a formação do arquiteto.

\section{Sobre as tecnologias}

A partir do estudo dos diferentes projetos e experiências que envolvem o uso de TIC, constata-se, nesta pesquisa, que as tecnologias parecem assumir um peso grande principalmente quando se tratam de contextos de populações e comunidades em situação de vulnerabilidade social. Isto porque, nestes casos, a adequação das soluções tecnológicas faz parte de uma realidade material bastante restritiva. Há, aqui, a premência de moldar as tecnologias aos limites dos recursos. Um importante desdobramento deste fato é o significativo desenvolvimento de novos hardware e software a partir das necessidades que se impõem nesses contextos. É, muitas vezes, nesses cenários de restrições que se apresentam, experimentam e se criam soluções tecnológicas inusitadas e inovadoras. Nos projetos em que fluem recursos financeiros, o aspecto tecnológico não costuma ser central. Nesses casos, a tecnologia é pensada dentro dos moldes e padrões convencionais de uso do momento, sem demandar atenção especial. Se, por um lado, esta adoção pressupõe, em alguns casos, uma postura pouco crítica em relação à tecnologia, por outro, num projeto com diferentes demandas, pode significar um desprendimento quanto a este aspecto em específico que favorece a priorização de outras questões 
também bastante importantes. Na verdade, a tecnologia demanda grandes esforços para ser contextualizada a uma determinada realidade, seja socioeconômica, seja instituída a partir de outros marcos cognitivos. Nos projetos que assumem as TIC como meio, não como fim em si mesmo, isto pode significar uma dificuldade extra frente aos objetivos almejados.

\section{As interfaces}

Do exame das interfaces emerge a convicção de que comunidades em espaços híbridos deveriam ser estruturadas a partir de interfaces computacionais que ultrapassem as telas - seja dos computadores, dos telefones móveis ou ainda da TV digital. Apoiando-se na evidência cada vez mais comum da computação ubíqua, tais interfaces devem estar integradas à vida cotidiana, a partir de objetos dispostos nos espaços físicos coletivos e públicos da própria comunidade, nos moldes da $D$-Tower ou análogos aos arranjos das obras Under Scan e Suspensión Amodal. As discussões estabelecidas no plano teórico desse trabalho levam a crer que estas interfaces, que trazem consigo as interações e trocas travadas no ciberespaço, quando implantadas no espaço físico da comunidade, têm maior poder de alcance, maior capacidade de penetração na vida diária de um maior número de pessoas. Reforçam as instâncias de comunicação e interação coletiva, no plano daquele recorte territorial, ainda que possam se estabelecer para além desse fragmento, residindo justamente nesse aspecto uma de suas maiores riquezas. As interfaces centradas em fragmentos urbanos devem assumir presumidamente seu caráter simbólico, de representação dos laços e trocas estabelecidos na comunidade, das redes sociais ali existentes, que podem, situadas como estão também no ciberespaço, extrapolar esses limites territoriais e as imposições da materialidade física. As interações que fluem através desses importantes meios devem, como se destacou anteriormente nesse trabalho, ser direcionadas pelas das ações de viés cultural estabelecidas também em espaços coletivos da comunidade. 


\section{Ainda sobre as interfaces}

Este trabalho enfatiza a importância da construção de interfaces especialmente desenhadas para dar suporte às ações nos ambientes virtuais, no âmbito da constituição de espaços híbridos em comunidades locais. Isso se coloca como um pressuposto, considerando em diferentes momentos, que deve ser reafirmado aqui, dado o caráter que as interfaces podem assumir, seja como elementos favorecedores e atratores, seja desestimuladores, impondo dificuldades à apropriação dos espaços virtuais de interação social. Entretanto, durante o desenrolar da pesquisa, houve uma mudança significativa no entendimento do caráter do que necessariamente significa esta construção.

As análises de diferentes projetos envolvendo o uso das TIC indicavam, no início, a necessidade de se fugir aos modelos convencionais dos portais web, a premência em se favorecer ambientes de produção e publicização de conteúdos e a importância da marcação das individualidades num contexto de redes, seja no plano dos indivíduos em relação a comunidade em si, desses frente a internet, e ainda da comunidade em relação a esta rede maior. Parecia haver a necessidade de construção de interfaces computacionais que abarcassem todas essas questões primordiais à constituição das esferas virtuais de interação. Ainda que há poucos anos atrás a disponibilização de ferramentas na própria web que cumprissem estas funções fossem ainda pouco usadas e desenvolvidas, somente este fato não justifica o entendimento da construção de uma interface computacional como algo que parte do zero, com inúmeros desafios e dificuldades a serem travadas principalmente no plano técnico, alheio às ferramentas e instrumentos disponíveis. A construção de uma interface para os ambientes virtuais de interação pode se dar a partir dos recursos disponíveis, tanto no plano tecnológico como de conteúdos. Foi esse entendimento que se alterou durante essa pesquisa, e que, também no plano do projeto Comunidades_online, parece ser revelado de forma mais explícita, através de algumas dificuldades presentes no processo de produção e no resultado final da interface criada. 
A construção a partir dos recursos disponíveis, no plano tecnológico, se dá com as práticas combinatórias, com os mashups, que partem da reunião de ferramentas e aplicativos de várias fontes, da mistura e agregação de diversos sistemas, dispostos em um único lugar de acordo com interesses específicos. Eles podem, inclusive, quando pensados no contexto de projetos envolvendo uso das TIC, ser propostos e realizados pelos próprios participantes, sem comprometer a autonomia, citada oportunamente neste trabalho como um possível entrave. A construção a partir dos recursos disponíveis, no plano de conteúdos, se alinha justamente aos pressupostos de adequação a demandas e realidades socioculturais, bastante discutidos durante a pesquisa, apresentados oportunamente em diferentes momentos deste trabalho.

Hoje, entende-se que há não só uma adequação, mas a possibilidade em se usar os inúmeros recursos disponíveis na internet para a construção de interfaces computacionais interessantes, atrativas, facilmente adaptáveis às necessidades e desejos de pessoas com diferentes perfis, inclusive em relação ao uso de diferentes tecnologias digitais. Interfaces que podem agregar inovações e explorações em relação ao design gráfico, se centradas em telas, e também em relação ao design de interação, e design para a experiência.

\section{Aç̄es culturais e inclusão diggtal}

Uma das conclusões importantes desta pesquisa diz respeito à consideração da importância das ações que dão suporte à justaposição entre dimensões concreta e virtual na vida cotidiana de uma comunidade local. A partir da análise de diferentes projetos e ainda da experiência em Cidade Tiradentes, pode-se dizer que o vínculo entre as esferas virtual e presencial em uma comunidade deve se dar no âmbito de ações culturais. 
Posto que há a necessidade de prover práticas de estímulo e incentivo voltadas a favorecer a apropriação de ambientes virtuais de interação coletiva, elas devem se dar a partir de ações de viés cultural. Essas ações podem envolver e reunir diferentes faces da vida das pessoas ao mesmo tempo, das habilidades e capacidades próprias ao corpo, às dispostas na mente e espírito. As ações dessa natureza parecem ser abertas e flexíveis o bastante para comportar diferentes demandas. As atividades culturais, quando agregadas às TIC, criam diferentes possibilidades de vinculação do uso dessas tecnologias às necessidades e desejos pessoais e de coletividades. Favorecem, por suas qualidades intrínsecas, processos de significação dessas tecnologias no contexto da vida das pessoas, e criam maiores chances de que elas façam parte de seus cotidianos e das suas narrativas.

As atividades culturais, quando agregadas às TIC, se estabelecem como verdadeiras ações de inclusão digital, entendida como um processo que tem como horizonte a qualidade das experiências das pessoas, grupos e comunidades locais a partir do uso dessas tecnologias.

\section{0 alcance das transformaçōes}

A consideração das comunidades como redes sociais possibilitou, nesse trabalho, o entendimento das transformações possíveis que se podem alcançar com o estabelecimento de espaços híbridos. 0 adensamento e ampliação das esferas de comunicação através das instâncias virtuais favorecem o fortalecimento e as trocas nas redes sociais construídas a partir de vínculos locais. Este fortalecimento se dá principalmente pelo estreitamento dos laços estabelecidos entre os nós de uma rede, pela ampliação das possibilidades de relações entre eles e pela ativação dos fluxos de recursos que se alojam e se mobilizam justamente nos seus entremeios. As redes sociais são fonte de suporte social e, sua potencialização traz, por si, benesses para aqueles que as constituem. Como se viu nesse trabalho, o capital social é o recurso próprio às redes sociais, e parece ser o bem disponível mais sujeito às intervenções no âmbito das iniciativas comunitárias envolvendo o uso e apropriação das TIC. 
Há que se pensar que as iniciativas preocupadas em inserir as TIC na realidade das pessoas que se encontram à margem deveriam investir na tarefa de ampliação das esferas de comunicação comunitária, que traz consigo poder de transformação, ainda que circunscrita a uma perspectiva de fortalecimento das redes sociais, da busca de eqüidades, de mudanças às vezes não percebidas objetivamente, como a partir da formação de um sujeito mais crítico, autônomo, consciente de seu lugar no mundo. A realização plena dessa ampliação e adensamento requer em si um esforço enorme, entretanto passível de se conseguir, ainda que em contextos de adversidades, a médio e longo prazo. Se a esses objetivos agregarem-se a geração de renda, a capacitação profissional e a disponibilização de serviços, passam a se desenhar metas que tendem a se transformar em impossibilidades, dado o esforço hercúleo necessário para pô-las em prática. Esses propósitos juntos se adequam a discursos, mas são muito pouco exeqüíveis. Ainda que estas ações sejam louváveis, a questão da apropriação qualitativa das TIC é mais imperativa.

Muito provavelmente, a falta de clareza das implicações dessas diferentes perspectivas rondam o planejamento dos programas públicos voltados à promoção do uso de TIC em ambientes de exclusão. Como se viu no capítulo 1, as iniciativas envolvendo o uso de TIC conformam diferentes dimensões e complexidades justamente porque possuem limites permeáveis que se estabelecem nas interdependências e subordinações de aspectos e contextos distintos, principalmente econômicos e políticos, e também pela própria pluralidade de desafios que as inovações constantes das tecnologias de informação e comunicação impõem. Parece difícil que uma iniciativa abarque satisfatoriamente o conjunto de variáveis interdependentes que as ações desta natureza pressupõem. Como se viu neste trabalho, trata-se de uma justa dificuldade em se avançar em várias frentes ao mesmo tempo.

Entretanto, se há uma limitação de certa forma intrínseca à implantação das ações e práticas envolvendo o uso e apropriação das tecnologias de informação e comunicação, haveria de se ter também uma justa medida entre as promessas dos discursos e as transformações possíveis no âmbito de qualquer projeto dessa natureza, público ou não. Trata-se de uma justa apropriação ao objeto tratado. 
Como se disse, as tecnologias digitais são meios, não fins em si mesmas. São destituídas de funções quando alijadas de propósitos factíveis construídos em outras esferas da vida, e devem ser tratadas assim, sob esta perspectiva. Não devem alardear, comportar e dar suporte a promessas que não se cumprem.

\section{A formaç̧̄o do arquiteto}

Foi inevitável, em inúmeros momentos, durante o desenvolvimento desse trabalho, indagar-se sobre o papel do arquiteto frente as práticas de design dos espaços híbridos no âmbito dos fragmentos urbanos. Em que medida seriam estes espaços, tal qual seus pares concretos, físicos, da alçada desse profissional? Por quê? Chega-se ao término da pesquisa acreditando-se na pertinência em se somar essa tarefa ao escopo de atribuições da Arquitetura, a partir de algumas constatações estabelecidas no plano da participação na experiência em Cidade Tiradentes e dos estudos teóricos. Como se disse anteriormente neste trabalho, a criação desses espaços está diretamente associada a produção de ambientes virtuais de interação, que por sua vez demanda, no mínimo, por um lado, conhecimentos técnicos específicos na área da computação e sistemas de informação, por outro, conhecimento sobre os processos de interação social, e todo o arcabouço de constituição das redes sociais, sejam elas estabelecidas em espaços online ou offline. 0 arquiteto, ainda que não tenha no seu repertório base construído durante os anos de formação na academia - conhecimentos específicos nesses assuntos, possui grande destreza em transitar por áreas disciplinares distintas as suas. Isto se mostrou bastante claro no desenvolvimento do projeto Comunidades_online, inclusive com relação aos outros pesquisadores envolvidos. A sua formação multidisciplinar requer esta habilidade de criar ligações, de estabelecer relações entre diferentes campos do saber, e isto o qualifica a conceber e desenhar também espaços que nascem a partir de uma pluralidade de aspectos entrelaçados, como se viu. Isso 
não se restringe às questões de conteúdo. Pode-se, ainda, admitir que o arquiteto tem a habilidade necessária para gerenciar as diferentes ações e diálogos que requer a criação desses espaços.

Assim, diante da perspectiva de se ter cada vez mais as tecnologias digitais combinadas às ações diárias, cotidianas, diante da ubiqüidade das TIC, e das possibilidades mesmas de construção de espaços híbridos na escala dos fragmentos urbanos, seria pertinente supor que o próprio escopo de disciplinas oferecidas na formação desse profissional fosse revista. Principalmente, no sentido de acrescentar matérias à sua formação, de forma sistematizada, que possam auxiliá-lo no desempenho de outras tarefas com as quais vão se deparar.

\section{Os objetivose as hipoteses}

A participação na experiência em Cidade Tiradentes, aliada aos estudos teóricos, possibilitou alcançar os propósitos estabelecidos. O trabalho analisou diferentes maneiras que as tecnologias de informação e comunicação podem ser inseridas em comunidades locais. Apontou os contornos das práticas que tendem a explorar as potencialidades do uso das TIC de forma a poderem resultar em transformações, para a comunidade e para seus indivíduos. Considerando o adensamento da comunicação a partir das tecnologias digitais em comunidades locais, explorou a qualidade e amplitude dessas transformações, do desenvolvimento comunitário e do fortalecimento de vínculos sociais locais. Examinou as configurações das instâncias virtuais de interação que podem favorecer e potencializar as redes sociais em espaços online, principalmente explorando a infra-estrutura material, e os suportes e instrumentos lógicos e físicos disponíveis para instituir a comunicação em ambientes virtuais em comunidades locais.

Os resultados obtidos confirmam a hipótese de que os espaços híbridos em fragmentos urbanos se constróem a partir da justaposição das dimensões concreta e virtual com a ampliação e o adensamento das esferas de comunicação, no plano das comunidades locais. 0 trabalho demonstrou a pertinência em 
se considerar o espaço híbrido em fragmento urbano como estrutura formal e material. Estabelecido em uma realidade objetiva que entrelaça o espaço físico e o ciberespaço, esse espaço híbrido é, entretanto, dado à experiência a partir da perspectiva do adensamento das esferas comunicacionais das redes sociais, num determinado recorte da cidade.

As análises estabelecidas também levam a crer que a implementação de instâncias híbridas de interação em comunidades locais em situação de vulnerabilidade social instaura possibilidades de transformação de condições sociais. A ampliação ou o adensamento das esferas de comunicação das redes sociais que se constituem a partir de territórios e lugares fragilizados favorece uma maior fluidez de recursos no âmbito delas mesmas, possibilitando transformações que levam a melhorias na qualidade de vida das pessoas, seja no plano individual ou coletivo. 0 fortalecimento do capital social e a instalação de processos de empoderamento geram mudanças, ainda que pouco perceptíveis de imediato a olhos menos atentos, e em uma escala avessa a quantificações.

\section{Desdobramentos futuros}

Esta pesquisa aponta para estudos futuros a partir de três questões que poderiam trazer novos aportes à reflexão iniciada aqui. É importante produzir conhecimento a respeito das especificidades do gerenciamento de projetos envolvendo o uso de TIC de forma geral, e especialmente no âmbito das políticas públicas, dado que os governos são seus principais implementadores. É necessário explorar o design de interfaces computacionais de suporte para instâncias de comunicação e interação coletiva que se estruturem para além das telas dos microcomputadores, dado seu potencial de alcance e penetração na vida diária de um determinado ambiente urbano. Por fim, seria pertinente investigar com atenção os procedimentos metodológicos e avaliativos que permitam aferir mais precisamente a qualidade dos recursos relacionados ao capital social que fluem nas redes sociais fundadas em bases 
locais. Indicando, dessa forma, melhores maneiras de direcionar as práticas envolvendo tecnologias de informação e comunicação nas esferas online e offline. 


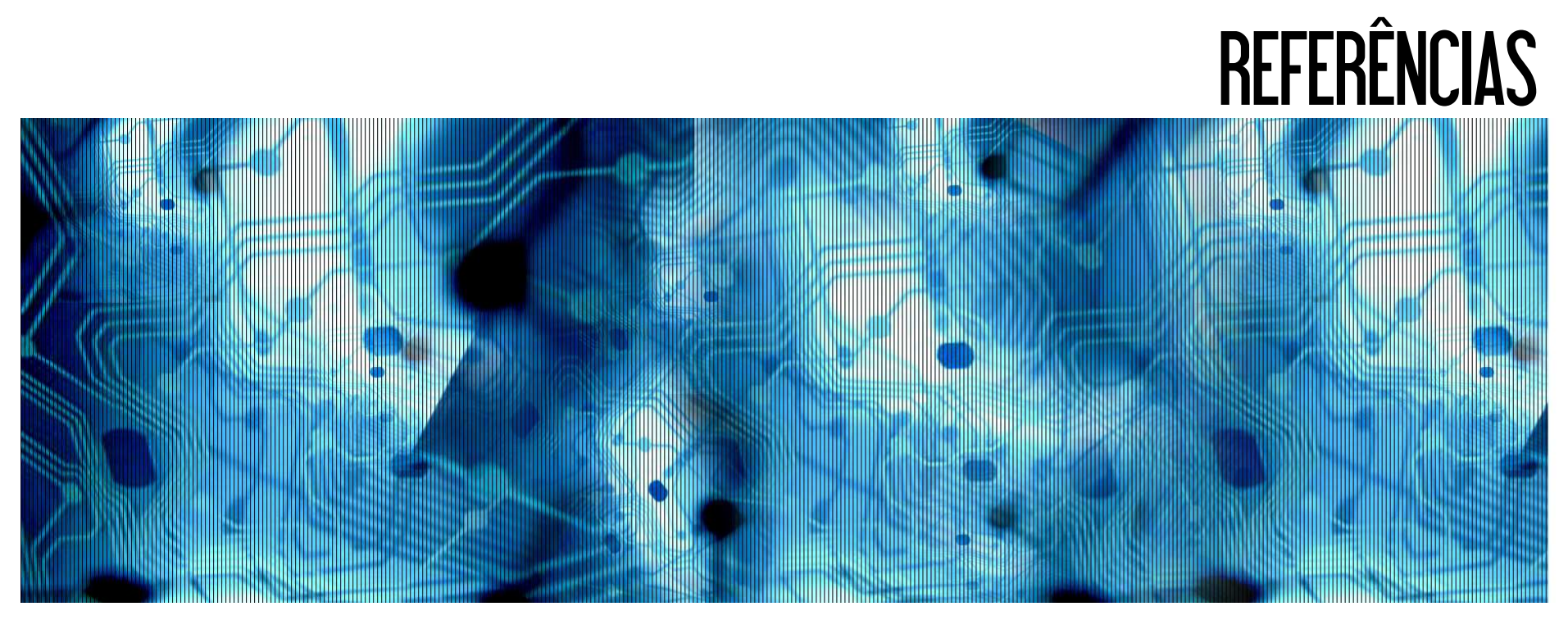


ALLEN, C. (2004). Tracing the evolution of social software. Life With Alacrity. Disponivel em: <http://www.lifewithalacrity.com/2004/10/tracing_the_evo.html>. Acesso em: 21 ago. 2006.

ARAM, J. D. (2004). Concepts of interdisciplinarity: configurations of knowledge and action. Human Relations, London, v.57, n.4, p.379-412.

ARAÚJO, R. B. (2003). Computação ubíqua: princípios, tecnologias e desafios. In: SIMPÓSIO BRASILEIRO DE REDES DE COMPUTADORES, 21., 2003, Natal. Anais... Natal: UFRN. p.1-71.

ARNOLD, M. (2004). The Connected Home: probing the effects and affects of domesticated ICTs. In: BOND, A. et al. (Ed.). Artful integration: interweaving media, materials and practices. Palo Alto: CPSR. V.2.

ATKINSON, P.; HAMMERSLEY, M. (1994). Ethnography and participant observation. In: DENZIN, N.K.; LINCOLN, Y.S. (Ed.). The Sage handbook of qualitative research. California: Sage.

ATKINSON, P. et al. (2001). Editorial introduction. In: (Ed.). The Sage handbook of ethnography. California: Sage.

AUGUSTIN, J. P.; GILLET, J. C. (2006). La Animacion sociocultural: estrategia de accion al servicio de las comunidades. Bogotá: Universidad Externado de Colômbia. 
AUTO-SUSTENTAÇÃO: definição. (2007). Disponível em:<http://www.ibtsonline.org/index2.php>. Acesso em: 25 jan. 2007.

AVATARS. (2008). Disponível em: <http://web.media.mit.edu/ dharry/infoavatars/>. Acesso em: 28 abr. 2008.

BARREIRA, C. R. N. (2004). Corpos virtuais: representações do corpo nos web-chats. 130p.

Dissertação (Mestrado) - Faculdade de Filosofia, Letras e Ciências Humanas, Universidade de São Paulo, São Paulo, 2004.

BEAMISH, A. (2001). Approaches to community computing: bringing technology to low-income groups. In: SCHÖN, D.A.; SANYAL, B.; MITCHELL, W.J. (Ed.). High technology and low-income communities: prospects for the positive use of advanced information technology. Cambridge: MIT.

BLANCHARD, A.; HORAN, T. (2000). Virtual communities and social capital. In: GARSON, G.D.; PENN, $H$. (Ed.). Social dimensions of information technology: issues for the new millennium. Harpenden: Idea Group.

BOLTER, J. D.; GROMALA, D. (2003). Windows and mirrors: interaction design, digital art, and the myth of transparency. Cambridge: MIT.

BRANCALEONE, C. (2006). Comunidade, sociedade e sociabilidade: revisitando Ferdinand Tönnies. Trabalho apresentando no 2.Seminário de Sociologia e Política, IUPERJ, Rio de Janeiro, 2006.

Disponível em:<http://www.iuperj.br/publicacoes/forum/csoares.pdf>. Acesso em: 5 mar. 2008. 
BRASIL. Ministério da Ciência e Tecnologia. (2006). Inclusão social. Disponível em:<http://www.mct.gov.br/index.php/content/view/9751.html>. Acesso em: 11 jan. 2007.

CAMPOS, S. (2005). Entrevista. Disponível em:

<http://www.camarae.net/newsletter/2005/newsletter15setembro05.htm>. Acesso em: 20 jan. 2007.

CARROLL, J. (2005). The Blacksburg electronic village: a study in community computing. In: VAN DEN BESSELAAR, P.; KOIZUMI, S. (Ed.). Digital cities III, information technologies for social capital: crosscultural perspectives. Berlin: Springer.

CASA BRASIL. (2007). Disponível em:<http://www.iti.br/twiki/bin/view/Casabrasil/WebHome>. Acesso em: 14 jan. 2007.

CASTELLS, M. (1999). The Social implications of information \& communication technologies. Report prepared for UNESCO's World Social Science Report. Disponível em:

<http://www.chet.org.za/oldsite/castells/socialicts.html>. Acesso em: 20 fev. 2003.

. (2000). A Sociedade em rede. 4.ed. São Paulo: Paz e Terra. (A Era da Informação: economia, sociedade e cultura, 1 ).

(2002). O Poder da identidade. São Paulo: Paz e Terra. (A Era da Informação: economia, sociedade e cultura, 2 ). 
. (2003). A Galáxia da internet. Rio de Janeiro: Jorge Zahar.

CHIT CHAT CLUB. Site do projeto. (2006). Disponível em: <http://www.chitchatclub.org>. Acesso em: 28 abr. 2008.

Imagens. (2008). Disponível em: < http://www.flickr.com/photos/tags/chitchatclub/>. Acesso em: 28 abr. 2008.

COBO ROMANÍ, C.; PARDO KUKLINSKI, H. (2007). Planeta web 2.0: inteligencia colectiva o medios fast food. México: Grup de Recerca d'Interaccions Digitals; Flacso.

COHILL, A. M. (2000) Networks and the knowledge democracy: nine challenges for communities. Disponível em: <http://www.bev.net/cohill/ > Acesso Em: 23. mar. 2005.

CO-LINK. (2008). Disponível em: <http://www6.ufrgs.br/co-link/>. Acesso em: 10 jan. 2008.

COMMENT FLOW. (2008). Disponível em: <http://web.media.mit.edu/ dietmar/myspace.html>. Acesso em: 28 abr. 2008.

COSTA, A. A. (2004). Gênero, poder e empoderamento das mulheres. In: SEMINÁRIO TRABALHO E SAÚDE DAS MULHERES DOS SETORES QUÍMICO, PLÁSTICO E PETROLEIRO DA BAHIA - A QUÍMICA DAS MULHERES, 2004, Salvador. Disponível em:

<http://www.agende.org.br/docs/File/dados_pesquisas/feminismo/Empoderamento\%20-

\%20Ana\%20Alice.pdf>. Acesso em: 17. mai. 2008. 
CRESWELL, J. W. (2003). Research design: qualitative, quantitative, and mixed method approaches. 2 ed. Thousand Oaks: Sage.

DAY, P.; SCHULER, D. (Ed.). (2004a). Community practice in the network society: local action / global interaction. London: Routledge.

(2004b). Intergrating practice, policy, and research. In: Community practice in the network society: local action / global interaction. London: Routledge.

DE SOUZA, C. S. et al. (1999). Projeto de interfaces de usuário: perspectivas cognitiva e semiótica. In: CCONGRESSO NACIONAL DA SOCIEDADE BRASILEIRA DE COMPUTAÇÃO, 19., 1999, Rio de Janeiro. Anais: educação e aprendizagem na sociedade da informação... Rio de Janeiro: Entrelugar.

DENZIN, N. K.; LINCOLN, Y.S. (2006). Introdução: a disciplina e a prática da pesquisa qualitativa. In: . (Org.). O Planejamento da pesquisa qualitativa: teorias e abordagens. Porto Alegre: Artmed.

DERTOUZOS, M. L. (1998). O Que será? Como o novo mundo da informação transformará nossas vidas. São Paulo: Cia das Letras.

DIAS, L. R.(Coord.). (2003). Inclusão digital: com a palavra, a sociedade. São Paulo: Plano de Negócios; Ministério da Cultura; Telefônica. 
DiMAGGIO, P.; HARGITTAI, E. (2001). From the 'digital divide' to 'digital inequality': studying internet use as penetration increases. Princeton: Center for Arts and Cultural Policy Studies. . (Working Paper, 15).

DIVISÃO política do município de São Paulo: mapa. (2008). Disponível em: <http://www.arikah.net>. Acesso: 3 jun. 2008.

DONATH, J. (1995). Visual who: animating the affinities and activities of an electronic community. In: ACM INTERNATIONAL CONFERENCE ON MULTIMEDIA, 3., 1995, San Francisco. Proceedings... San Francisco: ACM Press.

. (1996). Inhabiting the virtual city: the design of social environmentos for electronic communities. PhD. Thesis - Massachusetts Institute of Technology, 1996. Disponível em: <http://smg.media.mit.edu/people/judith/Thesis>. Acesso em: 15 ago. 2004.

. (2006). Signals, cues and meaning. Disponível em:<http://smg.media.mit.edu/classes/IdentitySignals06/SignalingDraft.pdf>. Acesso em: $1 \mathrm{abr}$. 2008.

DORNELLES, J. (2004). Antropologia e internet: quando o "campo" é a cidade e o computador é a “rede”. Horizontes Antropológicos, Porto Alegre, ano 10, n.21, p.241-271, jan./jun.

D-TOWER. (2004). Disponível em: <http://lab.v2.nl/projects/dtower.html>. Acesso em: 26 abr. 2008. 
D-TOWER DELINCHIN. (2008). Disponível em:<http://www.d-toren.nl/site/index.htm>. Acesso em: 26 abr. 2008.

ECHOLOGUE. (2008). Disponível em:

<http://web.media.mit.edu/ orkan/projects/echologue/installations.html>. Acesso em: 28 abr. 2008.

ELECTRONIC SHADOW: $025^{\circ}$ Fuso Horário. (2006). V!rus01, Nomads.usp., São Carlos. Disponível em: <http://www.nomads.usp.br/site/virus01/electronicshadow/25fuso.htm>. Acesso em: 13 jan. 2008.

EQUIPO TÉCNICO AUPEX (Coord). (2001). Nuevos centros del conocimiento: I Manual de buenas práticas de la alfabetización tecnológica de extremadura. Badajoz: Junta de Extremadura; AUPEX.

. (Coord.). (2003). Participación tecnológica: II Manual de buenas práticas: metodologia de la alfabetización tecnológica de Extremadura. Badajoz: Junta de Extremadura; AUPEX.

ESTALELLA, A. (2005). Los Revolución de los weblogs, o una alternativa a las noticias pre-cocinadas. Disponível em:<http://www.cibersocietat.net/recursos/art_div.php?id=53>. Acesso em: 24 out. 2007.

ETZIONI, A.; ETZIONI, O. (1999). Face-to-face and computer-mediated communities, a comparative analysis. Information Society, Santa Monica, v.15, n.4.

FERNANDES, R.C. (1997). O Que é terceiro setor. In: IOCHPE, E.B. (Org.). Terceiro setor desenvolvimento social sustentado. São Paulo: Gife; Paz e Terra. 
FIRMINO, R.; DUARTE, F. (2008). Cidade infiltrada, espaço ampliado: as tecnologias de informação e comunicação e as representações das espacialidades contemporâneas. Arquitextos 096.01, mai. Disponível em: <http://www.vitruvius.com.br/arquitextos/arq096/arq096_01.asp>. Acesso em: 12 jun. 2008.

FISCHER, G. (2002). Beyond 'couch potatoes': from consumers to designers and active contributors. First Monday, v.7, n.12. Disponivel em:<http://www.firstmonday.org/issues/issue7_12/fischer/>. Acesso em: 21 ago. 2006.

FOMENTO à elaboração e implantação de projetos e inclusão digital (ação 6492). (2006). In: BRASIL. Ministério da Ciência e Tecnologia. (2006). Inclusão social. Disponível em:<http://www.mct.gov.br/index.php/content/view/42431.html>. Acesso em: 11 jan. 2007.

FONTES, B.; EICHNER, K. (2004). A Formação do capital social em uma comunidade de baixa renda. Redes - Revista hispana para el análisis de redes sociales, v.7, n.2, out./nov. Disponível em: $<$ http//revista-redes.rederis.es>. Acesso em: 23 mar. 2008.

FORNI, P.; SILES, M.; BARREIRO, L. (2004). ¿Qué es el capital social: cómo analizarlo em contextos de exclusión social y pobreza?. East Lansing: The Julian Samora Research Institute; Michigan State University.

FOTH, M. (2006a). Encouraging residents to take social ownership of an online community network through PAD: participation, animation, design. Disponivel em:<https://eprints.qut.edu.au/secure/00003674/01/Al\&S_foth_v3nc.pdf>. Acesso em: 13 ago. 2006. 
(2006b). Network action research. Action Research, Thousand, v.4, n.2, p.205-226, June.

FOUREZ, G.; MATHY, P.; ENGLEBERT-LECOMTE, V. (1997). A Model for Interdisciplinary Work. Bulletin of Science Technology Society, Thousand, v.17, n.2/3.

GAVED, M.; ANDERSON, B. (2006). The Impact of local ICT initiatives on social capital and quality of life. Colchester: University of Essex. (Chimera Working Paper 2006-6).

GAVED M.; MULHOLLAND, P. (2005). Grassroots initiated networked communities: a study of hybrid physical / virtual communities. In: HAWAII INTERNATIONAL CONFERENCE ON SYSTEM SCIENCES, 38., 2005, Big Island. Proceedings... Los Alamitos: IEEE Press.

GERGEN, M. M.; GERGEN, K. J. (2006). Investigação qualitativa - tensões e transformações. In: DENZIN, N.K.; LINCOLN, Y.S. (Org.). O Planejamento da pesquisa qualitativa: teorias e abordagens. Porto Alegre: Artmed.

GOMES, J. J.; DELFA, C. V. (2004). La Transfornación de la experiencia virtual a través de la mensajería instantânea. In: CONGRESSO ONLINE DEL OBSERVATORIO PARA LA CIBERSOCIEDAD, 2., 2004. Disponível em: <http://www.cibersociedad.net/congres2004/index_es.html>. Acesso em: 28 nov. 2004.

GOTVED, S. (2002). Spatial dimensions in online communities. Space \& Culture, London, v.5, n.4, p.405-414, Nov. 
GRANOVETTER, M. (1973). The strength of weak ties. The American Journal of Sociology, Chicago, v.78, n.6, p.1360-1380, May.

GREENWOOD, D. J.; LEVIN, M. (2006). Reconstruindo as relações entre as universidades e a sociedade por meio da pesquisa-ação. In: DENZIN, N. K.; LINCOLN, Y. S. (Org.). O Planejamento da pesquisa qualitativa: teorias e abordagens. Porto Alegre: Artmed.

GURNEY, P.; AGUIRRE, B. (1980). La Teoria sociológica de Ferdinand Tönnies. Revista Interamericana de Sociologia, México, v.9, n.29, p.145-154, enero/dic.

GURSTEIN, M. (2004). Effective use and the community informatics sector: some thoughts on Canada's approach to community technology/community access. In: MOLL, M.; SHADE, L. (Ed.). Seeking convergence in policy and practice: communications in the public interest. Ottawa: Canadian Centre for Policy Alternatives. v.2.

HAMPTON, K. (2001). Living the wired life in the wired suburb: Netville, glocalization and civil society. Ph.D. Thesis - Department of Sociology, University of Toronto, 2001.

(2002). Place-based and IT mediated "community". Planning Theory \& Practice, Oxford, v.3, n.2, p.228-231, Aug.

HAQUE, U. (2006). Arquitetura, interação e sistemas. Arquitetura \& Urbanismo, São Paulo, ano 21, n.149, p.68-71, ago. 
HARRY, D.; OFFENHUBER, D., DONATH J. (2007). The Projects - towards a sociable architecture for virtual worlds. DESIGNING FOR USER EXPERIENCE, 2007. Disponível em:

<http://web.media.mit.edu/ dharry/theprojects/the_projects.pdf>. Acesso em: 28. abr. 2008.

HOUAISS, A. (2002). Dicionário eletrônico Houaiss da língua portuguesa. Rio de Janeiro: Objetiva.

HUHTAMO, E. (2000). From cybernation to interaction: a contribution to an archaeolgy of interactivity. In: LUNENFELD, P. (Ed.). The Digital dialectic: new essays on new media. Cambridge: The MIT.

(2007). Twin - touch - test - redux: media archaeological approach to art, interactivity, and tactility. In: GRAU, O. (Ed.). Media art histories. Cambridge: MIT.

INFORMATION SPACES. (2008). Disponível em: <http://web.media.mit.edu/ dharry/infospaces/>. Acesso em: 28 abr. 2008.

INSTITUTO POMBAS URBANAS (2006). Disponível em:<http://www. pombasurbanas.org.br>. Acesso em: 11 mar. 2006.

INTERNET. Fases. Disponível em: <http://novaspivack.typepad.com/RadarNetworksTowardsAWebOS.jpg> . Acesso em: 10 jan. 2008. 
ISHII, H.; ULLMER, B.(1977). Tangible bits: towards seamless interfaces between people, bits and atoms. In: CONFERENCE ON HUMAN FACTORS IN COMPUTING SYSTEMS, 1997, Atlanta. Proceedings... Los Angeles: ACM/SIGCHI.

JENKINS, H. (2006). Convergence culture: where old and new media collide. New York: New York University Press.

JOHNSON, S. (2001). Cultura da interface. Como o computador transforma nossa maneira de criar e comunicar. Rio de Janeiro: Jorge Zahar.

JONES, Q. (1997). Virtual-communities, virtual settlements and cyber-archaeology: a theoretical outline. Journal of Computer-Mediated Communication, v.3, n.3, Dec. Disponível em:

<http://jcmc.indiana.edu/vol3/issue3/jones.html>. Acesso em: 25 mar. 2008.

KARAHALIOS, K. (2004). Social catalysts: enhancing communication in mediated spaces. Ph.D. Thesis Massachusetts Institute of Technology, Massachusetts, 2004.

KAVANAUGH, A. L.; PATTERSON, S. J. (2003). The Impact of community computer networks on social capital and community involvement in Blacksburg. In: WELLMAN, B.; HAYTHORNTHWAITE, C. (Ed.). The Internet in everyday life. Malden: Blackwell.

KAVANAUGH, A. L. et al. (2005). Community networks: Where offline communities meet online. Journal of Computer-Mediated Communication, v.10, n.4,. Disponível em:

<http://jcmc.indiana.edu/vol10/issue4/kavanaugh.html>. Acesso em: 12. jan. 2008. 
KOLLOCK, P.; SMITH, M. (Ed.). (1999). Communities and cyberspace. New York: Routledge.

KRETZMANN, J.; MCKNIGHT, J. (1993). Building communities from the inside out: a path toward finding and mobilizing a community's assets. Chicago: ACTA.

KRETZMANN, J. et al. (2005). Discovering community power: a guide to mobilizing local assets and your organization's capacity. Asset-Based Community Development Institute. Disponível em: http:<www.northwestern.edu/ipr/abcd/kelloggabcd.pdf >. Acesso em: 15 jan. 2007.

LAKATOS, E. (1995). Sociologia geral. São Paulo: Atlas.

LEMOS, A. (1997). Anjos interativos e retribalização do mundo. Sobre interatividade e interfaces digitais. Disponível em:<http://www.facom.ufba.br/ciberpesquisa/lemos/interac.html>. Acesso em: 18 mar. 2005.

(2005). Ciber-cultura-remix. In: TAVARES, M.; VENTURELLI, S. (Org.). Cinético digital. São Paulo: Itaú Cultural.

LÉVY, P. (2000). Cibercultura. São Paulo: Ed.34. 
(2001). As Tecnologias da inteligência: o futuro do pensamento na era da informática. São

Paulo: Ed.34.

LOZANO-HEMMER, R. (2002). Alien Relationships form Public Space. In: Transurbanism. Rotterdam: V2_Publishing/NAI Publishers, p. 138-159.

MANN, S. (1996). Smart clothing: wearable multimedia computing and 'personal imaging' to restore the technological balance between people and their environments. In: ACM INTERNATIONAL CONFERENCE ON MULTIMEDIA, 4., 1996, Boston. Proceedings... Boston: ACM. p.163-174. Disponível em:<http://www.eyetap.org/papers/docs/1997_mm.pdf>. Acesso em: 21 jan. 2008.

. (1998). Wearable computing as means for personal empowerment. In: INTERNATIONAL CONFERENCE ON WEARABLE COMPUTING, 1998, Fairfax. Disponível em:<http://wearcam.org/icwckeynote.html>. Acesso em: 21 jan. 2008.

MANOVICH, L. (2002). The Language of new media. Cambridge: MIT.

. (2007a). A Interação como evento estético. Tradução de Raquel Cardoso de Castro. Lumina, Juiz de Fora, v.1, n.1, jun. Disponível em:<http://www.ppgcomufjf.bem-vindo.net/lumina>. Acesso em: 23 jan. 2008. 
(2007b). What comes after remix?. Disponível em:<http://www.manovich.net/>. Acesso em: 21 fev. 2008.

MANZINI, E., MERONI, A. (2005). PicnicKit: riti alimentari nomadici. Apresentação de slides. Politécnico di Milano, Laboratorio di Disegno Industriale 1. Milão, 25 de maio.

MARTELETO, R.; OLIVEIRA E SILVA, A. B. (2004). Redes e capital social: o enfoque da informação para o desenvolvimento local. Ciência da Informação, Brasília, v.33, n.3, p.41-49, set./dez.

MENESES, J. (2004). El Caso de Orkut.com: uma reflexión sobre la exploración de nuevos caminos para la sociabilidad online em la tradición del estúdio de las comunidades virtuales. In: CONGRESO ONLINE DEL OBSERVATORIO PARA LA CIBERSOCIEDAD, 2., 2004. Disponível em:

<http://www.cibersociedad.net/congres 2004/index-pt.html>. Acesso em: 15 dez. 2004.

MILANI, C. R. S. (2004). Teorias do capital social e desenvolvimento local: lições a partir da experiência de Pintadas (Bahia, Brasil). Organizações e Sociedade, Salvador, v.11, Edição especial, p.95-113.

MILGRAM, P.; KISHINO, F. (1994). A taxonomy of mixed reality visual displays. IEICE Transactions on Information and Systems, Tokyo, v.E-77, n.12, Special issue on Networked Reality, Dec.

MITCHELL, W. J. (2000). Replacing place. In: LUNENFELD, P. (Ed.). The Digital dialectic: new essays on new media. Cambridge: The MIT. 
MOSSBERGER, K.; TOLBERT, C. J.; STANBURY, M. (2003). Virtual inequality: beyond the digital divide. Washington: Georgetown University Press.

MUSGRAVE, S. J. (2005). Community portals: a false dawn over the field of dreams?. The Journal of Community Informatics, v.1, n.2, p.32-44, Jan. Disponível em:<http://www.cijournal.net/index.php/ciej/article/view/182/128>. Acesso em: 21 ago. 2006.

NARDELLI, N. (2007). Design para a experiência e as tecnologias de informação e comunicação. Dissertação (Mestrado) - Escola de Engenharia de São Carlos, Universidade de São Paulo, São Carlos, 2007.

NARDI, B.; O'DAY, V. L. A. (2000). Information ecologies: using technology with heart. Cambridge: MIT Press.

NASCIMENTO, E. (1994). Hipóteses sobre a nova exclusão social: dos excluídos necessários aos excluídos desnecessários. Caderno CRH, Salvador, v.21, p.29-47.

NEUHOLD, R. (2004). O Conceito exclusão e seus dilemas. Revista Urutágua: revista acadêmica multidicisplinar, Maringá, n.5, dez./mar.

NOMADS.USP. (2006). Projeto comunidades_online. São Carlos: s.n. Relatório técnico-científico: parcial Fapesp 03/06421-6. 
. (2007). Projeto comunidades_online. São Carlos: s.n. Relatório técnico-científico: final Fapesp 03/06421-6.

. (2008). Site. Apresenta as pesquisas do grupo, e informações sobre suas atividades. Disponível em:HTTP: <www.nomads.usp.br>. Acesso em: 18 mai. 2008.

NORMAN, D. A. (1999). The Invisible computer. Cambridge: MIT.

OAKLEY, P.; CLAYTON, A. (2003). Monitoramento e avaliação do empoderamento ("empowerment"). Tradução de Zuleika Arashiro e Ricardo Dias Sameshima. São Paulo: Instituto Polis.

OPAZO, G. R. (2002). Relaciones interpersonales en los chats de internet. In: CONGRESO ONLINE DEL OBSERVATORIO PARA LA CIBERSOCIEDAD, 2002. Disponível em:

<http://cibersociedad.rediris.es/congreso>. Acesso em: 28 out. 2004.

PAVAN, C. et al. (2007). Connotea: site para a comunicação científica e compartilhamento de informações na internet. Revista Digital de Biblioteconomia e Ciência da Informação, Campinas, v.5, n.1, p.77-94, jan./jun.

PEDROSO, M. (2003). Desenvolvimento humano no município de São Paulo - 2000: uma cartografia socioeconômica como contribuição ao planejamento de políticas públicas. Dissertação (Mestrado) Pontifícia Universidade Católica de São Paulo, São Paulo, 2003. 
PINHEIRO, M. A. (2007). Cultura dos links: conjunção e conexão nas redes. Revista FAMECOS: mídia, cultura e tecnologia, Porto Alegre, n.32, p.17-22, abr.

PINKETT, R. (2002). Creating community connections: sociocultural constructionism and an assetbased approach to community technology and community building in a low-income community. Ph.D. Thesis - School of Architecture and Planning, Massachusetts Institute of Technology, Massachusetts, 2002.

PLURALL: projeto. (2007). Disponível

em:<http://www.pucrio.br/sobrepuc/admin/vrd/indexplurall.html>. Acesso em: 10 jan. 2007.

PORTUGAL, S. (2007). Contributos para uma discussão do conceito de rede na teoria sociológica. Oficina do CES: Centro de Estudos Sociais, Coimbra, n.271.

POWAZEK, D. M. (2002). Design for community: the art of connecting real people in virtual places. Indianapolis: New Riders.

PRATSCHKE, A. (2002). Entre mnemo e locus: arquitetura de espaços virtuais, construção de espaços mentais. 162p. Tese (Doutorado) - Instituto de Ciências Matemáticas e de Computação, Universidade de São Paulo, São Carlos, 2002.

PREECE, J. (2001a). Online communities: designing usability, supporting sociability. Chichester: John Wiley. 
. (2001b). Sociability and usability in online communities: determining and measuring success. Behaviour and Information Technology, London, v.20, n.5, p.347-356.

PREECE, J.; ROGERS, Y.; SHARP, H. (2005). Design da interação: além da interação homemcomputador. Porto Alegre: Bookman.

(2005a). Conflito e cooperação em interações mediadas por computador. Contemporânea: revista de comunicação e cultura, v.3, n.1, p.38-74, jun. Disponível em:<http://www.contemporanea.poscom.ufba.br/2aprimo\%20j05w.pdf >. Acesso em: 18 fev. 2008.

(2005b). Enfoques e desfoques no estudo da interação mediada por computador. 404nOtF0nd, Salvador, n.45, jan. Disponível em:<http://www.facom.ufba.br/ciberpesquisa/404nOtFOund/404_45.htm>. Acesso em: 15 mai. 2007.

PRIMO, A.; CASSOL, M. (2005). Explorando o conceito de interatividade: definições e taxonomias. Disponível em:<http://usr.psico.ufrgs.br/ aprimo/pb/pgie.htm>. Acesso em: 9 fev. 2006.

RADIOACTIVE. (2008). Disponível em: <http://smg.media.mit.edu/projects/Radioactive/>. Acesso em: 28 abr. 2008.

RATTNER, H. (2003). Prioridade: construir o capital social. Revista Espaço Acadêmico, ano 2, n.21, fev. Disponível em:<http://espacoacademico.com.br/021/21rattner.htm>. Acesso em: 14 dez. 2004. 
RECUERO, R. (2001). Comunidades virtuais - uma abordagem teórica. In: SEMINÁRIO INTERNACIONAL DE COMUNICAÇÃO, 5., 2001, Porto Alegre. Anais... Porto Alegre: EDIPUCRS.

REIS, E. P.; SCHWARTZMAN, S. (2002). Pobreza e exclusão social: aspectos sóciopolíticos. World Bank. Disponível em:<http://www.schwartzman.org.br/simon/pdf/exclusion.pdf>. Acesso em: 27 out. 2006.

REN, Y.; KRAUT, R.; KIESLER, S. (2007). Applying common identity and bond theory to design of online communities. Organization Studies, Berlin, v.28, n.3, p.377-408.

RESPONSABILIDADE SOCIAL. (2007). Disponível em:<http://www.ibtsonline.org/index2.php>. Acesso em: 25 jan. 2007.

REZENDE, A. C. (2004). Estudo sobre o cognitivismo e o hipertexto, e a disponibilização de material didático na internet. In: CONGRESSO IBERO-AMERICANO DE GRÁFICA DIGITAL, 8., 2004, São Leopoldo. Anais... São Leopoldo: UNISINOS.

RHEINGOLD, H. (1993). The Virtual community: homesteading on the electronic frontier. Perseus. Disponível em:<http://www.rheingold.com/vc/book/>. Acesso em: 20 mar. 2008.

(2002). Smart mobs: the next social revolution. Transforming cultures and communities in the age of instant access. Cambridge: Basic Books. 
RIBEIRO, J.C. (2001). Comunidades virtuais eletrônicas - convergência da técnica com o social. In: CONGRESSO BRASILEIRO DE CIÊNCIAS DA COMUNICAÇÃO, 24., 2001, Campo Grande. A Mídia impressa, o livro e o desafio das novas tecnologias: anais... São Paulo: INTERCOM.

RIZEK, C. S. (2007). Comunidades e pobreza urbana: do protagonismo à gestão. In: ENCONTRO NACIONAL DA ANPUR, 12., 2007, Belém do Pará. Salvador: ANPUR, v.1, p.90-110.

RÖSSLER, O. E. (2001). Relativity is interface. In: INTERNATIONAL SYMPOSIUM SCIENCES OF THE INTERFACE, 2000. Abstracts... Disponível

em:<http://193.197.168.165/symposium/abstracts/18/oroessler/>. Acesso: 22 jan. 2008.

ROZIER, J. (1999). Hear \& there: an augmented reality system of linked audio. M.Sc. Dissertation Department of Engineering and Computer Science, Cambridge, 1999.

ROZIER, J.; KARAHALIOS, K.; DONATH, J. (2000). Hear \& there: an augmented reality system of linked audio. I: INTERNATIONAL CONFERENCE ON AUDITORY DISPLAY, 2000, Atlanta. Proceedings online... Atlanta: Georgia Institute of Technology. Disponível em:

<http:WWW.icad.org/websitev2.0/Conferences/ICAD2000/ICAD2000.html>. Acesso em: 29 abr. 2008.

SÁ FILHO, C. A. C. (2006). O Ciberespaço e a cidade: influência das TIC na dinâmica cultural e política de comunidades. Dissertação (Mestrado) - Escola de Engenharia de São Carlos, Universidade de São Paulo, São Carlos, 2006.

SANTOS, D. M. (2007). Relatório técnico-científico: final Fapesp 03/04382-3. São Carlos: EESC-USP. Relatório técnico. 
SANTOS, D. M.; TRAMONTANO, M. (2006). Interfaces ou lugares de diálogo comunitário. In: CONGRESO IBEROAMERICANO DE GRÁFICA DIGITAL, 10., 2006, Santiago do Chile. Anais: post digital - el factor humano... Santiago: Universidad de Chile. p.75-79.

SANTOS, E. S. (2006). Desigualdade social e inclusão digital no Brasil. Tese (Doutorado) - IPPUR Universidade Federal do Rio de Janeiro, Rio de Janeiro, 2006.

SANTOS, R. C. (2005). Por Um novo conceito de comunidade: redes sociais, comunidades pessoais, inteligência coletiva. Interface: comunicação, saúde e educação, São Paulo, v.9, n.17, p.235-248.

SERVON, L. J. (2002). Bridging the digital divide: technology, community, and public policy. Malden: Blackwell.

SHEDROFF, N. (2005). Experience design 1. Indianápolis: New Riders.

SILVA, J. O. (2004). A Transformação social na visão da sociologia clássica. In: SEMINÁRIO DO CENTRO DE CIÊNCIAS SOCIAIS APLICADAS, 3., 2004, Cascavel. Anais... Cascavel: Universidade Estadual do Oeste do Paraná.

SILVEIRA, S. A. (2001). Exclusão digital: a miséria na era da informação. São Paulo: Perseu Abramo. 
(2005a). A Mobilização colaborativa e a teoria da propriedade do bem intangível. 167p. Tese (Doutorado) - Faculdade de Filosofia, Letras e Ciências Humanas, Universidade de São Paulo, São Paulo, 2005.

(2005b). Software livre e inclusão digital. São Carlos: s.n. Palestra proferida no ICMC-USP, São Carlos, 7 dez. 2005.

(2007a). Nanoblogs, twitter e jaiku: a nova fase da blogodfera. A Rede, São Paulo, ano 3, n.32, p.42-43, dez.

(2007b). Redes virais e espectro aberto: descentralização e desconcentração do poder comunicacional. In: SILVEIRA, S.A. et al. Comunicação digital e a construção dos commons: redes virais, espectro aberto e as novas possibilidades de regulação. São Paulo: Perseu Abramo, 2007.

SKY EAR. Projeto. (2004). Disponível em: < http://www.haque.co.uk/skyear.php>. Acesso em: 10 mar. 2008.

SOCIEDADE CIVIL. (2007). Disponível em:<http://www.ibtsonline.org/index2.php>. Acesso em: 25 jan. 2007.

SORJ, B. (2003). brasil@povo.com: a luta contra a desigualdade na sociedade da informação. Rio de Janeiro: Jorge Zahar. 
SOUZA E SILVA, A. (2000). Habitar o digital. In: CONGRESSO IBERO-AMERICANO DE GRÁFICA DIGITAL, 4., 2000, Rio de Janeiro. Anais... Rio de Janeiro: Universidade Federal do Rio de Janeiro.

. (2001). Interface, conexão, liberdade: construindo e imaginando espaços - na rede digital. In: CONGRESSO BRASILEIRO DE CIÊNCIAS DA COMUNICAÇÃO, 24, 2001, Campo Grande. Anais... Campo Grande: INTERCOM.

SPIGAROLI, A. et al. (2005). As Tecnologias de informação e comunicação como ferramentas potencializadoras para a inclusão: um desafio para a sociedade. In: PELLANDA, N.; SCHLÜNZEN, E.;

SCHLÜNZEN JR., K. (Org.). Inclusão digital: tecendo redes afetivas / cognitivas. Rio de Janeiro: DP\&A.

SPYER, J. (2007). Conectado: o que a internet fez com você e o que você pode fazer com ela. Rio de Janeiro: Jorge Zahar.

STAKE, R. E. (2000). Case studies. In: DENZIN, N.K.; LINCOLN, Y.S. (Ed.). The Sage handbook of qualitative research. 2 ed. California: Sage. p.435-454.

STARNER, T. et al. (1997). Augmented reality through wearable computing. Presence: teleoperators and virtual environments, Cambridge, v.6, n.4, p.386-398, Aug.

SUSPENSIÓN AMODAL. Imagens. (2008a). Disponível em: < http://www.lozano-

hemmer.com/eimagenes.html> Acesso em: 28 abr. 2008. 
Site. (2008b). Disponível em: <http://www.amodal.net.html>. Acesso em: 28 abr. 2008.

TELHAN, O. (2007). Social sensing and its display. 90p. M.Sc.Dissertation - Massachusetts Institute of Technology, Massachusetts, 2007.

TEXT RAIN. (2008). Disponível em: <http://www.camilleutterback.com/textrain.html> Acesso em: 28 abr. 2008.

THE HUG SHIRT. (2008). Disponível em:

<http://www.cutecircuit.com/projects/wearables/thehugshirt/ >. Acesso em: 28 abr. 2008.

THE PROJECTS. (2008). Disponível em: <http://web.media.mit.edu/ dharry/theprojects/>. Acesso em: 28. abr. 2008.

THIOLLENT, M. (2000). Metodologia da pesquisa-ação. São Paulo: Cortez.

TRAMONTANO, M. (2007). Instalando / installing: arte y cultura digital / art and digital culture.

Santiago: Troyano.

TREVISAN, N. (2005). Por mares nunca dantes navegados: estudos para a inclusão da população de baixa renda na sociedade da informação. Dissertação (Mestrado) - Escola de Engenharia de São Carlos, Universidade de São Paulo, São Carlos, 2005. 
TURNER-LEE, N.; PINKETT, R. (2004). An Asset-based approach to community building and community technology. In: DAY, P.; SCHULER, D. (Ed.). Community practice in the network society: local action / global interaction. London: Routledge.

UNDER SCAN. Background. (2005). Disponível em: <http://www.lozanohemmer.com/texts/UnderScan.pdf>. Acesso em: 28 abr. 2008.

Imagens. (2008). Disponível em: < http://www.lozano-hemmer.com/eimagenes.html>. Acesso em: 2 abr. 2008.

USINA - Centro de trabalho para o ambiente habitado. (2003). Plano de ação habitacional e urbano: Cidade Tiradentes. São Paulo: Sehab. Documento interno de uso restrito.

VELASCO, N. (2006). A Poética da interface. Intermídias, Serra, ano 2, n.5/6, 2006. Disponível em:<http://www.intermidias.com/miolo/comunicacao_home_teoria.htm>. Acesso em: 10 jan. 2008.

WARSCHAUER, M. (2006). Tecnologia e inclusão social: a exclusão digital em debate. São Paulo: Ed. Senac.

WEISER, M. (1993). Some computer science: issues in ubiquitous computing. Communications of the ACM, New York, v.36, n.7, p.75-84, July. 
WELLMAN, B. (1999a). Living networked in a wired world. IEEE Intelligent Systems, New York, v.14, n.1, p.15-17, Jan./Feb.

(1999b). The Network community. In (Ed.). Networks in the global village.

Boulder: Westview. Disponível

em:<http://www.chass.utoronto.ca/ wellman/publications/globalvillage/in.htm>. Acesso em: 11 mar. 2008.

. (2001). Physical place and cyberplace: the rise of personalized networking. International Journal of Urban and Regional Research, Berlin, v.25, n.2, p. 227-252, fev.

WELLMAN, B.; BOASE, J.; CHEN, W. (2002). The Networked nature of community: online and offline. IT \& Society, v.1, n.1, p.151-165.

WELLMAN, B.; LEIGHTON, B. (1979). Networks, neighborhoods and communities. Urban Affairs. Quarterly, Beverly Hill, v.14, p.363-390.

WELLMAN, B. et al. (2001). Does the Internet increase, decrease, or supplement social capital? Social networks, participation, and community commitment. American Behavioral Scientist, Thousand Oaks, v.45, n.3, p.437-456, Nov.

ZELLNER, P. (1999). Hybrid Space. New forms in digital architecture. New York: Rizzoli. 
ZINMAN, A. (2006). RadioActive: enabling large-scale asynchronous audio discussions on mobile devices. M.Sc.Dissertation - Massachusetts Institute of Technology, Massachusetts.

ZINMAN, A.; DONATH, J. (2007). RadioActive: enabling persistent mobile communication for groups. In: COMPUTER/HUMAN INTERACTION CONFERENCE, 2007, San José. Proceedings... San José, Apr./ May.

ZUFFO, J.A. (2005). A Convergência digital e a interpenetração de mercados nas tecnologias da informação. Revista Fonte, Belo Horizonte, n.3, dez. p.72-78. 


\section{APÊNDICES}

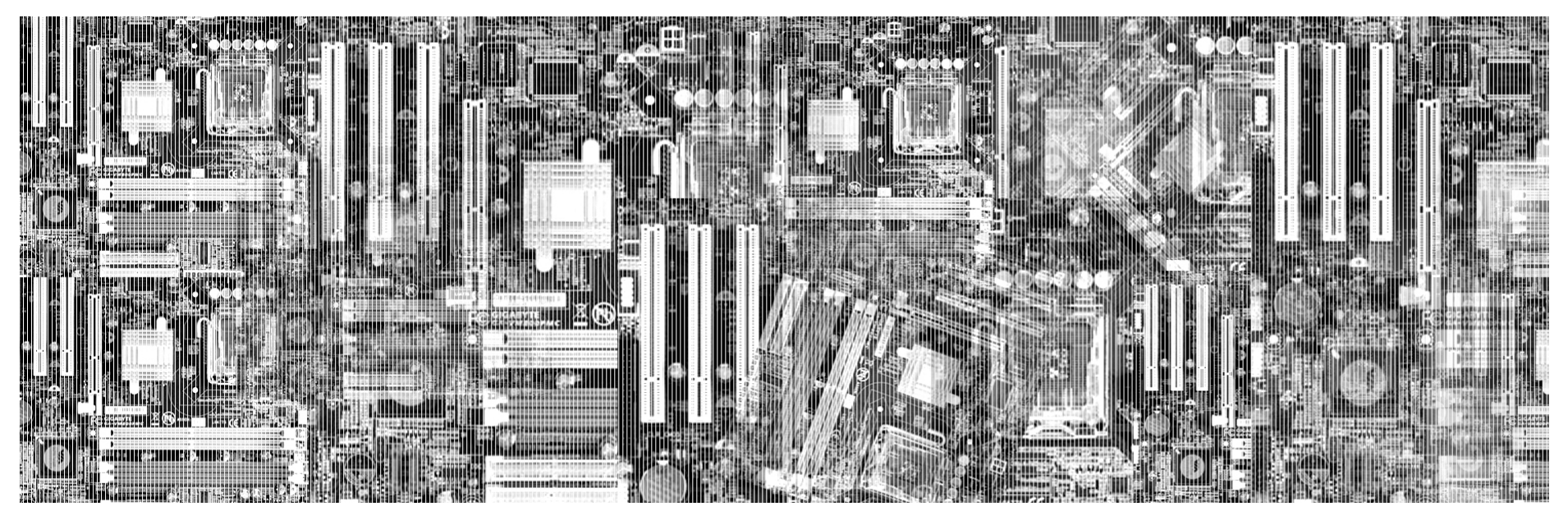




\section{Apêndice A}

\section{Quadros resumos das iniciativas envolvendo IIC}

A seguir apresentam-se quadros resumos das iniciativas evolvendo TIC citadas no capítulo 1.

\begin{tabular}{|c|c|c|}
\hline & projeto & Acessa São Paulo \\
\hline & país & Brasil \\
\hline & data de implantação & 2001 \\
\hline & principais proponentes & Governo do Estado de São Paulo \\
\hline & site & http://www.acessasp.sp.gov.br \\
\hline & características principais & $\begin{array}{l}\text { iniciativa governamental } \\
\text { telecentro } \\
\text { acesso livre, portal web }\end{array}$ \\
\hline descrição & \multicolumn{2}{|c|}{$\begin{array}{l}\text { Projeto que oferece o acesso à internet banda larga através de telecentros } \\
\text { denominados infocentros. São espaços públicos com computadores para acesso } \\
\text { gratuito e livre à internet. Nos infocentros não são ministrados cursos de } \\
\text { informática, e há a presença de monitores para incentivar a dinâmica social e } \\
\text { ofertar conteúdos voltados ao desenvolvimento comunitário e cidadania. Está } \\
\text { disponível nos infocentros uma coleção de Cadernos Eletrônicos (versões } \\
\text { impressa e eletrônica) que são apostilas sobre temas básicos relacionados à } \\
\text { informática. }\end{array}$} \\
\hline fontes & \multicolumn{2}{|c|}{$\begin{array}{l}\text { ACESSA SP: site oficial. Apresenta detalhadamente o projeto, e disponibiliza } \\
\text { conteúdo para usuários e monitores. Disponível em: } \\
\text { <http://www.acessasp.sp.gov.br>. Acesso em } 11 \text { jan. } 2007 . \\
\text { DIAS, L.R.(Coord.). (2003). Inclusão digital: com a palavra, a sociedade. São } \\
\text { Paulo: Plano de Negócios. }\end{array}$} \\
\hline
\end{tabular}




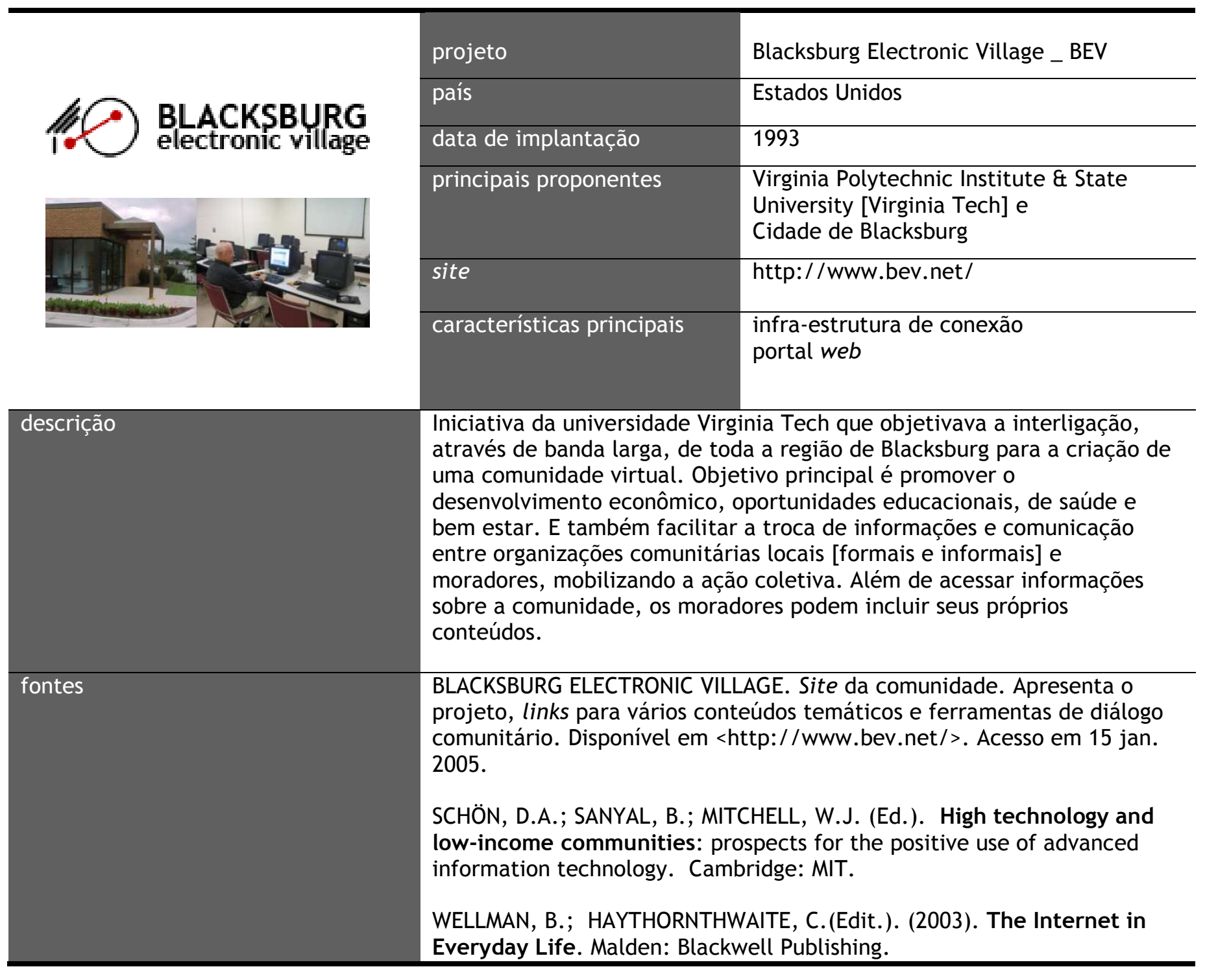



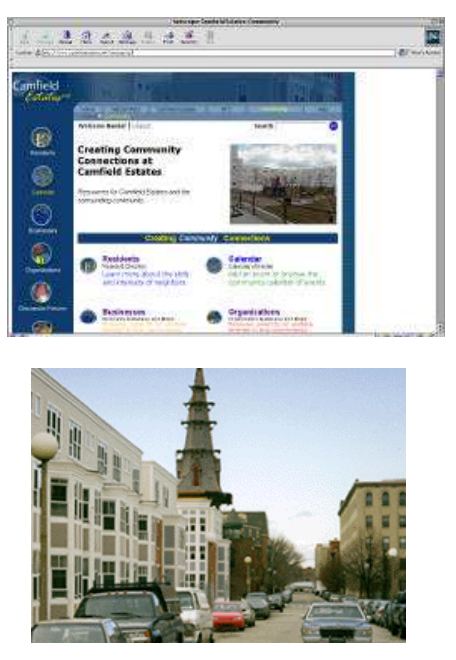

descrição

fontes

data de implantação

principais proponentes

site

características principais
Camfield Estate

MIT Creating Community Connections

Project

Estados Unidos

\section{0}

Camfield Tenants Association (CTA)

e Massachusetts Institute of Technology (MIT)

http://www.camfieldestates.net/

pesquisa acadêmica

acesso doméstico

telecentro

portal web

Os objetivos do projeto são: promover uma comunidade forte e saudável no conjunto habitacional Camfield Estates; introduzir grandes níveis de capacitação e auto-suficiência para os residentes da área; criar conexão entre residentes, organizações e negócios locais, e outros membros comunitários; habilitar os residentes de Camfield Estates a serem os criadores e produtores de suas próprias informações e conteúdos na internet; estabelecer em um modelo para outros assentamentos no país, modelos estes de como os indivíduos, famílias e comunidade podem fazer uso produtivo das TIC. Outro objetivo é também identificar fatores críticos na interação entre tecnologias comunitárias e iniciativas de construção comunitária em assentamentos de baixa renda e sua vizinhança.

CAMFIELD ESTATES. Site oficial da comunidade. Apresenta ambientes de interação e link para documentos sobre o projeto, assim como para instituições parceiras. Disponível em <http://www.camfieldestates.net>. Acesso em 17 mar. 2005.

PINKETT, R. (2002). Creating community connections: sociocultural constructionism and an asset-based approach to community technology and community building in a low-income community. Ph.D. Thesis - School of Architecture and Planning, Massachusetts Institute of Technology,

Massachusetts, 2002

WARSCHAUER, M. (2006). Tecnologia e inclusão social: a exclusão digital em debate. São Paulo: Ed.Senac. 


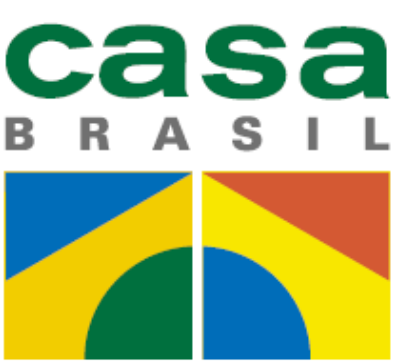

Conhecimento e cidadania morando juntos.

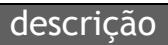

fontes

\section{Casa Brasil}

\section{Brasil}

2004

data de implantação

principais proponentes

site

MCT Ministério da Ciência e Tecnologia

ITI Instituto Nacional de Tecnologia da Informação

www.iti.gov.br/twiki/bin/view/Casabrasil/WebHome

características principais

iniciativa governamental

telecentro; outros módulos (multimídia, auditório,

reciclagem, rádio, biblioteca)

Programa de inclusão digital e social do governo federal voltado à população de baixa renda. Trata-se da implantação de espaços comunitários multifuncionais que têm como finalidade funcionar como centros de alfabetização tecnológica, de uso gratuito e acesso irrestrito, em comunidades de baixo IDH (Índice de

Desenvolvimento Humano), grande densidade populacional, e preferencialmente onde existam níveis de violência e desemprego elevados, por meio de parcerias com instituições locais. Cada unidade de Casa Brasil abriga um telecentro, com uso de software livre, e pelo menos mais dois outros módulos, que podem ser uma biblioteca popular, um auditório, um estúdio multimídia, uma oficina de produção de rádio, um laboratório de popularização da ciência ou uma oficina de manutenção de equipamentos de informática, e um espaço para atividades comunitárias, além de um módulo de inclusão bancária nas localidades onde for possível.

\section{CASA BRASIL: site oficial do programa. Disponível em:}

<www.iti.gov.br/twiki/bin/view/Casabrasil/WebHome>. Acesso em 31 jan. 2007.

CASA BRASIL. Disponível em:

<http://www.inclusaodigital.gov.br/inclusao/outros-programas>. Acesso em: 16 jan. 2007. 


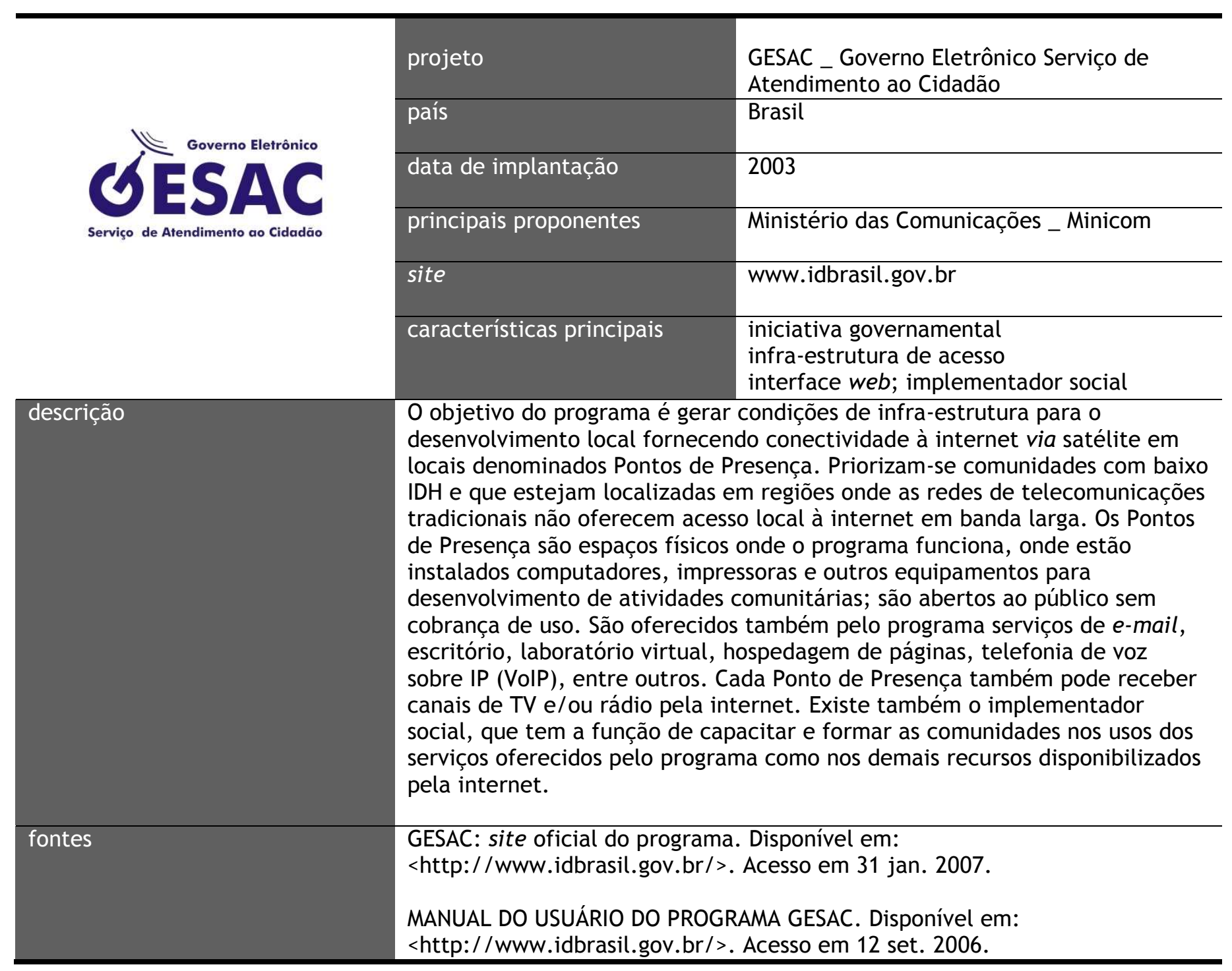




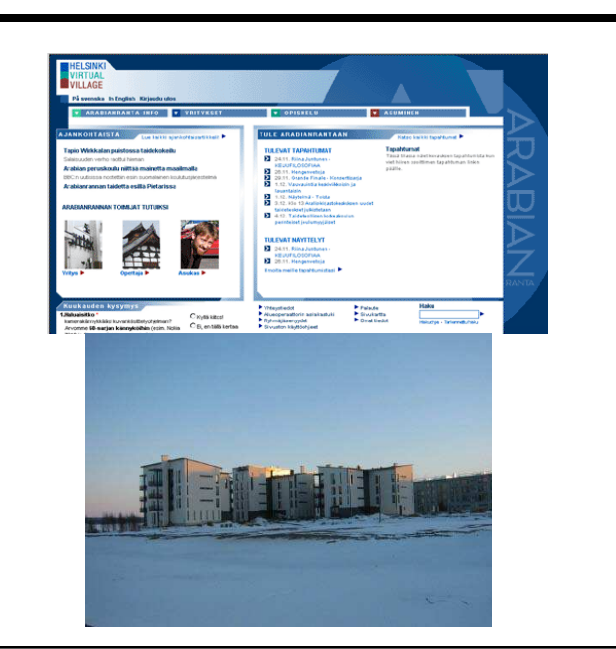

descrição

\begin{tabular}{ll} 
projeto & Helsinki Virtual Village _ HVV \\
\hline país & Finlândia \\
\hline data de implantação & 1999 \\
\hline principais proponentes & $\begin{array}{l}\text { Cidade de Helsinque, através de diversos } \\
\text { departamentos }\end{array}$ \\
\hline site & www.helsinkivirtualvillage.fi \\
\hline características principais & $\begin{array}{l}\text { desenvolvimento local } \\
\text { infra-estrutura de acesso } \\
\text { acesso doméstico e tecnologias móveis } \\
\text { portal web }\end{array}$ \\
\hline
\end{tabular}

Trata-se de um projeto de re-desenvolvimento de uma área portuária industrial degradada, Arabianranta, em Helsinque. Envolve uma forte parceria público-privada entre empresários, pesquisadores, e

planejadores urbanos, provendo a área com infra-estrutura de rede de conexão de banda larga para serviços domésticos. O objetivo, entre outros, é a criação de uma comunidade virtual equipada com TIC de última geração, através, principalmente, do portal na web de HVV Helsinki Virtual Village. O objetivo principal é criar uma infra-estrutura tecnológica para promover trabalho, crescimento econômico e bem estar, ou seja, proporcionar infra-estrutura para atrair empresas, indústrias, turismo, educação, e geração de empregos. Visa também criar na área um pólo de arte e design.

HELSINK VILTUAL VILLAGE. Web portal do projeto. Apresenta suas diretrizes e objetivos, inúmeros serviços oferecidos ao público em geral e serviços específicos ligados as instâncias que fazem parte do projeto.

Disponível em <www. helsinkivirtualvillage.fi>. Acesso em 17 out. 2004.

PENNANEN-REBEIRO-HARGRAVE, P.; KANGASOJA, J. (2003).Virtual Village Reality - Futuristic housing in a socially mixed neighbourhood in Helsinki.

The Sixth Sharjah Urban Planning Symposium. June 1-2, Sharjah, UAE.

SHAW, W. In Helsinki Virtual Village... Disponível em

<http://www.wired.com/wired/archive/9.03/helsinki.html>. Acesso em 18 fev. 2003. 


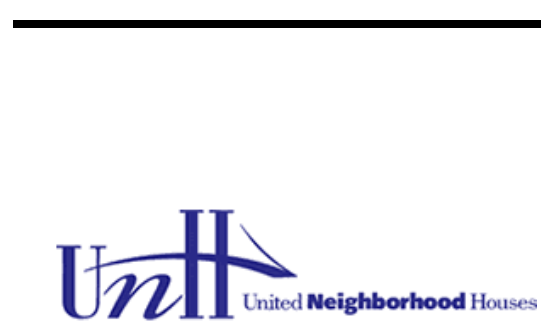

11 United Neighborhood Houses

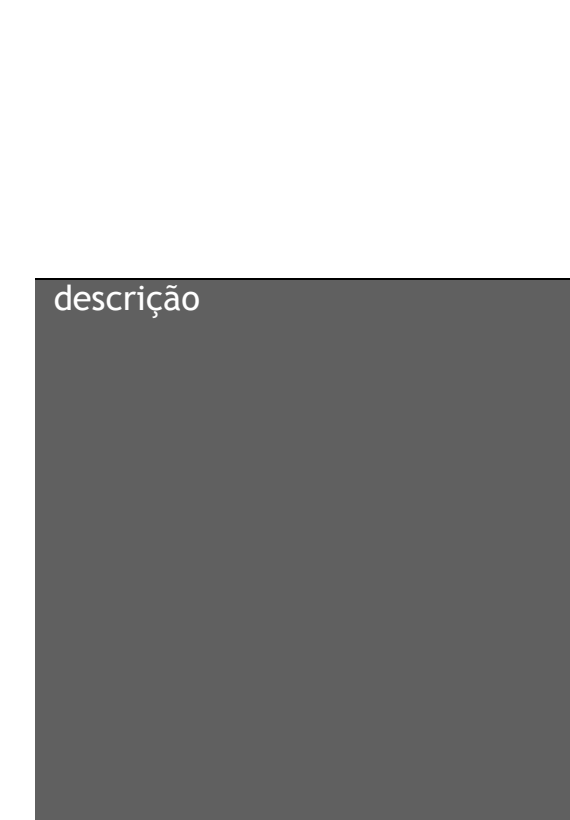

fontes projeto

país

data de implantação

principais proponentes

site

características principais
Information Technology Initiative

\section{Estados Unidos}

1995 / 1996

United Neighborhood Houses of New

York, Inc.

Trata-se de um projeto destinado a instalar um sistema de redes de

computadores em 5 centros comunitários e uni-los com uma larga estrutura de

retransmissão WAN [rede de área estendida] que poderia (1) aumentar a

qualidade de seus programas facilitando a integração e coordenação de

serviços para indivíduos ou famílias, (2) equipar os centros com ferramentas

computadorizadas para facilitar suas administrações, planejamentos e

avaliações, (3) facilitar informações compartilhadas sobre usuários individuais

e (4) prover os participantes dos centros, residentes das comunidades e

grupos, de acesso a computadores e infra-estrutura de informação, através do

desenvolvimento de centros de aprendizagem de tecnologia voltados à

comunidade (chamados family rooms), com equipamentos multimídias,

sistemas de computadores conectados à internet para uso recreacional, de

educação, e preparação e capacitação para trabalho.

CASE STUDY REPORT Information Technology Initiative. Relatório. Disponível

em:

<www.ntia.doc.gov/otiahome/top/research/EvaluationReport/case_studies/3 64094066e.PDF>. Acesso em: 1 abr. 2005.

SCHÖN, D.A.; SANYAL, B.; MITCHELL, W.J. (Ed.). High technology and lowincome communities: prospects for the positive use of advanced information technology. Cambridge: MIT. 

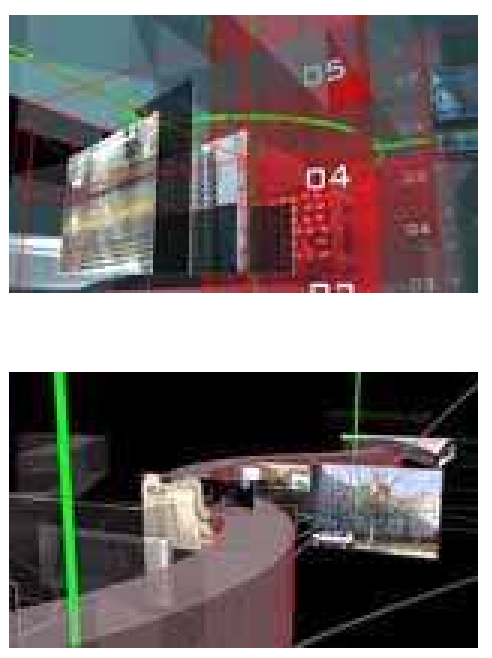

descrição

fontes

\begin{tabular}{ll} 
projeto & $\begin{array}{l}\text { Les Courtillières de Pantin } \\
\text { Projeto Second Time Zone Territories 03 _ } \\
\text { STZT 3 Pantin }\end{array}$ \\
\hline país & França \\
\hline data de implantação & 2000 \\
\hline principais proponentes & $\begin{array}{l}\text { Arq. Claire Pététin e Philippe Grégoire } \\
\text { D.A.P.A. Ministère de la Culture et de la } \\
\text { Communication } \\
\text { Secretaria da Cultura da Prefeitura de } \\
\text { Pantin }\end{array}$ \\
\hline site & - \\
\hline características principais & $\begin{array}{l}\text { requalificação de espaços coletivos } \\
\text { design de interface gráfica } \\
\text { telecentro }\end{array}$
\end{tabular}

Intervenção em um conjunto habitacional de baixa renda, visando a integração social de seus moradores. A intervenção começou não no espaço concreto, mas pela criação de uma interface computacional gráfica colaborativa, com objetivo de estimular o surgimento de uma comunidade virtual formada pelos moradores. 0 projeto envolveu várias ações, entre elas a instalação de um telecentro, chamado de InfoKiosk, a instalação nos computadores de um ambiente virtual 3D que reconstruiu Les Courtillières

em uma interface com formato de vídeo games. 0 projeto Second

Timezone Territories [STZT] é baseado em experimentos que provêem

meios de expressão e lugares na internet para habitantes de vizinhanças conflituosas e excluídas.

PRATSCHKE, A. (2002). Entre mnemo e locus: arquitetura de espaços virtuais, construção de espaços mentais. 162p. Tese (Doutorado) -

Instituto de Ciências Matemáticas e de Computação, Universidade de São Paulo, São Carlos, 2002.

TRAMONTANO, M. (2003). Vozes Distantes: organizacão e sociabilidade em comunidades informatizadas. In: CASSINO, J., SILVEIRA, S. A. Software livre e Inclusão digital. São Paulo: Conrad. 


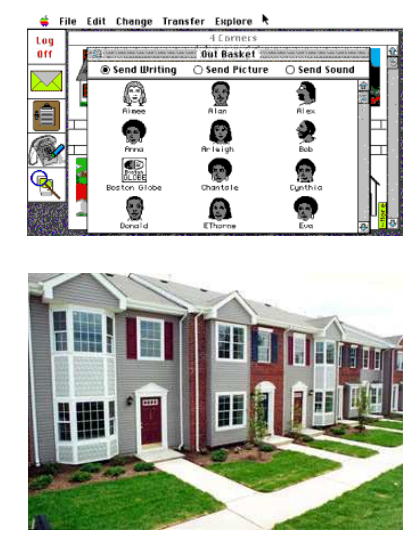

descrição

\section{projeto}

país

data de implantação

principais proponentes

site

características principais
Making Healthy MUSIC _ Multi-User Sessions In Community

Estados Unidos

1995

Massachussets Institute of Techonology; MIT

Media Laboratory

pesquisa acadêmica

acesso doméstico

projeto de interface gráfica

O projeto providenciou a instalação de um sistema de rede de computadores para os residentes de um conjunto habitacional na vizinhança de uma escola primária e para algumas instituições públicas do seu entorno [universidade, biblioteca, entre outros] para prover melhorias principalmente na área de saúde e na qualidade de vida da população residente e dos alunos. Foi utilizado um sistema chamado MUSIC [Multi-User Sessions In Community], que usa texto, gráficos, voz digitalizada e recursos sintéticos de fala,como meio de interação em ambientes de rede compartilhados, projetado para dar suporte a atividades no ambiente virtual comunitário.

MUSIC. Site do projeto .Disponível em: < http://xenia.media.mit.edu/ acs//>. Acesso em 15 jan. 2005

SCHÖN, D.A.; SANYAL, B.; MITCHELL, W.J. (Ed.). High technology and lowincome communities: prospects for the positive use of advanced information technology. Cambridge: MIT. 

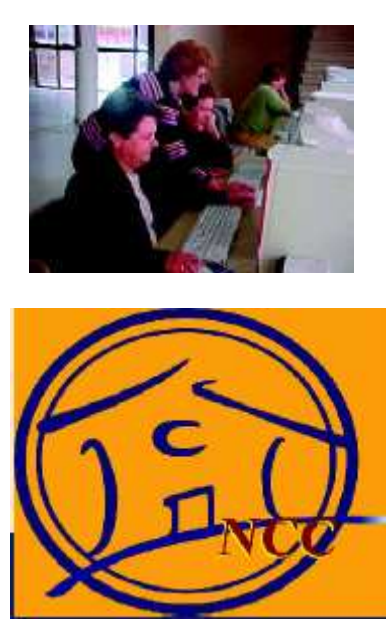

descrição

fontes projeto

país

data de implantação

principais proponentes

site

características principais
NCC Novos Centros de Conhecimento Extremadura

Espanha

1999

Junta de Extremadura

[Consejería de Educación, Ciencia y Tecnología]

Asociación Regional de Universidades Populares

de Extremadura (AUPEX)

www.nccextremadura.org

iniciativa governamental,

desenvolvimento regional, telecentro

alfabetização digital: projetos e atividades

produção conteúdo

Os telecentros NCCs, também chamados centros de alfabetização tecnológica,

são espaços públicos implantados em diferentes locais de Extremadura, de acesso livre a cidadãos e organizações sociais, culturais e econômicas. Buscam, além de prover a aquisição de destreza básica em TIC dos usuários, o aproveitamento da internet para gerar valor cultural e social. A sociedade, através de suas organizações, cria os conteúdos dos projetos. Os projetos concretos são gerados a partir dos interesses e da demanda da sociedade da região. Os NCCs são espaços físicos e virtuais que visam promover acesso democrático dos cidadãos as TIC; difundir cultura local e regional a partir da participação e do compromisso

coletivo dos cidadãos; desenvolver habilidades e capacidades empreendedoras necessárias para afrontar planejamento futuro da região; gerar espaço de encontro social e virtual capaz de convocar a diversidade de organizações sociais; criar redes de colaboração entre instituições, empresas, associações e pessoas com afinidades de interesse, e promover efeitos multiplicadores de iniciativas e projetos empreendedores na região.

EQUIPO TÉCNICO AUPEX (Coord). (2001). Nuevos centros del conocimiento: I manual de buenas práticas de la alfabetización tecnológica de extremadura. Badajoz: Junta de Extremadura; AUPEX.

. (Coord.). (2003). Participación tecnológica: II manual de buenas práticas: metodologia de la alfabetización tecnológica de extremadura. Badajoz: Junta de Extremadura; AUPEX. 


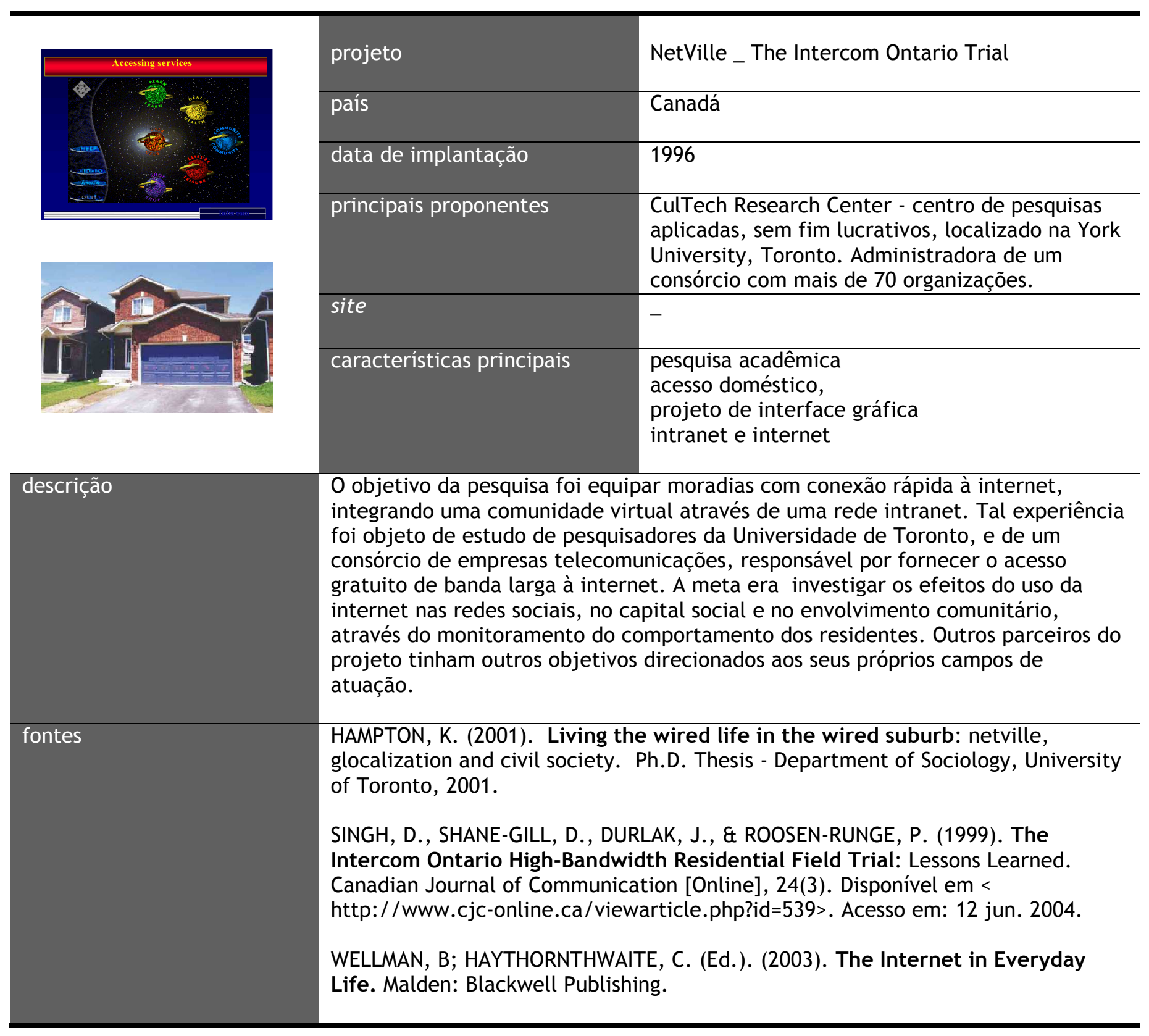




\begin{tabular}{lll}
\hline & Projeto & OLPC_One Laptop per Child \\
\hline data de implantação & Estados Unidos \\
\hline principais proponentes & OLPC \\
\hline site & http://www.laptop.org \\
\hline características principais & $\begin{array}{l}\text { iniciativa do terceiro setor } \\
\text { desenvolvimento de equipamentos } \\
\text { redes }\end{array}$ \\
\hline $\begin{array}{l}\text { O projeto objetiva o desenvolvimento de um laptop de \$100. Trata-se de } \\
\text { uma iniciativa da organização sem fins lucrativos One Laptop per Child criada } \\
\text { por membros acadêmicos do Media Lab do MIT, para projetar, fabricar, e } \\
\text { distribuir os laptops, que sejam suficientemente baratos, para fazer com que } \\
\text { cada criança do mundo tenha acesso ao conhecimento, tendo assim uma } \\
\text { nova e moderna forma de educação. OLPC é baseado em teorias } \\
\text { construcionistas de aprendizagem, desenvolvidas pioneiramente por Seymour } \\
\text { Papert e Alan Kay, assim como nos princípios expressos no livro Vida Digital, } \\
\text { de Nicholas Negroponte. }\end{array}$ \\
\hline fontes
\end{tabular}




\begin{tabular}{|c|c|c|}
\hline & projeto & $\begin{array}{l}\text { Piraí Digital } \\
\text { Programa Piraí__ Município Digital } \\
\text { Brasil }\end{array}$ \\
\hline & data de implantação & 2002 \\
\hline & principais proponentes & $\begin{array}{l}\text { Prefeitura Municipal de Piraí } \\
\text { Universidade Federal Fluminense UFF }\end{array}$ \\
\hline & sites & $\begin{array}{l}\text { http://www.piraidigital.com.br/ } \\
\text { http://www.pirai.rj.gov.br }\end{array}$ \\
\hline 20 & características principais & $\begin{array}{l}\text { iniciativa governamental } \\
\text { infra-estrutura de acesso } \\
\text { desenvolvimento local, telecentros, tótens }\end{array}$ \\
\hline descrição & \multicolumn{2}{|c|}{$\begin{array}{l}\text { O projeto baseia-se em uma rede de comunicação com acesso à internet em } \\
\text { banda larga que interliga todo o território do município (sistema híbrido } \\
\text { com suporte wireless [SHSW®]). A rede contempla todos os prédios da } \\
\text { administração municipal, escolas (todas possuem laboratório digital), } \\
\text { telecentros e diversos terminais de acesso comunitário, todos gratuitos e } \\
\text { com software livre. A partir da infra-estrutura física, foram implantadas } \\
\text { diferentes áreas de atuação com objetivos específicos: GOV } \\
\text { (desenvolvimento do e-governo, governança eletrônica, quiosques com } \\
\text { acesso direto a internet); EDU (informatização das escolas da rede pública, } \\
\text { bibliotecas, APAE e Centros de Estudos Municipais, nova pedagogia, } \\
\text { desenvolver conteúdos digitais, inclusão digital, Universidade à Distância); } \\
\text { ORG (telecentros com serviços e cursos, inclusão digital, conteúdos digitais: } \\
\text { cultura, formação profissional e a empregabilidade); COM (acesso à internet } \\
\text { para a população a preços baixos, integração com as empresas); SAÚDE } \\
\text { (gestão integrada dos centros de assistência a saúde, formação, programa } \\
\text { saúde mental digital). }\end{array}$} \\
\hline fontes & \multicolumn{2}{|c|}{$\begin{array}{l}\text { PIRAI DIGITAL: site oficial. Apresenta detalhadamente o projeto, incluindo } \\
\text { prêmios, tecnologias e parceiros. Disponível em: } \\
\text { <http://www.piraidigital.com.br/>. Acesso em } 02 \text { fev. } 2007 . \\
\text { PROGRAMA GESTÃO PÚBLICA E CIDADANIA - Histórias de um Brasil que } \\
\text { funciona. (2004). São Paulo: Programa Gestão Pública e Cidadania. }\end{array}$} \\
\hline
\end{tabular}




\begin{tabular}{|c|c|c|}
\hline & projeto & Plurall \\
\hline & país & Brasil \\
\hline & data de implantação & 2006 \\
\hline & principais proponentes & $\begin{array}{l}\text { ONG Movimentos em Rede } \\
\text { PUC _ Rio de Janeiro }\end{array}$ \\
\hline & site & www.plurall.net \\
\hline & características principais & $\begin{array}{l}\text { desenvolvimento de equipamentos } \\
\text { solução em software } \\
\text { redes }\end{array}$ \\
\hline descrição & \multicolumn{2}{|c|}{$\begin{array}{l}\text { O Plurall é uma solução terminais-servidor (thinclient), desenvolvida em } \\
\text { código aberto, que possibilita a montagem de redes locais de informática a } \\
\text { partir de um servidor e de computadores antigos, sem disco rígido, reciclados } \\
\text { como terminais. Na prática, a solução viabiliza uma infra-estrutura de } \\
\text { informática produtiva, que pode ser criada e mantida por pessoas com um } \\
\text { conhecimento básico de redes e informática em geral. }\end{array}$} \\
\hline fontes & \multicolumn{2}{|c|}{$\begin{array}{l}\text { PLURALL: site oficial. Apresenta detalhadamente o projeto, incluindo } \\
\text { tecnologias e parceiros. Disponível em: < http://www.plurall.net>. Acesso } \\
\text { em: } 02 \text { fev. } 2007 \text {. }\end{array}$} \\
\hline
\end{tabular}




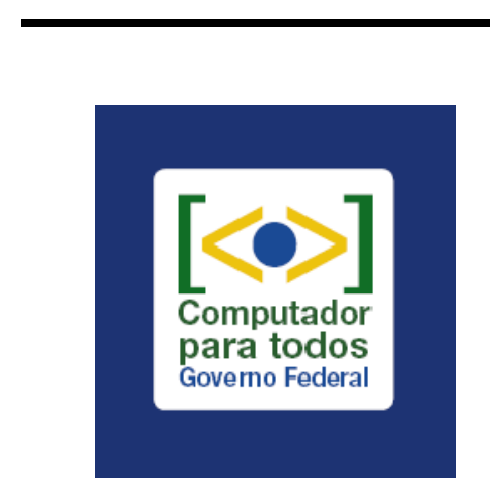

descrição

fontes projeto

país

data de implantação

principais proponentes

site

características principais
Projeto Cidadão Conectado_Computador para Todos

Brasil

2005

Governo Federal

http: / /www.computadorparatodos.gov.br/

iniciativa governamental

acesso a equipamentos

O objetivo principal do projeto é possibilitar a população que não tem acesso ao computador a aquisição de um equipamento, através de linhas de

financiamento especiais. 0 programa estimula a produção de computadores com isenção de impostos e abre linhas de crédito diferenciadas para o varejo, micro e pequenas empresas e para a população de baixa renda. 0 sistema operacional e aplicativos dos computadores são em software livre, e permitem acesso à internet. 0 projeto prevê ainda que todo cidadão que adquirir o Computador para Todos terá o direito a suporte, tanto para atendimento técnico (problemas com hardware, defeitos de fabricação, etc.), como para o uso dos aplicativos.

COMPUTADOR PARA TODOS: site oficial. Apresenta detalhadamente o projeto, incluindo tecnologias, requisitos para a participação e legislação. Disponível em: < http://www.computadorparatodos.gov.br/>. Acesso em: 02 fev. 2007.

COMPUTADOR PARA TODOS: Manual de aplicação da marca. Disponível em: < http: / / www.computadorparatodos.gov.br/>. Acesso em: 02 fev. 2007. 

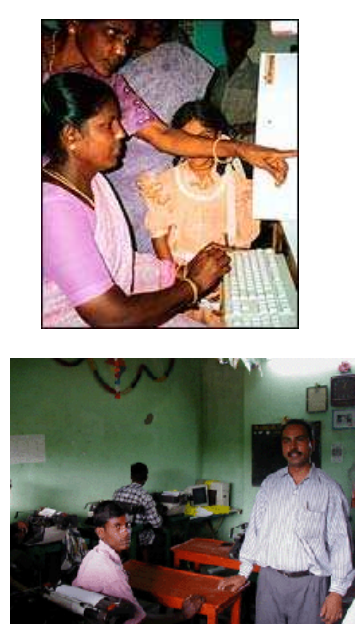

descrição

fontes

\section{projeto}

país

data de implantação

principais proponentes

site

características principais

\section{SARI Sustainable Access in Rural India}

İndia

2001

Instituto Indiano de Tecnologia de Madras

MIT Media Lab

Harvard University Law School

I-Gyan Foundation

n-Logue Communicaitons Pvt. Ltd.

\section{$-$}

infra-estrutura de conexão

telecentro

design de interface

A iniciativa pretende promover um sistema de comunicação auto-sustentável para populações rurais pobres da Índia e demonstrar como as redes de comunicação promovem o desenvolvimento social e econômico, melhoram aspectos ligados à saúde e educação, ajudando no combate à pobreza. 0 projeto busca demonstrar que tais objetivos podem ser alcancados de modo sustentável, através da

implantação de telecentros instalados [TeleKiosks] com suporte das línguas locais e com possibilidades de transformação de textos em fala - para as pessoas cegas e que não sabem ler.

SARI. Site. [Sustainable Access in Rural India]. Apresenta o projeto de forma detalhada, assim como links para papers e outros documentos, como para contato com pesquisadores e instituições parceiras. Disponível em:

<http://edev.media.mit.edu/SARI/mainsari.html>. Acesso em: 18 mar. 2005. 


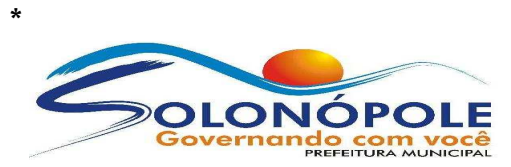

[marca da gestão atual projeto

país

data de implantação

principais proponentes

site

características principais

\section{Solonópole}

Brasil

2001

Prefeitura Municipal de Solonópole

http: / /www.solonopole.ce.gov.br

iniciativa governamental

infra-estrutura de acesso

portal web, telecentro

Projeto voltado a implantação de uma rede de comunicação com acesso à internet em banda larga (sistema wireless e cabo). A cidade esteve

interligada através dos serviços públicos: hospital, centros de saúde e

escolas, secretarias municipais, e também dos estabelecimentos

comerciais, e domicílios particulares. 0 projeto esteve centrado no uso de

software livre, na implantação de telecentros, na disponibilização de

provedor de internet gratuito ou a preços reduzidos aos moradores da

cidade, na informatização dos serviços públicos municipais. Quando da

mudança na gestão administrativa da prefeitura houve interrupção do

programa. Inúmeras questões quanto às ações implantadas foram

questionadas e revistas.

fontes

DIAS, L. R.(Coord). (2003). Inclusão digital: com a palavra, a sociedade. São Paulo: Plano de Negócios.

SÁ FILHO, C.A.C. (2006). O Ciberespaço e a cidade: influência das TIC na dinâmica cultural e política de comunidades. Dissertação (Mestrado) -

Escola de Engenharia de São Carlos, Universidade de São Paulo, São Carlos, 2006.

TREVISAN, N. (2005). Por mares nunca dantes navegados: estudos para a inclusão da população de baixa renda na sociedade da informação. .

Dissertação (Mestrado) - Escola de Engenharia de São Carlos, Universidade de São Paulo, São Carlos, 2005. 


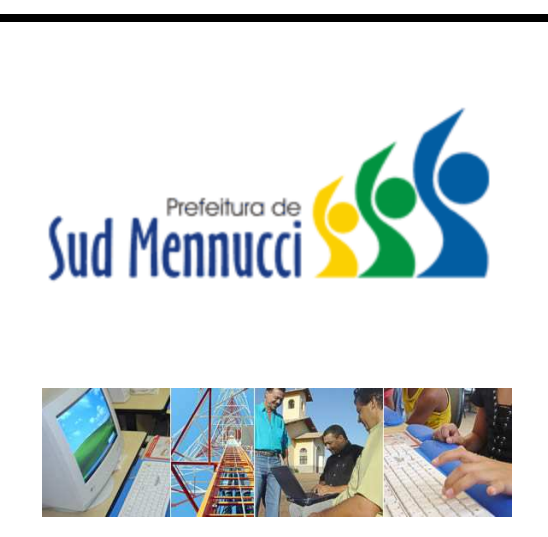

descrição

fontes

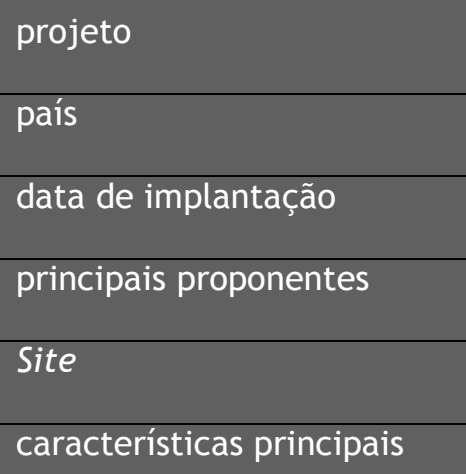

Sud Mennucci _ Cidade Digital

Brasil

2002

Prefeitura Municipal de Sud Mennucci

http://www.sudmennucci.sp.gov.br

iniciativa governamental

infra-estrutura de acesso

Trata-se da implantação de infra-estrutura de acesso ilimitado e gratuito a internet com alta velocidade por meio de distribuição de rede via ondas de rádio. A rede municipal wireless opera em $2.4 \mathrm{ghz}$ com um transmissor

central capaz de enviar sinais em um raio de $15 \mathrm{~km}$. A biblioteca pública

municipal possui um telecentro com 10 computadores que dão acesso livre

a internet a qualquer morador. As três escolas públicas do município são

equipadas com 60 computadores; nos horários livres das aulas, à noite e nos

finais de semana, o uso desses equipamentos é extensivo a toda população,

com direito a monitoria de funcionários treinados. Existe na cidade mais de

trezentos pontos de internet, entre particulares, comerciais e públicos.

FELA, R. (2006). Sud Mennucci, a cidade on line. Disponível em:

<http://www.overmundo.com.br/overblog/sud-mennucci-a-cidade-on-

line>. Acesso em: 5. fev. 2007.

SUD MENNUCCI: site oficial. Apresenta detalhadamente o projeto, incluindo tecnologias e parceiros. Disponível em: <

http: / /www.sudmennucci.sp.gov.br>. Acesso em: 02. fev. 2007. 


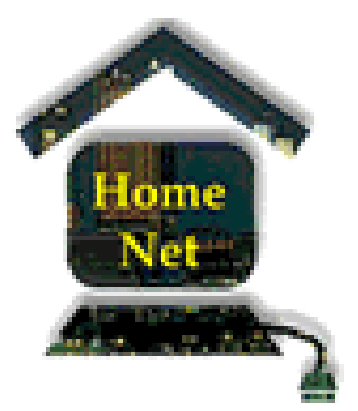

descrição

fontes projeto

país

data de implantação

principais proponentes

site

características principais
The HomeNet Project

\section{Estados Unidos}

1995

Human Computer Interaction Institute

Carnegie Mellon University

pesquisa acadêmica

acesso domiciliar

internet

Projeto de pesquisa cuja finalidade foi entender uso que as pessoas fazem da

internet nas suas casas. 0 projeto consistiu no fornecimento de serviços de

internet para um grupo de famílias, e na documentação cuidadosa de como os

membros destas famílias usavam os serviços online, como e-mail, chats,

boletins de notícias, e próprio uso da web. Através do exame detalhado dos

dados experimentais, inclusive quantitativos, e entrevistas, pôde-se medir

como as pessoas estavam interagindo com a comunicação e os serviços de

informação eletrônicos e o impacto destes serviços. O projeto desenvolveu uma

arquitetura de ações e procedimentos operacionais que permitiram um

monitoramento detalhado e confidencial. 0 projeto coletou dados para

responder a duas perguntas: 1 ) uma vez que a internet está facilmente

disponível, como os cidadãos "comuns" a usam? 2) que impacto este uso tem em suas vidas?

HOMENET: a field trial of residential internet services. Apresenta a pesquisa

com dados de seu primeiro ano de estudo. Abr. 1995. Disponível em:

<http://homenet.hcii.cs.cmu.edu/progress/report1.html>. Acesso em: 31 mar. 2005.

THE HOMENET PROJECT. Apresenta a pesquisa, seus pesquisadores e afiliados, além de links para diversos artigos relacionados ou não diretamente à esta.

Disponível em: <http://homenet.hcii.cs.cmu.edu/progress/>. Acesso em: 31

jan. 2005.

WELLMAN, B; HAYTHORNTHWAITE, C.(Ed.). (2003). The Internet in Everyday Life. Malden: Blackwell Publishing. 

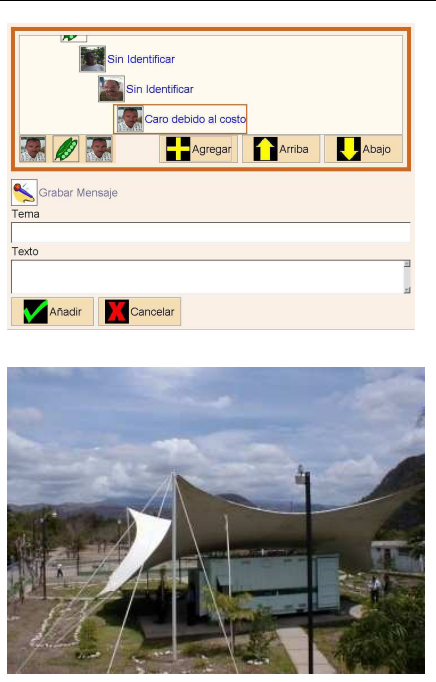

descrição

fontes

VAN Bohechio _ Village Area Network

\section{República Dominicana}

$2000 / 2001$

data de implantação

principais proponentes

site

características principais
Massachussets Institute of Techonology Media Lab's / eDevelopment Group

\section{$-$}

telecentro, tecnologias móveis

infra-estrutura de conexão

design de interfaces gráficas

Este projeto engloba três iniciativas diferentes na comunidade rural de Bohechio: VAN_village area network, ligado a implantação de infraestrutura de conexão à internet, LINCOS _ Little Intelligent Communities ligado à provisão das TIC em ambientes comunitários e CKS _ Community Knowledge Sharing, uma interface gráfica desenvolvida para usuários com baixa escolaridade. 0 projeto provê serviços TIC para dispositivos móveis e

fixos para comunidade rural via rede digital wireless. 0 objetivo é prover serviços e capacidades para alavancar o desenvolvimento econômico de comunidades rurais, aumentando o padrão de vida e de recursos médicos e educacionais. Centrado em um telecentro comunitário multi-propósito LINCOS, a VAN estende os serviços do telecentro para fora do centro da comunidade e dá suporte a serviços móveis e novos serviços com

computadores em centros outros locais. Várias aplicações estão sendo exploradas com a utilização da VAN em Bohechio, no sistema educacional, como suporte para o desenvolvimento de atividades de agricultura, em

sistemas de comunicação de voz de baixo custo e infra-estrutura de antenas. BEST, M. L. The Wireless Revolution and Universal Access. Disponível em <http://cyber.law.harvard.edu/digitaldemocracy/best-wirelessrevolutionsept03.pdf>. Acesso em: 16 fev. 2005.

SHAKEEL, H. U.(2001). Community knowledge sharing: an internet

application to support communications across literacy levels. PhD. Thesis

Massachusetts Institute of Technology, 2001.

PILOT PROJECT BOHECHIO VILLAGE AREA NETWORK. Apresenta projeto.

Disponível em <http://edev.media.mit.edu/vanbohechio.html. Acesso em: 6 jan. 2005. 


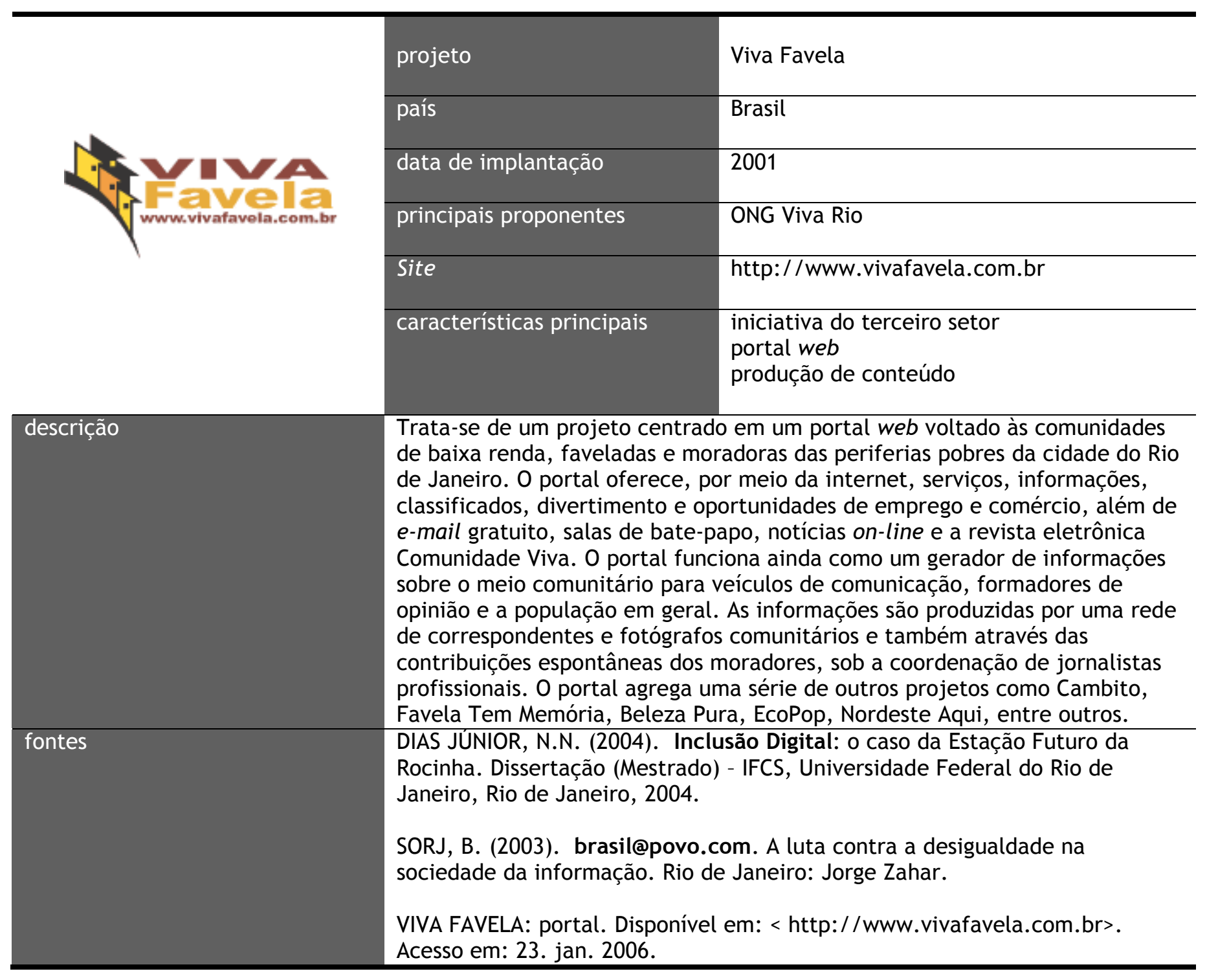




\section{Apêndice B}

\section{Quadros resumos das ferramentas de comunicaç̧̃o na internet}

\section{Bate-papo: chat}

Chat é uma palavra inglesa que em português significa bate-papo, tagarelice, conversação. Chat, no universo da informática, diz respeito a ferramentas de comunicação em tempo real, onde as pessoas, dentro de um mesmo ambiente, podem trocar mensagens. Conhecidas também como webchat e salas de bate-papo, este serviço de internet foi criado no final dos anos 1980, a partir do estabelecimento do protocolo IRC Internet Relay Chat, baseado também no modelo cliente servidor. Trata-se de uma ferramenta cuja dinâmica está centrada na reunião online de pessoas para conversas coletivas. As conversas nos chats são baseadas em textos escritos em sua grande maioria, entretanto existem aplicativos que possibilitam a publicação de imagens, áudio e vídeo, e que também podem ser acessados a partir da web. Aqui também o número de pessoas que participam das conversas varia muito; contudo, como se trata de uma ferramenta de interação simultânea, há os limites impostos pela inteligibilidade e entropia. As ferramentas são programadas para estipular estes limites e criar novos ambientes quando estes se excedem. Além das interações interpessoais, estas ferramentas podem ser usadas também para a realização de entrevistas com a presença de moderador.

\section{Blog}

O desenvolvimento da ferramenta weblog se deu nos anos 1990, e sua utilização mais intensa foi percebida no início dos anos 2000. O termo weblog é fruto da junção das palavras inglesas web, referente ao serviço de internet, e log, que significa algo próximo de diário de bordo. Porém, é mais 
comum usar simplesmente blog para referir-se a esta ferramenta, que combina comunicação assíncrona, interfaces amigáveis, e as potencialidades de produzir hipertextos, além de serem, na sua maioria, hospedados em portais gratuitos. Um blog nada mais é do que um site, uma página web, cujos conteúdos, mantidos por um ou vários autores, têm uma determinada periodicidade e são organizados em sequiência e ordem cronológica a partir da última atualização, sendo também permitido aos leitores expressar suas opiniões em relação aos conteúdos apresentados. Possuem versões para formatos de conteúdos específicos, como imagens (fotolog ou fotoblog), vídeos (vlog), áudios (audiocast ou podcast) e televisão (videologtv) e também para diferentes dispositivos. Os moblogs são blogs que podem ser alimentados diretamente de equipamentos móveis, como telefones celulares. Os blogs estão disponíveis a partir das telas de computadores de mesa, de mão ou laptops, e também de telefones celulares conectados.

\section{Comunicador instantâneo}

As ferramentas de envio e recepção de informações de caráter contínuo em tempo real pela internet são conhecidas em inglês como Instant Messaging. No Brasil adotou-se os termos MSN e messenger para designar este tipo de sistema, uma referência direta a um determinado produto ${ }^{1}$. Foram desenvolvidas a partir do ICQ (sigla baseado na pronúncia em inglêsdas palavras I seek you) lançado em meados dos anos 1990. Esta tecnologia disponibiliza funções específicas que permitem criar lista de pessoas que disponham do mesmo sistema para saber se estas estão conectadas ou não, e assim interagir. Pode-se estabelecer diálogos entre um e um, e entre muitos e muitos, de forma isolada ou paralela. Através destes comunicadores instantâneos, que pressupõem interlocutores online, é possível a conversação em áudio, por webcam, a troca de informações textuais, de imagens, e arquivos em diferentes formatos, em tempo real. São sistemas de comunicação síncrona, mas quando integrados a e-mail, passam também a estabelecer conexões assíncronas.

${ }^{1}$ MSN vem de Microsoft Service Network e messeger de MSN Messenger. 


\section{Fórum de discussão}

As ferramentas de trocas de mensagens organizadas por áreas temáticas recebem nomes variados, tanto em português como em inglês, entre eles fórum de debates, fórum de mensagens, mural, mural de discussões, grupos de notícias, web forums, bulletin boards, newsgroups, discussion forums, entre outros. Trata-se de uma aplicação de interação multi-usuários assíncrona, que ainda privilegia a linguagem verbal escrita, e que possibilita além dos debates e discussões, uma estrutura de publicação organizada de conteúdos. Esta ferramenta se parece com um mural para a exposição e troca de informações, acrescido da possibilidade de diálogo. Trata-se de uma interação de muitos para muitos.

O mural é uma ferramenta indicada para usuários com fluência em Web, e motivados para a discussão do assunto proposto pela comunidade. Resultados positivos aparecerão se um grupo de participantes estabelecer uma rotina de funcionamento onde cada um ganha o hábito de acompanhar as discussões com alguma freqüência (SPYER, 2007, p.48).

Os fóruns nasceram no final da década de 1970 com os BBS (Bulletin Board System) e a usenet, e hoje são acessados a partir dispositivos conectados à rede, móveis ou fixos. Diferencia-se dos mailing list basicamente por estarem disponíveis a partir da web, entretanto, podem estar ou não associados a ferramentas de e-mail. As temáticas dos fóruns são infindáveis, como são os interesses das pessoas. 0 número de pessoas que participam desses murais podem variar bastante, assim como o tom adotado na interação, do formal ao informal. Além do e-mail, outras funcionalidades podem estar associadas à ferramenta fórum, para usuários e administradores.

SPYER, J. (2007). Conectado: o que a internet fez com você e o que você pode fazer com ela. Rio de Janeiro: Jorge Zahar. 


\section{Listas de discussão e correio eletrônico}

O correio eletrônico, (electronic mail; e-mail) é um sistema de envio e recepção de mensagens na através da internet. É uma das primeiras ferramentas criadas a partir da conexão de computadores, ainda em 1971, e uma das mais conhecidas, utilizada principalmente nas atividades de trabalho e vida cotidiana. Embora consiga transportar qualquer formato de informação, a linguagem dos textos verbais escritos é a mais utilizada nesta aplicação. Trata-se de um modo de comunicação assíncrono, no formato um para um, e pode ser utilizado por meio de dispositivos digitais móveis e fixos. Utiliza-se de um sistema servidor cliente (instalado, ou disponível na web), e protocolos específicos, os mais conhecidos SMTP (Simple Mail Transfer Protocol) e POP3 (Post Office Protocol versão 3).

Quando o e-mail é utilizado no formato um-muitos, torna-se uma lista de discussão (lista de e-mails, lista de distribuição, listas de correio eletrônico; em inglês: maillisting, mail list, mailing list, listserver). Trata-se de um sistema que permite que uma mesma mensagem seja enviada a um grande número de pessoas, que possuem algum tipo de interesse comum. “[...] funciona a partir de um refletor de mensagens eletrônicas que gera um endereço de e-mail especial para cada grupo criado, que então transmite seu conteúdo a todos os inscritos, proporcionando a experiência da comunicação grupal.” (SPYER, 2007, p.50). As listas de discussões podem ser abertas ou restritas, possuir ou não moderadores, e apresenta possibilidades de incorporação de outras funcionalidades, como agenda, compartilhamento de arquivos, entre outros. São usadas também para publicidade, ou para a divulgação de notícias, cujos correspondentes conceituais no modelo analógico poderiam ser as malasdiretas e newsletters com seus conjuntos de assinantes.

SPYER, J. (2007). Conectado: o que a internet fez com você e o que você pode fazer com ela. Rio de Janeiro: Jorge Zahar. 


\section{SMS_Short Message Service}

O SMS, em português serviço de mensagem curta ou torpedo, é um sistema de envio e recepção de mensagens de texto pequenas através de telefones móveis digitais, criado no início dos anos 1990 . Trata-se de uma espécie de serviço de pager para celulares, com mensagens de até 160 caracteres na tecnologia padrão CDMA (Code Division Multiple Access) e 255 no padrão GSM (Global System for Mobile Communications). A diferença é que se o celular estiver desligado ou fora da área de serviço a mensagem é guardada até que seja possível lê-la. Hoje o envio de SMS pode ser feito da internet, e engloba outros dispositivos móveis de mão, e não é só baseado em textos, mas também em voz e imagens. Trata-se de comunicação assíncrona, nos moldes um para um, e um para todos quando se trata de publicidade e outros eventos.

\section{Videoconferência}

As ferramentas de videoconferência estabelecem a comunicação pessoa-a-pessoa, ou entre um grupos, a partir de lugares diferentes, em tempo real, através de dispositivos que permitem a transmissão simultânea de áudio e vídeo. As videoconferências podem ser baseadas em estúdio, salas preparadas para este fim, com equipamentos específicos, ou a partir de computadores pessoais equipados com hardware e software adequados. No primeiro caso a interação se dá para além do modelo WIMP e das interfaces tipo GUI. Trata-se de sistemas que requerem tecnologias especiais, que integram outras aplicações que permitem cooperação entre os usuários, por exemplo, através de recursos de compartilhando informações, como as anotações em quadros-brancos, e de materiais de trabalho, como textos, imagens e vídeos. Os primeiros sistemas de videoconferência apareceram em meados dos anos 1960, nos anos 1980 foram impulsionados pelo desenvolvimento de equipamentos responsáveis pela compressão de dados para sistemas desta natureza, chamados codecs. As videoconferências evitam deslocamento físicos, propiciam economia de recursos, e são muito utilizadas em ambientes de negócios e acadêmicos. 


\section{Voz sobre protocolo internet}

Os aplicativos de voz sobre protocolo internet (IP, Internet Protocol), conhecidas como VolP (Voice over Internet Protocol $)^{1}$, constituem-se importantes ferramentas de comunicação a partir da internet ao permitirem a transmissão de voz. Grosso modo, basea-se no processo de digitalização a voz, que disposta em pacotes de dados, trafega pela rede e se converte em voz quando chega ao destino, como redes peer-to-peer, sem servidores. Tais sistemas demandam software e protocolos especiais, e também equipamentos como microfones, caixas de som ou fones de ouvido. Permitem a integração com as redes de telefonia convencionais, fixas e móveis, com sistemas de SMS, possibilitam conferências em áudio, além de outras funcionalidades de caráter colaborativo.

${ }^{1}$ E também como telefonia internet, telefonia em banda larga, voz sobre banda larga, entre outros.

\section{World Wide Web}

A World Wide Web, também chamada simplesmente web, w3, ou pela sigla www, cuja tradução aproximada poderia ser rede de alcance mundial, é a face mais conhecida da internet. Teve início no início dos anos 1990, a partir do desenvolvimento do protocolo de comunicação de dados HTTP, sigla de Hyper Text Transfer Protocol (Protocolo de Transferência de Hipertexto), criado pela equipe coordenada por Tim Berners-Lee, que viabilizou o modo gráfico da internet. Ou a busca, consulta, distribuição e adição de informações através da rede mundial de computadores. A web é muitas vezes confundida com a própria internet, porque a grande maioria das informações disposta na rede está agregada em torno do formato de hipertexto, de um sistema de endereçamento próprio, do modelo de requisições e respostas clientes e servidores, e em linguagens de marcação (a mais conhecida HTML HyperText Mark-up Language). São estas convenções, programas e aplicações que permitem o acesso a informações hipermidiáticas a partir de computadores remotos, e que fazem da web a principal ferramenta da internet. 
A web é considerada uma espécie de repositório mundial de informações digitalizadas, um espaço virtual que reuni uma quantidade de informações até então inimaginável, sem precedentes. Suporta, integra e dá aportes a diferentes sistemas, plataformas, aplicações e ferramentas que permitem, isolada ou conjuntamente, a comunicação e interação um-todos, todos-todos, um-um e todos-um, seja de forma síncrona ou assíncrona, através de browsers distribuídos em dispositivos informáticos de diferentes naturezas, móveis e fixos. 